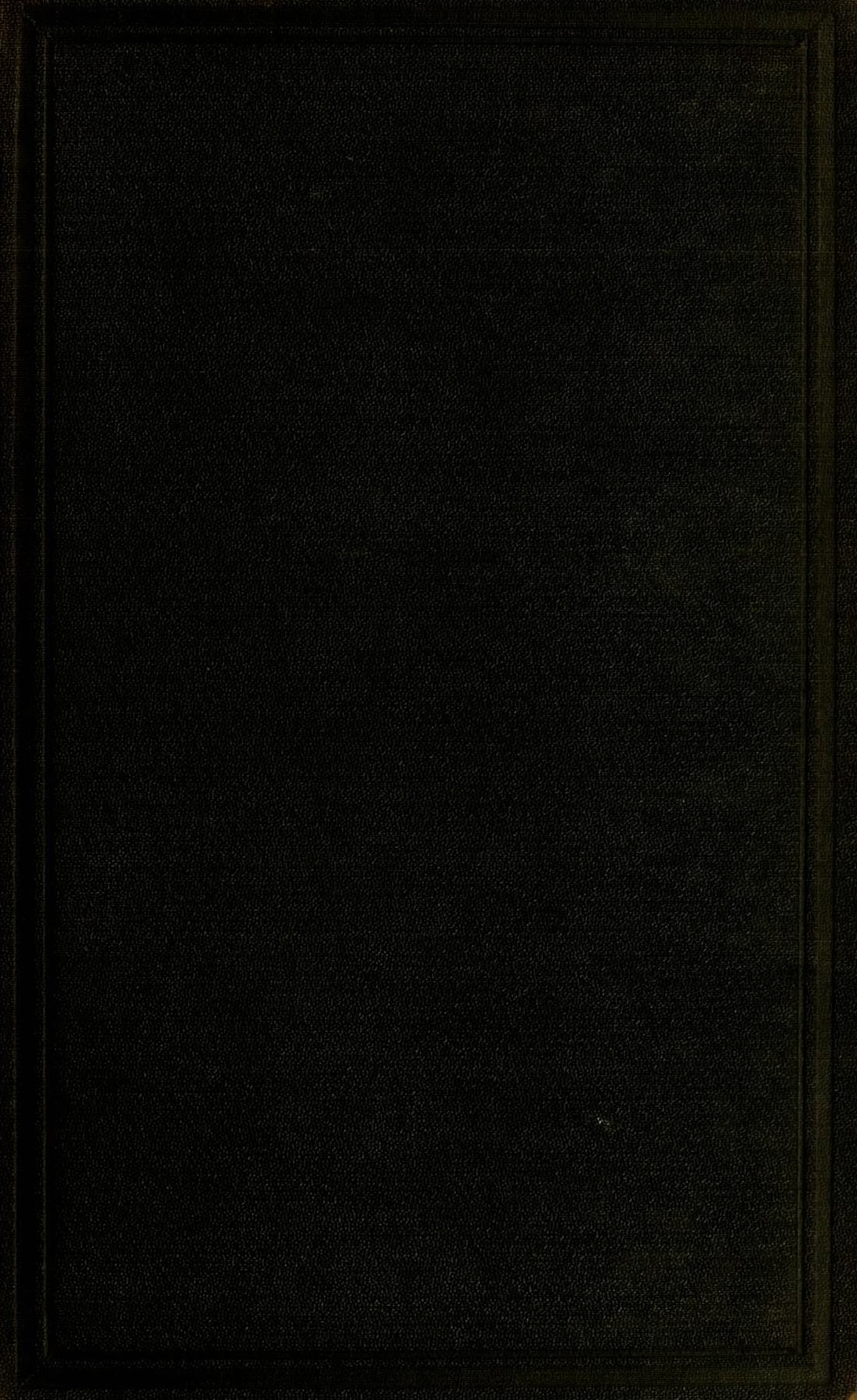



Complimentes of the

U. S. Fish Commission. 



THE FUR-SEAL AND OTHER FISHERIES OF ALASKA.

SH

II

A 1455

1889

KELL

\section{IN VESTIGATION}

OF TIIE

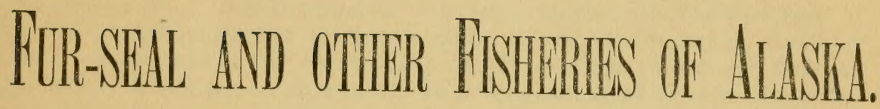

REPORT FROM THE COMNITTEE ON MERCHANT MARINE AND FISHERIES OF THE HOUSE OF REPRESENTATIVES.

WASHINGTON:

GOVERNMENT PRINTING OFFICE.

1889 . 


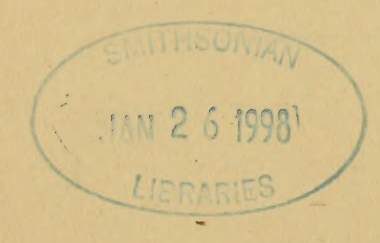




\section{FUR-SEAL FISHERIES OF ALASKA.}

JANUARY 29, 1889.-Recommitted and ordered to be printed. Mr. Dunn, from the Committee on Merchant Marine and Fisheries, sub-
mitted the following

\section{R E P O R T:}

[To accompany bill H. R. 12432.]

The committee was directed to " investigate the fur-seal fisheries of Alaska and all contracts or leases made by the Government with any person or companies for the taking of fur seals or other fur-bearing animals in Alaska; the character, duration, and condition of such contracts or leases; and whether and to what extent the same have been enforced and complied with or violated ; the receipts therefrom, and the expenses incurred by the Government on account of any such contract or leases; and to fully investigate and report upon the nature and extent of the rights and interests of the United States in the fur seals and other fisheries in the Bering Sea in Alaska; whether and to what extent the same have been violated, and by whom; and what, if any, legislation is necessary for the better protection and preservation of tine same."

\section{FIRST,-AS TO THE SEAL FISHERIES.}

The fur-seal rookeries of Alaska are located on the Pribylov group of islands, situate near the center of that part of Bering Sea lying within the boundary of the territory ceded by the Emperor of Russia to the United States.

The isIand of St. Paul has an area of 33 square miles, and St. George, 27 square iniles.

Lieutenant Maynard, U. S. Navy, who was detailed by the Secretary, pursuaut to the act of April 22, 1874, to inquire into the condition of the seal-fisheries in Alaska, in his report says (Executive Document No. 43, first session Forty-fourth Congress) :

They (the seal islands) are enveloped in summer by dense fogs, through which the sun rarely makes its way, and are surrounded in winter by fields of ice driven down from the Aretic by northern gales. They have no sheltered harbors, but slight indentations in the shore line afford a lee for vessels and a tolerable landing-place for boats in certain winds. The shores are bold and rocky, with strips of sand-beach and slopes covered with broken rocks, at intervals between the cliffs, and the interior of both is broken and hilly; neither tree nor shrub grows upon them, but they are covered with grass, moss, and wild flowers. For nearly one hundred years fur seals have been known to visit them annually in great numbers for the purpose of bringing forth and rearing their young, which circumstance gives them no inconsiderable commercial importance. The seals oceupy the islands from the breaking away of the ice in the spring until it surrounts 1 hem again in the early winter; that is, from about ihe middle of May nntil Deceruber. 
- It is further shown by the testimony before the committee that on their return to the islands, after their temporary absence during the winter, these animals generally select the locations on the rookeries which they had formerly occupied. It appears, too, that all the Alaskan fur seals are born on these islands; that they are distinct animals, and have none of the characteristics of fish, and will drown in the water until they are taught to swim by their elders.

In former years fur seals were found in great numbers on various isl: ands of the South Pacific Ocean; but after a comparatively short period of indiscriminate slaughter the rookeries were deserted, the animals having been killed or driven from their hawnts; so that now the only existing rookeries are those in Alaska, another in the Russian part of Bering Sea, and a third on Lobos Island, at the mouth of the river Plate in South America.

All these rookeries are under the protection of their several Governments.

The best estimate as to the number of these animals on the Alaska rookeries places it at about four millions; but a marked diminution of the number is noticed within the last two or three years, which is attributed by the testimony to the fact that unauthorized persons during the summers of 1886,1887 , and 1888 had fitted out expeditions and cruised in Alaskan waters, and by the use of fire-arms destroyed hundreds of thousands of these animals, without regard to age or sex.

The law probibits the killing of fur seals in the Territory of Alaska or the waters thereof, except by the lessee of the seal islan's, and the lessee is permitted to kill during the months of June, July, September, and October only; and is forbidden to kill any seal less than one year old, or any female seal, "or to kill such seals at any time by the use of fire-arms, or by other means tending to drive the seals away from those islands." (Rev. Stat., sec. 1960.)

Governor Simpson, of the Hudson Bay Company, in his "Overland Journey Round the World," 1841-42, p. 130, says :

Some twenty or thirty years ago there was a most wasteful destruction of the seal, when young and old, male and female, were indiscriminately knoeked in the head. This imprudence, as any one might have expected, proved detrimental in two ways. The race was almost extirpated; and the market was glutted to such a degree, at the rate for some time of 200,000 skins a year, that the prices did not even pay the expenses of carriage. The Russians, however, have now adopted nearly the same plan which the Hudson Bay Company pursues in recruiting any of its exhausted districts, killing only a limited number of such males as have attained their full growth, a plan peculiarly applicable to the fur seal, inasmuch as its habits render a system of husbanding the stock as easy and certain as that of destroying it.

In the year 1800 the rookeries of the Georgian Islands produced 112,000 fur seals. From 1806 to 1823 , says the Encyclopædia Britanica, "The Georgian Islands produced 1,200,000 seals, and the island of Desolation has been equally productive." Over $1,000,000$ were taken from the island of Masafuera and shipped to China in 1798-99. (Fanning's "Voyages to the South Sea," p. 299.)

In 1820 and 1821 over 300,000 fur seals were taken at the South Shetlind Islands, and Captain Weddell states that at the end of the second year the species had there become almost exterminated. In addition to the number killed for their furs, he estimates that "not less than 100,000 newly born young died in consequence of the destruction of their mothers." (See Elliott's Rep., 1884, p. 118.)

In 1830 the supply of fur seals in the South Seas had so greatly decreased that the vessels engaged in this enterprise "generally made los: 
ing voyages, from the fact that those places which were the resort of seals had beeu abandoned by them." (Fanningr's Voyages, 1).487.)

At Autipodes Island, off the coast of New South Wales, 400,000 skins were obtained in the years 1814 and 1815.

Referring to these facts, Professor Elliott of the Smithsonian Institution, in his able report on tho Seal Islands, published by the Interior Department in 1881 , says :

This gives a very fair ilea of the manner in which the business was conducted in the South Pacific. How long would our sealing interests in Bering Sen withstand the attacks of sixty vessels carrying from twenty to thirty men each? Not over two seasons. The fact that these great southern rookeries withstood and paid for attacks of this extensive character during a period of more than twenty years, speaks oloquently of the millious upon millions that must have existed in the waters now almost deserted by them.

Mr. R. H. Chapel, of New London, Conn., whose vessels had visited all the rookeries of the South Pacific, in his written statement before the Committee on Commerce of the House of Representatives, said:

As showing the progress of this trade in furseal skins and the abuses of its prosecution, resulting in almost total annihilation of the animals in some localities, it is stated on good anthority that, from about 1770 to 1800 , Kergnelen's Land, iu the Indian Ocean, yielded to the English traders over 1,000,000 skins; but open competition swept oft tho herds that resorted there, and since the latter year hardly 100 per anumm could be obtained on all its lonir coast. Afterwards, Messafnero Island, near Juan Feruandez, was visited, aud 50,000 a year wore obtained; but as every one that desired was free to go aud kill, the us ual result followed-the seals wero exterminated at that island, and also at the Gallipagos group, near by.

Falkland and Shetland Islands, and South American coasts, near Cape Horn, cams next in order; here the seal were very abundant. It is stated that at the Shetlands alone 100,000 per annum might mave been obtained and tho rookeries preserved, if taken uncler proper restrictions; but in the eagerness of men they killed old and young, male and female; little pups a few days old, deprived of their mothers, died by thuusands on the beaches, carcasses and bones strewed the shores, and this produetive fisliery was wholly destroyed. It is estimated that in the years $13 \% 1$ and $18: 2$ no less than 320,000 of these auimals were killed at the Shetlands aloue. An American captain, describing in after years his success there, says: "We went the first year with one vessel and got 1,200 skins; the second year with two vessels, and obtained 30,000 ; the third year with six vessels, getting only 1,700-all there was left."

A small rookery is still preserved at the Lobos Islands, off the rirer La Plata; this being carefully guarded under strict regulations by the Government of Buenos Ayres, and rented to proper parties, yields about 5,000 skins per annum. As late as the year 1854, a small island, hardly a mile across, was discovered by Americaus in the Japan Sea, where about 50,000 seals resorted annually. Traders visitert it, and in three years the club and knife had cleaned them all off. Not 100 a season cau now be found there.

\section{In the Ammual Report of Secretary MeCulloch for 1868, ho says :}

The protection of the fur-bearing animals is a matter of importance hardly to be overrated. In consequence of information received last spring, the captain of the Fayanda was directed to visit, as early in the season as practicable, the islands in Beriug Sea where the fur soal chiofly abounds. On his arrival at St. Paul's and St. George's Islands, he found there soveral large parties engaged in huntiug the animals indiscriminately, and in tratice with the vatives in ardent spirits and other forbidden articles. Quarrels had arisen and the natives complained that tho reckless aud unskillful movements of the new hunters had already driven the animals from soms of their usual haunts. The captaiu of the cutter instituted such measures as he felt authorized to institute for the maintenance of the peace and the firutection of the animals from indiscriminate slaughter.

The preservatiou of these animals by the observance of strict rogulations in hunting them, is not only a matter of the highest importance in an ecommical view, but it inatter of life or death to the natives. Hitherto, seals have been hunted under the supervision of the Rnssian company, and exclusively by the natives, who are trained from children to that occupation, and derive from it their elothing and subsistence. They have been governed by exact and stringentrules as to the time of hunting, and the number and kind of seals to be taken. * * * The United States can not, of course, administor such a trado as a Goverument mouopoly, and the ouly alternativo 
seems to be to grant the exclusive privilege of taking these animals to a responsible company for a series of years, limiting the number of skins to be taken annually by stringent provisions. A royalty or tax might be imposed upou each skin taken, and a rovenue be thus secured sulicient to pay a large part of the expense of the Territory.

Hon. C. A. Williams, of New Lomlou, Comn., one of the principal shareholiters in the Alaska Commercial Company, who has been engaged in the business of whaling aud seal-huntiug as the successor of his father and wrandiather in that pursuit, was called before the committee, and testitied to facts from his own experience and that of his house; he said :

The history of sealing goes back to about 1790, and from that to the early part of this century.

In the earlier period of which I speak there were no seals known in the North Pacific Ocean. 'Their particular Launt was the South Atlantic. They were discovered by Cook, in his voyages, on the island of Desolation, by Widdall, in his voyages to the south pole, on the island of South Georgia and Sandwichland, and by later voyagers, whose names escape me, in the islands of the South Pacific Ocean. When the number of seals on those islands were first brought to the votice of British merehants they pursued the hunting of these animals on the island of Desolation.

The most authentic authority wo have about tho matter is derived from reports made by these voyagers as to the nnuber of seals taken from those places, and althongh they are not entirely accirate, I think they are fully as accurate as could he expected, considering the lapse of time. On the islaud of Desolation it is estimated that 1,200,000 fur seals were taken; from the Islaud of South Georgia a like number were taken, and from the island of Messafuero probably a greater number were taken. As to the Sandwichland the statistics are not clear, but there can be no doubt that over half a million seals were takes from that locality, and in 1820 the islands of Sonth Shetland, south of Cape Horu were diseovered, aud from these islands 320,000 fur seal were taken in two years. There were other localitios from which seals were taken, but no others where they were found in such large numbers. The market for fur seals in those dlass was China. The trade which the British and Americans had with China was very mueb agaiust them because of the high rates of exchange upou the coin.

In the trade with Chiua some exchangeablo medium was necessary, and they found in the fine furs of varims kinds, particulibrly the fur seal aud sea otter, a good medium of exchange. These skins of which $I$ have spoken were sent mostly to Chine, although some portions went to England and France and Germany, and were exported from there to Russia. They were used in the manufacture of eaps and capes and small articles of that character. The Chinese used them for lining garments and making dresses of luxury and comfort for their mandarins. The market price for theso skins in China, as nearly as can be found now, was $\$ 4$ to $\$ 0$, but it often happened that when there was a large quantity in the market the price of skins was depressed, so that they would bring scarcely 50 cents apiece. Captain Delano carried a cargo of 38,000 skins to China and sold them for $\$ 16,000$, which shows the result of a depressed market and the uncertainty of all ventures of that sort. The trade went ou until these loealities were all exhausted of their fur-hearing auimals. Then the trate went into a state of desuetude, and was ended. There were a few skins brought in from the Cilpe of Good Hope occasionally, but I do not think they averaged 1,000 skins a year from all these places.

The canse of the extermination of seals in those localities was the indiscriminate character of the slawghter. Sometimes as many as fifteen vessels would be hanging aromud these islands itwaiting opmortmuity to got their eatch, and every vessel would bo governerl by iudividual interests. They would kill everything that came in their winy that furnished a skin, whether a cow, a bull, or a middle-grown seal, leaving the young pups just born to dio from neglect aud starvation. It was liko taking in licit of cattlo anci killing all the bulls and cows and leaving the calves. The extermindion was so completo in these localities that the trade was exhausted, and voyages to those places were abandoned. About 1870 , nearly fifty years after the discovery of the South Shetland Islands, when the ocenpation of Alaska by the cession of Russia to the United States of the Bering Sea was brought about

The Chaman. I want to interrupt you to ask a question bearing on that point. Were those rookeries in the Sonth Seas never under the protectorate of auy government at all?

The WrTNEss. Never. I was going to say that wh $n$ the cession was made by Russia to the United States of this territory, anil the subject of the value of fur seals, or the possible valise, was bronght to mind, p:nplo who haul becu previously engageel in that husiness rovisited theso southeru localities, after a lanso of nearly tifty years, and no seals were fuund on the islimil of Desolation. These islands have been used 
is the breeding place for sea-elephants, and that creature can not be exterminatoul on that islaud, for tho reasou that certain beaches known as "weather beaches" aro there. The sea breaks rudely upon these beaches, and it is impossible to land upon them. There aro clitis, something like 300 to 500 feet, of shoro ice, and thes sua-elephant finds a safo resort on these beaches, and still preserves enough lifo to malio tho pursuit of that animal worth following in a small way.

I have vessels there, and have had, myseif and fither, for fifty or sixty years. B'it this is incidental. The island of South Shetland, and the island of South Georgit, and the island of Sandwichland, and tho Diegos, off Cape Horn, aud one or two ot liev minor points were found to yield more or less seal. In this period of fifty years in these localities seal life hal recuperated to such an extent that there was talin from them in the six years from 1870 to 1876 or 1877 , perhaps 40,000 skins.

Q. After they had been abandoned for fitty years?

A. Yes; to-day they aro agrain exhansted. The last year's search of vessels in that, region-I have the statisties here of a vessel from Stonington from the Sunth Shetlind Islauds, reported in 1s88, and she procured 39 skins as the total result of seitrch on those islands and South Genrgia.

One of my own vessels proeured 61 skins, inclurling 11 pups, as the total result of her voyage; and, except about Cape Horn, there are, in my opinion, mo seals remilining. I do not think that one hundred seals conld be procured from all the locialities mentioned by a close search. Any one of those localities I have named, under proper protection aud restrictions, might have beon perpetuated as a breeding place ficr seits, yielding as great a number per annum as do the islands belonging to the Unitel States.

Now, the trade in those localities is entirely exhansted, and it wonld heimpossible in a century to restock those islands, or bring them back to a point where they would rield a reasonable return for the investment of capital in hunting skins. That, in brief, completes the history of the fur seal in the South Atlantic Ocean.

\section{DANGER OF THE EXTERMINATION OF THE ALASKA ROOKERIES.}

We have already mentioned that the present number of seals on St. Paul and St. George Islands has materially diminished during the last two or three years. The testimony discloses the fact that a large number of British and American ressels, manned by expert Indian sealhunters, have frequented. Bering Sea, and destroyed humdreds of thousants of fur seals by shooting them in the water, and securing as many of the carcasses for their skins as they were able to take on brari. The testimony of the Government agents shows that of the number of seals killed in the water not more than one in seven on an average is secured, for the reason that a wounded seal will sink in the sea. So that for every thousand seal skins secured in this manner there is a diminution of seal life at these rookeries of at least 7,010 . Adderl to this is the fact that the shooting of a female seal with young cunses the death of both. If the shooting is before delivery that, of course, is the end of both; if after, the young seal dies for want of sustenance.

During the season of 1885 the number of contraband seal skins placed on the market was over 13,000 ; and in $1856,25,000$; in 1887, 34,000 ; and in 1888 the number of illicit skins secured by British cruiser's were less than 25,000 , which number would have been largely increased had not the season been very stormy and boisterous. American eitizens respected the law and the published notice of the Secretary of the Treasury, and made no attempt to take seals.

From this it appears that, during the last three years, the number of contraband seal skins placed on the market amounted to over 97,000 , and which, according to the testimony, destroyeil nearly three-quarters of a million of fur seals, causing a loss of revenue amounting to over $\$ 2,000,000$, at the rate of tax and rental paid by the lessee of the seal islands.

SECOND.-AS TO THE CONTRACT OR LEASE.

The only contract or lease made by the Government with any persons or companies for the taking of fur seals or other fur-bearing animals in 
Alaska was a lease of the right to take fur seals for their skins for a period of twenty years from May 1, 1870, on the islands of St. Paul and St. George to the Alaska Commercial Company of San Francisco ; for which privilege said company agreed to pay to the United States a rental of $\$ 55,000$ per annum and a revenue tax, or duty, of $\$ 2.6: \frac{1}{2}$ per skin taken and shipped from the islands; to furnish to the inhabitants of said islands free of charge 2,500 dried salmon aunually; 60 cords of fire-wood; a sufficient quantity of salt, and a sufficient number of barrels for preserving the necessary supply of meat; to maintain a schinol on each islanu for the education of the natives, for a period of not less than eight months in each year.

T'o secure the payment of the rental a deposit of $\$ 50,000$ in United States bonds is required, and for the complete performance of the coveuants of the lease by the lessee, a bond in the sum of $\$ 500,000$ is exaeted.

The lessee is permitted to kill 100,000 fur seals on St. Paul and St. George Islanls, and no more, and is prohibited from killing any female seal or any seal less than one year old, and from killing any fur seal at any time except during the months of June, July, September, and October, and from killing such seals by the use of fire arms or other means tending to drive the seals from said islands, and from killing any seal in the water adjacent to said islands, or on the beaches, cliffs, or rocks where they haul up from the sea to remain.

\section{THIRD.-THE AWARD AND EXECUTYON OF THE LEASE.}

In reference to the letting of this contract, your committee have carefully examined the evidence submitted to the House of Representatives by the Committee on Ways and Means at the first session of the Fortyfourth Congress, accompanying the report of said committee made thereon, pursuant to direetion of the House:

To examine into and report whether said lease was made and execnted in pursuanco of law, and whother said lease, as made, was to the best alvantage of the United States, according to the offers of the bidders.

As a result of that investigation the Committee of Ways aud Means reported that:

The correspondence between the Secretary of the Treasury and the biditers and the Treasury Department, together with the contraet as made, may be found in Ex. Doc., first session Forty-first Cougress, No. 108. The committee in considering the question whetber the award to the Aliaska Commercial Company was made to the best advantage of the Uuited States, have been obliged to consider first, whether, admitting that a more favorable offer in money had been made by others, the Treasury Department could have omitted to respect the clear and palpable discrimiuation in favor of that company by the act of Congress.

The action of the Secretary, based upon opinions of his official legal advisers, appears to conclude this question in the negative. It is very evident that no new and inexperienced parties in the business, nuprovided with the necessary capital, implements, and knowledge, could have complied with the requirements of the law, which had to be incorporated into the contract itself. In order to preserve the fur seals from total annihilation, as has been done in the South Pacific Ocean, and indeed everywhere except on a small island belonging to Peru, and two small islands belouging to Russia, noue but experienced, judicious, and cautious parties should have been intrusted with the privilege of killing them. The old fur-seal fisheries bare been destroyed by the foolish ararice of those who had access to the seals, who, in their thirst for large immediate gains, have killed in excess of the proper number each season, which led to the eventual extermination of the seals themselves at those points.

It does not appear tbat either of the parties who put in bids for this lease had hasl auy experience of the business, or were provided with the necessary facilities for the faitlful execution of the lease had it been awarled to them, except the Alaska Commercial Company, whe were the successors of Hutchinson, Kohl \& Co., and in possession of 
the business at that time, with persons in its employment of skill and experience, and which was eomposed of capitalists of conceded strength and high character. If the lease had been made with any firm or company who hat failed in its execution, or who had proved fitithless to the obiigations ineurred, the loss to the Treasury might have proved very serions, in the extermination of the seals aud the loss of the large revenue now being derived therefrom, and likely to be continued for many years to come, under the present management.

In conclusion, they concur in the opiuinn that the lease with the Alaska Commercial Company was made in pursuance of the law ; that it was made in the iuterest of the United States and properly granted to the Alaska Commereial Company; that the interest of the United States was properly protected in all tho requirements of the law, and that all the lessees have faithfully complied with their part of the contract.

This report was adopted by the House, and your committee, after a full consideration of the testimouy on which it rests, found no sufficient reason for reviewing the action of said committee and the House in the premises.

No testimony has been presented to your committee, nor any intimation that testimony existed, other than that taken by that committee, that would conflict with that conclusion.

\section{FOURTH. THE PERFORMANCE OF THE CONTRACT BY THE LESSEE.}

All the witnesses concur in the statement that the Alaska Commercial Company has fully performed the covenants aud stipulations of said contract, and observed the law and regulations preseribed by the Secretary of the Treasury relating thereto.

It further appears firom the testimony that in addition to the requirements of the lease the lessee has contributed liberally to the welfare, comfort, and prosperity of the native inhabitants of the islands; it has built a comfortable house for each family on both islands, for which it charges no rent; provided stores free of charge, and maintains a physician on each island all the year at its own cost, and provides medical attendance and mediciues to the natives withont charge, and maintains and supports the native widows and orphans.

The native laborers receive 40 cents for removing each seal-skin, or $\$ 40,000$ for the catch of 100,000 seals, and are paid $\$ 1$ per day while engaged at other labor. In 1887 they had on deposit to their credit in San Francisco, drawing interest, the sum of $\$ 64,732.11$, and other natives of the Aleutian chain have been induced to accumulate savings amounting to $\$ 29,396.17$.

Goods and merchandise are supplied by the company at an advance of 25 per cent. above San Francisco wholesale prices.

Their chief article of food is seal meat, which costs them nothing. Dried salmou are furnished by the company under its contract; and as they pay no reut and their fuel is free, their living expenses are but little. See, further, Appendix A, hereto.

FIFTH. THE RECEIPTS AND EXPENSES OF THE GOVERNMENT ON ACCOUNT OF SAID CONTRACT.

The total amount paid by the lessee on account of said contract up to Jume 30, 1s\$8, inclusive, was $\$ 5,597,100$. The total amount expended by the Government during the same period was about $\$ 250,000$ for salaries and trareling expenses of ageuts of the Treasury Department at the seal islands, and about $\$ 150,000$ for the revenue-cutters cruising Alaskan waters. 
To the amount already received ciirest from the company should be adided the sum received by the United States from customs duties on Alaskat dressed seal-skins imported from Europe, amomnting to $\$ 3,4^{\prime 2} 6$,(:.'0. to which should be added the sum of $\$ 5()^{\prime \prime}, 000$ ( $11:$ toms duties on jmported seal-skins taken by said compauy under its contact wiils Russia, making an aggregate amount received by lhe (xoverument on account of this industry of $\$ 9,525,233$, being $\$ 2,3-5,2 \$ 3$ in excess of the amount paid to Russia for the Territory.

SIXTH. THE NATURE AND EXTENT OF THE RIGHTS AND INTERESTS OF THE UNITED STATES IN THE FUR-SEAL AND OTHER FISHERIES IN BERING SEA.

The rights aud interests of the Government in the fur-seal and other fisheries in Alaska were acquired by purchase from Russia and conveyed to it by the treaty of cession.

The fur-seal rookeries were discorered in 1786 by Pribylov, a Russian subject, and in 1799 the right to take fur-seals was granted to the Russian American Company by the Russian Emperor. From the date of discorery down to the date of the transf'r of Alaska to the United States, Russia claimed aud exercised exclusive jurisfliction over those islands and asserted her owuership of these fur-bearing animals and disposed of them accordiugls. No one ever questioned her right or asserted an adrerse claim. No foreign vessel was permitted to touch at either of said islands during the entire period of liussia's occupation. Seal life was protected by her nars, both on the islands and in Bering Sea.

By the treaty of cession this right was transferred to the United States. It iucludes the right to protect seal lile on the islauds and in that part of Bering Sea included within the boundary of the territory conveyed.

The right of linssia to patrol the waters of Beriug Sea and protect seal life was asserted and exercised for nearly a century, undisputed and unquestioned; and the United States having acquired that right by purchase from Russia, has maintained it from the beginuing. To illustrate: The killiug of fur seals by manthorized persoms was prohibited by act of Congress; the right to take a specifierl number each year for a period of twenty years at a fixed rate of tax aud rental was authorized, with direction to the Secretary of the Treasury for the time being to renew the privilege to proper and responsible parties at the expiratiou of each period of twenty years.

The penalty affixed to the violation of the statute prohibiting seal-killing is fine and imprisonment and confiscation of vessels, their tackle, ap- parel, and furniture.

The object of this law was, first, to protect this valuable industrs, upon which the entire population of the islands depended for subsistence; and second, to secure the United States a perpetual revenue therefrom.

It is clear to Jour committee from the proof submitted that to prohibit seal-killing on the seal islands and permit the killing in Bering Sea would be no protection; for it is not on the islauds where the destruction of seal life is threatened or seals are mulawfully killed, but it is in that part of Bering Sea lying between the "eastern aud western limits" of Alaska as described in the treaty of cession, through which the seals pass and repass in going to and from their feeding grounds, some 50 miles sontheast of the rookeries, and in their aunual migrations to and from the islands.

This was known to Cougress when the act entitied "An act to prevent 
the extermination of fur bearing aumals in Alaska " was passed, for in that act, as well as the preceding and subsequenc acts in reference to Alaska, Congress expressly asserted our jurisdiction orer the marine territory acquired by the purchase as well as over the laur, and extended the laws of the United States over the entire territory embracel within the boundary specified in the treaty, as will appear from the following enactmenis:

(1) The first legislatire action in reference to Alaska was the act of July 27,1568 , appromxiating $\$ 7,200,000$ in payment of the price stipulated in the treaty with Russia, of certain territory "therein described" and ceded to the United States. In other words, the appropriation was to pay for the territory described in the treaty of cession.

(2) By the act also approved July 27, 1868, it is proviclen :

The laws of the United States reluting to customs, commerce, and navigation are extended to and over all the main-land, islands, aud waters of the territory ceded to the United States by the Emperor of Russia, etc.

(3) By the act ajproved March 3, 1873, the twentieth and twenty-first sections of "An act to regulate trade aud intercourse with the Indian tribes and to preserve peace on the frontiers," approved June 30, 1S:3.t, be, "and are hereby, extended to aud over all the main-land, islantis, and waters of the territory ceded to the United States by the Emyeror of Russia," etc.

(t) By joint resolution March 3, 1869, "the islands. of St. Paul and St. George in Alaska are declared a special reservation for Goverument purposes," etc.

It will be observed that these islands, which are declared to be in Alaska, are situate near the center of what Mr. Sumuer designates as " our part of Bering Sea."

(5) By the act approved July 27, 1865 (Rev. Stat., sec. 1956), it is provided that " 110 person shall kill * * * auy fur seal or other furhearing animals withiil the limits of Alaska Territory or in the waters thereof."

The "limits" of Alaska Territory are defined by the treaty of cession as follows:

The eastern limit is the line of demarkation between the Russian anil British possessions in North America, etc.

The western limit within which the territories and dominion conveyed are contained pass through a point in Bering Straits on the parallel of 65 degrees 30 minutes north latitude, at its intersection by the meridian which passes midway between the island of Krusenstern or Ignalook and the island of Ratmanov or Nocnarlorook, and proceeds due north, without limitation, into the same frozen ocean. The same western limit, beginning at the same initial point, proceeds thence in a course nearly sonthwest throngh Bering Straits and Bering Sea so as to pass midway between the island of Attoo and the Copprer Island of the Kormandorski couplet or group in the North Pacific Ocean to the meridian of 193 degrees west longitude, so as to include the whole of the Aleutian Islands east of that meridian.

See treaty of cession by Russia to the United States, March 30, 1S67, for complete description of boundary.

In other words, the eastern limit of the territory cerled to the United States is the boundary between the British and Iiussian possessions, and the western limit a line rumning in a southwesterly direction from the frozen ocean throngh Bering Straits and Bering Sea to the Yorth Pacific Ocean, thus diriding Bering Sea into two distinct and separate parts.

The northern boundary is the frozen ocean, and the southeru the southern coast of the Alentian chain of islands. 
These are "the limits of Alaska Territory," as laid down in the treaty, our title deed; the boundary of the territury referred to in the act apfropriating the purchase-money, and repeated in section 1956 , Revised Statutes, which prohibits the killing of fur seals "within the limits of Alaska Territory."

It seems clear to the committee that the act prohibiting the killing of fur seals "within the limits of Alaska Territory" was intended to apply to all the acquired territory, land and water, embraced within "the limits" specified in the treaty of cession, just as the laws relating to customs, commerce, and navigation, aud to trade and commerce wit. the Indian tribes were, by the acts just referred to, extended over "all the main-land, islands, and waters of the territory ceded to the United States" by the Emperor of Russia.

The Territory of Alaska consists of land and water. Exclusive of its lakes, rivers, harbors, and inlets, there is a large area of marine territory which lies outside of the 3 -mile limit from the shore, but is within the boundary lines of the territory transferred by Russia to the United States.

The rivers, lakes, harbors, and inlets, as well as the 3-mile belt of water contiguous to the shore, are part of the territory of the United States, and come under the operation of their laws without being specially named; and if the statutes extending the laws of the Uniter States over Alaska had omitted the word "waters," and had used the words "main-laud and islands of the territory ceded," instead of the phrase " main-land, islands, and waters" of the territory ceded, there is no question but that the lakes, rivers, harbors, inlets, and the 3.mile belt would have been included as part of the territory of the United States.

While it is true that an act of Congress relating to Alaska or any other Territory applies to its entire area, yet, in this case, out of abmulant caution, and in order that there might be no room for doubt or question, the law-makers used the words "all the main-land, islauds, and waters," haring direct reference to the large area of marine territory on the west, which Mr. Sumner, speaking for the treaty, told the Senate was "our part of Bering Sea."

National territory consists of water as well as laud. (Halleck's International Law, section.13.)

The object of the act of July 1, 1S70, was (as expressed in the title) "to prevent the extermination of fur-bearing" animals in Alaska," and the title would be a misnomer if its operation were restricted to the main-land, islands, and the 3-mile belt of water.

When this act was passed it was known to Congress that the Pribylov group of islands were the ouly seal islands in Alaska, and that there were not only no other seal rookeries in Alaska, but that there was no other place in the Territory, on the main-land, or on any other island where fur seals haul up or are ever to be found, except in the waters of Bering Sea; therefore the only places where they could be killed in Alaska were on the seal islands and in the waters of Bering Sea, and the prohibition necessarily applies to those two localities; for it would be idle to prohibit seal-killing in localities where these animals are never to be found. By the same act the Secretary of the Treasury was directed to lease the privilege of taking fur seals for their skins on said islands at a fixed tax and rental for a period of twenty years, thereby removing the prohibition as to one of the localities frequented by these animals, viz, the islauds of St. Paul and St. George, and leaving the 
prohibition to apply exclusively to the waters of Bering Sea, the only other place where fur seals are to be found in Alaska.

\section{SEVENTH.-THE OPERATION OF THESE STATUTES.}

Congress having made provision for the protection of seal life in Alaska, and appropriated money to equip the vessels of the revenue marine for that service, the Secretary of the 'Treasury dispatched reveune-cutters to Alaska, with iustructions to seize all vessels found engaged in killing fur seals in Alaskan waters.

Pursuant to these instructions, a number of British and American vessels were seized, their cargoes of contraband seal skins confiscated, and the vessels condemned by decree of the United States District conrt.

As early as 1881, it having been reported to the Treasury Department that unauthorized persons were killing seals in Alaskan waters, the Secretary caused a notice to be published in the newspapers printed at all the Pacifie ports in this country stating that the law prohibiting seal killing in Alaskan waters would be enforced against all comers, aud the penalties inflicted. Since then this notice has been published every year up to and including the present year 1888.

In 1881, one D. A. D'Ancona, of San Francisco, addressed a letter to the Secretary of the Treasury, making inquiry as to the extent of jurisdiction claimed by the United States over Bering Sea. In repiy the Secretary informed him under date of March 12, 1S81, as follows:

The law prohibits the killing of any fur-bearing animals, exeept as otherwise therein provided, within the limits of Alaska Territory or the waters thereof, and also prohibits the killing of any fur seals on the islands of St. Paul and St. George, or in the waters adjacent thereto, except during certain months.

You inquire in regard to the interpretation of the terms "waters thereof" and "waters adjacent thereto" as used in the law, and how fur the jurisdiction of the Uuited States is to be understood as extending.

Presuming your inquiry to relate nore especially to the waters of western Alaska, you are informed that the treaty with Russia of March 30,1867 , by which the Territory of Alaska was ceded to the United States, defines the boundary of the territury so ceded. This treaty is found on pages 671 to 673 of the volume of treaties of the Revised Statutes. It will be seen, therefore, that the limit of the cession exterds from a line starting from the Aretic Ocean and running through Bering's Strait to the north of St. Lawrence Islands.

The line runs thence in a sontluwesterly direction, so as to pass midway between the island of Atton and Copper Island of the Korminamilurski conplet or gromp in the North Pacific Ocean, to merldian of $193^{\circ}$ west lengitnde. All the waters within that boundary to the western end of the Aleutian Archipelago and chain of islauds are considered as comprised within the waters of Alaska Territory.

All the penalties prescribed by law against the kiling of fur-bearing animals would therefore attach against any violation of law within the lwuits Wefore deseribed. Very respectfully,

\section{H. F. FRENCH, Actïng Secretary.}

This decision was repeated by the Department April 4, 1881, and on the 16th of March, 1886, the late distinguished Secretary of the Treas. urs, Hon. Daniel Manning, sent the following letter to the collector of customs at San Francisco:

Treasury Departarent, Mfarch 16, 1886.

SIR: I transmit herewith for your information a copy of a letter allilressed $b 5$ tho Department on March 12, 1s81, to D. A. D'Ancona, conceruing the juristiction of the United States in the waters of the Tarritory of Alaska and the prevention of the killing of fur seals and other fur-bearing anminls within such areas, as prescrilsed by chapter 3 , title :23, of the Rovised Statutes. The attention of your predecessor in 
office was called to this sulject on April 4, 1S21. This communication is adressed to you, inasmuch as it is mulerstood that cortain parbies at your port contemplate the fitting out of experlitions to kill fur seals in theso waters. You are requested to grive due publicity to such luster's in order that such parties may be informel of the construction placed by this Department upon the provision of law ruferred to.

Respectully, yours,

D. MANNIXg, Secretary.

\section{Collector of Customs, \\ San Francisco.}

It having been claimed by the Canadian anthorities, in their brief reluting to the seizure of Cantalian vessels in Bering Sea by our pre. nue-cutters, that ex-Secretary Boutwell had decided that the United States had no jurisdiction over Bering Sua outside of the three-nile limit, the attention of Mr. Bontwell was called to the matter by Mon. IV. W. Eaton, late chairman of the Foreigu Affairs Committee, United States Senate, to which Mr. Boutwell malde the following relly:

Wasmington, January 18, 1888.

SIR: Since the receipt of your letter of the 16 th instant I have examim witl care the letter addressed to me, as secretary of the Treasury, by T. G. Phelps, esp., then collector of customs at tbe port of Sian Francisco, daterl Mareh 25, 157:, and also my oftimal reply thereto, dated April 19, 15\%:, in relation to tho purpose of certain yarticy to eftrture fur seal on their annual migration to the islands of St. Paul aud St. Creorue throngh the Ouimak Pass and throngh the neighboring approaches to the islamis. Upon the examination of the correspondence my recollection is in a degree refirshed and my knowledge of the cireumstinces revived.

'The fonrth sentence of Mr. Phelps's letter appears to proceed upon the iclea that it was the purpose of the bunters, as their purpose was then muderstood by him, to take the seals upon the Prcific Ocean side of the Aleutian range of islands and near the passes mentioned and through which the animals were clestined to move, and such was the view taken by we and on which my reply was based.

Nor cau I now see that there is ground for any other reasonalile construction of the correspondence.

Mr. Phelps apnears to have apprehended a diversion of stals from the Onimak Pass and the narrow straits near that pass, and his sugerestion of a remedr was lmitul to the same field. Therefore, neither upon my recollection of facts as thit $y$ were un. derstond hy me in $187 \%$, nor upon the present readiug of the correspondence, do I admit the claim of Great, Britain that my letter is an arlmission of any right ariverse to the claims of the United States in the waters known as Bering Sea. My letter had reference solely to the waters of the Pacific Ocean south of the Aletitian Islauls. Very respect,fully,

Hon. W. W. EATON, Washingtun, D. C.

On the 12th day of October, 1870, Secretary Boutwell wroto to the collector of eustoms at San Franciseo as follows :

Your eommunication of the 27 th ultimo is receiver, in relation to the illeral killing of the fur seals at places in Alaska other than the islands of St. Paul aud St. Geor re. In reply, I transmit luerewilh a letter abliresserl to the collector at silka, iustrueling

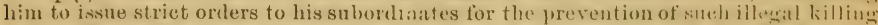
and traftic and for the bringung of the offeuders to punishment; and also for the suizure of all such seal skms illegally taken as aforesaid, and for their tramsmittal in your port for forfeiture. *** (See Wx. Doc. No, 83, first session Forts-fourth Congress.)

In October of last year the question as to the right of the United States to exclusive dominion and juristiction over our part of Bering Sea came before the United States district court in Alaska, in the cases of the United States vs. The British sehooners Dolphin, Anna Beck, Grace, and $A d a$, charged with violating the law prohibiting the killing of fur seals in Alaskan waters.

A stipulation, signed by the Queen's commsel, Mr. N. W. T. Drake, on the part of the British owners, and Mr. A. K. Delaney, upon the part of the United States, was filed, in which it was agreed and conceded that 
the masters of the ressels named were taking fur seals in that portion of Bering Sea which is claimed by the United States under the treaty with Russia of March, 1S67. To the libel of information the Queen's counsel of British Columbia filed a demurer, alleging that the district court of Alaska had no jurisdiction over the subject-matter of the action, for the reason that the schoner was more than 1 marine leaguo from the shore when seized, and that the act of Congress of July 27 , 1863 , is unconstitutioual in that it restricts free navigation of the Bering Sea for sealing purposes.

In overruling the demurrer the court said :

The question of the constitntiouality of the act of Congress of $J_{n} l_{y 2} 27,1868$, scarcus]y deserves notice, since it has been sustained by this court. (See Vuited States rs. Ni-ison, 29 Eerleral Reporter, p. 20:2. See same case aftirmed by the Uniterl States vircuit court for Oregon, Weekly Federal Reporter of April 19, 1. 112. Seo also the Louis: Simpson, 2 Sawyer.)

Here was a eoneession by comsel for British Columbia that the act of Congress extending the laws relating to customs, commerce, and narimation over all the main-land, islauds, and waters of the territory cedrel to the United States by the Emperor of Russia, extended said laws over all that portion of Bering Sea lying east of the sea boundary-line designated in the treaty.

In its decision the district court said (Dawson, Judge):

The conclusion I have reached is that the demurrer must be overruled, and it is so ordered; and that the judgment of forfeiture to the Unitel States be entered inainst each of the vessels separately, together with their tackle, apparel, furniture, and cargoes, saving to the masters and mates their private property, such as nautical instruments and the like, and that a staj of proceediugs for niuety days be grauterl, as per stipulation filed.

No appeal was taken from this decision. Our exclusive jurisdiction over these waters having thus been asserted and exercised by the legislative and executive branches of the Govermment, and their action aflirmed by the United States district comt, is there now any reasou why that jurisdiction should be relinquished?

The reasoning that would justify this Government in reversing its attiturle on this question must be sufticient to convince the common understanding that justice and honesty demand it. The relinquishment of a vested right, repeatedly asserted and exercised by a great power, jealous of its homor aud dignity, coupled with a surrender of national territory, acquired in good faith from a neighboring State, whose honor would be questioned if we admit our title is defective, can only be justified by the adverse claimant assuming the burden of proof and estab. lishing beyoud question his own perfect title, the United States heing in possession and claiming ownership. Until it is demonstrated that liussia, om grantor, had no title to these waters, or that she did not as. sert or exercise dominion over them, our right must be conceded f for it is admitted on all hands that whatever vitle Russia had at the date of the transfer of the territory we acquired and still possess.

The sixth article of the treaty of cession provides that--

The cession herehy mate cmovess all the rights, franchises, and privileges now belonging to Russia in tho salil territory or dominion, and appurtenances thereto.

For the period of on: humber and fort years, dating from their diseovery, these Alaskan waters were under the exclusive juristiction of Russia, and her dominion over the reserved half of Bering Sea is still asserted and extreised; and the same is atckowledged by the United States and other nations. 
Treasury Department Circular No. 13, of January, 1882, contained the published notice of the Russiau cousul at Yokahoma, warning foreign vessels as follows :

Notice.-At the request of the local authorities of Bering and other islands, the undersigued hereby uotifies that the Russiau Imperial Government publishes for general knowledge the following:

"(1) Without a special permit or license from the governor-general of Eastern Siberia foreign vessels are not allowed to carry on trading, hunting, fishing, etc., on the Russian coast or islands in the Okhotsk and Bering Seas, or on the northeast coast of Asia, or within their sea boundary-line.

"(2) For such permits or licenses foreign vessels should apply to Vladivostock, exclusively.

"(3) In the port of Petropaulovsk, thongh being the only port of entry in Kamcbatka, such permits or licenses shall not be issued.

"(4) No jermits of licenses whatever shall be issued for hunting, fishing, or trading at or on the Commodore or Robben Islands.

"(5) Foreign vessels found trading, fishing, hunting, ete., in Russian waters without a license or permit from the governor-general, and also those possessing a license of permit who may infringe the existing by-laws on hunting, shall be confiscated, both vessels and cargoes, for the benefit of the Govermment. This enactment shall be onforced henceforth, commencing with A. D. 1832 .

"(6) The enforcement of the above will be intrusted to Russian men-of-war, and also Russian merchant vessels, which, for that purpose, will earry military detachments and be provided with proper iustructions.

-

"Yоконама, November 15, 1881."

"A. Pelikan, "H. I. R. M. Consul.

This warning was published fifteen years after the transfer of the eastern half of Bering Sea to the United States aud gives notice to all concerned that Russia will enforce her jurisdiction over the westers half within her "sea boundary-line."

\section{RUSSIA'S TITLE TO BERING SEA.}

The sea of Kamchatka, as it was formerly callerl, was discovered by Vitus Bering, a Russian subject, in 1725. From the late of discovery until the purchase of Alaslia, its waters were surrounded by Russian territory, except the narrow straits leading to the Frozen Ocean and the southwestern outlet to the North Pacific. Within a few years from its discovery tradiug companies were formed and trading stations established on its coasts and islands by Siberian merchants and traders, and on the northwest coast of the North Pacific. The glowing accounts of the rich products of the new possessious stimulated Russian enterprise ; companies were formed, ships were built, and factories established at different points on the coasts and islands.

In 1745 the Alentian Islands were discovered, and in 1768 the whole archipelago aud the peniusula of Alaska were explored by an expedition ordered by the Empress Catharine. The coast of British Columbia was discovered by Vancouver in 1790, and in the same year Gray entered the Columbia River, so that the title of Russia is the earliest on the northwestern coast. Subsequently there were four other Russian expeditions: The first, under Commoilore Billings, in 1785; the second, under Krusenstern, of the Russian nav5, in 1503; the third, under Lientenant Kotzebue, in 1515; and the fourth, under Admiral Luitke, in 1826.

As early as 1764 the Russian Goverument granted to certain morchants the exclusive right to trade upon the Alentian Islands, reserving to itself a tithe of the profits; and in 1783 a trading company, which was originally formed at Okhotsk, established its headquarters at Kadiak 
with branches at Algonak and Unalaska Island, and on Kenayan and T'shugatshain Bays. Numerous other companies were subsequently formed, but in 1797 the different interests were consolidated and a new company formed, with headquarters at Irkutsk, which made application to the Czar for au imperial charter. The imperial commission, to whom the application was referred, said :

Having received information from all sides of disorders, ontrages, and oppressions of the natives caused in the colonies by parties of Russian hunters, as well as of groundless claims advanced by foreign navigators to lands discovered by Russians, it had some reason to hope that placing the business of that distant region in the hauds of one strong company would serve, on the one hand, to perpetuate Russian supremacy there, and on the other would prevent many disorders and preserve the fur trate, the principal wealth of the country, affording protection to the natives against violence and abuse, and tending toward general improvement of their condition." (Bancroft's Hist. Alaska, p. 378.)

In accordance with this recommendation an imperial ukase was issued December 27, 1799, as follows:

By the grace of a merciful God, we, Paul the First, Emperor and Autocrat of all the Russias, ete. To the Russian American Company under our highest protection:

The benefits and advantages resulting to our Empire from the hunting and trading carried on by our loyal subjects in the northeastern seas and along the coasts of America have attracted our royal attention and consideration; therefore, having taken under our immediate protection a company organized for the above-named purpose of carrying on hunting and trading, we allow it to assume the appellation of "Russian American Company," under our highest protection; and for the purpose of airling the company in its enterprise we allow the commanders of our land and sea forces to employ said forces in the company's aid if occasion requires it, while for further relief ant assistance of said company, and having examiued their rules and regulations, we hereby declare it to be our highest imperial will to grant to this company for a period of twenty years the following rights and privileges:

(1) liy the right of discovery in past times, by Russian navigators, of the northeastern (western) part of America, beginning from the fifty-fifth degree of north latitude and of the chain of islands extending from Kamtchatka to the north to America, and southward to Japan, and by right of possession of the same by Russia, we most gracionsly permit the company to have the use of all hunting grounds and establishments now existing on the northeastern (western) coast of America, from the abuve-mentioned fifty-fifth degree to Bering Strait, and on the same also on the Aleutian, Kurile, and other islands situated on the Northeasten Ocean.

(2) To make new discoreries not only north of the fifty-fifth degree of north latitude, but further to the south, and to occupy the new lands discovered, as Russian possessions, according to prescribed rules, if they have not been previously occupied by any other nation, or been dependent on another nation.

(3) To use and protit by everything which has been or shall bo discovered in those localities, on the surface and in the bosom of the earth, without any competition by others.

(4) We most gracionsly permit this company to establish settlements in future times, wherever they are wanted, according to their best knowledge and belief, and fortify them to insure the safety of the inhabitants, and to send ships to those shores with goods and hunters, without any obstacles on the part of the Government.

(5) To extend their navigation to all adjoining nations and hold business intercourse with all surrounding powers upon obtaining their free consent for the purpose, and unler our highest protection, to enable them to prosecute their euterprises with greater force aud advantage.

(6) To employ for navigation, hunting, and all other business, free and unsuspected people, having no illegal views or intentions. In consideration of the distance of the loealities where they will be sent, the provincial authorities will grant to all persons sent out as settlers, hunters, and iu other eapacities, passports for seven years. Serfs and house servants will only be employed by the company with the consent of their landholders, and Government taxes will be paid for all serfs thus employed.

(7) Though it is forbidden by our highest order to cut Government timber anywhere without the permission of the College of Admiralty, this company is hereby permitted, on account of the distance of the aluiralty from Okhotsk, when it needs timber for repairs, and occasionally for the construction of now ships, to use freely such timber as is required. 
The remaining paragraphs are not pertinent to the subject we are cousidering. We quote only the last one :

In conclusion of this our most gracions order for the benefit of the Russian-American Company (under highest protection), we enjoin all our military and civil authorities in the above-meutioned localities, not only not to provent theu from enjoying to the fullest extent the privileges frianted by us, but in case of need to protect them with all their power from loss or injury, and to render them, upon application of the company's anthorities, all necessary aid, assistance, and protection.

To give effect to this, on most gracious order, we subseribe it with our own hand, and give order's to coutirm it wilh our imperial seal. Given at st. Petersburg, in the year after the birth of Christ, 1799 , the 27 th day of December, in the fourth year of our reign.

\section{PaUl.}

This assertion of dominion was not disputed or questioned by any of the lowers; the right of the autocrat of Russia to eontrol and dispose of these possessions was conceded, tacitly at least, by all the nations. His title rested upou (1) discovery; (2) first occupation ; (3) peaceful and undisputed possession for more than half a century. By virtue of this imperial decree, the Innssian-American Company, as early as 1799, without protest or objection from any quarter, were invested with ab. solute control of all the territory embraced in its charter, from Bering Straits to the 55th parallel on the American coast, and as far south as Japian on the continent of Asia, subject only to the ultimate sovereignty of the Czar.

'Twenty-two years later, upon the complaint of the company that foreigu traders were interfering with the rights conferred by its charter, the Emperor Alexander issued the celebrated ordinance extending bis dominion to the 51st parallel on the North American coast, and prohibitmg foreign vessels to approach within 100 miles of the shore. We quote the first three sections:

Whereas it appears from reports submitted to us that the commerce of our subjects on the Alentian Islands, and along that part of the coast of northwestern America belonging to the Russian dominjon, is exposed to injury and varions molestations, owing to the existeuce of secret, illucit trade; and whereas it appears that the principal cause of such molestations is to be found in the want of regnlations establishing the limits of navigation along these shores, and preseribing the order of procednre in maritime matters along said shores, as in general on the eastern coast of Siberia and the Kurile Islants, wo have resolved to regulate these matters by a special ordiuance herewith appended.

Transuitting said ordinance to the administrative senate, we order that it be pub. lished for general information, and the proper steps be talsen to cary it into execu. tion.

"Ordinance-concerning the restriction of navigation aud regulativg the coastiun traflic aloug the coasts of eastern Siberia, northivestern America, the Alentian and Kurile Islands, ete.

"SECrION 1. The transaction of commerce, and the pursuit of whaling and fishing, or any other industry on the islands, in the harbors and inlets, and, in general, all along the northwestern coast of America from Bering Strait to the fitty-first parallel of northern latitude, and likewise on the Aleutian Islanls and along the eastern coast of Siberia, and on the Kurile Islauds; that is, from Bering Strait to the sonthern promostory of the islaud of Urup, viz, as far south as latitude 45 degrees 50 minutes north, are exclusively reserved to subjects of the Rnssian Empire.

"Sic. 2. Accortingly, no foreign vessel shall he allowed either to put to shore at any of the coasts and islands under Russian dominion as specified in the preceding section, or even to approach the same to within a distanco of less than 100 Italian miles. Any vessel coutruvening this provision shall be subject to contiscation with her whole cargo.

"Skc. 3. Exempt from this prohihition aro: Vessels cast away in a storm, or com. pelled to put to shore on account of complete want of foud provisions, provided they are unable to lami anywhere else except at a coast belonging to Russia. In such calses the vessels are reynireal to furnish proof of the real existence of causes necessitating the uxemption. Ships sent out by frieully powers for merely scientific purp'sis: itre also exempted from tho precediug requlation (section 2 ). Such shipa mnat,

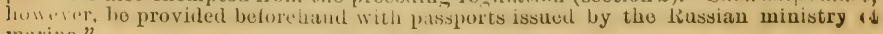
marine." 
With reference to those portions of this ordinance which extended liussian dominion four degrees farther sonth, and prohibited toreign vessels from approaching to within a distance of less than 100 miles from the shore, the Gorernments of Great Britain and the United States entered protests.

Mr. Adams, then Secretary of State, conceded the boundary named in the charter of the Russian-American Company, viz: The fifty-fifth parallel on the coast of the North Pacific Ocean, but resisted what he designates as "a new pretension," the claim of Russia to the coast between latitude 51 and 55. He also repelled the exchsion of American ships from the coast of the North Pacitic Ucean, stating that "with the Russian settlements at Kodiak, or at New Areh Augel (Sitka), they, the United States, may fairly claim the advantage of a free trade, having so long enjoyed it unmolested, aud becanse it has been and would continue to be as adrantageous at least to those settlements as to them."

The committee cite these extracts to show that the contention had reference to a section of the coast of the North Pacific Ocean and entirely remote from Bering Sea.

In reply to the suggestions of Mr. Politica that "the extent of sea, of which these possessions form the limits, comprehends all the conditions which are ordinarily attached to shut seas (mers fermes)," Mr. Adams replied, "It may suffice to say that the distance from shore to shore on this sea, in latitude $51^{\circ}$ north, is not less than $90^{\circ}$ of longitude, or 4,000 miles ;" having direct reference to the Pacific Oceau.

The committee have carefully examined the protests and the correspondence in reference to the matters in controversy, as well as the treaties of 1824 and 1825 , which settled thom, and find that they all had reference to that section of the coast and waters of the North Pacific Ucean between the 51st parallel of north latitude and Mt. St. Elias, and east of the 141st meridian.

In all the correspondence, projects, and treaties there is no allusion to Bering Sea or to auy region of country within 1,000 miles of its easteru border; so that the dominion asserted and exercised by Russia over that sea from its discovery in 1725 to its partition by the treaty of cession in 1867 had never been denied or questioned. (See treaty between Russia aud the United States, A pril 5-17, 1824, and the treaty between Russia aud Great Britain, February 28, 1825, published with evidence.)

\section{EIGHTH.-THE VALUE OF THE MIRINE TERRITORY ACQUIRED BY} THE TREATY OF OESSION.

By referring to the debate on the purchase of Alaska, and the con. temporaneous discussion of the subject by the periodicals and newspapers of this country, it will be noticed that the acquisition of the products of Bering Sea, its fur-bearing animals and fisheries, were regarded as an important if not the chief consideration for the purchase.

Mr. Sumner, speaking for the treaty, said in the Senate, after enumerating the land furs of Alaska:

The seal, amphibions, polygamous, and iutelligent as the beaver, has always supplied the largest inultitude of furs to the Russian Company.

Speaking of the walrus he says these animals are found in these waters in great multitudes, and are of great value for their ivory. He then adds :

I meution the sea-otter last; but in beanty and value it is the first. In these respects it fir surpasses the river and land ottor, etc, * * * I come now to the fish-

H. Rep. $3883-$ - 
eries, the last head of this inquiry and not inferior to any other in importance; perhaps the most importaut of all. What even are sea-otter skins by the side of that product of the sea, incalculable in amount, which coutributes to the sustenance of the human family? * * * Salmon exist in unequaled numbers, so that this fish, so aristoeratic elsewhere, becomes common enough. * * * Herring seem to be not less multitudinous than thosalmon. Their name, derived from the German heer, signifying an aruy, is amply veritied. The cod is perhaps the most generally diffused and abundant of all, for it swims in all the waters of this coast from the frozen ocean to the southern limit, and in some places it is in immense numbers. Behind all these is the whale, whose corporal dimensious strictly represents the space which he occupies in the fisheries of the world, hardly diminished by petroleum or gas.

\section{Speaking of fishing banks or soundings, he adds :}

The sea and straits of Bering as far as the frozen ocean have been surveyed by a naval expedition of the United States under Commander John Rogers.

From one of his charts now before me, it appears that, beginning at the frozen ocean and descending through Bering Straits and Bering Sea, embracing Kotzebue Sound, Norton Bay, and Bristol Bay to the peniusula of Aliaska, a distance of more than 12 degrecs, there are constant uniuterrupted soundings from 20 to 50 fathoms, thus presenting an immense extent proper to this respect for fishery.

Our own fisheries, now so considerable, were small in the beginuing; they were small even when they inspired the eloquence of Burke in that most splendid page never equaled even by himself. But the Contiuental Congress, in its original instructions to its commissiouers for the negotiation of peace with Great Britain, required as a fundamental condition, next to independence, that these fisheries should be preserved unimpaired. While this proposition was under discussion Elbridge Gerry, who had grown up among the fishermen of Massachusetts, repelled the attacks upon their pursuit in words which are not out of place here. "It is not so much fishing," he said, " as enterprise, industry, employment. It is not so much fish, it is gold, the produce of that voeation. It is the employment of those who would otherwise be idle, the food of those who would otherwise be hungry, the wealth of those who would otherwise be poor." After debate it was resolved by Congress that "the commou right of taking fish should in no case be given up."

For this principle the eldest Adams contended with ability and constancy until it was fired in the treaty where it stands side by side with the acknowledgment of independence.

The acquisition of this wealth of marine products was presented to the Senate by the chairman of the Committee on Foreign Affairs as the most important achievement of the treaty; and no ome questioned the right of Russia to sell and transfer it to this country, and no suggestion was made in the Senate or elsewhere that this valuable marine territory was not included in the proposed purchase.

On the 17th of February, 1568, the President transmitted to the House of Representatives a message in relation to Russian America, accompanied by documents from the Department of State and the Secretary of the Treasury, all of which are printed in Executive Document No. 177, Fortieth Congress, sccond session. From these documents we make the following extracts. Under date of May 10, 1867, the American minister, Mr. Clay, writes from St. Petersburg to Secretary Seward as follows :

Sur : Your dispateh No. 241, April 1, 186i, i.,closing the treaty between Russia and America, ceding us all Russian America, was dnly received. I awaited the expression of European aul Russian sentimests 11 reference thereto before answering you.

I congratulate you upon this brilliant achievement, which adds so vast a territory to our Uniou; whose ports, whose mines, whirse waters, whose furs, whose fisberies are of untold value, and whose fiedds will prodnce many grains (even wheat), and become thereafter, in time, the seat of a hearty white population.

On the 4th of April, 1S67, Quartermaster-General Meigs wrote to Mr. Seward as follows:

My Dear Sir: I am surprised to find it stated that objections are made to the acquisition of Russian America. I eau conceive of no greater boon to the Pacific States, and I can not suppose that Atlantic Senators will deny to the people of those States the fisheries depending upon Russian America now within their grasp. We neert such a nursery of seamen, such a commerce, as the fishcries will produce. They will 
feed the coasts and islands of the Pacific, and the vigorous climate will breed a race of harly alventurers to repeat on the Pacific, softened by Christian civilization, the deeds of the Norse Sea-Kings on the Atlantic.

As a lover of my country, anxious for the growth and prosperity and strength and virtue of the untion, I should value Russian America, its fisheries and mines, beyond the hot plains of Mexico or the fertile plantations of Cuba.

I trust that no effort neerled to secure this great acquisition will bo omitted. Tho execution of the treaty will erown our generation with the praises and thanks of future ages.

In "A memorandum description of the Russian Imperial system of Russian America," transmitted to Secretary Seward by the American minister at St. Petersburgh, November 21, 1867, it is stated as follows :

The Aleutian Islands may attract transient traders, but no permanent settlers. To inhabit them one uust be an Alent, and if it were not for the sea surrounding the islands, this country, owing to its unfavorable climatic conditions and the sterility of its ground, would have never been inhabited at all.

In the summary of the products of Alaska furnished the State Department by Professor Baird, of the Smithsonian Institution, he says:

Animals.-Furred animals, such as sea-otter, river otter, sable furred seal, mink, foxes, black, silver, red, etc., abound in great numbers. Red deer are on the south and reindeer on the north side.

Fish.-Herring, salmon, halibut, and colfish abound in exhaustless numbers. In Bering Sea great whales are very numerous.

On the '2d day of September, 1867, Mr. W. W. Miller wrote as follows:

I have watched anxiously for the proceedings of the House to appropriate the purchase money to carry into execution that treaty. The sum our Government is to pay is a mere pittance for that vast region and its many substantial benefits which must acrue from its acquisition.

The privilege of fishing on those banks, with Sitka as a free port in perpetuity, is, of itself, worth the price we are paying for the whole territory with all its incidents.

Mr. Charles Brewer, who was, during the years 1826, 1827, 1828, first officer of the American brig Chinchella, trading between the Sandwich Islands, Sitkil, and China, writes under date of December 16, 1S67, as follows:

The coast of Alaska abounds with fish of various kinds, such as salmon, halibut, and codfish, and I think the fisheries of that territory are of more value to our possessions of California and Oregon than those of Newfoundland to New England.

In the years 1826 to 1828 we sold our cargoes direct to the Russian Gorernment, and received our pay entirely in fur-seal skins, which skins were all taken upon the northern part of that coast and the adjacent islands, as also lurge quavtities of ivory (walrus teeth) and walrus skins, and brought into the port of Sitka in the vessels of the Russian-American Company.

The committee cite these documents because they were transmitted to the House of Representatives, with many others of a like character, by the President under a resolution of the House, December 19, 1S67, "calling for correspondence and information in relation to Russian America," to enable the House to take proper action on the pendiug bill appropriating the purchase-money; but chiefly because it seems to the committee to have been taken for granted that by the purchase of Alaska the United States would acquire exclusive ownership of and jurisdiction over Bering Sea, inclnding its products-the fur seal, seaotter, walrus, whale, colfish, salmon, and other fisheries; for it is on account of these valuable products that the appropriation of the purchase-money was urged.

The extracts above quoted in reference to these products are empliasized by the fact that the fur-seal fisheries alone have-already yielded 
to the Govermment a revenue greater than the entire cost of the Territory.

It seems clear to the committee that, if the waters of Bering Sea were the "high seas," these products were as free to our fishermen and seal. hunters as the Russians, aud there was, therefore, no reason on that account for the purchase. But it was well understood that Russia controlled those waters; that her ships of war patrolled them, and seized and confiscated foreigu vessels which had violated the regulations she had prescribed conceruing them ; and the argument in favor of the purchase was, that by the transfer of the main-lancl, islauds, and waters of Alaska we would acquire these valuable products and the right to protect them. This protection can only be effective by the employment of means similar to that adopted by Russia. Armed vessels shonld patrol Alaskan waters and enforce the laws of the United States.

It must be remembered that only a small number, comparatively speaking, of the fur seals remain on the islands the entire season, and that millions of them traverse Bering sea for miles in quest of food, and cover large areas of water. Now, if the protection only embraced the islands and the 3-mile belt of water surrounding them, a vast number of seals would be left to the mercy of the seal-hunters, and the destruction of the rookeries would be swift and certain.

In settling the policy of the Goverument in connection with the future disposition of the Pribylor Islands the present and prospective condition of the inhabitants of the Aleutian chain of islands from Oonalaska to Attou, inclusive, should not be neglected. There are to day about 1,000 persons inhabiting these islands who mainly derive their means of subsistence from the sale of sea-otter skins taken by them. They also take some fish about the shores, possibly in quantities sufficient 10 sustain life, but this catch is not available for sale or barter, so as to in any way increase their income or enable them through it to better their material condition. The pursuit of the seaotter is now so eager and persistent that the animal can not hold its orrn against the hunters, and in a few jears, donbtless, will be exterminated from its haunts in the localities above referred to.

Had the Government in the past prohibited the huntiug of the sea otter by auy but Aleuts aud not permitted white men married to Alentian women to rank as native hunters, and also confined the Aleut in his hunting to the use of spear and arrow (not allowing fire-arms), it is possible that the animals might have been maintained in perpetuity, but not only were such restrictions placed, but even the rules made have been disregarded, and the extinetion of the sea otter is not far distant. When that time arrives the inhabitants of the Aleutian chain will be left in a deplorable situation unless timely consideration is giren to their ease. As it is to-day the people of Attoo, the westernmost island, would hardly have been able to maintain existence for the past three yearrs had not the present lessees of the seal islands anuually sent a vessel with supplies and necessaries from Oonalaska to their island, a distance of about 700 miles, to aid this impoverished community, getting a return in skins (the only trade of the people), insufficient at their retail value to compensate for the coal consumed in making the trip.

Before suggesting methods of relief for the Alentians let us look for a moment at the past and present condition of the Pribylor Islands, their people, and their seal product. Before the cession of Alaska the Russians under their rule employed upwards of 200 Aleuts as laborer's on the islands of St. Paul and St. George. After the cession, under the operation of the treaty, a large number of these people elected to 
leave the seal islands and return to their former homes (possibly fearing the same hardships under American rule that they had experienced under Russian, viz, enforced labor, with a compensation of only $\$ 10$ per annum, coarse and poor food, and wretehed shelter), so that only about 150 laborers remained to do the work of taking seal skins under the lease made by the Government. This number in eighteen years has diminished to a present number of less than 80 laborers.

The ratio of births on the island does not keep pace with the proportion of deaths, mainly because the laws of consanguinity in the Greek Church, of which these people are devout adherents, only permit marriage between people so remote in kin that it is impossible in a limited population for the people to marry. Young men may find wires in Uonalaskin and elsewhere and bring them to St. Patul and St. George, but the women of these islands, if they marry abroad, must follow the settlemeut of the husband, as he can not come to the seal islauds aud he emrolled as a sharer in the seal fund, so called. It may be proper here to state from what source this fund is derived and to whose use it is limited. When the United States Government leased the privilege of taking 100,000 seal skins ammually on these islands it stipulated that all work connected with the killing and skinning should be done by the natives of St. Paul and St. George Islands. The lessees fixed the com. pensation for this work at 40 cents per skin, say $\$ 40,000$ per annum, to be divided amougst these laborers for less than six weeks' work. Other labor than that abore specified is paid by the lessees at the rate of $\$ 1$ per day.

The native inhabitants of the two islands named, in addition to the above, are by the lessees furnished with comfortable frame houses for each family, sufficient fuel, seal meat, aud salt fish, medicines and medical attendance, schools with competent teachers for eight months of the year, and all entirels without charge and at the expeuse of the lessees, and in addition are enabled to purchase on the islands such articles as they may desire, at a cost not exceeding the price of the same goods in San Franciseo. From this statement it will appear that the inhabitant of St. Panl and St. George enjoys privileges and benefits that make his lot very desirable in the eyes of his fellow men of the Alentian chain.

The "inhabitant" is equally sensible of his advautages and is naturally unwilling to have the population of his islands increased and his undivided share thus diminished. So long as there were laborers sufficient to do the sealing and so long as the Aleuts of the chain had the sea otter to look to as source of support, the state of affairs was well enough; but now that the time has come when the population of the seal islands is insufficient to properly do the work of killing, skinning, and salting, and the assured speedy extinction of the sea otter will leave the Alents from Oonalaska to Attoo in a state of destitution, the question of what to do in the premises becomes urgent and demands attention.

The Pribylov Islands, when diseovered by the Russians in $\mathbf{1 7 9 0 ,}$ were uninhabited and people from the Alentian Islands were transferred to them to earry on the required work. Under Russian rule life there was deemed a hardship, from which the people desired escape. Under American rule the conditions are all changed and the desire of the Aleuts now is to have a settlement on these islands. The people being all of one race or tribe, and their distribution being an enforced one originally, it is but just that the resources of the islands occupied should contribute toward the support of all the penple. 'The people are docile 
and childlike, devout in their religious services, and with kind and judicious treatment can be guided, preserved, and elevated, provided a comfortable material condition can be assured for them. To accomplish this the action of the Government and that of the lessees must be in unison and the requirements of the situation be freely comprehender.

As now represented there seem to be indications that more laborers are imperatively needed on the seal islands, and that to meet this demand the lessees should be permitted, under regulations, to trausfer a part or all of the destitute population of Attoo (the westemmost island) to the seal islands and establish them there under the conditions that low govern the natives resident on those islands; that, as sources of support now arailable to the inhabitants of Oonalaska and the other islauds to the westward diminish, means should be taken to insure a proper supply of food and shelter to the people and sufficient occupation to preserve and develop a sense of self-respect and prevent a feeling that they were to be sustained without efforts on their own part.

These ends can, it is believed, be accomplished by utilizing the seal meat now necessarily wasted on the Pribylor Islands, either by the process of canuing or by means of cold storage, and from this supply furnishing the chief food of the natires. In this labor of prepariug and dis. tributing the services of a considerable number of natires could be made available. The details of such plan would need much consideration, but could without difficulty be worked ont. The main objection of the canuing process would be that which manifested itself when the effort was made to derive income from the oil obtainable from the seal blubber, viz, the smoke and smell proved offensive and disturbing to the breeding seils on the rookeries and the Government decided that it was unwise to further pursue the effort. But possibly improver methods could now be applied or the meat preserved in some other manner. The women could be instructed and encouraged to further develop the little industries they now practice, such as weaving grass basliets, making nets, etc., and thus contribute in a minor way to the general well-being.

It is possible also that about Atka a fishery could be established for taking and salting some of the fish products about that islaud. It is not supposed that these endeavors would be pursued with the expectation of realizing a pecuniary protit from them, but in the hope of sustaining and improving the natives, and it is believed that if the Government, the lessees, and the people work in accord, the desired end could be attained. In this matter all interests are identical. Tho Gorernment has its obligatious to the people and desires also to continue its present revenue from the seal islands. The lessees need the help of the natives to properly prosecute their work according to their contract.

- The people need watchful care and guidance to strengthen them to resist the temptations that assail a people just emerging from an inferior state. Their only grievance now put forth is that the Government and the lessees prevent them from enjoying the pleasures of the liquor which ruins them, be it American whisky or native brewed quass. But all these possibilities depend upon the absolute protection of seal life by the Government. Not only in the seal islands, but also and with more importance in the limits of Bering Sea, south of the seal islands, in the passes between the islands and to the extent of national jurisdiction south of the Aleutian Chain, the statutes now in existence in relation thereto must be executed with a decision and firmmess that al. mits of no misconception, else a most interesting race of people will fade away. A profitable industry, unique in its knd, will be destroyed and 
here will remain to the Government of its valuable purchase only a waste of barren volcanic rocks.

The executive department of the Government has ample power and authority under existing law to make and enforce all necessary regulations to earry into effect the recommendations here made.

\section{CONCLUSION.}

The committee have examined numerous wituesses who are familiar with this industry and the nature and habits of the fur seal, with reference to the best method or system to be adopted by the Goverument to secure the greatest amount of revenue, preserve the seal rookeries, and provide for the welfare of the native inhabitants of the islands. All these witnesses concur in testifying to the wisdom of the existing law on the subject, and favor the retention of the present system. All other existing rookeries are managed substantially in the same way by the different Governments to which they beioug, all following the lead of Russia, who managed aud protected our rookeries by a similar method from their discovery until their transfer to the United States.

It did not require the tes imony of witnesses to sonvince the committee that the Government itself could not successfully manage this business, or that it would be wisdom on its part to repeal the laws which protect seal life in Alaska, and open these waters to all comers and invite the speeds destruction of this valuable industry.

It is conclusively established by the testimony that th is business must be controlled by one direction, by proper and responsible parties as required by the statute, with direct and single responsibility to the Goverument.

Your committee, therefore, recommend that the act entitled "An act to prevent the extermination of fur-bearing animals in Alaska," amended as recommended by the committee, be continued in force, believing that not only the system it adopts, but the method of carrying it into effect, are well adapted for the purpose intended.

In conclusion your committee find the following facts:

First. That if the law protecting seal life is enforced the preservation of the seal rookeries will be assured, the rerenue continued and increased, and the uative inhabitants of the seal islands maintained without cost to the Government.

Second. That the Alaska Commercial Company has fully performed its contract with the Government and has contributed liberally to the support, maintenance, comfort, and eivilization of the inhabitants of not only the seal islands, but also to those of the Aleutian Islands, Kodiak, and the main-land.

Third. That the fur-seal industry will have paid into the Treasury over $\$ 9,000,000$ ciuring the period of the present lease.

Fourth. That the chief object of the purchase of Alaska was the acquisition of the valuabie products of Bering: Sea.

Fifth. That at the date of the cession of Alaska to the United States linssia's title to Bering Sea was perfect and undisputed.

Sixth. That by virtue of the treaty of cession the United States acquired complete title to all that portion of Bering Sea situate within the limits prescribed by the treaty.

The committee herewith report a bill making necessary amendments of the existing law relating to these subjects and recommend its passage. 
Section one of the hill amenils section 1963 of the Revised Statutes in two material respects.

As the statute now reads the Secretary of the Treasury does not think he is anthorized to alrertise for bids aud make another lease of the seal islauds until after the present lease expires. The amendment requires him to do so within one year prior to the expiration of the existing lease, so that there will be no cessation of responsibility. Section 1969 of the Revised Statutes imposes "a rerenue tax or duty of \$2 per skin nuon each fur-seal skin taken and shipped away from the islands of St. Paul and St. George."

The amendment repeals that section, and requires "the sum of not less than $\$ 3.50$ per skin for each fur-seal skin taken and shipped away from these islands," to be paid by the lessee in addition to the $\$ 50,000$ per annum as a consideration for the lease.

The amendment also declares the true meaning and intent of section 1956 of the Revised Statutes which prohibit the killing of fur seals, etc., in the waters of Alaska, and requires the President to issue an annual proclamation aud cause oue or more Government vessels to cruise said waters, in order to prohibit the unlawful lilling of fur seals therein.

The amendment increases the revenues of the Government from this source by at least $\$ 150,000$ per annum.

Sections 4 and 5 provide for the temporars protection and preservation of our valuable salmon fisheries in Alaska and requires the Commissioner"of Fish and Fisheries to diligently prosecute his exploration and investigation of the salmon and other foot fishes of Alaska and report to Congress, in order that such additional legislation may be enacted as may appear necessary to place the salmon fisheries of Alaska under permanent and regular conditions of production and preservation. 


\section{Appendix A.}

Subsequent to the closing of the testimony in this inrestigation the governor of Alaska submitted to Congress a special report in reference to the operatious of the Alaska Coumercial Company under its contract with the United States.

In that report the governor asserts that he visited the Pribylor Islands and personally investigated the operations of the company and the condition of the native inhabitants.

As a result of his observation and examination he is convinced that the company has not only strictly complied with its contract, but has largely contributed to the welfare, comfort, aud education of the islands, in addition to the requirements of the lease; and, while adhering to his former eriticism of the operations of the company in other parts of Alaska, he strongly approves and commends the conduct of the company and its agents in the performance of the stipulations of the lease and the treatment of the natires. He also states that in his intercourso with the native inhabitants he "heard no complaints concerning their treatment either by the agent or any one else connected with the company."

Inasmuch as the law makes it the duty of the goveruor of Alaska "from time to time to inquire into the operations of the Alaska Seal and Fur Company, and annually report to Congress the result of such inquiries and any and all violatious by said company of the agreement existing between the United States and said company," the committee deem it proper to include in its report all that portion of Goreruor Swineford's report which has reference to that subject.

\section{REPORT OF GOVERNOR STINEFORD AS TO TIIE SEAL ISLANDS.}

Section 5 of the act providing a civil government for Alaska provides that the governor" shall, from time to time, inquire into the operations of the Alaska Seal aud Fur Company, and shall aunually report to Congress the result of such inquiries, and any and all violations by said company of the agreement existing between the United States and said eompany." In viow of this provision, I have considered it my duty to inquire into the operations of that company, as was undonbtedly the intention of Congress generally, iusteal of confuing my inquiries merely to the question of whether or not it had violated its agreement with tho Goverument. Tho result of ins inquiries into the operations of the company, aside from its sealing business, together with my views as to how they affeet the best interests of the Territory and the welfare of its people, ${ }^{\circ} \mathrm{I}$ have embodied as plainly and sucenctly as possiblo in the foregoing pages. In doing so I have been governed by no other motive or desire than the good of the Territory, whose iuterests and weifare I have esteemed it a paramount chity to guard and promote to the best of my understanding and limited ability.

So far from having been actuated $\mathrm{bv}$ auy personal feeling, I wish to say that if the system of leasing tho seal islands, withont restriction as to trado in of ber parts of the Territory, is to be continued, very littlo in the way of reform is likely to be accomplished log dispossessing the present lessees in favor of somo other individual or corporation. It is the system, or principle, that most merits condemmation. Any other corporation granted the same exclusive privileges would naturally strive to make the 
most of the opportunities presented, and I can see no prospective good to accrue to the Territory through the dispossession of one monopoly merely to make place for auother and possibly worse one.

So far as its operations on the seal islands are concerned, it affords me pleasure to be able to report an altogether satisfactory condition of affairs; one which is wholly creditable at least to the company. I am perfectly satisfied that the company is, and has been all aloug, faithfully coniplying with all the terms and conditions of its agreement with the Government; in fact, it is doing even more in the matter of providing for the wants and comfort of the natives than its contract requires. I do not believe, as has frequently and persistently been charged, that it has ever taken in any one year more than the number of seals authorized by law, for the simple reason, if there be no other, that it has not been, and is not now, to its interest to do so. That could only be done by and with the connivanee of the Government agents and the customs authorities at San Francisco, and in the absence of any evidence it wonld not be right or proper to question the honesty of those officials.

The provision of the lease restricting the number of seals that may be killed to 100.000 annually is its mosì valuable feature, as a moment's consideration will convince any person who is possessed of the slightest appreciation of the law of supply and demand. IVhile I can not aver a positivo knowledge in tho premises, I neveriheless feel quite safo in asserting that the company has never violated either that or any other express provision of its lease or contract. It is true $\mathbf{I}$ did not have an opportunity of visiting St. George, owing to the then prevailing bad state of the weather, but I spent the best part of two days on St. Paul Island, where the princepal rookeries are loeated, and where seventeen-twentieths of the seals are killed. I was here afforded every facility by the company's general agent for acquiring such iuformatiou as I desired; the books of the company, as well as those of the Treasury agent, beiug open to me, while there was no restriction or espionage whatever to prevent me from obtaining any information the uative people might wish to impart.

I conversed freely with many of the most intelligent Aleuts and creoles, and as all the killing is done by them, for which they receive a compensation of 40 cents per skin, it is fair to assume that they would know of it had there been any violation of contract in regard to the numbers killed; their accounts, lowever, show payment for the legitimate number only, and it is far from reasonable to suppose that the com. pany would bazard the possession of so valuable a frauchise by entering into collusiou not only with the Government agents but with a hundred or more natives for the purpose of defrauding the Government. While I could find no evidence upon which to base even a suspicion of fraud in the number of stins taken, careful observation and inquiry forced upon me the conclusion that the company was not only honest in its dealings with the Government, but, as I have said had done and was doing much more for the comfort and welfare of the natives than its agreement enjoins upon it.

I found the natives all comfortably housed in neat frame houses, built for them by the company, and which they are permitted to occupy for no other consideration than that the premises shall be kept clean. There are about sixty of these natives' houses in the village of St. Paul, all presenting a neat, tidy exterior, and, so far as my observation extended, all well and cleanly kept on the inside. No offal or offensive refuse of any kind is allowed around the houses; the streets are kept clean, and the sanitary regnlations and conditions are better than those usually enforced in eastern villages. The school-honse is large enough to accommodate all the children of sehool age on the island, and will compare most favorably in all respects with similar buildings in the States and Territories. The school was having its annual vacation at the time of my visit, bu I met a number of native children who could speak English, and a fow comparatively young men who conld read and write, and was informed by the teacher and the Government's agents that the school, which is kept open from September to May, was making excellent progress.

A dispensary in charge of a skillful physician is maintained by the company on each of the islands, both medical attendance and medicines being snpplied free of charge. The agreement with the Government requires tho company to furnish the inhabitants of the two islands with 60 cords of fire-wood annually, but for some reason or under some arrangement coal is being furnished them instead of wood, the allowance being 10 pounds a day to each bouse. This would be a little more than a ton and three-quarters for the year to each house, and allowing that only thirty of the houses are occupied, the cost to the company would be more than the ralue of the wood it originally agreed to furnish. This amount of coal is, of course, insufficient, and the people are compelled to buy enough fuel to mako up the deficiency; that the company sells to them at the rate of $\$ 1.50$ per 100 pounds of coal, or three sticks of cord-wood for 50 cents.

In the event of a renewal of the company's lease or the leasing of the islands to any other corporation or individual, I think a much inore liberal provision for a free supply of fuel to the natives should be made. 
From the stores at St. Paul and St. George-I assmme that the conditions at St. George aro the same as at St. Paul, the same general agent being in control-the natives are furnished goods and provisions, if, indeed, not as tho company claims at only 25 per cont. advauce on San Franscisco wholesale prices, most assuredly at very much lower figures than have yet obtained anywhere elso in Alaska.

There aro two hundred and nineteen men, women, and ehildren, exclusive of the few whites, on St. Paul, and one hundred aud twelve on St. George. These three hundred and thirty-one people, of whom it is safe to say less than one-third are adults, are paid by the company each year, for not to exceed three months' actual labor, $\$ 40,000$, which is divided among them, not exactly on a community plan, but in shares of the first, second, third, and fourth class, the classes being arranged by and among themselves, and founded upon the relative skill of the workmen and value of labor performed. As, for instance, of the \$34,000 paid the present year for killing and tlaying the 85,000 seals taken on St. Paul, the men of the first class received $\$ 526$ oach, those of the second class perhaps $\$ 50$ less, and the other two classes from $\$ 300$ to $\$ 400$ per man. 'These amounts, after the division is agreed upon, are placed to the credit of the individual persons composing the soveral classes on the books of the company, and cas be drawu in cash whenever wanted, except that, oither on its own motion or at the request of the Government agents, the company insists unon retaining an amount sufficient to insure each individual $\$ 2$ per veek duriug the ling period of enforced idleness which intervenes between the close of one killing season and the commencement of another.

A number of the more provident watives have very considerable amounts standing to their credit with the company, on which they are allowed 4 per cent. interest, and by the iveaus just stated tho improvident ones are compelled to save enough for the support of themselves and families. If they do any extra work, they are paid for it ; the company likewise pays them 40 cents each for skins of the pup seals, of which the law permits them to kill as many as maiy be needed for foot; at least for as many as they desire to sell for that price after they are neatly tanned. Many of these pup skins, however, they make up into blankets, coats, caps, etc., which are eagerly sought for by the officers of the revenue steamers; but I was informed they were not allowed to sell thom except through tho office, and not even then without first having obtained the Government agent's permission.

There aru a great many blue and white foxes on St. Paul Island, and of these they aro permittel to trap not to exceed 500 each winter, for the pelts of which tho company allows them 40 and 60 cents each, respectively. The people are seemingly much attached to the company's general agent, who struck mo as being a man of the most humane and kindly feeling, and I heard no complaints from the natives concerning their treatment either bv the a gent or any one else connected with the company. So far as the relations existing between themselves and the company aro concerned, they are probably as well, if not better, off than an equal number of white workmen to bo found anywhere in the States.

On the other hand, it seems to me that the authority exercised over them by the Government agents is rather arbitrary and oppressive. Whilo at Oonalaska, on my return trip from the Arctic, I was called on by a delegation claiming to represent the people of St. Paul Island, who complained bitterly of the restrictions placed upon their actions by the Government agents. As I have stated, they are not permitted to sell anything without permission, and tho delegation in question complained that on days when the store was open the assistant agent assumed the right to act as elerk not only, but also to decide for them what tbey should and should not buy. They claimed that he had discharged the second chief from the position to which he had been elected for no other reason than that he had gone fishing without first having obtained permission; that no ono is permitted to leave tho island withont consent of the agent, and instanced cases where they had been refused permission to receive visits from friends and relatives, though the company was perfectly willing they should come, and offered to givo them free transportation on its steamers. In 1layingr seals a few of tho skins are accidentally cut, and these, togother with those which aro pronounced "stagy," are rejected by the company.

These skins, tho delegation claimed, would be of use to the people in various ways, but instead of being allowed to keep them, they are cut up and thrown away by order of the Goverument agents. This is the delegation which I have referred to as complaining that the fire-arms sold to them br the company had been taken a way from them, for what reason they professed not to know. I do not know of my own persomal knowledge concerning the truth of the statements made to me by tho complaining delegation; but I do know that the natives of the islands aro not permitted to sell property, recognized on all hands as belonging to themselves, without first obtaining permission of the Government agents. It would seem to me, in view of the fact that none but Government vessels and officials and those of tho company are allowed to call at or land upon theso islands, that the natives might bo pormitted to sell withont let or hinderance that which is admittedly their own; nor does it appear to me at all 
necessary to their well-being that they should be restricted to the enjorment of only strch rights and privileges as the Goverument agents, in their wisciom, may see fit to prescribe. On the contrary, it seems to me that the duty of these agents, so far as their relations to and with the natives aro concerned, lies in the direction of protecting them in the full enjoyment of all their just rights and privileges aud not in the way of their abridgment.

In my last annual report I submitted very briefly my viows as to the policy which should, in my opinion, be adopted by the Government in regard to the fur-seal industry. A visit to the rookeries has not served to change or modify those views. I can see no good reason why the present monopoly of the business may not be abolishecl, not only withont loss to the Government, but to it s very great arlvantage, so far as the amount of revenue to be derived is concerned. The present system of farming ont the rookeries is not only obvoxious to every sense of right and justice, but, as I think I have shown, is in a very great degree inimical to the best interests of the Territory. But if it be concluded that the plan briefly outlined in my last report is impracticable, then I respectfully suggest that the law antherizing the lease of the seal islands should be so amonded as to positively prohibit the lessees, under penalty of forfeiture, from engaging, either as a corporation or as iudiriduals, clirectly or indirectly, in any other business than the taking of fur stals within the limits of Alaska Territory.

If it is considered that thero is no other way of dealing with the question so as to perpetuate the industry, and at the same time secure a revenue to the Government; if the business must be monopolized in order to prevent its destruction, then, on behalf of Alaska, in this my last official report, I beg and pray that the monopoly thus created and perpetuated hy Congress may be restricted to the leased islauds, and not be permitted to spread itsolf all over the Territory, to the detriment of almost every other interest within its borders.

Very respectfully,

\section{A. P. SWINEFord,} Governor of Alastia.

While the scope of the resolution directing this inquiry by the committee did not embrace the iuvestigation of affairs in Alaski, except as to the Government reservation of St. Paul and St. George Islands, the cowmittee admitted evideuce showing the condition of the natires of the seal islands, as compared with that of the native imhabitants of other parts of Alaska, and particularly as to those parts of the Territory in which said eompany had trading stations, and came in contact with these inhabitants, as well as to their present condition compared with their condition under the Russian Goverument. On these points numerous witnesses were examiued, all of whom testified that the conclition of the native inhabitants, not only of the seal islands, but in all other parts of the Territory to which the operatious of the company extend, had materially improved since the transfer of the Territory to the United States; and that these people who inhabit localities at or near which the company have trading stations are better eared for, more cirilized and prosperous, than those inhabiting other sectious of the Territory beyoud the limits of the company's operations.

The following extracts from the testimony on this subject are herewith submitted:

Washrngton, D. C., September 24, 1888.

George R. Tingle, sworn and examined:

By the Chamran:

Q. Please state your official position.-A. I am tho United States Treasury agent, in charge of the fur-seal islands of Alaska at the present time.

Q. Have you had occasion to observe and judge of the geueral efieet that this lease has ou the natives, and whether this lease enables the Alaska Commercial Company to exereise over the business interests and general prosperity of the nut ives any influence?-A. Yes, sir; it euables them to exercise a very large influence throughout Alaska.

Q. Is it injurious? $-A$. The basis of their business is the fur-seal indnstry. Without this contract it would not be there. This contract enables the company to maintain stations in other portions of the Territory where there are natives eongregated, 
and where they collect more or less land furs. This business they could not maintain without the fur-seal contract because a number of these stations aro nou-paying.

Q. You mean unprofitable?-A. I mean unprofitable, maintained at an actual cash loss annually. Most of their stations pay something. The most valuable fur that they have herotofore gotten has been the sea otter, but of late years the sea otter has been hunted so vigorously by white hunters and others that the supply of that fur is very largely reduced.

Q. By competition?-A. Ies; by competition. Their business in Alaska is principally on the fur-seal islands, aud their business elsewhere has no conueetion with that aud does not keep people out of the Territory at all. Since I have been thero their vessels have been at the service of any person wishing to travel up to Alaska. It carried missionaries, traders, and their fimilies, miners, aud others who happen to be at the stations; such always got passage. I have never kuown an instanco where they refused passage to any ono who undertook the establishment of a storo or trad. ing-post at any point in Alaska. The company has its stations at all points rehere it is at all probable they will have a profit, aud it does all the business it can, but it is in competition with many others.

Q. Is their influence in any respect, in your opinion, deleterions to the public interest?-A. Not to the natives. If it wero not for this compary I believo the natives in many portions of Alaska would be in a starviug condition. If this company did not wo there and carry provisions to them and take what fow furs they bave tho matives wouk have to go somo place else, for they would be in a half-starved condition, aud no better than they were under Russian rule, which was certainly deplorable. The presence of the Alaska Commereial Company in Alaska has been, in my judgment, a greater civilizer to the people of $\Lambda$ laska, and has been of more benefit to them that all the Rev. Sheldon Jackson's crowd of missionaries has over been.

[Testimony of W. B. Taylor, ex-Treasury agent.]

Q. The fur trade there was open to free eompetition throughout the Territory?A. So far as I know. I know of no reason why, if they contorm to the general law which is applicable to fur trading; that is, the employment of natives, any other company has not the same right that the Alaska Commercial Company has to carry on business; but so far as I liave been able to ascertain in regard to that, the business has not been a profitable one for more than one company, and in fact I think the Alaska Commercial Company could not carry on the business were it not that they have had the fur-seal island busiuess, which mado it necessary for them to own two vessels, and they could use them in the same trade to carry on business. And that is one reason why they have been ablo to carry on the other business and to extend the trade in the interior and through the Territory, and I look upon that trading business as a Gorlseud to those people. Withont it the Government would be obliged to make provision to care for then-I mean the natives throughout the Territory; of course the same thing is adapted to the seal islands, but it is the general trade $\mathbf{I}$ am speaking of now, becainse if yon refer to the revenue reports which have been made from time to time, son will find there a large number of small settlements that have been fouml in a starving condition almost every year that they have been visited, and large numbers of these people have died of starvation, and they have given them supplies over and over again.

Q. Do you mean the company?-A. No; the Government has. These supplies have been deait out by the revenue-cutters to keep these people from starving in localities whers there is no trading, and in localities where they have trading, and collecting furs, ivory, ant whalebone, and such things as that and tracle them to traders-the Alaska Commereial Company, I suppose, do the bulk of the business in that waythey can get provisions, monev, food, clothing, and all that which is necessary, and can exist. Just how many people thero are in Alaska dependent upon that trade I am not in a position to state, but it runs iuto the thousands.

Q. Involving the main bulik of tho natives?-A. Yes, pretty much all of them. I look upon that tradiug as absolutely necessary by the Alaska Commercial Company or sons company who continues to do that in order to keep theso people from starving.

Washington, D.C., September 17, 1888.

Dr. H. H. McINTrre, called and examined.

By Mr. JeIfries :

Q. Please state your name and occupation.-A. H. H. MeIntyre; I aru superintend. ent of the seal fisheries of Alaska for the lessees. 
Q. How long have you been in the employ of the Alaska Commercial Company ?A. Since June, 1870.

Q. Does the company build any houses:-A. We have built a large number of houses at Oonalaska and several in other parts of the T'erritory. The sea-otter business was formerly profitable, but during the last three years in the entire Aleutian Archipelago it is non-paying.

Q. It is open to competition?-A. Yes, sir; and in the portion west of Athka we get almost nothing. I think in the country west of and including Athka we have during the last year spent not less than $\$ 4,000$ or $\$ 5,000$ to obtain $\$ 500$ worth of furs.

Q. For what purpose?-A. To keep up stations and to keep the people from starving. At Attoo Island there are about one hundred penple now. From there we get absolutely nothing, except a dozen or two of fox skins. Now it is proposed to take the people from that island and carry them to Oonalaska, and thence to the seal islands, if they can be iuduced io go and if the Government gives us permission.

Q. Are you supporting thern without remuneration?-A. Yes, sir.

Q. Are the sea-otters diminishing in numbers?-A. Yes, sir; because white hunters who have better facilities for killing them than the natives follow them long distances from the coast and kill old and young iudiseriminately. The native hunters can not compete with white hunters without assistance, and under most favorable circumstances are beaten by them.

Q. Would it seem that that may soon result in their extermination ?-A. I think it will.

Q. Who are engaged in the extermination of these sea-otters $: A$. White hunters entirely, independent of the company and in competition with each other.

Q. Do traders from San Francisco and other places go there?-A. Yes, sir; six or seven vessels are on the sea-otter grounds from some of these places this season, while the company has but one, and this one is manned wholly by native hunters, with their skin boats and otter spears.

Q. They get the trade while you feed the natives?-A. Yes, sir.

Q. What would be the condition of these people if the Alaska Commercial Company should fail to provide for them ?-A. They would be left in a very deplorable coudition. I do not think they could get the means of subsistence. I think they would starve.

George Wardman sworn and examined.

\section{Cross-examination by Mr. JeFfries:}

Q. You are editor of the Pittsburgh Press, are you not?-A. Yes, sir.

Q. How long did you say you had been on St. George Island?-A. I was stationed there four years; that was my station.

Q. Subsequent to that you had been over the entire Territory of Alaska ?-A. Previous to that, in 1879.

Q. You have written a book on Alaska?-A. Yes, sir.

Q. I want to ask you now how the natives of St. George Island compare with the other natives of Alaska-I mean the different parts of Alaska?-A. Well, the natives of St. Paul and St. George rauk about alike, and they are considered tho native aristocracy of the Territory. There is one of the St. George girls, Natalia Merculiff, who had several offers of marriage from Oonalaska men; but she would not marry them. She said she would rather live siugle all her life than marry them. She could not marry anybody on St. George or St. Paul becanse she was connected by ties of consanguinity, some remote to the forty-seventh degree, with about everybody on the two islands. The Russian Church does not permit the marriage of such relations. She bad the reputation of being a very nice and decent girl-the best of the lot, the general report went. The real facts in the case I do not know.

Q. You have been on the Aleutian Islands?-A. Yes, sir.

Q. I want to ask yon now, from jour own observation, what do jou say as to the condition of tho uatives of Alaska before and since the trausfer of the Territory to the United States, whether it has beeu improved or not?-A. You mean natives generally?

Q. Yes, sir.-A. When I marle that cruise in the Rush in 1879 , down about Fort Wrangel and Sitka they had some mission schools, and the general reputation of the native women there was exceedingly bad; that is, they would send girls to the mission schools until they learnecl to wash and clean themselves, and then sell them to the miners. That was common report, but I never knew anything like that on the Aleutian Islands. The women at Athka were considered the handsomest and neatest women in the Territory, and I think they were the best looking women I saw except on the seal islands. 
Q. What do you say in regard to the natives of Alaska who have come in contact with the Alaska Commercial Company, as to whethor they aro better or worse in those localities where the eompany has stations ?-A. I think they are improved consideribly, particularly at Oonalaska, where the company also maintains a school.

Q. Did the company build houses i-A. They built houses. They took out the old barabacas and made frame houses.

Q. That, you know, has nothing to do with the lease.-A. Nothing whatever. The Alaska Commercial Compauy has no monopoly at Oonalaska. Auybody that wants to can go there and do business.

Q. That is so anywhere in the Territory except on the seal islands ?-A. Yes, sir. As I stated when I was here last summer, there was competition for tho fur trade at various points-Kodiak, Unga, Oonalaska, St. Michaels, and other trading points.

Capt. L. G. Shepard, sworn and examined.

The Charmax. The subjeet under investigation by this committee is the contract and loaso made by the Unitod States Government with the Alaska Commereial Company for the purpose of taking fur seals in Alaska, and the extent to which this has been enforced or complied with, etc., by that company at any time.

Q. State wluat position you occupy.-A. I am eaptain of the United States revenuecutter Richard Kush, and made two cruises to Alaska in the summers of 1887 and 1883.

Q. Did you observo the condition of the natives in other parts of Alaska to any great extent ?-A. Yes, sir; along the Alentian Islands.

Q. How did the natives of St. Paul and St. George compare with those of other parts of Alaska?-A. They are better elothed and better cared for on those islands, have much better houses to live in than those living in other settlements, excepting at Oonalaska. In a uumber of other places, the houses are partly underground. In Oonalaska the company has mado about the samo provisions as have been made on the islauds; has built at least forty houses which they allow the natives to occupy free of rent.

Q. The eondition of the natives on St. Paul and St. George is better than the natives elsewhere in that Territory?-A. Yes, sir. I uuderstand the natives of those islands cousizer themselves the aristocracy of western Alaska; it is looked upon as a privilege to be allowed to live there.

\section{JACOB H. Moulton, recalled and examined.}

\section{By the CHamran :}

Q. Wiil you please state if at any time you have occupred an official position under the Government in connection with the administration of the lease of the seal islands of Alaska, and at what time.-A. I was special agent of the Treasury Department at the seal islands from 1877 until 1885 , eight years.

Q. State what your duties were there.-A. My duties were to see that the law in regarl to the killing of seals was complied with and to talio general charge of the native population of the island.

\section{Cross-examination by Mr. Jeffries :}

Q. What do you sas, Mr. Moulton, as to tho coudition of the natives who have come in contact with the Alaska Commercial Company as compared with the other people of Alaska who have not cme in contact with that cowpany or with its agents?-A. I know the people very well in Ounalaska, as we always visited there goiug and coming. That is the only point of A laska I ever risited except one spring $I$ went to Kocliak. The condition of the natives of St. Panl is mueh superior to the natives of Oonalaska. while the condition of the natives of Oonalaska is much sunerior to the natives of Kodiak. That is as far as I observed. I know of nothing outside of those three points-the seal islands, Oonalaska, and Kodiak.

Q. Do you know whether the company has done anything in regard to ameliorating the condition of the people of Oonakaska ?-A. Yes, sir.

Q. What have they done?-A. They have built houses there.

Q. Have they furnished a doctor ?-A. Yes; a doctor and a school-house.

Q. Is that included in the contract with the seal islands ?-A. No, sir.

JosEph B. JoHnston, sworn and examined.

By the Chairman:

Q. Stcte to the reporter your name and place of resilence, and the official position that you occupy, if any.- $\mathbf{A}$. My namo is Joseph B. Johnston, United States commissioner, stationed at Oonalaska. I reside there, and I havo resided there for the last two years.

Q. Ifave you occupied that ofticial position cluring those two years? $-\Lambda$. Yes, sir. 
Q. From your olservations during your official residence there, is it your opinion that the lease of the seal islands aud their alministration by the Government under the present policy exercises a deleterious intluence ro public interests in Alaska genererally?-A. I think not; I know to the coutrary.

Q. Do you know anything in their operations there which leads you to conende that their influence is unfavorable to immigration aud the settlement of the country?-A. I know nothing of that kiud.

Q. Du you know of any act of the company or its agents which would tend to prevent and discuurage other people from engaging in trade and commerce in that Territory?-A. I do not, and I vever beard of any.

Q. I will be glad if you will state to the committee in a general way the result of yonr observation as relating to the administration of that interest there and the interests of the company in the Territory, $-\Lambda$. In the Territory in general or simply in regard to those islands.

Q. Their general influence and conduct.-A. I think the influence is good. I have traveled considerably over the Alentian Islands; in fact, everywhere except at Attoo and $\Lambda$ thka. I have always foumd the company exerted a very good influence amongst all the natives.

Q. Do they treat them humanely and kindly?-A. Yes, sir.

\section{Cross-examination by Mr. JefFries :}

Q. How loug have you been a United States commissiuner of Alaska?-A. Since the 13 th of September, 1886 .

Q. Are you the son of ex-Senator Johnston, of Virginia?-A. Yes, sir.

Q. Where do you make your headquarters?-A. At Oonalaska.

Q. How many other commissioners are there fur Alaska?-A. Three.

Q. Where are they?-A. One is at Sitka, one at Juneau, and the third at Fort Wrangel.

Q. Have you traveled pretty extensively over Alaska?-A. I have over the Alentran Islands and sontheastern Alaska, near Sitka.

Q. Then you have some idea of the comparative condition of the natives on the seal islands with the other parts of Alaska which you have visited ?-A. Yes, sir.

Q. What ?o you say as to their condition?-A. It is much superior to any other part of Alaska that 1 have been in.

Q. What do you eay as to the condition of the natives of Oonalaska since the Alaska Commercial Company commenced business there, compared with what it was furmerly?-A. I think it has improved wonderfully.

Q. What have they clone for them?-A. They have given them houses to live in frec of rent, ant have furuished them a doctor and medical attendance free of charge.

Q. Yc:1 are familiar with the law governing the lease of the seal islands generally?A. Yes, sir.

Q. Are they required to do anything for the people of Oonalaska under their contract?-A. No, sir.

Q. Have the company built any honses on any of the other of the Aleutian Islancis? $-\Lambda$. Yes, sir.

Q. Where?-A. At Belkovski, at Unga, at Wozensinski, Mozuria, and at other places.

Q. At these points the company have trading stations?-A. Yes, sir.

Q. Is it wherever the company have trading stations that they make accommodations for the natives in regard to houses and furnish them medicines and dress? Is that the rulo of the company?-A. That is the rule.

Q. Now, what do you say as to whether or not the condition of the natives of Alaskit-I an spealsing mow ontside of the seal islands-is improvod wherever ther have come in contact with the Alaska Commercial Company?-A. I believe their condition has been very much improved.

Q. Do you know Mr. Webster? But $\mathrm{I}$ believe you have testified to that.

By Mr. FeltoN:

Q. Do I understand they are better clothed and better honsed than they were beforc? $?-A$. Yes, sir.

Q. Anl a restraint is kept upon the selling of intoxicuting liquors?-A. There is no sale of intoxicating liquors.

Q. Becanse these things are for the advantage of the company as well as for the natives of the islands? $-A$. Yes, sir.

Lours KrMmeL, sworu and examined.

Q. What is sour residence?-A. My residence is La Fayette, Inel.

Q. Have you at any time been an official of the Government, and if so in what ea. parety and where? - $\Lambda$. Yes, sir; I was assistant Treasury agent at the seal islands, stationcd ou St. Georgo Islaud. 
Q. Do you think the company exereises au influence on that Territory that prevents tho oceupation and settlement by emigrants?- $\Lambda$. I do not think they interfero with that in the least.

Q. You do not think their influence bas interfered with anything of that sort, ?-A. No, sir.

Q. Has their influence on the natives been deleterious or beneficial?- $\mathbf{A}$. Boneficial.

Q. You are satisfied the influence has been beneficial to the natives generally?A. 'Their condition has improved considerably.

\section{Cilarles A. Lutz, sworn and examined.}

\section{By Mr. JEF FIIES :}

Q. What is your profession ?-A. Physician.

Q. Aro sou a graduato of medicino?-A. I am a graduato of lle University of Pennsylvania.

Q. Where have you practiced in former times?-A. I have been mostly connected with the St. Luke's Hospital, South Bethleheni, Pa., and Merey Hospital, in Pittsburgh. I also practiced a short time in Philadelphia.

Q. Have you been stationed in Alaska recently"-A. Since 1884.

Q. Whereabouts in Alaska?- $\Lambda$. I was most of the timo on St. George's Island, and during the summer I visited some of the other stations.

Q. IIave you been around to other portions of Alaska?-A. I visited St. Mielanels and two or three other places.

Q. St. Michaels is up on Bering Sea 700 or 800 miles north. How do the natives of St. Michaels compare with the natives of St. George?-A. I think the natives of St. Georcre are very much superior.

Q. What do you say as to the influence of the Alaska Commereial Company upon the natives of the section of the country where it is brought in contact with tho people? Is it good or bad?-A. It is very beneficial to them.

Tromas Wilkixson, sworn and examined.

\section{By Mr. JEFFRIES :}

Q. Where do you live :-A. San Francisco.

Q. How Jong have jou been living there?- $\Lambda$. I have lived at San Frauciseo two years; at Oakland ten years.

Q. What is your present business?- $\Lambda$. Mining business in Alaska.

Q. What part?- $-\Lambda$. Unga Island.

Q. Where is that?-A. East from Oonalaska about 250 miles.

Q. 'That is one of the Aleutian Islands?-A. Yes, sir.

Q. Have you visited many parts of Alaska?-A. Most of it, I think, sir.

Q. Been pretty nearls all over tho whole Territory ?-A. Yes, sir.

Q. Have you been on the seal islands?-A. On St. Paul only.

Q. I would like for you to state with regard to the condition of the natives of St. Paul Islaud as compared to the natives in the other parts of. Alaska that jou have risited. - A. I think they are much more improved on St. Paul Island than in some other parts of Alaska.

Q. What do you kuow as to what the company has dono for the natives in Oonalaska?-A. Wéll, they have built houses and given them free of rent, built schoolhouses and churches.

Q. What do say as to the different natives at such points as they come in contact with the Alaska Conmercial Company as compared with the natives of other parts of the Territory where they do uot come in contact with the company? - A. I think they aro much further advauced than in the Territory where they aro not reached by the company.

Q. Then you would say that the influence of the company has wrought good for the natives of Alaska; is that your judgment?-A. Yes, sir ; iecidedly.

Q. What portion of Alaska is it that is most densely popmlated with white people?A. Unga Island, Juneau, and Douglas Island, and up the Yukon, to which immioration teuds, and mining to the business portion. There aro many inincrs at the lukion River, more than at any other part of the 'T'erritory.

Q. IIow about southeastern Alaska?-A. I have not traveled a great deal through there.

Q. Sitka?-A. I stopped thero and was at Sitka abont a week. Oonalaska is fur ahead of Sitka in regard to the natives there.

Q. How about Kodiak?-A. I was thero twice. They all looked contented there, about the same as in Oonalaska.

Q. Has the company a station there ?-A. Yes, sir; seliools and churelies; aud they sce to be well contented.

$$
\text { H. Rep. } 3883-\text { III }
$$




\title{
Appendix B.
}

\section{COMMUNICATIONS FROM COMMISSIONER MARSHALL MCDONALD.}

\author{
WASHINGTON, D. C., January 28, 1889.
}

Sin: I have the honor to transmit herewith, for the information of your committee, a copy of certain statements in regard to the conditions under which the salmon fisheries of Alaska are now being prosecuted, the same haviug been transmitted to me by Mr. Redding, commissioner of fisheries for California.

I beg to suggest to jour houorable committee that prompt measures are necessary upon the part of the Gorernment to place the salmon fisheries of the Alaskan region under such conditions as will insure their permanence. To prevent the ascent of the salmon to their spawn. ing grounds will certainly result in a fer years in the destruction of this valuable fishery. The erection of dams or barricades across the ricers, aud the use of fixed contrivances for the capture of salmon in the rivers should be prohibited by law, under sufficient peualties actively and stringently enforeed.

I respectfully transmit herewith memorandum of such legislation as appears necessary to provide for present emergencies, and will lay the foundation for such additional legislation as may be necessary to place the salmon fisheries of Alaska under permanent and regular conditions of production.

I have the honor to be, very respectfully,

MARSHALL MLDONALD, Commissioner.

Hon. Poindextier Dunn,

Chairman House Committee on Fisheries.

The streams on the eastern shore of the Aliaska Peninsula and the large islands, especially Kodiak and Afoguak, are all small, ruming from lakes which are the objective point of the salmon for spawning purposes. These streams are in some cases mere rivulets where they empty into the ocean at low tide, and the largest 200 to 300 feet in width, with but 1 to 3 feet of water when the tide is out. We are told the salmon return to the place where they were spawued, and having arrived at maturity at sea, seek their native water, there to spawn aud die.

This past season parties on the Karluk River, on Kodiak Island, conceived the idea of putting up a tight dam, merely using stakes and wire nettiug, intending no doubt to take what fish they required and allow the remainder to pass up to the lake, but no less than four other canneries started for the same place; consequently, to supply all, the rirer was closed from in May to Uctober, the fish surging back and forward with 
the tide. The result was one company packed over 100,000 cases of salmon, and all the rest filled all their cans and made a perfect success. No care was taken of the surplus fish, and teus of thousands rotted on the banks. The remarkable success of these eanneries and the wide publicity given as to the pack havo so excited those engaged in tho industry and more who know nothing of the business to organize expeditions, and all on this grand scale, to pack salmon in Alaska, that something over twenty-five new parties will be in the field, and all old canners will be doubling up on their present plant.

Now, the point is, let this number of people locate ou these small streams, shut the fish off from their spawning ground, and in five years there will not be a fish left. 'To-day there is not a location east of the Peninsula and Aleutian islands but is taken up, and it is a mistaken idea that the fish of commerce abound in every stream. Many of them have the dog, humploack, gaboose salmon, which are white in color and not good to can. The salmon interests of Alaska will yield from $\$ 4,000,000$ to $\$ 5,000,000$ annually if properly fostered and the fish legitimately caught; but under this damming process an unlimited supply can be had for a few years and then we have the Sacramento River over again-no fish. Karluk River, on Kodiak Issland, will be the objective point for sereral cammeries. Afoguak Island, Chignuk Bay, are points now known on which plauts will be put up.

Kodiak Island is some $\mathbf{8 0}$ miles in length, and there are moro or less streams, all of which will be prospected or have already been. Now, if all these expeditions are allowed to proceed and catch fish in this way this year, there will be no doubt as to their success in packing the fish, and another year must see the number doubled, and how long will it take to locate every stream in Alaska, and they are not so numerous as many suppose? The first of these ressels will be starting by the middle of February, and immediate steps should be taken by the Secretary of the Interior, if he has the power, to suppress this illicit mode of fishing. The penalty should be severe, and upon conviction of the guilty parties the informers should get a large reward.

The Government cutters are cruising in those waters, and could malie a rigid examination of those known and prominent places, especially Karluk River, Afoguak, and Chignuk Bay. If the seal are worth protecting, how much more the salmon; and as there is no law the Gorernment should take immediate and severe action. If the Secretary of the Interior has the power, notice should at once be giren in our papers or at custom-house that this mode of fishing will not be allowed.

\section{WASHINGTON, D. C., January 26, 1889.}

SIR: In response to your request for information concerning the saltwater fisheries of Alaska, I have the honor to make the fullowing report:

\section{THE FOOD-FISHES.}

Corl and halibut are the principal salt-water foorl-fishes of the northern Pacific as they are of the northern Atlantic coasts. The species are identical in the two oceans. In the Pacific Ocenn both species hare practically the same distribution and the same center of alumblatec. Cod have been recorded doubtfully from as far south as the Farallone Islaurls, off San Franciseo. 'They ocemr on Heceta Bank, oft the coist. 
of Oregon, in the vicinity of the Straits of Fuea, and on the coast of British Columbia. From this joint they range continuously northward along the Alaslian coast to St. Lawrence Island and Norton Sound, in the northern part of Bering Sea. They are most abuudant in the Alaskan region between Sitka and probably the central part of Bering Sea, becoming scarce in the northern part of that sea, and affording the most extensive fisheries along the coasts and islands and upon the off'shore bankis south of Tenai and Aliaska P'eninsulas, along the line of the Aleutian Islands, as far to the westward as Atlia, and in the southeru part of Bering Sea.

The halibut also ranges from the Farallone Islands to Bering Straits, and is exceelingly abundant along the central Alaskan coast, associated with the corl. Satmon of several species, for which the Alaskan rivers are justly noted, are also sometimes captured in salt water, but only in the bays and harbors respecting which no question of ownership can arise. These and the remaining food and bait fishes of Alaska are briefly discussed, as to their distribution, abundance, and uses, in the inclosed report by Dr. T. H. Bean, the ichthyologist of this Commission.

'IHE FISHING-GROUNDS.

The natives are greatly dependent upon the catch of halibut for sup). plying their own wants, but the only important commercial fishery conducter at present in salt water is direeted toward the cod. Cod and halibut banks are found among the islands of southeastern Alaslia, and a very limiterl fishery is carried on in that region, and also along the coast to the northwark of Sitka as far as the Kenai Peniusula. The principal swounds resorted to are, however, located on the submerged continental platean south of the Kenai and Aliaska Peninsulas, and in the vicinity of Onimak and Uonalaskin Islands. That portion of the submerged plateau situated between Middleton Island, south of Prince William's Sound, and the Islind of Oonalaska is covered with a succession of banks and island groups, which afford almost continuous fisling-grounds, whose richness in marine products is only comparable with that of the great fishing-banks of eastern North America.

Parts of this region have been resorted to for the capture of con during nearly thirty jears, but of conse only to a very limited extent compared with the fishing-gromnds of the eastern coast. The fishing has been carried on mostly within easy reach of the land in the vicinity of the Shumagin Islands, Oonalaska, and Kodial. The existence of well-defined ban's in this region has been known for a long time, their positions and characteristics having been determined in a general way from information obtained from the fishermen and from the occasional soundings of exploriug vessels. The extent and contours of these banks and their exceeding richness in all parts have, however, only been ascertained during the past jear through the researches of the Fish Com. mission steamer Albatross, which spent about two months in making a preliminary survey of the region.

Five of these bauks were developed by the steamer Albutross, and several others partly explored. They are located, as a whole, much nearer the coast line than the offshore banlis of New England and the British Provinces, the most of them being within easy reach of secure harbors. They are limited on the outer side by the steep slope bordering the continental plateau, which varies in wielth from about 80 miles at the eastern end to abont 40 miles at the western end, many of the banks reaching from this slope to the main-land or to the shores of the 
adjacent islands. The entire length of the plateau, so far as it has been explored, is over 600 miles and the extent of the fishing-grounds examined about 23,400 square geographical miles. All of this area abounds in cod and halibut, but some localities afford much better fishing and a better grade of fish than others, as is the case in all fishing regions. Good fishing occurs among the islands, and in the bays and harbors which indent the main-land coasts, especially at the month of Cook's Inlet and in Prince William's Sound, but the largest and best fish are taken offshore in the deeper waters.

The banks examined by the steamer Albatross during the summer of $188 S$ are as follows:

I'ortloek Bank.-This bank lies to the northward and eastward of Farliak Island and extends from near the island to abont latitude $149^{\circ}$ IV. It covers an area of about 6,S00 square miles inside of the 100 . fathom line, being not greatly inferior in size to George's Bank, the total area of which is about $\$, 400$ square miles.

Albatross Banti lies to the southeastward of Kadiak Island. It extends the entire length of the island and reaches from the coast to the 100 fathom line. It is practically an extension of Portlock Bank and has an area of about 3,700 square miles. Many excellent harbors and conrenient anchorages are located along the inner edge of this bank.

Between Thatiali: and the region of the shumagins but few somndings and trials for fish were malde, but these were suflicient to prove the existence of rich fishing-grounds in this locality, corering an estimated area of 4,400 square miles.

Shumagin Banki lies sonth and east of the Shumagin Islands, between which aind the 100-fathom line it has an area of about 1,800 square miles. This is one of the best linown of the Alaskan grounds and has been much resorted to by the fishermen.

Between the Shumagins and Sanalih Bank about 1,800 square miles of excellent fishing-grounds have been partly explored.

Sanatih Banti lies south and east of the Sanakh Islands and covers an area of about 1,300 square miles. Good fishing-grounds are also reported from the region lying to the north of the Sanakh Islands and west of the Sandman Reefs. It has not, however, been explorerl.

Davidson Bank extends from the region of Ugomok eastward to the vicinity of the Sauakhs, and contains an area of 1,600 square miles inside of the 100 -fathom eurve.

Between Unimati Pass and the westorn ond of Oonataska Istand an area of abont 2,000 square miles has been partly explored. Good fishing was found wherever trials were made.

The Aleutian Islands.-Cod are abundant along the line of the Alentian chain, as far as the island of Atka, and perhaps farther west, but as these islands, to the westward of Oonalaska, are elosely bounded by very deep water on both the northern and the sonthern sides, the fish are found only in the immediate vieinity of the islands. Good fishing occurs abont Oonalaska and between there and Onimak Island, exceptionally rich gromuds for large fish being said to exist off the northern and southern entrances to Unimak Pass.

Bering Sea.-Very little cod fishing has yet been done in Bering Sea, and not much can positively be said of its resources in that respect, except with reference to a few localities.

Captain Bryant wrote of this region that "Bering Sea is a mighty reservoir of corl and halibut, so that he never threw orer his lines witli. ont bringing up fish in whatever part of the seat he might happen." 
Professor Davidson, of the U. S. Coast Survey, has described its prin. cipal characteristies in the following brief manuer:

The soundings of this sea and of the Arctic Ocean north of Bering Strait indicate it as the most remarkable submarine plateau of such great extent yet known. On tho eastern half of this sea soundings of less than 50 fathoms are found over an extent of 18,000 square miles.

Bering Sea has been surveyed only in the eastern and northern portions and adjacent to the Aleutian chain of islands. The depths in. crease very gradnally from the shores of the Alaskan main-land, on the eastern side, and from the vicinity of Bering Strait in the north toward the central and southern portions of the sea, the greatest known depths, excepting along the Aleutian Islands, 100 fathoms, occurring to the sontheast of St. Matthews Island and to the east of the Priby. lor group. The soundings of the U. S. S. Tuscarora in 1874 indicate a deep trough of 600 to 1,681 fathoms, bordering the northern side of the Aleutian Islands from Oonalaska to Tanaga.

Cod and halibut have been taken as far up as St. Lawrence Island and Norton Sound, but are said to be scarce in the northern part of the sea. These fish are also a favorite food of seals and sea lions, and are therefore not to be found in abundance around the rookeries of those animals. Vessels from San Francisco occasionally visit the southern and eastern parts of the sea, and have reported good fares, but the grounds about Oonalaska, the Shumagins, and Kadiak are given the preference, as being located nearer the markets and having good harbors close at hand.

The Albatross entered Bering Sea through Onimak Pass, but did not exteud her investigations beyond the immediate ricinity of the islands arljacent to the pass, the work upon the southern grounds being considered the most important which she can undertake on the first cruise. The following information respecting the Bering Sea grounds was, however, obtained at the Shumagin Islands : While at Humboldt Harbor, Popoff Island, the 1st of August, the schooner Arago, owned by Lynde \& Hough, of Sau Francisco, arrived in port from a trip to Bering Sea, with a fare of 103,000 cod. She had been absent from San Francisco since April 12; began fishing May 1S, and left the grounds July 12.

They found the best fishing in latitude $56^{\circ} 40^{\prime} \mathrm{N}$., from 10 to 15 miles off'-shore, in depths of 19 to 24 fathoms, the bottom being sandy. This spot is some distance south of the entrance to Bristol Bay. The Arago is of 176 tons burden and carries twenty-one men and twelve dories. Tramls have been tried, but were unsuccessful, as the fish caught on the hooks were quickly destroyed by the numerous small crustaceans living upon the bottom. All fishing is now done with hapd-lines from dories. A few lerring were taken along for the first baiting of the hooks to secure a supply of halibut, after which the latter species was exclusively used as bait. Mr. Torbin, the first mate of the Arago, stated that he had been engaged in fishing on the banks both to the north and south of the Alaskia Peninsula and considers the Bering Sea fish superior to the southern. Fog and rains are also less prevalent in Bering Sea than to the south of the peninsula.

A bank lying about 20 miles to the northward of Onimak Pass, called Slime Bank by the fishermen, has afforded some of the largest cod taken in Alaska and is oceasionally resorted to by the fishermen. Only one ressel besides the Arago, the Dashing Wave, was engaged in fishing in Bering Sea during 1Sss. Only a single trip is usually made by a vessel in the cour'se of one senson. This year the Dashing Wave intended making a secoml trip, b t the attempt was subsequently abandoned. 
THE OKHOTSK SEA.

The shallow waters of the Okhotsk Sea were noted for their cod fisheries before the Alaskan grounds were opened to American enterprise, and they are still visited to a limited extent by American fishing ressels from San Francisco. The grounds mostly resorted to at present are said to lie about 30 or 40 miles north of Saghalin Island, on the westeru side of the sea. Other good grounds are located on the eastern side of the sea, off the coast of Kamtschatka, and in the Kurile Straits. In 1566 abont fifteen American vessels visited the Okhotsk Sea, but in recent years, and especially since the $\Lambda$ laskan grounds have become better known, the number has been much less.

\section{GENERAL NOTES.}

Cod are present on the Alaskan grounds duriug tho entire jear, but cold weather tends to drive them off from the shallow grounds into deeper water. The best seasous for fishing occur at different times in different localities. A part of the shore fish approach the islands in separate schools, as is also the case on the Atlantic coast. These schools are classed as follows, in the order of their appearance, which continues from about May 1 into September, namely: The herring school, the lant school, the capelin school, and the squid school. The last-mentioned school is composed of the largest fish, areraging about 12 pounds each, but the bank fish are still larger.

The majority of the Alaskan coll sent to market are, in size, below the average of the George's Bank fish, bit it is to be remembered that the Alaskan fishery has so far been chiefly limited to the immediate vicinity of the islands, where the fish are much smaller than mpon the bauks. A length of $2 S$ inches is generally regarded as the standard for the eastern fish. In the trials made by the steamer Albatross the average size of the fish in each catch varied from abont 25 to about 31 iuches. These were, however, all short trials with hand-lines, and the fact is recognized among fishermen that the smaller fish tale the bait first, the larger ones being finally "tolled" up to the hooks. The visit of the Albatross to this region was also not male at the best season for obtaining large cod. The fish generally took the hook rapidly, both cod and halibut being secured at most of the trials.

The bait question will give no concern for many years. There is everywhere an abundance of fishes, squid, and clams, suiterl to this purpose, and it is now the custom to start out with only a sufficient amount of eured bait to begin fishing. The hooks rutckly supply live bait, which appears never to be lacking. Ialibut, yellow-fish, herring, sculpins, pollock, lant, and even salmon, are among the fishes used.

I have the honor to be, very respectfully,

MARSHALL MCDONALD,

United States Commissioner of Fisheries.

\section{Hon. Poindexter DUNN,}

House of Representatives, IVashington, D. O. 


\section{THE FOOD FISHES OF ALASKA.}

By Dr. T. H. BeAN.

There are at present known from the Territory of Alaska one hum dred and thirty-five species of fishes, nearly all of which inhabit either the fresh waters, the shallow waters aloug the shore, or moderate depths of the ocean. Only two species of deep-sea fishes are recorded. No exploration of the deep waters had been attempted until the cruise of the Albutross in the Gulf of Alaska in 18S8. The collections made during this cruise are in Washiugton, but have not yet been stuclied.

Of the one hundred and thirty-five species known to exist in Alaska one hundred and eight are marine and the remainder either fresh-water or anadromous. Sixty-two of the species are valuable for food, not including some other fishes which are extensirely eaten by natives but are not usually classed as food fishes.

The food fishes are abundant, as a rule, and most of them are exces. sively common. Serenteen of the species grow to a rery large size, partieularly the halibut, the cod, the burbot, the cultus cod, the beshowe, the pike, Jichardson's whitefish, the nelma or inconnu, the lake tront, the Dolly Varden, Clark's trout, Gairduer's trout, and the five species of Pacific salmon. Most of the useful species are very widely distributed in the waters of the Territory.

Flounders exist everywhere, but the larger kinds are limited to the Gulf of Alaska and Bering Sea. In the far Nortl, while the number of individuais is very great, there are no large species. There are as many species of flounclers and flat fishes in the seas of Alaska as in the corresponding latitudes of the western Atlantic. The whole number of edible kinds in this family is nine; one of these, the stellate flomn. der, has, perhaps, the most extensive distribntion in latitude of any species of the family, ranging as it does from the southern part of California to Mackenzie's River or throngh about 37 degrees of latitude. The halibut, which is identical with the well-known species of the Atlantic fishing-banks, is very abundant in the Gulf of Alaski and in Bering Sea, except in localities where it is destroyed by fur seals and other fish-eating mammals.

In Bering Sea the halibut is usually found up to the ice line. Its northeru limit in summer appears to be in Norton Sound (latitude $64^{\circ} \mathrm{N}$., longitude $163 \mathrm{~W}$. from Greenwich), where it occurs in the months of July, Angust, and September. Mr. Turner states that it is not common at St. Michaels and rarely is foumd there above 20 inches in length. Among the Aleutian Islands it is a permanent resident and is said to reach the enormous weight of 300 pounds. At the seal islands large halibut, too large to be destroyed by the sea-lion and the fur seal, are caught by the natives near the shores. The species is stated to range westwarl to the Okhotsk Sea. We may, therefore, consider it as established that Bering Sea furnishes suitable grounds for the permanent residence and reproduction of the halibut.

The cod family number six species of food fishes, one of which, the burbot, inhabits fresh waters. This burbot is identical with the eastern speeies of the same name; in some of the Alaskan rivers, notably the Yukon, it reaches the enormous length of 5 feet, and specimens weighing 60 pounds have been recorded by Dall \& Turner. This would make it a rival of the corl in size. Most of the members of this family in northern Alaska are small, but the individuals of the species are excessively abundant in the Aretic portion of the Territory. The polar 
cod, which is the same as the species of that name in the Nortin Atlantic, is one of the most important and valued of the food fishes. The Signal Service party at Point Barrow, in 1881 to 1883 , found them quite plenty at most seasons of the year. Murdock mentious this tish as one of the most important to the natives. It is found at St. Michaels in winter only. In Plover Bay, Siberia, we found plenty of them in August and September. The species grows to about 1 foot in length.

The wachna, so ealled by the Russian-speaking population, has received the name of tom cod from the white traders. The Eskimo call it ekathloouk. This is an Aretic species, but was not obtained by the Point Barrow party during their stay. $\Lambda$ t St. Michaels it is a constant resident and always abundant. It is an extremely valuable fish, both for men and dogs. The species abonnds in Bering Sea, and we found it very common in Cook's Inlet. It does not reach a greater length than 15 inches, and the maximum weight is a little more than a ponnd.

The little tom coll, which belongs to the same genus as the tom cod of New England, has not yet been obtained around the shores of Bering Sea, but in the Gulf of Alaska it is extremely plentiful, and is an excellent food fish. Its size is small, searcely reaching 1 foot in length.

The pollock of Alaska is a much smaller speeies than our pollock, and very differently marked. It has dark longitudinal bands along the sides, and is a very slender fish. Although not used for food, it is one of the best-known baits for corl. At the Shumagins and on the banks in the vicinity of Kodiak it is very common, and extensively used for bait. This species is abundant also in Bering Sea, and extends to the Okhotsk. It reaches a length of about 2 feet and a weight of 5 or 6 pounds.

The Alaskau cod is one of the most valuable fishes in the Territory, and one of the most plentiful. It grows as large as the Eastern coil, from which it does not differ specifically. It eougregates in schools, and is distinguished by the fishermen according to the kind of food upon which it may be feeding. The schools of cod are known by the same names as in the East. For example, the shore fish about the Shumagins and Kodiak, named in order of their appearance, are, the herring school, the lant school, the capelin school, the squid school, and the winter school. Besides these, there is an abundance of bank fish, made up of larger individuals than the shore fish. The favorite food species, as indicated by the names of the schools, are excessirely abundant. There is reliable information to the effect that sehools of herring many miles in extent appear frequently about the fishing shores.

I have taken forty good-sized capelin from the stomach of a rather small cod on Marmot Islaud bank. In fact, bait is so plentiful that fishermen can get their supplies upon the grounds with the greatest ease. In Bering Sea the cod are just as abundant as in the Gulf of Alaska, but the banks are less clearly marked ont. Cod have been eanght on the American shores as far north as $64^{\circ} 30^{\prime}$. The greatest centers of abundance known at present to the fishermen are about the Shumagin Islands, Cook's Inlet, and throughout the Aleutian chain. Young cod are among the commonest shore fishes at Karliak, the Shumagins, and Oonalaska, and the principal fishing for the large fish in most lo. ealities is at distances from the shore so small, that the men go out to the gromds and bring in their eateh in dories.

There is in the Gulf of Alaska and in Bering Sea, especially at Uonalaska, a small fish ealled eusk, which is not closely related to the cusk of New England, but belongs to the family of Trachinidre. This fish seldom exceeds a foot in length and is not used for food, but at tho Shumagin Islands it is one of the most valuable of all the baits for cod. 
The sculpins are among the most numerous of fishes in Alaska, constituting nearly one-fifth of the entire known fauna. Probably the largest sculpins in the world are found in that country. I have seen specimens measuring 30 inches. Two of the species are excellent for food and many of the others furnish food for fishes and other aquatic animals. The species which I have personally tasted and found to be acceptable food are distinguished by strips of seales along the sides.

The family of Scorponida, which in New England waters is represented by the well-known red fish, Norway haddock, or brim, includes seven species in Alaska. These are among the choice food fishes of the Territory. They appear to be limited to the Gulf of Alaska. The name usually applied to this fish is rock bass. The red rock bass grows to a length of 18 inches; the black-banded rock bass, 15 inches; the black rock bass reaches a length of 20 inches; the elouded rock bass, 12 inches; the mottled rock bass, nearly 2 feet, and the other species about 15 inches. All of them take the hook very freely and are found usually in moderate depths.

The so-ealled rock cods, members of the family Chirido, are also very abundant and highly prized as food. They belong to the genera Hexagrammus, with the species of small or moderate size; Pleurogrammus, also of moderate size; Ophiodon, which is one of the largest fishes in the Territory, and Anaplopoma, another very large species. The species of Hexagrammus are styled rock coll, although they have no relation to the corl family. Another name for some of the species is green fish, because of the green color of the flesh before cooking. Among the Russians they are known as torpoog. One of the species extends as far north as Port Clarence. All of them are found in Bering Sea. The largest species grows to a length of 18 inches.

The Pleurogrammus has sereral common names: Athka fish, Atlkia mackerel, striped fish, and yellow fish. In the western part of the Gulf of Alaska and about the Alentian Islands this fish oecurs in great schools. In deep water about the Shumagins it is very common, and is one of the finest known baits for colfish. It is also very abundant off Athka. It can be taken in purse-seines like, the mackerel, and, when prepared in the same way, it strongly resembles tiris fish in taste. It deserves to be ranked among the most important of the commercial species. The Ophiodon, commonly called enltus corl, is a very valuable food fish and a very common one from Santa Barbara to sonthern Alaska. It grows to a length of over 3 feet and sometimes weighs nearly 40 pounds.

The Anaplopoma is known to the Indians of Washington Territory and nortward as the beshowe. This fish, withont any reason whatever, has sometimes been styled the black cod, but this name should be at once sulp. presset. In the deep water off Puget Sound aud southeastern Alaskia very large individuals are eanght, some of them more than' 2 feet in length. When smoked, like the halibut, it is highly estecmed. Small quantities have been shipped to New England for trial in this way, and met with great favor.

The sand lance or lant is extremely abmolant about the shores of Alaska, extending northward at least to the Aretic eircle. It is chiefly valuable as food for cod, salmon, and other fishes.

The pike of Alaska is rery plentiful in the Bristol Bay region, the Yukon. and the Kowak. It reaches a length of 39 inches, amd is a very valuable food fish.

The smelt of $A$ laska resembles our own. It is a rery important foud fish, both in the fresh and the dried condition. It is most abundant in Bering Sea and northward. 
The capelin occurs around the entire coast of Alaska, and furnishes food for the cod, halibut, salmon, and other commercial fishes.

The surf smelt of southern Alaska is also a very raluable species for food and bait.

The eulachon is a rery important food tish, both fresh and ciried, and it is very attractive to other fishes. The fat or oil made from this fish is used as a substitute for butter, and to some extent to take the place of eod-liver oil. Salted eulachon are prepared on the rest shores of Shellikoff Strait, and are said to be excellent for the table.

In the fresh waters there is a great wealth of white fish, seven species being known in the Territory. One of these, Richardson's white fish, reaches a weight of over 30 pounds.

Related to the white fish is the inconnu, a very excellent food fish, which grows to a length of 4 feet, and sometimes weighs 50 pounds.

The grayling is rery common in Alaska in the spring. It is a very handsome fish and much valued for food.

The trout of Alaska are very large and excessirely numerous. The lake trout, so well and favorably known in our Great Lakes and elsewhere, is very abundant and groms very large in Alaska. Dr. Dawson found specimens measuring 30 inches in length.

The Dolly Varden trout is found crerywhere, being known from the Colville and from various points throughout the limits of the Territory. It reaches a very large size, and, in the sea-run condition, is extensively salted in Kodiak under the name of salmon trout.

Clark's tront attains to a weight of 20 pounds. It is very abuudant at Sitka, Kodiak, and as far north as Bristol Bay region.

Gardner's trout, also called the steel head, is known from southern Alaska and probably extends northward at least to Bristol Bay. It sometimes exceeds 20 pounds in weight.

The great salmon of the West coast are all found in Alaska. The quinnat salmon, which is the largest of the fire species, abounds even as far north as the Yukon. Speeimens weighing over 80 pounds are found. Canneries using this and other species are located in rarions parts of the Territory-Sitka, Kodliak, and Cook's Inlet, and the fish is salted as far north as the Yukon. The abundance of salmon in Alaskan waters is marvelons. In the summer season every village along the coast is reddened with the drying frames containing ukali in course of preparation for winter use.

The herring of Alaska resembls our own sea herring very closely. They occur in comntless multitudes, are fat and of excellent quality, and supply a notable amount of food for large fishes, and food and bait for fishermen. Te have taken them all around the coast as far north as Port Clarence and they are said to occur as far north as the Colville River.

The spined dog-fish is very common in the Gulf of Alsska and it is a great nuisance to the fishermen. It s liver might be utilized for oil, as they are on the New England coist, and the remainder as a fertilizer.

The sleeper shark is sufficiently common at Kodiak, appearing during the salmon run in schools of 30 to 50 . Turner has seen specimens weighing 310 pounds. The uatives drain the oil ont of the livers and use them as food.

A fresh-water lamprey is particularly abmndant in the Yukon and furnishes a vast amount of fool, which is highly relished by the natives. It is caught in enormous numbers through the ice and left to freeze where it falls. Turner says that a native provided with a stick, having left upon it seceral prongs, ean easily pull out a wagon-loat by a couple hours' labor. 


\section{Appendix C.}

liussin, 1824.-Convention between the Unitod States of America and His Majesty the Emperor of Russia, velative to navigation, fishing, \&c., in the I'teifie Ocean, conchuder at St. I'etersunrg A pril 5-17, 18-4; rati. ficution alvised by Senate January 5, 1825; ratified by President January 7,1825 ; ratifieations exchangen at Washington January 11, 1825; proclaimed January 12, 1825.

[Convention between the United States of America aud Russia. Translation from the original, which is in the French language.]

In the name of the Most Holy and Invisible Trinity.

The President of the United States of Ameriea and His Majesty the Emperor of all the liussias, wishing to eement the bonds of amity which unite them, and to secure between them the invariable maintenance of a perfect concord, by means of the present convention, have named as their Plenipotentiaries to this effect, to wit:

The President of the United States of Ameriea, Henry Middleton, a citizen of said States, and their envoy extraordinary and minister plenipotentiary near His Imperial Majesty; and His Mlajesty the Emperor of all the Russias, his beloved and ficithful Charles Robert Count of Nesselrode, actual privy counsellor, member of the council of state, seeretary of state directing the administration of foreign affairs, actual chamberlain, Knight of the Order of St. Alexander Nersky, Grand Cross of the Order of St. Wladimir of the first class, Knight of that of the White Eagle of Poland, Grand Cross of the Order of St. Stephen of Hungary, Knight of the Orders of the Iloly Ghost and of St. Michael, and Grand Cross of the Legion of Honor of France, Knight Grand Cross of the Orders of the Black and of the Red Eagle of Prussia, of the Amnunciation of Sardinia, of Charles III of Spain, of St. Ferdinand and of Merit of Naples, of the Elephant of Demmark, of the Polar Star of Sweden, of the Crown of Wiirtemberg, of the Guelphs of Hanover, of the Belgic Lion, of Fidelity of Baden, and of St. Constantine of L'arma; and P'ierre de Poletica, actual counsellor of state, Knight of the Order of St. Amme of the first class, and Grand Cross of the Urder of St. Wladimir of the second;

Who, after having exchanged their full powers, found in good and due form, have agreed upon and signed the following stipulations:

$\Lambda \mathrm{R}^{\prime} \mathrm{T}$. I. It is agreed that, in any part of the Great cean, commonly ealled the Pacific Ocean, or South Sea, the respective citizens or subjects of the high contracting Powers shall be neither disturbed nor restrained, either in navigation or in fishing, or in the power of resorting to the coasts, upon points which may not already have been occupied, for the purpose of traling with the natives, saving al ways the restrictions and conditions determined by the following articles:

AnT. II. With a view of preventing the rights of navigation and of fishing exercised upon the Great Ucean by the citizens and suljects of XLIV 
the high contracting Powers from becoming the pretext of an illieit trade, it is agreed that the citizens of the Uniterl States shall not resort to any point where there is a Russian establishment, withont the permission of the governor or commander; and that, recipnocally, the subjects of Russia shall not resort, without permission, to auy estal). lishment of the United States upon the Northwest coast.

ART. III. It is moreover agreed that, hereafter, there shall not be formed by the citizens of the United States, or under the anthority of the said States, any establishment upon the Northwest coast of Amer. ica, nor in any of the islands adjacent, to the north of fifty-four degrees and forty minutes of north latitude; and that, in the same manner, there shall be none formed by Russian subjects, or under the authority of Russia, south of the same parallel.

ART. IV. It is, nevertheless, understood that during a term of ten years, counting from the signature of the present convention, the ships of both l'owers, or which belong to their eitizens or subjects respectively, may reciprocally frequent, without any hindrance whatever, the interior seas, gulfs, harbors, and ereeks, upon the coast mentioned iu the preceding article, for the purpose of fishing and trading with the natives of tho country.

Aпт. V. All spirituous liquors, fire-arms, other arms, powder, and munitions of war of every kind, are always excented from this same commerce permitteil by the preceding article; and the two Powers engage, reciprocally, neither to sell, nor suffer them to be sold, to the natires by their respective citizens and subjects, nor by any person who may be under their authority. It is likewise stipulated that this restriction shall never afford a pretext, nor be advanced, in any case, to authorize either search or detention of the vessels, seizure of the mer. chanclize, or, in fine, any measures of constraint whatever towards the merchants or the crews who may carry on this commerce; the high contracting. l'ower's reciprocally reserving to themselves to determine upon the penalties to he incurred, and to inflict the punishments in case of the contravention of this article by their respective citizens or subjects.

ArT. VI. When this convention shall have been duly ratified by the I'resident of the United States, with the advice and consent of the Senate, on the one part, and, on the other, by His Majesty the Emperor of all the linsian, the ratifieations shall be exchanged at Washington in the sprace of ten months from the date below, or sooner if possible.

In fath whereof the respectivo Plenipotentiaries have signed this convention, and thereto affixed the seals of their arms.

- Done at St. I'etersburg the 17-5 April, of the year of Grace one thou sand eight hundred aud twenty-four.

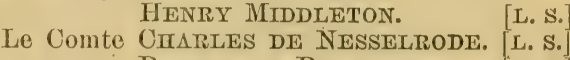

$$
\begin{aligned}
& \text { Pierre de Poletica. [L. S.] }
\end{aligned}
$$

IiUssin, 1867.-Convention between the United States of America and His Majesty the Emperor of Russia, for the cession of the Riussian possessions in North Americu to the United States, concluded at Washington Mareh 30, 1S67; ratificution alvised by Senate April 9, 1S67; ratified by I'resi-

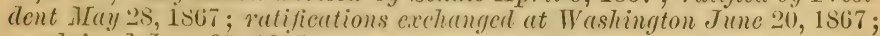
proclaimed June $20,1867$.

The United States of America and His Majesty the Emperor of all tho liussias, heing desirous of strengthening, if possible, the good un. derstanding which exists between them, have, for that purpose, ap- 
pointed as their Plenipotentiaries, the President of tho United States, William H. Seward, Secretary of State; and His Majesty the Emperor of all the Russias, the Privy Counsellor Edward de Stoeckl, his Lnvoy Extraordinary and Miuister Plenipotentiary to the United States;

Aud the said Plenipotentiaries, having exchanged their full powers, which were found to be in due form, have agreed upon and signed the following articles :

ART. I. His Majesty the Emperor of all the Russias agrees to celle to the United States, by this convention, immediately upou the exchange of the ratifications thereof, all the territory and dominion now possessed by his said Majesty on the continent of America and in the adjacent islands, the same being contained within the geographical limits herein set forth, to wit: The eastern limit is the line of demarcation between the Russian and the British possessions in North America, as estab. lished by the convention between Russia and Great Britain, of February 2S-16, 1825, and described in Articles III and IV of said convention, iu the following terms:

Commencing from the southernmost point of the islaud called Prince of IVales IsIand, which point lies in the parallel of $54^{\circ} 40^{\prime}$ north latitude, and between the one hundred and thirty-first and one hundred and thirty-thircl degree of west longitude, (meridian of Greenwich,) the said line shall ascend to the north alour the channel called Portland Channel, as far as the point of the contineut where it sirikes the fifty-sixth degree of north latitude; from this last-mentioned point, the line of clemarcation sball follow the summit of the mountains situated parallel to the coast, as far as the point of intersection of the one hundred aud fort 5 -first degree of west longitude, (of the same meridian;) and finalls, from the said point of intersection, the said meridian line of the one hundred and forty-first clegree, in its prolongation as far as the Frozen Ocean.

IV. With reference to the line of demareation laid down in tho preceding article, it is understood-

1st. That the island called Prince of Wales Island shall heloug wholly to Russia, (now, by this cession to the United States.)

2d. That whenever the summit of the momntains which extond in a direction parallel to the coast from the 56 th degree of north latitude to the point of intersection of the 141 st degree of west longitude shall prove to be the distanco of more than ten marive leagues from the ocean, the limit between the British possessions and the line of coast which is to belong to Russia as above mentioned, (that is to say, the limit to the possessions ceded by this convention, ) shall be formed by a line parallel to tho winding of tho coast, and which shall never exceed tho distanco of ten marino leagues therefrom.

The western limit within which the territories and dominion convejed are contained passes through a point in Behring's Straits on the parallel of sixty-five degrees thirty minutes north latitude, at its intersection by the meridian which passes midway between the islands of Krusenstern or Ignalook, and the island of Ratmanoti, or Noonarbook, and proceeds due north without limitation, into the same Frozen Ocean. The same western limit, beginning at the same initial point, proceeds thence in a course nearly southwest, through Behring's Straits and Behring's Sea, so as to pass midway between the northwest point of the island of St. Lawrence aud the southeast point of Cape Choukot. ski, to the meridian of one hundred amd seventy-two rest longitude; thence, from the intersection of that merichian, in a sontlwesterly direction, so as to pass midway between tho island of Atton and the Copper Island of the Kormandorski couplet or group), in the North Pacific Ocean, to the meridian of one hundred and ninety-three degrees west longitude, so as to include in the territory conveyed the whole of the Aleutian Islands east of that meridian.

ART. II. In the cession of territory and dominion made by the preceding article are included the right of property in all public lots and syuares, vacant lands, and all public buildings, fortifications, barracks, and other edifices which are not private indivinnal poperty. It is, howerer, un- 
derstood and agreed, that the churches which have been built in the ceded territory by the Russian Government, shall remain the property of such members of the Greek Oriental Church resident in the territory as may choose to worship therein. Any Goverument archives, papers, and documents relative to the territory and dominion aforesaid, which may now be existing there, will be left in the possession of the agent of the United States; but an authenticated copy of such of them as may be required, wiil be, at all times, given by the United States to the Russian Government, or to such Russian officers or subjects as they may apply for.

AR'. III. The inhabitants of the ceded territory, according to their choice, reserving their natural allegiance, may return to Russia within three years; but if they should prefer to remain in the ceded territory, they, with the exception of uncivilized native tribes, shall be admitted to the enjoyment of all the rights, advantages, and immunities of eitizens of the United States, and shall be maintained and protected in the free enjoyment of their liberty, nroperty, and religion. The uncivilized tribes will be subject to such laws and regulations as the United States may from time to time adopt in regard to aboriginal tribes of that country.

ART. IV. His Majesty, the Emperor of all the Russias shall appoint, with convenient despatch, an agent or agents for the purpose of formally delivering to a similar agent or agents, appointed on behalf of the United States, the territory, dominion, property, dependencies, and ap. purtenances which are ceded as abore, and for doing auy other act which may be necessary in regard thereto. But the cession, with the right of immediate possession, is nerertheless to be deemed complete and absolute on the exchange of ratifications, without waiting for such formal delivery.

ART. V. Immediately after the exchange of the ratifications of this convention, any fortifications or military posts which may be in the ceded territory shall be delivered to the agent of the United States, and any Russian troops which may be in the territory shall be withdrawn as soon as may be reasonably and conveniently practicable.

ART. VI. In consideration of the cession aforesaid, the United States agree to pay at the Treasury in Washington, within ten months after tho exchange of the ratifications of this convention, to the cliplomatic representative or other agent of II Majesty the Emperor of all the Russias, duly anthorized to receive the same, seven million two inudred thousand dollars in gold. The cession of territory and dominion herein made is hereby declared to be free and unincumbered by any reservations, privileges, franchises, grants, or possessions, by auy associated companies, whether corporate or incorporate, Russian or any other, or by any parties, except merely private iudividual property-holders; and the cession hereby made conveys all the rights, franchises, and privileges now belonging to Russia in the said territory or dowinion, and appurtenances thereto.

ART. VII. When this convention shall have been duly ratified by the President of the United States, by and with the advice and consent of the Senate, on the one part, and, on the other, by His Majesty the Emperor of all the Russias, the ratifications shall be exchanged at Vashington within three months from the date hereof, or sooner if possible.

In faith whereof the respective Plenipotentiaries have signed this convention, and thereto affixed the seals of their arms.

Done at Washington the thirticth day of March, in the year of our Iord one thousand eight huncled and sixty-seven.

IVILLTAII H. SEWARD.

idouARD DF STOECKL.

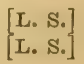


Russia.-Conention between Great Brituin and Russia. Signed at St. Petersburg, February 2S-16, 1825.

[Trauslation.]

In the name of the most holy and undivided Trinity.

His Majesty the King of the United Kinglom of Great Britain and Ireland, and IIis Majesty the Emperor of all the liussias, being desirous of drawing still closer the ties of good understanding and friendship which unite them, by means of an agreement which may settle, upon the basis of reciprocal convenience, different points connected with the commerce, navigation, and fisheries of their subjects on the Pacific ocean, as well as the limits of their respective possessions on the northwest coast of America, hare named plenipotentiaries to conclude a convention for this purpose, that is to say:-His Majesty the King of the United Kingdom of Great Britain and Ireland, the Right Hon. Stratford Canning, a member of His said Majesty's most honorable privy Council, \&c. and His Majesty the Emperor of all the Russias, the Sieur Charles Robert Count de Nesselrode, II is Imperial Majesty's privy coun. cillor, a member of the council of the Empire, secretary of state for the department of foreign affairs, \&c. and Sieur Pierre de Poletica, His Imperial Majesty's councillor of state, \&c. Who, after having communieated to each other their respective full powers, found in good and due form, have agreed upon and signed the following articles:

ART. I. It is agreed that the respective subjects of the IIigh Contracting Parties shall not be troubled or molested, in any part of the ocean, commonly called the Pacific ocean, either in navigating the same, in fishing therein, or in landing at such parts of the coast as shall not have been already occmied, in order to trate with the natives, under the restrictions and conditions specified in the following Articles.

ART. II. In order to preveut the right of navigating and fishing, exercised upon the ocean by the subjects of the High Contracting Parties, from becoming the pretext for an illicit commerce, it is agreel that the subjects of His Britanic Majesty shall not land at any place where there may be a Russian establishment, withont the permission of the Goreruor or Commandant; and, on the other hand, that Russian subjects shall not land, without permission, at any British establishment, on the north-west coast.

ART. III. The line of demarcation between the possessicus of the High Contracting Parties, upon the coast of the Continent, and the islands of America to the north-west shall be drawn in the manner following:

Commencing from the sonthernmost point of the island called Prince of Wales island, which point lies in the parallel of 54 degrees 40 minutes, north latitude, and between the 131st and the 133 d degree of west longitude (Meridian of Greenwich), the said line shall ascend to the north along the channel called Portland Chamel, as far as the point of the continent where it strikes the 56th degree of north latitude ; from this last mentioned point, the line of demarcation shall follow the summit of the mountains situated parallel to the coast as far as the point of intersection of the 141st degre of west longitude (of the same mic.idian); and, finally, from the said point of intersection, the said meridian line of the 141st degree, in its prolongation as far as the Frozen ocean, shall form the limit between the Russian and British possessions on the contineut of America to the north west. 
ART. IV. With reference to the line of demarcation laid down in the preceding Article it is understood:

1st. That the islaud called Prince of Wales Island shall belong wholly to Russia.

$2 d$. That whenever the summit of the mountains which extend in a direction parallel to the coast, from the 56th degree of north latitude to the point of intersection of the 141st degree of west longitude, shall prove to be at the distance of more than 10 marine leagues from the ocean, the limit between the British y.ossessions and the line of coast which is to belong to Russia, as abovementioned, shall be formed by a

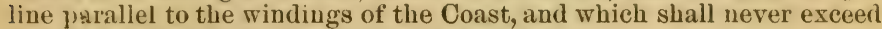
the distance of 10 marine leagues therefrom.

ART. V. It is moreover agreed, that no establishment shall be formed by either of the two parties within the limits assigned by the two precerling Articles to the possessions of the other; ennsequently British subjects shall not form any establishment either upon the coast, or upon the borier of the continent cemprised within the limits of the Irussian possessions, as designated in the two preceding Articles; and, in like manuer, no establishment shall be formed by Russian subjects beyond the said limits.

ART. VI. It is understood that the subjects of His Britanic Majesty, from whaterer quarter they may arrive, whether from the ocean, or from the interior of the continent, shall for ever enjoy the right of navigating freely, and without any hindrance whatever, all the rivers and streams which, in their course towards the Pacific ocean, may cross the line of demarcation upon the line of coast described in Article III, of the present Convention.

ART. VII. It is also understood, that, for the space of 10 years from the signature of the present Convention, the vessels of the two Powers, or those belonging to their respective subjects, shall mutually be at liberty to frequent, withont any hindrance whatever, all the island seas, the gulfs, havens, and creeks on the coast mentioned in Article III. for the purposes of fishing and of trading with the natives.

ART. VIII. The port of Sitka, or Novo Archangelsk, shall be open to the commerce and vessels of British subjects for the space of 10 years from the date of the exchange of the ratifications of the present Convention. In the event of an extension of this term of 10 years being granted to any other Power, the like extension shall be granted also to Great Britain.

AR'T IX. The above-mentioned liberty of commerce shall not apply to the trade in spirituous liquors, in fire arms, or other arms, gunpowder or other warlike stores; the High Contracting Parties reciprocally engaging not to permit the abovementioned articles to be sold or delivered, in any manner whatever, to the natives of the country.

AR'T X. Every British or Russian Vessel navigating the Pacific Ocean, which may be compelled by storms or by accident, to take shelter in the ports of the respective Parties, shall be at liberty to refit therein, to provide itself with all necessary stores, and to put to sea again, without paying any other than port and light-house dues, which shall be the same as those paid by national vessels. In case, however, the master of such vessel should be under the necessity of disposing of a part of his merehandize in order to defray his expenses, he shall conform himself to the regulations and tariffs of the place where he may have landed.

ART. XI. In every case of complaint on account of an infraction of the Artieles of the present Convention, the civil and military authorities

$$
\text { H. Rep. 3883-IV }
$$


of The High Contracting Parties, without previously acting or taking any forcible measure, shall make au exact and circumstantial report of the matter to their respectice Courts, who engage to settle the same, in a friendly manner aud according to the princinles of justice.

ART. XII. The present Couvention shall be ratified, and the ratificatious shall be exchanged at London, within the space of 6 weeks, or sooner if possible.

In witness whereof, the respective Plenipotentiaries have signed the same, aud have affixed thereto the seal of their arms.

Done at St. Petersburg, the 2S-16th day of February, in the year of our Lord, 1825.

CoMTE DE NESSELRODE. [L. S.]

STRATFORD CANNING. [L. L.

PIERRE de Poletioa. [L. S.] 




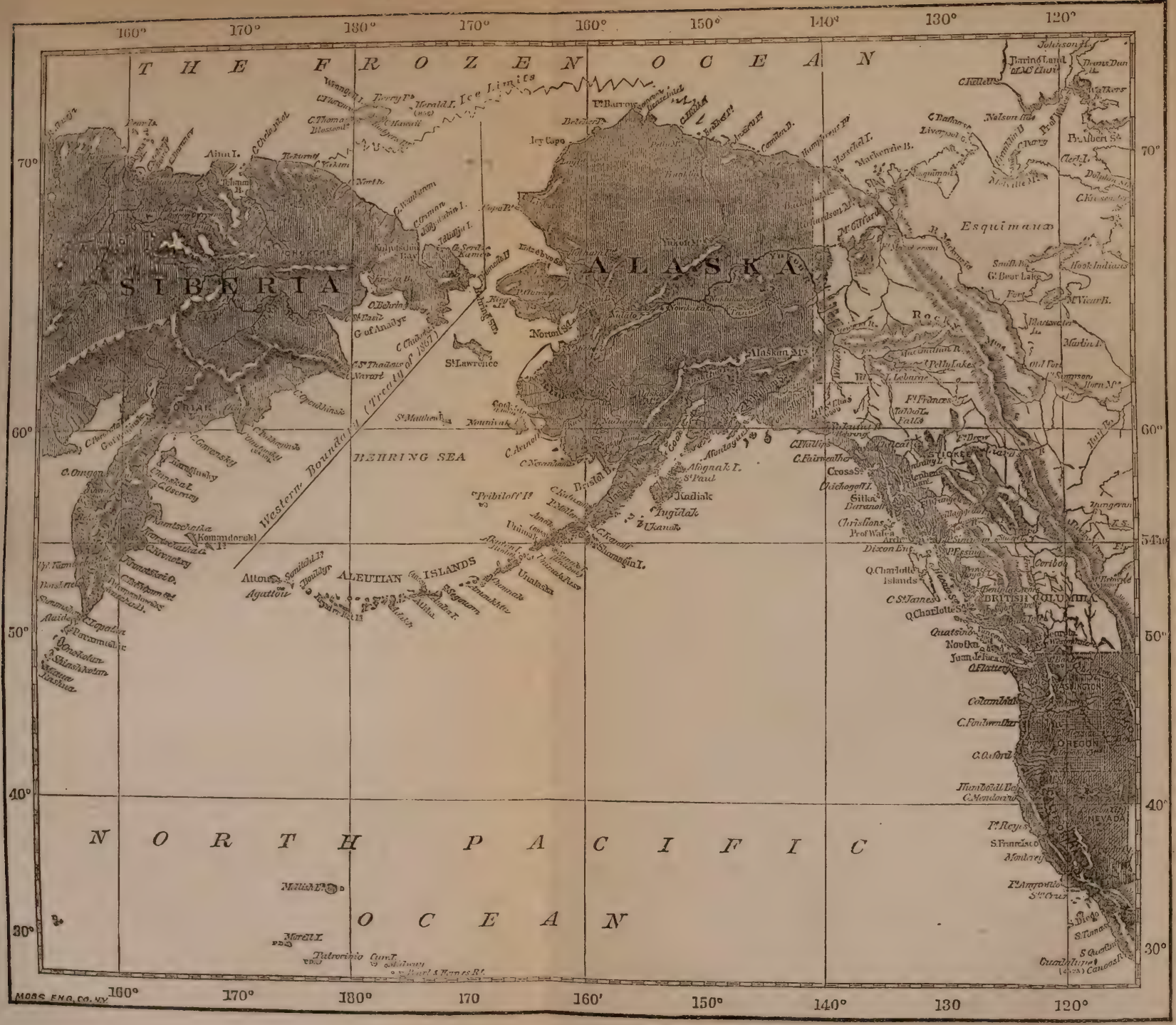




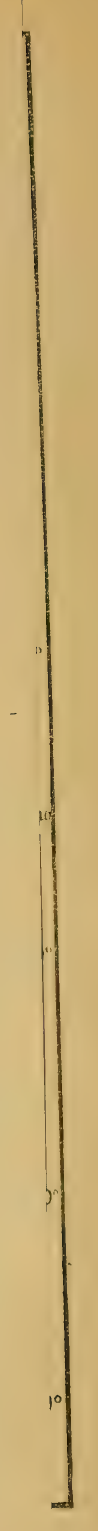




\section{FUR-SEAL FISHERIES OF ALASKA.}

Commitiefi on Merchant Marine and Fismeries, Washington, June 8, 1888.

The Committee on Merchant Marine and Fisheries, in pursuance of the following resolution, adopted by the IIouse of liepresentatives, proceeded to execute the order of the Iouse. The resulution is as follows :

Fesolicd, That the Committeo on Mferchant Marine and Fisheries ho authurized and directed to fully and thoronghly investigate the fur-seal fisheries of Alaska, and all contracts or leases mate by tho Government with any persons or companies for tho taking of fur-seals or other fur-loearing animals in $\Lambda$ laska; the character, duration, and conditions of such contracts or leases, and whether and to what extent tho samo have been enforced and complied with or violated ; tho receipts therefrom and the expenses incurred by the Gorernment on account of any sneh contracts or leases; and to fully investigate and report upon the nature and extent of the rights aud interests of the United States in the fur-seal and other fisheries in the Bering sea, in Alaska; whether and to what extent the same have been violated, and by whom; and what, if any, legislation is necessary for the better protection and preservation of the same; that said committee be authorized to sit during the sessions of the House, send for persons and papers, and administer oaths, employ a messenger if found necessary, and that all expenses of such iurestigation shall be paid out of the contingent fund of the House.

\section{WASHington, D. C., May 26, 1888.}

SIR: On behalf of the Alaska Conmereial Company, of San Francisco, Cal., I respectfully request that said company be allowed to ap)pear by counsel before your committee during the investigation of its affiars by said committee under the recent order of the House of Rep. resentatives.

Very respectfully,

N. L. JEFFRIES,

Attorney for the Alaska Commercial Company

Hon. Poindexter Dunn,

Chairman Committee on Mlerchant MLarine and Fisheries.

\section{TESTIMONY OF S. M. BUYNITSTY.}

S. Ml. BurnitsKy, sworu and examined.

By the Cramenar:

Q. Are you personally fumiliar with the location of the Fur-ieai Islands and rookeries in the Bering Sea? and if so, state your means of knowing about their locations and conditions. $-\Lambda$. I spent aliont three montus in 1570 on the island of St. George. $\Lambda$ that time I visiterl for a few dass the island of St. Paul.

9984 - 1 
Q. These are the ftir-seal islands?-A. Tes, sir; the Pribylov group, which consist of tro islands. After receiving your summons, Mr. Chairman, I looked up my report of December 30,1370 , to the Secretary of the Treasury, and I find that I can give every part of it as true. It is very brief and at the same time it is a comprehensive statement of the condition of tho fisheries.

Q. Well, sir; we'll be glad to have that. You cau just put that in.A. This report is to be found in Executive Document No. S3, of the Forty-fourth Congress, first session, on page 41. It is only threo pages of print, and I think it contains a great deal of information on points which are not liable to mutation or change; of the couditions of the island and the habits of the seals and the way of buuting there; and a part of the report refers to the economical aspects of the fisheries at the time, which of course has undergone an immense change since that time, eighteen jears ago.

Wasmington, D. C., December $30,1870$.

Sir: By letter of instructions of May 25, 1870, I havo been detailed to tho islandis of St. Paul and St. George, Alaska Territory, there to act under the orders of Capt. Charles Bryant, special agent of tho Treasury Department, and also to obtain and report to the Department such information as might be acquired relative to the sealfishery and the commercial interests of tho islands and of the country generally. Concerning my action at the islands, nnder the instructions of Capt. Charles bryant, I beg leave respectfully to refer to Mr. Bryant's official reports. As to tho information which I have been able to acquiro relative to the seal-fishery and the commercial interests of the islands and of the comntry, I have tho houor to subiuit the following:

The islands of St. Paul and St. George, owing to their isolated position, their climate, and tho configuration of their shores, seem to havo been particularly designed by nature for the proparation of the species of seals commonly known under the name of fur-seal, and scientifieally classified uncler the appellation of phoca ursina. The number of fur-soals congregating every summer at the islands aro literally beyond computation. At the commencement of tho spring they begin to appear in the Bering Sea, coming from the Pacilic through tho straits of the Alontian Islands, chietly through Oonimak Pass. Full-gromn males (called bulls) aro tho earliest visitors at the islands of St. George and St. Panl. They approach the islauds in the last days of April, and after a careful survey of their habitual resting grounds, settlo thereon to await tho arrival of tho females, which takes placo considerably later. The seals invariably select for their resting grounds (rookeries) such beaches as aro strewn over with largo bowlders, affording a safe hold against the sweep of the surf; flat, sandy beaches aro carefully avoided by them, probably on account of the danger to which the new-born seals would be exposed of being carried of by the sea beforo they have learned to live in that element. From the day of their settling on the ronkeries to the epoch of the appearance of the females the bulls slcep almost without interruption.

Toward tho end of May they begin to look out for the coming of their families. The females (cows) generally recognize their former mates, and land at their respectivo rookeries. Thero being a considerable difference between the male and femalo in regard to age of puberty (six jears for the malo ant two for the female), this species is necessarily polygamous, and an average family numbers about ten cows to ono bull. The rookeries nearest to the water aro cecupied by tho propagators, whilo the minor individuals of the tribe have to camp on the slopes, where they are moro exposerl to the danger of being cut off from tho sea and to liecome tho prey of the hunter. Tho hunting begins as soon as the resting-grounds aro inlly occupied, which generally happens about the end of Jume. It is earried on until the middle of November, when the seals leave the islands, to disappear for five months in the vast expanse of the Pacific. The surrounding, driving, killing, and flensing of tho fur-seals laas been reduced to a science lry tho natives of tho islands. A day is waiter for when the direction of the wind allows of a rookery being approached so that the game can not scent the hunters; a party of from twenty to thirty men, armed with clubs, cautionsly advance along the shoro until the retreat of the animals toward the sea is cut off by the line of hunters; then, at a signal from the chief of the expedition, tho men rush up the cliffs and drivo toward the interior of the island as many seals as have been surrounded.

When the herd has been driven a certain distance from the shore a halt is made, and a sorting of the game as to age, sex, and condition of the fur is effected. This operation requires the exerciso of a life-long experience and is of the utmost impor- 
tance, as tho killing of females, which aro easily mistaken for young males even by tho natives, would endanger the propagation of the specics, and tho slaughtering of males under two or over four years old would bo a useless extermination, their furs having littlo valuo for trade. Tho sorting onco accomplished, all tho animals not destined for killing aro allowed to escapo toward the rookery, and tho balaneo of tho herd is driven to the slaughtering grounds, situated near tho salt-liouses. Great caro is taken, when driving, that the animals do not becomo overheated, for should this happen the skins would become worthless, the fiur falling off. On reaching the slaughtering grounds the drove is allowed a rest of two or three hours, after which, at a signal given by ono of tho chiefs, tho killing is effected with wonderful rapidity. I havo seen a drovo of sixteen hundred seals dispatched by thirty men in a little moro than an hour of timo. As soon as tho animals aro killed all availablo hands, men, women, and children, rush to the work of flensingr, which has to bo finished as soon as possible to prevent the carcasses from stiffoning. Every part of tho animal is turned to account; skin, flesh, blubber, and intestines. The skins aro immediately taken to tho salt-house and placed in large vats, the fur side down, and the flesh side plentifully sprinkled with salt. When the skins havo been thoronghly saturated with salt, which process requires about forty days, they are taken up and shaken; then another lighter coat of salt is applied, and they are booked up in folds realy for shipment.

The commereial value of fur-seal skins depends nuon their size, and particularly upon the quality of the fur. 'The greatest proportion of first-class skins are obtained from seals three years old.

London is the most important and almost the only market for fux-seal skins; there they aro manufactured into elegant furs by a series of technical operations, tho secret whereof is jealously kept by a single firm. "The prices obtained in Loulon by American traders for seal skins shipped in 1867 and 1868 ranged from 16 s. to $30 \mathrm{~s}$. per skin, according to quality. The cost of each skin rendered at Lon don, including compensittion of natives, expenses for salt, shipment from the islands to San Eraucisen, trausshipmont for Europe, freights, and commissions, amounted to $\$ 1.50$ in gold. This was tho figure of costs when the price paid by the traders to the natives for each skin was nominally 20 to 40 cents, but actually less, as tho samo traders realized on somo articles furnished to the natives a profit of nearly 100 per ccut. At present, when tho Alaska Commercial Company has fixed the prico to bo paid to the watives at 40 cents per skin, and the advanco on San Francisco prices of commodities brought to the islands at only 25 per cent., the aboro figure of costs will be considerably increased. Somo increase of costs will bo occasioned by the obligations assumed on tho part of the company as to the establishment and keoping of gratuitous schools for the nit ives, as appears from the instructions of the company to its agents, a copy whereof is lierewith submitted. So that in future tho actual cost of each seal sizin reudered at London will amount to not less than \$2, exclusive of the pro rata of tho rental and the tax imposed by the condition of the lease.

The fat or blubber of all tho seals killed for their skins is not moro than suflieient to supply the want of fuel at tho islauds. Although every chip of drift. mood is carefully collected by the natives and brought with great pains to tho villago from tho remotest points, almost all of it is used up in tho repairs continually required by tho rapidly decaying wood-work of their miserable dwellings, and only a small quantity may be reserved for the purpose of kindling the seal-blubber fires.

The summer temperature at the islands being $45^{\circ}$ and the mean temperat ure of tho year but $38^{\circ}$, the dwellings, which are nothing better than cellars coverecl with turf, have to be heated all the year round. Notwithstanding the enormons quantity of seal blubber consumed at the islands, a considerable anount of it might be converted into seal oil for exportation. Thousands of old bulls, which have becomo useless for the purposes of propagation and are an incumbraneo to the rookeries, might be killed for their blubber, and thus a new and profitablearticlo of traclo addet to the resources of the islands. Unfortunately, the market price of seal oil is lower than the tax offered on this article by the competitors for the loaso of tho islands, and cousecquently this branch of industry has no chance of being developed.

Tho population of the islands, numbering 240 on St. Panl amd 1:5 on St. Georine, are mostly Alouts, somo half-breeds, and a for descondants of Kimeliatiliales brought over from Kamchatka by tho vessels of tho Russian-American Company. 'Their mother tongue is tho Aleutian, a languago spoken, with slight variations, all over the Aleutian Islands and the sontheast coast of Alaska peninsula. The Russian language is understood by all and intelligently spoken by wany. They all belong to tho Grxeo-Russian Catholic Church and aro sincerely attached to their religion.

According to the statement of the natives of tho islands of St. Paul and s't. George a notablo improvement in their material welfaro has taken place since tho transfere of tho Territory to tho United States. Still their prosperity is far from being in harmony with the importance of their share in the production of wealth. Their dwellings-damp, insalubrious hovels, constructed of drift-wood aud sols-aro particularly 


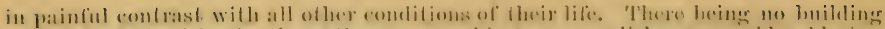
malerials at the islands, tho nalives are mable to aceomplish any consielerable im-

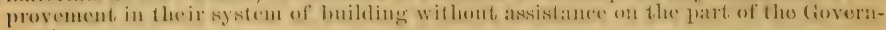
mont.

'The prevalenee of inflammat ury diseases of the lmugs, mostly due to the miserable

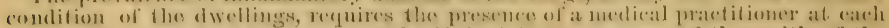
island. 'Tho recall this summer of tho lnited States troops, and therewith of the contract doctors who were attached to tho military josts at tho islands, leaves tho

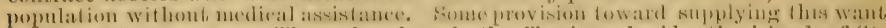
is alosolntely necessary. The only jlace in tho 'Torritory besirles the islands of St.

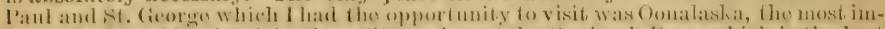

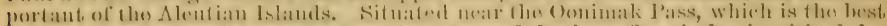
entranco to Bering Soa, and possessing a grood harbor, Oonalaska is visited by vessels engaged in the fur trate more than any ofler port, mot excepting Ritlial.

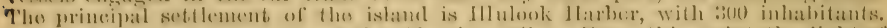

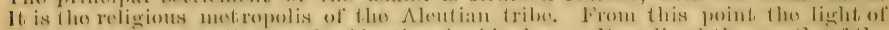

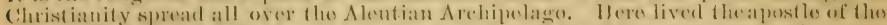

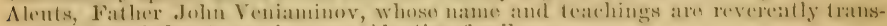
mited from fithor to son in overy Alontian fimily.

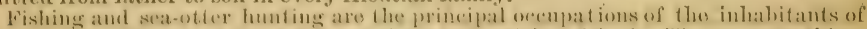

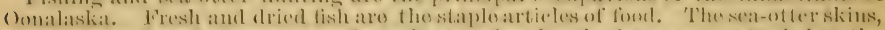

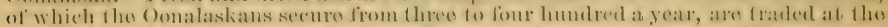
rate of from $\$ 15$ to $\$ 35$ for clothing, hardwaro, crockery, sugar, tea, and tobaceo.

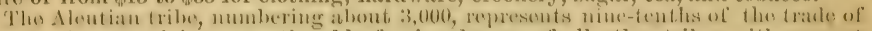
tho 'Jorritory, and is unquestionably fia in alvanco of all other tribes with respect lo moral, religious, and social dovelopment.

$1 \mathrm{im}$, sir, very respectiully, your obedient servant,

Hon. George S. Boetwert,

s. N. Bursitskx, Clerl. Secretary of the Tireasury.

(2. Does that cover the entire range of your linowlerlge of the sul)ject?-A. 'This report was written alter my first visit. I haso spent. nine months on the island of st. l'anl, in charege of that island, sinee making that report.

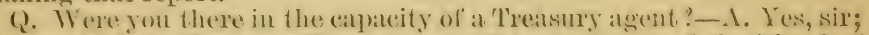
all agent of the Treasury I Department. I took charge of tho island of Nit. Paul on . July 31, 1 sir and was relieved the next spring, April "24, 18ï. 1)uring these nine months I hat an opportunity to study moro rosely the chatrater of the population. IThile on St. (ieoreges it was a question low to keep the peoplo alive; they were short of provisious. On the island of st. P'at in the winter months there is no sealing; there are no oflicial duties for the agent, and I latel time to stuly the population, and I clevoted much of my time to the starting of a school there. I dial the same on st. Cerorges, lut my time having beren very limiter there, I could not attend to it so much as at St. l'aml. Mlost of the alults speak intolligently liussian, and so do a good many of the children. Now, throweh the ability of a good many of the chibhen to speak liussian, I was able to start an linglish school. I sate my (xplanation in liussian, so those who understood liussian gate these explanations in Alentian; and in this way, after nine months, I sueceeder in preparing this seluobl to be led amb taught by a teather who could not command two languages. I took a great cleal of interest in the progress of the population. They are a very good people, and deserve ing of the very best care.

(g. The lease of the Government requires certain things to be done for the benefit of the population by the Alaskit Commereial Company. What were your observations upon that subject; what is the company doing for the population in that respect?- At At the time of my stay the arent of the eompany there was II. II. Me Intyre, and I never hat to make any presentation to him in that respect. I salw thateverything which was stipulated, and more, was done for the comfort of the natives. 
Q. WVill you state in retail the nature of the care hestowed upon the netive popinlation hy the company ; or is that contaned in your resjort? - 1 . I refer to it in this. Now, I will state a point which is imwontant, and which rloes not apjear in this, and that is, that the comjouny fixes the priees of the commonlities sold to the natives at no greater

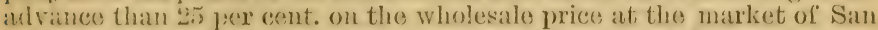
Fancisco. 'This was, I think, done at my sugrestion, il I reeollect well.

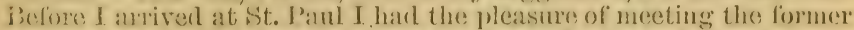
fresident of the eompany, (ieneral Miller, and I calleal his attention to thati point, ander les said he would (lo as I sugeresterl. As to the eomgeasation for the work clone for the conspany by the matives, it is paid in money at cortain fixed prices. My idea was flat the amomnt of the eompensation and ralue of that, compensat ion would not be cletermined ot hrowise 1 ham by the company, who land a monopoly to fumish supplios; and if the natives had not a fixed standard of prices for the supplies furnisher them, the company mipht say: "WVo will pay for each skin $\$ 1$, and then charese then $\$ 1$ for cath pound of sugar." "Well, the presiclent of the eompany immediately issurel regulaticus and oremes to their

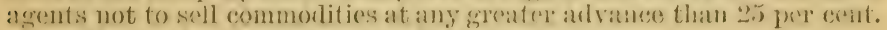
alove flue wholesale price in Säan libureiseo.

(1. Have you is eony of the resulations here, or dirt yon emborly it

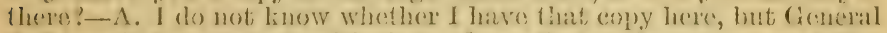
Jefleies will be able to lomish that. I saw that no rlegarture was takan fom that rule lyy the agent of tho company at the stome. Oceasionally

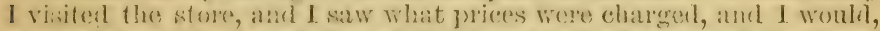
eren whlout the linowledere of the agent, ask the raten of the island

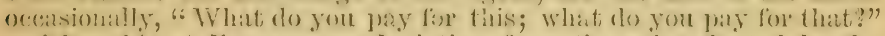

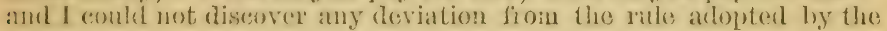
(:) 11 )

(). Vou are satis!ied, then, that they arlhered firithfilly to the regu-

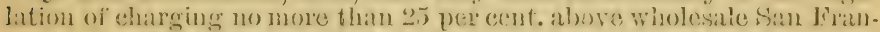

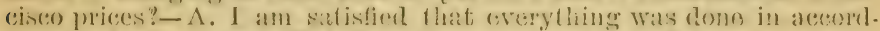
ance with the lease. Mast I not been so sabistied, I cestainly vould have reported it.

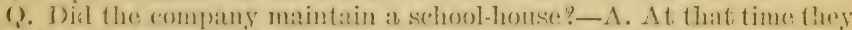

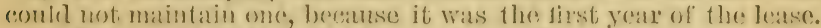

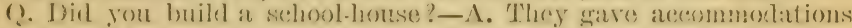

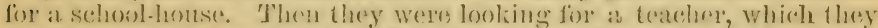

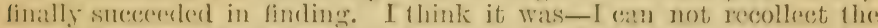

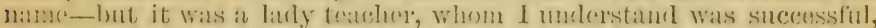
but daving that winter we could not have any teateher, and I volunterened

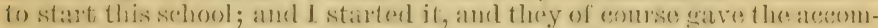
morlations. There: was is very good building which was well hraterl,

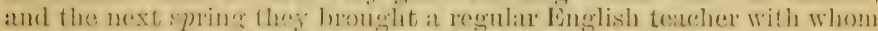

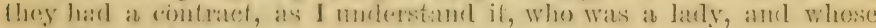
name I cau not recollect.

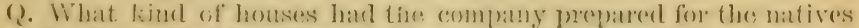
fhere?-1. At that time they had five or six enttages built; that was the starting point. I think they huilt half a dogen eottages, which were an immense improvement over the losels in which they lived in the ground.

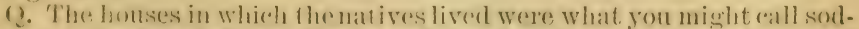

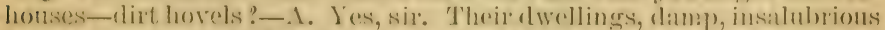

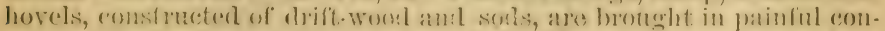
trast with all of here comolitions of their life. There heamer mo materials at 
the islands, the natives are unable to accomplish any considerable improvement in their system of building without assistance on the part of the Government. Prevalence of inflammatory diseases of the lungs, mostly due to the miserable condition of dwellings, requires the pressence of a medical practitioner at each island. The recall this summer of the United States military posts at the islands leaves the population withont medical assistance.

Q. Iave you any information whether the company furnishes any assistance to the natives in the matter of medical assistance?-A. At the time of my stay on the islaud of St. Paul there was a German doctor whom I cousidered to be a very good medical practitioner, Dr. Kraemer, in the employ of the company.

Q. Did he charge the natices for treatment, or was lis treatment free ?-A. Yes, sir; it was entirely free.

Q. Have Jou any information as to whether the company have maintained an establishment of that kind since then, so that the natires could be furnished medical assistance? - A. I can not now recollect. I may have inquired into it, but I can not recollect. I must state, Mr. Chairman, that recently I lost a member of my family, and my memory is rery weak since, and I have not jet recorered fully, so you will have to excuse me on that point. It might be proper for me to state, Mr. Chairman, that before the act authorizing the leasing of the islands was passed I was a great partisan of the idea entertained by Secretary Boutwell at the time, of administering tho islands like any other Govcrnment reserrations, cntirely by Government agents. It was considered by Secretary Boutrell then that a monopoly of some kind was absolutely necessary; but while sereral members of Congress who introduced the bill for the leasing were in favor of private monopoly, Secretary Boutwell was in favor of a Government monopoly; and, being thon fresh from Russia and not very well aequainted with the management of Indians here, I thought that the idea of Secretary Bontwell was the better one, and I was trying to assist him in carrying ont that idea. Since, I have learned a good deal more about tho management of affairs in this country by means of Government officers, and I would not now encourage-I wonld not assume the respousibility, of recommending the measures which I recommended to Secretary Boutwell then. This management of the economical side of the fisheries is, I find, exceedingly complicated, and a couple of Government agents would be entirely powerless to manage it.

Q. You mean two Government agents would be powerless.-A. Powerless to sell tho skins and handle them and make any profitable business out of them, and sell them at figures at which a private company may sell them in a foreign market. I understand the company has agents at London, and that they have used a great deal of labor and means in pushing the trade. They hare been successful in raising the price of tho skins in the foreign market to a very considerable extent. I ean not stato the percentage; I haven't that, and I lo not lnow what the present prices are in London. I find, however, that in my report the prices paid in London for seal skins shipped in 1867 and $186 S$ ranged from 16 to 30 shillings per skin.

Q. How mueh is that in American money?-A. Dividing by 4, I say it is from $\$+t$ to $\$ 7 \frac{1}{2}$. The average was, therefore, about $\$ 5$.

Q. That is, about $\$ 5$ for seal skins undressed, as they go from the islands ? $-\Lambda$. That is all the expense, the taking and selling them and shipping to London paid. If we take that under the law there is a tax on? the skins, the abore prices wonld not pay at all. Now, if the Govern- 
ment undertakes to manage that business at the start under these conditions, I do not see what rerenue coula be derived.

Q. That is, if the Goverument changed its policy and took the skins and prepared them and sent them to the London market, jou think it would be doubtful if the Goverument could get as much net as it does now ; is that what you mean?-A. That is what I mean; the Gorernment would not get anythiug whaterer, and would have to support the: natives at an expense to the Treasury. That would have been undonlutedly the result then. Now, to day, I do not know what these are; it might be a special agent of the Goverument might make $\$ 10$ a skiu, but I dio not know.

Q. Do you know what skins are worth in London now ?-A. I do not; General Jeffries will tell you; but I say, on the prices that were com. manded for the skius about 1S70, the Goverument operation would have been a loss.

Q. What is your obserration as to the effect upon business and the neal interests of Alaska generally by this lease to the Alaska Commercial Company ; that is, what effect it has generally upon the commercial and business interests of Alaska outside of the seal islands? IVhat are its relations to the population of Alaska, not of the natives alone, but of the business population and inhabitants of Alaska?- $\Lambda$. On that subject I have no information of my own knowledge, as I had no opportunity. I never visited any other place in Alaska but the two islands and an island in Alaska where the steamer coming up stops. I made some notes about the island of Oonalaska: "The only place in the territory besides the islands of St. Paul and St. George which I had an opportunity to risit was at Oonalaska, the most important of the Aleutian Islauds, which is situated near the Oonimak Pass, which is the best en. trance to Bering Sea, and possesses a good harbor. Oonalaslia is visited by vessels engaged in the fur trade more than any other, not excepting Sitka. The principal settlement on the island is Illnook Irarbor, with 300 inhabitants. It is the religions metropolis of the Aleutian tribe. From this point the light of Christianity spread all over the Alentian Archipelago. Here lived the apostle of the Aleuts, Father John Veniamiov, whose name and teachings are reverently transmitted from father to son in every Aleutian family.

"Fishing and sea-otter hunting are the principal occupations of tho inhabitants of Oonalaska. Fresh and dried fish are the staple articles of food. 'The sea-otter skins, of which the Oonalaskans secure from three to four hundred a jear, are traded at the rate of from $\$ 15$ to $\$ 35$ for clothing, hardware, crockery, sugar, tea, and tobacco. 'The Aleutian tribe, numbering about 3,000 , receires nine-tenths of the trade of the Territory, and is umquestionably far in advance of all other tribes with respect to inoral, religious, and social development." That was absolutely true in 1870.

Q. The Alaska Fur Company deals with other furs than seal furs, do they not?-A. At the time I was at Alaska there were two stores thero that traded with other furs, principally of sea-otter furs.

Q Are any other companies engaged in tho trate in Alaska, excejt the Alaska company?-A. I know at that time there were two; there was Taylor \& Bendel, and there was auother small store, the name of which I forget. laska.

Q. There was some fur trading on the Yukon and otherp rivers. Do you know anything about it?-A. Nothing except from hearsay. 
Q. You do not know what companies are engaged in fur trading along the upper coast of the Bering Sea?-A. No, sir.

Q. At Oonalaska was there a lively competition in fur tratte?-A. At the time there was quite a competition.

Q. Have you any knowledge as to whether the Alaska Commereial Company is able arbitrarily to fix the price of furs; I mean other furs than seal furs? - $A$. I do not know of any other means than by buying out the competitor; that is the only way.

Q. And to confine competition?-A. At that time there was competition. I have heard since, occasionally from parties not rery friendly disposed to the Alaska Commercial Company, that they harl stamped out competition; parties had been compelled to retire, but I do not know anything of my own knowledge.

Q. That is mere rumor?-A. That is mere rumor; I can not testify about that. I want to state that it was the very beginning of the establishment of the leasing system, and that no clefinite results could have been ascertained at tho time. It was all new, all fiesh. The start was satisfactory, and when I came back I had to report to Mr. Boutwell that most of our prejudices-and they were very strong-against leasing to any company, not against the Alaska Company, but against the policy of leasing, had to a great extent subsided ; and if they continned as they commenced I did not see that any harm was done, and I was satisfied that the natives (whose interest I took rery much to heart, becanse they were in some respects comutrymen of mine, and for whose welfare my old country, Russia, was morally responsible) and their interests would not be injured; on the contrary, there was an improvement in their well-being. The cottages that were built certainly were better dwellings than the old ones, and there was a promise ( $\mathrm{I}$ do not know how far it was kept) that every family would be furnished with a comfortable wooden cottage above-ground.

Q. Were they better clothed, did you observe, and were the natires personally improved?-A. They had all the clothing they wanted, aecording to their tastes. 'They ordered such things as they' wanted and the agents of the company brought them.

Q. What was the state of feeling among the natires on these fur seal islands toward the company ; was it one of satisfaction or discontent? $\Lambda$. There was at the time some dissatisfaction, but it was mostly of our own creation; that is, MIr. Charles Bryant, of Fair Haven, who was chief Govermment agent there, acting under the impression that the plan of Mr. Bontwell would be alopted by Congress, spoke throngh an interpreter, employing me as an interpreter, to the natives, and made promise of a very fine compensation and that sort of thing, and when the lease came to their knowledge, and when they learned that they would hare to rork for the company and be dependent on the companyand not upon the Great Father, of whom the agent spoke, there was some dissatisfaction; but at the end of the first season at St. Panl I found that they had entirely reconciled themselves to the situation and were cheerful, and were indulging in dancing. The only complaints which appeared in my time were against the efforts made by both the company and the Govermuent agents to suppress the brewing of intoxicating and poisonous drinks, which was known by the name of quass. That is a Russian woril, but by no means is it in Russia as bad as in the Alentian Islauds. Quass is a sour beverage used all over Russia, and is made from grain without any sugar at all. It is made from brewing rye to the point of oxydation, and is entirely a sour beverage. The Aleutians arlopted that name for something that is entirely different, 
where the fomentation is earried on to where it produces alcohol in a considerable quantity, and then they put some berries in it which have a tendeney to produce some poisonous substance. I saw a case during my stay there, where a woman indulged in quass one evening and was found dead in the morning. The doetor said it was nothing else thas drinking that beverage. Now, they wanted that beverage very badly, and that was a very great grievance against the company. The company took rery stringent measures so as not to sell any family moro sugar than was absolutely necessary for their tea.

Q. Did the company induce or promote the introduction of intoxicating liquors there at all ? $-\Lambda$. No, sir ; on the contrary, the agent of the company, Mr. MeIntyre, was a temperance man himself, and he was very stringent, and sometimes I eren had to intercele for the natives. I would say, after the consultation with the dloctor, "let him have some." That was on preseription of the doctor; not that he was actually sick, but in cliange from his habits to total abstinence it was necessary to gradually bring him to temperance labbits. But the agent was very stringent.

Q. Did the use of intoxicants prove luurtful by producing breaches of the peace and disturbances of good order among the natives when they were permitted to have them at all; was the tendency that way ?A. They would get loud and boisterous, but I do not linow that they ever fight. I never saw a fight among the Aleutians.

Q. Uave you any knowledge of murters, or violence, or fisticufls while you were there? - A. Not any murder, and I do not imagine how a murder could occur. They are a very good-natured people. I speak only of the Alentian tribe; I do not speak of the Indian tribes that inhabit the eontinent.

Q. I am directing my attention to the Pribylov Islands.-A. Most of the inhabitants are the $A$ lentian tribes tiat were brought over by the Russian company years ago.

Q. I want to understand the effect of the administration of the Alaska Commercial Company upon the social condition of the natives.-A. I ean only gire you my experience of what it was there the first nine months. The measures taken and the orders issued by the company and their agents were directed toward an improvement in the moral and material condition of the natives, and some results were obtained then by the building of a few houses and by eliminating the use of intoxicants, and by starting a school.

Q. Hare they a church?-A. They have churches on both islands.

Q. Administered by Catholie or Russian priests? $-\Lambda$. $\Lambda$ the time there was a liussian priest, I think, on St. Panl and a native subpriest at St. George. I do not know that they are able now to educate native priests there. Under the Russian administration there was a branch consistory of the Russian ehurch at Sitka where they edueated natires for assistant clergymen, and then promoted them, as Father Veniam. inov was a native Alentian.

Q. By your observation was there any neessity for the presence of a peace officer upon these islands to preserve order and settle difficulties ? - $\Lambda$. Not the slightest; they were afraid of an officer of any kind, whether an agent of the company or an agent of the Government; they considered them powerful anthorities and would not work against them unless the two agents would incite them arainst each other. 'That might happen. In my time there was nothing of the kint. MIr. MreIntire was a perfect gentleman and was willing to do anything suggested, as the agent of the company. If there was rivalry between the agent of the 
company and the ageut of the Goverument, I do not know to what lengths they might go. The Aleutiaus are not a fighting population at all. They are a quiet, peaceable people.

Q. Well, by whom was all the work doue for the company given on the island; it necessarily had some work done, taking the seal skins and preparing them for market, ete.; by whom was that work performed? $-\mathrm{A}$. By the natives.

Q. Exclusicely ?-A. Exclusicely. At the time there were no laborers other than natives. The foremen were in the employ of the Government. There was a gentleman by the name of Webster employed by the company. He ordered the work, and under his orders and those of the elected chiefs, who also received orders from the agent of the company, and then transmitted them to the working gangs and superintended the whole work.

Q. Were they fairly compensated for their work, do you think ?-A. In regard to the compensation, I have a note here: "The price paid by the traders to the natires for each skin was nominally from 20 to 40 cents, but actually less, as the same traders realized on some articles furnished to the natives a profit of nearly 100 per cent. At present, when the Alaska Company has fixed the prico to be paid to the natires at 40 cents per skin and the advance on San Irancisco prices for commodities brought to the islands at only 25 per centum, the different figure of costs will be considerably increased." What the present rates are I can not say. At the time it was 40 cents a skin, and that was very good compensation for the labor performed.

Q. How was that paid-in money? - A. It was paid in money; in hard cash. There was a lot of silver half dollars there.

Q. Coined by the United States ?- $\Delta$. Coined by the United States; and, I am sorry to say, they gambled with that money. The natires would gamble two or three nights in succession withont goin g to sleep. I hope they have abandoned that habit now.

Q. Dirl any oflicer or other employé of the company than the natives themselves gamble with them; in other words, did any one besides the natives gamble with them and win their money from them?-A. No; there was not a white man on the island who would condescend to gamble with them. The stakes were small and the air in tho horels was so stifling that no white man could enjoy it. It was confined among themselves, but I judge some reckless characters will be found in every community. There were lots of fathers of families who were saving every half dollar they could get, and I suppose they are rich men now.

Q. Are any ineans provided for the deposit of their savings? Was there any such thing as a savings-bank or safe deposit?- $-\Lambda$. There was nothing at the time except that the Alaska Commercial Compauy's agent had a book for that purpose, and I understood that he deposited that in San Francisco, and there invested it in good investments. I do not know how it was done, but I know at the time the deposit might be drawn by any native at sight.

Q. Have you any linowledge of the method by which the earnings of the natives were adjusted; was it upon their own plan or upon the plan of the company? $-\Lambda$. Yes, sir. There is a statement here whero the assistant 'Treasury agent, Francis 'Tessen, reported to Uaptain Bryant; this was after my time, but the same system continued:

August 15 a division was mallo among the natives of the earnings of this year's sealing, which amomnted to $\$ 29,67.4 .60$, and was divided by the chief in my presence, as follows: Thirty-eight first-class shares, at 114 per cent., 8135.11 per share; 20 second-class shares, at 90 per cent., 5.3.) L.r. per share; 10 third-class shares, at 80

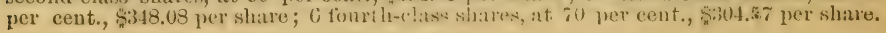


Thes fourth class are a shiftless lot of men who do not care to work very hard.

Q. Who fixes that classification?- $-\Lambda$. That is fixed by tho chiefs. It is a traditional custom there. I do not lnow whether it continues now, but at the time it was a long-established practice.

Q. The idea is that it is based upon merit?-A. Upon the skill of the men and their application to work. Those who ent most skins are the worse, and those who ent less skins are the best workers and get the largest share; but at the same time there was not a rery great difference between the earnings of the first-class men and the carnings of the third-class workers, as it was $\$ 455$ for the first elass and $\$ 304$ for the fourth. There was $\$ 150$ difference only between the two extremes. At the price in San Francisco, which is an advance of 25 per cent., the earnings of one man, $\$ 304$, represented there quite a comfortable existence, seeing that their clothing need not be of a very elaborate style. All they want is to keep warm.

Q. Wero there any disputes or contentions between the inhabitants and the company as to settlements in closing up the business transactions ? - A. Not in my time. The only case to my personal knowledge that I can remember in my three months' administration on St. George. Islaud and nine months on St. Panl was a case of insolence on the part of some boys-young boys from nincteen to twenty-against the assistant agent of the company. They said they would not ohey him, and would kill what they pleased. He said, "You are prohibited by law from killing female seals." They said, "Just to spite you, we are going to kill a female seal; " but they never killed any. The agent reported the caso to me, and $I$ came out and told them they had no right to kill female seals; that it was not the agent of the company, but the law. The next clay they were on the best terms with the same assistant agent.

Q. Does your report, which will be copied by the stenographer, contain an accurate description of the manner of taking an account of seal skins ? - A. Well, as to the counting I clo not linow about that.

Q. Does it describe the manner of taking and what kind of seals aro taken?-A. Yes, sir; that is there.

Q. Are not females taken at all ?-- $-\Lambda$. No, sir; not at all.

Q. WVell now, please, will you explain how the skins are counted, how the Government's interest is protected, and what the agents do there towards limiting the taking within the requirements of the law, and how they aro counted ?-A. The way it was done in my time was this : After the killing the agent gare me a written report of the number of skins taken and the number of seals taken and I would enter it on the book. Then the rerification of this report eame at the time when the skins were to be shipped from the warehouse to the company's steamer to go down to San Fraucisco. No skin could be put on board a ressel without the presence of the Government agent, when they were counted.

Q. They counted them as they went on the ressel?-A. They were counted from the lighter to the ressel. If a skin fell orerboard from the lighter and could not be fished, it was noted. 'Sometimes a bundls which is rery heary fell orerboard and could not be recovereit, but single skins are more easily handled. They drew them from the lighter and two tally-men counted them aud the Goremment agent sat on board and kept a tally. The agent of the company kept a tally and the mate of tho ship kept a tally; and the three tallies would generally afree within a ferv skins.

Q. Were they counted again after that? - A. I do not lnow of my 
personal knowledge, but I have heard from reliable witnesses that they are counted in the same way on unloading at San Francisco in the presence of the officers.

Q. They are shipped from there to the custom-house in San Trancisco?-A. Yes, sir; and there again comnted by the officers.

Q. So they are counted again at San Francisco and the tax paid so much per skin?-A. Yes, sir.

Q. Have you any means of making an estimate of the probable number of fur-seals that risit these islands and rookeries? - $A$. I saw an approximate estimate made by Mr. illiott. I do not know that I ever inclulged in auy figures as to that. I simply expressed my impression here [examining report]; no, I see I did not indulge in any guessing.

Q. You say that Professor Elliott has malle some estimate of that?A. Yes, sir; I say I did not mako any estimate. I do not think any estimate would be within a million or two. I think he puts them at five millions, but it may be three or seven millions, as they are countless. It is a sight never to be forgotten by one who saw it, and it recurs sometimes in my dreans-that rast extent of beach eorered hy these animals.

Q. Have you any knowledge of the fisheries of the Bering Sea-car, halibut, salmon?-A. Yes, sir; I have seen some halibut caught by natives, but not as an article of trade, simply as an article of foor. They subsist mostly on cod and halibut and every description of fish which they can find. They dry and preserve it for winter.

Q. Did you form any opinion of the number of Goverument agents that are necessary there under the present system to overlook the interests of the Govermment and protest it? Under the present law there is one general agent and three assistants, I beliere. Is it necessary to have so many?-A. I do not know. Under orlinary circumstances I do not know that there is necessity for so many; two would do, but taking into consideration the possibility of sickness, death, and that sort of thing, I think one would not be sufficient, because there might, be an emergency. It was considered necessary to have them on aceount of the impossibility of keeping any one agent for any length of time there without injury to his health; he would want to go down and reeuperate.

Q. Is there an agent of the Govermment there all the year romm? A. Yes, sir; the year round.

Q. What is the necessity, then, for the Govermment agent remaining there after the season is passed ?- $\mathrm{A}$. I do not think there is any ; I do not see any necessity for it.

Q. As I understand it the taking of seal skins commences in June and winds up in September. The seals leave the rookeries, as a general rule, in October, and there are no seals from the last of November to about the last of May or the 1 st of June; is that correct?-A. I think that is about correct. Some single old bulls stay longer; not the family bulls, they go with the females. At the commencement of spring they begin to appear in the Bering Sea, coming from the l'acifie, throngi the straits of the Aleutiau Islands, chiefly through the Dunimas Pass. Full-grown males (ealled bulls) are the earliest visitors at the islauds of St. George and St. Paul; they approach the islauds in the last days of $A$ pril, and await, the arrival of the females, which takes place considerably later. The seals invariably select for their resting-ground (rookeries) such beaches as are strewn over with large bowliers, affording a safe hold against the sweep of the surf; flat santiy beaches are carefully aroider? by them, probably on account of the dauger to which 
the new-born seals would be exposed of being carried off by the sea before they have learned to live in that element. From the time of their settling on the rookeries to the epoch of the appearance of the females the bulls sleep almost without interruption. Towards the end of May they begin to look ont for the coming of their families. The lumting begins ats soon as the resting grounds are fully occupied, which generally happens about the end of June. It is earried on until the midlle of November, when the seals leave the islands to disappear for fire months in the vilst expanse of the Pacific. The end of the season can not be stated otherwise than approximately. Sometimes it will be two weeks later and sometimes it will be two weeks earlier. I should say the latest average is about November 15.

(Q. What are the opportunities for fraud upon the Govermment in the taking and connting of fiu skins? Is there any opportunity for seals to be taken withont the knowledge of the agents; taken from these islands and seas abont the islands?-A. I do not know. No consider. able number. Of course, a counle of slins might be sunggled by the eook of the slip in his locker, and nobody would know that. But I think the mate would look sharply after that, and he is instructed by the company to look after that sharply.

Q. Is there, in your opinion, any opportunity for the company itself, on that plan, to practice large fraudis upon the Government in taking skins and smuggling them away from there? $-\Lambda$. I do not think it would be practicable, even if they wanted to do it. There are too many people looking after that. I could imagine a collusion between the company and the Corernment officers, but that is a very wild scheme to imagine. Some one might refuse to enter into the scheme, and some one entering into it might quarrel afterwarls and turu state's evidence. It is rery dangerous, and $l$ do not think there is any inducement. I do not kinow of a single man who would enter into any such condition. There is no inducement for the eompany doing it. There is no human possibility for there being any inducement or any reason for their doing it.

Q. In other words, you do not think it would be to their interest?A. Not at all ; it would be to their interest to pay for more skins, rather than to save taxes on a few odd thousands at a great risk and peril.

By Mr. JEFFRLE:

(2. Of what cuntiy are you a native?-A. I am a native of Russia.

Q. Of course you speak tho liussian language, and read and write it, that being" your native language ?- $\Lambda$. I speak Iussian as perfectly as 1 spoke it twenty years ago.

Q. How long were you on the islands of St. Panl and St. George?-A. Three months on one and nine on the other. I was about one year on the two islands.

Q. You went.ul as an agent of the Treasury Department?-A. Yes. I was not oflicially styled agent. I was a clerk in the Secretary's oflice detailed from the Department to assist the agent.

Q. What time in 1870 did you go up ? - A. In July.

(2. That was at the begimning of the operations of the Alaska Company under its lease? -A. That was before. When I sailed there was 110 law and no lease. I went under the orders of the Secretary to seo that the law prohibiting the killing of the animals was enforced.

Q. As I miderstand it, there had been an order of the Treasury Department forbidding the lilling of firr seals, and the natives were in straits for food, and that was what you referred to in an auswer to a 
former question here abont St. George Island. You went there to see about arranging for food?-A. The instructions wero to prohibit the killing of fur seals for the sake of furs, but to allow the matives to kill such seals as wero necessary for food.

Q. The Alaska Commercial Company had nothing to do with that?A. No, sir. The company had no official existence on the islands until October 19, 1S70. That was the first vessel that brought the news of the establishment of the new system.

Q. Now, where are these seal islands located?-A. They are located in the middle of the Bering Sea.

Q. Which one is the nearest to the mainland?-A. The mainland is so far away that it is very difficult to say which is the nearest. Thero may bo a few miles difference in the distance, but I should think 200 miles. I never paid any attention to that.

Q. About how far from the mainland are these islands located in the Bering Sea?-A. If you draw a radius of 200 miles, taking one of the islands for a center, I think you will strike land.

Q. How large is the island of St. George; how many miles long, and how many does it average in width? $-\Lambda$. Iou can find that information here somerhere. It is not in my report. If you permit me to speak from remote recollection-as I stated to you, my memory of late has been weakened-the island of St. George would be 7 miles one way and 4 miles the other. The island of St. Paul would be $1 \tilde{5}$ miles one way and 6 or 7 the other.

Q. Now, has the Alaska Commercial Company's lease, so far as you know from your connection with the Goremment and your experience on tho islands, any rolation to any-part of Alaska excent those two islands?-A. Not any relation so far as I know.

Q. Does it relate exclusively to the seal rookeries?-A. It relates exclusively to them.

Q. Aro thero any seal rookeries belonging to the United States at any other point in Bering Sea, except tho Pribslor group? - A. I do not know of any such seal rookeries.

Q. Do you linow whether the Alaska Commercial Company has a leaso from Russia for tho seal rookeries in Bering Sea west of oirs in the Asiatic waters?-A. I have seen official documents to that effect some several years ago.

Q. About how far, in your juclgment, are these rookeries from the rookeries belonging to the United States? I just want:your judgment. Is it more than 100 miles ?-A. It is orer 200 miles. I would put it at 300.

Q. Do you know what the limitation under their lease with Russia is in regard to the number of fur-seal skins that may be tako on the Russian Islands?-A. No, I do not recollect; but I will try. I must havo seen the figures somewhere. My impression is $25,000, \mathrm{I}$ think.

Q. Do you or do you not know that the only limitation is that they are not to tako less than 1,000? I will put the leaso in eridence before we get througin.-A. I do not know.

Q. Assuming that to be so, I want to ask you whether there would bo any object in taking an excess of skins at St. Paul and St. Georgo when they had other islands whero they could tako as many as they wanted?-A. Not unless there was a very marked differenco between the prices paid for the privilege on one side and the privilege on the other.

Q. You hare stated that you heard from some persons or person who was not friendly to the company that the company had stamped 
out competition in tranle at a certain place or places. Now, do you remember who it was that was stamper out? Do you know any particulars? $-\Lambda$. No, I do not remember the particulars.

Q. Did that report come to you in any anthentic way?-A. No, sir; it was simply a casual remark from some one who was talking about the matter.

Q. Now, was that in relation to the fur-seal islands?-A. No.

Q. Nobody has a right to compete with them on the fur-seal islands?-A. No.

Q. So far as the company hare relations to the Alentian Islands and the main land, they have no relation to the Gorernment, have they ?A. Not any more than any parties sending ressels and goods for that Territory.

Q. You or I as individuals, or a firm, or a company, can go to Alaska and trade, and have all the adrantages the Alaska Commercial Company have and all the privileges except as to the fur seals? $-\Lambda$. Of course that is a Gorernment reserration and nobody can land unless permitted.

Q. What I wish to make plain to the committee, if it be true, is that the Alaska Commercial Company's business with the main-land and on the Aleutian Islands and ererywhere else in Alaska except upon the seal islands is managed just as anybody else's business is managed.-A. I do not know any provision of law or regulation of the Treasury Department that would authorize any discrimination between the company or any other company or trader with regard to the trade in the Territory outside of the fisheries.

Q. So that the business of tho Aliska Commercial Company in relation to the Gorernment is confined to two small islands in the middle of the Bering Sea; is that true?-A. It is true.

Q. What is the formation or topography of those islands, voleanic or otherwise? $-\Lambda$. From my recollection it is volcanic.

(2. Dothes produce anything ; does anything grow there of use to the inhabitants? - A. Well, there is some rery coarse grass, some moss, and a kind of blackberries.

Q. There is nothmg there for which anyono would emigrate?-A. No.

Q. Now, will you tell the committee what sort of people are the native inhabitants of those islands, in regard to their character and docility?A. I think I have spoken already sufficiently on that point, but I will state it once more. I can not imagine a more peaceable, quiet population than the Alents.

Q. Now, in relation to their habitations, of which you have spoken, I want to ask you if they were not formerly mostly under ground?A. Yes, sir; they were mostly under ground.

Q. Were they damp and untholesome?-A. Yes, sir.

Q. What do you know of the treatment of the natires by this company as compared with their treatment prior to their becoming citizens of the United States? - A. I think it will be a sufficient answer to say that while the Alaska Commercial Company has no right to treat tho natives otherwise than as freo people, tho employés of tho Russian Commercial Company had all tho power and almost the right to treat them as slaves. It depended entirely upon the character of the employer.

Q. $\Lambda$ s I understand it, the Russian company had the power of life and ileath orer these people?-A. Legally, not; but practically it might have happened under the administration of Baranof. Governor 'Baranof' gave the whip to a Russian officer.

Q. What, in your judgment, from your experience of that business 
in those islands, would be the effect of opening up the business, that is, remoring the restrictions so that everybody conld go in there and kill fur seals ?-A. The probable effect would be to drive the seals from those islands to the Russian group.

Q. That is, driving them from the American islands over to the Russian islands ? $-\Lambda$. That is the most probable effect. 'That was conceded at the time by all who studied the question. Secretary Boutirell knew that very weil.

Q. Would it have been difficult when they established the boundary between linssia and the United States to have retained these islands in Russian waters or not? $-\Lambda$. I have nerer tried to draw a straight line inside these.

Q. You say that the effect would be to drive them over to those islands? $-A$. The probable eflect.

Q. Hare you heard it stated by any one that it was the expectution of the Russians that onr people, not understanding the business, wonld drive the seals over there?-A. I may have heard a remark to that effect, but I hare no definite recollection of that. I have seen it somewhere in writing, but I do not know by whom or on what authority.

Q. Do you know if the Alaska Commereial Company employed or retained in its service men who managed the business for the Russians; natives and experienced hunters?-A. I can not understand-do you speak of the two islands?

Q. Yes, sir; whether they retained any men, experienced seal hunters that the Russian company had employed, or whether they discharged them ? $-\Lambda$. I do not know of any man employed by the company ou the islands except the natives. I have not seen a single Russian there except inyself.

Q. I want to ask you in the erent the business was destroyed by being thrown open, what would become of those natives; how are they fitted for earning a livelihood if that business was destroyed ?--A. They could not earn any livelihood at all. They would have to die by starvation or be supported by the United States. They are entirely dependent upon that trade.

Q. Where are those seals born? Where do the female seals give birth to their young ? $-\Lambda$. They are born on the rookeries.

Q. Are they an animal or a fish, or what are they; how do you classify them ? $-A$. They are hot-blooded animals borm on the laud; they are not a fish.

Q. And born on the. United States territory, are they?-A. Ies; all those born on the islands of St. Panl and St. George.

Q. That is in United States territory ?-A. Yes, sir. "Fisheries" is a misnomer all the way through, and always was.

Q. What do you know about their habitually returning and seeking the same rock, the same rendezvous; I mean the older seals?--A. IVell, I hare heard it stated many a time by the old in!abitants there, the chiefs, that they would come to the same rock, to the same borlder, year after year, and that they had cut the ears of some young seals so that they would know them, and they wonld notice that seal coming to the same rock and the same spot on the rookery year after year.

Q. So far as it eame within your linowledge did the company perform its contract or not? $-\Lambda$. So far as I know, it did to the letter, and in spirit also. There was a tendency then to create the most favorable impression, and to conciliate the views of the Treasury Department, which was known to have been hostile to that plan. 


\section{TESTIMONY OF H. A. GLIDDEN.}

\section{H. A. GLIDDEN, sworn and examined.}

By the Chatriman:

Q. State whether or nof yon were at any time an agent of the Treasury Department charged with the duty of overlooking the contract of the Government with the Alaska Commercial Company; and if so, when.-A. I arrived there the 31st of May, 1853, and I left there about the Sth of June, 1885.

Q. Now will yon state the locations of these islands?-A. They are located in about the middle of the Bering Sea. I suppose they are 57 degrees 30 minutes north latitude and 170 degrees west longitude.

Q. How far are they from the main-land?-A. I shonld judge it is about 500 miles; but my information is only what the boys said to me. I judge they were 500 miles from our coast, and about 700 miles from the Kamchatkan coast.

Q. What condition were tho natives in when yon got there-I mean the matives on the islauds ?-A. In what respeet? Their general condition?

Q. Just state thier general condition and appearance.-A. I do not, know how to answer that. Thiey are of Esquimans and Russian descendants. Some of them look like Chinese, as they have the almond eye.

Q. How did they live? How were they provided for?-A. Well, they lived in frame houses. There were about sixty frame houses there on St. Paul Island. I know more about that island than about St. George, although I went to St. George every jear while I was there. They were dressed as well as laboring people hero are generally dressed.

Q. Do you mean well-to-do laboring people?-A. Yes, sir.

Q. How were their houses furnished-with what degree of comfort inside ?-A. Their houses, as a rule, had beds and ordinary wooden-bottom chairs, tables, stoves, and such things as that.

Q. How were they supplied with other comforts inside of their houses ?-A. The Alaska Company furnished them 60 tons of coal a year-40 tons for St. Paul and 20 tons for St. George-which it distributed to thom free of cost. They burned, in addition to that, blubber from the seals. The seal first is skimned, then under that is a layer of fat, which is blubber, and that blubber is ent off from the rest of the carcass. They use that food for fuel, and during the killing season they pile that up and the company draw it to them in their wagons.

Q. Do they make any eharge for that?-A. They make no charge for that at all. Then they have salt to preserve it in hogsheads or bius in the ground. This they use for fuel. When the seals are killed during the year they take as much of their carcass as they want and tise that for food, and whenerer it is out of season to kill them, and when. erer they want seal meat, a drive of seals is made, and they are al. lowed to kill two or three hundred for food.

Q. Are these the young or old seal?-A. They are the same age at which they kill in the killing season-from two to five ycars old; that is what the killing age is when they kill them for fur? The skins of these are salted, when they are good, and go to the account with the company. In adidition to this the natires are great loves of crareliers. There are comparatively few of them that malie bread-al fex of them can make bread aud do make it-and they will go to the sture and buy $9984-2$ 
crackers every Saturday and every Wednesday, when they get all the crackers they want.

Q. What were your observations of the prices charged them for such commodities or articles as they bought from the store at the time?-A. I was in the store a great deal because I had a curiosity to watch the natives trade. It is as good as a show to see them trade, as they have so many peculiarities about them. The prices charged for ererything I saw were as reasonable as I could buy for in San Franciseo at retail.

Q. Do you know anything about the regulation of the company in regard to cbarging 25 per cent. above the wholesale price at San Francisco, referred to by the preceding wituess?-A. They charge 25 per cent. above the wholesale price in san Franscisco. I examined their bills, and so far as I saw there was no evidence of any variation from that rule. There are some things I did not notice, but these were unnecessary articles, jewelry and such things, which I never looked into The natires are very fond of jewelry and very fond of dress.

Q. Were any intoxicating liquors sold there at the time you were there, or furnished to them in any way?-A. No, sir; never. Uuder my instructions and directions, they dil furnish in a few instanees intoxicating liquors to natives when they were sick, on the order of a doctor.

Q. In the way of a prescription?-A. Yes, sir.

Q. Was there any physician there at that time?-A. Yes, sir; and the physicians and medicines were free.

Q. Uuder whose employ?-A. He was employed by the Alaska Compauy, and he was a vers excellent physician too, because my wife was very sick for about three months, when she did not leave her room, and he doctored her all the time. He is a very able physician.

Q. Aud no charges were made against the natives for medicines or his services?-A. No, sir. And very often when a person is sick he goes to the kitchen of the company to get food. The native are no cooks. They can put a carcass in the pot and boil it, but that is about all they can do with it. When they are sick and want something extra, they get an order from the doctor and go to the kitchen and get foodif they want a soup or something of that kind.

Q. What were their educational facilities when you went there?-A. They had a very fine school-house, better than the average of our schoolhouses in the State of New York. They had blackboards, maps, globes, and ererything which an ordinary school would have. They had an excellent teacher. The first year $I$ went there there was a gentleman from New York who was a teacher. They are good schools, but the natives and priests do not like the children to attend English schools. They are opposed to it in some way because they think that it might attract them away from the church, which is the Greek Church.

Q. They insist upon keeping up the Russian language ?-A. Yes, sir, as far as possible. In the last few years the teacher they had was a native Russian, a young man who came to this country when about thirteen years of age and engaged with the company to teach school, and he could talk both Russian and Euglish. He is a very excellent teacher and took a great deal of interest in it.

Q. What was the attendance at the school; what percentage of the children attended ?-A. When I first went there they would not go to school, and it used to be the custom to go and hire somebody to go and bring them into school. I pursued a different course. I issued an order-there the agent is the supreme ruler, and when au agent issues orders they are generally obeyed promptly-I issued an order that they 
must come to school, and in case the children did not, I should fine the parent 50 cents for every day his child was absent, unless he had a sufficient excuse. Well, I pursued that course, and in the first month I collected about \$13.50. I made them pay it, because they could not help but pay it. I told the company I wanted them to charge to a man so much, and they would bring him in there and make him pay it. It grew gradually less and less, and the last year I was there I believe I hid not collect scarcely anything at all, and the attendance was full. There was a better per cent. of attendance, I renture to say, than any school you might find in the State of New York to-day. That is what I shonld call compulsory education. I so reported it to the Treasury Department.

Q. Did tho children seem to be proficient in their studies ?-A. They are usually dull, and it is very interesting to attend an examination, as I did one day, and see great boys fifteen or sixteen years old read from a primer, and think they were doing excellently well. A very few of them make good scholars and get into arithmetic and geography, and so they know how to spell pretty good.

Q. Was any church there when you were there?-A. The Greek church.

Q. Any church edifice?-A. Yes, sir; they are the most religious people in form I ever lived amongst. Their church days and holidays are pretty much continually. That is where I had another trouble; not exactly trouble, but I thought when they had holidays itwould not do to withdraw every scholar from school and I would notexcuse them always. They could not go to church unless they got an excuse from me, without it cost them half a dollar, and sometimes whenI thought it was not necessary I would not do it. But I never had any trouble with them.

Q. Are their moral habits good, as a general rule?-A. So far as I know.

Q. Did you observe any necessity for civil officers, such as constables or magistrates, to preserve good order of society ?-A. No, sir. The agent made the law, administered and executed it. That was about the sum aud substance of it. There was no trouble at all.

Q. Was there any trouble arising from breach of the peace or disorders of that kind?-A. I never had but one case while I was there.

Q. Was it between natives?-A. Yes; I tined them $\$ 10$ and let them go. I never had but one.

Q. Was that occasioned by intoxicating drink, or was it a business or gambling matter?-A. I guess they were playing pool. The natives had a pool table there.

Q. Are they disposed to gamble?-A. Yes; from tire oldest to the youngest, they would gamble in one way or another.

Q. Did any sharp American come in there and gamble with them and get their money ?-A. No Americans gambled with them at all.

Q. Did any white people gamble with them at all?-A. No, sir.

Q. It was all among themselves?-A. Yes, sir; a very few of them play poker for money; but they were very few.

Q. Well, now will you explain the manner of taking these seal skins?A. The seals, when they come over, come in classes, the female seais and the bulls occupsing a rookery by themselves. Then what are called bachelors-

Q. What are those?-A. The younger seals which are not able to fight the bull seals on the rookery, and can not defend their families.

Q. The same sort of bachelors that we hawe here? - A, Les, sir. They haul out in a different locality on shore and lie there. 
Q. By themselves?-A. Yes; away from the fumilies ontirely. The natives, when it is time to drivo up tho seals, get between them and the water, and then they ean drive them anywhere by making a noise with a club or stick or tin pan, and then they drive them to the killing gromuls, which are sometimes one mile away and sometimes three.

Q. And then at the killing ground who superintends the selection of those ro be killed? $-\mathrm{A}$. They are there huddled up and then they are separated, abont difty at a time-corraled, as it were--and tho superintendent of that is one of the employes of the company. They kill them with a club, selecting those only whose finces indicate their age. The natives can tell at once by the face of a seal, as they have had so much experience. They knoek them first with a elub and then stiek them with a knife.

Q. Do they kill any females ? - A. They never kill females. I do not know of but two or three instances in my experience where a female seal was ever driven ont with the crowd.

Q. The word "bachelor" means male as well as the state of celibacy?A. Yes, sir. (Veeasionally they would drivo up an old bull who had had his day, and who could not fight any more, and he goes in with the rest of them.

Q. During what season are these seals taken ?-d. The season commenees the 1st of June and continues until they get their hundred thousand, if they want a humbed thousand. Sometimes they do not take so mueb. One year they only took 75,000 .

Q. How does the Government agent ascertain the number taken?A. The way I managed it was to allow my assistant to count all the skins when taken and drawn to the salt-house by the team from the killing fields, ard he eounted them in there. I did not pay any attention to that. When he had eounted them he brought mo the tally, and we have a record in a large record-book of what was killed each day. The natives knew when we got the number right themselves. They would watch that very carefully. When we came to ship them I did the ontire counting, which would be a check upon my assistant.

Q. You connted them into the ressel ?-A. Yes, sir; I counted them into the vessel.

Q. Was there any further count by the Government after that?-A. They are counted in San Francisco.

Q. At the custom-house ?-A. It is part of the inspector's duty to count them.

Q. Is that where payments are made by the company ?-A. Generally it is made upon the San Francisco count; but one year I came down on the vessel, and I went out to see how they counted them, and I was interested in it. I said to MIr. Gerstle, "I do not beliere you are paying for all the skins wo get." They can not count them the way they do and count them correetly. They count them this way [illustrating with his hands], fast, you linow. Their count eame out a little short of my count, so they paid on my count and not on the San Francisco count that time.

Q. How much wero they short of your count ? - A. I think about 100 skins.

Q. Have you any knowledge of the former condition of the vi. ives as compared with the condition of the natives when you found then. ?A. I only know from what 1 heard from the natives and others.

Q. Well, let us hear what you heard from the natives themselves ? $-A$. They agree to this, that they have more to eat and live better, but they do not get as much to drink. I had better state what I did. 
Q. Well, let us have that.-A. As Mr. Buynitsky said, they manufacture a beer called quass. When I went there my instructions were to do what I could to prevent the manufacture of quass. Well, I had been in the Gistillery business and I lnew how whisky was made. I took a good deal of pains about it, and I found how that was made. I found they could not make quass unless they had sugar. Wo were not selling to each family more than a pound of sugar a week, but the natives would combine, those of them who would like to have a spree, and they would put a pound a week aside until they got enough to maike quass. So I told the agent I wanted him to ship all sugar, except what was used in the kitchen, off the island, and not to sell a pound of sugar to anybody without my permission. He shipped away about sixty barrels of sugar, and they have not made quass since. There has been one occasion since when three of them went aboard a vessel and they got some from a cook or assistant cook.

Q. So that is a species of moon-shining there ?--A. Yes, sir; these fellows had not been in the habit of drinking, and before they got to shore-the vessel being about half a mile off-their feet were tangled so that they betrayed themselves. We had them up to the police court, and tried and fined them $\$ 10$ apiece. That is the only case of drunkenness I had there.

Q. Did the company and the Government agent co-operate earnestly in prerenting the distillation of intoxicants?-A. Yes, sir.

Q. Did the use of intoxicants tend to the disturbance of the peace among them ?-A. Not very much. They are good-natured fellows, but if it was continued, I do not know what it would be, of course. If they have auy trouble or complaint, they alwajs come to the Goverument agent and enter their complaint.

Q. Do you lnow whether there has been any complaint made on their part against the Alaska Commercial Company of interference in their business trausactions with that company?-A. No, sir; only they thought the Commercial Company ordered the sugar away, and they complained to me about that, but that was $m_{y}$ fault.

Q. You removed that to prevent the manufacture of quass ?-A. Yes, sir. In case of sickness, I would allow them to have sugar. They would get drunk on anything they could.

Q. What was your observation in regard to the compensation of the natives for their labors-such services as they rendered to the company? $-\Lambda$. I think they are the best paid working people in the world. I do not believe any laboring people in the world are better paid for the time they work than they are. When I was up there I took pains to figure over from the books in regard to that rery point, as $I$ was interested in it myself. I took the number of skins taken each year I was there and before-the time they are engaged in killing varies from twenty to thirty days-and I figured out the whole arerage for fourteen year's on St. Paul Island that the per diem compensation for the time they worked was $\$ 12.99$.

Q. That is what the laborers earned?-A. Yes, sir.

Q. Does this company employ any other native laborers except the natives on the island?-A. Yes, sir; they had permission from the Seeretary of the Treasury to take a few orer from Ounalashka, not for sealing labor, but for doing other work. There was a time when there was a great deal of sickness and a good many deaths there one year, and they lost about forly or fifty men.

Q. These were natives resident of Ounalashlia?-A. Yes, sir. The 
company had permission from the Government to bring out natives from Ounalashka to do extra work.

Q. They employ no laborers of the United States or otlifer countries? A. No, they employ no laborers except men to orersee the killing and one teamster, I think. No person is allowed to kill a seal except a niative. Nobody but they can do it; it is a trade. Now, in relation to the division

Q. That is a point I want to get at there.-A. After I went there, the divisions were on a little different system from what MIr. Buynitsky gave. I requested the agent of the company to keep erery man's time and the value of his time, the number of hours of work, of the kind of a workman he was; because in the division as previously made, I found when they were made by chiefs, they were made by consultatiou with the heads of the church and the priests, and those persons who were in good standing with the church got a good division, and those who were not, although they might be equally skillful, would not get as much as they were entitled to; and there was some complaint. So I concluded I wonld take it out of the hands of the church and attend to it myself; and they never made a complaint of the dirision thus made, and it did not all go into the church and was more equal. The division is made upon the same way, first class, second class, etc.

Q. You mean the division and the rate of compensation of the labor is made according to the man's merits?-A. According to his merits; yes, sir. They have from twenty-some thousand to $\$ 32,000$ a ycar to be distributed there.

Q. Among how many people?-A. I think there were sixty-one laborers at that time. The number varies each year. I do not believe I have that for each year, but I have a statement of the amount of money that is distributed each year. Then, when the division is made, it is brought into the store and read off to the whole crowd. You have to have two interpreters when you want to communicate with the nativesone Russian, who understands English and Aleutian, who talks the English language, and then to the matires in Russian and Aleutian both. If they erer have any trouble they want to talk to the agent.

Q. Does your observation lead you to conclude the condition of the natires has been improved under our administration abore that of the Russian administration?-A. They had been brought from about threequarters barbaric and sarage state to good, respectable, half-civilized men. You can not make a native in his house be neat in most instances. They will not do that. But they dress better, and thes are more polite and more like white people, and they imitate them very largely. For instance, they come into $\mathrm{my}$ house and see a carpet on the floor, and immediately they want a carpet, too, and everything of that kind. The women all like to be well dressed. They will take a Harper's Bazaar and see a pattern and make a dress very like that. Some of the men are pretty good mechanies. They pride themselres upon their small feet, and you can not get one to wear a coarse shoe. They trapse through the snow in thin kid shoes. If they get a good dress, the women will go to the field and pack seal meat in it. The men make the women do the hard work, and do nothing except during the sealing season. The women pack the meat from the sealing ground. The men are sometimes willing to bring water for the women; but it is only through talking to them, and telling them that is the way we do where we live that they can be influenced to do it.

Q. Now, do you reach any conclusions as to whether the policy of leasing the privilege of taking fur seals is better for the Government 
than for the Government to take charge of it itself directly through its own agents, or whether it should all be thrown open?-A. The Government now, without any care or risk, gets $\$ 317,000$ a year for the lease, and for the $\$ 2.62$ paid for the seal tishing, which pays about 4 per cent. net on the cost of the Alaska purchase, I do not believe, taken any way, they can make more.

Q. You do not believe the Government could take charge through any agents and make a profit?-A. I do not believe the Government could pun it through agents. In the first place, it would open the way to an immense sight of stealing, if they wanted to steal. Then they would have to pay a man who had business head enough to run it a good salary; they would hare to provide their own vessels and steamers; they would be obliged to have agents in San Francisco and in London, and all the necessary equipments for doing an exteusive business, and they could not do it. Now, if you throw open the competition, I do not think you would have a seal left in five years.

Q. That is, you mean, if the reservation was abolished and it was left to any persou to go in and eateh seals?-A. Yes; you would not have a seal left there.

Q. You think it would mean the total destruction of the seals?-A. Yes, sir; already the sea-otter is almost extinct.

Q. Under the law I think there is a prohibition against taking seaotters in certain seas. $-A$. They do not allow anybody but natives to kill, or a man who has married a native. Men sometimes marry squaws just for that purpose. They do not kill otter when the skins are not good. They conld not find a market for them.

Q. How long were you in the service?-A. Three years.

Q. Fou reached the conclusion then that it would not be wise for the Goverument to change its policy ?-A. It would be rery unwise; you must have what is called a monopoly.

Q. Under a reservation?-A. Yes, sir; but it is monopoly, of course. The holding of it by some company is the very best policy they can have.

Q. What are the opportunities and temptations of fraud against the Government?-A. There is no chance. These skins are counted in to the salt-house. The natires are there, and they are sharp, and they can see them, and you cau not fool them. The rery moment you undertake to get more skins than the company were entitled to they would detect it.

Q. They consitler they are entitled to pay for erery skin ?-A. Yes, sir; they know they get 40 cents for every skin accepted by the company. Sometimes they cut a skin so it is not good for auything much, and that is rejected. That, of course, they do not get pay for. The slrin is cut in pieces and then buried.

Q. Are they paid in money or goods?-A. They are paid in money.

Q. When they buy gools, do they pay in money?-A. Yes, sir; they pay in cash. It is an arithmetical problem of how jou can pay $\$ 30$, 000 with $\$ 10,000$ in bank.

Q. In the report of the governor of Alaska to Congress, he states that the company habitually fixes the price for all, so far as they buy in Alaskia at other trading statious, and only receire in payment for it coin which the company had marked, so they could identify it as their currency, and charged extravagaut prices, and would not sell goods to any native or trallers unless the goods were paid for in this marked coin. Do you know ansthing of that lind ?-A. I know that I went orer to the Western Fur and Trading Company, a competing company there 
doing business from tho outsicie, over which the Alaska Company had no control. They were a competing company. I do not believe that the compans was erer guilty of doing such a thing.

Q. Was it in competition with the Alaska Commercial Company ?A. Yes, sir. I know that they pay from $\$ 50$ to $\$ 80$ now for sea-otter skins.

Q. In money or goods?-A. I can not tell you that. I guess there are few hunters who are not inciebted to the company for goods they get through the winter to live on.

Q. Of course the Alaska Commercial Company has no relations to the Goremment except in regard to the seal islands and as to the furseal skins ?-A. Ies; in that respect they lave a monopoly subject to the control of the Government.

Q. Then in regard to other points?-1. They aro points of competition. There is nothing to prevent anybody else going and trading and buying furs anywhere in the Territory, except on the seal islands.

Q. Do they have competition?-A. I do not think they have. I think the Western tur and Trading Company has sold out. I know thero are white hunters in there who employ uatives to hunt the sea otter, but whether they sell to the Alaska Company or not I do not know; I guess not entirely, though. I do not think there is anything in that. I never heard the story there. There are a good many sea-otter hunters who make it their business.

Q. There are other furs besides the otter, I suppose, taken in Alaska ? A. Oh, yes; also ivory (walrus tusks), which is an article of commerce up there. I do not know what the natives on the islands west of Oonalaska would do unless the Commercial Company was there. They have brought a good many from an island west of Oonalaska because they were in a starving condition.

Q. That is the westernmost island?-A. Yes, sir; there is another question you asked Mr. Buynitski, which perhaps you would like me to answer, and that is whether the company furnished all they agreed to under the lease. They are required by the lease to furnish 80 barrels of salt salmon. Of course they do not furnish the salt salmon; they furnish corned beef. They are required to furnish barrels to salt meat in, and salt sufficient; they are required to keep for eight months a schoolhouse, and furnish books, etc.; this they do. In addition to the requirements of the lease, they furnish good frame houses for every family to live in. The company have built those houses and furnished them. I do not mean that they furnish them with inside furniture, but that they have built these houses and provided them for the natives.

Q. Charging no rent ?-A. No rent; it is free. They also furnish a physician and medicine, which they are not required to do, and widows are supported by the company for a year at any rate, and longer if necessary; but they generally have some relatives who can support them.

Q. Are there any cases of absoluto pauperism there; anything such as anyboly being starved to death from exposure and want?-A. No, sir; nothing of that kind. The company draw them blubber for fuel, which they are not required to do, and they furnish them with food from the kitchen in case of necessity. It is for the advantage of the company, in order to keep the natives healthy. It is to their interest to keep them healthy and satisfied.

Q. As to the granting of this lease, this exclusive privilege to take fur seal, to the Alaska Commercial Company, has it the effeet to give it a dominating influence, tending to give a monopoly of the commerce of Alaska, the fur trading and business of Alaska o Did you see any 
tendency of that sort? - A. No, sir; wot in the least. The only advantage it gires them is that they are compelled by the seal business to send their steamers up into that country, and in doing so, when they go, they can just as well send supplies to other stations for distribution with but very little expense. 'That is the only advantage that I can see.

\section{By Mr. JEFFRIES :}

Q. I want to ask you-on one occasion you state they only took 75,000 seals. Why did not they take any more ? $-\mathrm{A}$. The market did not demand a hundred thousand. It dropped, and they only took 75,000 in order to allow it to go up.

Q. It is true that the price of seal slins depends to some extent upon fashion; is it a matter of eaprice?-A. Very much so.

Q. Do you know whether or not this company has taken suitable pains to stimulate the fashion for seal skins ?-A. I consider they do.

Q. Do you know what the prices of seal skins were before the company came in existence? - A. I do not.

Q. The amount of the eatch, then, depends somewhat upon the condition of the market?-A. Certainly.

Q. Would there be any object in taking an excess of 100,000 unless there was an extraordinary demand for seal skins?-A. No; if they would do that the market would break, and it would make seal skins cheap. They could make just as much money from 100,000 as 200,000.

Q. Did not the company furnish stoves for the houses ?-A. I do not know as to that.

Q. They are comfortable houses, are they not?-A. Yes, sir.

Q. Are the houses lined?-A. Yes, sir. The fact is, the village of St. Paul, from my judgment, and what 1 can hear, is the prettiest village in the whole Territory. People came there by a cutter, and they said, "This looks like a New England village." You can not find any one as good anywhere else in Alaska.

Q. Now, I understand you to say that to throw this business open to competition and allow everybody to come in and kill seals would destroy the business. - $A$. I think so. The seal is a very sensitive animal, and it does not like to be disturbed, and it must not be disturbed. If they are, they will not go there at all.

Q. I want to ask you, from your experience and knowledge of the business, whether it is not necessary that it should be controlled by one direction? -A. Yes, sir; there is no doubt of that.

Q. Therefore it is not a monopoly in an objectionable sense; it has to be controlled by one direction?-A. It is a monopoly which gires one individual the privilege; that is all there is in it; and it must be so, in my judgment.

Q. But it is not such a monopoly as where one company is given an advantage over another that both are entitled to; not in that sense?A. No. Suppose there are two companies that bid for this, and suppose their bids are equal, and you give it to one and not to the other. That is a monopoly for that fellow.

Q. It would have been a monopoly for the other fellow, if he had had it?-A. Yes, sir; for anybody who has it.

Q. And if the Government had it, it would still be a monopoly ? A. Certainly; you must make it so. You can not have two parties in there getting seals; it conld not be regulated that way.

Q. So that objection to monopoly, in an offensive sense, does not apply to this?-A. I do not think so. I have discussed that point a good many times. 
Q. In speaking of the main-land or coast along the Alentian Islands, I would ask you whether there are not tracting vessels which buy skins?A. Yes, sir; and steal seal skins. 'Tinat is the great trouble we hadto wateh marauders. 'That was more trouble than anything else.

Q. Do you know anything about seals being killed in the waters by manthorized persons?-A. No, sir. I havo seen somo killed, but not in the water; they wero on board of a vessel wo eaptured.

Q. The principal food the natives use there is tho seal?-A. Yes, sir; they eat a good deal of that, and at times they hang up a good deal of it, and it keeps pretty well in a frozen state. We try to get them to salt it down, but they do not like it salted.

Q. Do you know about how much money these people have deposited in San Franciseo?-A. I do not know. Some of them have over $\$ 3,000$-one man has, I know. I have understood it was some $\$ 20,000$ and upwards.

Q. What have you to say in regard to the history of the seal as having been driven off from other parts; have you any such knowledge?A. Only from what I read in Elliot's work. I have read that in the Shotland Islands, where at one time they existed in great numbers, there are none there now at all.

Q. Do you know any seal rookeries except near the Islands of the Argentine liepublic near the Platte River, and the liussian rookeries on these islands, anywhere in the world ?-A. No, sir.

\section{By the CHATRMAN :}

Q. If the Government restrictions were remored, and people were enabled to go in thero with ressels for the purpose of killing these seals, would it be possible to actually kill all the seals that visit the rookeries?-A. 'The seals would not be there to kill. 'They had experience of' that. I am told betore tho lease there were two or three companies there, and every man took what he wanted. They just staked the ground off like is mining claim.

Q. Suppose the field was thrown entirely at the merey of the liunter? A. It would be pretty hard work for the hunter to get natives who understand the business. Tho senso of smell of seals is very acute. If you get on the windward side of them, you can get elose to them; but if you went over on the other side you could not get within half a mile, as they would take to the water. They do not seem to object so much to the natives.

Q. Your opinion is that, instead of an indiscriminate hunting and destruction, and their being killed out, they would probably leave tho rookeries :-1. Both would ocemr. In the first place they would shoot them and kill them answay.

Q. 'They would kill females as well as males?-A. Yes; they would not care, as the female fur is really the finest fur. I do not beliere you can manage that in any other way exeept to give it to ono company or individual. I do not believo it would be practicable for the Government to engago in tho business. No.

Q. That is you mean you do not think it would be profitable?-A.

Q. Of course it would be possible to preserve the seal lifo and keep parties from the islands, but now tho economie question comes in as to whether it would be profitable and more advantageous for tho Gorernment to maintain the administration of the reservation in its own hands, or whether it is better to leaso it to an individual or company ? $\mathrm{A}$. I think if the seal life is destroyed I do not beliera the natives could live thero. 
There is nothing to live on. Now, they not only live there, but they contribute a good deal to the other islands and churches on the other islands. They send down seal meat to their friends at Oonalaska, which the company's boats take down fiee of charge. Erery year they send down part of a load of seal meat. I think it better for the Gorernment to lease the islands as it now does.

By Mr. JEFFRIES:

Q. Do you know anything in reference to the question as to whether the Alaska Commercial Company is opposed to immigration to that Territory?-A. I think under the law outsiders have no business there.

Q. I mean to Alaska Territory proper, not to the islands?-A. No.

Q. What do you know in regard to carrying persons on their vessels to Alaska in changing stations, and all that?-A. I know this, that they have taken missionaries up there and traders from up the Yukon, and have bronght traders down on their steamers and not charged them for it.

Q. They have furnished transportation both to traders and goods?A. Yes, sir; and I told them they were foolish to do it.

Q. Have they ever refused to do it?-A. No.

Q. In what capacity were you acting during your stay on the islands of St. Paul and St. George in Alaska?-A. I was chief Treasury agent; there were three assistant agents.

Q. Who were the other agents-your subordinates?-A. John H. Moulton, George Wardman, and Louis Kimmel.

Q. State if you know of the company sending in uatives of the seal islands to Sain Francisco or elsewhere for the purpose of educating them.-A. Yes, they sent James Butrin to Vermont, where he was at school, intending to use him as a teacher, but he died soon after his return. Later they sent Simeon Molovedoff' to San Francisco to erlueate him.

Q. How large are the seal islands, respectively?-A. The St. Paul Island is about 12 or 13 miles long. I thiuk it is 13, and I think it will average about 3 miles wide. It is in the shape of a triangle. It is very narrow at the village. The St. George I do not know so much about; that Mr. Wardman will tell you of.

Q. Is it as large as St Paul?-A. It is a different shape, but I think it does not contain so many square miles.

Q. What is the form or topography of this island?-A. It is hilly. It is a voleanic formation there everywhere.

Q. What does it produce, if anything?-A. It does not produce any. thing-some berries grow there. Grass grows and a sort of wild rye which never ripens. Also many varieties of flowers.

Q. Is there any communication that you know of between Sitka and the seal islands?-A. None, except revenue cutters, which come orer.

Q. What do sou say about the increase or diminution of the number of seals on the rookeries of St. Paul and St. George?-A. I dirl not notice any ehange, but they vary in different years, in St. George par. ticularly. Mr. Wardman cau tell you about it on St. George. I conld not see any particular difference. They come there and have their young and go away; the period of gestation is eleven months, and then they come back in the spring following. They are there during the season in countless numbers.

Q. How do you characterize them-as animals or fish ?-A. I should not think they were fish. 


\section{By the Chatrman :}

Q. Have you any knowledge of the Commercial Company ever using or attempting to use any improper influences on the Government agents there to influence their reports?-A. They nerer had a chance to look at mine; they never saw them. It was never suggested to me what $I$ should report on. They never asked me anything about it.

Q. Ynu have no knowledge of any improper influence having been offered by the company or any agent of the company?-A. Not at all. By the way, reports from the islands are made by the chief agent.

Q. Do you know of any riolations of the contract between the company and the Government ?-A. I know of no violations except to do more than they were required to do. Ther are always very willing to do anything, as I said before, either for the natives, the Government, or other people, that is reasonable.

Q. As agent of the Government there, were you charged with the duty of looking after violations of the laws of the United States in Bering Sea by vessels and others?-A. Yes.

Q. Was there much trouble in that respect?-A. Yes, sir; a good deal sometimes.

Q. By foreign vessels, by hunters of our country as well as foreigners :-A. Yes, sir. There have been a number captured there.

Q. What is the quest of those hunters? Do they hunt in the open seas, or do they attempt to hunt on these seal islands?-A. They come to seal islands in the night, on moonlight nights. We took a vessel loaded with seals while they were on the islands. We got into the vessel and took possession of it, while they were on the island killing seals.

Q. Does the Gorernment keep a comple of revenue ressels there?A. They did not while I was there. They landed one officer on a little island 6 miles from St. Paul to watch. I understand now they keep a revenue cutter there most of the summer. In evers report I made I recommended that they should keep a revenue cutter there.

Q. I was just about asking Jou if it was not necessary that some vessel should be kept there-A. I think a ressel should be kept there through the entire season.

Q. Do you go up there in the winter ?-A. No, sir; you want to go away from there by the 1 st of November.

Q. Speaking of the season, you mean the sealing season ?-A. I mean the sealing season. Up to the last of October they should have a vessel tbere. Tho seal skins get stagy, so that they are not good, but they hunt them just the same. When the hunters go to eatch they take anything they can get, good, bad, and indifferent.

Q. What time does the company take their catch?-A. From the 1st of June until the 10th of August, generally about thirty-five working days. If it rains any of the time or it is too hot, it is delayed off, but it is generally about thirty days. They take the eatch as soon as they can.

Q. Are they enabled to take their catch without disturbing the rookeries seriously ? - A. Yes, sir; they do not disturb the rookeries at all.

Q. They do not disturb the seals on what is called the breeding grounds?-A. No, sir. sir.

Q. They just drive the bachelor seals off by themselves ?-A. Yes,

Q. And no female seals are ever destroyed by the company at all ?A. No, sir.

Q. There is no reason, then, why the number should ever diminish ?A. I should think not. 
Q. That is, if the laws of the Government were observed for them ?A. Yes, sir.

Q. Do you believe seal life can be preserved without Goverument protection over them?-A. I do not.

Q. What was your estimate of the value of those rookeries?-A. I could not estimate them. The seals are there by the millions; you can not count them.

Q. Well, estimate the value by the earning eapacity.-A. Three hundred thousand dollars is the way they earn now.

Q. That is what the Goverument gets. Do you know what the com. pany gets ? -A. No; I do not.

Q. That comes in addition?-A. Yes, sir; and it is a part of their expenses. Of course, what they pay ont is part of their expenses, which would be in addition.

Q. Yon take it for granted that they make some money?-A. I imagine they do.

Q. Would you think the rookeries, as an absolute property, with power to protect the seals, may not be worth $\$ 5,000,000, \$ 10,000,000$, $\$ 15,000,000$, or $\$ 20,000,000$ ? - A. I can not tell. They will have to fight to hold the rookeries.

Q. Isay, though, property under the protection of the law of the Government, as people own other things-as a man owns a cattle-ranchsay with the same measure of protection accorded to it?-A. I can not estimate the value.

Q. I think Professor Elliot estimates it at $\$ 12,000,000$ or $\$ 15,000,000$. Do you think that is excessive ?-A. I should think it was. I think I should put it inside of that. Its value depends upon the continuance of the seal life, upon the caprice of fashion, upon the expense of defending, and many other contingencies.

\section{TESTIMONY OF GEORGE WARDMAN.}

\section{George Wardman, sworn and examined.}

\section{By the CHATRMAN :}

Q. Just give us a general narrative statement. You have heard the list of questions asked; so please proceed and state whether you have been an agent of the Government in Alaska, mention the date when your connection with it began, and your observations in regard to it.-A. I became an officer of the Government in the seal islands by appointment on the 4th of April, 1851, and I proceeded out to San Francisco, and from there to the seal islands, and arrived there in the May following. I was then ordered by Colonel Otis, who was then chief officer in charge, to take charge of St. George Island. I remained in that capacity, in charge of St. George Island, until the 29th of May, 1S85, when I received a notification of my removal. Then I did not have anything more to do with it.

I was four years upon the islands, except with intermissions, when I calme down twice. In $1879 \mathrm{I}$ made a trip to Alaska, generally in the United States steamer Rush on order by Secretary Sherman, on wbich I visited a number of places and saw some things of which you asked some witnesses without getting a very definite answer. I proceeded to Fort Wrangel; from there to Sitka; from there to Kodiak, and to Athka and Kishka and Attoo and Oonalaski and to St. Michaels. All theso points were occupied by individual traders, as you were asking about 
traders. There were traders at Fort Wrangel, where they bought furs from everybody that came in there. At Sitka there was the same sort of business going on. There was no organized company, no incorporated company. From there we went to Kodiak, and there there was the Western Fur and Trading Company and the Alaska Commercial Company, and 2 miles across, upon Wood Island, the Russian-Ameriean Company, whose principal business was to put up ice for San Francisco, for which they received subsidies, but never shipped their ice. The natives who lived upon that island put up their ice and furnished furs, for which they were paid out of the store, so there were three companies at Kodiak. At Ounga there were two companies, the Alaska and Western Fur and Trading Company. At Belkofsky there were two companies, the Western Fur and Trading Company and the Alaska Commercial Company.

At St. Michaels, which is near the mouth of the Yukon River, the landing place for the Yukon furs, there were also two companies, and the relatious of the two companies at that time, the Alaska and the Western, was such at St. Michaels, where we staid, I suppose, three days on shore there, that I know the agent of the Alaska Company went over with the revenue steamer people to the Western Fur aud Trading Company's agency, and they all took dinner together. These companies were in existence at that time, 1879, and their relations, so far as I could see, were perfectly friendly. We had a dance at Kodiak, and the Rus. sian-American Company and the Western Company and the Alaska agent were, all hands, at the dance together.

Q. Did there seem to be a healthy competition?-A. There was a pretty lively competition, I understood, in the trade. At Athka, I recollect, there were two companies and the trade was very poor. Over at Kishka and at Attoo the people were very poor; I think there were only four or five sea-otter skins in the company's fur-house.

I asked the agent at Oonalaska, who covered that district, why he did not break up the station at Attoo and remove the people, and he said it was because the people did not want to leave there. They were attached to their old homes. It had formerly been a good hunting ground, but the sea otter had left, and they did not want to remove the people, as the people felt very badly about it. They had to maintain a store, and they put the store in charge of the priest, who acted for both the company and the church. That was a very poor community. I will now answer some questions you asked awhile ago.

Now about the seal islands. I was about four years in charge of St. George. I visited St. Paul several times on the steamer that left our island to go over there. They are 40 miles apart. St. Paul is 40 miles due north from St. George. On a clear day you can see St. Paul from St. George. They can seo St. George from St. Paul almost any day because of the high, rocky cliffs on this island. The other island, St. Paul, is sandy, and of a lower formation. I was on the island four years and am pretty familiar with the inhabitants. I am familiar as anybody could be in that time, because I attended to my duties and watched the affairs of the natives; and my impression is that the natives of that island were as well off as a mechanic in San Francisco at $\$ 1,000$ a year. They had free house rent, they had free fuel, free fish, free meat, free medical attendance, free drugs, free schools, free schoolbooks, and the only tax imposed upon them was by the church. They had only to buy tea, tobacco, crackers, ealico, etc., and things they needed to wear. The prices of goods were on a list hung up in the store at St. George. - I think a 48-pound sack of flour was 75 cents, and 
these little bright plugs of tobaceo were 10 cents, aceording to my recollection. Calico was about $S$ to 10 cents a yard, and sugar was about 15 cents when we had it. Judge Glidden ordered it away at one time. Canned goods I do not remember about, but I never heard any complaint.

Q. Was the Company regulation in regard to the 25 per cent. advance on San Franciseo wholesale prices adhered to?-A. That is what I understood. They have a regular scale of 25 per cent. over the wholesale San Francisco rate and the prices were tacked up in the store. I used to go in the store myself whenever there was a trading day, which was twice a week, but as I never charged my mind or made a memoranda, I only remember these things from seeing.

Q. Yon spoke of the natives having these things from an agent; was it from the agent of the Company or the Government?-A. They were furnished by the Alaska Commereial Company. A part of them were furnished under the regulations of the lease and a part voluntarily. The medieal atteudance, I believe, is voluntary; I do not know that there is any regulation on the subject. They also have salt. Although the lease requires the Company to furnish salt for the salting of meat, this was an insignificant part of what they used, beeause they do not like salt seal meat. But they do use it on the blubber, which they can take off twenty thousand carcasses which they kill in St. George. It is the women's duty to take it to the village on their backs. They get boxes and pack this blubber down in layers with a layer of salt, and the salt house is open and when they want salt they send or go down to the salt honse and go to shoveling it in and taking it away and there is no account made of that at all. They receive 20 tons of coal a year.

Q. You mean on that island?-A. I mean on St. George. The company pays these men for bringing their own coal ashore and putting it into the coal-house. Then I used to take the key and keep charge of the coal till cold weather, when I weighed it out to them. The natives are paid for bringing their own coal ashore the same as the company's coal. When it is landed it is weighed, which I superintended for our island. These men are paid for everything they do, for every bit of laboring work they perform. The coal is not required under the lease; there were so many cords of wood required, and they substituted coal for it.

Q. Was that amount of coal equal to the amount of wood required?A. I think it is equal to a good deal more. It was good steaming coal. It is put at Fort Nanimo, Vancouver Island, into steamers or other vessels, and there shipped to the islands. They use the same kind of coal, the company, the steamer, and the natives. It all comes out of the same pile.

As for the counting of the skins, the system we used on the island was, that I was always present at the killing when I was on the island, and $I$ was present when the skins were carried into the salt-house, and I had two natives court the skins by tens, alternating; one counting oue and then the other the next, and I tallied down ten. The chief stood on the other side of the door of the salt-house, and he kept a tally with me of the skins counted out, so they would know they got paid for all the skins they took.

Q. Do they get paid by that count?-A. Yes, sir. I entered the result upon the books in the governuent house and the chief delivered his account to the company's agent, and they took his count for it. The chief and myself were alway's pretty correct, and if there was any difference we had another count, counting it out again, but there was 
never much difference; sometimes there mav have been a skin or so difference. In the final count to the steamer we took them out in bundles. If there were any bundles left they staid in the salt-house until the next year. Our quota at St. George was 20,000 skins, and the quota was 80,000 at St. Paul. If their were two or three bundles over, as sometimes happened, they went into the salt-house and went on to the next year's quota.

Q. Then, is there further count elsewhere?-A. The mate of the ressel counted them. I counted them out of the salt-house into the lighter, and the natives pulled out to the steamer, which was off-shore about a half or a quarter of a mile, according to the water and wind, and the mate counted them there. The steamer people counted them for their own satisfaction; the steamer did not connt them for anything except for their own satisfaction, as the mate wanted to know what he was getting. Their count never amounted to anything.

Q. The next count took place where?-A. At San Francisco. The skins are taken out of the steamer right on the wharf by the Goverument laborers there and packed in casks. They are shipped in bulk from the island, but in San Francisco they are packed in casks, and as they go out they are tallied again by the Government inspector. The laborers pack them in casks, and they work in open daylight.

Q. Upon that count the company makes payment to the Government?-A. That is what I understood, both at the custom-house and at the company's office.

Q. Had you any knowledge of any cousiderable discrepaney between the count at San Francisco and that on the island?-A. No, sir. I have never counted in San Francisco, and I lnow nothing of it. I heard of the count not having accorded with the London count and the San Francisco count. There are a hundred thousand skins, and it seems almost impossible to get them straight.

Q. Was there as much difference as to indicate any fraudulent counting?-A. No, sir; it is just a question of one fellow being smarter than another in the counting.

Q. It's a question exclusively of accuracy? - A. Yes, sir.

Q. And nothing to indicate any fraud?-A. No, sir. It is just as where the chief and myself counted in 20,000 at the island, and then we would stop, and when we come to count out we might have two or three more.

Q. In your experience there do you know of any fraud perpetrated upon the Government or any attempts at fraud?-A. No, sir.

Q. Were there any considerable inducements for fraud existing there ? - A. They were never proposed to me. I never saw a chance for anybody to swindle either the company or the Government. The company left it for the Treasury agents to see that the count was right. They wanted the agents to make it right. If possible they wanted to have no discrepancy between the island count and the San Francisco count, so it was left entirely to the Gorermment agents and the natives to get the counting straight. The company's people never troubled themselves about it, they expected the chief to do it on our island, and the Treasury agent. In fact it was the Treasury agent's business and the company agent did not trouble himself much about it.

Q. Did the company, in its arministration of affairs there, seem to take great care for the preservation of seal life as well as care over the natives?-A. Yes, sir. We could not get the natives to try to preserve the seal life. Boys of twelve and fourteen years old would kill the seal pups. They say they are mild sort of people, but they never have a chance to abuse a dumb creature but what they do it. The only time I 
had any person incarcerated was a boy about eighteen years old. I took him and put him in the cellar of the store and kept him there two days for killing pup seals. That is the only punishment I have intlicted, except fines, under Judge Glidden's order, in regard to absentees from school. I fined one or two 50 cents under the compulsory education system.

Q. What were your observations in regard to the relations between the natives and the company?-A. They were perfectly harmonious, except that the natives wanted to travel. They wanted to go to Oonalaskia and to San Francisco, and they would go to the company agent and he would say, "Ask the officer," and they would come to me, and I would tell them I had no right to order the company to convey the people to San Francisco, and because I would not give an order for that, I think they hated me more than the company. The fact was, I understool, the company had taken a number of natives down to San Francisco to please them. They go down there and lose their money; they get robbed and they get drunk, and the enmpany has to support them all the winter and take them up in the spring. "In that way they get $\$ 300$ or $\$ 400$ in debt and it is up-hill work for the company to get the debt off the books. That was the only objection; they were always wanting to go somewhere. They had relatires almost everywhere in Alaska. They had their uncles and aunts and cousins and brothers-inlaw and sisters-in-law over at St. Panl, aud they carried on a great racket abont visiting their relations and go down aud have "chi petes;" that means a great tea-drinking. The company has to import the same kind of tea for these creatures that was served by the Russian Company. The company has to make a special importation of this tea from China. They will not drink anything else. They do not like coffee, and they must have tea.

Q. How are they compensated by the company for their labor?-A. They are poid for taking skins 40 cents each. They are paid for labor on all other work 10 cents per'hour.

And in addition to the natives upon the island, the company takes over every year from Oonalaska about 40 natives to do the laboring work. The natives on St. George and St. Paul consider themselves aristocrats, and do not want to work on the landing or anything of that kind, which is only paid laborers' wages, because they can make $\$ 200$ or $\$ 300$ by working fire or six weeks. The company takes up those natires from Uonalaska and pays them for doing all the laboring work just as much as auy other hands. The Oonalaska men turn in and help in the killing more than the natives, and the natives get paid for all the work. I have seen white men doing the roughest work on the killing grounds, and they receive nothing except a regular salary, while the natives get paid for all that work just the same.

Q. Now, in regard to the distribution of the compensation which the natives receive? -A. When I first went up there the distribution was left entirely up to that time to a chief, who was selected by the natives and the priests, and they made such distribution as to them seemed most profitable. If a fellow worked pretty lively for the church he always got a good share, and a good steady poker-player would also get a good salary. They liked a good poker-player. I have seen the chief order men to turu out at 12 or 1 o'clock at midnight-just at break of day, jou know-and go down to the rookery to get the seals up. Some of the fellows were lazy and would not get out at once, and the result would be the drive would be late, the day would be warm, and some of the seals would die while on the drive. There were some shirkers when they $9984-\ldots 3$ 
were ordered out on the drive. It is the chief's business to get the men out, and when he reported a fellow for shirking, that was a record against him. A man who got out lively and worked well on the ground and did not cut the skins and did a good day's work was put down as a first-class mən. So they had three or four grades, and the money was divided between them. They all had more than enough to last them all the fear.

Q. Were there any serious controrersies about the division of the money ?-A. I never heard of any at all.

Q. What are their habits for peacefulness and good order?-A. They were very good indeed.

Q. No intoxicating liquors were used while you were there?-A. No, sir; they were sober by compulsion. There were one or two fellows who were very chatty once in a while when there was a steamer out, and it was found that a cook or somebody had smuggled whisky for them in order to buy some curios they make. They make little gut bags from the intestines of the sea lion, which they trade. But that was of course not with the consent of the officers, and it was suppressed as far as it could be. When the islanders wonld go on board the steamer early in the morning they used to go to the galley. They would sometimes start at 4 o'elock in the morning and go aronui the island to a rookery on the other sicle frow the village. In this way they got into the galles, and I think that is where they got the sugar to make quass afterwards; but there was never any serious trouble on our island.

Q. You never heard of any murders while you were there?-A. No, sir. I asked a mau one day if he would shoot if we took after a pirate and he said no, he would not. It was only with great persuasion I could get him to puil me off in the boat. It was no use putting guusinto their hands. I asked him why he would not shoot and he said he did not want to kill a man. They are very cowardly. I boarded afellow one day anchored off' St. George. I took some natives and went aboard of him about the. 10th of October, 1883, and I found he had about 300 skins bundled in the hold of his vessel and the captain was very drunk. He was on a kind of a big jamboree. The ressel's decks were clean and he had four or tive dories aud they were clean. He niade a mistake in regard to st. George, aud instead of going to the rookers on the opposite side of the island from the village, he was right on a line with the village. When I got there he had about 16 sea-otter skins--rery handsome ones they were, too-and these seal skins. I asked him what he was doing out in those waters and he said he was bound from Yokohama to San Francisco. I asked him what he was doing up there if he was bound from Yokohoma to San Franciseo, and he said be was out of water. I asked him if he saw stals around there and he said, "I have not killed a seal within 12 miles of land." Well, I said, "Yon know you have no business here, unless you are in distress." He said he was in distress for water. I went down with the mate into the hold where the water tanks were and I said, "These are pretty good sized tanks." He said, "Yes." Isaid, "How much do they hold?" He said, "A bont 900 gallons." I asked him how much were in them now, and he said it was about two-thirds full, which gave the water snap amay entirely. The captain got mixed in regard to the island and ran in at the wrong place. I took him down to the village and I asked Mr. Webster if he would take the vessel down to San Franeiseo if I would seize her, but hesaid he would not. I then asked the company's assistant agent if he would go down, and he said he would not.

Q. Who was Webster?-A. He was acting as agent for the company 
at the time. He said he had taken a vessel down once aud never got any thing from the Government and he would not go in it, especially with such a crew as they had. They had nine Japs and four tough-looking white men. I would not hare gone with them for all the surplus in the Treasury, and I could not keep the vessel at St. George for the reasou that there is no place to anchor safely aud if she had gone on the rocks under my charge, of course I would be to blame for it. I had an idea that if the company would be responsible and take her down from the island I would seize her, but I did not intend to go in her myself.

Q. Was that an American ressel or a foreign ressel?-A. It was an American ressel plying from San Francisco. She sailed from San Francisco in 1881 for huntiug and fishing. That is the way they clear, and they go off and shoot seals around the Bering's Sea and then they slip) over to Yokohama and sell them. There is no question about that. Then they go back to San Francisco.

Q. Do you know whether seals are killed in the Pacific on any island south of the Aleutian Islands?-A. They are killed off British Columbia, because I met evidences of it from Vaucourer to Sitka; because they sell fur-seals in Sitka and in Fort Wrangel; I saw them myself; and I think some at Kodiak. Sometimes on the killing-ground when a skin comes off we find the bullet which goes through the skin and is between the skin and the blubber. I hal quite a collection of slugs, bullets, and buckshot which the natives had taken out of the seals in skinning them.

Q. Have you any knowledge of the condition of the natires on the island compared with what it was before the Territory was ceded to the United States?--A. Yes, sir; wo had there a very intelligent halfbreed native. He spoke very good English, aud he could read aud write English very well. His name was Peter Resauzoff. Ho had been educated at Sitkaunder the Russian rule, when he was a boy. I thiuk his father was going to put him in the church, but he nerer rent in. He seemed to be a pretty bright f'llow and he was better educated than any of the children who had been to school on the island. He used to read Dickeus's stories. He can make a pair of pump-soled boots; he is a first-class carpenter, aucl can make a gun-tube out of a rat-tail file; he is a pretty good blacksmith, and could cutyour hair as well as a barber, and he was a pretty clever fellow. He said that those fellows dicln't like to work, but under the Iiussian rule they had to pack every skin from the village over to Garden Cove, which is 3 miles across the island. They had a landing on the south side of the island and they used to make the uatives pack all the skins orer there. They lived in barabakies at that time. A barabakie is a sort of dirt house. They lived at "Staroi Steel," or old village, aud the Russians made them pack skins from there clear acros sthe island, 3 miles, to a ressel on the other side. The Americans have put in better facilities for shipping skins. Peter said the natives all lived in barabakies at that time, and now they live in frame houses.

Q. Will you state how those houses were buiit and what ther were?A. A barabalie is first dug down about 2 feet below the surface of the earth and the earth is thrown out of that space. Then thes put up a frame, usually made of drift-wood, and then they cover the whole business with earth. That is what is called in the eastern part of this comn. try " root houses," where they put potatoes and such things to lie(e) them from freezing. They still live in such places at Attoo, Athka, and Kishka. Here is a rough drawing of the village of Attoo which I made 
myself, and this is Oonalaska. They still live in the western sett'ements in the barabakies.

Q. Have these barabakies floors?-A. Sometimes loose boards, but generally they get dried grass and put in them. At Oonalaska when I first went there, there were not, I suppose, less than one-half of the population that lived in barabakies, but at this time the people at Oonalaska are living in frame houses and barabakies are done away with. There is no obligation for the eompany to build frame houses at Oonalaska, and there is no obligation for them, of course, to build any frame houses on the seal islands, but they have not only built them on the seal islands, but also at Oonalaska.

Q. The Alaska Commercial (Oompany?-A. Yes, sir. Their idea was to do that because the natives had been dying off very fast with typhoid pneumonia, and that they would hare better health in these wooden houses than in those close places where there is no ventilation, and where they are dark and damp, and where they would huddle in immense numbers in order to keep themselves warm by human contact, and the constant exhalations of the human body were fearful in such a damp place. Of course they had to economize in fuel, as all they could get at Oonalaska in the way of finel was a little dry moss, click-i-snick. That was the system there. They get coal now at Oonalaska because the company furnishes it to them at a low rate, so they are better fixed for fuel as well as for houses.

Q. How are they clothed as compared with what they were formerly?-A. At Attoo you will find a fellow weariug a bird skin "parka, while the woman would have a blue kind of skirt with a little calico waist. Up on our island they had everything but bustles, and I guess they have those now. When they saw a picture of a nice dress they would take the money to the agent at the company's house and ask him to bring them a dress like that from San Franciseo.

Q. They dress, then, in the fashion?-A. Yes, sir; they get hold of a Harper's and they would see a dress and they would go to the oftice of the agent and deposit $\$ 10$ or $\$ 12$ and say, "I want you to buy me a dress like that one, direct from San Franciseo." He would bring it, and they would go to work and every one would have one made on that model, no matter how small the modei was. They are very elever abont all that. Two or three women did most of the dress making, and did it very well.

Q. You were speaking about how the houses were furnished?-A. We had one hundred and ten people there, including the priest's family, and he had ten or twelve. The number of families was from nineteen to twenty-fire, which varied a little by people coming to and fro from St. Paul. They had six sewing-machines among that community of twenty families and every family had an accordeon, so I think they were pretty well fixed. The men dressed well. You could buy a good suit in the store for $\$ 10$ or $\$ 15$; of coturse you could get some cheaper, but a suit good enough for anyboty - good enough for me to wear-the men would buy, and at the end of the season, after a good dividend, they would stock up in clothing. Besides, clothing was a good thing to use in a poker game.

Q. Does the health of the natives seem to hare been improred?-A. They think it has. There are somedesperate bad eases-the people are scrofulous. The greatest cause of death among the Aleuts in the Aleutian Islands is serofulous consumption, and the next, chronic bronchitis, and the doctors are doing what they can to eradicate the scrofula out of them. The doctors work at them all the time. Thej keep doc- 
tors on Oonalaska just the same as on the seal islands-that is, the Alaska Company - they will serve everyborly alike, and at Oonalaska the Alaska Commercial Company's doctor attended natires that traded with the Western Fur and Trading Company, too. I know that from the doctors themselves. Yes; I think the health of the people generally is improved. The fact is, the company wants to keep them sober and healthy. When they are drunk or sick they ean't work. That is the great objection to their getting drumk up there. I do not know that there is any high moral principle in the Alaska Commercial Company's wanting the men to be able to work. The men are not fit to hunt the sea-otter or to work unless they are sóber.

Q. They could not work or hunt when they were drunk ?-A. No, sir.

Q. Did you form any definite opinion as to whether it would be better in an economical sense or better for the development of the Territory if the policy of the Gorernment was changed as to leasing the seal islands?-A. I could never see any reason why there should be any change.

Q. What is the distance of these two islands?-A. St. George and St. Paul are distant from the main-iand abont 250 miles. Bristol Bay is the nearest point eastward, and it is 250 miles from St. George.

Q. The operations there have no comnection with the commerce of Alaska?-A. No; not in the slightest. No more than if the seals were down here in the Capitol Gromils. I do not see how the seal islands are connected with the general business of Alaska in any way whatever.

Q. Is the preservation of seal life now better under this reservation and lease system?-A. It is, undoubtedly, in my estimation. Old man Webster told me-he said one year, I thiuk it was in 1869, before the lease was male, there were not less than 300,000 seals killed there in the two islandis, and his estimate was made by the killing of the company he was working for, and he knew what they were doing, and the result was that for two or three years after they only took about 30,000 on the islands. There were only three companies operating, and they took 300,000 skins. Anyboly conld come there and nobody conld keep them out, but there was nobody operating there that year, except those three companies. Webster was in a vessel that went up that year for whaling, and happened upon the seal islands by accident. They satw it was a good thing, and so they pitched in and killed all they could. I do not see what other system than the present conld be operated. The only thing is, you might make the islands yield more or less money, but the great trouble is there is too much money in the Treasury, and it might be we!l to put the whole revenue down to a dollar a skin, so as to get rid of the surplus.

Q. But that would be only transferring the surplus from the Treasury to the company ? - A. It might reduce the price of the skins to the consumer \$2. They could sell them $\$ 2$ a piece cheaper than now.

Q. The question is, will the consumer get that or the English chresser? A. I think they are sold at public anction in London. I think they are all sold at a trade-sale, divided into lots and sold in lots. It is a cquestion whether you want more or less from the islands. The system is all right.

Q. What wonld be your idea as to whether the Grovermment should discontinue the lease and take charge with its own agent?-A. Of course I think the present system is a proper one. If the forermment were to go into it it would open up a rast field, which is very varled and complex. The Govermment would have to have steamers, it would Lave to have agents, it would have to have stores, and goods, and money. 
We do not have that arbitrary system that the Russians work, and under which they could do it. 'They can do and thing they want of that kind, but I do not think that wili be a very good policy for us, myself. If you could have the thing managed trom here, like you could a railroad, or the telegraph, or the mail system you conld do it all right, but in this remote region, with 2,000 miles of rongh and impassable water for half the year, I do not see why outsiders could not come in and break up the whole business entirel. They might with the company, but they do not keep anything there, except for a month or so. Unly a small amount of money is in circulation, but of course it passes around from one to another, in the church and out again. I do not think the Government-operating scheme would be practicable.

Q. If the Gorermment shonld undertake itself to operate the rookeries it would have to buy supplies and sell to the natives, and that would involve the purchase aud sale of goods, as well as the general merchandise business, as well as supplying the natives and the wants of the people, and the markets generally for the seal skins?-A. Yes, sir. I am not willing to express any opinion upon that. The present system, I think, works well.

Q. You think that works successfully now for the preservation of seal life?-A. Yes; there is no doubt about that.

Q. And yieldiug a good revenue to the Government?-A. Yes, sir.

Q. Did your observation suggest any change in the policy of the Government which would be for the better preservation of those interests there?-A. Not in the general policy, as laid down in the lease; I think that covers everything.

Q. Is it very complehensive?-A. Yes, sir; that is, I do not know whether it positively expresses anywhere that the Government shall protect this islaud for the Alaska Commercial Company; but in the nature of business the Govermment is bound to protect all citizens, and especially its lessees.

Q. I think it prohibits all people anywhere except the Alaska Company from taking seal skins firom the waters, and it also prohibits the firing of guns and certain liuds of hunting, etc., in the waters of Bering Sea, Alaska?-A. Yes, sir.

Q. Do you think the Goverument onght to keep one or two revenue cutters or vessels there to wateh orer the waters?-A. I think the Gov. ernment ought to keep at least one reveuue steamer there in aud about these two islands up mitil the middle of October at least. The trouble has been in the Revenue-1Iarine Service. The appropriations were all right, and a fellow would be sent up to nominally protect the seal islands, but he would also be ordered to look for the north pole, as well as watch the seal islands. He might ind the north pole, but not around the seal islands. He would be away just at the very time when he would be needed around there. The pirates never gire us any trouble until after the 1st of September, because when the company's steamer is up aud dorn there, which is from the 20th of May until the 20th of Angust, it plies around a month or two, and other vessels pass up and down, and so the pirates keep shy of the place, but it is after they know the killing season is over and the company's steamer has gone, and the revenue steamer bas gone, that they slip around and get their work in. The first raid that occurred on St. George while I was there occurred on the $2 \mathrm{~d}$ of September, when they raiderl a rookery and killed some seals. They created a gap iu the rookery, and that gap nerer closed up that year. The seals never went back that year. When I saw it I thought it had been created by a sea-lion disturbance. A few 
days afterwards a native went to the rookery who had more experience, as that was the first year I was there. He found some young seals dead and some dying. There was a line where the keel of the boat had been hauled up. It was on the morning of the $2 d$ of September that the natives had reported a schooner stauding south, away down the horizon. On the 3d of September the revenue-eutter Rush arrived at St. George, and $I$ asked Captain Healy if he had met a schooner, and he said no, he had not seen anything of it. Yet the schooner, twenty-four hours before, had made a raid on the rookery. The weather is so bad that a vessel can not stay in these waters all the winter, but after the 1st of November it will not be found necessary. In November there are not many seals there. In a little while after that there is no inducement to make a raid on the rookeries, but there are a good many in the water south of us. Seals stay on our island until the 1st of December. I used to go ont every day and would notice that they got down thinner and thimner, until I might have counted all on the island. In the spring I could count for days all that were on the island. Then they began to come in quantities, but for days I counted seals about the beginning of the season.

Q. What is your impression of the number of seals that risit these rookeries aunually?-A. I never could make it so much as Professor Elliot has done. I made many estimates. I have been to all the rookeries on these islands many times, and compared them with the space occupied by the carcasses on the killing-ground, and I feel pretty confident that the total number has been overestimated.

Q. He estimated it at something less than $4,000,000$ on the two islauds ?-A. I think he estimates 250,000 to 275,000 on St. George. I have figured it out in several ways, and I think 20,000 that we killed would be 10 per cent. of the killable seals.

Q. Is that your estimate-10 per cent. of all that come?-A. I take that for one thing. I take our killing ground, where we kill 20,000 , and where we lay these seals along as close as we could, so as to give us greater area. We want to make room to take the next rear another piece, so that by the third year we could get back again. I measured off that space two or three different times where 20,000 carcasses lay, and where I considered they lay as close as on the rookeries. I came to the conclusion we had about 40,000 at Zapaduy, 30,000 at Staroiateel, and about 50,000 at North rookery, 10,000 to 15,000 on Little East rookery, and about 25,000 or 30,000 on Last rookery. That is all the rookeries. I conld never make it any more than that during that time. I measured the places carefully.

Q. Do sou put it at the same numbers annually?-A. About. I think the breeding seals on the rookeries come in about the same numbers; but the first year I was up there we killed 20,000 with great ease and in a short time, and I considered that we could kill more easily; aud I recommended Colonel Otis to make a bigger allowance for St. George, becanse we wanted to bring up our men's dividends a little. The next year he gave permission to take 25,000 on St. George, and they would take 75,000 on St. Paul. We got 21,000 or 22,000 that year. We had exceeded in our estimate the number that we could take at that time; and they had to finish our quota on the other island. Later in the season, perhaps two weeks after that, we could have got perhaps 10,000 more seals, but we certainly could not get them when we wanted them.

Q. Have the natives any other means of livelihood except this furseal business? - A. Nothing they can live upon. Their means of subsistence for a large part during the spring and summer are sea-birds 
and their eggs. They are rery numerous. In the beginning of the season they lire on these birds and eggs; but in the winter their living is precarious, as they only get a bird now and then. We had to kill about a thousand pups for them the 1st of November, and that would last them on up until after New Year's for fresh meat. Then they would fall back on old salt seal and buy corned beef. It was pretty tough times with them, as they like fresh meat. Salt seal is pretty tough eating. They would die of starvation but for the seals.

Q. There would be no reason for them to remain on the islands louger?-A. No, sir; they would die there if left without somebody to feed them.

Q. Did you observe while there the effeet of the fur-seal islands being leased, and the right to take fur seals being given exclusively to this company? Did it, in your opinion, hare a tendency to give a dominating influence in the Territory of Alaska in regard to the commerce and business in that Territory, to the detriment of others?-A. It is like any other business; where one concern has the most capital in rested and the largest facilities for doing business they are pretty sure to do it. The company had steamers, for they were obliged to go up there to the seal islands, and it paid them largely of eourse to do so. And while the steamer was there waiting on the killing, which would be for six weeks (now the steamer that took up supplies to the agents and all these people in May could not go down with a load of skins until about the middle of August; it generally left there about the 1st of August), meanwhile that steamer would have to anchor around the islauds in a precarious way; or that vessel could run up St. Michaels and go into a good harbor and get painted. In the meanwhile they received furs from the Yukon River, and while the steamer was getting fixed up and painted they receired furs there and delivered the supplies for that year, so that probably they delivered their supplies for the Yukon district and receired their furs from the Yukon district for nothing, while another company would have to fit ont an entire expedition to go there. Therefore, I think they had that advantage.

Q. That is an advantage that is merely incidental?-A. Tes, sir; unavoidably. I have an idea that if it was not for the seal islands and the trade there they would abandon that northern country altogether and anybody conld take it up that wanted it. Mostly the skins there are of a cheap character.

Q. I believe jon have stated that there are other traders?-A. There were at that time. Beaver was only worth 50 cents, but there came a litttle spurt in the fashion for beaver capes and muffs, and they got a little more. Now, I do not believe the bearer is worth the taking. Mink and martin are not of any value. Nobody wears a martin cape any more, except an old woman of about eighty years; they are out of fashion. They would not take muskrat, except to help the Indians along. Muskrat goes into cheap imitation furs, little muffs and boas, which cost about \$1.75.

Q. The most raluable were the sea otter and the silrer fox.-A. The sea otter are not north at all. They are about the Aleutian Islands, south of the seal islands. Seal otter are a rarity around us; we only see one once in a while. It was a curiosity to see one around St. George. There is not a seal that will pull out on one of the Aleutiau Islauds, and no man can see the difference between them and the Pribylov Islands. The eye of man can not distinguish why a seal should not pull out on the Aleutian Islands, yet not one will land there. It is very strange. They go aloug there, going up in the spring, nosing right along the shore, 
but will not pull ont. They will not haul out on the shore; they travel 600 or 800 miles along the British coast also aud never go ashore.

\section{By Mr. JeFFRIES :}

Q. Where do you live now ?-A. Pittsburgh. Press.

Q. What is your profession?-A. I am editor of the Pittsburgh

Q. You have written a book on Alaska?-A. Yes, sir.

Q. You were speaking just now alyout the fashion in furs. I will ask you whether seal skins are not exposed to the same mutation of fashion?-A. I think beaver sets at one time drove them out temporarily.

Q. I ask you in reference to the Goverument managing this business, and if the Government should undertake to keep up the fashion in seal skin, what kind of business it would be for the Government?-A. It would have to subsidize a good female lobbyist. I suppose it would have to put them on the best-looking temale lobbyists they could get, and let them prance around with them.

Q. If nothing was done to stimulate the fashion wonld not the prices go down for seal skins?-A. I should suppose so.

\section{RIDLEX PARK, PA., August 15, 1888.}

DeAr Sir: At the next session of the committee I desire to place Mr. C. F. Williams, of New London, Conn., on the stand as a witness on behalf of the Alaska Commercial Compans, now under investigation by your committee; also Mr. Thomas F. Morgan, of Groton, New London County, Coun., and respeetfully request that subpouas may issue therefor.

Respectfully submitted.

Hon. Poindexter Dunn, Attorney for Aiaska Commercial Company. Chairman, etc.

\section{TESTINONY OF W. B. TAYLOR.}

W. B. TAYLOR, strorn and examined.

Wednesdar, August 28, 1888.

By the OHAIRMAN :

Q. Mr. Taylor, were ron an agent of the Treasury Department in Alaska at any time? And, if so, state when and where--A. Yes, sir, I was, in 1881. I went "p in April and returned the latter part of August of that year.

Q. Well, sir, state as near as yon can the location and condition of the seal rookeries in the Bering Seal; what islands form it.-A. Well, sir, there are four islauds known as seal islands in Bering Sea: St. George and St. Panl, located 200 miles or thereabonts, north, and Copper and Bering Islands to the westward.

Q. I mean the Bering Sea, in Alaska.-A. Well, then, St. George and St. Paul, 200 miles north of Oonalaska, and about the same distance from the shore of the main-land. They are 40 miles apart.

Q. Now, will you just make a general statement of your visit and 
observations there in the course of the pirformance of your official cluties, and I will ask you such questions as are pertinent from time to time?A. Well, I hardly know where to commence.

Q. Just state the general condition you found the islands and seal rookeries in, and the substance of your obstrvations during the administration of your duties there.-A. I lamled on St. George Island first, I think, on about the 25th of May, 18s1, remained there a short timea few hours-and then proceeded to St. Paul Island, and without any positive instructions from the Treasury Department, except in a general way. I suppose itmight be well enough for me to state that when I received my appointment as Treasury agent I was then clerk of the Illinois house of representatives. It came to me wholly unexpected ; and inasmuch as the vessel left, as it was stated by telegraw, on the 1st day of May, and that was the 19th of April when I received the telegram that I had been appointed, I dit not know where the seal islands were at that time; neither did I know what my duties would be. All that I knew was that I should proceed at once to San Francisco to take the vessel. I made inquiry as to the whereabouts of the islands, but I could not get much satisfaction anywhere. At any rate, I resigued and went

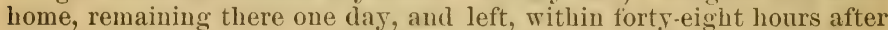
receiving the telegram, for San Francisco. I reached there in time to take the steamer on the 5th of May, but still somewhat in the dark as to what my duties were. Bnt, at any rate, I arrived, as I stated, on the seal islands, I think, about the "25th of May. When I got there I found that Mr. H.G. Otis was in charge at St. Paul. The understauding was that I was to go to St. Paul Island-that was my understanding-and remain there with whoever was in charge.

Q. Your position, then, was that of an assistant?-A. I was an assistant agent, but I ras not aware of it until I got there. I discovered that I was to be the assistant agent after I came in contact with Mr. Utis. Mr. James here is probably aware of that. A report which I made will explain perhaps the reasons why the associations with Mr. Otis were not altogether agreeable to me, aud I receired written instructions from him, after having been there about a week in the discharge of eargo, etc., to proceed to St. George, which I did with a great deal of satisfaction and pleasure. And that was my station during the summer. What information I can gire the committee will be in regard to St. George, although I returned to St. Paul afterwards, aud practically the same condition of things existed on St. George that existed in St. Paul, so far as my observation went. Now, do you desire that I should go into detail as to the seal business, killing, and everything pertaining thereto.

Q. Yes, sir, put in a general account. Now, this range of the investigation takes in, for instance, the condition in which you found the rookeries, and also the condition in which you found the native population on St. George Island.-A. That will necessitate my going back to my first landing on St. Paul.

When I landed on St. Paul Island I found that the people were in a very deplorable condition-made so by the frequent and constant use of what is known as quass, a beverage which they brew when thes are not molested by the special a gent of the Treasury. I found that at least one-third of these people were in a condition which made it impossible for them to do what was expected of them by the compans; in other words, there are so many men on the island, and their services are absolutely necessary to carry on ail the lusiness aurl do the seal work; but one-third of them were incapacitated for the reason I have stated. 
And I charged them, and I charge now, that the agent who had control over them was directly responsible for it.

Q. Do you mean the ehief Government agent or the agent of the company?-A. I mean the Government agent. It is all a matter of record, which you can find in my report to the Treasury Department. Finding those people in that condition, I took oceasion to make inquiry among the natives themselves who could talk English and obtained all the information I could get of things that oceurred durjug the winter and the causes which led to this condition of the people. Ilookerl upon it as a duty I owed to those who sent me there, regardless of the fact that I had a superior who bad been there the winter previons. As I stated I remained there one week but I should think that at least one-third of the people were in that condition, and a good mauy of them were diseased, made so, as I understand, from the fact of some sailors going ashore, just when I do not know, and the disease worked into the people. Whether it was that year or the year before or sereral years before nobody seemed to know; but at any rate the making and drinking of the quass was the direct cause of their incapacity, and becanse of that fact, as I understand, the company found it necessary to take a few natires from Oonalaska every year to do the necessary work, as they could not depend upon the people when they were in that condition.

To go back to St. George. If I had my notes I conld be more explicit as to dates-

Q. That is immaterial?-A. Our duties on the seal islauds commence with the killing, practically.

Q. Just before yon enter upon that will you now state as to whether any, and, if so, what, measures were taken by the agents of the company itself to counteract these vices and bad habits amoug the people, if any came to your knowlerge?-A. The company's agents complained to me of the condition of the people. They had frequently, so they told me, complained to MIr. Otis, but he had never taken any action; in other words, he was a man who was inclined to show his authority outwartly, and he would make so many threats to the people that he.wonld do so and so and wonld very seldom, if ever, carry them into execution, and the result of that was that the people had no regard or respeet for anything he said or did.

Q. Was the chief authority and power rested in the Gorernment agent for correcting these evils?--A. Yes, sir, altogether. The company's agents are absolutely powerless.

Q. They hat to rely upon him?-A. Entirely so. So far as the company's connection with the people is concented, if they want to communicate with the people in order to get any work out of them at certain hours of the day or night, whenerer it may be necessary, they conter with the Goverument agent, as a rule, and through him to the people, and in that way they get done what is necessary from day to day.

(2. Their dealings and transactions, then, were entirely through the permission and consent and authority of the Goverument agent and in accordance with the rules and requirements of the Government agent? A. Yes, sir. Mr. Otis laid down more rules, I believe, than any other agent that ever was on the seal islancis and executed a less number. When I arrived at St. George Island the condition of affairs there was directly opposite to those on St. Paul. Cantain Moulton was in charge there. So fin as I conld learn there had been no drinking or carousing or debanchery, and the people were in a fairly good condition, 
except some of them had bad colds, the result of barl weather; but in all other respects they were in condition to go to work. The work commences about the 10th of June. Do jou desire me to go into the details?

Q. I would like to have an account of how that is done, how the skins are counterl, the Goverument's interests protecter, ete. I want to know how they are taken, the general process, and how the natives are paid.A. About the first thing $I$ did after arriving at St. George was in conjunction with Mr. Wardman, who was my associate on the island as special agent of the Treasury. We visited the varions rookeries on the island and examined them carefully, and compared them with previous records as to their condition. We also visited the sea-lion rookeries and made an inspection of them also. That was previous to the commencement of the killing. So far as our observation went and from what we knew from information obtained from those who had been there a number of years, the rookeries were at that time about as full as they ever were. I think on the 10 th of June was about the time the first drive was made. The natives are called at an early hour in the morning by their chief and they proceed to the rookeries, going down to the sea-shore and dririug back from the shore the killable seals, which are males from three to four years of age.

Q. Do these herd by themselres, entirely away from the breeding rookeries? - A. Yes, sir; the breeding rookeries contain old bulls tire years old and upwards, and the cows aud bulls on the harems or rookeries are entirely separate and distinct from the killable seals.

Q. These are not disturbed ?-A. Not at all. The Gorernment agent, if he does his duty, does not permit them to be disturbed by any one. It is part of his dinty to look after the rookeries and see that they are not disturbed. The killable seals hanl up by themselves. Generally there is a space of from 100 to 200 yards between the young male seals and the breeding rookeries.

Q. These young seals are what are called bachelor seals?-A. Yes, sir; bachelor seals. And these droves of bachelor seals are driven back from the sea-shore in bunches of from 100 to 500 and each man takeshis bunch and drives it back until the entire drive is made, which perhaps may exteud over a space of half a mile or even a mile, and after the various bunches are driven back from the sea-shore they are driren to the killing grounds near the village; that is, they are so driven on St. George, and it is about the same condition of things on St. Panl. And then the natires go to their breakfists in the morning, leaving one or two to watch over the herds of seals, which number from 2,000 to 5,000 . After breakfast, generally abont half-past 7 or $S$, the company's men, consisting at that time of Mr. Norgan, now present, and Mr. Redpath and the natives, together with the two Government agents, Mr. Wardman and myself, proceeded to the killing ground. I might say I took a club myself and did my share of the killing all through the season, for the reason that that was the only exercise we had and I desired to be on the killing gromnd all the time; and I did that for those reasons, so that there was no time from the beginning of the season until the close of the season but what I was on the gromnd, not only participating in the killing, but looking after the seals and the killing of them and the protection of the skins as to the cutting, etc. After we arrived on the killing ground we wonld drive up bunches of $40 \mathrm{or}$ 50 from the drove and surround them and with clubs knock down the most valuable as to size and quality, and then we would permit the 
others to go into the sea. Not infrequently an old bull, and very rarely a cow, would get mixed up with these seals.

Q. No cows were killed? - A. I do not know of but one or two cows having been killed during the entire season, and they were killed by accident.

Q. They are not permitted to be killed?-A. No, sir; under no circumstances. We would surround these seals, and I should think would knock down about 25 per cent. of each bunch, which we drove off, and those that were too young to kill, or those that were badly cut and those that were too old were permitted to go back to the sea, which was only a quarter of a mile away from the killing ground. Sometimes it is close down to the sea shore. After they were dragged out from the bunch in which they were knocked down a native would come along with his knife and cut them around the neck, and around their arms, and around their tails, and another would take off the pelt. These pelts were thrown into a pile as the seals were killed and skinued, and then another employé, Professor Atkins, who drove the mule, or bull I think it was at that time, hitched to the cart, and had these pelts thrown into the cart and hauled to the salt house; and alter we had completed the killing for the day the company's representative, the Government agent or agents, as the case may be (there was always one of us), and the representative of the people wonld go to the salt house, and they wonld count these skius that had been killed during the day. We wonld throw aray skins which were badly cut, as they wonld not be accepted by the compang. Some days there would be tro or three, and I do not remember that there were ever many more than that, ont of $1,000,1,500$, or 1,800 for a day's work. After that count, the badly-cut skins, which were of no use, were thrown over the cliffs.

The natives were too indifferent to dress these skins for their own use; they are disinclined to work, and yon can not get them to do it without a good deal of tronble, so they are thrown over the cliff. After the counting had been completerl they were then taken and put into the kenches or salting bins, which were bins abont 14 feet square, ant each day's skins are put into these kenches until they are full; and after they have remained there seven days they are taken out and bundled, two skins being put into a bundle, and these are piled up ready for shipment. This is the routine of the daily work, and the Treasury agents keep an accurate and exact record of each dar's work, so if you refer to our report, which was sent in at that time, you will find the exact number of seals that were killed each and every day in this work, until the quota of that island han been completed. When we are killing seals, on the day that we have nearly reachen the quota we are very careful, and in fact we count down to the last one, and it is always considered an hoinor for the kilier to kill the last seal, and it is also so recognized, among these people, to kill the first seal. So that we know exactly the unmber of seal killed, and according to our count we tally down to the very last day of the killing, and if we want 50 seal to make the quota, we kill 50 seal and stop, no more and no loss. That euds the killing of fur seal on that island for that year.

After the killing has been concluded, they are bundled ready for ship. ment, ready for return in the fall. Then when they are shipped, these bundles are taken ont of the salt-house and counted by the ciovernment agent as they pass out, and sometimes there will be a few more or less after we have counted ont. An error in comnting will ocenr sometimes which you can not account for ; but it is usullly one or two, or three or four or five. 
Q. A mere question of inaccuracy?-A. That is all. If any slins are left over they have to stay in the salt houses until the next year, and they are comnted in the next year's quota. When this quota has been taken out of the salt house and put into the lighters which take them to the vessel-there is no harbor there aud vessels anchor about a mile or so out and they are taken out in lighters-they are receired into the vessel after passing through an automatic counter; the Government has nothing to do with that. The company have an automatic counter to satisfy themselres as to the accuracs of the count. After the ressel has been loaded at one of the islands or the other, or in fact both, the vessels proceed to Oonalaska to coal up there, taking three or four days, and then proceed to San Francisco. Then there are two agents of the Treasury Department who are detailed from the custom-house there to comut these skins as they come out of the ressel, and on that count the tax is paicl. There is always a discrepaney betweeu the seal-island count and the San Fraucisco count, but it is slight, not amounting to much one way or the other. It has always been so and will always be so. It is impossible for one man or two men to make two counts exactly alike in 100,000 skins as they go in or out of a vessel. Sometimes in the unloading one man throws one bundle and another another from the vessel, and you would be liable to get them mixed and in that way these little inaceuracies occur. This, in brief, is about the sum total of the drive, the killing, salting, shipment, and counting of the fur-seal skins on these two islauds.

Now, if you desire to know anything further I will be glad to answer you.

Q. What measures are adopted to prevent uunecessary waste aud destruction of seal life?-A. Well, sir, the Government agents bave, as I previonsly stated, entire control of the rookeries, and they risit them almost daily. It is their duty to look after that, for the reason that the natives are continually going around orer the island. WV do not permit any shooting on the island during the time the seal are there. We do not permit a native to go near the rookeries during the breeding season, and in fact we do not permit them to be molesterl in any way by any one; we do not do it ourselves. In that way the seals are entirely unmolested during the breeding season. I suppose you want to know something about the people and their condition.

Q. I will come to that directly. Let it be the next question-the character, habits, and condition of the native inhabitants of the seal islands, past and present, and the relations existing between them and the Alaska Commercial Company. Just give us a general account of that.-A. These islands, when they were taken by our Gorerument, were in what might be termed a deplorable condition, that is, the people on the islands. They lived in dug-outs or sod-honses, half under ground and half above, withont any conveniences or comforts whatever. They were taken out of these some years after that and put in comfortable cottages, so that all the people iive as comfortably as any other laboring people anywhere, and I consicler the people, as laboring people, are better housed and have more comforts than any other laboring. people either there or anywhere else. The company provide them with salt and they get all the seal meat they want for meat during the summer. They have a physician on the island to take care of them without any charge whatever. They have schools, half Russian and half English, and school-houses built by the company. They have a church on each island. They attend their church worship very regularly, and in fact their religions duties very often interfere with the sealing, and that 
is something that would be difficnlt to prevent. There are some days during the unloading or loading of cargoes on the vessel that these people are disinclined to work, for the reason that it is a religious day with them, although it may be a matter on which their year's supply of food is dependent. You have to resort to rather harsh measures to compel them to assist in the discharge of a cargo, which is very necessary, for the reason that there is no harbor, and they have to take advantage of fair weather to discharge a cargo.

Their habits as a rule are, perbaps, as good as they could well be under the restrictions that ther have. The Government ageut, if he does his duty, is always on the lookout for the manufacture of anything that would be an intoxicant, as that is their greatest eril; and even with a close scrutiny and watchfulness, these people, if they can get dried apples and sugar, will make aud brew an intoxicant. It is something which they relish more than anything else, and it has been found necessary to even deny them sugar.

Q. Is the sale of intoxicating drinks strictly prohibited by the com. pany and Goverument agents?-A. It is; but has not always beeu so. There is, in my judgment, no reason why the drinking of quass eould not be suppressed, and there is only one war to do it, aud that is by taking away from them these luxuries and sugar.

Q. That is, the material to make it of ?-A. They will make it if they ean buy sugar. The company keeps supplies of all kinds-clothing, food, groceries, provisions, camed goods-everything that they would need and require; and they can go there and buy them on credit until the end of the seal season, and then their pay is allotted to them. Right in that connection, I think it would he very well to state how that is done. When I was there the chitef of these people took it upon himself to make this allotment.

Q. Of the pay?-A. Yes, of the pay ; and I found among these people that they are human, like other people; and there is favoritism, more or less; and I found the more intelligent ones, those who really were the head and front of the organization, or whatever it might be, are the ones that receive the first-class shares. That, I think, that year was \$385. I may be wrong, but that is a matter of recollection. A few received that, and then came the second class. They are divided into three classes, and the second class receices something like $\$ 250$, and the third class \$185. Mr. Wardman aud myself diseussed that, and we concluded it was a very improper thing to leave that to the people, because every year some faithful men were entitled to receive more than they did receive, and some others, on account of this favoritism more than anything else, were paid more; some $\$ 385$ and some $\$ 185$. They were entitled to just as much as the others. I believe, now, that out of that grew the recommendation for a change, and now the company's men and the Government agent and a representative of the people make the allotment.

Q. All three?-A. Yes, sir; instead of leaving it to the chiefs.

Q. It was a sort of board of arbitration?-A. Yes, sir. And that, I suppose, is the rule now, and it is working rery successfully, because the Goverument agent is just as well aware of who is entitled to a firstclass share as anybody else, and so is the company's man. They know who are the best men and who are doing the most work.

Q. They try to make the allotment or payment, then, on a basis of real merit?-A. Real merit of the man and the amount of work he does.

Q. How much do the eompany pay ? $-\Lambda$. 'The company pay 40 cents a skin for erery skin taken, and then they pay these people a dollar a 
day for any other labor they perform. They do not seem inclined, however, to do anything except sealing. They are ten months in idleness, and have little inclination to do anything else except sealing, even though they are paid for it. There are some of these people who save their money, and have considerable sums to their eredit, on which the company pay them a rate of interest-how much I do not know-but they pay them interest on it. About one-half of them speud all they earn. That is, they do not exactly spend it all because the Govermment keeps back, I think, if they are married men, enongh to keep them for the year. In other words, they iustruct the Alaska Commercial Company to withhold from these people who are improvident a certain sum of mones, amounting, perhaps, to $\$ 3$ a week, out of their wages for emergencies. There are ahout one-half of them who gamble away their money by pitching half dollars.

Q. With whom do they gamble?-A. Among themselves.

Q. Do any agents, or officers, or employés of the company gamble with them?-A. No, sir. I nerer have seen anything of that kind at all. In fact, there is no affiliation of that kind; it would be repugnant to a white man to affiliate with them in a social way, or in any shape or form.

Q. They do not get their money arvay from them by that means?-A. No, sir; they only gamble among themselves, and it has been suggested a number of times that the Gorernment onght to prevent that; but that seems to be impracticable and out of the question for the reason of their ten months' idleness, when they have nothing whatever to do and no amusement except that; and as long as they keep it among themselres and a sufficient sum is withheld to keep them from want, they might as well squander their money among themselves, as it all comes back. Uf course some of them get the wor'st of it, and a t'ew older ones, who are more expert at gambling, have the bulk of the money in the spring. Then they spend it all freely ; it comes back and eirculates among their own people, and there is nobody harmed by it in any way.

Q. What prices do they have to pay for supplies they buy from the company. Did you exanne into the prices charged there?-A. The prices that they pay amount to about 25 per cent. increase over the actual cost at wholesale at San Francisco. The goods are all marked upon that basis. I did examine into that very carefully, and know the price of goods and what they sold for. I wonld estimate it was in the neighborhood of 25 per cent. That pays merely the cost of transportation, and these people, a great many of them, buy ererything they see in sight, if the company wonld sell to them; the company's agent knows the peculiarity of eitch and every individual on the island. They know who save their money and who spend it, and if they find any one is spending more money than they onght, they will not sell to them. They are inclined to buy whole pieces of goods, and silk handkerchiefs by the dozen, but they do not sell to them in that way ; they justdivide it up so that each one may have a little, that they may not speud all their earnings in that way.

Q. Well, under the contract with the Gorernment, the company is required to provicie a certain amomut of supplies and fuel, either wood or coal, food and salt fish, or something of that kind. Did you observe as to the observance of that part of the contract?-A. I was not there at the time these supplies were issuen. They were issued later in the fall; but I do know that they were issued and that there is no complaint, and the company in fact make it a rule not only to carry out, so far as I could observe, every provision of the law, but they go even fur- 
ther than that. They never permit any one to sufter on the island for anything, no matter how improvident they nay be. The instructions, I suppose, come from heatlquarters, and they will always provide ilem with fuel and food, even thongh they are not obligen ta; but still they do that, and they give them all the medical attendance and modicines they require without any cost to them. Amb so far as my observation went, there was never any neglect of anything which they needed to make them comfortable or anything of that kind.

Q. Is there any charge made by the company for medicines?-1. No, sir. The natives are able to see the physician at any tine. They are a very superstitions people, and they are running to the physician daily, so that they all gnake the rounds every day or two. The physician hats about all he ean attend to, though, of conrse, the most of the prescriptions do not amount to much except to satisfy their superstitions.

Q. You are informed that the doctor is a conseientions lian, and took the best care he could of them?-A. Yes, sir; they employed a guorl physician and pain him good wages, and so far as their services go, I do not see but what they are as goorl as anywhere else. They do not have anything else to do but to go around and visit the sick, or pre. scribe for them in the oflice the same as any other physician would do any where else. There are a great many things in detail, little matters, that I could not go into very well withont giviug them some consideration, and, in fact, I did not know until I arrived here this morning just the character and scope of this investigation and what it was. I did intend to have brought along a memorandum book which I kept of all these incirlents as they occurred from day to day, but I sumpose these are immaterial.

The Chamran. This is a general inquiry as to bow snccessful the administration of that interest has been under the poliey of the Goverinment, with a view to ascertaining whether the contracts have been faithfully carried out and eomplied with by the company and whether the Government's interest has been fully and faithfully protected, in order that we may adrise Congress whether it is wise to continue that policy hereafter or not.

Q. Is there any relation existing between the United States and the Alaska Commercial Company in reference to its business in Alaska ontside of the seal islands?-A. I know that the Alaska Commercial Company has a number of stations through Alaska.

Q. The Government has no commection with those?-A. The Government has no connection with them that 1 know of. At least I know that there is no duty of any kind imposed.

Q. These stations are not involved, of course, in this contract, but is there competition in that business?-A. There has been, but I believe there is not now. A number-well, not a number-but there was at that time in operation what is known as a defunct company, which I believe they called the TVestern Fur and Trading Company, that had business at Oonalaska, but they had been bought out by the Alaska Commercial Company.

Q. The fur trarle there was open to free competition thronghont the Territory? -A. So far as I know. I know of no reason why, if they conform to the general lat which is applicable to fur trarling, that is, the employment of natives, that any other company has not the same right that the Alaska Commereial Coinpany has to carry on business, but so far as 1 have been able to ascertain in regand to that, the business hats not been a profitable one for more than one company, and in linct I thiuk the Alaska Commereial Company conld not carry on the business 
were it not that they have had the fur-seal island business, which made it necessary for them to own two ressels, and they could use them in the same trate to carry on business. And that is one reason why they have been able to carry on the other business and to extend the trade in the interior and through the Territors, and I look upon that trading business as a Godsend to those people. Withont it the Gov. ernment wonld be obliged to make provision to care for them-I mean for the uatives throughout the Territory; of course the same thing is arlapted to the seal islands, but it is the general trate I am speaking of now, because if you refer to reveune reports which have been made from time to time, you will find there a large number of small settlements that have been found in a starving coudition almost every year that they have been risited, and large numbers of these people have died of starration, aud they have giren them supplies over and over agaiu.

Q. Do you mean the company?-A. No; the Govermment has. These supplies have been dealt out by the revenue-cutters to keep these people from starving in loealities where there is no trading, and in localities where they have trading and collecting furs, irory, and whalebone, and sueh things as that, and trade them to traders-the Alaska Commercial Company, I suppose, do the bulk of the business in that waythey ean get provisious, money, food, elothing, and all that which is necessary, and can exist. Just how many people there are in Alaska dependent upon that trade $I$ am not in a position to state, but it runs into the thousands.

Q. Involviug the main bulk of the natives?-A. Yes, pretty much all of them. I look npon that trarling as absolutely necessary by the Alaskia Commercial Company or some company who continues to do that in order to keep these people from starving.

Q. Now, Mr. Tuylor, I would like to have your opinion, based upon your information and study, of the present policy of the Government; that is, the leasing of the rookeries in all its bearings, as to whether it is a wise poicy to jursue or not.-A. That is a subject to which I have given a great deal of thoughtful consideration, and without regard to the Alaska Commercial Company or any other company that may be competitors for that lease. It is iny candid judgment that the present policy is the only feasible one that should be emplosed in the care of the seals, and I believe that any other policy which may be pursued would eventually result in the entire destruction of the seal.

Q. That would amount to the destruction of the natives also, unless they were otherwise provided tor-that is, on these particular islands?A. Yes, sir; absolntely. They would starve to death. There are about four humlred people there dejemient upou the seal business for their livelihond. Now I will give you some jeatsous why I have arrived at that concinsion. In the first place, if there is more than one company operating on these islands there would be at once a conflict. It conld not be otherwise. There can uot be but one management of these people, so far as their employment goes; but if you permitted more than one company to land their supplies, or to go on the island for the purpose of securing satal, there wonld be at once a conflict between the two companies, and the eompetition would be stronger, and one would charge the other with auy irregularities that might occur. These irregularities come into a good many things in conneetion with these people and in eomnection with the seal hrisiness. In the first place, if these people coukl get anything to drink, anything in the nature of intoxicants, they would rery soon destroy themselves. There would be no people there. They would all die off. 
In the second place, I can not conceive of any way whereby the rookeries might be divided to enable two companies to operate. If you would lease one rookery to one company and another to another company, then you come in contact with the people's interest, because I can not conceire of a plan whereby these people can work for two companies at the same time and divide the money of two companies at the sime time. It would undoubtedly be to the detriment of the rookeries. I believe the present cane of the ronkeries, in tact the condition of the rookeries at this time, would justify any one in making the assertion that these rookeries are in better condition to-day by far than they were twenty years ago, and it is the result of prudent, judicions care which has been given them that has placed them in that condition.

Q. You mean to say there must be absolute harmony of management and control in order to preserve seallife?-A. Yes, sir; and they must not be molested unecessarily, eithex. Now I will tell you another reason why. If you hare one or more companies, suppose you lease a rookery to each company or different companies. That company would drive these rookeries every day in order to get its quota of seal, and in that way they wonld drive the seal off and they would leave the rookery aud go somewhere else. The policy of the Alaska Commercial Company is not to drice the same rookery more than once in three days or once a week. 'They have four rookeries on St. George and I do not remember how many on St. Panl; so they do not drive more than once in three or four days and sometimes one rookery would not be driven more than once a week.

If a company bad but one rookery alone it would drive it every day, which they would be obligerl to do in order to get their number of seal; but sometimes it is necessary for the company to do this, and when the company finds the rookery is being molested too frequently they will leave that rookery a week or ten days, going to rookeries that have a larger number of seal in order to give them an opportunity to recuperate and get back to the former condition, and for that reason alone, if for no other reason, I do not believe it would be a prudent and a judicious policy to change the present one of leasing these islands. You may call it a monopoly, aud in fact it is a monopoly. The Alaska Commercial Company have a monopoly of the seal business and so would any other company have a monopoly of it; but if you want to destroy the life of the seal, I know of no better method of doing it than that of leasing it to more than one company for the reasons I have stater. That is my caudid judgment. I am not interested in any company or individual in any way, shape, or form, and that is prompted by my own observation.

Q. What would you think of throwing it open to the general pub. lie ?--A. That would ruin it in two years by destroying the seal. It will do it in two sears, if not in a year. That would be snicidal, foolhardy-such a policy as that. I believe that inasmuch as in one sense of the word it is a mouopoly, I believe it would be prudent to open the islands, after the expiration of this term of the lease, to the highest bidder in some way by act of Congress, and the same restrictions shouli be thrown around the islands that they have around them now, and there are some restrictions that onght to be thrown aromul if a new comprny goes there, because a new eompany will be inexperienced in a good many things and there are a great many things done by the Alaska company which a new company would not think of unless they familiarized themselves with it before they took charge; but I think the present laws are safe, so far as the Alaski Commercial Company is concerned, 
because they have done a great deal more than was expected of them by the law.

Q. What do you think it is proper for a company to do more than the law already requires?--A. Well, humanity as much as anything else, and the further fact that these people are absolutely in their charge; that is, in regard to their care and comfort.

Q. Has it not been to their interest to pursue that poliey there?A. I think so; I think it is all important to them for this reason: The law says, you know, that no one but those people who live on the islands shall be permitted to do the sealiug. Now, as I remarked earlier in my testimony here, the reason why the Alaska Commercial Company foumb it necessary to take some natives from Oonalaska to go up there and help with this bundling and other work which had not anything to do with the sealing business there was because of the fact that there was not a suficient number of men on the island to do it. If these people are not taken care of physically and in all other respects by the Alaska company you can easily see that they will soon die off and it will bo impossible to take any one to catch seal which they are taking now. That is one reason, and I have noticed that the company's agent has always been as anxions and earnest in the suppression of auything in the nature of excess in the habits of these people which would be detrimental to their interests as the Govermment agents have themselves. They have been just as anxious and more anxious to suppress it, aud there is not a little thing that oceurs, even little family jars and difieulties, but what always come under the observation of the company's men. They have a sort of guardianship of the people to that extent; and all these little differences are brought before the Treasury agent for settlement and in that way every little detail of the people, even the care and comfort of the houses, is brought to the attention of the agent, as the Treasury agents aro presumed to make them clean in their houses onco a week.

Q. Hare the company built better houses for the people than they formerly had?-A. Oh, yes; I referred to that. The company lave built nice little cottages to lire in. They lired in dug-outs and sodhouses previously.

Q. Do you recognize these as eorrect photographs of these dng-outs and the honses that have succeeded them ?- $A$. There is the original hut that I hare had pietured out to me. There is another [referring to a pile of photographs before him]. You cau see them at Uonalaska now. At Oonalaska, wheie the people are dependent upon their efforts for a livelihood, some still live in this kind of houses.

Q. How are these houses built ?-A. They are built out of sod, dirt, and grass across on the top, and they are about half in the ground. It is all dirt, regular earth.

Q. Is there any fire?-A. Nothing of the kind. There are some few that have fires, but most of them have not. Some of them are got up in very good shape, and some are in a rery beastly condition.

Q. WVill you lonk over those photographs and see if you recognize tho photographs as being correct of the buildings that have since been erected there?-A. Yes, sir ; that is a correct representation of St. George. 'ilhere is our old cotrage [pointing out on photograph]. Yes, sir, these are correct representations of both the people and villages of St. Paul aud St. George.

Q. Now, about the sehools; is there a pretty good atteudance? Is that a correct representation of the schools and school children?-A. There is a pretty good attendance; but there is one peculiarity of the 
people in regard to schools. They go to an English school from the time they are old enough nntil they become of age, and yet they will not talk English if they can help it. 'They eling on to the old Russian dialect and Alentian. I think, though, all understand pretty much all that is spoker to them.

Q. Do you think that prejudice is attributable to the influence of the Greek Church?-A. Yes, sir, I think so, and that the older ones feel that if they should dispense with their native tongue that the Greek Church would suffer by it; and for that reason I believe that is the cause of their peculiarity in this respect.

Q. By whom are the schools maintained? $-\Delta$. Well, they are maintained by the Alaska Commercial Company.

Q. Here are photographs of taking the seals, ete.; are these correct?-A. Yes, sir; it is very natural.

By Mr. JeFFries:

Q. I want to call your attention to the polieg which you have just discussed, and ask you if the opinion you expressed as to the present policy of the Government is not the opinion of all jersons who have been on the ground and hat a knowledge of the subject, so far as fou know. I mean with regard to the policy of leasing to a company.A. The opinion of all I have ever talkerl with, and all that know the condition of things on the seal islands, is in accord with my jurlgment. It is not my own ideas altogether, but it is my obserration and that of everybody I have ever talked with who has been on the islands. And I will say further in that connection that I believe if any fairminded, candid, unprejudiced man will go to the islands and examine into the condition of thiugs and remain there during the killing season, he will come to the same conclusion. I do not think he could come to any other.

Q. Now, there has been a good deal of seal killed in the waters of Bering Sua by unauthorized persons. I want to ask your judgment as to the effect of that upon the seal business if it is kept up-what it will be npon the rookeries.-A. That is something about which I think the Government ought to be more stringent, even, than they have been. I think that the Government onght to take it that Bering Sea is an inland sea, and so ought to have absolute control, regardless of any treaties or fishery laws, over Bering waters from a line drawn west of Attoo through the center of the Bering Sea. These waters are just as much in the territory of the United States as any part of their lauds. They are inland waters running ont to Attoo. There are only a very few ressels that go through the peninsula in all that $\$ 00$ miles distance, and it is to all intents and purposes an inland sea and should be so regarded; and I think the Government ought to take that position. And after we take that position I believe there ought to be more stringent laws enacted which will make it a penitentiary offense for any man to go into these waters and kill these seals, going and coming from the islands for this reason.

These predatory ressels are generally there in the spring of the rear when the cows are going to the seal islands to breed. They have their young very soon after they arrive, sometimes on the very day they arrive, and the most of the seals that are killed by these marauding vessels are cows with young. I do not think there is anybody that can give a very aceurate stalement as to the number that are lilled, but I think that probably from 5,000 to 8,000 will be an estimate, so far as $I$ can ascertain. And $I$ think that 5,000 to 8,000 meaus the death of 
that many young, becanse most of them have their young and are about ready to breed at the time they are caught, and this certainly ought to be stopped. These ressels will take occasion to hang around the islands, and when there is a heavy fog to go on the rookeries. Very often. Wheu I was there they left sixty different carcasses on the islami. 1 weut over to look at them. The Government agents there are utterly powerless to prevent the killing of seal, or to protect them in any way. There is no vessel there, and there is no harbor for at ressel, and I would like to make a recommendation in this connection. I believe with the expenditure of a very few thonsand dollars that the Goverument can build or construct a harbor that will be sufficiently large for a good strong steam launch, and with that steam launch the Government agent can protect the islands very well, because the vessels that prowl aromd are sailing ressels and they ean not alway's get ont fast and as stean lannch can eatch them ; and that is something that I think ought to be done.

The Cirnirman. You think there ought to be a steam launch at the disposal of the Gorernment agent there?-A. Yes, sir; on each of the islands. I do not know what it would cost, but it can be done, and a harbor sufficiently large cau be marle to take in a stean launch so as to have it in an emergency at all times. I beliere that ought to be done on both islauds. As it is to-day, these ressels come and lill 5,000 , $10,000,15,000$ seal every year, and when a revenue cntter does run them down they take them to Oonalaska or over to Sitka and dilly-dally around for six months and then release them. That is a poor policy, and I think it ought to be stopled. I believe more stringent measures ought to be exerted there and more stringent laws if necessary enacted, and the sooner it is done the better it will for the seal. I believe that every possible restriction and restraint should be placed aromil about these seal, and that is one of the important things to be done. Ont of twenty years, I do not think there has been more than three or four owners of vessels or masters of vessels that have been punished, when perhaps there have been a hundred or so prowling aromul in these waters. And yet we hare now two revenue cutters there. That would be my recommenation, that there be more stringent laws made to punish these people.

\section{By Mr. JEFFRIES:}

Q. When they kill the seals in the waters, about what proportion of them do they recover?-A. I do not believe more than one-fourth of them.

Q. The others sink?-A. They shoot them and they sink.

Q. Have you ever noticel any wounded ones that came ashore that have been shot?-A. No, sir; I do not think I did. There may have beeu some came ashore; but of conrse you know there are quite a number of dead seal that are killed in the rookeries. Whether they came ashore or were killed on the rookeries I have never examined, to find out, because I could not do it rery well withont disturbing the rookeries in the breeding season.

Q. Those that these marauding vessels killed on the rookeries, as well as those they lilled in the water, of course on those seals the Gorernment gets no tax?--A. No, sir; it is an outright theft.

Q. Those seal that they do not recover are brought into competition with those on which the company pays \$3.17 per skin?--A. Yes, sir.

Q. How far are the islands of St. George mol St. Patil apart?-A. From 38 to 40 miles.

Q. What sort of climate is it? Is it fogers ?-A. The weather during the summer months is almost a continuons fog; rain almost. 
Q. This affords an opportmity for surreptitious sealer's to visit the islands? - A. Not more than two days in it week conld we see them within half a mile of the island. I think there should be a revenue-cutter there from the 1st of 1lay until the 1st of Oetober; that there should be a revenue-eutter cruising around both of these islands duriug all of that period, and it shonld not be permitted to leave those islands, except to get coal, luring that time.

Q. What do you say alout having them cruise in the neighboring approaches, down towards the Aleutian Islands and the approach to the islands?-A. I do not think that it is necessary: anywhere between Oonalaska and the seal islands wonld perbaps be ail that in necessary. I do not think they find many seal below the peniusula; not enough to amount to anything.

Q. I have noticed in some reports that seals (lo not go in droves through Oonimak P'ass, but cover a large ex tent of water, and it was supposed to have been cinsed by their interception by these surreptitions sealers. Do you know anything about that?-A. No, sir; I am not familiar with that at all.

Q. Where are these seals born ?-A. They are born on the rookeries on the sea-shore.

Q. In United States territory?-A. Yes, sir.

Q. What are they-fish, animals, or what are they?-A. I do not regard the seal as any relation whatever to fish. It is just as distiuct an animal from a fish as a dog is fiom a mule. Their habits, their appearance, and eversthing pertilining to a seal is ti) all appearance ditterent, and its eye is as nearly human as any animal's 1 erer saw. It scems to have as much human in it as any animal; as much as a log. I know in making a drive we can tell whether a seal has been driven before by its actions, and they are very playful. Sometimes young seals will come around the village, just as playful, so far as anything of that kind is concerned, as a cat or a dog wonld be, but of course yoli can not domesticate them, because they will not cat anything ontside of the water.

Q. Will you please describe the first approach of the seals to the islands in the spring; how they eome to the islands, their first apmroath? I want their manner of coming.-A. The old bulls come in the latter part of May. They plant themselves on a rookery or on a harem, which is, on an average, about 20 feet square.

Q. I want to ask you whether they come to the same rock or hamnt on the rookery on which they hat been previously?-A. Yes; almost as a rule they come to the same ground they hat on the previous rear. I know the boys told me that an old bull had been coming for seven years to the same rock.

The Cirniriran. So he was a homestealer?-A. Tes, sir; the bulls are there a couple of weeks before the cows, and they have the gromud all staked off as out west where there is a homesteati. They are coutintally fighting every bull that comes in there and drive bim away, and the weaker bulls must go back. They lieep coming by the humdreds aud thonsands, and by the 25th of May the first cows put in their appearance, that is, the year 1 was there. No, I think that was the 2sth of llay that the first hunded was there; about that time. Then the cows commenced coming in, and ats they came in these bulls cortal them, and those along the shore get all they can take chayge of say from ten to forty, and then the cows get located and have their position on the harem, aud there they remain all summer after they once come. 
Q. When does the young seal first go to the water ?-A. I do not think I can be accurate in any statement as to that. I did know.

Q. Can they swim, or hare they to be tanght?-A. They hare to be tanglit. Their mothers take them out-1 have seen them very often do that and the young ean not swim at once. The cows will talie them to the seat-shore, where she teaches them to swim, and if they happen to go down she will dive and bring them up.

c. Where do the younger and bachelor seals take up their position while the bulls and irows are on the rookery ?-A. They stay at one end of the rookery, and it is generally back. That is, the bulls have got so that they are nearly strong enowigh to hold a harem of their own and they go back, hoping that later on the rookerics will become orercrowherl and that they will have a chance for a harem. But the killable seals are generally at one end of the rookery. They senparate in that way, so that we do not molest the rookery in iriving the seal.

Q. Now, I want to ask a question in regard to the natives of Oonalaskil. Is it not a fact that while the Oonalaska natives brought up are patul wages, the natives of st. P'aul aud st. George receive the whole 10 cents per skin for the whole number of skins taken? $-\Lambda$. That is my molerstanding. In fitet, I know that the natives rectived their full quota.

Q. So that the natives on the island got all the pay that was intended in their quota, and the Oonalaskia natives were pairl their wages, and that the natives lost nothing by the fact that the others got pay?-A. Not at all. It was necessiry for the eompany to bring the people up to get the work done that was needed.

Q. How does the comprany act with the natives with respect to their religious notions :- -1 . 'Whe company gives the natives all the liberty in that respect that they could ask for; in fact. they do not restrain them in any manner, shape, or form. The only thing that the company does in any way to interere with the religions worship, and that is periectly proper, is to compel them, it necessary, to help in the discharge of a cargo, for the reason, as I stated hefore, that on eertain clays the water was bat to dischatrge a cargo, owing to the smef, and some dars when they have religions duty or holidays the company has to get them to go to work in getting a cargo ofit, and in all respects they have absolute freelom from any restraint by the Goremment agent or the company.

Q. Does the compluy povidea sehool for the natives on each island?A. Jes, sir; they have a sehoul-house on each island, and a sehuol teacher paid by the company, which afiords them all the schoul facilities they would get in the Enited States proper.

Q. Are you fimiliar with the conditions of the lease?-A. Somewhat.

(2. And of enurse you are familiar with the Treasury regulations and the law. That was goum business and instructions?-1. I was at the time, but I am a little rusty now.

Q. I want to ask you the general question whether during your administration of affirirs there the company performed all its corenants aceording to the law and its eontract fully to the letter, so far as your observation extended :- - I. Yes, sir. I think they have stated very explieitly that they have done eren more than was required.

(Mr. Taylor siated that he had at home notes and menoranda made while in the performance of his duties as assistant agent of the Treas. mry Depatment, which would refresh his memory on mamy points, and asked leave to forward such supplemental statement, to the committee as he might desire $(0$ malie after eonsulting his memorandal. Leare was granted lim to do so.) 


\section{W. B. TAYLOR, recalled and examined.}

\section{By the CHATRMAN :}

Q. One point I want to call your attention to, and that is to ask you whether there are any indueenints or temptations to perpetrate fiamd against the (rovernment on the part of the company which you observed and that you guarded against?-A. No, sir ; I lo not know of auy thing in the way of inducements to defiand the Goverument ont of anything.

Q. You hal no reason to suspect auy fraululent pratetices being carried on?-A. No, sir; and under the restrietions of the Treasury ageuts and the lease which regulate the transactions there, I do not see how it is possible for any eompany that may have control of the island to defrand the Government. Certainly no attempt has been marle, so far as I can observe, or any disposition to do so. In fact, it would be a very unsafe thing for a company to do, because I think that they realize that their lease of the island is dependent upon their not violating the prorisions of the law, and I know that their agents there have been extremely cautious and particular in carrying out every part of the law, as well as all instructions from the Treasiry Department.

Q. Now, in addition to the additional means and precautions for the prevention of offenses against the Gorermment and depredations upon the rookeries by mliceused hunters, suggested by you, Mr. Morgau thinks it would be a very valuable regulation if all vessels entering the Bering Sea were required to first enter at Oonalaska and report there, and if ureessary to give bond for good faith and obedience to the laws of the United States, that is, they wonld not riolate the laws of the United States. What do you think of such a repuirement as that of foreign ressels aud all vessels? - d. I think if there was a law enacted which would make it necessary for all vessels passing into the Bering Sea from any direction, either from the western, or any ressels between the Pacific Ocean and Bering Sea, should be obliged to enter and clear at Oonalaska, it would be an excellent thing. And in addition to that I should recomment that on their return they shall also be obliged to enter at Ooualaska.

Q. Going aud coming?-A. Going aur eoming. In that way the officers of the Govermment at Oonalaska could ascertain whether they har anything aboard that was contraband, and whether they had riolated any provision of the law; and that would not only cover the sealing islands and sealing business proper, and repredations to their interests, but it would cover and prevent any liguor's and fire-arms and ammunition and everything of that sort being brought there which is contrary to the law.

Q. You speak of Bering Sea; of cumrse you mean Bering Sea in Alaska-our part of the sea?-A. Yes, sir; I speak of Bering sea in Alaska, our portion of it. Of comse the natural comrse of a ressel passes within a very short distance of Oonalaska now. In fact, there is no vessel, except vessels there for no good purpose, but what do pass through very close to Oonalaska. Every one of them would go to A ttoo and go into the Bering Sea, unless to evade a revenue.cutter, and I should suggest that they shomld not pass in or ont of our waters in the Bering Sea without having to pass the port of Oonalaska.

Q. You suggest that they should hoth enter it going and coming?A. Yes. sir; both in and out. I think that in a large measure would do away with all these depredations.

Q. I believe we have no (ansom-house north of Oonalaska ?-A. Mo, sir. There is a place whexe they can monloal, amb the Goremment vessels cau ascertain whether they are there for any good or bad purpose. 
Q. You think that regulation, coupled with the former recommendations that you suggested, that a rerenue-cutter be kept there during the season aud steam-launches supplied the Govermment ageuts, would coustitute a complete protertion to the interestis of the Goverument in that sea?-A. I think, sir, all that is necessary; if these restrictions were placed around the islands and the waters of the Bering Sea the depre. datious in that sea would entirely cease and there would be no complaint. The dificulty heretofore has been that one revenue-cutter has been obliged to cover a territory of 800 miles loug and 700 or 800 miles wide north and south, and they would get around to the seal islands about twice during the season. They never happen to be there when needed, and as far as their rendering any service whatever is concerned, they werc: practically usel ss so far as the seal islands were concerned. That has been the experience, I helieve, of all who have been there. And I think if those restrictions are thrown in the way of all vessels that go in and ont of those borders, there will be no longer any diffenlty in the way of providing and caring for the seals, and it strilies me from what I have real of the depredations since I Tas there, that it is growiug worse and worse every year, and I think that our Goverument onght to act without any further delay if they would preserve the seal; and I look upon it as being one of the greatest industries in the world as it is.

Q. You think in an economic sense it is important to preserve this interest?-A. Yes, sir. The expenditnres in comnection with the islands have been comparatively nothing as compared with the receipts. I think you will find that the revenue derived from the seal islands is greater accorling to the interests orer and above the actual expenses and greater than anything else we receive in the way of revenne.

Q. Thus fal it is very profitable?-A. And it behooves the Government to protect them, and the best means of protecting them is the one to be considered, in my judgment.

Q. If it was tinally to be determined by the Government after an ad. judication and full consideration that the Bering Sea is a closed sea and that under the treaty of cession by which we acquired it from Russia and under the law of nations the Goremment of the United states is entitled to exercise alssolute and complete dominion and jurisdiction over the Bering Sea in Alaska as a closed sea and as inland water, would you think it a wise policy to abandon and surrender auy yortion of that jurisdirtion and open that sea as a high sea to all nations?-A. No, sir ; I think if you open any portion of it you might just as well open all of it, or if you give them auy part of it whaterer. I do not care if you give them an absolute permit to go up in the Norton Sound and into the Yukon; I do not care what the purpose is ; or to auy other points, there are a good many vessels that would go up there and violate the laws, and I think the only way is to make it absolutely beyoud question - make it cover all the waters of the Bering Sea and not leave a loophole for them to crawl out of; for if you do you will have more or less trouble and complications growing out of it, as we have seen on the sea-board here for the last twenty jears. Aud I think the lease ought to be explicit and plain to absolutely cover those points. I do not see any other way that we can have absolnte control and maintain the position that we onght to take. That is my jurlgment.

Q. You do not think, then, that the value of the seal fisheries and the seal rookeries could be preserved under an open policy?-A. No, sir; I do not. I think if you open it they will be destroyed without question.

Q. Do you think it necessary to protect the seals in the sea and down 


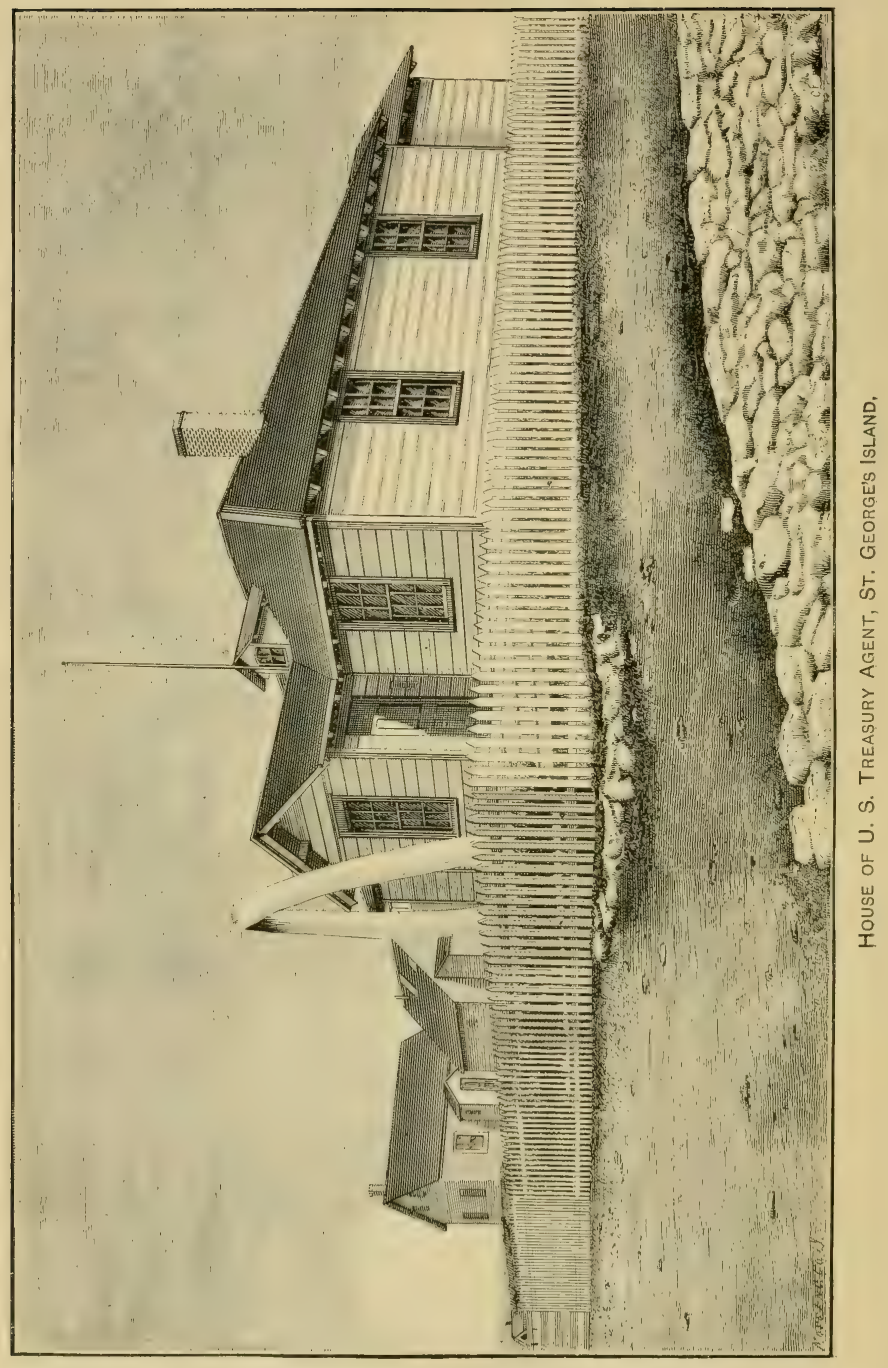


in their fecding grouuds in the Pacific, if possible, in order to preserve their full value and the perpetuity of seal life? Do you think they ought to be protected everywhere as well as on the rookeries?-A. Yes, sir; I think they onght to be protected not alone on the roolieries, but on the waters of the Bering Sea. I rlo not think it is necessary to go ontside of the Bering Sea, because there is no considerable number of them.

Q. Are they so dispersed in the Pacific that they wonld not be liable to lestruc ion?-A. Yes, sin; they are scattered very much, and uo hunters do much hunting in the Pacific, as I understand. Another reason why they should be protected in all the waters of the Bering Sea is this: A large number of seals that are on the islands of comse eat a seat many fish every twenty-four hours, and the fish have become well aware of the fact that there are a good many seal on the seal islands, and they stay out a longer clistance from the islands and they do not come near tha shore. It becomes necessary for the seal themselves, the cors, to go a good distance into the sea in order to obtain food, and it is there where most of the damage is done by these vessels. They cateh them while they are out.

Q. So on the rookeries they go ont raily for food?-A. The cows go out every day for food. The bulls do not go; they stay on the island all summer. The cows go 10 and 15 miles and even fiuther-I do not know the average of it -and they are going and coming all the morning and evening. The sea is black with them around about the islands. If there is a little fog and they get out half a mile firom shore, we can not sen a ressel-100 yards even. The ressels themselves lay around the islands there where they pick np a cood many seal, and there is where the killing of cows occurs when they go ashore. I think this is it wonld be to take 25,000 more seal on the islands than are now taken. I think there is some damage done in the killing and shooting of the cows, and leaving so mauy young without their mothers.

Q. Is it your opinion that a larger number of seals may be takeu annully without detriment to the rookeries?- $\Lambda$. No, sir; I would not recommend that. The time may come, but I think that one jear with another they are taking all they ought to take, for this reason:

I believe that the capacity of the bull seal is limited, the same as any other animal, and I have very freguently counted from thirty to thirtyfive, and even, at one time, forty-two cows with one bull. I think if there were more bulls there would be less cows to one bull, and in that way the increase would be greater than now. While the number of seal in the agoregate is not apparently diminished, and in fact there is undombtedly an increase, yet if you take any greater number of seal than is taken now, this ratio of cows to one binll would be greater, auri for that reason there would be a less number of young seals, undoubtedly. I look upon the breeding of the seal as something like the breeding of any other animal, and that the same care and restriction and judguent should be exercised in this breeding.

\section{TESTIMONY OF T. F. MORGAN.}

At the request of the attorney of the Alaska Commercial Company, Mr. T. F. MoRGAN was sworn and examined.

\section{By Mr. JEFFrIES:}

Q. What is your full name ?-A. Thomas F. Morgan.

Q. What is your residence?-A. Groton, Comn. 
Q. How many years have you spent in Alaska; when did you go there and when did you leave there?-A. I first went to Alaska in 1868. ago.

Q. When did you leave there the last time?-A. Last August a year

Q. Have you been in Alaska every year since 1863?-A. No, sir; the summer of 1868 , the winter of 1868 , the summer of 1869 , wy to the the of August, 1S69, when I left there, and I retmonel to the United States, and remained in the United States until the spring of 1 sit, when I returned to the seal islauds, and I have been there every seal season since 1874 .

Q. That is, for the last fourteen years?-A. The last fourteen years.

Q. What part of Alaska have you visited ?-A. Sitka, Kodiak, Oonalaska, and the Pribylov group.

Q. Have you been to St. Michaels ?-A. No, sir.

Q. Are you an employé of the Alaslia Commercial Company ?-A. Yes, sir; I was until last September, and I suppose I am now, on a leave of absence.

Q. I would like you to take these photographs showing the condition of the natives. You brought these with you? - A. I brought these large ones. The stereoscopic views were taken by a gentlemau in 1870 , I think.

Q. I want you to state whether you linow them to be correct riews of the original habitations of the natives on St. Paul and St. George Islands?-A. These stereopticon views are all of St. Paul Island, and they are a correct representation of the drellings and buildings on St. Paul, as I knew them in 1868 and 1869.

Q. You were there before the company's lease went into operation at all-before they had a lease? - A. I was there when the American ensign was first raised on St. Paul Island. That wạs in April, 1stis.

Q. State whether yon have there any correct representation of the present abodes of those natives, of houses built by the Mlaska Commercial Company?-A. The larger photographs here were taken last year.

Q. Are they a correct representation of the homes of thuse people?A. They are.

Q. Who built those houses ?-A. The Alaska Commercial Companj.

Q. Were any charges made the natives for these houses, or the use of them?-A. None, except the church.

Q. I mean the residences.-A. No charges for the residence or sehool buildings.

Q. What are furnished in the houses? Are stores furnished them?A. When the natives were first put into these frame houses a number of the buildings mere built on the site of the old huts on Barabracas. Now, the old dwellings had no stoves; their cookinge was tone in small turf houses over an open blubber fire. Their bread was hilked in Rus. sian ovens, something like what we call the old Dutch oveu in this comntry. These were all the cooking ovens they had. When the company's employés destroyed their huts and erected the frame houses some of the natives who used them wanted pay for the habitilious destroyed. They had no stoves, and the company made a rule that when a mam moved into a new house he was to be furnished a conking stove, and those were furnished them. When they became worn ont, if the native was able, he purchased a new stove. Widows and childiren who were not able to purchase a stove were furnishecl them. Sometimes it was a second-hand stove, and sometimes a new one. 

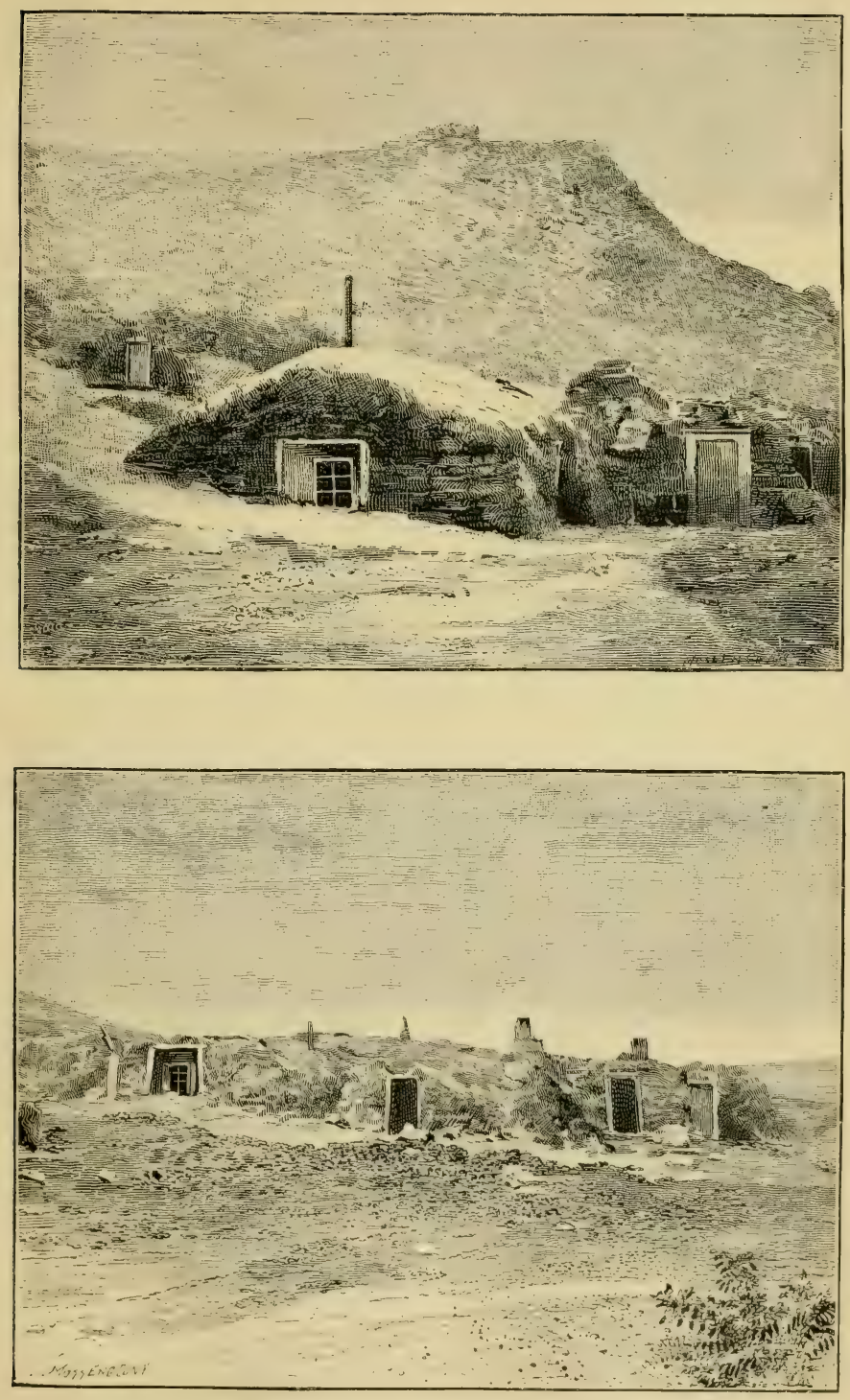

Olo Native huts. 




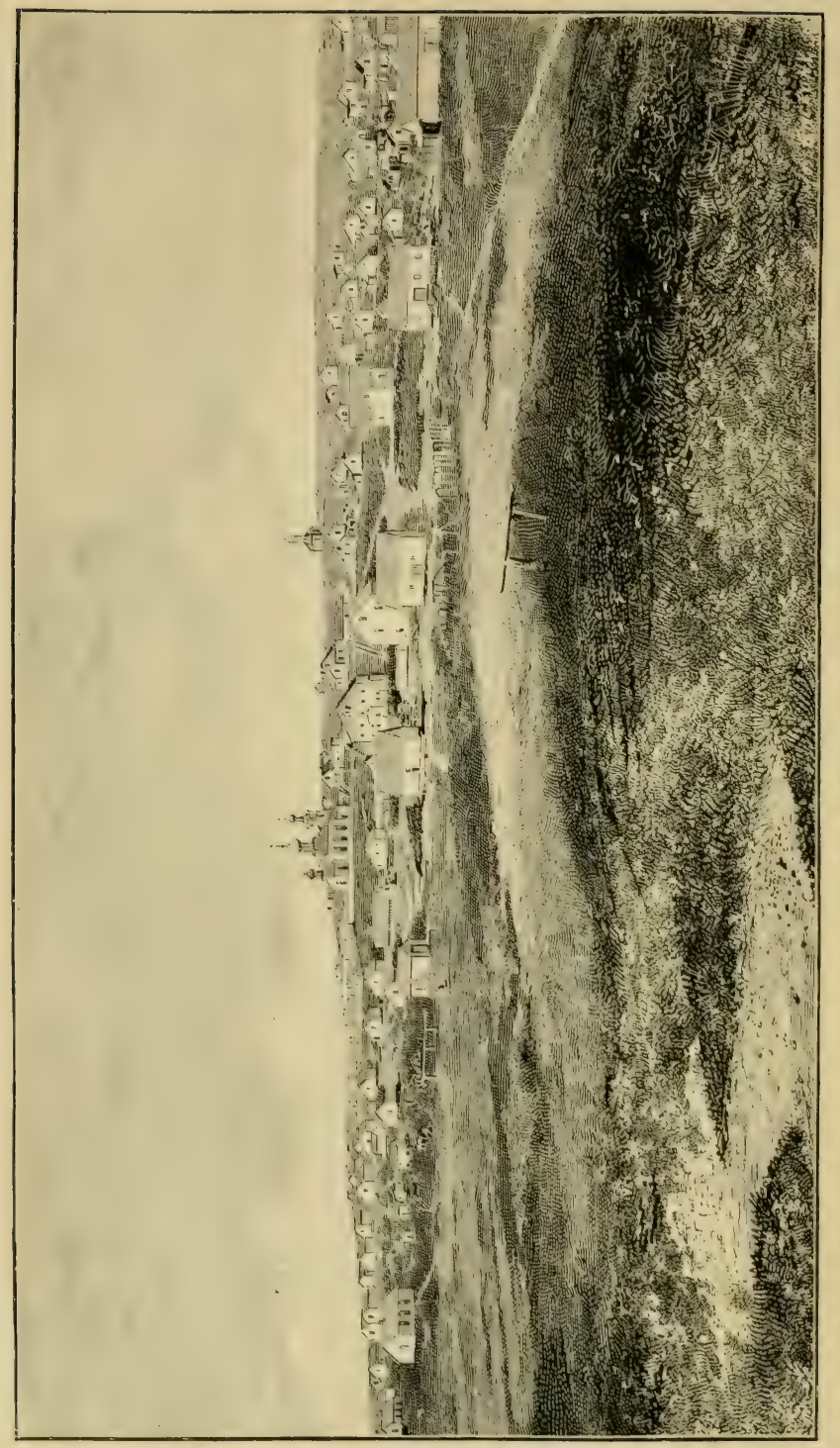

$\frac{0}{2}$
$\frac{1}{2}$
$\frac{1}{3}$
$\frac{1}{2}$
5
5 
Q. Now, will you please describe the interior of the building, as to its comfort?-A. A majority of the buildings are 16 by 24 feet, one story, with an addition 8 by 16 feet, and an entry way. 'The main part of the house is partitioned into two and sometimes three rooms-a living room, a sleeping room, or a living room and two sleeping rooms, and an ontry way-in which they keep their goods and fuel.

Q. They use it as a sort of lumber room ?-A. Not exactly as a lumber room; they use the overhead part as a lumber room and chickencoop. The houses are built with lumber shipped from San Francisco. The frames are generally 2 by 6 and 2 by 4 on the outside, boarded with inch rongh boards, and covered with building paper. Then there is a clap-board put outside of that. Inside they are staled up aud have a floor.

Q. Are they painted, whitemashed, or auything ?-A. Yes, sir; they are sealed t1p and covered with eloth, muslin, and this is filled with sizing, and there is wall-paper put upon that. The furnishing of the door casings and window casings are painted, the ceiling is covered with cloth and painted, and the majority of the natives now have carpets on their floor's, and have bedsteads, tables, and chairs, with pictures on the wall, and it is the policy of the company to have its agents instruct these people in beantifying their homes and in lieeping them elean.

Q. Have they made any progress towards civilization in the last twenty jears?-A. I think they have made remarkable progress, considering the condition they were in.

Q. Does the company endeavor to induce then in that respect?-A. Yes, sir; the orders to the agents were to that effect, and I think the agents have, as a rule, tried to teach these people to lire better.

Q. What are the orders of the company as to the treatment of the natives?-A. The orders of the company are that the natives shall be treated well. It is a standing rule that any employé of the company who shall misuse a native, it matters not what the provocation-if an employé should strike a native, no matter what the provocation was, his discharge would be tendered him the first opportunity. Those were the instructions when I took charge of the station, and they were given to me in these words. I asked if the native should be allowed to use certain insulting language no white man would be allowed to use, and the agent stated to me, "You know what the orders are, and if you disobey them you will be discharged."

Q. Are you familiar with the laws of the Alaska Commercial Com pauy, and do you understand its terms? - A. I do understand the terms, I think.

Q. And you have familiarized yourself somewhat with the law relating to the taking of fur seals? - A. Yes, sir; the regulations of the Treasury Department. That is part of the agent's duties.

Q. Has the company had any trouble with any Gorermment agents in Alaska during all this time that you have been there that you know of:- A. The company has not that I know of. There has beeu some personal friction between agents of the Treasury Department and ageuts of the company.

Q. Now I want to ask you whether the empany has any relations with the Govermment in any part of Alaska excepit on the seal islands ?-A. None that I know of.

Q. Inave they any (jovernment provisions for any part of Alaska except on the seal islands? - A. None that I know of.

Q. Can any company go to Alaska and engage in business anywhere 
except on the seal islands ? - A. I should feel at perfect liberty to fit out an expedition to go there anywhere except on the Pribylor group.

Q. State, if you know, whether or not the company has pertormed the stipulations of the contract and complied with the law and the Treas. ury regulations for the protection of fur seals in daska.-A. They most assureilly have. At any time the agent is iu doubt at all of what should be clone at any point that comes up between the people and the company, or between the Govermment agent or the company agent, the Government agent's decisiou is final.

Q. Has the company at any time taken an excess of its quota of seal skins aud shipped them fiom the island to your knowledge?-A. They have never shipped from the island an excess of 100,000 skins. There have been, as Mr. Taylor stated once, mistakes in counting, but they would always go over for the next year's quota.

Q. Now I waut to ask you whether it is possible for a company to ship slins in excess of its quota, that is, to any extent?-A. I think it is not possible.

Q. Will you explain now why it is not possible for the company to ship an excess of seal skius from those islauls?-A. In taking seal on those islands?

Q. Just describe how they are counted; talie your own time.-A. In taking the seals on those islands the Govermment agent in charge has control of the fishery from the day that the last seal of the quota is taken, which is generally the latter part of July or the first of August, until the first day of the next Jume. There are no seals driven except for food, and then they are driven by permission of the Government agent. After the first of June the company agent directs when and where the drive shall be made. When the seals are driren in and when the skins are hatuled to the salt-honse a sperial agent of the Treasury Department counts those skius into the salt-house.

Q. Let me interrupt you at that point. I want to know if, when the seals are killerl and their skins taken off, whether there is any account made by the chief or somebody by which the amount cau be paid to the natives, for taking the skins, is calculated ?-A. Not ererr year, but until a very short time ago the natives have alrays had a man to lieep count of the skins whenerer counted by the Goverumeut officer alone at the salt-honse, and the company also had to keep the account together with a native.

Q. As I understand it they got 40 cents a skin?-A. Yes, sir. The Govermment ofticer comnts the slins, and the natives are there and they are intelligent enough to know fiom the time it takes to take off a bunch of skins whether or not there are one thousand or twelre humbled. In the counting in they will tell you within fifty of how mauy were taken off that day. The natives have beeu in the business so long that if I send a man to report upon how many killable seals are upon a rookery, if I was going to make a drive that night and send a natire to examine a rookery and report how many seals were there, the natives would estimate within a very few seals and what we can get out of the bulk of seals lying on the rookeries. Of course there are some natives more apt at that than others. The Government officer comnts them in and out of the salt-houses. For the Alaska Commercial Company to get any number of skins, to amount to one or two thousand, it is impossible to drive them from the rookery and take the skins off, cure them, and ship them from the island withont the natives knowing it, and they would want 40 cents for erery skiu that was sent array. Not only this, if he 
knew there was any sub rosa work going on the whole iribe would have to be bought.

Q. He would have to pay the Government officers, too?-A. Yes, sir; unt only on the island but the inspector of enstoms at San francisco and the freight elerks on the roarl which transports the skins, and the treight department and the steamshin line, and the men that dispuse of them in Loudon.

Q. I suppose you know that the company has a contract with Russia to obtain seal skins on the Russian islands?-A. Yes, sir.

Q. Do you know what limit there is there with regard to taking fur seal ? - A. I do not know just what the limit is, but I think it is somewhere about 40,000 or 50,000 .

Q. Do you know that it provides that they shall not take less than 1,000 skins and that there is no limit in the amount?-A. No, sir; but I understand they are obliged to pay a certain price.

Q. I will show that later ou by other witnesses. Assuming that to be the case, if the compauy found the market wonk stand an excess of over 100,000 , which they are allowed to take in our waters, would they not take them firom the other islands where they could take as many as they chose?-A. Yes; I think labor is more easily handled there.

Q. Suppose that they wanted more skins?-A. They would take them from there. I know they have taken a larger quota from there.

Q. I want you to describe to the committee, so far as fon know, the nature of the seal, in regard to their being eatsily frightened away; what their characteristics are in that respect.-A. IVhen they first commence to arrive, the old bulls are the first, the old breeding bulls particularly. They arrive the latter part of April or the tirst of May. When they are first coming to the beach they do not come right out of the water and ruu up on the rocks to their general summer spot. The old males will come swimming in the water, and raise his head ont of the water and growl, call, and if he receives no answer he will generally at low water go in and lie near to the edge of the water. When the water rises he goes off. He is very cantions about going ashore. When he does he smells the rocks aud examines them very carefully.

Q. He is recommoitering?-A. Yes, sir; he is very particular where he goes. As soon in the spring as the first old male is seen or heard, the Gorerument officer issues orders that the natives shall not go near the rookeries. They have hat, in the winter, the privilege of shooting anywhere on the isiand, but as soon as the seals are arriving an order goes out that they must not go near the rookeries, for the very reason that this seal, the alvance guard, if he is lying in the edge of the water asleep and you walk at a distance of a quarter of a mile on the shore, and if the wind is blowing from you to the beach, he is in the water in a flash. After that male has crawled back away from the water a short distance and a second one comes along and he calls in the water, the one on the shore will answer and the second will go ashore much faster when one or two are hallooing on the rocks. Of course if they go near those that have obtained places on the shore there is a fight.

Q. What is the reason that the nse of fire-arms is prohibited during the sealing season? $-\Lambda$. For the reason that in the spring of the year the shooting of a gun and the smell of powder and the men rumning aloug on the rocks will deter the males from hanling up. If oncee on the shore, and they arrive in numbers all the way from fifteen or twenty to twentyfive, they wonld be harder to disturis for this reasm. They have fonght for their own territory and intend to hohel it; and then if the seal was driven from back of the rookery and starts to rush to water, the one be- 
tween him and the water wonld fight him back for mvarling his territory.

Q. What are the instructions of the company as to the number of seals to be killed on these islands; are you directed to kill any in excess of the quota? - A. Most assuredly not. We are instructed in the spring that we shall take so many.

Q. The agents of the eompany are instructed not to take any excess of seals over what is allowerl by the contract?- - d. Nota seal. If they are taken it is a mistake that they do it. The number of seals taken on those islands were never to exceed 100,000 .

Q. What will be the effect upon the seal rookeries if this surreptitious and unlawful killing in the Bering sea is to be permited ?-A. In my judgment it wonlit erentually exierminate the seal. If you would teil me exactly how far this shall be allowed to go I can give you better information of the tume it will take to exterminate them. If they are allowed to land there it will tako but a short time.

Q. What number of seals are recovered that are killed in the water?A. I conlel not state it as a positive fact, but I simuld say not over 50 per cent.

Q. Have any seals been killed by manthorized parties on the Pribylov Islands, to four knowledge?-A. Yes, sir ; I can not state the date, because it was several year's ago; but we have harl raids on the rookeries several seasons.

Q. IVas a revenue entter ever in that neighborhoorl?-A. Yes, sir; there was a schooner's crew landed at Starrie Artille Rooliery. WV had watchmen at Zaporhie and East Rookers. Starrie Artille Rookery is at the east end of high elifls, which ruin 4 or 5 mile:s to the west end of the island, and we thought it impossible for a vessel to come there without heing seen. The boats which landed han left the ressel west of the island and pulled a distance of 8 or 10 miles to the rookery, landed and killed about 600) seals, I should think.

Q. Abont how many white men have you on the island, inchuling the governor and company people? I speak in case of an attack. Sup. pose a buccaneer came with some fifty armed men, how many dirl you have there who could resist them ?-A. We had seven white men on St. George.

Q. What protection have you beside these seven men if a buccaneer should come with an armed crew ? - A. Nothing but the natives. A man that was desperate enough to take chances, and knew the situation, I do not think it wonld be at all a difficult job to come and load a schooner. If I wanted to make an outlaw of myseli, I could take all the skins I want, and not have any trouble at all, for the very reason that I know the points on St. I'aul where they take a vatch of from 25,000 to 35,000 skins, and it is customary there for the native sealers, a gang of abont twenty-five or thirty men, to go to the town, 12 miles off, every Saturday evening to attend divine services on Sunday. They do not return until Monday morning. During that tine there are but two white men left. It is true they have telephone connection; but there is a long, low neck of land, a sand-spit like; it is about a mile long, and if a crew should laud in a fog and cut the telephone connection, why, threes men conld put those two in a cabin, and wait until the natives camo down Monday morning, and hold them up and put them to work loak. ing the schooner.

Q. How many white men have the company at Oonalaska? - 1 . Some six or eight; blacksmith, agent, assistant agent, ete.

Q. What is the condition of the natives at Uomalaska compared with 
their condition when you first went there?-A. Their condition is better now than when I first went there. They are living in better cabins. The company has erected some twenty-five or thirty.

Q. Has the commany done that at an exponse?--A. Yes, sir; and the honses are good, serviceable louses, and the most desimable men are living in them.

Q. That has uothing to do with the seal ? - A. Not at all.

Q. When a supply is taken from Oonalaska up to the seat islands the pay they reserve has nothing to do with the gats going to the natises of the islands for taking the skins? - $A$. Not at all; they are paid outside of that.

Q. So they deprive the natives on the island of nome of that money? A. They do not receive anything from the proceeds of the eateh at all. There is a little misunderstanding about these men, 1 think.

The real realson was not-in fact the island nativess conld do the work. It was for this reason: The Aleut on the islandis is paid the ents for driving, skimning, and salting a skin. All other work is paial \&1 a dity, or 10 cents an hour or a fraction of an hour, and if he works orertime at times they are pais double for overtime. 'The native whe an make from \$25 to $\$ 35$ a day during the season looks nym 81 a day for working in the salt-house, bundling and hamblung the skins after they ane salteri, ats very small pay, and he is not as rapis in his work as he wonld be if he worked for more money, preterring not to do that work. To liscilitate the bunding of skins and getting them ready fon shipment, the super. intendent on St. P'aul-now this plan has beren prisued on št. P'aul, but never on St. George - instead of paying them 81 a day for the reatson a man says, "I can bundle two hundied bindles a day, and thera is a man who only bundles one hundred, and he gets the same as I do, so I will only bundle a humbed skins for a day's work," and so to expeedite the work of bundling the superintendent gave them a cent a bundle; so that a man who could bundle twe hundreal skins a day got paid for two hundred bundles, and a man who conld bundle only one humdred skins a day got only paid for one hundred. Some men eonld bundle skins enough to make $\$ 2$ to $\$ 2.50$ a day.

Q. When these people get too olal to work and have not anything to live on, what becomes of them ?-A. If he has a lamily and they do net support or provide for him the company supports him, and all widows and indigent people. But to go batek to this question of the man from Oonalaska. The next year's they informed the sujerintendent that they wanted a cent and a half a skin. Uf comse lhere were no other men to do the work, and a cent and a half had to go. They were in. formed that if they pursued this policy we would have to bring men there to do that work. They had a cent and a half rhat yoar. 'The wext year, the sea otter hunting having heen rerg porr for some time, lheres were a great many poor people in Oonalaskat that the company hat to support, heeause they eould not sepe them starve; so these suen weres very glad to go to the seal islandis and do any work moloating and loading ressels and do this bundling. Any island man flat wished to work eonld work for 81 a day, or if he preferreed it he could loaf, as we had men to (lo that work. In 1852 and in lsi3: there was an copidenie on st. P'aul, and during that year ont of a population cif simething over 300 souls there were 56 or 59 ) deaths.

Q. What was the camse of that sudemin?-A. It was a kind of preumonia the doctor callext it. My ophinion is that the cantse of it was on aceonnt of their method of living during the winter. "Fhe infin, after the seal season is over and they have their money coming to them, like $9981-5$ 
to gamble and prefer to lay around the house. There is nothing to drive them out, an? they have not to hunt. Not having oceasion to go out, they remain in the house, and they keep the rooms hot and sit around and smoke and play eards, and the women pack all the water and do all the ont-of-deors work, and this ont-loor work makes the women more liable to resist the effects of the bad spring weather. When the steamer comes we have an epidenic of conghs and colds, for the reason that the men live in the heated houses and untit themselves for work. So when they are callerl upon to unload the ressel are liable to have colds. It was at snch a time that we had the typhoid puenmonia, and it swept off a large number of the males.

Q. What do they use priueipally for food? - A. Seal meat and birds.

Q. Have you ever eaten any seal meat?-A. Yes, sir.

Q. They like it?-A. Yes, sir; and it is very good meat.

Q. As I understum it they have no rent to pay; they have nothing to pay for the fuel, which is furnished them by the company, and also seal meat; but their expenses are for clothing and such articles of luxury as they buy at the stores.-A. Fuel is furnished them, a ton of coal to family; it is about that.

Q. So it is rery little expense which they have for living?-A. Medicines and medical attendance are fumished and the widows and orphans, paupers, we call them here, are supported by the Alaska Commercial Company. If a man had some money and had no more than a mother to support, but kicked her ont of doors, the Goverument ageut and the company's agent would see that he eared for her.

Q. What is the policy of the company in regard to intoxicating liquors, quass, or whatever you call it? $-\dot{A}$. The policy of the company has followed out the regulation of the Treasury Department, that it is not to be manufactured or sold on the island. If the Goverument officials were energetic enough to issue orders to stop it, it ean be stopped. The company's agents are always instructed from headquarters to cooperate to prohibit that or any other evil.

$\mathrm{Q}$. Would it be detrimental to the eompany to have the laborers use that intoxicating liquor?-A. Most assuredly. I have seen the time when I did not dare to put a lighter off to a vessel for fear of drowning the erew of Alent.. In discharging a ressel they would sometimes have a quiet brew in the village, and it was all that I could do to get them to work. They would slip ofl and go back for their intoxicant, and I did not dare to put them off' in the lighter for fear they would be drowned.

Q. Ioes the company provide that these people shall be tanght?A. Yes, sir; I do not think the laws provide there shall be any Russian taught iu the school. I think it prorides for eight months' schooling. The reason for the Russian being tanght is this: The Government ageut there issued an order which hardly amounted to compulsory education; that is, every child should go to school-and there was some, friction between the old people in the town and the anthorities as regards that. There was an old man on my island, Egor Kolochiff, who had been teaching the children the church catechism and had his school commencing at 9 and letting out at 12 . Uur school-teacher was at the school-house and rang the bell at 9 o clock and was ready to teach and there was noboly there; they rere all at Kolochiff's. The men lookerl at it in this way, aml said that as soon as the children forgot the Inus. sim language they would forget their religion. The Gorernment officer at that time had told them that it was absolutely necessary to have the linglish school kept; that the company paid the money and the 
children had to have an English sehool. The matter was talked over and finally the men who were opposed - at that time they had no regular priest-aud these old men talked the matter over, and we made this compromise with them, that the children should go to the English school from 9 to 12 o'clock, and at 1 o'clock they should have the use of the building and fuel in order to teach them Russian until the next morning at 9 if they wished. In that way we remored all sense of newness and suspicion from the children and had a very good school from that time out.

Q. They ended by learning both languages?-A. It will end by the Russian giving place to English and I think there have been some steps taken by the church there to have the church services printed in English and Aleut.

Q. Is the Alentian language a written language?-A. Yes, sir.

Q. Do the natives generally speak Alentian as well as Russian ?-A. Generally both. In 1869, when I went there, Alent was the most common language and it will never be relinquished. The liussian was used in trade. At present every native on the island speaks that language and very little Russian.

Q. What is the sentiment of that people towards the Government of the Uniter States as compared with it previously during the Russian administration?-A. It is very good. The teaching of the priests that come there is very good.

Q. Do they seem torealize that they have bettered their condition by a transfer of allegiance?-A. Yes, sir ; the only complaint that I had was that when the Russians were there they conld have intoxicants and while the Americans were there ther could not; but upon being asked, "Will you go back to the old Barrabriea and old straw covers for the sake of intoxicants?" they said "No."

Q. As a matter of fact what do you say as to their condition under this Government and the Russian Goverument; has it been improved ?-A. Very much.

Q. What would become of them if the seal rookeries were to be destroyed and the seal they live on on the islands? $-\Lambda$. They would have to be remored where they could obtain fish the year round or be supported on the island by the Government.

Q. What are produced on the islands except seals?-A. There is nothing there.

Q. What is the conformation or topography of these islands?-A. They are mountainous, hilly, and rocky.

Q. Does anything grow there?-A. There is grass, flowers. There is gond food for cattle during certain montlis of the year, but you could not maintain a stock farm on either isiand. There is about three years, possibly, out of five that your cattle would live during the winter.

Q. How much summer do you have there?- $\Lambda$. We have a fair temperature during the mouths of June and July; Angust, September, and October.

Q. Do you know about the average range covering those months?A. It arerages about $t 1{ }^{\circ}$ during the summer, with a maximum of $60^{\circ}$ and a minimum down to $36^{\circ}$.

Q. How mauy clear days do you have during the sear ?-A. I could not say that.

Q. During the sealing season, which is generally until August, the weather is not so that the sun is visible?-A. Not shining, but so jou could place it through the clouds. 
Q. This is more general than it is in the other months ?-A. Ob, no; we have more sun after September, and late in the fall we have more clear days.

Q. What time does the sun set tiere?-A. At half past 7 or 8 in the evening in June.

Q. Have you any sunlight there when it is night at 2 o'clock?-A. I killed seal up to balf past 11, and I went to work again at half past 2. It was not suu-up), but it would be daylight. The sun would rise about 3 o'clock.

Q. Did I ask sou whether the condition of the natives at Oonalaska had been improved?-A. I think they have.

Q. You have already made a statement in regard to the company building houses ?-A. Ies, sir ; they built quite a number of houses.

Q. I did want to ask yon this, which was referred to awhile ago. In the range of the Aleutian Islands, the sea otter is the principal object of pursnit?-A. The sea-otter and the fox.

Q. This is open to the world? -A. Yes, sir.

Q. Are they becoming extermiuated?-A. In my judgment they are. There are a great many white hunters. An Inlian will hunt until he gets enough for his immediate wants; then he will lay by until he spends the proceeds of his hunt; but a white man hunts week days and Sundays.

Q. A goodly number of white men have gone there aud married natire women for the purpose of gettiug advantage of the law.-A. Yes, sir; there was a regulation of the Department that no persou should engage in hunting sea-otters except natives, and white hunters came there; aud another regulation was that if any white man married a native woman he should have the privilege of hunting, and so a good many upprincipled men have married them.

Q. How long would you think it would be before the sea otter business would be exterminated, if continued?-A. I am not a judge of that. There are people who dwell with them who conld give you better information. At Attoo, when this comntry was ceded to the United States, it was a good station for huntiug the sea-otter, but at the present time the people are very poor.

\section{By the ChaIRMAN :}

Q. As the resuit of your extended observation of the seal islands and study of the subject, what do you think of the existing policy of the Govermment, aud also whether you think this is best for the preservation of seal life, aud the best economical policy of the Govermment, and also whether you think it is the best policy to continue for the good of the natives on the island? - A. I thmk it is the only way to perpetuate seal life. I think the interests of the Goverument, the jeople, and whatever corporation should hold the lease are identical. If the Gorermment wants to preserve the fishery, the only way to preserve it in my judgmeut is to lease it to some responsible corporation under about the same conditions of the present lease. I think that is the only way the business ean be carried on snecessfnlly-is for it to have one head, one recognized methor of doing business, as it has now uncter the existing conditions. The people are provided with a livelihood, and the fishery is handled in such a way that there are no more seals taken than can reasonably be used from year to year.

Q. Were the rookeries in the last years of your risit as full as at the begimning? - A. There is a large increase in the number of animals since $186 \mathrm{~s}$, when I first went there. There is a large increase since 187t, 
when I went back. The breeding rookeries oceupy more territory than they did then. That is a point, in my opinion. to be looked to-the prodncer. If you remore all the killable seals, that is, rapidly, and leave the families, the breeding bulls that are there on the fisheries, in two or three years you could take your hundred thousand seal, as you do not interfere with the protucers. I think that is the only poliey to pursue.

(2. Have vou ever formed an estimate of the probable number of seals that visit the rookeries annually?-A. I have attempterl to do it, but it is hard to do.

Q. You are aware that Professor Elliot, in his book, estimates in the neighborhood of $4,000,000$. What do you think about that rstimate? A. I think that Professor Elliot has orerestimated it. Then he was there the way he figured ont the estimate was that he laid down the carrasses of seals and measured around them and then measured the rookeries.

Q. He estimated the arerage size of a harem ? - A. Not ouly a harem, but erery size of seal, each old bull. He measured the four.year old, the three-year old, the two-year old, and the one-year old grown male, and then he takes the extent of territory where the seal had laid and measured that, and computes his figures from the territory; but they do not lie all over the territory which he marked out.

Q. He measured all around, taking a giren area?-A. The seals did not cover the whole area as thoroughly as he measured it. The only time he could make his measurement was after the seals liad left. These were male then. You can not measure a rookery while the seal are lying there. Bnt he observed the gromil covered by the animals during the season and slietehed ont the letails and where they were lying and measured that after they had left there.

Q. Do you think under careful treatment aud the present policy a larger number might be readily taken off after a rear with safety ?A. Possibly, hut I would not suggest that they should increase the catch rery fast. I should go carefully, and observe the effect, increasing at the rate of $5,000,10,000$, or 15,000 .

Q. From your observation there would you suggest ans better means of gnarding and protecting the interests of the United States in the Bering sea and in these rookeries?-A. To protect the fisheries?

Q. To profect the seal fisheries and keep that sea generally against lawless depredators.-A. In my opinion, the only way to protect the seal fisheries is to declare Bering Sea closed waters as far as the hunting seal are concerned. Take the Aleutian chain of islands as a southeast boundary.

Q. For instance, you are aware that unless the sea is a closed sea it is hardly in the power of one nation to rleclare it so, after it has been once arkinowledged and used by the world as a high sea?-A. Has Bering Sea been so used? I always understood it was not.

Q. That is the very question that is pending in the courts, you are aware. But if it is a closed sea-A. You ought to protect your fishery.

Q. Assuming that it is a closerl sea, what measures would fou suggest the Gorermment should adopt for the better protection of the seal rookeries am the other interests in that sea? - A. If all vessels going into the Bering Sea were obliged to stop at Oonalaska-there is a deputy collector there and a custom-house, and it is al port and a valuable on -if they were obliged to enter there and clear for fishing, or whaling, or trading, when going through the passes into that sea. you would know what their errand was. 
Q. What ressels went there, and what for?-A. And if any other vessel went in there it should be liable to a fine and seizure. I understand now that any ressel taking liquor into that country has to give bond not to sell it to the natives in that country, and if they take firearms on board they have to give bond not to sell the watives a gun.

Q. They are also required to give bond that they will not sell firearms to the natives?-A. Yes, sir.

Q. I do not understaud whether it is our regulation or a Russian regulation.-A. It is ours, because on the seal islauds when the company wish to take breech-loading fire-arms they are required to get a permit from some department to land them there. And I know that medical stores that are taken up there on the islands are taken by a permit. I think if all ressels were obliged to enter at Oonalaska they conld be accounted for, and then the revenue-entter would know how many ressels were in the waters, what their business was, and then if there is a regulation that any ressel taken there with a sealskin was liable to coufiscation, of course it would deter any parties from hunting seals.

Q. If they were required to give bond to observe the laws of the United States in any respect, would not that be important?-A. It is so. There is no question now but that certain ressels come into Bering Sea and earry up breech-loading arms and liquors and trade with the natives in those settlements up along Bering Straits in the Fukon district.

Q. If under the law of nations and the treaty between the United States and Great Britain this is a closed sea, and if muler that treaty and the lans of nations the United States has absolutely and complete dominion and jurisdiction over that part of the Bernig Sea that is within the territory ceded to the United States, would it be a wise thing for us to abandon any portion of that jurisdiction and open that as a high sea to all nations or not? Would it be a wise policy? - A. It would be very unwise as far as the seal fishrries are concerned. These are to be protected as a special interest if for 110 other reason.

Q. Now, for instance, in regard to the salmon, cod, and halibut fisheries, would it be a wise policy to open those and the seal fisheries to all nations ? - A. It would be very unwise to allow any nation to disturb the seal. As far as the salmon is concerned, I think that the irlea of establishing a limit is a strong clitim on our protection, because a 3. mile log limit would be sufficient.

Q. You are aware of the fact that the United States is about the only country that has no law prohibiting foreigners from fishing within the 3-mile limit?-A. So I understand.

Q. The Spaniards have been fishing on the coast of Florida, and complaint has been made here. I think a seizure was made within a year or two. In the absence of a law prohibiting coast fisbing, the salmon fisheries then would be liable to be depredated upon, would ther not?A. I am not well poster on the salmon fisheries, and I think they are taken mostly within the months of rivers and lip the rivers, and not ont in the seas or bays.

Q. I do not know that we have any law prohibiting foreiguers from fishing in our rivers, unless it is a local law of the State for the protection of game and fish. There is no law of the Government in regard to it?-A. In my opinion unless there is-

Q. The States themselves protect the fishing within the State. What is your judgment generally as to opening that sea to the use of inhabitants of the whole world as any other high sea? $-\Lambda$. As regards its effect upon the seal fisheries?

Q. Yes; and upon our interests generally.-A. I think it would bo 
suicidal. I do not think there is a possible question. but if , on will allow these maranding sehooner's to go into bering Seal and hunt anywhere, say io miles off, that it is only a matter of time, and not a long time, before the seal fishery is ruined. The cool, and halibut, and salmon fishing I am not conversant enongh about, any mort than by an irlea how it will affect that fishing in our portion of the waters on tho Connecticut coast.

Q. In other words, fishing seems to be open to all nations coming there, and the other fellow has bait gombl--A. On the northwest eoast it is just the other way. We have the bait gourd, the water, and the big fish.

Q. And the bait too?-A. And the bait, too.

Q. So you think if we had it all, the policy would be to keep it all ?A. I gencrally think when I have got a good thing I do not want to give it to my neighbors without an equiralent. There is no question. but what these schooners have had an elfect upon the rookeries in the last three years in the difference in the way the seals arrive. A large number of these seals come ashore wounded and carry ing lead. I thiuk last season I took out of 18,000 or 20,000 as much lead as I coutrl hold in my hands this way, bullets and shot. I do not know that I saw but one seal that would have died. This one was wounded with fom buekshot, and was breathing though the womce and not though his nostrils; that was a fresh wound. There is no question in my mind but what a very large percentage of those animals taken mear. the shore are females. I was requested by officers of revonue ressels to investigato certain skins they seized there, and that is where I gut ny information in that respect.

Q. Do you think it is important for the Gorermment to keep) a revenuecutter in these waters during the sealing season?-A. I do.

Q. In addition to the precautions you mention of reyuiring ressels to enter at Oonalaska?-A. Une cutter to cruise the se: would be sufficient. If you will allow ressels to go there within a limit of !), 10, or 20 miles, sou want sufficient vessels to keer? theni off. It is almost impossible for the men there to wateh over these vessels, for they might get lost in a fog and drift inside of that limit, and if he intended to be dishonest it is the easiest thing in the world for him to slip orer on the island and kill a few seals.

Q. Is whale fishing carried on to any extent?- $\Delta$. Not near these islands or Oonalaska.

Q. They will generally go through that sea?-A. They go mp by it.

Q. Have you ever formed an estimate of the ralue of the seal rookeries as a property, if it was reducible to possession and coutrol ?-i. I have always felt and said that if the United States (xoverninent would give alsolute protection I would be perfectly willing to mathen for the

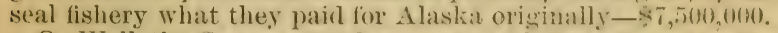

Q. Well, the Govermment has very nearly goteven on its fruchase?A. Yes, six; and it is more valuable to-day than in 1568 , when they first got it.

Q. How has it worked that?-A. In ist the eomulumy issued a re. port in regard to the rookeries. At that time I was on st. Cienrge Island, January, 1877. 'There were two men in the ('mploy of the eompany who were available to make that rejout. ()ne wais Mr. I)aniel Wroster, an excellent man, who was there in 1865 aml 1 s! 9 , amol he went over the rookeries aud insprecterl all aromnd the islands. Thro inal in. creased largely on the west entl of St. I'aul. There is a ronkery there now that will produce probably $j, 000$ or 10,000 seal. In Licks not 
a seal banlel unt there. There was a rookery known as the Sonthrest Bay; another, Zoltoi ; Middle Hill had a few there, and now there is not a space unoecupied. Now, Zapodnie has extended to the west all of a mile, and now Zoltoi, Middle Hill, and Zapodnie are virtually one rovkery ; they have come together. On the northeast point, in $1 \mathrm{~s} 6 \mathrm{~s}$, the breeding rookery was the northeast point extending around, a hauling rookery which is always just at the edge of the breeding rookery, on the westward and that oceupied not more than half a mile; then there was a long, sandy beach of $2 \frac{1}{2}$ miles that seals did not hanl up) on. At the present time the breeding rookery has exteuded so as to corer the old hanling gromol and the banling gromed has extended to the sand to the westward, a distance of $2 \frac{1}{2}$ miles. On the hill, which is another rookerr, were large vacant spots, where no seal hauled, and these spots have closed up). It is the same condition of affairs on St. George.

Q. Then the result of your obserrations is that there has been an increase in numbers? - A. Yes, sir; there was a question in the minds of sone pesple there whether the seals were increasing or not, for at parts of the island where, in 1868 and 1569 and 1870 , there were a thonsand seals, in tsitis and 1577 they could not get a seal over there. The reason for that was that when the breeders were on the right of the beach aud the last anci whenerer a young male came along the old bulls would drive him ont and he would irnise arombl, and yon conld see it was like a road between the two, and there he would haul ont separate, and of comse that kept narrowing the space until it mas shut out entirely. These bachelors had to haul off at some other place. In 1870, 1871, and 1872 they had a number of such places where they hauled out, and in 1877 they were choserd ont, but there were new places opening up all the time. Occasionally the hanling grounds changed, and there seemed to be no reason particnlarly for it. All these places conld be accounted for why they ehanged. It seems that a seal, as with other animals have old males and females, and when the females get in heat the old males drive the young olf. It is just the same as with eattle.

\section{T. F. MoRGAN, recalled and examined.}

\section{By Mr. JeFFries:}

Q. You stated something in reference to the moneyed value of the seal islands. I think you said if you were guarantied protection, you would be willing to take it at what the Government paid for Alaska. I want to ask you whether there are not some other cousiderations besides protection. For instance, is it not possible that the seals might abaudon the rookeries, as they have done once, I think, in Aiaska, and as I think they have done elsewhere? In the next place whether you would not want some assurances that the price of seal skins would be maintained. What do you think of that?-A. May be in making my estimate, I dir not take in the question of demaml; I was ouly taking in the question of supply. I had nerer figured on what I was going to do with my skins; but erery jear this has been the source of supplying 100,000 seal skins, and I beliere they have always been sold.

Q. Do son know what the prices of seal skins were when they commeinced doing business?-A. I do not, sir; not outstanding.

Q. You never heard ?-A. No sir.

Q. Do you know or do you not know the first year's business was doue at a loss, and that seal skins were worth less than \$5, and that it cost $\$ 6$ or $\$ 7$ to lay the skins down in the market.-A. I do not know about this. 


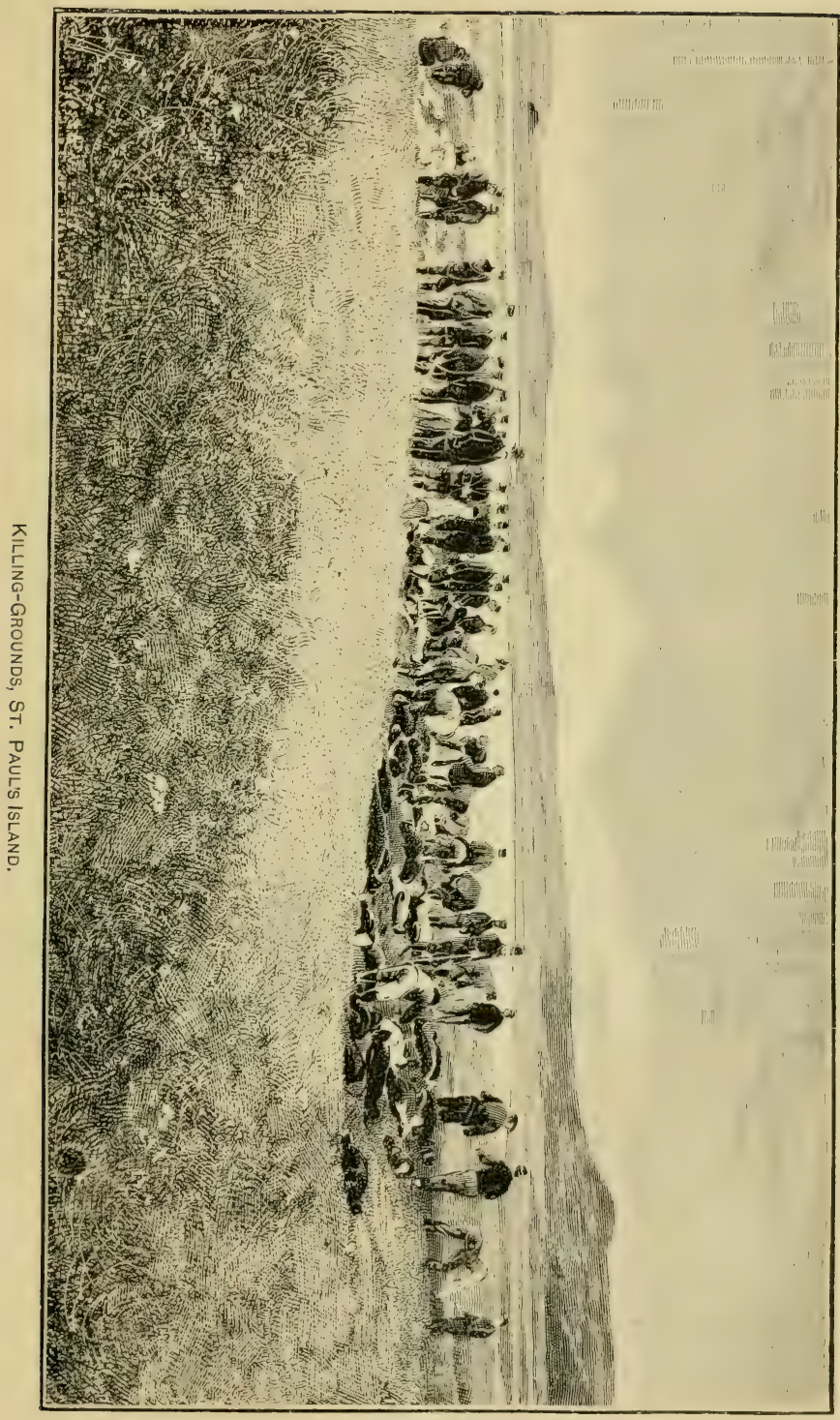





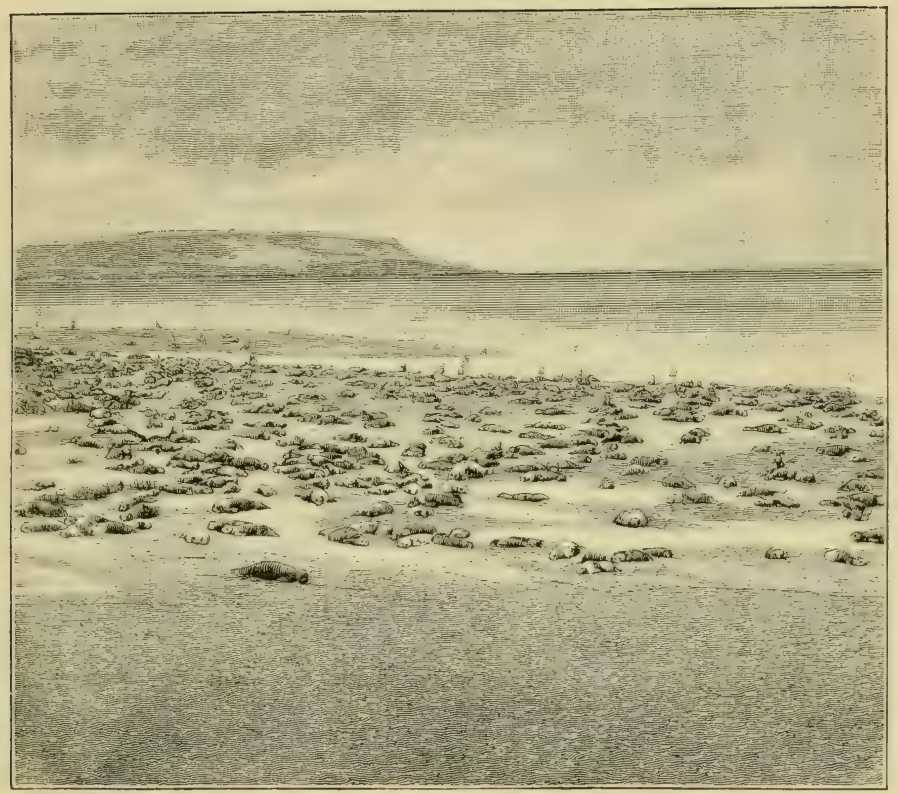

HAULING-GROUNDS AT ZALTOI SANDS, ST. PAUL'S ISLAND. 

Q. Did jou know that the prices of seal skins depend a good deal upon the fashion?-A. I should suppose so.

Q. Do you happen to know, as an agent of the company, whether it costs the company anything to stimulate the fashion in seal skins ? - A. No, sir.

Q. Is it within your knowledge that within the last ten or fifteen years mink skins were worth $\$ 15$ to $\$ 20$ ? $-\mathrm{A}$. Possibly twenty year's ago; I know mink skins were worth a good deal of money. I remember a man in-

Q. Are they worth 50 cents a piece now ?-A. I do not know.

Q. Can you sell them at all ?-A. I know nothing about it.

Q. They are just as good as they were teu years ago?-A. A good class of mink would be, I suppose.

Q. What is the reason for the falling off in the price?-A. Possibly the change in fashion; but I do not know anything about that. I was only figuriug that from the fisheries I should take 100,000 seal skins, if protected.

\section{By the CHATrMaN :}

Q. You based your estimate upon an idea of a fixed and same ownership? -A. I was figuring on what the market had been. As regarils the price the Alaska Commercial Company gets for their skins, that is a part I did not consider. I have been taking care of the supply, and somebody else has been taking care of the other-the demand. I should suppose so.

\section{TESTIMONY OF C. A. WILLIAMS.}

Mr. C. A. WiLlinjIs, strorn and examined, by request of attorney for the Alaska Commercial Company.

\section{By Mr. JEFFRIES:}

Q. Where do you live?-A. In New London, Conn.

Q. How long have you lived there?-A. Fifty-uine years.

Q. How long has your family been living in Massachusetts and Connecticut?-A. Since 1642, I think.

(Q. Was one of sour family a siguer of the Declaration of Independence, and if so, which one?-A. Yes, sir; my great great uncle was a signer of that document.

Q. What is your business?-A. Shipling, generally whaling, sealing, and allied pursuits.

Q. How long have you been engaged in that business?-A. I have been engaged in the whaling business, personally, for forty years.

Q. And whom did you succeed?-A. My father.

Q. And whom did he succeed?-A. His father.

(2. So that for generations you and your forefathers have been engaged in the whaling and sealing business?-A. Yes, sir.

Q. Have, jou any ressels at sea now?-A. I have; yes, sir.

Q. Hare you erer been at sea yourself?-A. Yes, sir.

Q. Have you been in the North and South Pacific Oceans, and Bering Sea?-A. Yes, sir.

Q. Are rou familiar with the eharacteristies and habits of the fur seal ? - A. I am, from reading, and from conversations with my captains; not personally.

Q. Will you state to the committee what you know with regard to their habits and as to where their haunts have been hitherto, and how 
they have been exterminated or been driven away? Take your time, aud state it to the committee in jour own way.-A. With regard to the habits of the fur seal as an animal I know that at certain seasons of the year the cows come upon the land for the purpose of giving birth to pups and the ordinars purposes of reproduction. They come regularly to certain hamts familiar to them, remain there usually through six months of the year, go through the process of delivering their young and shedding their coats. At the proper time in the season they take their departure from these haun ts for points practically unknown. When they are on the land they are at the merey of whomsoerer hunts them, mnless there are restrictions. The listory of sealing goes back to about 1790 , and from that to the early part of this century.

In the earlier period of which I speak there were no seals known in the North Pacific Ocean. Their particular haunt was the South Atlantic. They were discovered by Cook in Lis royages, on the island of Desolation, by Widdall, in his voyages to the south pole, on the island of South Georgia and Sandwichland, and by latter voyagers, whose names escape me, in the islands of the South Pacific ()ceau. When the number of seals on those islands were first brought to the notice of British merchants they pursued the hunting of these animals on the island of Desolation. The most authentic authority we have about the matter is derived from reports made by these royagers as to the number of seals taken from those places, and althongh they are not entirely accurate, I think they are fully as accurate as conld be expected, considering the lapse of time. On the island of Desolation it is estimated that $1,200,000$ fur seals were taken; from the islaud of Sonth Georgia a like number were taken, and from the island of Masafuero probably a greater number were taken. As to the Sandwichland the statisties are not clear, but there can be no donbt that over half a million seals were taken from that locality, and in 1820 the islands of south Shetland, south of Cape Horn were discovered, and from these islambls 3:0,000 fur seal were taken in two years. There were other localities from which seals were taken, but no other's where they were found in such large numbers. The market for fur seals in those days was China. The trade which the British and Americans had with China was rery much against them becanse of the high rates of exchange upon the coin.

In the trade with China some exchangeable medium was necessary, and they found in the fine furs of various kinds, particularly the fur seal and sea otter, a good medium of exchange. These skins of which I have spoken were sent mostly to China, although some portions went to England and France and Germany, and were exported from there to Russia. They were used in the manufacture of caps and capes and small articles of that character. The Chinese used them for lining garments and making dresses of luxury and comfort for their mandarins. The market price for these skins in China, as nearly as can be fomd now, was $\$ 4$ to $\$ 6$, but it often happened that when there was a large quantity in the market, the price of skins was depressed, so that they would bring scarcely 50 cents apiece. Captain Delano carried a cargo of 38,000 skins to China and sold them for $\$ 16,000$, which shows the result of a depressed market, and the uncertainty of all ventures of that sort. The trade went on until these localities were all exhausted of their fur-bearing animals. Then the trade went into a state of desuetude, and was ended. There were a few skins brought in from the Cape of Good Hope occasionally, but I do not think they areraged a thousand skins a year from all these places.

Q. What is the condition now of those rookeries that jou have enu- 
merated ?-A. I shall come to that. The cause of the extermination of seals in those localities was the indiscriminate character of the slanghter. Sometimes as many as fifteen ressels would be hanging aromd these islands awaiting opportmity to get their match, and every vessel wonld be governed by individual interests. 'They would kill everything that came in their way that furnished a skin, whether a cow, a bull, or a middle-grown seal, leaving the somng pups just born to die from neglect and starvation. It was like taking a lieri of cattle and killing all the bulls and cows and leaving the ealves. The extermination was so complete in these iocalities that the trade was exhausted, and royages to those places were abandoned. About 1870 , nearly fifty year's after the discovery of the South Shetland Islands, when the oceunation of Alaska by the cession of linssia to the United States of the Bering Sea was brought about-

The Cmamanan. I want to intertupt yon to ask a question bearing on that point. Were those rookeries in the South Seas never under the protectorate of any goverument at all?

The WI'Ness. Never. I was going to say that when the cession was made by linssia to the United States of tinis territory, and the suinject of the value of fur seals, or the possible value, was brought to mind, people who had heen previonsly engaged in that husiness revisited these southern localities, alter a lapse of nearly fifty years, and no seals were found on the island of Desolation. These islands have lreen used as the breeding place for sea-elephants, and that creature ean not be exterminated on that island, for the reason that certain beaches known as "weather beaches" are there. The sea liraks rudely mon these beaches, and it is impossible to land upon them. There are eliffs, something like $3(00$ to 500 feet, of shore ice, and the sea elephant finds a safe resort on these beaches, and still preserves enough life to make the pursuit of that auimal worth following in a small way.

I have ressels there, and have had, myself and father, for fifty or sixty years. But this is incedental. The island of South Shetland, and the island of South Georgia, and the island of sandwichland, and the 1) ienos off Cance IIorm, and one or two other minor points were found to yield more or less seal. In this period of fifty year's in these localities seal life had recuperated to snch an extent that there was taken from them in the six years from 1870 to 1876 or 1877 , perhaps 40,000 skins.

Q. After they had been abandoned for fifty years?-A. Yes; to-day they are again exhausted. The last fear's search of ressels in that region-I have the statisties here of a ressel from Stonington from the Sonth Shetland Islands, reported in 18ss, and she prortured thirty-nine slins as the total result of seareh on those islands and sonth (ieorgia.

One of my own ressels procured sixty-one skins, including eleven pups, as the total result of her voyage; and, except about Cape IIom, there are, in my opinion, no seals remaining. I do not think that one humbed seals conld be procured from all the localities mentioned by a close seareh. Any one of those localities I have named, moler proper protection and restrictions, might have bern perpetuated as a breeding place for seals, yielding as great a number per annum as do the islands belonging to the United States.

Now, the trate in those iocalities is entirely exhansted, and it wonld be impossible in a century to restock those islands, or bring them back to a point where they would yield a reasonable return for the investment of capital in hunting skins. That, in brief, completes the history of the fur seal in the South Atlantic Ocean. 


\section{By Mr. Jetrates:}

Q. How many seal rookeries are there at, present in the world? - 1 . Three.

(3. Where are they located ?- - T. The smallest and least important of all, hut the one which is of historical value, is that in the Lobos Islamels, in the mouth of the livere Lat Platte, betomging to the govermment of Monterideo. It has beren muder govermment prestection, I think I can salialy say, for mearly filty geats. There atre restrietions placed npon the killing of seal, lont they are not suftedent to bring the rookery to its highest value, but still alre (mongh fo preserve seal life.

These islamels have heen leased lor a term of ten or twenty gears by the govermment to private farties, and the skins taken all go fo laridon, and atre sold at the ustal time of sale there. (O) ing to the latiturle in which those seals exist. the fur is mot of the finest. The fur bears no enmparison to that of Alaska seaks, mo those of the limssian islands of Uopper and Bering, in tho Bering Sea.

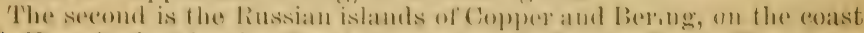
of Kameloatka, in the liussian portion of bering seat. These two

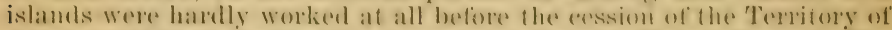
Alaskat and the islamels and wateres thereof to fhe United states. Thes liussians previous to that drew all their supply of seal skins from the

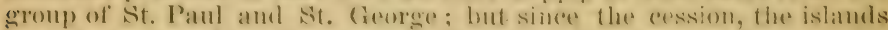
have beren leased hy litssia to a complany of Amerioan citizens, who

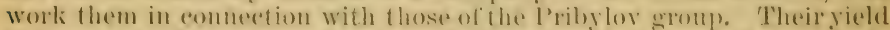
is about 10,000 shims per ammom. They might in pressed fo do a little better than that, hut it would be injulievous. The fur is not eroual to the fur of the Alatsal seal, althomeli is sairl that fur seals that inhabit these islands went to them from the Pribyloy groul). That in the litussian tradition.

'The third is that we have moler eomsideration, the islamels of st. Paul and St. (ienrege. It is the largest rookery of fur seals that wats over known, and with the excention of the seats taken on the sionth Shetland lstamel and some other somthern puints, they are the finest tur animals. Simes the enatement of the law of the Juited sitates leasing those istames they have bexn worlied regulaty hy the Alaska ('ommereeial company. They take from them abunt a humber thomsand skins anmally. Their mitmer of working the island, earing for the seals, and studying their habits and treating them in such at way and in a measure domestientiog them, has beren mate so eareful a study that the matter has now resolved itself into as regular and acemrate a piece of farming as the care of a cattlo ranch.

liesularly every seasom the hulls appear, then the (eows eome alterward and stal about the shore a wating the time of the delivery of the youms. 'They remain about six months, and leave in the antumin. The chass of seals from which skins ate taken atre what we form batehelor seals. 'They are a elass of yomong males that have not arrived at the dignity of mambool, and are mot allowed by the old bulls to take elatrge of the cows as they come up, or interfere with their harem.

(Of eourse what i may sily mpon that point ! eamost speak from peresomal observation. I only kmow fom very earoful comversations with

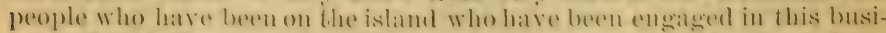

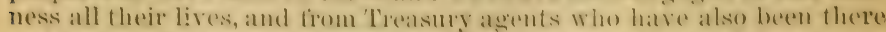
and know these points. From Mr. Cillint s figures, lam of the impres. sion that not one in tire of the bateleder seals ane killed. and that there is a sufticient supply of hulls for the eows of the hatem. 'The harem does not usually exered ifenty eows to the bull, amb the possibility which you 
mentioner of the exhaustion of the brexling seals made itself evident at one time to the linssians, when they commenced under the linssian Fur Company the killing of these animals; and they having had an experience which rembered it necessary to restrain the killing lior two or flues vears, made such rules amb revenlations with resard therefo as to permit a proper growth of a suffieient number of bulls, and those regulations have bexen carefully olserved and followed by this company since, and to them they have added their own observations. It has been made with them a matter of eareful sturly. So fax as the company has any reason to know, there is no lack of bulls for service, not (locs it ap)pear as if there would be in the future. If the depreflations of mulicensed hunters are restrained I am inclined to think that there atu be no doubt but what 100,000 seals, which are taken from these islands ammually, are somewhat within, I think I may safely say, 15 or "2) pere eent. of the number which can be taken without injury to the herd. If you were considering them as a herd of cattle on your ranch, you could kill a larger proportion of your ealves without injury to gour herd.

The company has never askerl for any extension in killins, and it is not a question which womld be determined alone by the possibilities by any means, but it is a question which would be equally determined by the market and demaurl. While it has happened dning the continuance of the lease up to this point that the company has twice taken less than 100,000 by a considerable number-- taking, I thmk, one year 75,000 only, and another year only $s(0,0)(0$ - there has never yet been a year in which they have asked for jermission or eren wished to take more than 100,000. 'This question of the market is one which-

(). Before you go on with that I want to ask you some other questions; then you can begin on the market. When did the Russians be. gin to worli the Pribylor groul)?-1. I think it was about 1790 .

Q. Under what process ware they workerl?-A. At first when the Russians came to know this country of liering sea their hunting expeditions were confined mostly to the taking and killiug of the sea ot ter which abounded about the Aleutian chain. That was then the fur of most value in China, and the fur seal was not anywhere near as profitable in trade as the otter, and were rather pissed by. After a little time the attention of the liussian hunters was called to the fact that immense bodies of these fur seals came with great regularity every season through the passes of the Alentian Islands, and went somewhere. They did not know these islands, but noting this fact for a year or two, some enterprising eaptains amongst them made search and sighted the island of st. George filst, and afterward St. Paul, and landing on them discovereal the home of the seal. Then the population which ocempied these islatuds and main-land about there were all hunters and searchers for pelts. They divided into a great many parties, established little locations on these islands for the taking of these skins, and they went on very much in the way in which the hunt commenced in the sonth Atlantic, until they came to a realizing sense of the fact that exhaustion was going on. 'Tine attention of the governors there and in the home country was called to the fact, and restrictions began to be plated upon the taking of the seals. They were marle in a somewhat arbitrary manner, and the eompanies were driven off, and an examination was mate into the charaster of the roskeries to see what damage had heen dome. It was fomml that a great many seals hat been ruthlessly killed and probably a great many driven away. It was supposerl at that time that the commencement of seal life on the islands of bering and Copper probably took place by reason of the indiscriminate killiug on those islauds, 
diverting the seal from their usual haunts and making them seek some other localities.

Q. Was there a large number of seals which left the Pribylor group and went over to the Russian islambls?-A. You eould hardly expect them to go in a borly. There had hathly heen sealing or seal life to any extent on the Commander lslands or Coppere and bering. It had not attracted the attention of the linssians, lut after the indiscriminate killing on the islands of St. P'anl and St. (ieorge, it wats noticed that seal life inereased rapidly on the other islands, and the suppesition is a natural one that they were diverted from the islands on which they had heretofore been umlisturbed and songht other plateds. The Rilsisians restricted the killing entirely for four or five years. After that they permitted killing of a certain number. 'Then the so-calied linssianAmeriean Fur Company was formed, and the privilexes of those islands given to that company to take fims. This Russian Company, I think, contimued to take from 15,000 to 20,000 skins from those islands and shipped them in those days to Germany (Hambure, I think) and London, and in the regular enurse of business the trade all fell into the hatuds of one German house, (Oppenheim of (o., and they mate al entrate with this Russian Fur Uompany to take their catceh to the number of 20,0 , (ono skins at something like ten shullings per skin delivered in Lomblon. The skins were transported around ciape Horn and delivered in London. Skins at that time were shipped in what was ealled parchuent; that is, they were drienl, not salted. The skins were taken from the animals and dried and shipped as goat skins now are. When they arrived in Iomdon they hat to be softened again, which somewhat depreciated their value. It was not until somewhere in the fifties that the first shipment of saltod skins took platee, and it was ensiderent a lailure in London; but after some further trial, the house of Uppenheim was satisfied that salted shipments mate better fur, and they made contrate with the Russian Fur Company for fur seal salted, at 14 shillings. That eontraet was in foree and insage at the time of the ression of Alaska. Skins were going forward delivered in London at it shi!lings.

Q. IIow much is that in Ameriean woin ? - A. Saly t shillings to the dollar is very nearly 83.50. It would he as near that as possible, delivered in Lomblon; that is, after the voyage aromel Uape Horn.

By Mr. JEFFRIES :

Q. Now, as I understand you, the first instanee that the Government undertook to restriet the killing of tur seal and protect them in any way in the Bering sea was a short time prior to the formation of the liussian Ameriean Company, as it was known?-A. Jes, sir; that is in Bering Sea.

Q. That charter was granted, I think, in 1799 by Emperor l'anl for twenty years, and renewed from time to time?-A. Yes, sir: I think so.

Q. Entil about the time of the e'ssion of Alaska to the United States?-A. Yes, sir.

Q. Xow you ean go on with the question you were talking about when I interrupted you about the marliets.-. This trade there went on with the liussians until the time of the cession. It was not a profitable trade. The liussian Ameriean Gompany was always falling into arrearages and debt, and was alwals bringing the Russian (borernment into its debt, and my own impression is that the liussian (iorerument, at the time they disposid of those islands, did not eonsider that there was any particular value in the seal trale, as it hanl al ways been a source 
of drain from the company. The company was composed of high officials, mostly in Russia, and it was considered a good thing, because if the seals did not pay the (rovermment would. It was to be gotten out of them in some way. They had an establishment on a grand soale. They sailed their own ships and exereised martial haw over that regrion and handled these Aleuts, who were there like so many machines which you move from onei sland to another. They took them firom the Alentian Isiands and carried them over on those islands, and I think the highest wages they paid them was 10 cents a day for killing, packing, and loating the skins on board their ships, and they gave them the necessary provisions to sustain life, but they were all of the coarsest and chuapest. They were simply looked upon as a higher grade of animal than the seal. The people lived in huts in the gromul, with a turf roof, aud they had nothing but their religion and their priests to keep their attention other than that of their business.

The Uramanan. In that commetion I wish you would refer to these photographs and state whether they are correct representations of their habitations there.

The Wristst. Пere are stereoseopic views of the old houses in which these people live, and those were the best they had ; and, in faut, they were all they had. Here are some more reesnt of the native huts. That, was the hnt in which they lived and their whole life was in aceord with that. They had nothing much to hope for. These islands when first discovered had no inhabitants, but there were natives on the Alentian chain.

\section{By Mr. Cummings :}

Q. Are these photosraphs of the Alentian Islands? These, you say, are of the Pribylor group.-A. These aie the houses in which they live, and that is about the manner of their life. St. P'aul and st. George, I mean, not of the Copper Islands. ПTere are a comple of views of seal on the rookeries [handing photograph]. As time went on the trade, as I said before, in these skims was not remunerative to this Russian company, and they were continually filling bak on the Gorernment for a recomp of their losises; conseguently, when the transfer was marle it does not seem to me that they consilered these fisheries of much value.

Q. Iunderstand the Inussians brought the Aleuts over first?-A. They brought them from the Alentian Islands, where they foumd a goorl hunting ground and a comfortable existence, placed them on those islands to kill real and load the skins on board their vessels, hut the people of the Alentian Islands considered it a great hardship to bes taken there, because the service was very hard and the climate was hatrsh, the living poor, and there was no possible living for them ontsicte of the work which the Russians gave them. There is nothing else on the island except the fur seal.

Q. Did you import any more Aleuts after the contract with the (xorermment?-1. No. After the cession was marle, and after the lease was made to this company, a Treasury regulation directed that the Aleuts then inhabiting St. Paul and St. Greorge should take the seal, and that no other labor shomld be hrought on the island to take the soal ; and these perople, who number something like 347 or :350 men, women, and children of all kinds, peceive from the Alaska (ommenecial

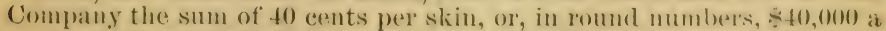
year, which is divided amongst thoses people solesy for their labor of perhaps two months. They receive that compensation, and earning as they do so largely, as you can see, $\$ 40,000$ divided amongst less than 
400 people for two montlis' labor, they are arerse to any làbor other than that of driving, killing, and delivering the skins at the salt-honse. Necessarily there is much other labor to be clone there. 'The seal skins have to be salted in the kench-house, they have to be romted and handled and taken to the beach and put ou board the steamers, and the regular pay for that is $\$ 1$ per day.

The man who is earuing $\$ 350$ or $\$ 400$ for two months work is disinelined to work for $\$ 1$ a day; consequently permission was given to the company to briug from the Alentian Islauds such other laborers as might be necessary to do this other work, the latorers brought up being paid entirely and distinctly apart from the $\$ 10,0: 10$ which went to the natives. This $\$ 10,000$ goes to them, aud auy other labor brought in has to be paid for by the company at the rate of 81 a day or 1 cent a bun. dle for bunllung the skins. There were a great many people on the island who bundled a hundred skins, some who bundled two hundred, and they soon found ont that the extra exercise was not rewarded, and $\$ 1$ a day did not cover it; but at 1 eent a bundle, if one bundled two hundred and fifty in a day, he would make \$2.50. But that other jayment of 40 cents a skin is a heritage of the natives of St. George and St. Paul Islands, aud was originally divided amongst these people in aecorlance with the decision of their chief and their priests; but since theu I think Mr. Taylor said that the Gorermment agents and the com. pauy's agents, realizing that there was an unlue faroritism exercised towards some natives, instituted a kind of tribmual by which each man's work shonld receive a fair share of this dirision, whether they were in high faror with the chief or priests or not; consequently the matter is now arranged so, and the division is entirely equitable with regard to the money receired. In this mauner families are comuted of those who are not able to labor, women and children, and they receive a proportion of this seal money, as it is called, and are thereby eared for as if they had a laborer in the family. Consequently the latborer ou St. Paul and St. George lits a sure prisition hy the acts of the Goverument in requiring that those people should take all the seals, and each gets his share of this 40 cents per skiu.

Q. What becomes of the extria force of laborers when the shipment is made? Doyou return them?-A. They return to the Aleutian Islands. When the steamer takes on board the skius she goes to Oomalaska and these people return on her.

Q. Where do they board on the island; do the company board them or do they ereet huts of their own?-1. I should have to as k Mr. Mor. gan.

Mr. Morgan. The company proviles them with lodging aud food, nuless they have relatives on the island to go to.

Q. How many extral laborer's are there?-A. How many do you bring up, Mr. Morgan?

Mi. Morgan. From 35 to 45 each year. They are taken from the poorer class at Oomalaskia, men not suceessful in hunting. They are usually composed of old men, too old to hunt the sea otter.

Q. Who procures the labore's at the Alentian! Islauds ?-A. I beliere they are sent up by selection of the coumbany's agent at Oomalaska. The people of the Alentian Islands get a living from hunting, mostly, and many of these have grown old and some are not suceessful, and they are very glad to supplement the failure of the otter hunt br securing labor on St. Paul and St. Greorere. The endeavor is made to select such laborers as are most in ueer of something they can earu, and those are sent up. 
The Crandrax. The forermment exercises no control orer that on the Alentian Islands? I mean in regard to the sea-ottre hunting; there is no Govermment resurvation?-A. No sir; that is open to ererybortr.

\section{By Mr. Cunnmings:}

Q. Do you have contracts with them ?-A. Those we send up ?

Q. Yes.-A. (To Arr. Morgan.) Are there contracts made with them? Mr. Morgan. The methor of engaging men at Oonalaska is to call them together at some couvenient place, and the superintendent of the Alaska Commercial Compans asks these meu, "Do you want to go to work?" And those that want to go to work go on board the ressel and are transported up. When they are there they go to work, and the boys earn $\$ 15$ a month and the men $\$ 25$ to $\$ 50$.

Q. I understand they get a dollar a day and their board and lodging.

Mr. Morgar. Some of the smaller boys that can not do a man's work are paid as low as $\$ 15$ a month.

Q. Does the company supply them with board and lodging?

Mr. Morgan. Yes, sir; and rations and transportation.

The WITNEss. They are snpplied with board, lodging, houses, churches, and schools, all at the expense of the compauy. Under their contract the company is obliged to furnish to the natives of these islands certain matters-schools and a certain amount of provisious and a certain amount of fuel, and as you will see from these photos the company, in excess of that, have built at their own expeuse wooden cottages, which have taken the place of the old habitations.

\section{Bỹ the Chatrinan :}

Q. Will you look over them and irleutify them, as I wish to have cuts made of them. Identify them by numbers, so that the stenographer will be able to iclentify them. Mrr. Morgau, will you state what these photographs here are, numbered from 1 to 4 ?

Mr. Morgan. From Nos. 1 to 3 they are the houses they had out there when the Territors was cerled to the United Stites.

Q. And the only kind of houses they had?-A. Yes.

Mr. MorgAn. These heuses (from 4 to 5 ) were erected by the company and they are assigned to a family; each family is assigued a house. There is no charge ever made to the natives, either for the cost of erection or rental of ans sort. The fee, so to speak, rests in the company, in orier that a certain degree of control way remain with them and the Treasury agent, in case the party does not take proper care of his house. The natives are furnished bs the company with all that they require in the way of foul. Seal meat of course they are entitled to by the act of Congress, and such minor things as they need in course of their subsistence they purchase from the store which the company keeps upon the island, which are sold to them at a regular scale of prices established by the company, and printer and hung mp in the stores, subject always to the inspection of the Govermment agent, and the rate of prices is fixed at 25 per cent. abore the wholesale cost of goods of the same character in San Francisco. The goods are purchased in San Francisco as closely, that is, as cheajly, as possible, for a good article, and 25 per cent. of the wholesale cost is added to cover the expense of transportation and landing, ete., and at that price it is sold to the natires, and that price is tabulated and hung up in the store, always exposed for reference.

\section{By Mr. Cunnmas:}

Q. Printed in Russian?-A. In both languages.

Q. Do rou pay them in eash or in orter's in the store?-A. We pas $9984-6$ 
them in cash. We nerer pas them in orders; we have nerer giren them ansthing of the sort.

Q. Are they at perfect liberty to leave the island whenever they wish ?-A. They are under no restrictions whaterer, except such as the Treasury agent exercises.

Q. The company exercises no restriction?-A. None whatever. Not only that, but the company furnishes to each island a physician, and dispensary and medicines, and no charge is erer marle for medical attendance or any medicines furnished.

Q. You were speaking of schools; how are the schools established? Who pays for them?-A. The company. It is in their contract that they shall furnish schools, and ther furnish the teacher and have built for the people a school-house on each island and furnished a teacher and transported and pay them their salaries.

Q. What are the natives taught-

The ChaIrman. Allow me right there. [Exhibiting photograph] I take this to be the school building.

The Witness. That is the school building on the island, and this is another view and shows the school building which was erected by the company [see photographs 7 and 8 ] and this is the school building on St. George [see photograph 9].

Q. These are the scholars there, right outside of the school-house [see photographs 10 and 11 ]?-A. Yes, sir.

Q. You were speaking of restriction?-A. There is only one restriction that is placed upon the people by the company and by the Gorernment agent and by every one who ean possibly bring any influence to bear upon them, and that is to restrict them in the use of a liquor called quass, which they brew themselves. The only complaint that the Alent ever makes and has ever been heard to make is that while under the Russian rule he was allowed as much "drunk" as he wanted, under the American he is not; but still, he prefers his situation, with his house and school and church and comforts uuder the American rule. Yet, in erery possible way he gets quass; therefore the company at its own instance and at the request of the Treasury agent has limited to the lowest point the supply of sugar which they allow them to bus in order that they can not distil this intoxicant. There is no other restriction placed upon them in any way.

Most of the people are desirous, when they have money, of buying everything that is put before them, and if a tendency toward uudue extravagance is noted, we refuse to sell them goods and endeavor to get them to place their money where it will be secure. We have endeavored to explain to them, and to get them to place their money in sarings banks in San Fraucisco; but they look upon that with suspicion and were disinclined to do so, but they are willing to place their money with the company. The company receives their deposits and gives them books for it, and as their deposits accumulate it is sent to San Francisco, and the company purchase an equivalent amount in United States bouds, which are labeled. The deposits of the uatives are always kept apart and considered as a sacred trust, and this deposit is never used in any other way. These bonds draw 4 per cent. interest, aud the natives receive the same. Here is a table which will show the deposits which we have been able to induce them to save up) to this time (see page 64 and following of reply of the Alaska Commercial Company to the charges of Gov. Alfred P. Swineford). The total amount of their sarings up to August, 1887, was $\$ 94,128.28$, but in that is included (to which $\mathrm{I}$ would like to eall your attention) twenty-nine thousand and odd dollars which 


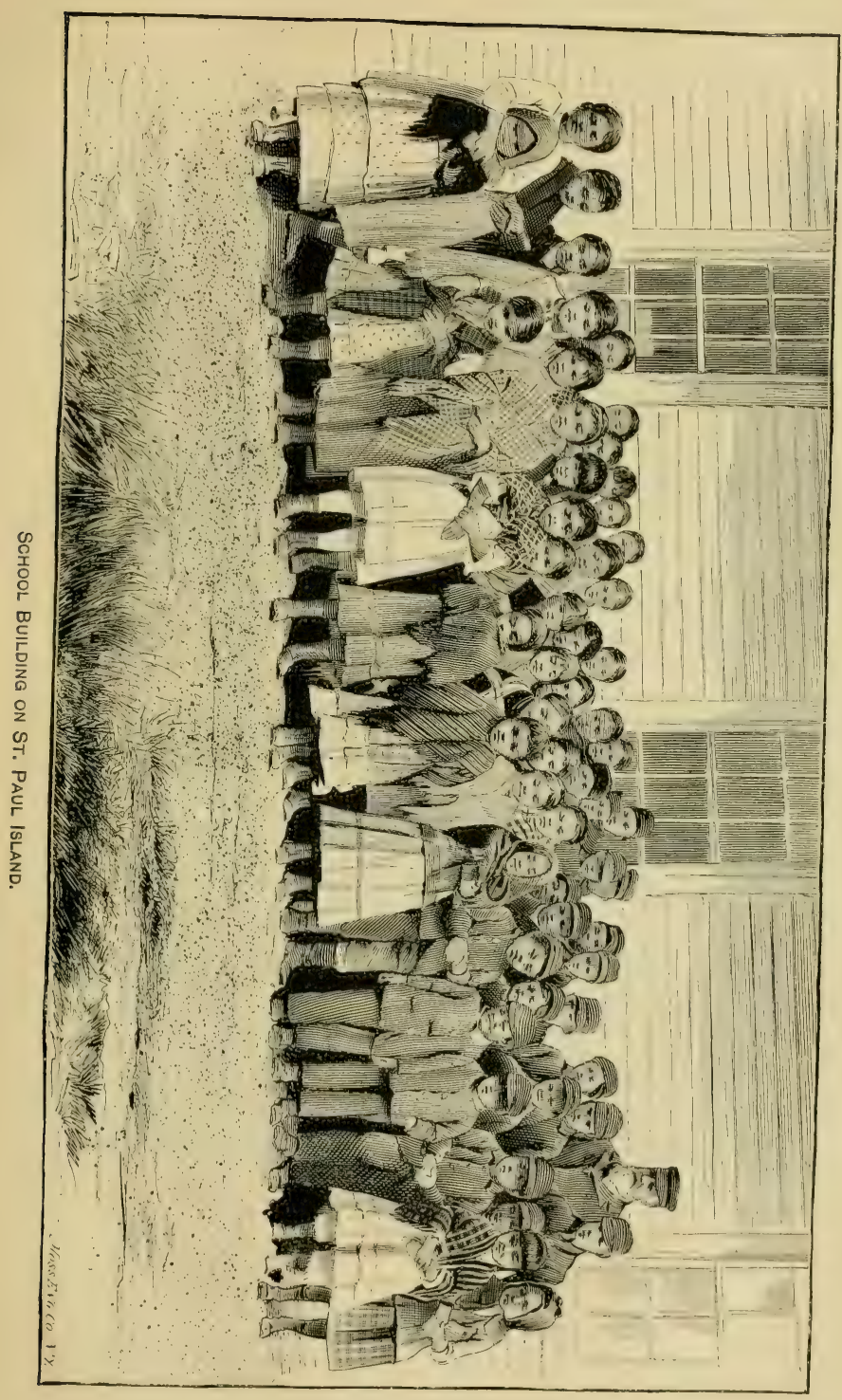





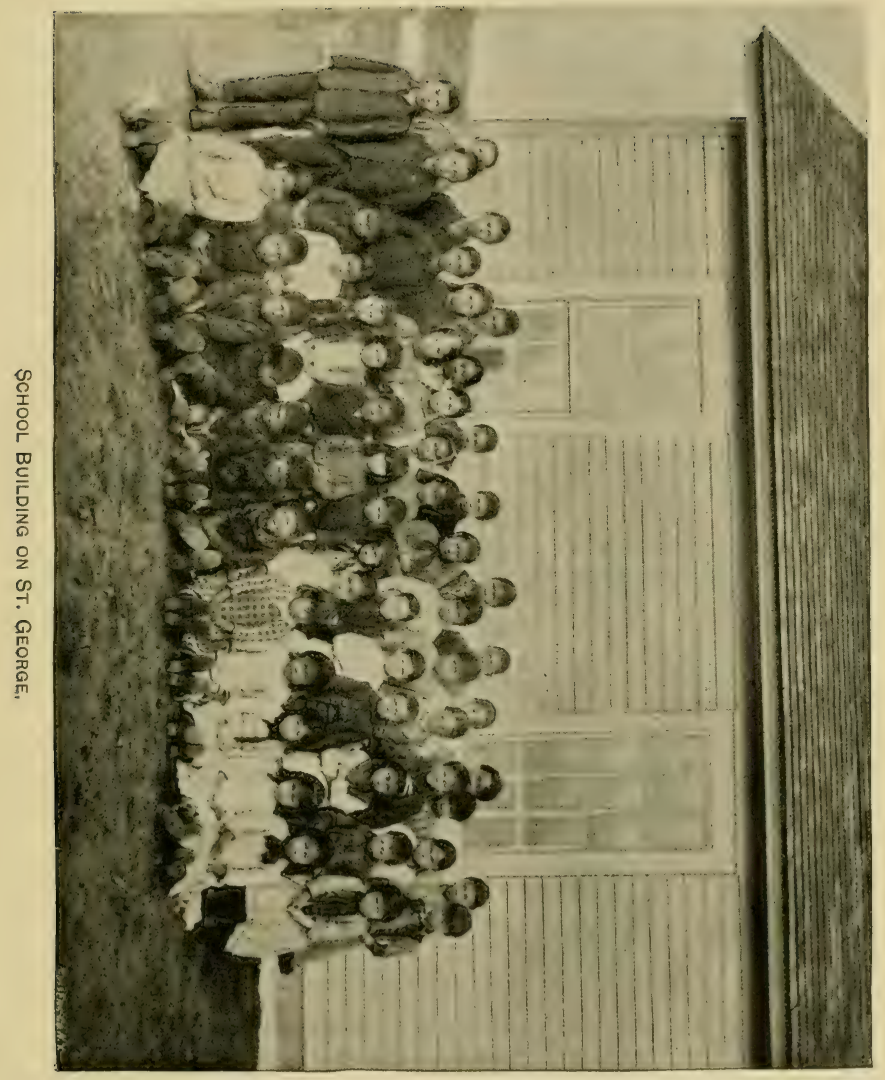



is the savings of the Oonalaska and Kodiak people who are not upon this Government reservation, and whom the company have influenced to save a little rather than have them waste their money.

Q. You had better explain whether the company has independent furtrading stations at these places.-A. They have stations at Oonalaska and at Kodiak and some other places, and the people there have accumulated some money which now amounts to twenty-nine thousand and odd dollars, for which they hold the company's obligation in their bank book as security, for which the company holds ninety-four thousand and odd dollars in bonds of the United States, which are kept apart and held for them. You will see some of these people have very good accumulations. There is one man that has $\$ 900$; another has $\$ 1,800$, and one has $\$ 3,000$.

\section{By Mr. Felton:}

Q. How do you account for that ?-A. Some of them are saving men and others are great gamblers.

Q. Do they occupy any position by which they get more money than others ?-A. No, sir. They are first-class men, who save their money, and the others do not. But they are great gamblers. I would like to state one thing: I would like it to be understood that no gambling is ever permitted, iv fact, it is never thought of, between any of the employés of the company and the natires, or between any white man and the nativês. It would be quite impossible to say to these men, "You shall not pitch half dollars." We can not stop that. But their moner still remains among them. It is a case of "If I lose it, you have got it."

The Charrman. The employés of the company never win it from them?

The Wrtness. Never; and it would never be allowed for a moment.

Mr. Cummings. I suppose you are unable to say whether any of them are good poker players or not?

The WITnEss. They are probably better pitchers of half dollars than poker players.

\section{By Mr. Felton:}

Q. I was not quite clear in my mind as to what you said about the school. If I understood you correctly, the schools are for the purpose of edncating the children of those who remain upon the island.-A. Yes, sir; the children of the islands of St. Paul and St. George. sir.

Q. And that they are supported entirely by the company?-A. Yes,

Q. No portion of the money which is provided by Government for schools in Alaska is used for this purpose on the island?-A. No. The schools there are entirely the contribution of the company.

Q. Is there anything in the contract which requires the company to do this? -A. Oh, yes; I think they are required to furnish a certain amount of teaching, and that is done by the company, and good teachers sought, and they are carried up there from the East or wherever it may be.

Q. The company in this matter is simply living up to their contract?-A. Yes, sir ; living up to their contract.

\section{By Mr. Cummings:}

Q. I noticed in the list here there are church funds ?-A. The church building is the property of the natives.

Q. These churches are sustained by the natives?-A. Yes, sir; they have a bishop resident in San Francisco, aud frequently the bishop makes 
a risitation there, and the whole church system is maintained there as it would be elsewhere where the Uatholic or Greek Church has geweral supervision.

Q. The company has nothing to do with that?-A. The compaur has nothing to do with their religion whaterer. The company simply adranced the money for the coustruction of that church, which the natires themselves paid as they earned it and as it was constructer?. These natives also contributed. That was the old church [referring to photograph]. A new one has been built.

Q. I presume it is the Greek church?-A. It is the Greek chureh.

And so with regard to all other matters, wherever the company is brought in contact with the natives, and it is brought in contact with them constantly, it is for the interest of the company, putting aside every philanthropic thought, it is for the interest of any company working those islands, held under a lease from the Government, so far as it is possible for them, to elevate the position and moral condition of those people, and every effort has been made by the compauy to do that.

Mr. Jeffries. State why, please.

The WITNEss. Because the labor upon those islands is performerl by those people, and the company is dependent upon them sor the killing and driving of the seals in the first place and the taking of the skins to the salt-house, and they must have operators that are competent and able and willing, and if there was any friction between the company and the people, if they were physically incapacitated, the whole rontine of the system would be thrown out of joint, and consequently the company makes no pretense of elaiming in any way a goorly-goody state of things there. We endeavor to live fully up to the contract, and more than that to regard our own interests so far as we can by a careful regard for the good of the people, morally and physically. For that purpose we suppress their quass so far as we can, and for that reason provided them houses instead of the holes in the ground we found them living in. These houses are covered outside with clapboard, and ceiled inside, and the native is beginning to appreciate appearances to an extent that they like to get a bit of a picture to hang on the wall, say, for instance, a "Harper," and they like a bit of carpet and such little im. provements as grow with an advanced civilization. All these things tend to show that there has been, since the laws made by Congress, a decided advance and improvement in the status of the natives.

\section{By the CHAIRMAN:}

Q. What is their method of dress now compared with their former method of dress? - A. The former method of dress was vers simple, perhaps a little shirt or wrap of skins, but now they want the best that can be brought from San Francisco, and especially the women want the latest style of articles that is to be had. They look over Harper's Bazarar to see, perhaps, what the latest fashions are at the seaside and import them. And those people have to be restrained as to their money from an expenditure that would be absurd for them. They would bur a whole piece of stuff in order to have a sufficiency when the quantity enough for a dress is all that they have any use for, and a restriction is placed on them in order that they may save money and add to their funds. In regard to the schools there is this explanation to be made, perhaps: When the schools first started and we endearored to teach them English it progressed somewhat, but it dawned upon some of the elders that if the rising generation became instructed in English they 
would forget Russian, and as they forgot the Russian they would forget the precepts and practices of the church, and there would be no one to saly the prayers, and consequently they objected seriously to the childr: il being instructed absolutely in the English language.

(2. The chureh service is printed entirely in Russian?-A. Tes. You see how that would operate with them.

Mr. Felton. It was considered a precious thing by them?

The IV iTness. Yes; and it was met by teaching them both languages. TV L have an English school and we have a liussian iustructor, as it seems desirable to please the elders to get along.

\section{By the CHATRIIAN :}

2. I believe Mr. Taylor said sesterlay, part of the day they were tanght English and the remainder of the day was devoted to Russiau.A. Yes, sir; I think it was what he said.

?. Will you state what the company does for the poor and aged and infirm-the indignt? - A. All that class of people generally styled patuper's are provided for by the compang. As the family becomes incaldacitated from laboring by loss of its head or sickness or by any thing, whatsoever may be the cause, and if it is carelessness and irregularity and bat habits, an endeavor is made to make the person provide for themselres, but they are never allowed to suffer. They are fed, clothed, ant housed without charge by the company. No charge is made to any portion of the native population in any way for this service.

Q. I understood from Mr. Morgan yesterday there is no charge for seal meat and uo charge for fuel?-A. There is no charge for any necesialy of life. No charge is made for shelter, for houses, for church, for yrovisions; when I say provisions, I mean dried meat, and no charge is made for fuel, which is part of the company's contract.

Mr. Cummings. What is the contract?

The WrTnEss. I think it is about a ton to a family. That is about what is sufficient for them through the year. When they were first put into the houses, each house was furnished with a store. If they used nI) those stores and burned them ont and wanted another, then they furnished one themselves with what they had accumulated. But when they first started we furnished them. I think there is no class of laboring men in the United States or anywhere who receive anything like the proportionate compensation that those people receive. Their occupation includes perbaps about two and a half months, with about six Weeks of actual sealing, and for that those 350 people receive $\$ 40,000$ wages, divided amongst themselves, and their shelter, food, clothing, and care, and medicine, aud they are tanght in the schools, and the company makes large contributions also to their church.

The Charman. Are they yaid for any other labor they perform ?

The Witrass. For any other labor they perform they are paid at the rate of a dollar per day; but as I sair before, they do not like that kind of labor, because they earn so much in the sealing season, and therefore we have to have supplementary labor.

\section{By Mr. JEFFRIES :}

Q. What did they haw for fuel before the company took charge of then ? - A. Not much; pieces of driftwood-whaterer they could pick ux).

\section{By Mr. Cummings:}

Q. Do you find it necessary at times to make discharges- discharge men who work on the islands?-A. No, sir; we can not discharge them; 
they are entitler to work there; they are well treated and they are generally willing. They are a childish sort of people. They are not a people who are aggressive in any way unless they get quass and get drunk, and they are very ready to do their work generally. They sometimes get a little quass abroad and get offensive and unwilling, and in cases of that sort the company has no right to interfere in any way, and it is immediately referred to the Government agent. The Gorerument agent is a sovereign there, and his word is law.

Q. He has charge of all the police arrangements?-A. Yes, sir; the Treasury agent is supreme.

Mr. JEFFRIES. I would like to ask you-it is a little out of place-but do you know the fact that the company and the Treasury Department at one time several years ago tried to induce the natives to change their meat, and instead of eating salt meat, to eat fresh meat furnisher by the company in lien of that without charge? Do you remember now about that? Probably it was while you were in Germany.

The WITnEss. The company has always furuished dried fish, and I know they furnished seal meat.

Mr. TAYLoR. Mr. Chairman, may I say a word on that point?

The Chamrinan. Certainly.

Mr. TAYLOR. When I was there I recollect that the population had been killing seal pups and it was stopjed for two or three years, and the natires complained in the spring of the year that they diel not have fresh meat, so as Government agent I permitted them to kill a fer pups early in the rear, or rather late in the fall, for their foor. It is now proposed to erect an ice-house to put the seals in during the summer, so they may be used, the older seals-the carcasses of those from which the skins are taken for the market. These are to be put in the ice-homse there and kept all the year round so as to keep fresh meat. I mention that in this connection. That is the idea now.

Mr. JefFries. You can go on now and go back to where you starter? from.

The Witness. If there is anything further that any of the committee would like to ask, or details of these matters, so far as my knowledge goes, I should be happy to answer any questions, but, as already stated, the general management both of the seals and the general managenent with regard to the supervision of the Treasury agent is, so far as I know and so far as the company know, conducted for the best interests of the natives, and also for the best interests of the company. There has never been any occasion in which there has been any collision between the company's agents, resident on the island, and the Government agents, and there has nerer been an oceasion but what the Gor: ernment ageut has been recognized as the final authority in any watter which may come up.

By Mr. FeLTON :

Q. I would like to know-I do not know that it is just the proper time-but I would like to get the idea of those conversant with the habits and nature of the seal, as to what their oppinion is upon the effect of the indiscriminate killing of them while they are coming to and going from the islands.-A. That is a question which I think most any of us here can answer. If yon note the conformation of the Aleutian Islands, which form a wall, and note the gaps through which the seals come from the Pacifie Ucean seeking the haunt on these islands, that is the whole point. When they come through these rarions passes, generally through the Oommak Pass, the sea is reasonably shallow, aud the 
cors come laden with pups, waiting until the last moment in the water to go ashore to deliver, because they cau roll and scratch and help themselves better than if they haul out when heary with pup, and so they stay in the water playing about until their instinct warns them it is time to go ashore, and during that time they are massed in great quantities in the sea.

Q. Now, in that view of it, the destruction of them there is almost practically the same as the destruction on the islands ?-A. Yes, sir.

Q. And the conditions are as bad? -A. Yes, sir ; and often worse, for this reason : If you kill a pup 5ou destroy a single life, but in killing a cow you not only destroy the life that may be, but the source from Thich life comes hereafter, and when they are killed there in the water in a shot-gun or a spear, the proportion saved by the liunters is inobably not one in seven. That was their own estimate; that ont of eight shots they would save one seal and seren were lost. If they were tilled on the land, those seren would go towards filling out their score.

By Mr. JEFFries :

Q. In that comnection, please state if it be a fact that at that time the cows are with pup.-A. I already stated that, and that fou not enly killed the cows and pup, but you kill the sonrce of life of future jillis.

Q. Of conrse this is a matter of opinion, and a matter of opinion that only one rho mulerstands the habit of these seals could judge of. The same instinct that has driven seal a way from other rookeries throughont The worlh-mould not that same instinet, if they learu the fact, which they must learn the same as the other did, teach them that it is unsafe for them to go to these places, and in order to reach those places they have to go in this mamer, and would not that result in their leaving lhos: islands; whether they were killed on the island and driven away w whether they were killed in approaching the islands, would it not be the same?-A. In that connection, it would be proper to state here that the Russians, who are acquainted with the habits of the seal and accustomed to taking them, stated at the time of cession, "We solil the seals, but the Americans will soon drive them back to us; they will have the rocks and we will have the seals." The theory was that the indiscriminate slaughter of seal by the American people, not beiug restricted, would drice the seal over to the Russian Islands, and they reached that opinion from the experience of the earlier days of their seal-hunting; they had seen what resulted from the indiscriminate killing, and that eaused the Russians to believe that the seals would be driven orer to the other islauds. "Now," they said " the Americans nare got the seal, but they will only hare them for a season, when we will have their mouey and the seals, too."

By the Chatrian:

Q. Will you state just when and under what circumstances your comfans, or the persons comprising your compans, commenced operations (nin those islands, and what were the conditions after the cession and 7ior to the ceding of those islands and reservation by the Gorernment at the United States? Just state the history of the transaction in that (nnnection.-A. Immediately after the cession and before restriction bad been placed by the Gorernment?

Q. Yes, sir.-A. Mr business at that time led me into the Pacific. I was living at the Sindwich Islands, where I hat been for some years, $\therefore$ i.d had seaing ressels in those waters prior to that time; and it was a 
most natural suggestion to my mind, the Gorerument having acquired these islands, that I should send a seal ressel there; so I arrangeri to have one of my vessels go there immediately, and an experienced cap. tain from the East came out. Mr. Morgan came also with him. That vessel proceeded to Sitka, to take out the necessary permit there fron: the oflicer in charge. I think it was General Davis who was in charge. Parties in San Francisco-Hutchinson, Kohl, and others-were in:pressed with the same illea, and, I think, aiso sent their vessels to Sitka and on to the seal islands.

One or two parties in a smaller way also rentured, and the result was that at the opening of the seal season in 186 s there were gathered there, mostly at St. Panl Island, some ire or sir vessels for the first installment of seal hunters. They were indejendent of everyboly but themselves. Every man was for what he conld get, and the ressels of Messrs. Hutchinson, Kohl \& Cc., and Captain IIor gatu and my people. each pursued their own way and got what they conhl ; but they realized if such action was continued it would lead to the same results that occurred in the South Atlantic, viz, extermination.

Q. How long did they continue hunting?-A. That rear alone.

(2. How mauy seals were taken? Have you any idea?-A. I think we took 42,000, and I think Hutchinson, Kohi \& Co. took something like 80,000 odd, and perluaps 20,000 or 30,000 move were taken by other parties.

Q. My recollection is that Professor Elliot puts down the takiug of seals for two years prior to the enactment of the statute in 1870 creating it reservation and restrieting the killing, at something like 300,000 . Have you auy knowledge of that ?-A. I think he juts it too high, for I find there was no killing in 1869. 'This year of 186s was the year which opened the ball, so to speak, and brought a realization to the minds of the San Francisco people and myself that if some restriction was not placed upon ths intiseriminate slaughter by every person who chose to go there, these rookeries would soon be exhansted. Representatives of Hutchinson Kohl \& Co. and of my own house eame on to Washington and made representation to the Government of the effect of this course, and stated what would be the result there and the ruin that would eusue, and recommended that this very law, or a similar one, should be passed for the preservation of these rookeries. That was the initial step, with regard to govermmental action looking to their preservation. I do wot think, when the Govermment made the purchase from Russia, that any one outside of a dozen people, perhaps, who had been acquainted with the sealing heretofore, had the slightest knowledge of there being any value in those islands, or that the Government was going to get anything of value on tside the mainlaud of Alaska.

The snggestions which were made were acted mpon and resulted in the present act, in 1s69, prohibiting seal killing on those islands. There Was no killing there except such seals as were kilied for food for the natires by permission of the Treasury Department or its agents on the on the islands.

Mr. JEFThes. As I understand you, in 1868 a few people took those seals, and sou came here to Washington aud called the attention of Congress aud the Treasmy Department to the lats existing there, aud that the seals were in danger of being destroyed if the islands were left open for the people to come there and take them ?

The WiTnEss. Yes, sir.

Q. The perple who now form the Alaska Commercial Company called their attention to the facts?-A. Yes, sir. 
Q. And it was through their influence that the Government reservation was created by Congress, and the laws for the preservation of the seals were made by Congress? - A. Yes, sir.

Q. Then followed the act for which you all worker, you people?-A. Yes; of course we recomuended that.

Q. To wrevent the killing of fur bearing animals of Alaska and for the lease to the company?-A. Yes, sir. Whether it was to be a chimplay composed of the people who male the representation or uot, I can iruly siry that we desired that so valuable a properry should be prescrved, rather than to go as the Souti Atlautic properties had gone. There was alisolutely no other way.

The CifArras. Is the compaliy composed mostly of those salme individuals?-A. Of such as are living of them. Twenty rears makes great ihanges, you know. We have the same original lessees or thrip representatives.

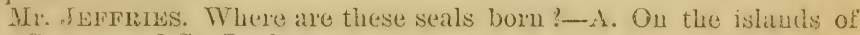
St. George and St. Paul.

Q. In the United States ?-A. On United States soil.

Q. What are they, a fish or an animal?-A. Animal.

Q. There is no question ahout that?-A. Tone by naturalists.

\{. They are not treated as auything else by uaturalists or auybody else?-A. No.

Q. How long do they remain on their returu to the islands?-A. Four or four and a half months, I suppose, would cover it.

Q. Are the pups capable of swimming when born?-A. No.

Q. They have to be taught?-A. Yes, sir.

Q. They are taught by their mothers and ellers?-A. Yes, sir.

Q. Then they go somewhere, you don't know where?-A. When they gatler for their migration, they leave the islatuds and go down through the passes of the Aleutian Islands, and further the deponent knoweth. not, and nobody else.

Q. When do they return from that expentition to their homes?-A. In May they commence to returu, the old bulls coming first and the cows after them.

Q. They come as a sort of alvance guard and reconnoiter?-Yes, sir.

Q. They look around to see if the rookery has been disturbed while they have been gone?-A. They come and look over the groumd very cantiously as Mr. Taylor stated very fully yesteriar. The first one that comes does so with great cantion aud ane. After he has located himself uthers come, and hearing his call on che islauds haul out with a little more assanance, and thas the old bulls come there and get their houses in oriler, waiting for the cows to come.

Q. It would only be a matter of imagination to state what they wonkd (10) if ting foumd things changed and diffesent from what they hat

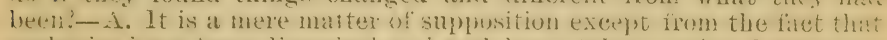

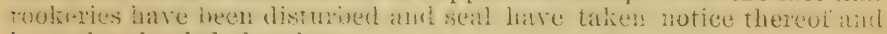
have then hauled elsewhere.

'The Cramaras. Sumpose if they arriverl and found the gromut onempied by hunters who kill them as they come.

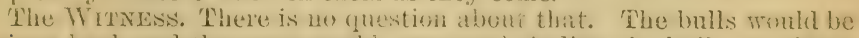
driven batek and the coms wonld cone and finding the balls not there, they would also look for some other place. The first year pobathy they would not realize what was to be donce aul they might make ciforts to g't ashore and deliver their pups.

Ir. Morgan. You ask what would be the effect of somelondy interfering with the roukery wheu these old bulls come. I will give gou this 
instance. Last fall a schooner lander? at one of the rookeries and killed serenteen cows and bulls right on the breefing rookery near the water, within 15 feet of the elge of the water. They cinbbed the seals and scattered the brains on the rocks, and a spot was soiled probably as lairge as this room. The rext year early in May this very spot in the thickest part of the breeding rookery that had been soiled was totally bare. It was as bare as this floor. The seal would come and crowd up to the margin of this spot, but would not hanl there, and did not until the next year, when the weather and action of the elements had totally obliterated all traces of it. Now, if a bull comes np and smells and discovers anything of that sort-and that lasted through a long winter-they leare that spot aud haul in some other place, and if a whole rookery was so soiled, there would be no seal to baul there.

MIr. TAYLOR. Mr. Morgan, is it not true that when the company rendered seal oil on the island that it drove the seal from the rookery, which was not very far distant?

Mr. MORGAN. That was when they were rentering oil by burning the blubber in trring pots set up there, and the smoke from the furnaces drifted off across the water and the wiml blew it on the rookery so that it disturber the seal when the wind was from that direction. When the Russians were on those isiands, they had regulations which prohibited the building of tires for cooking purposes at certain points when the wind was in a direetion to drive the smoke of the burning blubber on the rookeries.

Mr. TAYLOR. I only spoke of those things to show how sensitire the seal was to anything aud everything.

The Witness. I am glad you give me an onyortunity to state somethiug in that direetion. The lease of these islauds provided that the company should be permitted to take so many slins and pay so much, and to have the privilege of taking so much seal oil on which at tax was due for each gallon taken; but it is chargen that they did not take the oil, and therefore that valuable prodnct that ought to inure to the Gorernment was lost. The explanation the gentleman has made cover's the whole ground. The company male an effort to take the oil, but the only way was to use the blubber of the animal for fuel, and it was found offeusive to the seal and that it was imperiling the rookery in spots and places and the company therefore so represented to the Department and they excused them from taking any of the oil. This omission to take oil was for the general good of the rookery and not on the prart of the company to avoid any obligation.

Mr. JEFFrLES. On that point, an inspection of the contract shows you were not obliged to take any seal oil.

The Witness. We had to pay the tax on what we dirl take; and after we had done it we found the market price for seal-oil did not justify it, and as we were not obliged to do it, we did not take it.

The CHAIRMAN. That is the ground upon which the Secretary changed the regulation and rules, and released the company from the oil-tax?

The Witness. Yes, sir.

\section{By Mr. JEFFRIES:}

Q. What relation do you bear to the Alaska Commercial Company ?A. I am a trustee, a director of the company.

Q. Are you a share-holder?-A. Yes, sir.

Q. Are any of the share-holler's of the Alaska Commercial Company foreigners? Is not the stock all held by citizens of the Uniterl states?A. Entirely. 'The lease wouh be forfeited if there were foreiguers interested in any way, directly or indirectly: 
Q. Now, who were the men that originally comprised, that is, the charter members of the company, who were original members? I refer to the men who were up there in 1868 and who formed the company.A. H. M. Hutchinson, William Kohl, Lewis Sloss, Lewis Gerstle, Gus. tare Niebaum, who was a Russian subject who eame over under treaty. He was in command of one of the Russian Fur Company's ressels, and came over as an American eitizen, and has always lived since in San Francisco.

The Chamrinan. He became an American citizen under the operation of the treaty?

The Witness. Yes, sir, and he is one of the directors of the com. pany now. Richard H. Chapel, H. P. Haven.

Q. Is he the gentleman who ran for governor in Connecticut some years ago?-A. Yes, sir. C. A. Williams, Samuel Willits, and several more; I can not recall the names. Mr. Parrot, of San Francisco; Cap. tain Morgan, of Groton, Conn., and Mr. Morgan here.

By Mr. JeFFRIES:

Q. So far as you have named them, those gentlemen were interested in the seal islauds in $186 \mathrm{~s}$ ? - A. Yes, sir; all of those parties were interested in the original expedition which went ont in 1868 , either the one which I represented or the one which was represented by Hutchinson, Kohl \& Co.

Q. And they came down here and represented the facts of the case to the Government?-A. Yes, sir.

Q. Then the Alaska Commercial Company was formed ?-A. Yes, sir.

Q. Now, what other gentlemen were taken in when the compauy was formerl, in addition to those jou have already named? - A. Withont a list of the stockholders I do not think I could answer.

Q. John F. Miller, was he one?-A. Xes, sir.

Q. Who was he?-A. John F. Miller was at that time collector of the port at San Francisco, and he was afterwards United States Senator. He was a general in the war, and had an admirable record.

Q. He is dead? - A. Yes, sir. Mr. Chapel is dead, Hutchinson is dead, Miller is dead, Parrot is dead, and Haren is dead.

Q. What is the capital stock of the Alaska Commercial Company?A. $\$ 2,000,000$.

Q. At present, and for the last few years, who are the parties who latse directed the management of the company and dictated its policy and managed it generally; all these gentlemen? - A. Lewis Sloss, Lewis Gerstle, Captain Niebaum, and myself.

Q. Who is president of the company ?-A. Lewis Sloss.

Q. What sort of a man is Lewis Sloss? $-A$. He is an estimable gentlomau, highly esteemed and respected.

Q How does he stand in San Francisco?-A. He stands very high there.

(?. Is he one of the trustees of the Coleman assignment?-A. Yes; and he is a man who is associated with every important work and gusod work there. He is an homorable merchant.

Mr. JEFrRIEs. I would like at some point in the future, if the chatir. man will allow me, to ask the same question of a member of the com mittee present-Nir. Felton.

M1. FELTox. Me is unirersally known as one of the best, clererest, and most representative men on the Pacific coast. He is a rery fair, square, and honorable man. 
Q. Fou would rely upon Mr. Sloss's statement, would fou not?-A. I would rely upon it from my owa knowledge, extending thirty years.

Mr. Jefrimes. Here is a renly of Mr. Sloss, which Mr. Sloss makes moder his signature, to a statement of Governor sirineford, who has eriticised the company. He had been misinformed by some of the people and wrote some criticisms upon the company, and Mr. Slosm mate a reply. I ask you if you believe any statement he would put his name to is entitled to be believed? - A. I shouk not hesitate so far as anything which came within his knowledge was concerned, and I should place implicit reliance mon it. I think he would be rery careful not to state anything that he did not know.

Mr.JEFFries. Now, Mr. Williams, that compray, after it commenced operations under this contract with the Goverument, also made a contratet with liussia-substantially the same company, perhaps under a different name-for the control of some rookeries in Bering Sea, in Russian waters.-A. An association known as Hutchinson, Kínl \&̇ Co., in Sam Frauciseo, of which I was a member, obtained from the Iiussian Goremment a lease to the islands of Copper and Bering, on the coast of Kanchatka, for the purpose of taking seal skins from there. We operated at first, I think, two year's, and we also operated the American lease, and realized at the expiration of the two years that the interests of the stockholders of the American lease were somewhat injured by the separate operation of the Russian lease as it was held; and therefore at that time-I think it was the secoud year-we arranged with the Alaska Commercial Company the privileges of that lease for the term of their lease, in order that the whole operation might come under one management, and that the inthences upon the market might not be ariverse, the one to the other.

Q. In keeping the accounts and the management of the business, they are distinet and separate?-A. Entirely.

Q. Now, how are you protected by the Russian Gorernment? Are there depredator's about those islands? - A. There have been attempted depreclations; but the Russian Government has a rather positive way of their own, and the marauders do not fire well with these people, and they seldom repeat their efforts. They have about these waters generaily a Russian ressel cruising up the Siberian coast, and the people are warued that if they still presist in poaching and are taken they will be stumuarily dealt with.

Q. In former times, when whaling was earried on in the Aretic, did parties passing up aud along the Fimchatka coast uudertake to do any sealing or anything of that sort? - A. No. The Russians protect that coast. Although there was a while ago a large fleet of American whalemn who passed through Bering Sea to the Arctic, there was never any attempt to molest the seals, either in the water or un the laukl.

Q. Was it then regaried as Russian waters by sea faring men-I mean the Beriug sea?-A. It was.

6. So tar as yon know, dial finssia then and ever since exercise dominiou over those waters? - A. Bering Sea? Oh, decidedly. She allowed a free passage to the Aretic through those water's so long as there was no interference with her seal interests.

(2. Wats Rusisia, to your knowledge, in the habit of granting permission in ressels to risit certain proints on the coast of Beriug Sea, or were they allowed to land withont permission?-A. They were allowed to iant on the wortheru coast withont any permission. Above Norton 
Sonnd the shores on either side are tonched at by whitics and traders without permission.

The Cmamman. What distance is Attoo from the Commander Islands?-A. It must be about 500 miles, I should think.

\section{By Mr. JeFFries :}

Q. Now, Mr. Williams, I understand that lease with the Gorermment relates to the Pribylov group of islands known as St. Paul aun St. George, and the right to take fur seals for their skins on those Islands?-A. Solely.

Q. Have you any relation to the United States Government in respect to any other part of the Territory of Alaska?-A. None.

Q. None whatever?-A. None.

(2. So far as the Aleutian Islands, and the main-land, and all the coast of Alaska except these two little islands in the middle of the Buring Sea are enncerned, anybody in the United States has as good a riglut to go there and do business there as you have?-A. Exactly.

Q. Fou do business on the maiu-land and on the Aleutian Islauds?A. Yes.

Q. What ro you do there?-A. Te collect the sea.otter furs mostly, and from the main-lanr such other furs as parties trading and hunting there may have to dispose of.

Mr. JEFFRIEs. In a statement which Mr. Sloss has prepared for the committee, I want to read a brief extract, and ask you whether it is a fact or not:

It (the company) has nothing to do with mines, either of coals or precions metals, forests, quarries, graiu, fruits, or vegetables, and makes no investment in the "incomparably creat resources" referred to, save onls in furs and the skins of wild animals. It in nowise competes with the col and salmon tisheries or any of the canneries. It.s vessels are intended primarily for its own use, in its own business, but it freely carries the mails and offers to all who desire it the full accommodation which any can obtain from a common carrier. Yet it competes with no line of steamers or other vessels for the carrying trade, and leaves the field open to any who seek it.

So far as son know, is that a true statement?-A. It is absolutely true.

Q. Now he takes up here the Petroff map, which divides Alaska into five divisions, the first being the southeastern division:

The company does no business at all of any kind with sontheastern Alaska-

In regard to that portion of Alaska, sour empany has no trading station?-A. No; it has no connection with it.

Q. (Reading:)

The company does no business at all of any kind with sontheastern Alaska-that is, the portion lying south and east of Monnt St. Elias, called the southeastern division. It is here that Sitka, the seat of government, is situated, and where the greater part of the white population of Alaska resides. It extends from Mount St. Elias to Portlaud Canal, and contains 28,980 square miles, being larger in area than either Connecticut, Delaware, Marylaud, Massachusetts, New Jersey, Vermont, or West Virginia, and is nearly as large as Indiana. Compared with this large district, the Pribylov Islands leased to this compauy are very insignificant in area. St. Paul is 13 miles long and less than 6 miles in point of greatest width, and contains about :33 squnare miles, a large part being rocky, rugged cones of volcanic rock, whilst a great deal of the remainder is drifting sand dunes. St. George Island is about 10 miles in extreme length, and about $4 \frac{1}{4}$ miles in greatest width, and contains about 27 square miles. Its greatest elevation is 920 feet above the sea.

Q. So far as you know, that statement is true?-A. It is.

Q. Now the second division is called the Kadiak division on the main-land?-A. Yes.

If we go northward and westward from sontheastern Alaska we pass berond Mount St. Elias. and inte what Mr. Petroff calls the Kadiak division, the eastern limit of 
Which is the eastern boundary of Alaska, north of Mount St. Elias. The main Alaskan range bounds this division on the north and west. In this he embraces a part of the Aliaska peninsula and the island of Karliak already mentioned. We are now, however, speaking of the main-land.

Upon the wain-land of this division the company has five substations, including the peninsula of Aliaska - two on Cook's Inlet, one on Euglish Bay, one on the peninsula, and one on Prince William's Sound. The latter is called Nuchek, and is the "establishment" referred to by Governor Swineford as being " 300 miles to the westwaril of Sitka," and the nearest station to it. At this place this company has one white man as a subagent and a few Aleuts as employés. The population is all Indian, and the only people with whom the company trades are Indiaus. The Indians are the only hunters and they bring to the company chietly the skins of the marten and mink, with a few others. The company has a small store of supplies for the Iudian traders, and its boats go there generally twice a year. The entire business is only between $\$ 3,000$ and $\$ 4,000$ a year. This station is not at all remunerative and its abanclonment has been contemplated for some time. There is no mining in the neighburhood, no fish industry, no canneries, and no white population.

The two stations of the company on Cook's Inlet are Toyonok and Kenai; that on English Bay is Alexandrovsk, and that on the peninsula is Katmai. At Tuyonok the company has one subagent, who is a white man, and also has a small store. There are no white or Alentiau hunters there, only Indians and but few of them. They bring in mink, martin, bear, aud deer skins only. The trade is very small. There is no town there, and but very little surrounding population. An occasional ship comes in and the Indians freely avail themselves of the best offer for their peltries.

Katmai, on the peninsula of Aliaska, is a substation of very small importance, and one man only with a small store is kept there at occasional intervals. It is practically abandoned. The trade is insignificant.

We have now presented the entire operations of the company on the mainland in the Kodiak division. This division contains 70,834 square miles, and how much of that large territory is affected by the Alaska Commercial Company's operations can thus be seen at a glance. If so little business, at such few insignificant points, on the mere margin of the country, has such a "pernieious influence " on that mainland and is such a blight to its general prosperity, its whole vitality and inherent strength must be very susceptible indeed.

Kenai was once a station of the old Russian-American Commercial Company. It now bas ouly one subagent and a swall store. The hunters are likervise Indians, there being no white hunters or Aleutians there. The trade with this company is very small. At this place the Arctic Fishing Company does considerable business in salmon-to the extent probably of upwards of $\$ 6,000$ per annum, and has its own vessels and imports its own supplies for its employés and those with whom it trades. The Indians also do the fishing.

Alexandrovsk, situated in English Bay, contains about eighty-eight people. Of these, one is a white man, twelve are creoles or lalf-breeds, and the remainder are Aleutians. The white man is the agent of the Alaska Commercial Company, who alone and without any emplojés manages the business, including one small store of supplies. The trade is quite small and is principally confined to the sea otter, huuted exelusively by the Aleuts and creoles. Occasionally vessels of others visit this point and compete for pelts, which are readily obtained by the offer of contraband articles by way of barter.

\section{Q. The next is the Aretic division :}

With this vast tract this company has nothing whatever to do. The interior is virtually an unknown and unexplored region. As to the coast trade, we have no knowledge or sources of information not possessed by the public at large. We believe that the facts, as stated by Mr. Petroff, are correct.

\section{The fourth is the Yukon division :}

This division lies immediately to the sonth of the Aretic division, contains 176,715 square miles, and comprises the valley of the Yukon River as far as it lies in Alaska, and its tributaries north and south. It extends east and west from Bering Sea to the British Possessions, and is bounded south, in part, by the Kociak division already reviewed, and the Kuskovim division, shortly to be roferred to. No State or Territory in the United States at all approaches in area this vast Ynkon division, excepting only Texas. Yot, within its wide domain, the Alaska Commercial Company has but one station or trading post, and that is at St. Michaels, or Michaelovski, situated on Norton Sound, which its vessels visit once a year only, it this place the company has a store and an agent and assistant agent, a captain aud engineer to each of tiro small river steamers, a carpenter and a laborer. Its business is with the 
traders, who 11 mber about a dozen. It never comes in contact with the natives or inuters, but obtaius all the commolities it purchases from the traders at agreed rates, and in turn sells its supplies to the traders at fair prices.

The company also runs two small steamers from St. Miehacls up the river in summer to carrs supplies to the traders, and to bring down the peltries there purchased. It also at times receives orders or commissions for articles to be purchased at San Frauncisco, which it always fultills at fair aud reasonable rates, and delivers tho articles at St. Miehaels or ou the river. The tracters referred to also have two small steamers of their own ruming from St. Michaels to carry supplies up to their stations on the river and return with pelts. These traders also have stations at various places on the river, where they keep supplies with which to barter with the hunters for peltries. There are eight of these stations on tho river: Fort Reliance, Tauanah, Novikakat, Nulato, Anvik, Mission, Andreivsky, and Kotlik. The entire business of the Alaska Commercial Compauy in this division amomnts to about $\$ 30,000$ per anuum.

\section{The next is the Kuskovim division-}

This lies directly south of the Yukon division; northwest of the Kodiak division; exteuls to Bering's Sea aud includes the Kuskovim Bay, river, and valles, and Bristol Bay, with the Nushegak Rirer aud valley. It contains 114,975 square miles, and is larger than the whole Territory of Arizona.

The Alaska Commercial Company has not a siugle station in this division. It had one formerly at Kalmakovski, but it was abandoued about ten years ago. Wo send a vessel once a year to the Kuskovim River, to a point 15 or 20 miles above the mouth, to meet and trade with a single tracler, Mr. Sipary, who accumulates during the year in the interior and neighborhood the pelts of mink, marten, bear, and other cheaper skims, and gets his supplies from our company. The trade amounts to about $\$ 10,000$ yer anmum. Mr. Sipary is a principal in the business, and does his own trading with the hunters. We also send a vessel once, and sometimes twice, a jear to Nushegal, ou the river of that name, where we trade with a single trader, Mr. John W. Clark, from whom we buy peltries and to whom we furnish supplies. The business covers about $\$ 10,000$ per aunum. Mr. Clark has about eight emplosés, and bas established stores of his own at Nushegak, Togiak, and Illamua. The Àlaska Commercial Compauy does not come in contact with the hunters or any other trader than Mr. Clark.

At this point, Nushegak, there are several companies doing a large business in salmon canneries. These are tho Arctic Packing Company, Bristol Bay Canning Company, and the Alaska Packing Company. 'This is one of the fiuest salmon fisheries on the coast, the salmon beiug found in immense numbers on the Nasherak and other streams emptying into Bristol Bay. Tho American fishermen have been establisbed here for many years and do a very large business.

Two of these fishing companies are of California and one of Oregon. The Alaska Commercial Company has nothing whatever to do with this business.

The total popalation of the Kuskovim division by the last census was 8,911, mostly Eskimos. The number of whites and creoles together only amounted to 114 . There has been no obstruction to immigration, except such as the uatural eondition of the country presents. Between the Kuskovim and the Nuskegak Rivers the villages of the Indians are so very numerons and they are so very poor that they could not exist were it not for the abundant supply of salmon in the summer, when they lay in a supply for themselves and dogs. They absorb the whole or nearly all the salmon of the Kuskovim River, in connection with the other natives, who also go there from the delta of the Yukon River. This leaves nothing in the salmon line for traders. This dense Indian population extends from Kuskovim Bay far up the river.

The headquarters of the Kuskovim is an unknown and unexplored region.

The country between Kuskovim Bay and Bristol Bay on the river Togiak, sometimes called the Togiak division, is so poor in natural products songht by white men that it is not visited by whites and has no trade. The natives there are poor in the extreme. They live in a state of nature of the most primitive character.

Now, I have read you these extracts, and I want to ask you whether, so far as you know, they are true?-A. They are.

Q. They state the facts?-A: They do.

Q. From these I find there are altogether in the employ of the Alaska Commercial Company on the mainland in Alaska nine white men, who comprise the entire force of the Alaska Commercial Company on the mainland of Alaska Territory. I do this, Mr. Chairman, for the reason it is charged that the company has an army of ocenpation by which they control immigration. They do not, and they have ouly nine 
men stretching alomg the consis almost to the British P'ossessions, and without any communication between these nine men, who are sereral hundred miles apart.-A. They are strung aloug orer 1,500 miles of coast line in all.

\section{By the CHATRMAN :}

Q. What do ther do ?-A. They simply represent the company when traders bring the furs down. They maintain the stores for the exchange of goods for pelts; and I might say bere that that whole business, which we call the mainlanil business, is of so little value that were it not for the fact that the eompany by reason of the lease has to keep steamers and vessels of its own, ther would not for a moment think of pursuing this business-the comntry is so large and distances so great, and the supply of pelts brought in from the different stations is so small and scattering.

Q. Will you state just here whether or not the nutive hunters aud traders could find a market for their furs if some other company dil not maintain a trading station? How would they reach a market for their furs? $-A$. The only way in which tisey conld wonld be br some vessels eoming there, otherwise it would be quite impossible. Sometimes ressels might toueh on the northern dirision, but the Aretic division, to which the gentleman referrer just now, has a considerable amount of Indian trade in finrs, and various vessels go across Bering Straits and sell to Russian traders on the Siherian coast. The company conld, if they ehose, send a ressel up there and divert that trade, but it is too insufficient, for one reason, and another reason is-perhaps the principal one-that it always pertained to the inhabitants of Russian Siberia, and it was considered rather an act of courtesy to let the trade alone.

If the company leasing the seal islands were prohibited-suppose such a case-from doing any trading with the mainland, the trappers and hunters and general collectors of furs on the mainland rould suffer to just the extent that any business woul? suffer from whom its best support was withdrawn. If the Alaska Commereial Company was prohibited from maintaining these fer stations and the nine or ten men which it has in that Territory and buying the furs of people who collect them they would be absolutely forcen to accept whatsoerer in the way of trade ther might get from the few ressels sent from British Columbia.

Q. What elass of people collect these furs?-A. They are known in the West as hunters aud trappers.

Q. Are they natives?-A. The most of them are white men who hare taken to the roods and are like those who live on the froutiers. The Intians themselres collect furs, and these people collect from the Indians and they bring them to the points where the Alaska Commercial Company's agents buy them.

Q. Your company, then, buys second-hand from the traders?-A. Yes, sir.

\section{By Mr. Cunmings:}

Q. These tradlers are in the interior?-A. Thes have stations on the rivers and in the interior.

\section{By the Chairman:}

Q. These traders trade with the natires?-A. Yes, sir.

Q. Is there competition amongst them?-A. Yes: there are quite a number seattered through the countrr-men who have gone up there induced by the reports of the mining prospects, who found, when they got there, that the prospects were not equal to the reports. The long 
winter was before them; they were in the interior, and they could not get out of the country. They must do something.

Q. How are the prices of fur there, and what prices are paid for furs?-A. The prices are fixed there by the competition which arises from ressels from San Francisco and ressels from British Columbia or from Puget Sound, which are always looking after possibilities in that trade. So these people always have a choice of parties to whom they will sell, and who make the prices for their wares. They are in no sense placed under a compulsion to sell to any single individual or company.

Q. Does jour company or anybody else have a monopoly of that fur trale with the native hunters; are the natives dependent for the sale of their furs upon any one company?-A. Not in one single instance that I know of. There is always a number of ressels to choose between by the hunters.

\section{By Mr. JEFFRIES :}

(2. Now I want to ask you what the policy of the company is in regard to the natives and in regard to immigration. It has been charged that you oppress the natives on the main-land and Alentian Islands, and perhaps elsewhere; that you crowded out their traders, and that you are opposed to immigration. Please state to the committee what are the facts in regard to it. $-\mathrm{A}$. Any charge of oppression of the natives is so unjust and so roid of truth on its face that it does not require an answer. We can not oppress the natives, even if we desired. They are seattered over an enormous territory, and we could not get at them to oppress them; and it never has been done. In regard to immigratiou, we have always assisted parties who desired to go there. People who wish to go to the Territory on the steamers going up are taken at less, considerably, than the tariff rates of other steamers, not to compete with other steamers, but merely to oblige the people who want to go into the country. There has never been a case where we have met with parties of miners or other people in the country, who have failed to meet with success, where we have refused to carry them if they had no means to pay freight or charge. On several occasions, when there was what is called a mining boom in San Francisco and Portland, and a lot of people would rush up there, we, realizing from our experience of the country what the probable result would be, namely, disappointment, placed additional provisions in our stores up there, and instructed the agents to sell to those people as their needs might be at the regular prices, and never to sell in quantities to any one person in order that he might speculate on the wants of his neighbors; and if they had not means to purchase, to see that none suffered, but to see that they were fed and brought out of the country.

Q. Do you come in contact with the natives except at towns where you have trading stations?-A. Not at all.

Q. How (o) you treat the natives ont in this country? What is done there ? - A. The principal orcupation of the people out in this enutry is hunting the sea-otter. Of enurse in hunting the sea-otter they require a certain outfit; and they hunt in parties, in their eanoes, along the chain of Aleutian Islands at one station or another. It is the habit of this company, where these people are mable to buy an outfit for themselres, to furnish whatever may he necessary, and charge it against them, this to be reje:ir? with the proceeds of their catch, when they came hack; not the company taking the skins, but the natives selling $9984-7$ 
their skins to whomsoever they pleased, and then paying the company back their advance.

Q. Have you built houses there?-A. Yes; we built houses for those people. And while they are gone on this expedition, it is absolutely necessary we should help maintain their families. sir.

Q. These houses that you built were without charge, gratis ?-A. Yes,

Q. They have nothing to do with the seal islands?-A. No, sir; excent some are taken up there for laborers.

Q. No contract with the Government ?-A. No, sir.

Q. Here is a letter of instruction from Mr. Lewis Gerstle, president of the company, dated May 7, 18s6. He was then president of the company ?-A. He was.

Q. This is a letter of instruction to your agent at St. Michaels, Alaska. This letter says :

\section{Mr. M. LORENZ,}

San Francisco, May 7, 1886.

Agent, St. Michaels, Alaska :

Dear Sir: We have been informed that a large number of miners have already started to the Ynkon and Stewart River mines, and it is probable that many others will be attracted to that section of the Territory in consequence of the supposed existence of rich diggings in that district. Considering that the company's station at St. Michaels is the nearest source of supply, an extra awount of groceries and provisions have beem sent to you to meet the possible demancls likely to be made upon you during the coming winter. It must not be understood, however, that the shipment referred to is made for the purpose of realizing profits beyond the regular schedule of prices heretofore established; our ouject is to simply avoid any possible suffuring which the large increase of population, insufficiently provided with articles of food, might occasion. Hence you are directed to store the supplies as a reserve to meet the probable contingency herein indicated, and in that case to dispose of the same to actual customers only, and in such quantities as will enable you to relieve the wants and necessities of each and every person that may have occasion to ask for it.

In this connection wo deem it particularly necessary to say to you that traders in the employ of the company, or such others as draw their supplies from the stores of the company, doing business on their own account, must not be permitted to charge excessive profits; otherwise all business relations with such parties must cease, as the company can not permit itself to be mado an instrument of oppression toward any one that they may come in contact with.

It is useless to add that in case of absolute poverty and want the person or persons placed in that unfortunate position should be promptly furnished with the means of subsistence without pay, simply reporting such facts at your earliest convenience to the home office.

Asking your strict compliance with the foregoing instructions, which we hope will be carried out with due discretion on your part, I am, with lind regards to yourself and Mrs. Lorenz,

Yours, truly,

LeWIS GerstLe,

President.

Q. Is that an authentic, genuine order of the company ? - A. Yes, sir ; it is.

Q. That was in May, 1886 ?-A. Yes, sir.

Q. I have asked you how many agents you have on the main-land. Now I will ask you in regard to the Aleutian Islands. How many white men, under the company's control, are on the Aleutian Islands ?A. I really could not say; I would have to ask Mr. Morgan that; I should suppose, though, five or six. [To Mr. Morgan.] How many are there?

Mr. Morgan. Twénty-five or thirty.

The IVITnEss. Twenty-five or thirty, Mr. Morgan says.

Q. I hare seen it charged that the company was mutilating their coin. How about that?-A. It is a charge that has no foundation whatsoever 
in fact. These people had a fancy for punching holes in the coin and then to string it upon their necks. They have a fancy to stamp an image mpou their coin to make a charm in rarious ways; so the silver coin which is in circulation there get more or less marked. Wherever such coin has come into the stores of this company it has been their unvary. ing custom to put it aside, and when a sufficient collection was made to bring it to San Franciseo and sell the coin to the mint for bullion, in orter to get that class of coin out of the country. The idea of the company marking the coin for any purpose is absurd.

(i. Now I will call your attention to the trade in seal skins for the market, and in that connection, so the committee may understand, I will ask you to read the paper I have here. Did you prepare this pa. per yourself entirely ? - A. I did, and will now read it as part of my testimony.

Estıuate of number and valne of dyed and dressed Alaska fur seal skins shipped from London to New York from 1872 to 1887 , inclusive:

Number of skins in sixteen years. .............................

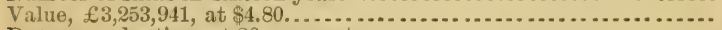

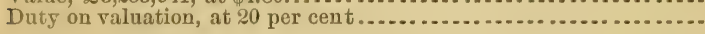

Average duty collected per annum............................

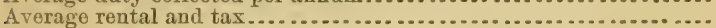

Average annual Government income from Alaskan seal skins........

In the sixteen years above noted the United States Government has received from Alaska seal skins from above sources..

825,000

$\$ 15,618,916$

$3,123,783$

317,500

512,736

$8,203,7 \% 6$

The sole hazard the Goverument encounters in this business is the possible loss of its herd of seals, either from its own negligence and want of proper precaution in protecting them or from the outbreak of some disease that might diminish their numbers. The Gorernment embarked in this business the capital sum it paid for the vhole Territory of Alaska. It has ahready been repaid this sum and more, and it has remaining the Territory of Alaska, with, in the words of the present governor, "her many varied and, as I believe, incomparably great natural resources to represent the investment of capital " first made.

The company has to eare for the natives and pay a rental of $\$ 55,000$ per anuum whether it takes a single seal skin or not. It has the hazard of the royage to San Fraucisco; that of ordinary railroad transit across the continent, and, superadded, the danger of skins heating, and spoiling thereby ; the hazard of the voyage across the Atlantic and the railroad risk from Lirerpool to London, and always the dlanger from fire. It has to keep ever in mind the realization that failure to deliver in London the regular supply of skins in sound condition and at usual dates, exposed as the slins are to all the risks above mentioned and to other's not enumerated, would entail a loss to them not alone of money; but of grip and hold on the business, that jears of patient and unvemunerative labor would hardly restore; and now it has to place on the market, after all these chances and charges, in competition with skins taken by unlicensed hunters and foreigu marauders, who pay neither rental nor tax, and who kill an average of at least seren seals to sare one skin, and have no more care for the Aleuts than ther have for the seal that they so mercilessly shoot or spear. The company could not aftiord to add a single risk to those they now bear, and if they can not have the prestige and partuership of the Government to the limited extent now accorded them, they would prefer to withdraw their capital and apply their energies in other channels. These skius hare no com. 
mercial value bejond that of the fur they bear, and if the fur be not applied to its present use, riz, the manufacture of garments for laclies? wear, the value of the seal islands, as a source of revenue to the Gorerument, is gone. For hatters' purposes the fur is not nearly as valuable as that of either rabbit or utri, and of these there is an unlimited supply. So that, in reality, the continuance of this business depends on the continuance of a fashion based on woman's fancy, and this not a foundation to "capitalize on."

\section{By Mr. Cummings:}

Q. What do you meaì by dressed and dyed slins; dressed and dyed by jou?-A. No, sir. Seal skins are sold in London at public anction. The salted skins once sold, the company's interest, directly aud indirectly, in those slins ceases. These sales are rers regular, and there are men from Russia, Germany, France, from America, and from England as buyers. They attend the auction sale and purchase these shins. After they purchase them they are dressed and dyed and theu matie into the garments which you see worn; but with that the company has nothing to do.

Q. In the foregoing paper you are giring the estimate of dressed and dyed skins?-A. For the reason that I want to show you where the Government interest comes in in this.

\section{By the CHATRMAN :}

Q. 'I'o extend it a little further: the Gorernment receives from the Alaska Commercial Company $\$ 55,000$ a year reut and $\$ 2.62 \frac{1}{2}$ for each skin taken from the islands, making in the aggregate a little orer $\$ 300,000$ per aunum. There is no account of what the Gorermment receives in the form of import duties when re-imported, aud I hare been trying to get at that and his object in the foregoing paper is to reach the question.-A. My object in the statement before submitted was to present to the committee a full raluation of the rookery to the Gorernment, not from the lease alone but from other sources as well.

\section{By Mr. JEFFRIES :}

Q. If jour tmarle were once lost it would be au expensire process to get it back?-A. It would be sears of perfectly umemumeratire labor to get it back. Just look at what it was when the Govermment male this first lease. If we had been called upon to pay the Government tax and reutal, we should have made a large loss. Th e sold those slins for from 19 to 21 and 24 shillings, delivered in London, and the best furriers of the time that were conversant with the tracle said to me, looth in Lomlon and New York, "You have takeu something there you can not carry. You never can pay the rates to the Government that you hare undertaken to pay, and pay expenses."

Q. As a firct di l you lose money ?-A. In the first years of the operation, the company lost 9 per cent.

\section{By Mr. CunnINGs:}

(?. You saly that if you were muder the same contract with the Cor. ermment that you are $m w$, with eren the nmmber of skins you took in 1sis, aceording to the state of the market in London, Jou would hare lost nones?-A. Les; what we pay to the Goremment, and to the natives in alsolute cash is $\$ 3.17$ to the (iovermment and 10 cents a slin to the natives for killing. There is 83.57 in cash to say nothing of other expenses. Then we had the expense of sending that venture uy) there aud paying the men mou it and transporting the skins to London. 
Now, we say in addition to the price of sending those skins we got about 21 shillings, which will be in round numbers \$5.25.

Now, you know there is $\$ 3.57$ in cash you have to pay the Govern. ment out of the $\$ 5.25$, then you have got the supplementary labor, then the parties who man these vessels to pay for this transportation to toncton; then you have to pay the storage charges, and you can see how much of that $\$ 5.25$ you can get.

Q. But say for 40,000 skins.-A. A single skin will illustrate it just as well.

Q. The more skins you had the more you made, if you made a profit.A. But the illustration is just as well on a single skin. The proposition is illustrated just as well by one as by a hundred thousand. As a fact, if we had this tax on skins we took the first year to the extent of what we have to pay the Government now, we would have been losers.

Q. You say jou did lose on the first year's operation?-A. Yes, sir. Mr. JEFFries. You made an assessment on the stockholders?

The Wriness. Yes, sir. I was going to say what these parties said to me directly, that we had undertaken a burden we could not carry, that we could not pay the United States Goverument that tax and get anything on it. I said then, and experience has shown since, there is a way in which this can be done. There had never been in the history of seal skins an established market; it had been a venture. I said that this commerce should be regulated, and that in the months of October and Norember, say, there shall be sold so many skins, and they shall arrive with certainty at their destinations and in good condition; that they shall be sold from the hands of the importer, the company, without speculation, that it shall be a perfectly fair and honorable transaction. Then if you can so regulate the killing on the islands as to furnish a class of skins most desired by the furriers, you gain their support. When a man strives to work a business in that way he can enhance the ralue of his product and get to an assured point where a regular commercial value will be recognized like the ordinary value of any commercial enterprise; and so, on that basis the company commenced its operations, and has followed it through with the utmost care.

By Mr. Oummings :

Q. So, on that account, you have regulated your killing to the market demand ?-A. Yes.

Q. Have you always killed the regulation number?-A. No, sir; in one year we took only 75,000, and in another 80,000 . As I think I stated earlier in the day, there are times when there seems to be a slackening in the trade, and it would be, so far as the policy is concerned, unwise to force the market. There has never been a time when the company felt desirous of going beyond the 100,000 .

Q. (By Mr. JefFrres.) What is the limitation under the Russian contract?-A. There is no limitation under the Russian contract except that we shall take 1,000 skins. The Russians are urging the taking of more skins.

Mr. JEFFries. I asked that because it is charged the company has been taking an excess of skins. The company is under $\$ 500,000$ bonds that it will comply with the law and its charter forbids this, and the risk is so great that the company would be foolish in taking an excess from these islands when it could lawfully take it from the Russian islands.

The Witness. The Gorernment association in this matter is of such value that I would not buy the seal islands for the purchase-money paid 
for Alaska. Suppose the Government sells the islands, who will take care of the Aleuts. What will be a guaranty of protection to the purchaser?

With erery assurance the Gorernment could gire us I should still feel that there was a slowness in the operation of the Gorernment which would rain the business. The Goverument has got the responsibility for these people, and in my mind, it can not escape it, and can mot afford to sell the islands. Whatever is to be done in the matter must be dove by the Gorernment.

Q. (By Mr. Jefreries.) I understood jou to say that after the fur is taken off the seal skins, the skin has little or no commercial value.A. It has none at all-I will not say none at all-but it is very slight.

Here a recess was taken until 2 o'clock.

\section{AFTER THE RECESS.}

\section{BJ Mr. JEFFRIES :}

Q. Tou spoke in your testimony of fashion being a controlling element in the price of seal skins. I ask you whether or not the mainto. nauce of the fashion is one of the expenditures of the company ? - $\mathbf{A}$. It is au absolute necessity for the company to carefully observe the usage of those skins. You know fashion is very fleeting and changeable, aud if the matter of persererance in regard to the usage of those skins is not considered they will be very likely to go ont of use; therefore it hehoores the company to uphold the fashion, and it has necessarily been a part of their business.

Q. Is it an important expenditure?-A. It is, and it is usual in St. Petersburg, in Tienna, in Berlin, in Paris, in London, and elsewhere to take such legitimate steps as are right and proper to keep this article before the public and make its use popular. It is a very considerable expenditure.

Q. Do jou regard it as a necessary expenditure?-A. I regard it as absolutely necessary.

Q. Whether the company or whether the Government manages it ?A. It matters not who has those skins to dispose of, they must use every effort to keep them in fashion.

Q. Has the company performed its contract with the Government in ererg respect in regard to its laws?-A. So far as I know it has fully, and done more besides.

Q. Have you instructed jour agents to comply strictly with the laws and regulations of the Treasury Department?-A. In every case; res.

Q. Do you kill seals with fire-arms at the islands or do you prohibit that? -A. No, sir; nerer; it is not allowed by the act.

Q. Do you kill the female seals or allow them to be killed ? - A. Jever with our knowledge.

Q. Do you kill any during the month of August for their skins ?-A. Not a seal; no.

Q. Do Jou kill any seals under two years old?-A. Not that we aro amare of.

Q. The agents are instructed not to ?-A. Yes, sir.

(2. In regard to the goods that you sell to the natives, how is itin regard to the prices and quality ?-A. The goods which we sell to the natives are purchased in Sin Francisco very closely, and to the wholesale prices at which thes are bought is added 25 per cent. to cover the cost of trans. 
portation, lading, etc., and at this price of $\mathbf{2 5}$ per cent. added they are sold to the natives, which makes them in almost every instance less than the retail price in San Francisco.

Q. Do you supply the fuel and food you are required to supply the natives under the contract?-A. We do.

Q. Medical attendance?-A. We do.

Q. And schools :-A. We do.

Q. So far as the agents of the Government and the agents of the company report to their respective chiefs, are the natives contented and happy and their condition bettered ?-A. So far as we have any knowledge their condition is improved and they are entirely satisfied.

Q. What would be the effect, if you have not already testified to it, of opening up Bering Sea to all commerce, American and foreign; what would be the effect upou the seal industry?-A. Of opening all the sea?

Q. Open all the sea so that anybody could come and kill seal anywhere in the waters of Bering Sea outside of the seal islands ? - A. It nould be a matter of a few years to exterminate the herd under such conditions.

Q. What is the effect of using fire-arms in killing the seals; what "ffect does that have?-A. It has the effect of seriously frightening' and alarming the seals, as they are very timid.

Q. You are not allowed to use fire-arms on the islands when the seals are about \%-A. No.

Q. What effect would it have of killing them in the water by the use of fire-arms? - A. The effect of alarming the seals and disturbing the regular order of their lives.

Q. What is the policy of the company in regard to the use of ardent spirits, whisky, etc., in Alaskat ?-A. It is to prevent the introduction and sale and use of them, so far as it lies in their power in any way.

Q. Has the company exported fire-arms and placed them in the hands of the natives of Alaska?-A. No.

Q. Now, if there is anything else which you want to say you can state it. If not, I will turn you over to the chairman, Mr. Cummings. - A. I think I have stated all that occurs to me. I shall be pleased, however, to answer any questions.

Q. I think I asked you whether the company was against immigration?-A. The policy of the company has always been to encourage immigration.

Q. The more people the company has there to buy their goods, the better it is for the company?-A. It is not only that, but if the people desire to go there, we have no wish to keep them out.

Q. What are the regulations of the company in regard to carrying people from one point to another on your vessels?-A. The order's are always to transport them if we have place and room for them.

Q. Are the commanders of your vessels instructed to transport men who have no money without price on their return home?-A. Of course, any one found in the country - that is a feeing that prevails largely through the western country and California when a man is in condition of need aud has made a failure in his efforts-to help bim along, feed him and bring him home.

Q. How are the rates charged to regular passengers on your steamers compared with the regular lines running to Sitlia, ete. ?-A. They are much less, but we do not pretend or care to run a passenger steamer to compete with them, but if these people desire to go in that way we tako them at much less rates than they could go on the regular steamer's. 


\section{By the CHATRMAN :}

Q. I believe you stated in the earlier part of your evidence that rou and those associated with you brought the valne and condition of the rookeries to the attention of the Government and advised the present policy of creating a reservation and leasing. Have the results confirmed your judgment as to the wisdom of that policy? - A. MIost decidedly. The policy was very much eriticised at the time when the lease was being put into operation. Secretary Boutwell, who had given the matter as he considered careful attention, was very much opposed to the plan, but I think that the development of the policy and the results which have been obtained from it have been such as to convince all parties who then regarded it adversely that it was the only wise system. Secretary Boutwell himself some time last winter, when I hap. pened to meet him, in speaking of this said that he was perfectly clear in his own mind that there could be no question of the propriety of the policy of leasing rather than that of Government operation.

Q. Is it your judgment that the present policy had better be continued rather than either to reduce it to an exclusive Government operation or sale of the property?-A. I should say that the present policy was preferable to either a Goverument operation or a sale.

Q. What would be the difficulties of a Government operation?-A. I think the difficulties have manifested themselves in the statements I made as we went along in regard to the necessary operation of the com. pany in getting their skins from the island to the market. It is one of the peculiarities of this trade that the necessity exists that they should go to London rather than be sold at the nearest point here. London seems to be the center of the world's market for this class of goods. If the skins were sold in America the buyers from Russia, Germany, France, and England might have representatives here, but the probability is they would not, and the sale of skins here would be at a much less rate than it is abroad. The factory, so called, in which these skins are dressed ancl dyed is generally an elaborate establishment dereloped by a great deal of capital and a great deal of labor.

Dressing and dyeing is done to some extent in the United States; bnt the fact remains that, although the United States purchases and uses more than half of the annual eatch of seal skins, the purchasers prefer to have their skins dressed and dyed in London. Therefore the sale takes place there because in every case if the skins were sold here it would be necessary to send them to Loudon for dressing and dyeing, and they would have to be returned here. There are not such large factories here. Then the difficulty which the Gorernment would experience in intrusting such a business to a class of agents would be enhanced by the liability to a change of management from time to time as the administration might change in the country, and such a business as that can ouly be conducted by the pursuance of a regular system, and the experience which the managers may gain as they go on with their business.

With regard to the sale of the islands, there is one objection that presents itself immediately as most forcible to my mind, and that is, what are you going to do with the people there? There are about four hundred people whose sole living and existence is in this business. If jou sell the seal islands to a company you can not sell the people. They can not get away; they know nothing else. If you sell the islands and the purchaser says to these people, "You must go away; I want to hare better and cheaper labor here; I do not propose to pay you $\$ 10,000$ for two months' work, when I can get it done better for $\$ 20,000, "$ in that 
case you turu four hundred people adrift on the world without any possible means of living. The islands produce nothing except a little grass, and I could not conceive of a policy that would admit of a sale of the islands without establishing a reservation somerhere for these people; and if you establish a reservation you have got simply four hundred yaupers on the Government's hands without any means of feeding them ex. cept by an appropriation. So it seems to me the Government in the purchase of that 'Territory has taken upon itself certain responsibilities which it must continue to regard. It eau not turn them orer, and the Gorernment should not be influenced by the mere matter of gain even if it goes into the millions. It is not a thing they should sacrifice life for, and it does not seem to me to be feasible.

Q. As the business has developed, could the Government justly or practically increase the rate of tax upon the privilege and the skins? Is there margin for an increase of the rates?-A. I do not know that I should be an impartial witness there. My opinion is the Government has got the better end of the stick now. I ain very clearly of the opin. ion-I want to answer every question you choose to ask me, but of course I do not desire to develop any more of the business affairs of the company than is proper-but I can simply say on the statement I hare of officials there to-day that a careful examination of these figures and a critical one will easily show that the returns which the Government have received from this lease are greater, taling into account the duties they collect on the dressed skins, than the profits the company receive net.

Mr. FELTON. You speak of gross now?

The WITnEss. I speak of the net profits of the Government, which is greater than that of the company.

The Charrman. Without inquiring into the private business of the company at all, I want to know-there is a popular idea that the company is making a great deal more money than the Goverument.

The WITNESS. If I could stand outside of myself and form an opiuion on this subject, which is difficult for a man to do, I should say without hesitation that I think, taking into account the hazards and risk: which the lessees take upon themselves, with the burdens aud eharges which are placed upon them by the Government, with the incidental charges which the necessities of the business require, that present tas and rental is all that they can afford to pay. This property is to be regarded somewhat in the light of a mining property. The possibilities may be extinguished at any time. They might lose the ship which is due now with a hundred thousand skins for the market.

Ir. JefFries. And that is now two weeks overdue?

The WITnEss. It is twelve days overdue. Disease might get amongst the seals, the Government might be laggard in its action with regard to orders aud unlicensed hunters, and the result would necessarily be that a large number of productive seal would be killed, and for the same reason a certain class of skins which are taken by these marauders and and which have paid no tax and no rental, and which are subjected to none of these charges, and which are inferior by reason of their ina. bility to cure them on the ressels as they are cured on shore, are throm upon the market in competition with our seal skins, which have paid the rental and tax and all other charges, and the market has no bowels of compassion for individuals, it gets the skins at the best rate it can. and consequently the company have to sell theirs and come into competition with them and accept the price, whatsoever it may be. The risks and hazards of the business, I sas, are more comparable to the hazards 
of a mining business than to those of a legitimate shore business, or a cattle ranch of a thousand acres of laud, where you can ride around it and round up the eattle. and watch it, and you know the number of cattle rou have, and you hare positire control. In this case you are deprireri of that

Q. Now, I would like to hare jour opinion as to the sufficiency of the present measures taken by the Gorernment for the protection of the rookeries, and your opinion as to whether any additional safeguards are necessary for their protection.-A. That the present measures are somewhat insufficient is shown by the fact that for the last three or four rears there have been increased depredations amumally upon the rookeries. More seals are taken within the limits of Bering Sea. Formerly seals were only taken outside of Bering Sea as they passed up) to British Columbia and off the mouth of Puget Sound in the waters of the Pacific Ocean. That was a legitimate place to take them and one against which no objection could be raised. Seals which come up) that way enter through the passages of the Alentian Islands nearest to the mainland, and it has alwars been the custom in British Columbia and our sound to intercept the seal and get what they could. Within the last two or three rears marauders have followed them through the passages into Bering Sea, and have witli guns aud spears taken the seals as they lay upon the water, as I stuted befire, waiting to hatul ashore and have their pups. The cows are heavy with pup, and they fo not like to go ashore until the last moment, and so they lie there in the water and this affords an opportunity for these marauders to shoot and spear them. This is done by gangs of Indians which they have. They hire gangs of Indians and take them with them. The effects of this shooting is not alone upon the seals which are at that point, but also upon those all around, and it startles them and raises a suspicion in their minds aud there is a general fueling of disturbance, such as trot uotice among cattle when bears are about or something of that kind.

The Gorerument's practice, through the Treasury Department, has been to protect these waters so far as they could with the revenue cutters which are at their command. Still it has frequently happened that a revenue eutter goes upon the seal grounds and then is ordered North for inspection, or for relief of a whaling crew, or something of that kind, aud they are gone pretty much the whole time of the sealing season, and there seems to be an insufficiency in the method of protection. T!nen there has been an insufficiency on the part-I say it rery respectfull Tof the Government, in not asserting the fact that they were going to protect the seals, and enforce the laws, so that the British Columbia ressels and our own country's vessels from the Sound, have been ready to say, "This thing has not been determined yet and I will take another chance. If I can fit out three ressels, and get one cargo, I can afford to lose the other tro," as the ressels are cheap and inexpensire, until I lnow that the Gorermment means to enforce its laws. If, as sugo-ster? resterday, Ooualaska is made a port of entry for all ressels going into Bering sica, to report and clear from there aud shows its manifest as to whether they liave legitimate and necessary articles for the royage Thich they professed, or whether they had concealed guns and large fuantities of salt and material generally used for taking seal, I think the thing could be rery closely kept under control. "If they were olliger also before learing Bering Sea to report at Oonalaska, it would would he well. It would be a natural thing for them to touch there. It would bring them very distinctly under the knowledge of the revenue 
officers, Treasury officials, and it would be almost impossible to carrs on this business of illicit taking.

Q. Do you think any measures of protection are necessary to be c. ercised orer the herds of seals south of the Alentian Islauds? - 1 . No. sir; I do not. I do not thiuk any are necessary, and I really do liot see how any could be enforced, hecause the moment the seals get througlz the passes they are in the Pacific Ocean, aud it wonld seem to me to be almost impossiblo beyond the 3 miles from land to assert auy contiol over them. In fact 3 miles from land yon do not see them ; where they go no one knows.

Q. Now, Mir. Williams, should it be finally ascertained and considered by our Gorermment that under the treaty of cession by which re acquired Alaska from Russia, and under the law of nations, the Enited States does possess and has absolute dominion and jurisdiction orer Bering Sea and the waters of Alaska, would you think it would be a wise policy to adhere to and maintain that juxisdiction and dominion complete, or would it be wiser to declare it the high seis in the legin sense?-A. In the light of to-day I shonld say licep what you have got,

Q. Hold it as a closed sea?-A. Fisheries wilhin those limits are yet to be developed, and it would seem to bo very nuwise to open uly posis. hle fishery contentions which are very likely to arise by such a course.

Q. You think that would be, then, the wiser policy, to maintain suele juristiction and dominion as we have, and to concecie to the ressels of other nations such rights as are not inconsistent with the interests which our nation has there and which need protection?-1. Exact that; the right of transit through the sea whererer they please, hut positive protection to seal life.

Q. You do not think it would be wise to grant anything else?-A. No, sir; not at all.

Q. And in no case to surrender the power of policing the sea ?- No, sir; under no circumstances.

Q. Could that power and jurisdiction be surrendered and jet pre. serre this seal lifie on these rookeries, and the value of our fisheries that may be dereloped there?-A. Only with very great risk, because if that right is surrendered and thereby the right to police tho sea, the depredations that are made upon the seal whererer they way be fonnd. wherever men thought they could carry them out without being taken in the act, would be carried ont. So it would be difficult in regard to the fisheries. Wherever they could kill these seals, they certainly wouli be there, and it would be impossible to prevent them.

Q. Hare you any knowledge of the extent and ralue of these salmun tisheries that is adjacent to Bering Sea, in Alaska ?-A. Not very accmate knowledge, because the things hare not been sufficiently dere]oped to make sure, but we havo positivo knowledge that theso Hsherie: are rery raluable, indeed. I would say also that a portion of these salmon fisheries are absolutely necessary to sustain tho life of the Imdian tribes who, at the salmon season, gather on the banks of these river:s. especially on the Kuskovim.

Q. This also applies to the Copper and the Tukon as well?-i. The Iun of salmon in the Xukon has, I think, no comparison with these other waters. I should fancy it was so from the fact that in this es]ecial Ituskorim locality the tribes so far as known hare heen in the habitet gathering in the salmon season and providing themselve: with the nexessary supply at tho time, and with drierl salmon lor the winter tor themselres and their dogs.

Q. Hare the matives any other means of subsistence except that froms 
hunting, furs, and fishing?-A. No; there are a few berries there in summer, but they soon pass. They have seasons of great suffering and death from starvation.

Q. From your general knowledge of the whole subject, would you deem it very important public poliey to maintain complete dominion and jurisdiction over Bering Sea as a closed sea if we are entitled to do so? A. I should deem it of the highest importance.

\section{By Mr. Cunmrngs:}

Q. Do jou ship any skius orer the Canadian Pacifie?-A. No, sir.

Q. How many skins did you take last year?-A. From the Pribylor?

Q. Yes.-A. Within the hundred thousand; ninety-nine thousand and some few.

Q. Do you sell at auction?-A. Yes, sir.

Q. What do they bring at an arorage per skin?-A. They brought on an arerage last year-I think it was 56 shillings in their salıed state.

Q. One more question: the depredators in the sea there, what are they mostly, Amerieans or Cauadians?-A. They are mostly Britisiı Columbia vessels.

Q. Where are those depredations committed? Do they kill the seals aloug the islands, or are they able to find them in the middle of the sea?-A. They shoot them as they find them, in the waters of the sea between the islands of the Pribylov group and the Aleutian chain, and the foggy season which is a prevalent characteristic of the weather is such that a vessel can approach within less than half a mile or a quarter of a mile of the island and not be seen, and can send her boats on the veaches and get off fifty or a huudred skins before the inhabitants of the island can find it out.

Q. The fog is very dense there?-A. Yes, sir.

Q. And the fog protects them?-A. Yes, sir.

Q. Have you any information as to how many ressels are concerned in the depredations on an average? $-\mathrm{A}$. I had a list; I think there were some twenty-four last year.

The Chairuan. There have been twenty vessels seized, ten of which were Americans.

The WITnEss. But they were not all seized; there were a good mans depredators which were not seized.

The ChaIRMan. These trienty are seizures.

Mr. Cunnings. Do their profits come from the seals they take off the land or the seals they take on the sea between the Pribylov group and the Aleutian chain?

The WITNESS. It is quite impossible to distinguish that. If one vessel has 1,500 or 2,000 skins and they go into the market, it is difficult to show where the profit would come from, whether from skins taken in authorized waters, or inside Bering Sea, except that you may generally count that a skin taken off the coast is less torn with shot and spear that those taken in Bering Sea. Sometimes you see skins taken on the sea that are so peppered really with buckshot as to present the appearance of a siere or colander, and they are absolutely worthless as skins except as pieces of them can be cut out and used for caps, etc.

Q. When they shoot the seals, how many do they really secure of the number killed ?-A. I think the best testimony we have of that is dejived from the $\log$ of a ressel that was seized last year, in which the eaptain had kept a journal apparently for his own information. The captain was shot by the explosion of his gun or some accident which ended fatally for him, and in this way the journal came into the pos- 
session of the Government or some parties who made it public. His estimate was that he got one in seren. That is to say, he put on the ressel oue in seven of the seal he shot at, the others sinking or getting away wounded.

Q. They were killing seven seals to get one skin ?-A. Yes, sir.

Mr. TAYLOR. There is an island I have not heard mentioned in the testimony, called Otter Islaud, about 7 miles distant from St. Paul, and on that island during the seal season a large number of seals will haul on the rocks when the rookeries on St. Paul Island are overcrowded? aud ressels going after these skins go on that island on that account. I know when I was there in 1881 some men from the island found sixty carcasses left on Otter Island of seals which had been killed there, and that is one reason I urged the importance of having a steam-launch so as to guard that island. There is not more than half the time that you can see the island. Mrr. Morgan calls attention to the fact that the captain who shot himself accidentally had just come from Otter Island, and the accident occurred while hoisting his boat alongside.

Mr. Morgan. He was on the island aud wounded one of his arms on account of his inexperience in handling the club used to kill the seal, and when he came on board the vessel he took his gun up to show how he injured his arm, and drawing it towards him the charge exploded and shot him.

By Mr. FELTON :

Q. Is it the general practice to sell these skins in the rough at auction?-A. Yes, sir.

Q. Invariably?-A. It is the invariable practice. The skins are sent to London. They are packed in San Francisco in casks and they are not taken out until they get to London. Then the casks are all opened. They are taken to Sampson \& Co.'s warehouse and there the skins are sorted into various grades. They have technical names by which they are known. Then they are placed in position for the buyers to examine them. They look at this lot and that lot, and make up their minds as to what they are going to do.

Q. Are these sales peremptory? Suppose the price is very low, such as would not pay zou any protit, do they ever adjouru a sale?-A. Te have but one rule about that, and that is to meet the market.

Q. You have never carried over any stock "?- -1 . I think on one occasion we carried orer 20,000 skins, but it was in the early part of the iusiness, and it created great dissatisfaction, and we found ourselves that we had made a mistake in varying from our rule, aud we hare never done so since.

Q. The reason I asked fou was this: I understood on one oceasion the price was such as not to afiord any protit on accomnt of a dull marLet, or want of slins, or something.-. I. IVe diul that year carry over, but we did not malie anything by it, as it clispleased the buyers. The have sold slins at a loss on one or two ocuasions. The rule is now tiree? and that is to meet the market whatever that may be.

Q. Whatever that may be?-A. Yes, sir.

(Q. That being the case would not that create a sort of combinationi of the huyers?-A. Buyers are so wirlespreal over America, litsisia, Germany, and France, that there is harlly a possibility of a combina. tion amongst them.

Q. I have been told that it's only in England where they properly eme and dre these skins; that is, that they do not do it so well in any other. part of the worlel. Is that so?-A. That is not strictly colvect. There 
are two places in America where the skins are as well dressed and dred as they are in England. One is the establishment of Treadwell \& Co., in Jew Fork, who have their works in Albany, and who have turned out as good work in garments dressed and dyed as can be found in England. They do but a very limited amount of work. They positively sefused to increase their works or extend their trade. They make a secret of their jrocess. Time and again efforts have been made to inance them to enlarge their works, but they have refused to do it. The other is an establishment in Brooklyn, the name of the man I forget for the moment, but he does about three thousand shins a year, and that almost exceeds his capacity. He does them very well, indeed. When his limit is reached he does not care to increase it. In fact, the feeling of most American buyers-and they buy more than half the skins-is that they prefer to have their work done in London, possibly from a prejudice or tradition, and certainly from the fact that it can be done there, whereas there is no capacity to do it here. But, in fact, the expenditure, I fancy, would be close on $\$ 1,000,000$ to put up in this country such a work and instruct the men to do the work as it is done in England.

\section{STATEMENTS AND STATISTICS RELATIVE TO THE FUR-SEAL FISHERY.}

[Sabmitted to Committee of Congress on Merchant Marine and Fisheries, 1888.]

Examination of tile earliest records of the fur-seal fishery shows that from the dat 6 of ntan's recognition of the value of the fur the pursuit of the animal bearing it has ineeu unceasing and relentless. Save in the few instances to be noted hereafter, there governments have interposed for the purpose of protecting seal life, having in riew benefits to accrue in the future, the animal has been wantonly slaughtered with no regard for age, sex, or condition. The matare male, the female heavy with young, the pup, dependent for life on the mother, each and all bave been indiscriminately zilled or left to die of want. This cruel and useless butchery has resulted in complete extermiuation of the fur seal from localities which were once frequented by millions of the speeies; and, so far as these localities are concerned, has obliterated an industry which a little more enlightened selfishness might have preserved in perDetuity to the great benefit of all ranks of civilized society. Nothing less than stringent laws, with will power to enforce them against all violators, can preserve for man's benefit the remnant of a race of animals so iuteresting and so useful.

The most valuable "rookery" or breeding place of these animals ever known to man is now in the possession of the United States. How it has been cared for in former sears, and brought to its present state of value and usefulness, will be shown later on. But the matter of its preservation and perpetuation intact is the important question of the moment, and that this question may be considered intelligently the evidence is here presented of the wanton destruction that has befallen these animals when left anprotected by the law to man's greed and selfishness, which, it is fair to say, is all that could be expected from the unlicensed hunter, whose nature seeks individual and imnediate gain, with no regard for a future in which he has no assurauce of personal adrantage.

The following statistics are gathered from the journals of early navigators, and uch commercial records as are now ava ilable are submitted.

Ëerguelen Land.-An island in sonthern Indian Ocean, discovered abont 1772. The thores of this island were teeming with fur seal when it first became known. Between the date of its discovery and the year 1800 over $1,200,000$ seal skins were taken by the British vessels from the island, and seal life thereon was exterminated.

Crozetts. - The Crozett Islands, in same ocean and not far distant, were also visited and hunted over and the seal life there totally exhausted.

Yassafuero. - An island in southern Pacific Ocean, latitude $38^{\circ} 48^{\prime} \mathrm{S}$. longitude $80^{\prime}=$ 31. W., came next in order of discovery, and from its shores in a few years were gathered and shipped 1,200,000 fur-seal skins.

Delano, chapter 17, page 306, says of Massafuero: "When the Americans came to this place in 1797 and began to make a business of killing seals, there is no doubt but chere were $2,000,000$ or $3,000,000$ of them on the island. I have made an estimate of zore than $3,000,000$ that have been earried to Canton from thence in the space of eeren jears. I have carried more than 100,000 myself and have been at the place 
when there were the people of fourteen ships or vessels on the island at one time killing seals."

South Shetlands.-In 1821-'2?, the Sonth Shetland Islands, a group nearly south from Cape Horn, became known to the seal hunters, and in two years over 320,000 seals were killed and their skins shipped from these islands.

South Geargia.-Later still, seal were found on the island of 'South Georgia, South Atlantic Ocean, and from this locality was obtained over 1,000,000 of fur seal, leaving the beaches bare of seal life.

Cape Horn.-From the coasts of sonth America and about Cape Iforn many thonsands of fur seal have ber'n taken, and of the life onee so prolific there nothing is now left sare such remnants of former herds as shelter on rocks and islets almost inaccessible to the most daring hunter.

This record shows the nearly complete destruction of these valuable animals in southern seas. Properly protected, Kerguelen Land, Massafuero, the Shetlands, and South Georgia might have been hives of industry, producing vast wealth, trainingschools for hardy seamen, and furnishing employment for tens of thousands in the world's markets where skins are dressed, prepared, and distributed. But the localities were no man's land, and no man cared for them or their products save as through destruction they could be transmitted into a passing profit.

The skins from the localities mentioned were marketed mainly in China, as exchange for silks, teas, etc. ; a portion went to Europe and in France and England were manifactured into caps, gloves, and other small articles, being simply unliaired and dressed. Their commercial value in China was about $\$ 5$ per skin for first class, and something less in Europe. But Delano, chapter 11, page 197, says: "Having agreed for a freight, Captain Stuart ordered his ship to Canton; he sold his cargo of seals, 38,000 , for only $\$ 16,000$, so reduced was the price for this article." There was no regular market established for them, and, under the conditions of their taking, there could be none; for at one time there would be a vast oversupply, while at another skins would be unattainable, and always the assurance that however plentiful might be the supply for a season the end was not distant, for utter destruction was the rule of capture and no reproduction was possible. Capital could not undertake to develop such a trade, for the end was in sight from the beginning.

In 1872, fifty years after the slaughter at the Shetland Islands, the localities before mentioned were all revisited by another generation of hunters, and in the sixteen years that have elapsed they have searched every beach and gleaned from every rock known to their predecessors, and found a few seclnded and inhospitable places before unknown, and the net result of all their toil and daring for the years scarcelr amounts to 45,000 skins; and now not even a remnant remains save ou the rocks off the piteh of Cape Horn. The last vessel at South Shetlands this year of 1888 , after hunting all the group, found only 35 skins, and the last at Kerguelen Land, only 61 including pups. So, in wretched waste and wanton destruction, has gone out forever from the southern seas a race of animals useful to man, and a possible industry connected with them. And it is plain that withont the aid of law, to guide and control, no other result could have been expected or attained.

The seal life of to-day available for commercial purposes is centered in three localities:

(1) The Lobos Islands, situated in the mouth of the river La Plata, owned and controlled by the Uruguay Republic, aud by that goverument leaserl to private parties for the sum of $\$ 6,000$ per annum and some stipulated charges. The annual product in skius is about 12.000. The skins are of rather inforior quality. Insufficient restrictions are placed upon the lessies in regard to the number of skins permitted to be taken annually, conserquently there is some waste of life; nevertheless, the measure of protection allowed has insured the preservation of the "rookery," and will continue so to do.

(2) Komandorski Conplet, which consists of the islands of Copper and Bering, near the coast of Kamchatka, in that portion of Bering Sea pertaining to Russia. These islands yield alont 40,000 skins per annum, of good quality, and are guarder by carefully restrictive rules as to the killing of seal, aualogous to the statutes of the United States relative to the same sulject. The right to take seals upon them is leased by the liussian Goverument to an association of American citizens, who also hold the lease of the islands belonging to the. United States, and are thus enabled to control and clirect the business in fur-seal skins for the common advantage and benefit of all parties in interest. These islands can hardly he said to have been "worked" at all for salted seal skins prior to the cession of Alaska by Russia to the United States. and the United States Goverument now profits by the industry to the extent of the duts of 20 per cent. collected on the "dressed skins" returned to this countrs from the London market. From 1873 to 1887 , inclusive, this return has been 121,275 skins.

(3.) The Pribylov group consists of the islands of St. Panl and St. Georere, and is a Government reservation in that part of Bering Sea ceded to the United States by 
Russia, together with and a part of Alaska. So exhaustive an account of these islands and their seal life has been given by Mr. H. W. Elliott, special agent of Treasury Department in 1874, and since intimately connected with the Smitlisonian Institution, which account has been made a part of 'Tenth Census report, that it would be intrusive here to attempt to supplement aught, and therefore only generalizations based on sajd report and such statements of life and procedure on the islands to-day are presented as may be pertinent in this connection.

These islands are places of anunal resort for the largest herd of fur seal the world has ever known, and the only one of great importance now existing. After most eareful examination Mr. Elliott estimated their numbers at over 4,500,000. After a thornugh study of the influences which act for or against the increase or diminution of the life of this vast body, taking into account the killing of 100,000 annually for their skins, Mr. Elliott says, "I have no lesitation in sajing quite confidently that under the present rules and regulatious governing the sealing interests on these islands, the increase or the diminution of the life will amount to nothing; that the seals will continue for all time in about the same number and condition." It goes witlout saying that if new influences for destruction are brought in, seal life would be diminished in proportion to the effectiveness of said influences.

It is safe to say that these animals are all United States property, having been born on United States soil and reared in United States waters in the twenty-one Jears that have elapsed since the cession of Alaska by Russia, and having the instinct of regular return to their home, which accords them a statns in law, they would seem to be entitled to the protection of their Government while they are in the acknowledged boundaries of their country.

The right to take 100,000 seal skins annually from these islands, under certain stipulated restrictions, is leased by the Government of the United States to an association of American citizens known as the Alaska Commercial Company. The comp:lny pays a rental of $\$ 55,000$ per annum and $\$ 2.62 \frac{1}{2}$ per skin, a total of $\$ 317,500$ per annum, for this right. They are also obligated to a certain care of the Aleuts inhabiting the islauds and to a partial provision for their needs, both mental and physical.

They pay to these Aleuts 40 cents per skin, or $\$ 40,000$ per annum, for their services in taking the skins. They have also built for them a church and school-house, and maintain teachers and physicians on the islands.

At the time of the cession of A laska to the United States these people were living in huts, or more properly boles in the ground, and had no ambitions or aspirations berond supporting their daily existence in a painful and laborious way. Now they are living in frame houses provided for them by the company, and have accumulated savings, invested in United States bonds in San Francisco, amounting, on August 1, 18s7, to $\$ 91,128.28$. It is safe to say that no laboring men within the boundaries of the United States are better paid or better cared for.

As to the manner in which the 100,000 seals, which furnish the annual quota of skins, are taken, Mr. Elliott says, "By reference to the habits of the fur seal it is plain that two-thirds of all the males that are born (and they are equal in number to the females horu) are never permitted by the remainiug third, strongest by natural selection, to land upon the same ground with the fomales, which always herd together en masse. 'Therefore this great baud of bachelor seals, or 'hollus chickie,' is compelled, when it visits land, to live apart entirely, miles a way frequently, from the breediug grounds, nad in this admirably perfect manner of uature are those seals which can be properly killed without injury to the rookeries selected and held aside so that the natives can $v$ isit and take them, as they wonld so many hogs, withont disturbing in the slightest lecree the peace and quiet of the breeding grounds where the stock is perpetiated."

In this convection it is proper to note that the company are not allowed to take any seal in the water, nor to wake auy use of fire-arms in their capture. And it will at once be perceived that if the seal in Bering Sea are laarassed and eaptured by means of fire-arms, spears, or drarr-nets, the runtine of their lives is interfered with, their habits broken up, females with joung killed, aud such general disturbance cansed that those not slaughtered will seek other hauling places and the United States thus iose their sole sonrce of income from Alaska, as well as the coutrol they now enjoy of a vaituable trade; and the imporerished Aleuts, who have no other means of gain open to them, would beeme a burden on the nation, instead of being the self-supforting and self-respecting eitizens they now are. Indeed, it was predicted by Rnssian authorities, conversint with seal life, at the time of the cession of the Territory that the reckless and indiseriminate killing of seal by the Americans would soun irive the Prybilov herd to the Russian islands, and that thus they (the Russians) would regain and retain all that was most valuable in the ceded territory. Bnt the wisclom of Cougress, appreciatiug the value of the islands as seal rookeries, was shown hy legrislative acts protecting the animal, and by leasing the right to take skins under restrietions to a responsible association of American citizens, with the result that at: the expiration of a twentr.years' lease the Uuited States Government will from its proceeds be fully re-imbursed for the outlay for the purchase of the entire territory 
of Alaska, and will also have its hert of seal intact, provided the Govermment will protect the seal in Bering Sea against unlicensed hunters and foreign maranders.

Immediately upon commencing operations under the lease it was apjarent that the interests of the Government and those of the company were so intimately interworen that a policy of entire good faith between the contracting parties was the ouly one that conld be pursued, and so well has this relation been snstained in the eighteen jears elapsed since the lease was made, that no word of complaint has ever been uttered on the part of the Government agaiust the company, and no complaint of improper action that has been made by parties inimical to the compauy has been in the least degree sustained, though twice, because of misrepresentation, the company has been subjected to most rigorous investigation by comuittees of Congress. The company has received just consideration at the hands of the Government, and though they have suffered to some extent from complications of a political character, arising from the improper acts of crews of foreign and domestic vessels who, in contravention of the laws of the United States have entered upon the waters of the territory and slaughtered malicously the seals, yet they feel assured that the Government will so assert and maintain its rights and authority that no cause of complaint will continue to exist.

Under Russian rule there were many years of faulty management, and at one time much danger of extermination of seal life at these islands, but in time the company came to regard seal life with so good an eyo to preservation and perpetuation that their rules and regulations in regard to these points'are still in force on the islands; but while they permitted free navigation throughout Bering Sea, they sternly prohibited any interference with seal life in the waters thereof, and so the United States Government will be forced to do if it would preserve and perpetuate its present splendid property.

Until about 1853 the skins shipped by the Russian American Company from these islands, over which they had absolute control, up till the time of the cession to the United States, went forward in the parchment (or dried) state at the rate of alout 20,000 per anuum. About 1853 a small trial shipment of salted skins was shipped in the hands of Messrs. J.M. Oppenheim \& Co., London, who had for many years previous been the leading firm who unhaired and dressed fur seals from Lobos Islands, Cape Good Hope, etc. The first experience with salted Alisskas proved a failure, the skins not having been properly cured; by degrees however, the skins came forward in better condition, and in the year 1858 Messrs. Oppenheim contracted with the Russiau Americau Company for an annual supply of from 10,000 to 12,000 salted fur seals at 10 s. 10d. per skin, delivered in London. This quantity was increased about the year 1864 to 20,000 per annum, the contract remaining in force until the time wheu the territory was handed over to the United States Government. In addition to the salted fur seal, Messrs. Oppenheim received annually from the Russian American Company about 10,000 parchment fur seal at a price materially below that of the salted skins. Messr's. Oppenheim shipped to the United States the first dressed and djed Alaska seals about 1860 , but their shipments only amounted to a few thousaud skins per anuum until 1865 . From that year until 1872 , when this firm was liquidated, the quantity shipped by them increased from 2,000 to 3,000 per anuum to probably 10,000 skins.

Such was the state of the trade in fur-seal skins at the time of the lease by the United States Goverument to the Alaska Commercial Company. Skins were of low value; there were no regular open sales; the dressing and dyeing were badly done, and the net result of sales was insufticient to meet the rental, tax, and charges imposed by the Goverument on the lessees at the date of the issue of the lease. The company undertook the building up of this business by the introduction of method and system on the islands, in the place of loose and careless management, by careful selection of skins and great attention to the enring of them, and by gnarantying regular supply as to quantity and quality to the London market. They were most ably seconded in their efforts by the London house of C. M. Lampson \& Co., to whom the skins were consigned, and to the critical aequaintance with ralue of furs to the sound judgment and unsurpasser business ability of the then head of that house, and to the confidence assured to the buyers by his name in connection with the sales the success of the undertaking in London is largely due. Up to the time that this company was formed the dressing of seal was efficiently done onls by the firm of Oppenheim \& Co., but on their liquiclation there was great dauger that the business would fall into weak hands and be so badly done as to render the manufactured fur seal unpopular. Realizing this fact, Messrs. Lampson \& Co. stepped in, and by liberal inducements led Messrs. Martin \& Teichmann to carry on the Alaska factory.

After a series of difficulties, such as strikes and trouble with the work people, who were determined that no more or better work should be done than of old, this factory has gradually succeeded, by continual improvement, in rendering the dressing and dyeing, formerly a most uncertain undertaking, a thoroughly reliable process. These efforts on the island and in London combined largely account for the measure of suc$9984 \longrightarrow 8$ 
cess the compauy has attained. In addition, homever, large expeuditure has been necessary in all the European centers to keep the artich before the public and iu their favor. The laws of trade take these skins to London for market i 'Two public sales are held each rear, usualiy in March aul November. At these sales attend buyers from Russia, (iermans, l'rauce, England, and America. The compauy sells the entire stock on hand at each occasion, and has no furtber comnection with the skins. Its rule is to meet the market, and it buys no skins for account, nor has it any interest in the dressing and dycing. That 1 his work is done so largely in London is the ehoice of the buyers, and as more than half of the Alaskat skins sold in London are returned as dressed skins to Amerina, the United States Gorermment adds to its revenue from the seal islands by the collection of 20 per cent. duty on the valuation of this return. It is estimated that 7i,000 dressed and dredi skins were shipped from London to Ner York in 1887 . To the intelligent inquirer as to the value of the system now in operation for baudling aud disposing of the aunual qnota of skins from the seal islauds, no donbt eau remain. that it is the best, indeed the ouly ode possible, to pursue with suceess. The Government itself could not enter into business and follow details cither with propriety or hope of profit.

To open the sea aud the mokeries to the taking of seal by ant who choose to seek them would be simply to surrender the herd to destruction. But a daugrer mentaces the system and the seals which the Government alone ean avert, viz, the intrusion of foreign vessels with armed crews in the waters of Bering Sea, with intent to liill seal in the water betweeu the Aleutian chain of islauds and the Pribjlov group. In this water the seal rest aud sport after their long migration "Here the females, heary with young, slowly nearing the land, sleep soundly at sea, by iutervals, reluctant to hitul out of the cool water upon the rookeries nutil the day and the hour which limits the perion of gestation." Here, with gun and spear and drag-net, these marauders desire to reap their harvest of destruction and for their selfish greed exterminate the animal which now, under the wise polic 5 of Congress, plas so important a part in the ceonomy and distribution of commerce. Three rears of open sea would suftice in these waters to repeat the story of tho Southern Ocean and the fur seal would be of the past, and a valuahle industry would be obliterated forever. Let the sea be open to all commerce that harbors no evil intent, but protect the seal life thatswims in its waters and "hauls" on its sloores.

Let the sea be as free as the wind to all legitimate commeree, but protect the muique possession of seal life that harms none and benefits thousands.

\section{A. Williams.}

64 QuefN STREeT, E. C., London, August 22, 1888.

DEAr SrR: We beg to acknowledge receipt of pour faror of the 10th iustant inclosing dranglot of a jraper to be submitted to Congress on merchant marine and fislieries.

We have rearl the paper with a great deal of interest and cousicler that it places the matter in a thoronghly impartial was betore its readers. It has been so earefulls prepared and goes into all details so fully that we can add but little to it. There are, however, oue or two points to which wo legr to draw your attention, and which you will find marked in red ink on the paper.

When speaking of the supply of fur-seal skins, we would suggest mentiouing the following localities:

(1) Cape of Good Hope.-From some islands off this cape, under the protection of the Cape govermment, a yearly supply of from 5,000 to 8,000 skins is derived. All these skius come to the London market, part of them being sold at public auction, the remainder beiug dressed and dyed for account of the owners.

(2) Japan.-The supply from this source has varied very much of late years, amounting sometimes to 15,000 skins a year, at others to only 5,000 . Last year, we understand, the Japanese Government passed stringent laws prohibiting the killing and inportation of seals, with the view of protectiug seal life and encouraging rookeries, and the consequence has been that this year very for skins have come forward.

(3) Fancouter's Island.-? or nany rears past, indeed long before the formation of the Alaska Company, regular supplies of fin'seals in the salted and parchment state have coure to the Lonilou nuarket, liilled mostly off Cape Flattery. The quautity, we should say, has averaged at least 10,000 per atmum. This catch takes place in the mont hs of March and April and we believe that the animals from which these slins are derived are the feinales of the Aliskis seals, just the same as those caught in the Bering Sea.

IIad this quantity been materially increased we feel sure that the breeding on the I'ribstoy lslimels mould have enfferer before wow; but, fortumately, the catch must necessarily be a limited one, owing to the stormy time of the jear at which it is made and the dangerous coast, where the seals, only for a short time, are found. It must, however, be evident that, if these animals are followed into the Beriug Sea 
and hunted down in a calm sea in the guietest months of the year, a practicaliy unlimited quantity of fomales might be taken, aud, as you say, it mould be ouly a fow gears till the Alaska seal. was a thing of the past.

Yours, very truls,

C. A. Williams, Esq.,

C. M. Lampson d Co.

New London.

\section{FUR SEALS.}

[From an article in Land and Water, July 14, 1877, by Henry Leo, F. L. S., otc.]

Wo como to the date when Captain Cook, soon after his returu from his vopage in the Resolution in 17\%1, presented au oflicial report on New Georgia, in which ho gavo an account of the great number of proboscis seals and fur seals he had met with on that island. The tirst named, Morunga clephantine, is a true seal, without fur, earless, and of an oxtraordinary size. It at tains to a length of from 20 to 25 feet, and its girth is even disproportionately great. It is furuished with a nasal appeudage, which las a certain fancied resemblauce to an elephant's truuk, and from this aud its great bulk it has reeeived the appropriate name of sea-elephant. Its blubber vields oil of a very superior quality, and it commercial valuo in this respect was as well known as that of the fur seal for its slim. Cool's information soon tempted enterprising merchants to fit out vessels for the capture of these animals.

It has been stated that during a period of fifty years not less than 20,003 tons of sea-elephant's oil, worth more thau $£ 1,000,000$, was annually obtained from New Georgia, besides an iucalculable number of fur-seal skins, of which wo havo uo statisties. Somo idca may be had of their numbers in former years when we learn that on the island of Mas Afuera, on the coast of Chili (an island not 25 miles in circumference), Captaiu Fanning, of the American ship Letsy, obtained in 1798 a full crop of choice skius and estimated that there wero lett on the island at least 500,000 sealy. Sabsequently there wero taken from this islaud littlo short of a million skins. Thoseal catchiug was cxtensively prosecuted there for many years, the sealing fleet on the coast of Chili alono then numbering thirty vessels. From Desolation Island, also discovered by Cook, and tho South Shetlands, riscorered by Weddell, ${ }^{\star}$ tho number of skins taken was at least as great; from the latter alono $3: 20,000$ wero shipped during the two years 1821 and 1822. China was the great market to which they were sent, and there the prico for cach skiu was from \$4 to \$6. As several thousand tous of shipping, chictly Euglish and American, wero at that time employed in fur-seal catching, the profits of tho carly traders wero enormous.

Doos the reader ask what has become of this extensive and highly remunerative southern fur trade? It has been all but annihilated by man's grasping greed, reckless improvidence, and wauton cruelty. The " woful want" has come that "woful waste" Las made. Without thonght of the future the misguided hunters persistentls lilled every seal that camo within their reach. Old and joung, wale and femalo, wero indiscrimiuately slaughtered, in season and out of season, aud thousauds of littlo jups not thought worth the trouble of knocking them on the lieal wero left to dio of hunger alongside of the llayed and gory carcasses of their mothers. Every coast and islaud kuown to be the haunt of tho seals was visited by ship after ship, and the massacre left unfinished by one gang was continued by the next comers and completed by others until, in cousequence of wone of the animals beiner left to breed, tbeir number gradually diminished so that thes were almost exterminated, ouly a fow stragglers remaining where millions were once found. I In some places wlieve formerly they gathered tomother in such densely packed crowds upon the shore that a boat's crew could mot find room to land till they had dispersed them for a space with oars and boat-hooks, not one fur seal was to be found even so long aro as 1535.

From other localities where tho seals have not heeu destroyed or driven away wo still anuually receivo a fow skius, stripped chiefly hy small jartios ot men iletached from ship's crews and left to "wateh out "for the arrival of the auimals duriug their breeding season and-to shoot them singly as they come on shore.

If the southern species is to bo saved from extiuction and the trate revived it must bo by strong protectivo measures; hut to be eflectual they minst bo sternly entererel. That this might be done has been proved by the suceess which has heen attained wherever regulations havo been adopted. For nearly half a centurs tho seal killiug

* Weddell was an intrepid sailor as well as a bighly intelligent obserrer. In 1-2:?, with two small ressels under his command, tho Jane, of Leith, 160 tons, and the licunfoy, of 65 tous, he penetrated 214 miles nearer the South P'olo than Cook or any other navigator had previonsly grone. Io met with the fur seal in South Georgia amd ou tho South Orkneys aud South Shotlands, aud unhesitatingly identified it with that of the Falklauds. 
on the Lobos Islands, at the mouth of the river Platte, has been held under proper and systematic control, and the trade has consequently been preserved, but the effect of judicions restrictions has been still more marked on the Pribylov Islands, leased by the United States Government to the Alaska Conmercial Company, which has its headquarters at San Francisco.

Mr. Heury Lee, our informant, in sending us the inclosed papers, adds the following remarks:

"I think I must have obtained my information from 'Weddell's Voyage towards the South Pole.' You will find there most important accounts of the enormous number of fur seals on the islands of the Antaretic. I know he said that not less than 1,200,000 skins had been brought from South Georgia and an equal quantity from Desolation Island."

See also the Encyclopedia Britannica.

\section{STATEMENT OF DR. H. H. MCINTYRE.}

(Called by the Alaska Commercial Company.)

Wasmington, D. C., September 17, 1838.

Dr. H. H. McIntyre, called and examined.

By Mr. JeFFries :

Q. Please state your name and occupation.-A. H. H. McIntyre. I am superintendent of the seal fisheries of Alaska for the lessees.

Q. How long have yon been in the employ of the Alaska Commercial Company?-A. Since June, 1870.

Q. How mauy seasons have you spent on the seal islonds?-A. I have been on the seal islands ever. year since 1870, with the exception of three-1883, 1884, and 1885-when I was absent.

Q. What do you say as to the probable number of seals on the Pribylor group, St. Panl and St. George's Islands?-A. I think the number has been very largely orerestimated in the reports of naturalists who have obserred the habits of the animals at the seal islands. They have made their mistake in supposing that all the ground which shows sigus of having been occupied by seals is covered by them simultaneonsly, when the fact is that the bachelor seals may be found to day upon a certain rookers, and at another time upon auother place. The result is, the same animals, in many instances, have been counted two or three times. I think the estimates are fully one-third or perhaps one-half too high.

Q. What is your impression or what is your knowledge as to whether the number is being maintaiued of late or not? - A. If you will allow me to go back for an explanation to the commencement of the business on the islauds, I will say, that during the first ferw years, from 1870 to about 1S8:, there was a constantly increasing number, before the begimning of the annual marauding, and the increase was then apparent each year. The boundaries of the rookeries were being constantly extended, the lanes throngh the rookeries, where the bachelor seals han up, were gradually closing up by the encroachments of the breeding rookeries, and were, in wany eases, completely closed before 1852. There was no question at that time as to the increase; but since 1882 the lanes through the rookeries have again opened, and grown wider from year to year. During the last two years the bachelor seals pass throngh these lanes as they did not formerly, and particularly during the last season the decrease in the number of seals has been very marked. 
Q. To what do you attribute that ?-A. To the marauding that has been carried on in Bering Sea.

Q. What do you know, if anything, about the seals having been direrted from their regular channels of approach, and where do you find that seals have been taken at other points? - A. We have been accus. tomed always to turu back from the killing grounds a sufficient number of large bull seals for service upon the rookeries, and this number has been greater or less in proportion to the apparent needs of the rookeries. Complete order has been observed in stocking the rookeries with male seals, and the business has been conducted generally, in this respect, as a well-ordered cattle ranch would bo. We have systematically allowed a sufficient number of bull seals to escape us for this service. IVhen we had exclusive control of the business and were unmolested by marauders, we had no trouble in keeping the proportion of the sexes so balanced as to secure best results in breeding; but since 1882, and more particularly since 185t, other parties have been killing seals, of which a considerable percentage is males old enough for serv. ice, thus destroying the equilibrium of the sexes, compelling us to turn back a larger number of service animals than formerly, the skins of which are particularly desirable for market, aud endangering the future productiveness of the rookeries. There are at present, in my opinion, too few bull seals to keep the rookeries up to their best condition. During this last summer we have had to let go animals for breeding purposes that we should have been glad to kill.

Q. Supposing you had required 5,000 or 10,000 more to fill your quota this year, could you have found them on the rockeries?-A. I think it doubtful whether we could have obtained any considerable additional number of marketable skins.

Q. State what proportion the number of seals captured at other places bears to the diminution of the number at the Pribylov group.-A. Going back to the early history of the business, the Indians about the Straits of Fuca and in the waters adjacent to Vancouver's Island were accustomed to send out their parties in canoes to the killing grounds a few miles distant, and secure there perhaps from 1,000 to 5,000 skins annually. Later in the history of the business, from 1.878 to 1852 or 1883, they acquired better facilities for hunting, and were enabled to go further off and hunt more systematically, with the result of largely increasing their catch. They sent to market during these years from 6,000 to 12,000 skins per year. After 1882 or 1883 the business was taken up by white hunters, vessels were regularly fitted out at Vietoria and Port Townsend, usually manned, at least in part, by Indians, and furnished with all the approved appliances for seal killing.

\section{By the Chairman:}

Q. Where did they do the killing?-A. During the first few years, in the Straits of Fuca and to the northward along the British Columbia coast. Later they pursued them across to Kodiak Island and to the westward among the Shumagin group abong the Aliaskan peninsula. Finally they went into Bering Sea, to some extent in 1882 and 1883 , and very extensively in the jears following, so that in the year 1585, perhaps twenty ressels were engaged in the business there, and this number was considerably increased in 1886 and 1587. The eatch during the two latter years was more than 40,000 skins per year actually sent to market, and probabls tive or six times as many more destroyed.

Q. These 40,000 seals were killed in the water-killed in Pering Sea, 
were they ? - A. Nearly all were killed in the water. In a few instances they went upon the Pribylor Islands and killed upon the land.

Q. What proportion of the seals shot in the water are recovered and the skins taken to market?-A. I think not more than one-fifth of those shot are recorererl. Miany are badly wounded and escape. We find every sear, imbedled in blubber of aumals killed upon the islands, large quantities of bullets, shot, and buckshot. Last year my men brought to me as much as a double handful of leat found by them imbetlded in this way.

Q. What effect does it have upon the value of a seal skin to bave it full of holes? - $A$. If it is tradly riddled it is nearly worthless.

Q. Can those holes be discovered before the skins are shipped to England?-A. Probably not.

Q. Why?-A. Becanse they are covered with blubber, and, being: small, they are only developed when the skin is dressed.

Q. Before it is put upon the market is it discorered?-A. No; it is discorered only after the blubber is taken off.

Q. Then the effect would be that the company is taxed $\$ 3.17 \frac{1}{2}$ for a skin that is riddled and worthless?-A. Yes, sir; that is so.

Q. Do they kill female seals in the water?-A. A majority of the skins taken by the marauders, in fact 80 or 90 per cent. of them, are females.

Q. Are those females usually with pup ?-A. During the early part of the season they are.

Q. So the shooting of one means the killing of two seals ?-A. Yes; and all the animals taken in Bering Sea by marauders of course reduces the number annually coming to the islands to this extent, and we have so many less from which to make our selection of desirable skins for market.

(?. I want to know what the regulation has been, or how the company manages in regard to taking the kind of skins demanded by the foreign market?-A. We always receive instructions from London as to what the market demands. There is very little variation from jear to year. At first, and until 1873, the agents of the company were not fully informed as to what the market required, and the skins sent forward were too sinall, but from 1873 to $188^{2}$, we were able to get exactly the sizes required, and very little fault was found by the London people. We liarl then, and at all times mintil the marauding was actively engaged in, a large surplus of animals from which to make our selection. After 1883 the sizes decreased, and have constantly decreased erer since. Last jear they sent an urgent appeal to take larger skins, as the sizes were rumuing down; but we were unable to respond, and during the present seison the eatch averages still smaller in size, as we were obliged to turn back for rookery service many bulls of desirable size for killing, and had very few surplus of anj marketable size from which to select.

Q. If the company were unable to take the kind of skins the market requires, wonld it be gond policy to take smaller skins to fill up the quota? - A. I do not think it would.

Q. What would the company do in a case of that kind?-A. It would, of course, be obliged to take a smaller number.

Q. The Gorernment would lose the tax, and the company would lose the profits?-A. Yes; if we send skins to market that are of so little value as not to meet taxes and expenses, of course there would be a loss. The company can not afford to do that.

Q. So that if you took 60,000 instead of 100,000 skins, the Government would lose the tax ou the difference, and the company would lose the 
profits ?-A. Yes, sir; and ilee effect is further, as I hare already stated, to cut down the number of animals on the islands from which we have to choose; and our men are particnlarly instructed never to kill bulls that seem to be urcessary for the preservation of the rookeries. It is our first care that a suffieient number of animals shall be preserved for the full preservation of the rookeries in their best condition of productiveness. This year we have been compellerl to let animals go back to the rookeries that we should have been glat to kill.

Q. To what do you attribute this diminution in the size of the skius taken? - A. To the fact that after turniug back our breeders a sufficient number of large male seals can not be had ou the islinds to meet the requirements of our trade.

Q. How do you account for the reduced number? Is it on account of the numbers taken by the company, and do you think the company ought to take less?-A. I think if the seal fisheries were protected again maraulers we should have no trouble in getting our full quotil of desirable skins. The maraulers should be asked to take less.

Q. You think the difficulty is, you have not hat complete protection for the herl? - A. I think 100,000 skins could be annually taken if there was no marauding.

Q. What position do you hold in the company?-A. I am general superintendent. MI duties are more particularly to see that the seal rookeries are pieserved, that no harm comes to them from improper management, aud that the natires are provided for as stipulated in our contract with the Government.

By Mr. JEFFries :

Q. What are your instructions, and what is your practice in regard to the treatment of the natices, and earrying out the instructions of the Department amd the law in regard to the seal rookeries?-A. II instructions have always been to see that every provision of the law is fultilled. The company goes much further than that, and provide's many things for the comfort and edncation of the natives not specified in the contract or rendered obligatory by any regulation of the Treasury Department. We have strictly followed all instructions issted by the Department, amd smplied to the natires luxuries that are almost unkuown to laborers in any other part of the world.

Q. What is the condition of the natives now?-A. It could hardly be better. They hare an amount of mones they do not know what to do with.

Q. How are they housed?-A. They hare comfortable houses for every family on the islauds.

Q. Who built them ?-A. The company.

(Q. The natives have never been charged anything for them?-A. Nothing whaterer. They have in addition to that gratuitous medical attendance and medicines; usaally coal comsiderably in excess of that required by our contract with the Governament; support for their widlows and orphans by the company; the privilege of travelng free of charge upon our vessels, and our coustant eare aud assistance.

Q. Are they provided with schools? - A. Yes, sir; for eight months in the year in well-constructed school-honses, under good teachers.

Q. How do the natives aprear to be satisfied with their change of allegiance?-A. They are well satistied. I think none of them conld be indnced to go back to their former morle of life.

Q. What was their condition when they first became citizens of the United States? $-A$. They were living miserably in underground houses, 
and cared for as poorly as conld be imagined. They had nothing to eat much of the time except what the conntry affordel. They were left at times for months without any breadstuff's whatever, living ex. clusirely on meat.

Q. Have they saved any money ? - A. They have sared nearly $\$ 100,000$, and now have it to their eredit.

Q. Where?-A. In the hands of the company. A part of it on interest in the company's savings trust fund.

Q. What has the company to do with Alaska Territory proper outside of the seal islands, so far as its relations with the Government are concerned?-A. I do not understand that it has any relation with the Goverument ontside of those isla nds, any more than it has in any other portion of the United States

Q. In so far as trading with the natives is concerned, and in the business carried on with the natives of Alaska outside of the seal islands, its relations are the same as those of any other company or citiden of the United States, or anybody else?-A. Yes, sir.

Q. Does the company attempt to exercise any control over Alaska outside of the seal islands?-A. I think not.

Q. What is the policy of the company as to immigration to Alaska?A. It has always farored it to the extent of carrying any one on its vessels whenever it could afford accommodations.

Q. How are the rates of transportation, excessive or low.-A. I think they are less upon our vessels than upon any other upon the coast.

Q. Do they ever trausport anybody without pay?-A. In cases where people get stranded in Alaska without money, as has frequently happened, they have brought them to San Franciseo without pay.

Q. What are the company's charges for goods to the natives of the seal islauds and other parts of the Territory?-A. The prices on the seal islands are absolutely less than the same class of goods can be purchased for in San Francisco, the general rule being to charge 25 per cent. above the wholesale price in market, while in other parts of the Territory the prices depend upou the distauces and the cost of supply. ing the different stations.

Q. Have you seen a report made by the governor of Alaska on the subject of the company's oppression in the Territory?-A. Yes, sir.

Q. What do you say as to the information on which he predicaterl h at report, was it correct or unfounded ?-A. It was entirely insuffitent.

Q, Hare you seen Governor Swineford since he made that report?A. Yes, sir.

Q. Where was that?-A. On the seal islands in June last.

Q. Did sou discuss that with hirn ?-A. Yes, sir.

Q. What did he say ? - A. He said he was agreeably surprised to fin? things so much better than he had expected at the seal islauds; and that in eases where he had been misinformed he should be ouly too glad to correct any error in his report and set himself right.

Q. Do you know the man Auderson whose affidavit accompanied the report?-A. Yes, sir.

Q. Was he alluded to in couversation with the gorernor ?-A. Yes.

Q. What did he say about Mr. Anderson ?-A. He said he had as. certained since coming to western Alaska that he was deceived by Mr. Anderson; that his character was not what he had supposed.

Q. I want to ask you whether or not the three-sear-old seals, or many of them, which should have returned this year did not returu because they had been kllled ?-A. That seems to be the case. The marauding 
was extensively carried on in 1885 and 18s6, and in previous years, and of course the pups that would have been born from corrs that were lilled in 1885, or that perished through the loss of their mothers duriug: that year, would have come upon the islands in 18S8, and we should have had that additional number from which to make our selection this year. The deficiency this year is attributed to that canse-to the fact that the cows were killed. And I would say further, that if cows are killed late in the season, say in August, after the pups are born, the latter are left upon the islands deprived of the mother's care, and, of course, perish. The effect is the same, whether the cows are killed before or after the pups are dropped. The young perish in either case.

Q. How far from these feeding grounds are these depredations committed?-A. Thirty to 60 miles south of St. George's island is where the most of the marauding is done.

Q. Between the Pribylor group and the Aleutian chain?-A. About one-third of the way down from St. George to Oonalaska.

Q. From your knowledge of the seal life and the habits of the seal, and the management of the business, what do you say as to the present policy being the correct one?-A. I think the only way in which seal life can be preserved is by the action of properly constituted authority ; and that authority must be either governmental or the authority of the lessee under the sanction of the Government. It can not be dowe in any other way. Of course that would imply entire control of the business. If there is no iuterference at any point to disturb the equilibrium of the sexes, the breeding of seals can be as systematically and intelligently conducted as that of domestic animals. If a portion of the breeding animals kept for service upon the rookeries is killed, it is erident the rookeries must suffer.

Q. You took your whole quota this year?-A. This year we took 100,000 skins. But, as I hare already reported to the company, it se ems doubtful whether the full number of skins on which we can afford to pay the tax can be obtained next year.

\section{By the Chairman:}

Q. If there had been no trespass at all by any other persons and vessels, are you satisfied that there would have been no material diminution of the number of killable seals?-A. Yes, sir; because the seals were extending and inereasing, and we always had a sufficient number during the first twelve or fourteen years of the lease.

Q. They increased while you were taking your full quota, did they?A. Yes, sir; and we took the full quota, except during two years. During those years we failed, not because we could not get enough seals, but because the market did not demand them. There were plenty of seals.

Q. Do I understand that you are about to be reduced to a less number, and also to the necessity of taking smaller skins?-A. We can get a sufficient number of small skins from two-year-old animals, but at present prices that would not pay. Only on the contingency of a higher market should we take skins smaller than we are now taking. It now appears doubtful whether we could get a paying market for much smaller skins than we are now taking.

By Mr. JeFfries:

Q. Are these skins taken by marauders sold in competition with Jours?-A. Yes, sir; they go to the same market and are sold to the same dressers.

Q. They pay no tax?-A. No, sir; we hare not only to come in com- 
petition with them, but we are also obliged to take smaller animals by reason of their having killed a portion of those upon which we relied in making our selection.

Q. Suppose twenty thousand skins were taken this season, what do you estimate that the loss to seal life would be?-A. At least one hundred thousand. Not more than one in fire of the seals killed, and hardly that number, in my opinion, would be recorered.

Q. Are the majority of them females?-A. Yes, sir; either with young or with nursing young left upon the islands.

[ want to state in regard to the natires that the mortality has been rery great among them within the last few years. Our number of laborers is reduced. TVe could use considerably more help from other parts of the Territory, if we were permitted to do so. So far we have emplosed only natives of the sea islands, all other labor being paid for by the month or day. But we are now in a position to provide for a number of the islanders from the Alentian Archipelago at the seal islands, if we are allowed by the Treasury officials.

\section{By the Chatritan:}

Q. In what way?-A. We would put them with the force of seal hunters upon the islands, and allow them to take their proportion of the seals. Our first-class men now receive about $\$ 625$ each for six weeks' work.

Q. What is the number that actually work? - A. About eighty men, and of these about twent 5 -fire are in the first class. The smallest amount paid to any of these libborers this year is about $\$ 200$ for six weeks' work.

\section{By Mr. JeFFries:}

Q. I want jou to state what the company's operations are at the seaotter grounds of Attoo?-A. It wonld be pertinent to include all the territory west of Uonalaska, because it is all practically in the same condition.

Q. In those regions the Gorermment has no relations to the company? - A. The company has always provided for the iuhabitants south of the seal islands, but it is under no obligation to do so. TVe provile employment for these otter hunters, assist them to fit out their huntiug expeditions, and in many ways exercise a fatherly care orer them.

Q. Does the company build any houses?-A. Te bave built a large number of houses at Oonalaska and sereral in other parts of the Territory. The sea otter business was formerly profitable, but during the last three years in the entire Aleutian Archipelago it is non-paying.

Q. It is open to competition?-A. Yes, sir; and in the portion rest of Athka we get almost nothing. I think in the country west of and including A thka we have during the last jear spent not less than $\$ 4,000$ or $\$ 5,000$ to obtain $\$ 500$ morth of furs.

Q. For what purpose?-A. To keep up stations and to keep the people from starving. At Attoo Island there are about one hundred people now. From there we get absolutely nothing, except a dozen or two of for skins. Now it is proposed to take the people from that island and carry them to Oonalaska, and thence to the seal islands, if they can be iudnced to go and if the Goverument gives us permission

Q. Are you supporting them without remumeration ?-A. Yes, sir.

Q. Are the sea-otters diminishing in numbers?-A. Yes, sir; because white hunters who hare better facilities for killing them than the natives follow them long distances from the coast and kill old and young in- 
discriminately. The native hunters can not compete with white hunters without assistance, and under most farorable circumstances aro beaten by them.

Q. Would it seem that that may soon result in their extermination?-A. I think it will.

Q. Who are engaged in the extermination of these sea otters? $-A$. White hunters entirely, independent of the company and in competition with each other.

Q. Do traders from San Francisco and other places go there?-A. Yes, sir; six or sever ressels are on the sea-otter grounds from some of these places this season, while the company has but one, and this one is mannerl wholly by native hunters, with their skin boats and otter spears.

Q. They get the trade while you feed the natives ?-A. Yes, sir.

Q. What would be the condition of these people if the Alaska Commercial Company should fail to provide for them ?-A. They would be left in a very deplorable condition. I do not thiuk they could get the means of subsistence. I think they would starve.

By the Chatriran:

Q. Does the Gorerument exercise any amount of supervision or eare over the natives of the Aleutian chain, such as it does over the Indlans in the Territories of the United States?-A. No, sir; it does absolutely nothing for the natires of Alaska.

Q. Are the natives regarded as eitizens?-A. The Alentian people seem to be regarded as citizens.

Q. They are entitled to citizenship under the treaty?-A. Yes, if they were citizens under the Russians before the transfer.

Q. Do they exereise any of the rights of citizenship; or I believe there is nothing for them to do, there being wo such organization as requires an election?-A. No, sir; there is nothing for them to do. There is no election in Alaska.

Q. So that they are entirely dependent upon the casualties of their business and the locality where they live. Du these white hunters and traders do anything for the natives in the way of providing for them as your company does?-A. No, sir; not to any extent whatever. They do nothing outside of trading with them.

Q. They buy their furs and pay for them?-A. Yes, sir.

Q. Does it require the consent of the Government to remore ans of these natives from their islands, or from one point to another? -A. No, sir; but we have been restricted by the Government, and our contract requires the employment of the natives of the seal islands exclusively for seal-killing. We can not take natives from other points to the seal islands without the consent of the Secretary of the Treasury, aud then only to do the rougher kinds of work, such as handling cargo, salting and packing skins, etc.

Q. Are there any laws for the protection of the sea-otters against the depredations of the hunters? - A. They were at first fully protected by a law which prohibited the killing of any fur-bearing animal in Alaska, but the regulations of the Treasury Department under this law have been gradually relaxerl, first by allowing white men who were married to native women to engage in hunting them, and allowing schooners to be fitted ont for their pursuit, until, at the present time, there seems to be almost no restriction upon the business.

Q. Formerly, was the hunting limited entirely to the natives? -A. Tes, sir. 
Q. Were they allowed to kill all kinds under the law ?--A. No, sir; but they have always killed, almost indiscriminately, old and young.

Q. Does the island of Attou prodnce anything on which the natives could subsist? ?-A. There is plenty of fish.

Q. But that is in the water?--A. There are a few geese, but with that exception I know of nothing, except, perhaps, a few water-fowls. Athka and Ounga are very nearly in the same position, with a still larger population.

\section{By the ChaIRMAN :}

Q. Is there any agricultural product upon any of the Aleutiau Islands :-A. None whatever. An attempt has been made at Oonalaska to raise a few hardy vegetables, but it has met with very little success. In former years they raised a few potatoes. These acquire sufficient size for eating only rarely and under most favorable circumstances.

Q. The natives are entirely dependent upon hunting and fishing?-A. Entirely.

\section{By Mr. JEFFRIES :}

Q. I want to ask you whether the seals approach the rookeries now in the same way that they did in earlier times?-A. They seem to come later and later each year for the last few years. Formerly our killing season commenced early in June. In 1874 and 1875 we took a large percentage of our catch before the 20th of June. During the last few years, howerer, we hardly got fairly to work before the 20th of June, and this year it was even later than this before any large drives were obtained. It is probably due to the insufficient number of large bulls. The pups being born later in the season naturally return to the grounds later each succeeding year.

\section{By the ChaIrMan :}

Q. As superintendent, you hare observed this business how long?A. Since the commencement of the present lease, eighteen years.

Q. As the result of your observation, what additional restrictions or regulations would you suggest for the better protection of the rook. eries?-A. I think no further protection is required upon the islands. If the seals are fully protected while they are passing to and from the islands, I believe there would be no trouble in keeping the condition of the rookeries up to the maximum.

Q. Is it necessary that protectien should be extended to the Pacific Ocean south of the Aleutian Islands during the season, and after they have left the rookeries ?-A. Yes, sir; I believe it would be a good policy, because the seals, after leaving the islands, are spread out over the North Pacific on the feeding grounds during the winter, but toward spring are found in great numbers down about the Straits of Fuca, and along the British Columbia coast.

Q. The seals are born soon after the cows reach the rookeries, are they ?-A. Yes, sir; following the seals in their migrations, we find them passing along by Kodiak and the Shumagin Islands, and finally through the passes into Bering Sea, and to the seal islands. While they are going through the Aleutian passes in the spring, many are killed. I presmune many more could be killed if the marauders were fully aware of their movements. If we would give the seals fullest protection, we must look atter the coasts of British Volumbia and the Alaska peninsula, if it were possible to do so, at all times. 
By Mr. FeLton:

Q. Is there any power to do that?-A. I think the seals should be regarded as our property, and should be looked upon, when away from the islauds, as eattle astray. They belong on those islauds. At any time when they are found away from the islauds they are, nevertheless, our property. They belong properly to the United States, and I believe their movements could be followed, and protection given them while they are arvay.

\section{By the CHAIRMaN :}

Q. Do you think such measure of protection essential to the preservation of the herd? -A. I doubt whether the depredations conld be carried on in the North Pacific Ocean to such an extent as to imperil the business, but in Bering Sea I have no question but what the rookeries could be broken up within a few years if left open to depredations. The result of recent marauding shows that the entire rookeries can be broken up within a few years.

Q. Do ressels going through Bering Sea touch at any port of the United States?-A. No, sir; they clear from San Francisco or Port Townsend for hunting and fishing. They go where they like, and return to those ports without having entered any harbor.

Q. Where do the British vessels clear from?-A. Mostly from Victoria.

Q. Do any other vessels hunt in those waters except the ressels of the United States and Great Britain?-A. No, sir; I have nerer known any others to do so.

Q. Are those vessels allowed to hunt and fish indiscriminately in the North Pacific and Bering Sea?-A. Yes, sir; I think there should be a regulation providing that all vessels should be compelled to touch at Oonalaska or Kodiak.

Q. In other words, Jou suggest a regulation that vessels in Bering Sea be required to touch at one or the other of those points?-A. Yes, sir; and on returning they should be required also to tonch and report what they have on board.

Q. You would include in that regulation the ressels of the United States?-A. Yes, and all others. The vessels of our company invariably do it now, and find it no hardship.

\section{By Mr. Felton :}

Q. But would you make an examination of the ressels to see what they had? - $\Delta$. Yes, sir. Every vessel should be examined to see what she has on board. The vessel's manifest must show that at all times.

Q. Do you know anything about maranding ressels having taken seal skins in Bering Sea and having secreted them?-A. Yes, sir; last year a British ressel took some 450 seals in Bering Sea, secreted them on a small island, and, leaving them there, returued to the same waters for more. They feared capture, and so wanted to make sure at least of the number they had already secured.

Q. Do jou happen to know whether Russia protects her rookeries on the other side of the line?-A. Yes, sir, fully; to the extent of destroying marauding ressels. In one instanec, I am told, they actually burned a marauding schooner.

Q. There is nothing separating us, as I understand the geography, except the line established by the treaty ?-A. That is all; it is sinply an imaginary line.

Q. Under oath do you say that the Alaska Commercial Company has 
or bas not performed its obligations faithfully, or has it violated any regulations in any respect ?-A. I should sas we have obeyed the regu. lations in every respect, aud done much more than our contract with the Government demands for the welfare of the people of Alaska.

\section{By the CHAIRMAN:}

Q. State something in detail of the provisions which are made for the natives of the Pribylor Islands; and what does the law require, aud what do you do in addition? - A. We are required by law to furuish them aunually with 40 tous of coal, 20 barrels of salted salmon, to keep the schools eight months in the year, and to proride for their maintenance and sup. port. I think those are the terms of our lease. In addition to that, we give to them every luxury known to laboring men in civilization. Our stores are provided with erery article that may be found in the best regulated country stores, and these artieles are sold at reasonable prices. To enable them to purchase these goods, we pay 40 cents for each seal, and the fund formed by this payment, when distributed, goes to each man at present engaged in the seal fisheries; not less than $\$ 200$ to any, and as high as $\$ 750$ aunually to the best men. There is no stipulation in our lease, but we fix the price voluntarily at 40 cents per skin. A much smaller sum would have amply maintained the natives.

Q. How do you pay them?-A. They are paid in cash. The fund is paid to the community and divided among the men according to the classification made by the compans's agent, with the sanction of the Treasury agents, who are present at the time.

Q. Are the natives consulted in that distribution?-A. Yes, sir; their chiefs are always present, and sometimes the elders. sir.

Q. Upou an understanding with them that is satisfactory ?-A. Yes,

Q. How is that dirision made; on what basis?-A. The uatives are divided at present into eight classes, with a difference between the classes of 10 per cent. in the distribution. For instance, while the lirst class receires $\$ 1$, the second receives 90 cents, the next receires 80 cents, and so on down through the eight classes.

Q. Is it on the score of capacity and efficiency?-A. Yes, solely. This fund, on being distributed, is placed to the credit of each man, and as he requires moner, he brings his pass-book to the cashier and receives silver in payment.

Q. Is that book in the nature of a bank book?-A. Yes, sir. This deposit remains with the company. The Treasury agent frequently examines the pass books in order that the men may always have something remaining to their credit against which to draw from week to week until the next auuual distribution is made. They are naturally vers improvident.

(i. What are the expenses of the natives? What constitutes their expense account each year, which is paid for out of their own money ? A. Clothing, groceries, faucs gouds of erery description; and their money has been so plentiful, that wo have been obliged to carry up there ever.F sort of timey article-musical instruments, toys, etc., and things perfectly useless to them because thes hare money in their hands and are anxious to spend it. Ther will not allow money to remain in hand if they can fiud anything to buy. Special orders were gireu us last fall for musical instruments, riolins, guitars, etc., because apparently they didn't kuow what other use to make of their surplus.

Q. How much house reut do thes pay?-A. None

Q. Do they pas anything for fuel? 
Mr. Williams. The natives pay nothing for fuel.

The Witness. The company take these articles up there outside of the regular line of goods.

Q. You say they pay nothing for fuel?-A. They pas for fuel in excess of 40 tons of coal, which is given to them gratuitously. The widows and orphans receire such an amount as ther need; but their fuel is cheaper from the seal blubber, which they obtain theinselves.

Q. For that they do not have to pay ?-A. No, sir.

$Q$. Are thes required to pay auything for seal meat?-A. Nothing whaterer. The company is now erecting meat houses in connection with ice-honses for the storage of meat, so that we cau keep seal meat through the season when we are not lilling seals, and thus enable the natives to have fresh meat through the entire sear.

Q. That is solely for the benefit of the natires?-A. Yes, sir ; solely for the benefit of the natires.

Q. They pay nothing for tuition? - A. No, sir.

Q. What about medical serrice?-A. The company's physiciaus upon the islands treat them gratuitously, and a drug store is kept well stocked for their free use. For this service they pay nothing.

\section{By the Chatrman :}

Q. Referring to the 40 tous of fuel, is that for one island or both ?A. That provision of the lease has escaped my mind. How is that, Mr. Tingle [turniug to Mr. Tingle]?

Mr. Tingle. Forty tons go to St. Panl aud 20 tous to St. George.

The IVITNESS. I had forgotten about this because by the terms of the lease we were obligerl to furnish wood, but were allowed to substitute coal for the wood by the Department. It is 60 tons for the tro islands.

Q. Do they preserve seal meat for winter?-A. Yes, sir; during the season when it is fresh. At some times they purchase considerable amounts of canned meats, hams, etc., but that quantity will be reduced when the meat-house is in operation, as they can preserre an abuudance of seal meat. Thes have been allowed for several years to kill a certain number of pup seals for meat during the winter months. I think that pricilege should be taken away from them. I do not think it is neeessars, and it takes that much from seal life.

Q. Is the seal a fish or an animal ?- $\mathrm{A}$. It is an animal, a mammalian, and nurses its young like other mammals. It is a misuomer to speak of the seal fisheries. They are in no sense fisheries.

Q. Do sou consider the seal rookeries and the herd of seal of suf. ficient permanent value to justify the Gorerument in making regula. tions for their preservation indefiuitely?-A. I thiuk they are. The Government may derice anumally from the seal fisheries a rerenue of half a milliou of dollars, and the expenses should not exceed $\$ 50,000$ per annum under auy circumstances.

Q. The Treasury Department dirides the expenses of the Government under these two heads: Salaries and expenses of agents in protecting the seal fisheries in Alaska from 1876 to $1857, \$ 129,385.81$; for the protection of the sea-otter hunting grounds aud the seal fisheries of Alaska, $\$ 163,808.62$ - which means the cost of ressels, reveune-cutters, and naral ressels eruising in those waters-for ten years. Would you consider that the expense properly attaching to the Pribylor Islands necessarily includes the two sums or only one?-A. I think it would be necessary to keep the present force upon the islands, aud to keep one revente-cutter in Bering's Sea for the preservation of the seal fisheries. 
Q. Has the Government to construct, equip, and maintain any more revenue-cutters for the protection of the seal fisheries than it would do under any circumstances?-A. I think not. There are but four rerenue-cutters now upon the Pacific coast. T'vo of those are kept upon the coast of California and Oregon, one cruises in Bering's Sea in summer, and one goes to the Arctic.

Q. After your years of observation there, what do you consider the real value of those rookeries held as a property and reduced to a capitai basis, if protection were secured to that property by the Government?A. That is a rery difficult question to answer, because the hazards of the business are unusually great. If the full protection of the Government was assured, the amount that would be offered by different persons would depetud very largely upon the character and temperament of the indiridual, whether he would choose to take extraordinary risks or engage in a conservative busiuess. I know of no other business that is so very hazardous in its nature. It is exposed to the chances of bad weather during the killing season, the risk of losing animals from natural causes orer which we have no control, to risk in shipping beyond a point where any insurance can be obtained, risk in market fluctuations that do not pertain to other goods arising from caprice of fashion, and unusual hazards in almost erery direction; hazards that are taken in hardly any other business.

Q. Jf course there would not be such a degree of security under private ownership. Would you consider it desirable property for a com. pans or person to purchase under existing conditious? - A. Not under the present existing conditions, but if assured of full protection bs the Government I think it would be; but the assurance should be absolute against all interference.

\section{By Mr. JEFFRIES :}

Q. Would it enhance the value if it was known that the Government was behind it and had a share in the risk? Would that not give it a standing abroad?-A. Undoubtedly; because abroad it would be understood as a Government enterprise.

By the CHATRMAN :

Q. Would it be practicable for the Government to administer that reservation by dividing the lease, giving one island to one persou and the other to another?-A. No, sir; I do not think it would. There would be constant conflicts between them, followed by a fur-seal trust.

Q. What would be the result of such conflicts to the herd?-A. That is a contingency that was never brought to my mind before; but the seals are found indiscriminately on the two islands; that is, seals born on St. George are found at St. Paul, aud vice versa. What the actual status would be between the lessees is, of course, a matter of conjecture.

Q. Would divided ownership affect the natives? - A. I think it would affect them unfavorably. They are carried from one island to another for a seasou's work, as we may need them. They belong to the same families, intermarry and intermix. I do not believe the business would be profitable under a divided ownership and the competition that would ensue.

Q. What would be the effect of withdrawing Government protection?-A. The seals would be completely and absolutely exterminated within three years.

Q. There would be no seal \&-A. No, sir 
Q. Is it vour opinion that the rookeries can be kept up to the present catch of 100,000 per annum indefinitely if the Government protection over them and existing laws are rigidly enforced?-A. Yes, sir; I think we have demonstrated that it could be done during the first fifteen ears of the present lease, when the lessees were unmolested.

Q. By more rigid protection the revenues of the Goverument, as well as those of the company, might be increased ?-A. I think it is very likely. If the market demands the skins at present prices the revenue to the Government can be somewhat increased.

\section{By Mr. JEFFries :}

Q. What do you think as to the advisability of the Gorernment managing the business on its own account?-A. The management of the seal fisheries requires special knowledge, the knowledge of experts, and that knowledge can be acquired only by many years' experience. It requires a knowledge of the habits of the seals, the demand of the market, the general commercial transactions pertaining to the business, and these could not be at once grasped by Government agents. Under our present civil-service rules we should hardly get the neeessary measure of experience.

Q. Are there relations existing between the company and the furriers abroad that it would be difficult for the Government to acquire. Is it necessary to keep the fur market supplied every year with seal skins? A. This company, when it undertook this business, had in every instance to build up its foreign trade, and it had to depend on the demand of the market so built up to make the business profitable. Under the prices that were obtaining during the first few years of the business it would hardly pay.

Q. Did you do business the first year at a loss ?-A. I think so.

Q. You have no interest in the company except as a salaried officer?A. No, sir.

Q. What do you say as to the result of the Government undertaking to manage the business?-A. I am sure it would be a failure.

Q. Are there any marauding vessels in Bering's Sea at this time?A. I do not know. There were several when I left there abont the middle of last August.

Q. Has the Goverument published a notice warning them to go out?A. Yes, sir; the same instructions as the year before.

\section{Bj the Chairman:}

Q. Would it aid the protection of the rookeries if the Government had one or two steam-launches at each island?-A. Yes, sir; if it had any means of taking care of them. But there is no suitable harbor for vessels of any class.

Q. What would it cost to construct a suitable place?-A. I do not think I am competent to answer that question. The sea is very rough at times, and the ice is a great obstacle in building a breakwater. It is a problem for an engineer. I believe it wonld require a very heary expenditure.

Q. Is it practicable at all ?-A. I have no doubt it is with a sufficient outlay of money, but I think it would require a pretty large sum. Ice comes in there in the months of February, March, and April in heary masses and completely surrounds the islands. The cakes are often 20 or 30 feet thick. It comes, of course, with crushing force in heary weather. 
By Mr. Fecton :

Q. If I understood you correctly, it was that the number of females killed by the marauders was about 80 per cent. ?-A. I think 80 or 90 per cent.

Q. And you also stated that the bulls are becoming scarce. It is a little curious to account for the two facts, and I was only able to do it from the fact that if 80 per cent. of those killed were cows, and the bulls were disappearing, there must be a larger number killed than you have figured.-A. It is not unlikely; out when we have left only exactly the number of bulls we need, and a few even of these are killed, it completely upsets our calculations, with the result of leaving too few of this class of animals to secure the full productiveness of the rookeries.

Q. You speak of the natires killing pups, do they kill males or females ?-A. They kill only the males.

Q. You think it would be a very good idea to stop them?-A. I think it would be.

\section{By the CHamman :}

Q. Is the flesh of those killed for the skins different from that of the pups?-A. The flesh of those killed for the skins bears the same relation to that of the pups that beef does to veal. Of course the natives like a change, but they have ample opportunity to provide themselves with other kinds of meat and plenty of money to buy with.

Q. By the proposed cold storage can you preserve that meat?-A. I think we can fully.

Q. You think the killing of pups is not essential ?-A. No, sir.

Q. How many pups are killed ?-A. Three to six thousand.

Mr. Tingle. We limit the number to 3,000 . Last year they killed 2,100 , and the year before 2,800 .

The Witness. But formerly they killed a much larger number.

By Mr. FeltoN :

Q. You speak of killing small seals; is the fur on the small skin better?-A. It is equally good, but the size of the slin is so much less that it is not so valuable.

Q. You speak of wanting the pricilege of taking the natives from some other islands to the seal islands; are the natives on the seal islands unable to do the work? -A. We have already had a sufficient increase of our laboring force from the other islands to do the heavy, rougher kinds of work, but as they are not allowed to share in the seal money, we have paid them for this work outside of the community fund arising from the 40 cents per skin, while the diminished number of natives actually resident upon the seal islands are receiving an increased amount of money.

Q. Is that a Treasury regulation or the law?-A. It is a regulation formerly made by the company, and sanctioned by the Treasury Department.

Q. Your iclea is that if you took other people there you would in justice be entitled to class them as natives of the seal islands? - $\mathbf{A}$. I think they should be classed with the natives of the islands. The company should not be obliged to pay for one-half of the work of taking the skins in addition to paying for the skins at the same price as when all the work was done by the seal islanders.

Q. As bearing on this question of whether it would be the better policy for the Govermment to lease the islands or do the business itself, I suppose a curreut knowledge of the habits of the seals is quite necessary\%-A. Yes, sir; there is no doubt of that. 
Q. How many superintendents has this company had during the time you have been there-I mean how many in charge generally?-A. I have now six assistants, besides five or six additional men who are employed as teachers, store-keepers, and teamsters.

Q. How long have they been there?-A. Some of them since the first year of the lease-eighteen years. Two have been recently taken into the serrice, and even these two have already had three or four years' experience. We do not regard them of much value until they have been at least two years on the islands.

Q. How long hare you been there?-A. Eighteen jears for the company and two years for the Government.

Q. Do you know how many Government agents have been sent there during that time?-A. I think nearly thirty. We figured it once, Mr. Tingle and I, but I have forgotten the exact number.

Mr. Tingle. It was twenty-two or twenty-three.

Q. Therefore you judge by the past we would find that there would be more changes under Government than under a corporation or company having it in charge?-A. I think so. It has been the policy of the company to keep a mau as long as he is efficient.

Q. Whereas it is hardly the business of polities to do it?-A. That goes without saying.

Q. If our control of the islands of Bering Sea is essential, not only for the preservation of the rookeries but for the protection of those who are interested with the Government as lessees, is it not equally important by way of preventing competition-which would, of course, reduce the price of these skins and occasion a loss to both the lessees and to the Goverument, because the Government would have to take a less rental and the company would have to take less for carrying on the business-would that not be another reason why we should protect the business?-A. I think it would. If the seal fisheries are allowed to be broken up it is a complete loss to the world, and a large number of people besides the lessees, and large interests other than those of the Government are directly or indirectly concerned in the business.

Q. You were speaking of the protection of the seals beyoud the 3-mile limit off the Straits of Fuca; can you suggest any system by which that can be done? Could it be done otherwise than by declaring the taking of seals as piracy, and would not that require the consent of other nations ?-A. I think the consent of other nations could be readily obtained, because other nations are equally interested in the preservation of the seals with the United States, and because the seals belong to the United States by reason of being born and living on these islands. When they are away from these islands they are simply on migratory tours. They go down to the southern latitudes to feed simply, but they belong at all times upon the islauds, and are astray when they are not there.

Q. It being conceded that the islands are their home, and no one being interested other than the American and Russian Governments, there would be no special reason why other nations wonld object?-A. Only the Governments of the United States and England are interested in the Alaskau seal fisheries to any great extent. The United States is interested in it as a producer of raw material, and England as a manufacturer of furs. If these two nations were agreed that seal life should be protected, I think there would be no trouble in fully protecting it. It is a question of quite as much interest to England as to the Dnited States, for she has a large number of skilled worlsment, and a large amount of capital engaged in this industry. 
By Mr. JEFFries:

Q. Supposing a treaty was made with England to that effect, would there be trouble trom any South Americau country or from Canada?A. I believe that an arraugement could be efiected with England, and that no other country would interfere.

Q. You think the United States would protect us against any small country, but not against a strong one?-A. Yes, sir.

Q. Russia has as much interest as the United States, she having seal rookeries?-A. Yes, sir; but Russia is decidedly inclined to protect herself, without asking permission from England.

Q. I warit to ask you in regard to the scarcity of bachelor seals. I suppose when female seals are killed, many of them are with pup, and, of course, that pup) is as likely to be a male as a female, and if one-half of all the pups killed in that way are males, that would account to that extent for the disappearance of bachelor seals?-A. Yes, sir; and I would like to empluasize the fact that it seems to me that the number of seals has been largely overestimated. It was formerly supposed that we could kill them to almost any extent without injury to the rookeries, but we find that the killing of 100,000 by marauders, in additiou to the 100,000 killed lawfully, is cutting in ou us. The rookeries do not produce enough to bear that strain upon them; in other words, seal lifi is not nearly so numerous as was supposed.

At this point the committee took a recess until 2 o'clock p. m.

\section{AFTER RECESS.}

\section{By the CHATRMAN :}

Q. Do you know Chester Seeber?-A. I am not personally acquainted with him, but I know of his having been commissioner at Oonalaska.

Q. Where is he now?-A. I believe he is in San Francisco.

Q. Here is a letter adrlessed to the committee by Mr. Seeber. WVill you read it and state to the committee what you, as agent of the company, would say in reply to it?-[The witness reads the letter.]-A. Mr. Seeber says the company uses the power which its contract with the Government gives it to monopolize the whole trade of westeru Alaska, to oppress the in habitants, and to retard the develojment of the country. I will say that there is not business enongh in western Alaska for two companies in the fur trade. The Alaska Commercial Compauy makes no profit from its business outside of the seal islands. The two companies in competition were losing money when the Western Fur and Trading Company, to which Mr. Seeber refers, closed out its interests to the Alaska Commercial Company--sold all its interests to our company at a higher price, in fact, than we were able to pay. We got property we did not want, and since that time the business has so much decreased that there is still less room now than when the Western Fur and Trading Company sold out. He says that we paid a higher price then for skins. That is true. Both companies paid too high for them, and the Alaska Commercial Company, to my knowledge, paid more for them, in some instances, than they were worth in London. The other company was doing the same thing. It was the result of legitimate competition.

He says the policy of the company is to discomrage prospectors and miners. That is filse. TVe have always had instructious from the president and managers of the company to give every facility to miners, prospectors, and other parties going to Alaslia. We have even carried 
sea-otter hunters on our vessels, knowing that they were to engage in business in opposition to us.

He quotes Mr. Petroff's statisties of the fur business of western Alaska. Those statistics were correct enough for 1850, but the trade has fallen off until they are entirely erroneous for 1S8S. I do not see anything else that requires an answer.

By the CHAIRIAN :

Q. Is there anything to prevent any other inclivilual or company from going into the fur trade if they choose, to do so?-A. Nothing whatever. The entire Territory of Alaska is as open to the world as any other part of the United States.

\section{By Mr. JEFFRIES:}

Q. Please tell the committee wherein the contract with the Government has any connection with the condition of trarle with the natives.A. It has no connection whatever. The contract relates exclusively to the seal islands and the seal fisheries.

Q. Will you tell the committee what relation this man has ever had with the Alaska Commercial Compans, or what his grievance is, if he has any?-A. I don't know what his grievance is, but the company has a grievance against him, because he left without paying his bjlls, amounting to $\$ 1,000$ or more, for board and borrowed money.

I should like to point out how I know the seals are diminishing in number. This chart [exhibiting chart] shows the lanes through which the killable seals, in going back of the rookeries, pass to the grounds from which we take them. The increase of seals trom 1872 to 1853 closed up these lanes, so that the killable seals were unable to get through, and this occurred as the result of the increase of the female seals and consequent extension of the breeding rookeries. The bachelor seals were, therefore, obliged to go to some other point to haul up. Since the excessive killing began, these lanes have again commenced to open wider and wider, until they are now open so wide as to allow the bacielor seals to pass through their old grounds back of the rookeries, while the places from which we drove seals for killing a few years ago have been in turn again partially abandoned. The bachelor seals haul up at a distance from the rookeries only when they are unable to reach satisfactory ground near by them.

By Mr. FELTON:

Q. In this letter Mr. Seeber says: "Revenue stemers are kept at the expense of the Gorernment throughout the summer months constantly in attendance about the seal islands, and any unfortunate ressel discovered in Bering. Sea is searched, and if fonnd to contain any furs, it matters not how or where the 7 were obtained, is seized and subjected to condemuation and sale." Is that a fact ?- A. I have nerer known a vessel to be seized unless it had furs ou board which were reasonably presumed to have been obtained in Bering Sea, contrary to law, and the fact that they are condemued and sold seems to prove that they were violating the law.

Q. Then it is not true?-A. It is not true that ressels are seized when pursuing legitimate business; and I would like to arld, that the agents of the Alaska Commercial Company never solicit the officers of the Gorernment, as he states, to do anything more than their duty in protecting the seals and the interests of the Government, for the interests of the Government and of the company are identical in this business. 
San Fraveisco, August $25,1888$.

To the chairman and members of the committee of the House of Representatices having in charge the investigation of the affairs of the Alaska Commercial Company.

Gextlemen: I address this letter to son, not for the purpose of pointing out any infringements on the part of the Alaska Commereial Company of its contract with the Government, but for the purpose of showing that the company uses the power which that contract gives to it to monopolize the whole trade of western Alaska, to oppress the iuhabitants, and to retard the development of the country.

The geographical couditions of western Alaska renders the country impenetrable, except by navigation of its vast rivers, which flow westward into Bering Sea. All the commerce of the country flows through this sea, and past the seal islands of St. Paul and St. George, which are held by the Alaska Commercial Company under lease from the Goverument (revenue steamers are kept at the expense of the Government, throughout the summer months, constantly in attendance about the seal islands, and any unfortunate vessel discovered in Bering Sea is searched, and if found to contain any furs, it matters not where or how they were obtained, is seized and subjected to condemmation and sale). This arbitrary action on the part of the Govermment, practiced at the solicitation and by the procurement of the Alaska Commercial Company, renders any attempt, however lawful, of auy individual to do any trading with the country perilous, aud in most cases results in irreparable loss.

Several years ago the Western Fur and Trading Company, comprising a company of gentlemen of this city possessed of large means and acknowledged business capacity, undertook to open up a trade with the conntry, and to that end established stations in different parts of westeru Alaska. The result was that skins for which the Alaska Commercial Company had formerly paid from $\$ 20$ to $\$ 30$ were immediately advanced to 125 to $\$ 135$. These latter prices were undoubtedly in advance of what the skins conld be sold for in the Loudon market, but as the Alaska Commercial Company had the neighboring seal islands to fall back upon, and which were certain to make good any loss that the company might sustain in driving its rival out of the field, it required but a fow years to force the Western Fur and Trading Company to retire, whereupon the prices of skins were at nnce dropped to the original prices. I mention this experience of the Western Fur and Tradiug Company for the purpose of illustrating the fact that a conpans having an exclusive lease of the seal islands becomes absolute master of all the territory tributary to Bering Sea.

The power that the Alaski Commercial Company possesses in Bering Sea prevents any movement towards the development of the country adjacent thereto ; the past year and a half has fully demonstrated that the country is rich in precious metals, and considerable gold has already come to this market throngh Bering Sea, the last steamer of the Alaska company baring brought down about $\$ 60,000$ of gold dust. It is the policy of the company to diseoniage prospectors and miners, and I have been told that at different times they have refused to sell them provisions when they were in a destitute condition. It may be asked why should the Alaska Commercial Compauy object to the development of the mineral resources of the country? The answer is, that it would open up the country, induce a large influx of population, establish greater facilities for travel and communication, and in that way endanger their trade.

To present to you some idea of the amount of business trausacted annually by this company, let me sall your atteution to the census report of Ivan Petroff for 1880 . Mr. Petroff, at page 66 of his report, says that while "the returns of shipments by the American traders in thirteen years (from 1867 to 1880) are necessarily below the real figures" *** "the market value (in London) of the annual yield of furs in western Alaska may be approximately stated as follows:

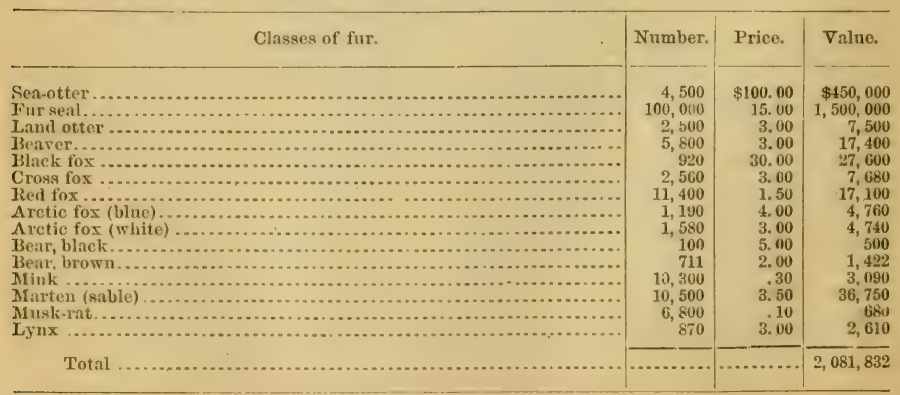


Now, as all of these furs (excepting the $\$ 255,000$ paid to the Gorernment under its lease) are obtained from the natives in exchange for goods, or for money that ultimately is returned to the company in exchange for goods, upon which a profit of from 50 to 200 per cent. is realized, it is easy to understaud the interest of the Alaska company in its efforts to maintain its primeval domains undisturbed.

1 had intended at the ontset including other matters in this letter, but as even this may not be relevant to the subject-matter of the investigation, I will await your pleasure.

Very respectfully,

Cimester SFeber, Formerly Commissioner for Alaska at Oonalaska.

Address: General post-office, San Franciseo, Cal.

\section{STATEMENT OF PROF. H. W. ELLIOTT.}

\section{Prof. H. W. ElLiott, sworn and examined.}

\section{By the Chatrian:}

Q. Without asking you any particular questions, will you state the general condition of the seal rookeries of Alaska in Bering Sea?-A. The fur seals of commerce and science (Callorlinus ursinus) are found in Bering Sea on four islands, which are used by them as breeding grounds, where, at certain seasons of the year, they go and "haul up" on their chosen breeding strips of land and rocks. A great amount, the largest part, of this seallife is found on our side of the boundary line in our part of Bering Sea, on what is known as St. Paul and St. George Islands of the Pribylov group. The breeding animals within our jurisdiction are found exclusively on those two islands. 'The other two islands belong to the Commander group, which lie about 750 miles to the westward of ours, and are wholly owned and controlled by Russia. They are known as Bering and Copper Islands. Then there is a tiny islet in the Ochotsk Sea, known as Robbin's Reef, on which these fur seals " haul up," but they do not breed there. Therefore, upon these four islands just mentioned the entire seal life of the North Pacific Ocean and Bering Sea is found ammully massed in reproduction. The condition of these rookeries at the time of my examination of them in 1873 and 1874 and 1876 was excellent. The seals were there in vast numbers, massed in regular order, subject to no disturbance, and, so far as I could see, no evidence of any plague or distemper among the swarming millions. I have received no evidence, and $I$ have heard no testimony since, that contradicts this statement. They are still in the same good physical condition that they were in then.

Q. Please state in that commection in what capacity you visited those islands.-A. I first visited those islands in Aprit, 1872, by the joint action of Prof. Spencer F. Baird, then assistant secretary of the Simithsonian Institution, and Secretary Boutwell, Treasury Department. The Secretary ailowed me to go up as an assistant Treasury agent, with the distinct understauding that I was to be allowed time to engage in these investigations, and when through, to return withont leave of absence. When I got up there I had an idea that I should be able to come back the same year, but I found things so different from what I had understood, that I made another visit in 1874 , and still another in 1876 , to satisfy myself of the truth of my statements, and the accuracy of my hypotheses; I went ont to them in 1874, under authority of a special act of Congress; and again in 1576 , on my own responsibility. 
Q. I wish you would state in that comnection what other fur-seal rookeries exist in the world.-A. To the best of my knowledge, there is a small, very small rookery on the Lobos Islands, just north of the mouth of the Rio de la Plata, on the eastern coast of South America, owned and protected by the Argentine Republic. South of these islets about 100 miles, at Cabo Corrientes, nuder the high cliffs, thero are a couple of small bluffy hauling grounds controlled by the same power. I do not know of any other breeding grounds located and protected elsewhere in the world.

Q. What do you know of the histors of the former existence of furseal rookeries in other parts of the world ?-A. What I know I have learned from a patient reading of all the old sailors' narratives, and from navigators aud merchants, and from returns of sales at Canton and other markets; but, on the whole, the knowledge that I have of the exact importauce and position of those rookeries is very unsatisfactory. I know, however, from analogy, that those interests, in the south seas must hare been the most valuable, and of much greater extent prior to their diseovery in $177 \mathrm{~S}$, and extermiuation in 1845 , by the combined efforts of all nationalities, than our own are to day.

Q. What has become of those rookeries; are they still in existence ?A. No, not even to any microscopic extent. A few scattered animals, howerer, must breed here and there in inaccessible places, because every year now several hundred skins are secured from the antarctic.

Q. So far as your knowledge of the existence of seal rookeries is concerned, is it true that they have all been practically exterminated aud destroyed, except those under our protection and Russia?-A. Yes, sir; there are no such breeding grounds anywhere eise to-day. It is remotely stated that fur seals hare in earlier tumes bred to a great exteut on islands off the coast of California; but certainly they do not breed there now, and have not for the last thirty or forty years. These Californian rookeries, however, never could have been extensive.

Q. WVill sou state the nature, character, and habits of the fur seal, and what measures have been adopted to prevent unnecessaiy waste and destruction of seal life?-A. The nature of the fur seal is that of a perfect amphibian. I think the fur seal is the most perfectly organized of all the amphibians. The fur seal is obliged by its nature to secure its living in the water and reproduce its species on the land; therefore in obedience to this law of existence it is obliged to " haul up" at stated periods every sear on these breeding grounds I hare mentioned. Its forefeet or "flippers" are exceedingly broad and powerful, and when it comes out of the water it moves forward stepping with consiclerable rapidity and much grace. It is an animal of great intelligence, much more so, I think, than most naturalists give it eredit for It speedily anticipates dauger aud readily understands the disposition of man not to disturb it. This trait has been conspicuously exhibited on the breeding grounds in $\Lambda$ laska, where right in sight of and less that 200 yards from the killing grounds of St. Paul, where the groans of the dying can be heard and blood of the slain smelled, the breeding seals on the Lagoon Rookery continue to come and increase year after year, knowing that they are never disturbed, and that man has no disposi. tion to interfere with them. This shows a very remarkable degree of intelligence.

Q. So that they will stand a considerable amount of noise and confusion, so long as it does not disturb the breeding rookeries?-A. Precisely so. They are in full sight of the village and ret feel easy. But if you disturb them, go among them, or attempt to drive off a few 
females, they will go away and shum the place hereafter. It would argue that they have a perfect understanding of their safety. I think these breeding seals repair to these islands with a distinct understanding of the fitness of the land as a whole. I am not ready to declare that every seal born thereon goes back to the exact spot of its birth, but I believe the seals are largely influenced by the knowledge that this is their home. 'The breeding seals, in coming up and landing, are undoubtedly guided to the several rookeries largely by scent, but this is only a supposition. In landing, if they come a little late and find the rookeries somewhat crowded, they will not attempt to force themselres through, but will go to another part of the rookery not quite so much occupied. When the females come, as they do, in large uumbers they can not as a body possibly find the same spot of last year's occupation, because they are often crowded off and forcerl to settle in a position elsewhere, so that females that have been born and have bred this year on one part of the rookery will be compelled in this way to go to some other part of it next season. Let anybody disturb them, howerer, go among them with fire-arms or clubs, or along the beach even, and they will soon take the alarm and leave. I am well satisfied of the truth of that.

Q. Were the Alaska Commercial Company the lessees when you were there?-A. Yes, sir.

Q. You observed the methods adopted by the company for taking, counting, and shipping seal skins?-A. Yes, sir; very closely. The method is a simple and direct one, and very easily observed and recorded. The habit of the company is to inform the chiefs or foremen of the natives every morning during the working season of their desire for a certain number and certain kind of skins. These men go to the natives and arouse them from their slumbers and start sereral of them at the break of day for some one or two of the hanling grounds where the "bachelor" seals or non-breeding males are. This separation of the bachelors from the non-breeding seals is one of their own volition. No young male can put his flippers upon the breeding grounds without an overpowering assanlt from an old bull, and until the young males attain the size and strength of an oid male they can not become the heads of families. They may make an attempt, they often do, but they are never able to get on the breeding grounds; therefore they are obliged by these angry, jealous old males to herd apart by themselves. Sometimes thousauds and sometimes tens of thousands, sometimes elose by and sometimes a mile away from the breeding grounds, they will continue annually to land until they are big and strong enough to repair to the rookeries and successfully fight for their rights. In this manner the seals are separated by their own volition into two sets, $i$. e., breeding and nonbreeding seals.

Q. Give an account of what the breeding seals do.-A. The breeding seals are composed, as we find them on the rookeries, of the old males and females. I call every full-grown male an old male. No male under six years old can put a flipper on these breeding grounds and stay there alive. The old males arrive first. They come cantionsly about the shores, and are the earliest arrivals. Along about the $2 \mathrm{~d}$, $3 \mathrm{~d}$, or 4 th of May the first old fellows will be seen. They may be noticed here and there, their heads popping out of the surf, looking around, and then soon after shaking themselves out dry on the ground that they have as a rule previously occupied. A few weeks later more and more old ones come. Along about the middle of May all the bulls have arrived as a rule. 
Scarcely a female has yet appeared. The old bulls locate themselves on the breeding grounds about 5 to 10 feet distant from each other. Those that first arrive locate near the shore. Those that come next have to fight to get iu at all, and gradually work back, keeping these bounds and dotted themselves like checkers on a checker board, fighting all the time, maiming and sometimes killing each other. About the 20th of May all the old bulls have arrived. They have got the breeding grounds pretty well pre-empted. A great many young males have attempted to land and have been forced off. About the end of May or the 10th of Jume the first cows appear. They do not land like the males. Their period of gestation is about to expire, and they can not bring forth their young in the water. About the 14th or 15th of June the cows begin to come in quite large numbers, and by the 24th they land so as to appear in great waves or streaks as they move up on shore; and by the end of June or the 20th of July the whole breeding ground has become covered with a solid mass of their bodies, so that it looks at a distance like a vast swarm of hiving bees. When the female lands she gives birth to her pup anywhere from a few hours to a couple of days. The labor pains are brief, three to five minutes; the pup is dropped, and is soon on its feet, with its eyes wide open. About the 20 th of July the entire breeding of the islands is at its height; that is, the cows have arrived, nearly all the pups have been born, and the cows have had coitus with the male, so that by the 4th or 5th of Angust it is pretty nearly over; the cows then scatter and this perfect organization of the rookeries is broken up. In the mean time the killing season has expired. The non breeding seals arrive nearly as early as the old males, but do not go ashore in any numbers. The great body of the bachelors generally arrive from the 14th to the 20th of June. The yearlings do not come in a body until about the 20th of July.

The natives and the company are jointly interested in getting the very best skins and getting them as quickly as possible, because every day after the opening of the season until the end of the season early in August the quality of the skin sensibly deteriorates. The best skins are from the seals that hare arrived first. After that the seal begins to shed bis coat and the skin is by the.4th to 10th August in that condition called "stagey." Therefore the desire of the company is to secure as early as possible its quota of skius. When this time arrives the natives are notified. They appreciate the importance of this, and on the morning of a killing day the company's agent gets up at the break of day, which is about one or two o'clock in that latitude, and goes out with his party. The seals are separated by walking in between them. The natives never like to drive up more seals than they can handle on any one working day. The seals as they are driven become warm and a good deal excited. This "drive" thus selected is driven on the land slowly over distances of about a quarter to a mile and a half up to the village. The natives walk along behind them and they go forward without much trouble. In this way they are brought over on to the killing grounds, and when they arrive there the natives come down from their houses armed with clubs and knives, and under the direction of an overseer the work of killing is taken up. Thirty or forty seals are driven out from the drove at a time and knocked in the head and instantly killed. The foreman, in adrance of killing this " pod," indicates what particular seals are to be spared, and after the slaying is completed these survivors are permitted to clamber out orer the bodies of the slain, away from this scene of carnage, and go back to the sea.

Q. Are there ever any female seals among those?-A. They never 
find any except occasionally an old, barren female, but they are rery rare; probably not one in a hundred.

Q. All the females go to the breeding grounds?-A. Yes, sir. The searlings, which embrace equal numbers of both sexes, never go on the breeding grounds. They appear about the 20th of July.

Q. Do they haul upon the breeding grounds ?-A. No, but upon these hauling grounds, and there is where the natives select the two, three, and four year old bachelors; the yearling males and females are spared. They are easily recognized, being much smaller and tinted much brighter on their backs and abdomens.

Q. They never kill the yearling females?-A. No, sir; it would not pay. The fur of a yearling is not worth handling; it is light and "fluffy."

Q. The work of selecting and killing, then, can be carried on without any disturbance of the breeding rookeries?-A. Oh, yes; as it is carried on now there is no interference with those breeding grounds.

Q. Under the system adopted by the Gorernment and the company, do you think the full breeding capacity of the entire herd can be preserved indefinitely?-A. Yes, sir. So far as we are concerned, I do not think we are able to cause an increase by anvthing that we can do on the islands, because we can not cause a greater number of females to be impregnated than are there, and as long as that is done, as it has been done and is done now, ererything is done that possibly can be done. When they leave the islands they are the pres of certain natural marine enemies, which we can not shield them from.

Q. What is necessary for their protection when they are off the island?-A. From their unnatural enemies or from man we can protect them, but not from their natural enemies. By those natural enemies, such as sharks and killer whales, they are held in check. They obtained a maximum limit of increase in the state of nature, I think as far back as 1848 or 1850 , when there were no more seals on those Pribylov Islands then than there are to-day. I do not think there are very much more there now than there were when I was there. Some of my friends insist there are not quite so many, and others insist that there are more; but I think they have not increased much since I was there.

Q. How does the present system of protection compare with that of the Russian Government?-A. It is essentially the same thing. We adopted it from them. But we have improved upon it. We have perfected a great many of their methods. We have improver the condition of the natives and changed the work, and by so doing we get better skins. But the principle of the thing is essentially the same as the Russians carried it on for a great many years. Their business methods, of course, hare been rastly changed for the better by the Alaska Commercial Company. Under the Russian régime things were slothful and very slovenly. The Russians made no effort to hold these islands, at the time of the transfer, simply because they did not then value their sealing industry - it was of small consequence then-a skin only being worth from $\$ 3$ to $\$ 4$ in London. They failed to properly develop the market, as the lessees have done under our Govermment.

Q. Do we give as much attention to the seals at Bering Sea off the islands as the Russians gave them ; that is, against unauthorized hunters?-A. I have no record of any raiding ever having been done by Americans or British previous to our acquisition; but if there had been, they would have been promptly repulsed.

Q. There is no account of a law ever having been adopted allowing or prohibiting the hunting and indiscriminate destruction of seals?- 
A. No. The exclusive trading claim of Russia to Behring Sea in 1821 was nerer questioned by Great Britain or by this Government.

Q. There is no account of the hunting of seals prior to our aequisition?-A. No, sir; and not for many years after.

Q. Do you think that protection in the waters away from the isl. ands essential to the protection of the herd in the rookeries ?-A. I think the indiseriminate hunting of seals in the open waters of Bering sea would result in the extermination of these rookeries in anywhere from two to three years.

Q. In spite of all the care we could take?-A. That would not have the slightest effect.

Q. You think simply making a reservation of the islands upon which the rookeries exist, and keeping other than authorized people away, would not be sufficient protection?-A. It certainly would not be, and I can explain why: It is fair to assume that very few of our people clearly understand what peculiar alvantages a fur-sealing schooner and her crew would enjoy in Bering Sea for the successful prosecution of their errand, if unchecked. In order that the full significance and importance of that action of our Government which arrests or restrains the pelagic sealer within those waters may be perceived, I offer the following epitome.

It is now well understood and unquestioned by those familiar with the subject:

(1) That the fur-seal of Alaska is obliged to annually haul out upon the Pribylov Islauds for the purpose of breeding and shedding its coat.

(2) That from the time of its departure from these islands in the fall of every year ip to that moment of its return to them in the following spring, it lands nowhero else.

(3) That it arrives en masse on these islands in June and July, and departs from them in a body during October and November.

(4) That when leaving the islands in the autumn, it hearls directly for and rapidly travels out from Bering Sea into the waters of the North Pacific Ocean; its paths aro bee lines from the Pribylov Gronp to and through the numerous passes of the Alentian Arehipelago, the passes of Oonimak, Akootan, Oonalga, Oomuak, and the Four Mountains being the most favored by it.

(5) That it returns to the Pribyloy Islands from the broad wastes of the North Pacific Ocean by these same paths of departure.

Therefore, if you will glance at a map of Alaska, you will observe that the convergence of those watery paths of the fur-seal as it traverses Bering Sea, going to and from the seal islands, resembles the spread of the spokes of a half wheol-the Aleutian chain forms the fellow, while the hub into which the spolies enter and meet is the small Pribylor Group.

Hence, it will be noted that as these watery paths of the fur-seal converge in Bering Sea, thes, in so doing, rapidly and solidly mass together thousands and tens of thousands of widely scattered animals at points, ten, fifty, and even one hundred miles distant, at sea, from their landing on the breeding rookeries.

Here, then, is the location and the opportunity of the pelagic sealer, anywhere from ten to one hundred miles south of and distant from the seal islands; there is his chance to lay at anchor over the shallow ber of Bering Sea, where he has the best "holding ground" known to mariners, and where he can safely ride out the wildest gales, with no danger of a lee-shore even if his tackle breaks; while on the other hand the immediate vicinity of any pass of the Alentian Chain is too dangerous for a prudent sailor-the tide rips there, the swift currents drift 
him in dense fogs, and the furious funneling storms of wind and sleet will never permit him to safely hover about these openings.

But above them, 50 and 100 miles to the south ward of the seal islands, in that watery avenue of the returning fur seals every June and July and August, he has a fine opportunity to shoot, to spear, and to net them until he shall have attained the full extent of their utter extermination.

His power to destroy them is also augmented by the fact that those seals which are most liable to meet his eye and aim are the female fur seals, which, heavy with young, are here slowly nearing the laud, soundly sleeping at sea by intervals, and reluctant to haul out from the cool embrace of the water upon their breeding grounds until that day, and hour even, arrives, which limits the period of their gestation.

The pelagic sealer employs three agencies with which to secure his quarry, viz: He sends out Indians with canoes from his vessel, armed with spears; he uses shotguns and buckshot, rifles and balls, and last, but most deadly and destructive of all, he can spread the " gill-net" in favorable weather.

With gill-nets " underrun" by a fleet of sealers in Bering Sea, across these converging paths of the fur seal, anywhere from 10 to 100 miles southerly from the Pribylov Group, I am moderate in saying that such a fleet could utterly ruin and destroy those fur-seal rookeries now present upon the seal islands in less time than three or four short years. Every foot of that watery roadway of fur-seal travel above indicated, if these men were not checked, could and would be traversed by those deadly nets; and a seal coming from or going to the islands would have, under the water and above it, scarcely one chance in ten of safely passing such a cordon.

Open those waters of Bering Sea to unchecked pelagic sealing, then a fleet of hundreds of vessels, steamers, ships, schooners, and what not, wonld immediately venture into them, bent upon the most vigorous and indiscriminate slanghter of these fur seals; a few seasons of greediest rapine, then-nothing would be left of those wonderful and valuable interests of our Government which are now so handsomely embodied on the seal islands; but which, if guarded and conserved as they are today, will last for an indefinite time to come as objects of the highest commercial good and value to the world, aud as subjects for the most fascinating biological study.

Shooting fur seals in the open waters of the sea or ocean with the pe. enliar shot and bullet cartridges used involves an immense waste of seal life. Every sea! that is merely wounded, and even if mortally wounded at the moment of shooting, dives and swims away instantly, to perish at some point far distant and to be never again seen by its human enemies; it is ultimately destroyer, but it is lost, in so far as the hunters are concerned. If the seal is shot dead instantly, killed instantly, then it can be picked up in most every case, but not one seal in ten fired at by the most skillful marine hunters is so shot, and nearly every seal iu this ten will have been wounded, many of them fatally. The irregular tumbling of the water around the seal and the irregular heaving of the hunter's boat, both acting at the same moment entirely independent of each other, make the difficulty of taking an accurate aim exceedingly great and the result of clean killing very slender.

By Mr. Feuton:

Q. It has occurred to me, as you have spoken, of the reason why these breeding grounds and what you cail hauling grounds are separate, but 
why do these young bachelors try to go upon the breeding grounds? A. The instinctive desire of a young male is to propagate his species, and he would commence when only two years of age if he could.

Q. The old bulls will not let them ?-A. No, sir. That is an explanation of this "hauling out." I am not prepared to say that they are obliged to "haul out" to shed their coats, but they are obliged to "haul out" to reproduce their kind.

Q. Then you think it is absolutely necessary for the Government to protect the herds in the open waters as well as on the rookeries?-A. I think it is absolutely necessary to prevent their molestation in the waters of Bering Sea if you desire to preserve these rookeries. I think it would also be an admirable project to include the waters of the North Pacitic, if it can be done, and I think it probably cau be.

Q. Do you think it is within our power to extend protection over them in the waters of the North Pacific?-A. I believe it would meet with the entire approbation of the British Government, and as it and Russia are the only great nations interested besides ourselves, if we secure their permission, I do not think we would have any difficulty. But we eertainly can protect them in Bering Sea, and we should do so.

Q. What is your idea of the number of seals that visit the Pribylov group?-A. My idea of the number of seals that visit these islands is based upon a very elaborate system of surveys. I'made these surveys after looking over the grounds and satisfying myself that I could not trust the estimates of man. One gentlemen said to me he thought there were about $16,000,000$ of them. Another gentleman was quite sure there were not $2,000,000$. I looked over the ground and I was dumbfounded as I attempted to count the seals swarming on these grounds; therefore I set about forming some intelligent basis of enumeration, and getting some unit of calculation. I puzzled myself over it many weeks, until I arriced at this discovery : I noticed in looking over the breeding grounds under bluffs that they were never crowded in there closer over a narrow space between the cliffs and sea than they were over boundless space, where they have plenty of room behind them; that they obeyed an iustinctive natural law of distribution; and that under no eircumstances did thev crowd in any one place closer than in another; that no matter how large or how small the breeding grounds were, just so many seals would always be found in exact ratio to the area. Having discovered this, I had what I was seeking-the basis for an intelligent calculation.

Then I set about making a survey of these different rookeries, and fixing with my azimuth compass and tape line an outline of the ground occupied, and measuring it after they left. It was easy to do that. On fiuding how much ground a seal occupied, and how many square feet an animal took, I had the basis for a fair calculation. I could quite safely calculate upon an average of 2 square feet to every animal, big and little, on the grounds. I made, as you have seen in my census monograph of the seal islands, a grand total of breeding seals and young on St. Paul Island in 1874 of $3,030,000$.

Right here let me say that I think that on those breeding grounds a fair average of twelve or fifteen cows to one bull will be made. You will see families where there are double that number of cows, and you will see other families where there are not half that number, but a fair average is twelve to fifteen cows to one male.

On St. George Island the rookery ground is very much smaller, and there are only 163,420 of these breediug seals aud young, making a 
grand total on both islands in 1874 of $3,193,420$, breeding seals and young.

Q. That does not include the bachelors ?-A. No ; it is impossible to fix them on any such basis, because they roam off at will and are without restraint. To-day you can look at their hauling grounds and it is fairly covered, while to-morrow there will only be a few scattered bands around on the same area. It is impossible to form a concise estimate of their number, and it ean only be made on general principles. I put it down in round numbers at $1,500,000$ non-breeding seals, counting yearlings. When the females arrive at the age of two years, they then appear on the breeding grounds; they are impreguated and bear their pups the following year. This makes a grand sum total of seal life on the Pribylov Islands of over $4,700,000$. I have presented in my monograph of the seal islands a full explanation of every step taken in this calculation, and it is not necessary to repeat it here.

\section{By the Chatrman :}

Q. Do you know anything as to the method of driving and counting? ?-A. The natives are paid 40 cents for the labor of taking each skin. The natives are naturally not disposed to skin any more seals than they are paid for. They are indolent by nature, and not disposed to do any extra work. They keep among themselves a tally of their work every day. It is kept by their overseers. The company's agent is equally solicitous every day to see that no skins go into the salthouses without a careful count. The natives make a count among themselves when they are bronght to the salt-houses, and the company's agent handles them one by one, and makes a still more careful count. They then go into the salt-houses. They are cured and bundled, two in a bundle uniformly. When the company's vessel arrives, and they leave the salt-houses and are put aboard, another count is mado by the company's agent, as he wants to know how inany skins are put aboard. Then the company's captain, who is equally responsible, makes a count. The Treasury agent stands by and oversees this count. There are five counts made by three perfectly independent parties, and by the natives. They then go down to San Francisco, where they are counted again. That San Francisco count is the basis upon which the tax is paid, I believe. That was the exact method in my time, and it strikes me as an excellent one.

Mr. TrNGLE. That was the manner of counting, by order of Secretary Sherman, up to 1885, when I was appointed. The Secretary of the Treasury found that it was not in accordance with law, aud by an order of the Secretary the count at the islands by the Treasury agent must be taken as the lawful one.

Mr. JeFFrIEs. Mr. Tingle is the agent appointed by the Treasury Department.

\section{By Mr. JEFFRIES :}

Q. This manner of counting was upon the principle that the company ought to pay tax upon the number of skins shipped?

IIr. Tingle. Yes, sir; on the number of skins shipped.

The Writness. Well, I do not see that by this omission of the San Francisco count that it prevents a perfect count. The natives are interested in having an exact count. The company's island agent is interested, because he has to pay the natives. The company's steam-ship captain is equally interested in making an honest count, because ho has to deliver 
them in San Francisco, and the Treasury agents are bound to do their duty, and do it. Therefore, if any more skins were taken the natives would have to be paid. They never like to take a skin more than is necessary, and if they did they would want something for it. If they were paid any thing this year, they would want more next year. So the natives, being fumiliar with the United States sealing laws and regulations, and the limit of the catch, generally notify the company's agent when they have got their catch. If more skins were taken than the law allows, these people would talk of it, and it could not be kept a secret.

\section{By the CHatrman:}

Q. Will sou gire us an account of the character and habits of the native inhabitants of these islands, past and present, and the relations existing between them and the Alaska Commercial Company?-A. The character of the natives of St. Paul Island, I think, would be rery properly summed up as one of docility and apathy. They are amiable, they are respectful, but they are indolent. There are among them a few examples of thrift, but most of them are very improvident. But living as they do, reared as they are, I think they are admirably fitted for the surroundings of their existence. I do not know any better behaved people that are idle nine months of the year. Our people, of course, could do the work quicker, but they could not decently live there. If our people lived there, in nine months of enforced idleness, they would "raise Cain," to use a biblical expression.

Q. What was their condition prior to the cession of the territory to the United States?-A. From some statements made to me by the old men of the villages, they lived very much as dogs might have lived in the kenuel of their master. They were ordered about, treated without the slightest reference to their physical condition; very little attention was paid to them. They vegetated in earthen houses with damp inte. riors and leaky exteriors. They were puny, feeble, and broken-spirited.

Q. How were they provided for during that time?-A. The Russians had a little store up there, but what little they had was mostly beyond the reach of the vatives. They paid the natives as they liked. They paid them an average of perhaps 10 cents a skin; but records of the Russian work arevery unsatisfactory. Bishop Veniaminov, in his work, "Zapieska ob Ostrovah Oonalashkenskaho Otdayla (St. Petersburg, 1840 ), thus states the relation and compensation of the seal island natives under Russian control; it was in this shape when we assumed charge in 1868; the bishop says:

The Aleuts serving the company here sustain the following relations between themselves and it, to wit: Each of them worked without solicitation, were ordered to do whatever was found, and to which they were directed, or at that which they understoor best. Payment for their toil was uot established by the day, or by the year, but in general for each thing taken by them, or standing or put to their credit by the company, for instance, especially, the skins of animals, the teeth of walrus, barrels of oil, etc. These sums, whaterex they might be, were placed by the company to their credit, for all general working and hunting was established or fixed for the whole year fairly. These Aleuts, in general, receive no specific wages aud they are all not alike or equal, their being usually three or four classes.

In these classes, to tho last or least the sick and old workmen are counted in, although they are onls burdens, and therefore they recoive the smaller shares, about 150 xubles $(i . e ., \$ 40)$ a year, and the other and better classes receive from 220 to 250 rubles per year $(\$ 55$ to $\$ 60)$. Those who are zealous are rewarded by the company with 50 to 100 rubles (\$10 to $\$ 25)$. The wives of the Alents who worked at the seal hunting received from 25 to 35 rubles ( $\$ 6$ to $\$ 9$ ) per annum.

When this statement of the wages paid seal island natives by the old Russian company is made the basis of a comparison with what the 
American Alaska Commercial Company has paid and pays these same natives to-day, the following showing is made:

\begin{tabular}{|c|c|c|}
\hline WVages of seal islanders. & 1868-1888.* & $1799-1867$. \\
\hline
\end{tabular}

* Uniler American order.

$\dagger$ Under Russian order basis of paper rubles in which all payments were then made by the Russian American Company.

In regard to the supplies furnished these people from the Russiar company's store, the list was a short one-everything brought up from Sitka. Blankets, woolen cloths and blue cotton, and hemp drilling, handkerchiefs, knitting-yarn and needles, thread, kuives, cheap crockery and ironware for domestic use, tea, a very little sugar, a very little flour, no canned goods of any sort, no shoes, no ready-made clothing except Russian caps, tobacco, and rum.

Veniaminov says that "these inhabitants subsist principally upon the flesh of fur seals and sea-lions, with the addition of roots and a little flour." He also says that these seal-island natives are better paid by the Russian-American Company than elsewhere in Russia-America.

Q. They had no established methods?-A. No, sir; they did as they pleased. The natives lived in abject poverty.

Q. What is their coudition now as compared with what it was before the acquisition of the territory ?-A. Their physical and sanitary condition is one of wonderful improvement. Still, the natives would surrender everything they possess to get strong drink. They would go back into their dirt houses if you gave them liquor. The liquor laws ought to be strictly enforced there.

(The witness here exhibited pictures showing the houses of the natives, the breeding and hauling ground, etc., and, at tho suggestion of the chairman, promised to furnish the committee with cuts of them.)

\section{By the Chatrman:}

Q. What is your idea of the value of those rookeries?-A. I have two plaus of valuation. Looking at it with the eyes of a naturalist, it is simply beyond price. Looking at it in a commercial point of view, it is simply a speculative one, and it is therefore impossible to place a practical valuation upon it.

Q. The value would depend upon the preservation of the herd? -A. I presume so, entirely, coupled with the condition of the fur market of the world at the time.

Q. If we let the balance of mankind go into Bering Sea and spread their nets across these great lines of returning seals, we will soon lose them?-A. Exactly.

Q. But under a system of protection of the herds upon the rookeries, and in the open sea, what would you estimate would be the commercial value of the rookeries and the herds?-A. My estimate would be a speculative one. It may be that this year I would make an estimate based on the present trade, and next year on this basis I would be obliged to make an estimate that might be entirely different.

Q. What is the present ralue?-A. I think the gross value of the surplus bachelor seals of the Pribylor rookeries to-day would be $\$ 2,000,000$. The bachelors are the only killable seals. I do not in 
clude the breeding seals. If tnore than the surplus males were taken and killed annually, we would not have any spare seals at all in three or four years.

Q. Would it not be well to adopt Jay Gould's plan, and take the annual earning capacity as a basis, preserving the full breeding capacity of the berd? $\mathrm{A}$. That would represent 100,000 surplus bachelor seals every year.

Q. Can any more be killed ?-A. I would not like to try the experiment.

Q. At present $\$ 1,500,000$ is divided between the Government and the company ?-A. Yes, sir; in gross, as the market valuation stands at the present hour.

Q. Deducting expenses both to the Government and to the company the commercial value would be such a sam as the remainder would pay upon, say at 6 per cent. ?-A. Yes, sir.

Q. If I remember correctly, you express the opinion that the gross value of the rookeries, and the herd, are worth the sum of $\$ 12,000,000$ ? -A. That is supposing everything could be sold. But that is a theoretical statement. That much in fact could not be obtained for them, becanse such a flood of skins would ruin the market, and render it practically valueless.

Q. Now, as the result of your observations there, what is your opinion as to perpetuating the present policy of the Goverument and leasing the rookeries? Would it be or not be better for the Government to take the seals and sell the skins, or sell the rookeries, with such protection as the Goverument conld give?-A. To lease them?

Q. No; sell out the islands. What wonld be your idea of the best policy of preserving the rookeries? $-\mathrm{A}$. Between leasing, selling, and self-management by the Government?

Q. Yes; viewed with respect to the importance of preserving seal life, and as an economic question, taking into consideration the condition of the natives and the duty of the Government towards the natives?-A. I think that selling them would be a very doubtful future for the seals. I do not think that the Government would ever be able to sell them for what it will realize under the present order of things, or any where near it. Then as to direct Governmental control, any man running it for the Government would be at the very outset charged with making corrupt combinations, and the scandal and noise would be so great that no reputable man would or could long hold the office. If he did, he would be so charged as to be a candidate for the penitentiary before the end of six months, even if he were innocent as a white-winged angel.

Q. You do not think it would be practicable for the Government to undertake the business?-A. No, sir; I do not think it would. It would not result in as clear a record and as handsome a return as it does now. It would harass the Secretary of the Treasury, and render the life of the Treasury agents a burden to themselves and their friends.

Q. What do you say of a divided lease; leasing one island to one company, and the other to another company? - A. They would have to bo leased on the same conditions, and jet the islands are very unequal in importance and wealth. I do not see how the Government could do it. There could not be any discrimination. They would have to be treated exactly alike. I do not see how the Government could improve on the present plan. And uuless that is done, I do not see that it would change the existing order of things.

Q. Would more than two companies interfere with the commercial value of the skins? -A. I have not gone so far as that. The tro com- 
panies would have to unite. They would have to form a "trust," I suppose. Self-preservation would sooner or later compel them to do that. The leasing principle would still be the same. They would have to be treated in precisely the same manner. It would be just as satis. factory to our peopleas well as those of the islands to have nne company as to have ten. There are ouly so many seals, and only so much can be done, no matter how many companies there are. I gave this sub. ject a great deal of attention when I wrut to Alaska, because I went up there with the idea in my mind that it would be a good plan for the Government to manage the business; but when I came to investigate it, I came to the conclusion that it was not simply a question of taking seals on the islands-it required, also, nice management abroad to make the business valuable.

\section{By Mr. JEFFRIES :}

Q. Did you go up there as a Treasury agent?-A. Tes, sir; as a Treasury agent, and also under the auspices of the Smithsonian Iustitution. I had every facility for studying the matter.

\section{By Mr. FeLToN :}

Q. The practical value of that business, does it not occur to you, resolves itself down to two factors; first, the preservation of the seals, and next the preservation of the commercial value of the fur?-A. There are two wings to the business; one rests on the seal islands and the other on the London market and sales.

Q. Both are necessarily important, when you come to determine the question of value, because we want not only to preserve the seals but the price at which it will pay to take them. Would not they really be the two factors presented? - A. Yes, from a commercial stand-point entirely so. But if they were not worth a cent in the markets they would still be just as valuable to natural science, and should be conserved for that alone.

Q. As to the relation existing between the United States and the Alaska Commercial Oompany in reference to this business in Alaska outside of the seal islands, have you any observations to make?-A. Yes, sir; I understand it very thoroughly. They have no more to do with the Government or the Government with them than any other citizen or company outside of the seal islands. Naturally, on account of its responsibility, the company pays great attention to euforcing the Government rules in regard to the introduction of fire-arms and liquor. If any liquor gets into the country the company will be made to suffer. Whether the company desires it or not, it will be lampooned a great deal, and on that account they desire and have aided the Government to enforce the law in suppressing the rum traffic.

Q. Is it true that the balance of the Territory is open to free competition?-A. Entirely so.

Q. Does the fact of their possessing this lease in any way enable them to destroy all competition in the fur business?- A. No, sir; I think if the business amounted to much, competition would soon be found. To my mind the amount of the land fur trade of Alaska amounts to a great bubble; when you look into the figures, it is pricked. I do not suppose $\$ 50,000$ worth of land furs cau be brought in at St. Michaels, Yukon region, in the course of a year, and of that the natives get nearly $\$ 40,000$. In the Bristol Bay regions the gross valuation of the land fur will not exceed $\$ 10,000$ a jear, and the natives get so per cent. of that. The next is Kuskovim where the amount of the fur rade certainly is not over $\$ 10,000$. Those three depots center all the iand fur trade of Alaska to-day that is worthy of mention. 
Q. Are there any other traders in there besides the Alaska Commercial Company ?-A. Yes, sir; miners tramping about; and traders have little ressels plying in and out all the time. With reference to any other interests of our people in the waters of Bering Sea outside of the seal. ing industry as embodied in the Pribylov Islands of Alaska, I know of nothing; no whaling to day; indeed, there has been none here since 1857. The whales have all tled up to the Aretie, through the straits of Bering, where they are preserved from utter extermination by the sheltering ice-floes of a frozen ocean. There are no cod or halibut fishing banks now known of the least importance in the confines of Bering Sea, and no vessels are engaged there. There are no white settlements on the shores or up the valleys of the rivers that empty into this sea on our side, and a mere beginning only made by our people at salmou canning on the Nooshagak River that debonches into Bristol Bay. I have reason to believe that this canning of salmon in Bristol Bay will eventually, as the demand increases for this food, be a very considerable business. But at the present hour nothing is being done by our people in the line of fishing in Bering Sea.

I myself do not think that the shoal bottom of this sea on our side-a broad, shallow bed, sandy, silty, and muddy - is one upon which any extensive schools of food fish have erer resorted for feeding or spawning, and I do not think that they do to-day. Codfish and halibut ary found most everywhere in Bering Sea south of St. Lawrence Island, but not in any number at any one place, being widely yet sparsely distributed. I do not believe that the open waters of Bering Sea will ever be resorted to by fishing vessels. That rast area of much superior fishing ground south of the Aleutian Islands and eastward from the peninsula of Alaska will engross fully the time and efforts of fishermen for an indefinite future.

Q. Does the company's transactions in that Territory amount to oppression upon the natives ?-A. My dear sir, any trader who oppresses the natives at once loses their trade, and pays a heavy price for it; therefore the natives are not oppressed by any resident fur trader. Nobody would think of such a thing. The minute the natires are outwitted, the word goes round among them, and profitable intercourse with that trader ends for them as well as himself.

Q. Would you say that any furtber legislation is necessary for the better protection of the fir-seal fisheries, or what additional measures would you suggest for the better protection of seal life and the interest of the Goverument in Bering Sea ?-A. There is in my opinion (without being a lawyer) enough law to-day on the statute-books to protect them. There may be a doubt in the mind of some lawyers as to whether we ean exercise this power in Bering Sea, which I think we onght to. I think the case is very clear. Historically our title has been asserted for eighteen jears in the face of the whole cirilized world, without the right being questioned.

Q. Where is that found ?-A. I will sketch briefly a statement of the Russian title to the waters of Bering Sea. Let me begin by saying that the discovery of Aliaska by the Russians, and its occupation by them between 1741 and 1799 is well known, and their claim of discovery, control, and ownership acknowledged freely in all history; but the formal proclamation to the world of absolute dominion over all Aliaska and its "seas and bays" was not made by the Russians until September, 1821. Why and how this declaration of supreme control was brought about shonld be well fixed in the mind of the committee in order that it may fully grasp the Russian's motive and aim; for it will be noticed that their supreme object of control in Alaska when the ukase of 1821 
was proclaimed was not a land claim alone-that was a secondary consideration; but the first great idea of Russia then was to establish her supremacy over Aliaskan waters and as far as she could to the southward; for it was as true then as it is to-day that the pelagic furs of that region were the only ones of real commercial importance to lier, as they now are to us, or to the rest of the world, for that matter.

In pushing their large sea-otter hunting parties down the northwest coast from Prince William Sound to the Sitkan Archipelago, the Russians, between 1796 and 1804, often met American and British vessels snugly anchored in the outer sounds and harbors of the Sitkan district; there they were busily engaged in trading with the natives, and succeeded in gathering a rich harvest of sea otter skins. Naturally the Slavic traders regarded them with undisguised jealousy and annoyauce; yet in those early days these vessels had precious stores of flour, of ammunition, aud of liquor and tobacco, which the Russians were sorely in need of and exceedingly anxious to buy; they were always accommodated by the Anglo-Saxon royagers, who managed to get along in this way without any open rupture. Finally, by 1812-'17, the Russians became well established at Sitka, with an abundant surplus of food stores and hunting supplies, and then the inroads made by these ontside traders, anchored in their harbor, became a matter of serious concern. Steps were taken at St. Petersburg to remedy this injury to Russian-American fur trade, and the imperial ukase of September 16, 1821, was given to the world for that purpose.

The proclamation of the Emperor of Russia asserting his dominion over all Russian-American seas and bays, and its northwest coast down as far as latitude $510 \mathrm{~N}$., was made after the entire general topography and hydrography of that region had been carefully mapped and charted. What the Czar meant by this edict of September, 1821, was then as well understood by the powers of the earth as it is now ; for as early as 1766 a chart* of the Kamchatkan (Bering) Sea and the North Pacific Ocean was made by order of the St. Petersburg Academy of Sciences.

To Great Britian, in especial, this edict was clear and intelligible, since in 1805 a finely engraved series of charts of the world was published in an immense oblong folio at London by Thomas Kitchin, sr., "aided by captains of the royal navy." In tbis volume is a chart which accurately bounds and designates the waters now known as Bering Sea and the North Pacific Ocean ; but on it Bering Sea is termed the "Sea of Kamchatka;" otherwise this nomenclature of land aud water in 1805 is exactly as it stands on our maps to-day. And this early authoritative map of Bering Sea and the North Pacific Ocean shows those waters in their landed bounds just as elearly and quite as accurately as our best hydrogaphic charts do at the present moment.

When, therefore, sixteen Jears later, the Emperor Alexander first asserted the supreme anthority of Russia over these waters $\dagger$ down from the Aretic Ocean to the lower end of the Queen Charlotte Island group, on the northwest coast of America, it was perfectly well understood by us, and in the British colonial office then, what he meant and what he was doing. This claim of Russia to absolute control of the waters of a well-recognized international high sea, to waters which, with an unbrokeu roll, laved the coasts of Mexico, the United States, British Columbia, and Russian America alike-this claim of dominion over the

"It bears the date of 1758 , and is to be found in Miiller's Foyages et dé convertes faites par les Russes le long des Cótes de la Mer Glaciale et sur l'Ocían Oriental, ete., Amsterdam, 1766.

t'The ukase of Paul, in 1799, August 11, confined this assertion of Russian dominion to the land and islands only of Russian-Amorica down to latitude $55^{\circ} \mathrm{N}$. 
North Pacific Ocean "to within a distance of less than 100 Italian miles" from the shores of the coast as far south as latitude 510 was at once vigorously protested by our Government and seconded by Great Britain.

This extension in 1821 of the Russian-American landed claim of 1799 from latitude $55^{\circ} \mathrm{N}$. down to $51^{\circ}$, plus the control of those open waters of the North Pacific Ocean, was the cause of Mr. Adams's vigorous protest made in behalf of our Government during 1822+'23 for, in opposition to this "new pretension" of landed marine assumption of owner. ship by Russia he addressed himself in emphatic pointed terms. But the court at St. Petersburg plainly anticipated that, and in its reply to the first communication of our minister the shrewdness of Muscovitic diplomacy drew by it from Mr. Adams a definite expression of what jarticular area the American protest was intended to cover. This defizition is especially made in the answer of Mr. Adams, July 22, 1823,* who objects to the marine control of a "great ocean," where "it may suffice to say that the distauce from shore to shore on this sea in latitude $51^{\circ} \mathrm{N}$., is not less then 90 degrees of longitude, or 4,000 miles."

To this assumption of Russia touching the North Pacific Ucean and its extension of the Russian territory from $55^{\circ}$ down to $51^{\circ} \mathrm{N}$. latitude on the northwest coast-to this assumption alone did our Government protest; and to make our meaning still more clear and decided, Mr. Adams declared, in a dispatch of even date, to Benjamin Rush, minister in London at that time:

* * * The right of carrying on trade with the natives throughout the northwest coast they (the United States) can not renounce. With the Russian settlements at Kodiak or at New Archangel (Sitka) they may fairly claim the advantage of a free trade, having so long enjoyed it unmolested, and because it has been and would continue to be as advantageous at least to those settlements as to them. But they will not contest the right of Russia to prohibit the traffic, as strictly confined to the Russian settlement itself, and not extending to the original natives of the coast.

In these emphatic lines do we find precisely that ocean and that coast orer which Russia claimed dominion and to which claim we objected. Mr. Adams did not ask that our people should be permitted to enter the Kamchatkan (or Bering) Sea, and trade around and at the seal islands, though he knew then from our traders, as well as we know now, that these fur-seal interests on the Pribylov Islands were the most valuable of all Russian fur-bearing sources in that whole region; that they were the exchequer of the Russian-American Company. He recognized, however, the right of Russia to shut them out, just as we shut them out to-day, otherwise he would have made a demand for trading privileges with them also.

Every line of the correspondence which passed between our Government and that of Russia in relation to this subject bears me ont in saying that the protest of Mr. Adams against the assertion of the ukase of 1821 related exclusively to the north west coast of the North Pacific Ocean and to the waters of that ocean alone; for he makes no reference to any other region, country, coast, or sea. Yet the ukase embraced the Aleutian Islands, where the southernmost islets of the Kressi group in that Archipelago reach down south as far as latitude $510 \mathrm{~N}$.

Russia was quick to notice that her assumption of control orer the waters of the North Pacific Ocean was untenable. She therefore, in her treaty of 1824, settling this matter with us, acknowledged it by article 1. But in this treaty there is no surrender of the Kamchatkan (or Bering) Sea by expression or inference. Russia, in this instrument,

\footnotetext{
* The details of this somewhat extender correspondence can be seen in the archives of the State Department and the Library of Congress at Washington. Space here will not allow of their expression beyoud the brief eitations.
} 
also stipulates with us that she will form no establishments on the northwest coast sonth of latitude $54^{\mathrm{c}} \mathrm{N}$., yet her title to the Alemtian chain, extending way below that point, as far sonth as $510 \mathrm{~N}$. latitude, is not disputed or invalidated.

Thus the reader observes that the Russians held ererything against us that they claimed in 1821 except the extension of their landed territory on the northwest coast from $54^{\circ} 40^{\prime}$ down to $51^{\circ} \mathrm{N}$. latitude, and their assumption of control over the "great ocean," "commonly called the Pacific Ocean or South Sea." These two points they surrendered, and them only, in their treaty with us of 1824.

In the Russian treaty with Great Britain (February, 1825), which quickly followed ours, we notice that the Slavonian terms of settlement are much more binding than upon us. The English are tied down firmly to that strip of the northwest coast which extends up from the foot of Prince of Wales Island to the base of Mount St. Elias. To the westward of $141^{\circ}$ of west longitude they are not permitted by articles 3 aud 4 to go. But Sitka is made a free port of entry to the British, and the right to them is granted of navigating "forever," free and ummolested, those rivers which take their rise in British soil and flow down to the Pacific through that "30-mile" strip between Mount St. Elias and the southern extremity of Prince of Wales Islaud. These streams are the Stickeen the Tahko, and the Chilkaht Rivers. The first named is the ouly navigable one.* In this treaty the British, like the Americans, make no objection to the reservation of the Aleutian Islands and the Kamchatkan (Bering) Sea, which Russia secured by it.

Therefore, in the bright light of this unquestioned authority of Russia over the waters of Bering Sea from $17.15 \mathrm{up}$ to the hour of its partial cession to us in 1567 , the Government of that empire drew in explicit terms a fine line of pelagie partition-that division of these waters which stands upon our maps to-day of Alaska officially recorded as the "western boundary of the United States." It is the lawful line of separation between the Siberian-Kamchatkau shores of Russia and ours of Alaska; without its binding legality we would have no title to the islands in Bering Sea or those of the Aleutian chain.

We turn to that treaty of cession, our deed of Alaska from Russia, and we find that this pelagic boundary runs through Bering Sea in a southwesterly direction from its initial point in Bering Strait to a point midway between the extreme western island of the Aleutian chain, Attoo, and Copper Island of the Commander group of Kamchatka. $\dagger$ We accepted that partition of Bering Sea as a matter of course ; for when this treaty of 1867 was under discussion in the Senate, Senator Sumner said, speaking then of the western boundary of our new territory to be purchased:

Starting from the frozen ocean, the western boundary descends Bering Straits midway lietween the two islands of Krusenstern and Ratuanov to the parallel of $6 i^{\circ}$ $30^{\prime}$, just below where the coutinents of America and Asia approach each other tho nearest; and from this point it proceeds in a course nearly southwest through Bering Straits, midway between the islaud of St. Lawrence and Capo Cloukotski, to the meridian of 17:0 west longitude, and thence, in a southwesterly direction, twaversing Bering Sea midway between the isiand of Attoo on the east and Copper Island on the west, to the meridian of $17: 3^{\circ}$ east longitude, leaving the prolonged gromp of the Aleutian Islands in the possessions now trausferred to the United states, and making the westeru boundary of our country the dividing line which separates Asia from America.t

*Several writers, in touching upon this sul,ject, have hastily assumed that the Yukon River eame within the seope of this peruit. The least study will dispel such an error.

$t$ Articlo I. 'Treaty of cession, 1867.

$\ddagger$ Ex. Doc. No. 177, 40 th Cong., 2d sess., p. 125. 
There is no ambiguity in this plain and emphatic assertion of the distinguished Senator who had the nndisputed charge of this subject; and, again referring to the subject in the course of his remarks, he declared that-

In the Aleutian range, besides innumerable islets aud rocks, there are not less than fifty-tive islands exceeding 3 miles in length; there are seven exceeding 40 miles, with Oonimak, which is the largest, exceeding 73 miles. In our part of Bering Sea there are tive considerable islands, the largest of which is St. Lawrence, being more than 96 miles long.

This announcement of the distinct understanding of our Goverument, made by its chief representative, the chairman of the Committee on Foreign Affairs of the Senate of the United States, not only gave notice to our own people but to those of the entire civilized world that our western boundary of empire was fixed by this treaty in Bering Sea, and that this pelagic boundary was the "dividing line" between Asia and America, and that "in our part of Bering Sea there are five considerable islands, the largest of which is St. Lawrence, being more than 96 miles long;" the others, not then specificaliy named by him, are the famous Pribylov or Seal Islands, St. Matthew, and Nunivak.

There was no concealment of the real purpose of Russia* when she made this cession of her Alaskan territory to us, and we were equally frank in accepting it. She declared her ownership of this sea of Bering, and proved her title by dividiug it with us in the presence of the nations of the earth, without a single remonstrance coming from any quarter. We accepted this partition of Bering Sea as final, and Congress by act (approved July 27, 1S6S, 15 Stat. L., 240) declared:

That the laws of the United States relative to customs, commerce, and navigation he, and the same are hereby, extended to aud over all the mainland, islands, and waters of the territory ceded to the United States liy the Emperor of Russia, by treaty concluded at Washington on the 30 th day of March, A. D. 186\%, so far as the same may be applicable thereto.

In obedience to this treaty stipulation and law, the highest authority in the land, the Treasury Department has regularly ordered and enforced that command of Cougress which prohibits the killing of fur seals and other fur-bearing animals within the waters of Alaska. The enforcement of this law is the cause of seizure during the last two years of both British and American sealing vessels, as they were engaged up there in busily killing fur seals without the permission of our Government.

NotE.-Chapter 3, title 23, Revised Statutes, section 1956. The record of the Treasnry Department has been in perfect accord with the law. A letter of Seeretary Boutwell, dated April 19, 1872, has been erroneously quoted as placiug the Treasury Departmert on record as opposed to the claius of control of tho waters of Bering Sea. The letter, however, will not bear this violent intarpretation, for it refers onls to the open waters of the Pacific Ocean, which fill the entrance to Oonimak Pass of the Aleatian chain.

Mr. Boutwell, himself, in a letter recently written, objects to this mistaken iuterpretation above citerl of his ofticial writiug, and declares that he referred only to those waters of the North Pacific Ocean outside of the "3-mile limit," as being beyond the control of our Government, and did not relate to Bering Sea.

The CHAIRMAN. In connection with that history, will you also make drawings of the Territory and boundary lines? Our dominion over that sea is very important.

The IVITNEss. I will furnish the drawings with pleasure.

Adjourned.

* See the significant letters of Mr. Clay, U. S. minister at St. Petershurg, and the informal memoranda sent to the Senate with the treaty by Secretary Seward. 



\section{EXPLANATORY NOTES AND COMMENTS UPON THE MAP OF ST. PAUL ISLAND.}

ST. PaUl. -This name was given to the island because it was described for the first time on St. Paul's Day, July 10, 1787, by the Russian discoverers. [June 29, Justinian calendar.]

UEFINITIONB FOR RUSSIAN NAMES OF THE ROOKERIES, ETC.-The several titles on the map that in-

dicate the sereral breelling-grounds owe their origin and have their meaning as follows:

ZAPADNIE signifies "vestward," and is so used by the people who live in the village.

ZOLTOI signifies "golden," so ased to express the metallio shimmering of the sands there.

KETAVIR signifies "of a whale," so used to designate that point where a large right whale was stranded in 1819 (?) ; from Russian "keet," or "rohale."

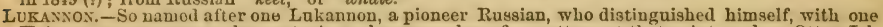
Kaiecov, a coutryman, by capturing a large number of sea-otters at that point, and on Otter Island, in 1787-'88.

TONKIE MEEs signifies "small (or " slender") cape" [tonkie, "thin ; mees, "cape."]

PoLAVina literaliy siguiut:- "half vee $y$," so used by the natives because it is practically balf-way be tween the s.lt-houses at Northeast Point and the village. Polavina Sorka, or "half-vay mountain," gets its name in the same manner.

NOVASTOSHNAH, from the Tussian "novaite," or "recent growth," so used because this locality in pioneer days was an island to itself; and it has been annexed recently to the mainland of St. Paul.

VESOLIA MISTA, or "jolly place," the site of one of the first settlements, and where much carousing was indulged.

MAROONITCI, the site of a pioneer village, established by one Maroon.

NAHSAYVERN1A, or " on the north shore" from Russian "sayvernie."

BOGA SLOv, or "word of God," indefinite in its application to the place, but is, perhaps, due to the fact that the pious Russians, immediately after landing at Zapadnie, in 1787, ascended the bill and ereeted a hugo cross thereon.

EINAHNUTTO, an Alentian word, signifying the "three mammae."

ToLstor, a Ritusian name, signifying "thick." It is given to at least a hundred different capes and headlands throurho t Alaska, being applied as indiscriminately as we do the term "Bear Creek" to little streams in the Western States and 'Territories.

The PROFI. E OF ST. PALL. - That profil of the south shore, between the Village Hill and Southwest Point, trken from the ste:mer's auchorage off the Village cove, shows the characteristic and remarkable alternation of rookery slope and low sea-level flats. 'This point of riewing is slightly more than half a mile true west of the Villago hill, to a sight which lirings Boga Slov summits and Tolstoi head. nearly in line. At Zapadnio is tho place where the Russian discoverers first landed in 1787, July 10. With the exception of the bluffy west end, Ein ahnuh.to cliffs, the whole coast of St. Paul is accessible, and affords an easy lanting, except at the short reach of "Seethah" and the rookery points, as indicated. The great sand beach of this island extends from Lukannon to Polavina, thence to Webster's house, Norastoshnah; from there orer, and sweeping back and aloug the north shore to Nahsayvernia headland, then between $Z$ i padnie and Tolstoi, tegether with the beitut iful, though short, sand of Zoltoi. This extensive and slinhtly broken sandy coast is not described as peculiar to any other island in Alaska, or of Siberian waters.

FRESH-WATER LAKES. - There are no running streams at any season of the year on St. Paul; but tho abunilance of fresh wat'r is plainly presented by the numerous lakes, all of which are " svayjoi," save the lagoon estuary. The four large reef's which I have locatel are each awash in every storm that blows from seaward over them; they are all rough, rocky ledgres. That little one indicated in English Day caused the wrecking of a large British ressel in j817, which was coming into anchor just without Zapadnio; a number of the crew were "maaskucken,"* so my native informant arerred.

DRIFT.wOOD.- Most of the small amount of drift-rood that is found on this island is procured at Northeast Point and Polarina; the north shore from Maroonitch to Tsammanah has also been favored with sea-waif logs in exceptional seasons, to the exclnsion of all other sections of the coast. The natives sar that the St. George people get much more drift-wood every jear, as a rule, than they do on St. Paul. From what $I$ could see during $\mathrm{m} v$ four seasons of iuspection, they nerer have got much, under the best of circumstances, on either island. They pay little attention to it now, and gather what they flo during the winter season, going to Polavina and the north shore with sleds, on which ther hoist sails, after loading there, and sead home before the strong northerly blasts.

Captain Et skine informs we that the water is free and bold all aronnd the north sliore from Cross Hill to southwest Point; no reefs or shoals up to within a half mile of lanil anywhere. English Bay is very shallow, anel no sea.going ressel should attempt to enter it that draws over 6 feet.

AUTHORTIES FoR L.ITITIDE AND LOXGIIUDN-All the positions of latitude and longitude which I place upon this map are taken from Captain Archimandritov's manuseript chart. During the whole month wi Julr, 1Sit, while I was bere with the Reliance, there was not a single opportunity for a solar observation, alchongh Captain Baker mado sereral at tempts to make some. Captain Erskine, howerer, has verified Arehinindritor's work, and says that it is rery nea' the correct thing. I could hare taken observations easily in the occasional clear Norember dars of 1672 , but unfortunately the chronometer which $I$ bal proved so defectivo that I abandoned the labor.

How TO REACH IVALRUS IoLET. - To visit Walrus Islet in a boat, pleasantly and successfully, it is best to snbmit to the adrico and direction of the natires. They leave the village in the evening, and, taking advantane of the tide, proceci along the coast as far as the blufis of Polavina, where they rest on their oars, doze, anel smoke, until the downing of daclieht, or later, perhaps, until the fog lifts enough for them to get a glimpso of the islet which thes seek; they row over then in about two hours with their bidarrah. They leare, howerer. with pertect indifference as to darlight or fog; nothing but a southeaster can disturb their tranquility when they succeel in landing on Walrus Island. Ther would find it as difficnlt to miss striking the extended reach of st. I'aul on their return, as they found it well-nigh impossible to push off from Polavina and tind "Morzovia" in a thick, windy fog and running sea.

OTter Islet: Slight correction,-Otter Island, or "Bubrovia," is ensily reached in almost any weather that is not very storm two hours to row over from the rillage, while I havo gone across once in a whale-boat with less than one hour's expendituro of time, sail, and oars, en route. A slight mistalie of the engraver causes Crater Point to appear as a bifurcated tongue. It is not so; but there is a funnel-shaped cavity here plainly emarginated from the sea, and on that extreme point, constituting and giving to it this name.

"Anything missing or beyond human ken, in the Aleutian vernacular, is "maaslncken." 




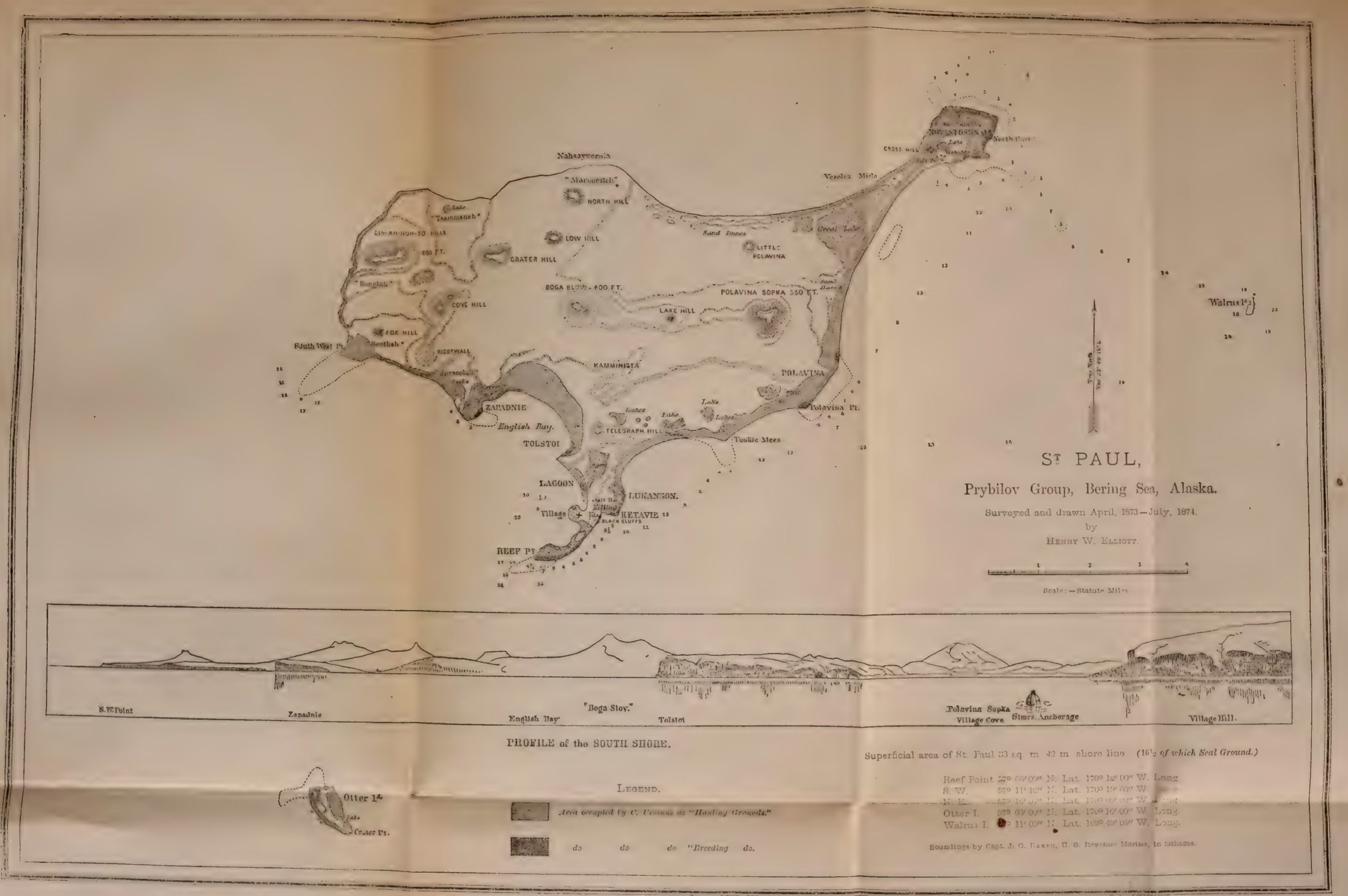






\section{EXPLANATORY NOTES AND COMMENTS UPON THE MAP OF ST. GEORGE}

ISLAND.

ST. George.-This title was given to the island b5 its discoverer in honor of his reseel, the sloop St. George.

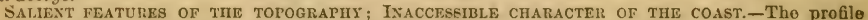
mhich I give of this island presents clearly the jden of that characteristic, bold, abrupt eleration of St. Gcorge from the sea. From the Garden core around to Zapainio beach, there is not a single natural opportanitv for a man to land; then, again, from Zapadnie beach round to Starry $\Delta$ teel there is not one sign of a chance for an agilo man to come ashore and reach tle plateau above. From Starry Ateel to the Great Eastern rookery there is an alternation, between the several breeding-grounds, of three low and gradual slopes of the land to sea-level; these, with the landing at Garden cove and at Zapadnie, are the only spots of the St. George coast where we can corve ashore. Au active person can scramble up at secreral steep places between the Sea Lion rookery and Tolstoi Mees, but the rest of that extended bluffy sea-wall, which I have just clefined, is wholly inaccessible from the water. A narrow strip of rough, rocky shingle, washed over by every storm-beaten sea, is all that lies beneath the mural precipices.

Prigtry Cascade at Waterfall nead. - In the spring, when the snow melts on the high platean, a beautiful cascade is seen at WVaterfall head; the feathery, filmy, silver ribbon of plunging water is thrown ont into exquisite relit. $\mathrm{f}$ by the rich background of that brownish basalt and tufa over which it drops. A nother pretty little waterfall is to be seen just west of the village, at this season only, where it leaps from a low range of blufls to the sea; the first-named cascade is more than 400 feet in sheer unbroken precipitation.

One or two small, naked, pinnacle rocks, standing close in, and almost joined to the beach at the Sea Lion rookery, constitute the only outlying islets or rocks; a stony kelp bed at Zapadnie, and one off the Little Eastern rookery, both of limited reach seaward, are the only hindrances to a ship's sailing boldis round the island, eren to scraping the bluffs, at places, safely with her yard-arms. I have located the Zapadnie shoal by obserration from the blufl's above; while Captain Baker, of the Reliance, sounded out the other.

AUTHORITIES FOI LATITUDE AND LONGITUDE.-The observations which fix the positions of Tolstol and Daluoi Mees are taken from Iinssian authority (Captain Archimandritov), while the lucation of the rillage was mailo by Lieut. Washburn Mraynard and mrself, in 1874, together with the degrees of rariation to the compass; we used an artificial horizon; the overcast weather prevented our rerification of the two other points given.

TREND OF OCEAN CURRENTS nERE.-A lthough small quantities of drift-wood lodge on all points of the coast, yet the greatest amount is found on the south shore, and thence around to Garden core; this drift-timber is usualle wholly stripped of its bark, principally pine and fir sticlss, some of them quite large, 18 inches to " feet in diameter. Several sears occur when a large driftage will be thromn or stranded here; then lons intervals of many seasons will elanse with scarcely a log or stick coming ashore. I found at Garden cove, in June, 1873, the well-preserved husk of a cocoanut, cast up by the surf on tho beach; did I not know that it was most undoubtedly thrown over by some whaler in these waters, not many hundred miles away at the farthest, I should have indnlged in a pretty reverie over its path in drifting from the South seas to this lonely islet. I presume, Lowerer, that the timber, which the sea brings to the Prilirlov islands, is that bornes down upon the annual floods of the Kuskokrim anil Nushagak rivers, on the maipland, and to the east-northestward a little more than 225 miles; it comes, liowever, in vers seant supply. I saw very littlo drift-wool on St. Matthew island; but on the eastern shore of St. Lawrence thero was an immense aggregate, which unquestionabiy came from the Yukion mouth.

SroT of Priby lov's LANDING,-One of the natires, "stareek, "Zachar ()ostigov ("the president"), told me that the "Iiussians, when they first landed, came ashore in a thick for" "at 'Tolstoi Mees, near the present Sea Lion rookery site. As the water is deep and bold there, Pribylov's aleop, the st. George, must have fairly jammed her bowsprit against those lofty eliffs ero the patient crew had intimation of their position. Tho old $A$ leut then showed mo the steep gully there up which the ardent discoverers climberl to tho plateau above; and, to demonstrato that ho was not chilled or wealiened by age, he nimbly scrambleal down to the surf below, some 350 rertical feet, and I followed, half stepping and half slivlinis over Pribylov's path of glad discovery and proud possession, trodden one June clay by him nearly a hundred years ago.

SUGGEATIONS FOR DETTEIR J.OADING AND IISCHARgING A CARGO.- With regard to the loading and unloading of the ressels at St. George, I beliere that it would be wise and economical to grade a wagon road over from the villawo to Garden covo: I think so because weeks and weeks have passed, to my persenal knowlerlgo, between the unlnading and tho loading of the steamer; when, luring all that season of weary, anxious wating for the surf to quist down at the village landing, thero was not a single day in wl-ich the ship conld not have discharged or receired her cargo easily and expeditiously on tho saud bearll at Garten covo. When tho St. Paul has 75,000 seal skius in her hold, taken on at the larger island, then his to pound "off and on" here, in for and tempest, for a week or two, or eren longer, waiting for a chance to get the 20,000 or 25,000 St. George skins (ready for her) in turn, her earro is tom costly to risk in this manner, inasmuch as the difficnlty can be reatlily obviated by the cart road I have indicated. The natives could and would hitch themselves into large hand-carts, and thus draw the skins acrosis and supplies back, with tho aid of a nule or two on the stiff grado; this wonld occur in ascending A hluckejak rilge from the village, and also up a short one aqain rising from Garten cove to the mesa tops. The distanco is only 23 to 3 . miles, aud 2 miles of that is nearls tit for wheels, as it lies to-dlay. I think, seriously, this should be dono; it may save or prevent in the fuiure the loss of a valuablo slip and her priceless cargo of human life and all its belongings. Thick fogs and howling gales of wind are dangerous and chronic here.

WIIAT THE skETCH-MIAP sHows. - The sketch-map of Alaska, which I have inserted in the lower corner of this chart of St. George, is to show, better than any language can, the relative position of these celebrated seal islands; and also to give a clear idea of their isolation and great distanco from Sitka, where most of our people think all d liska is centerel. In fact, Sitka, as far as trade and resources and population are cuncerned, is one of the most insirnificant spots linown to that country. Kadiak, Oonga, Belcovskie, aud Uonalaska each have a greater cirilizedpopulation than bas Sitka to.day, and each has a humdred-fold moro importance as a trate-center. As the abip sails, the Pribylovislancls are:

2,250 miles WN W. from San Francisco.

1,500 miles WN W. from Vancouver island, straits of Fuca.

1,400 miles WV N WV. from Sitka.

950 miles SIVN IV. from Kadiak.

192 miles N N IV, from Oonalaska.

700 miles ENE, from Commander islands, Russian territory.

All these distances are via Oonalaska, sare the last one. 


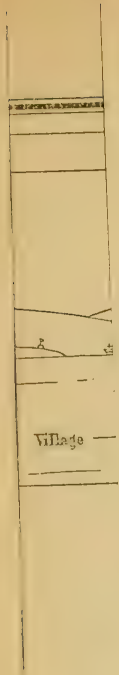

asteruz"

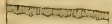

"GUL

(1.) at $\frac{3}{3}=2$

Gard

$\bigsqcup_{10}$

Tatawfo] मूa

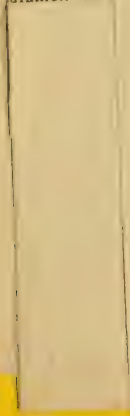





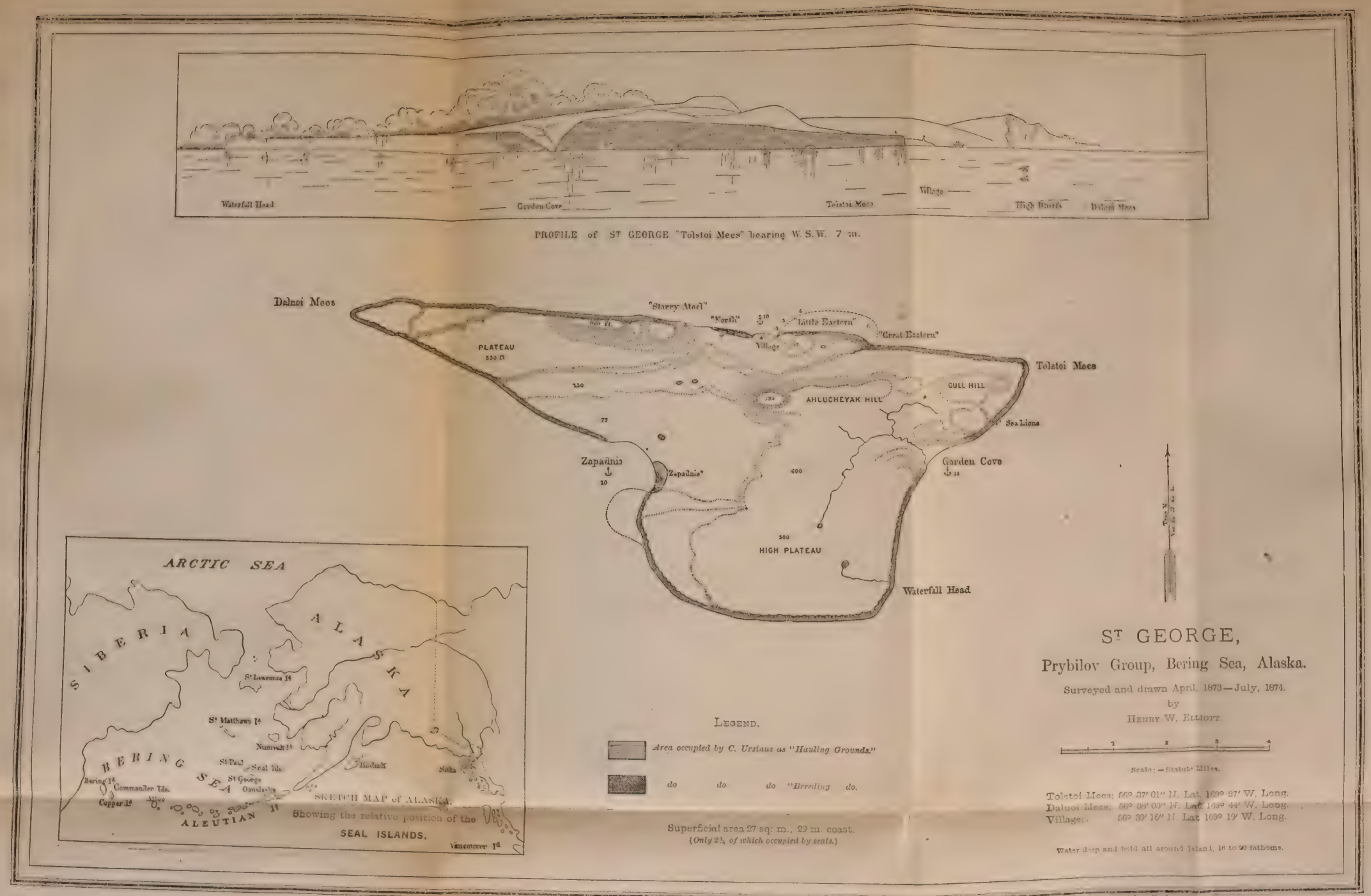







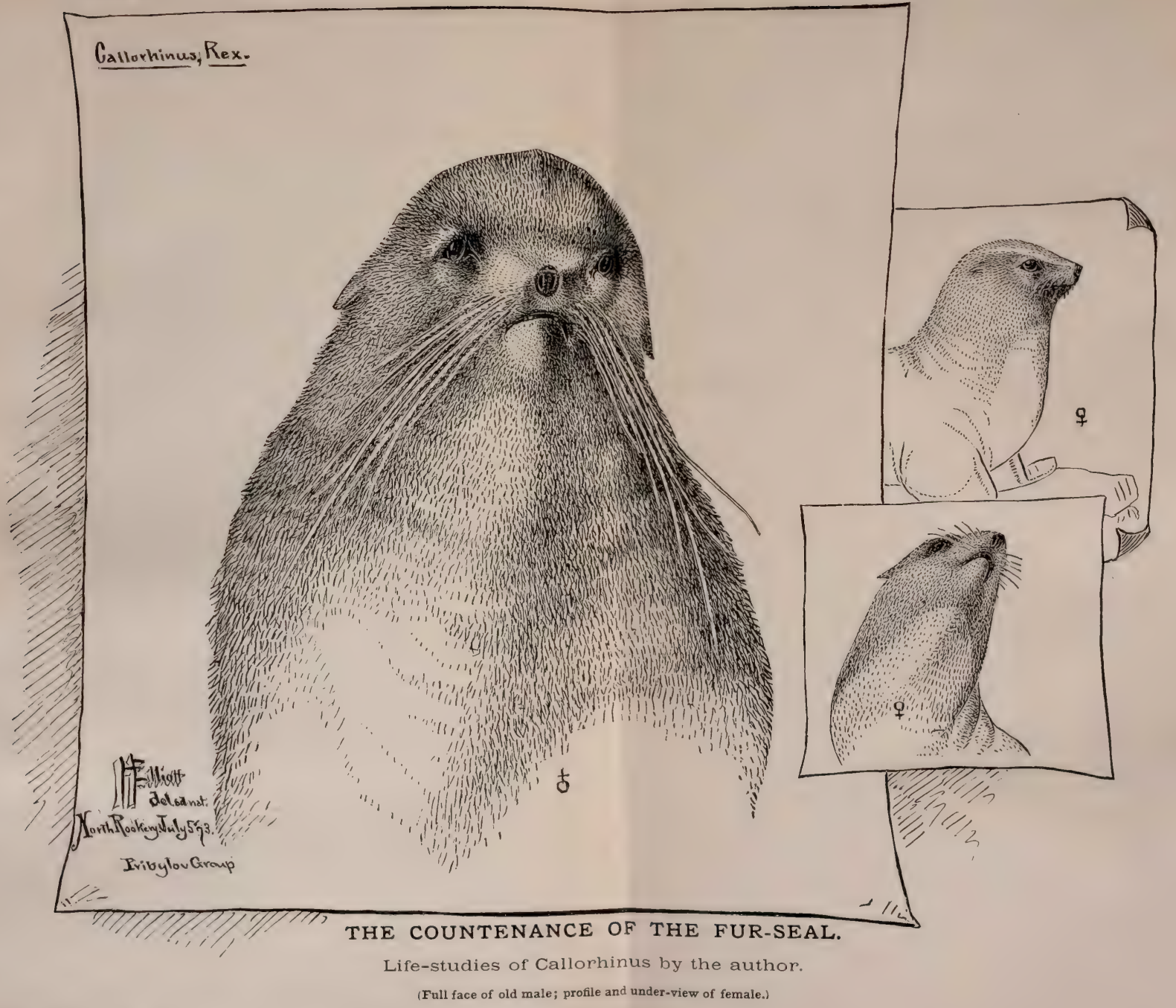


Plate 7. ivestigation-SEAL-ISLANDS.

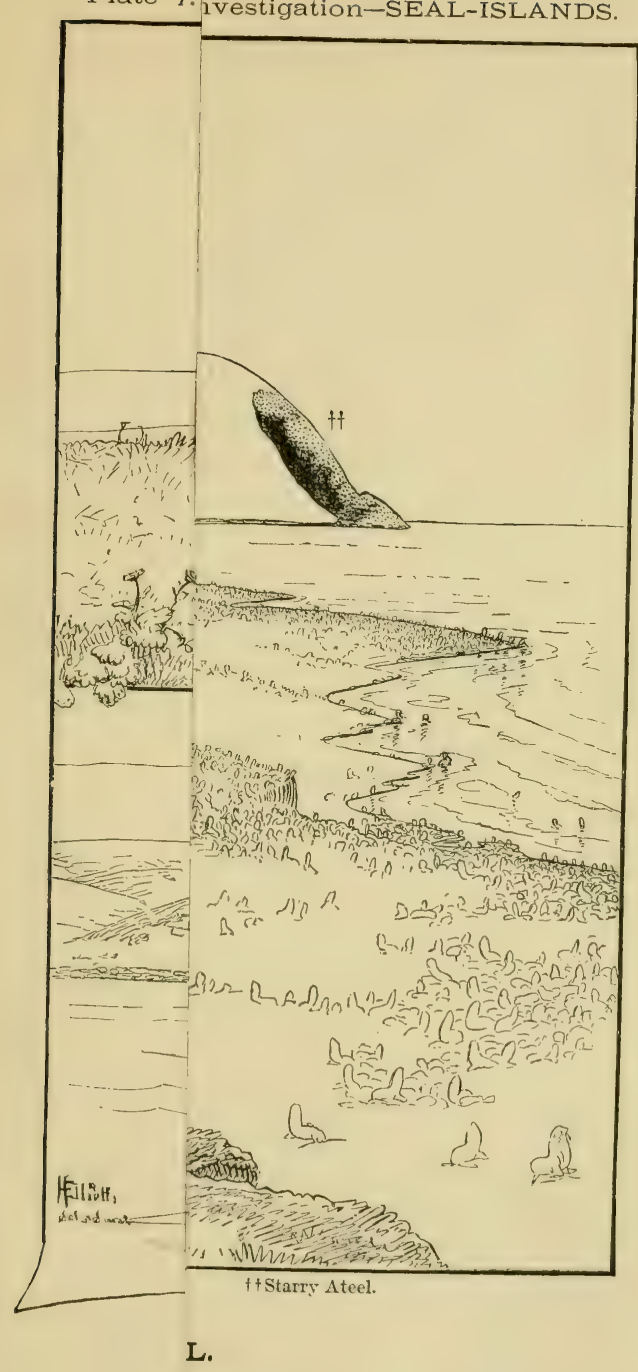





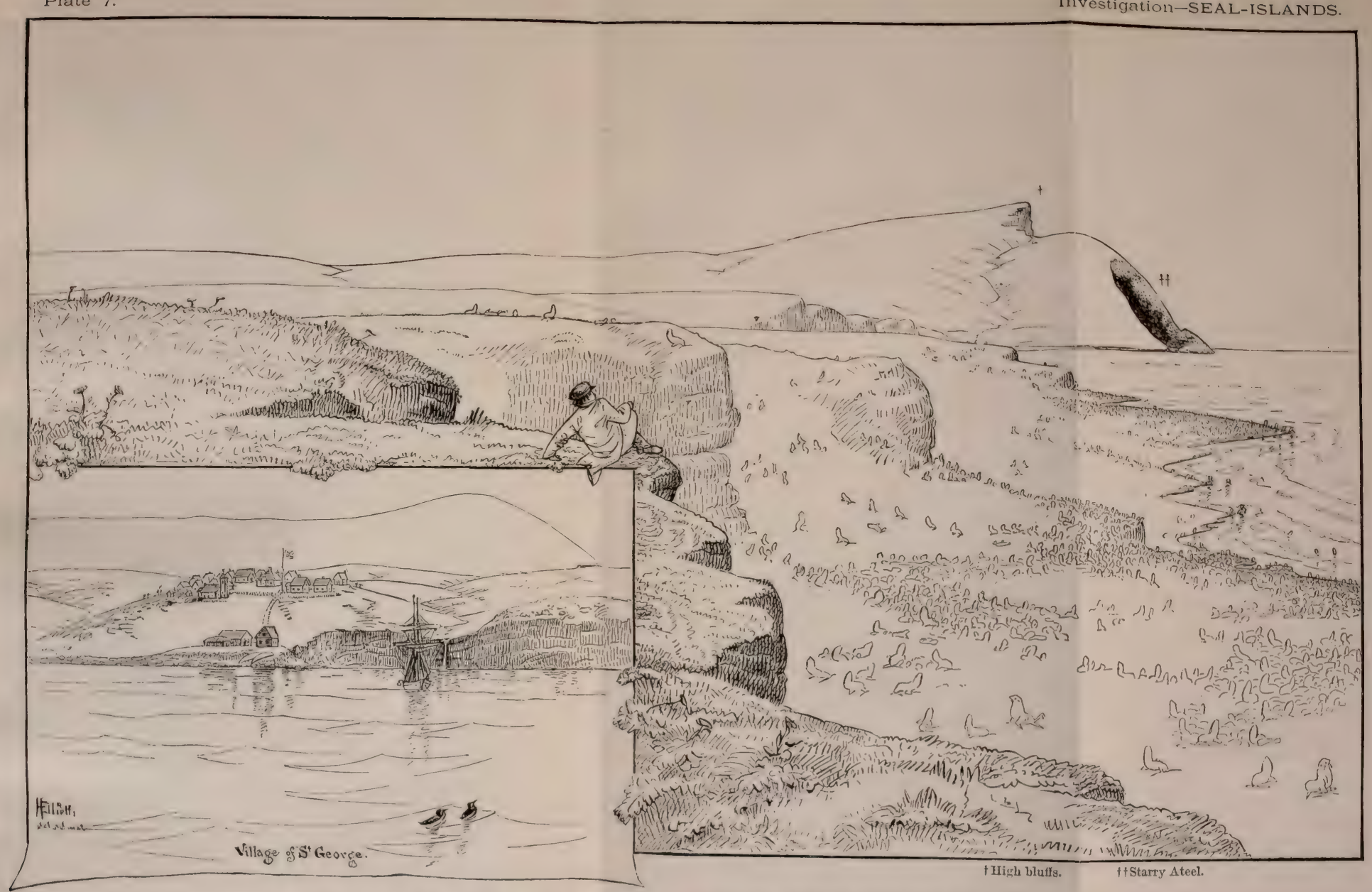

VIEW OF THE NORTH ROOKERY, LOOKING WEST TO STARRY ATEEL.

St. George Island, Pribylov Group. 


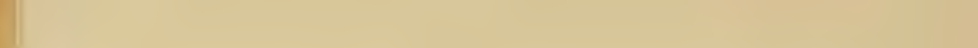




\section{SEAL-ISLANDS.}

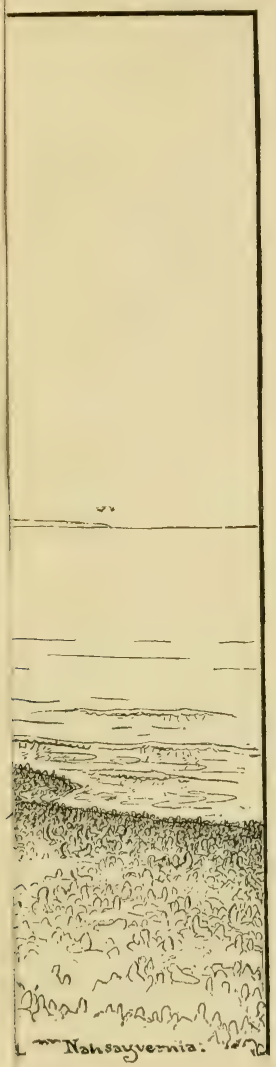

bokery: 



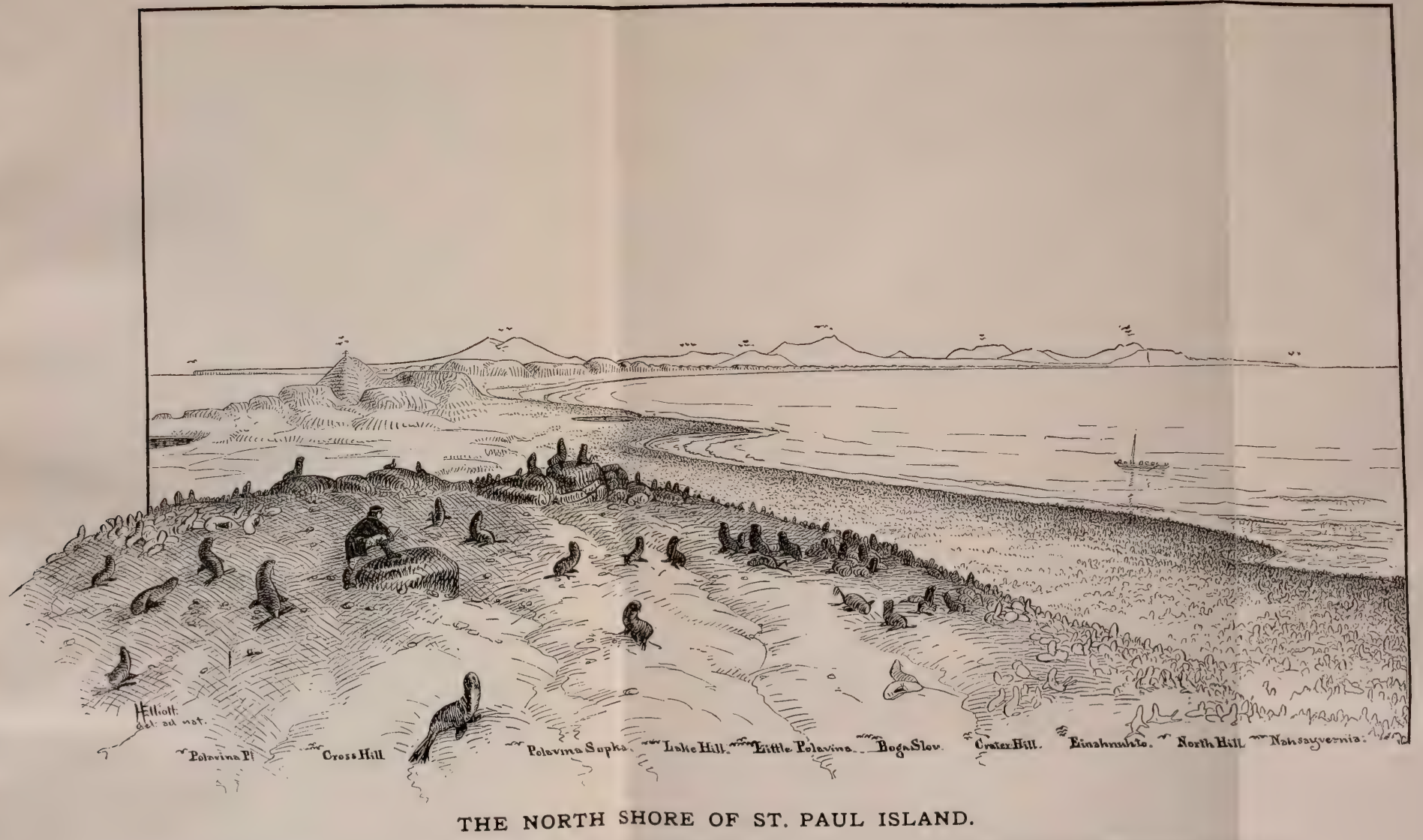

Viewed from the summit of Hutchinson's Hill, looking W. S. W. over a portion of the Great Novastoshnah Rगokery 

Plate $9 . \quad$ On-SEAL-ISLANDS.

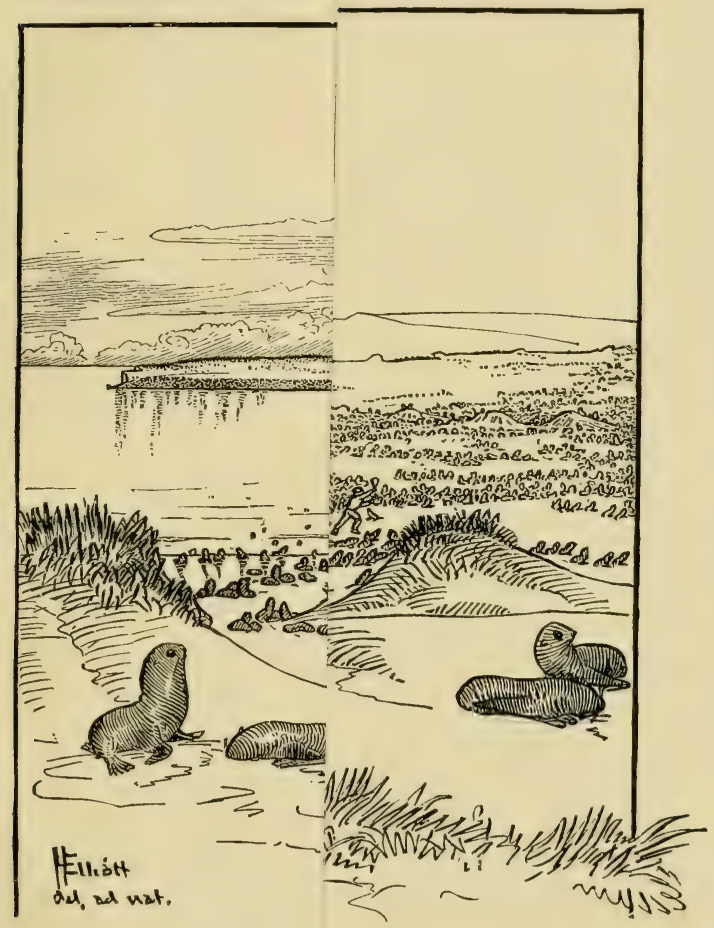

Zapadnie.

View over lstoi Sand-dunes. 



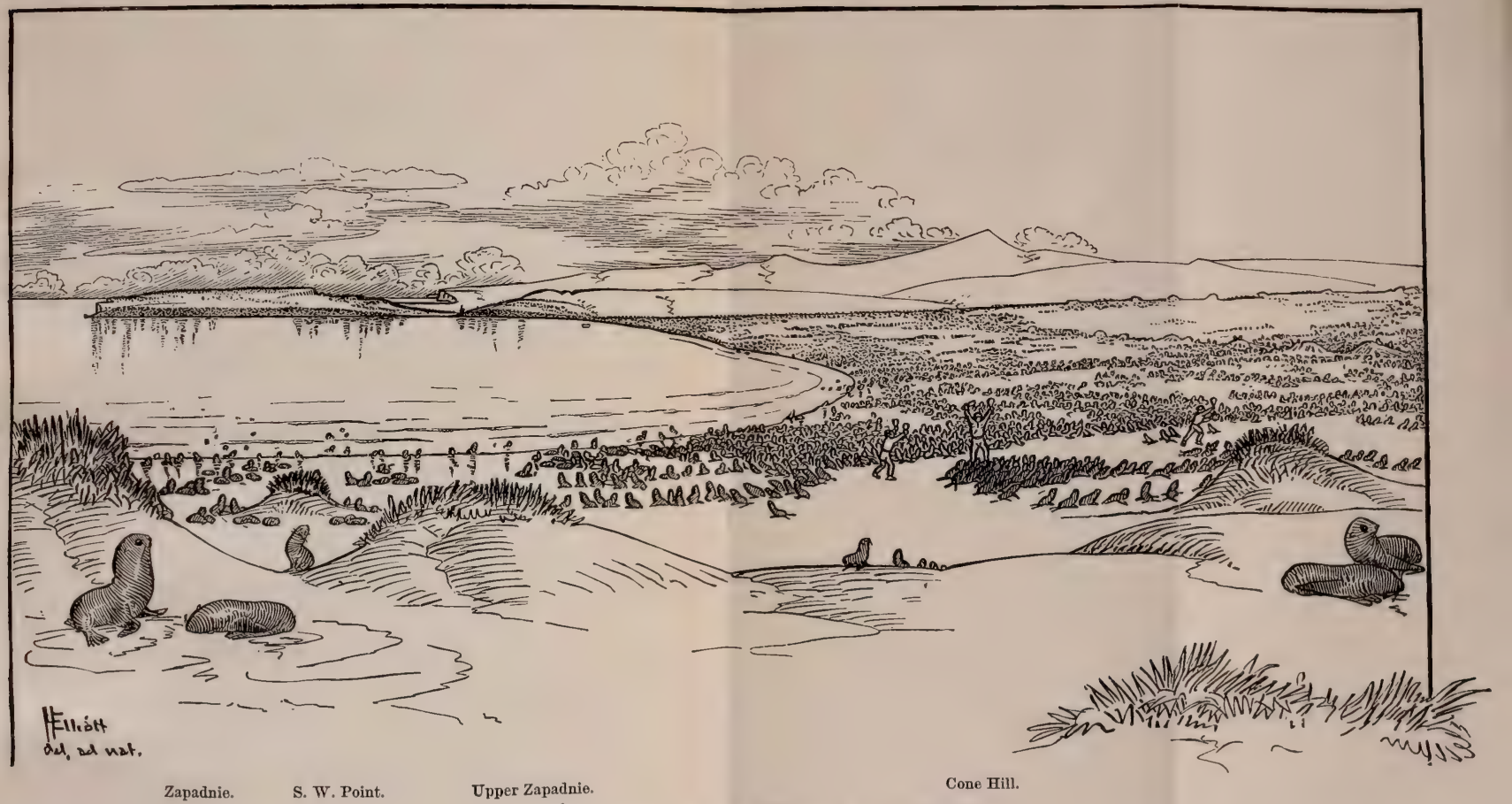

NATIVES SELECTING A DRIVE.

View over hauling-grounds of "holluschickie" at English Bay, looking west from Tolstoi Sand-dunes. 



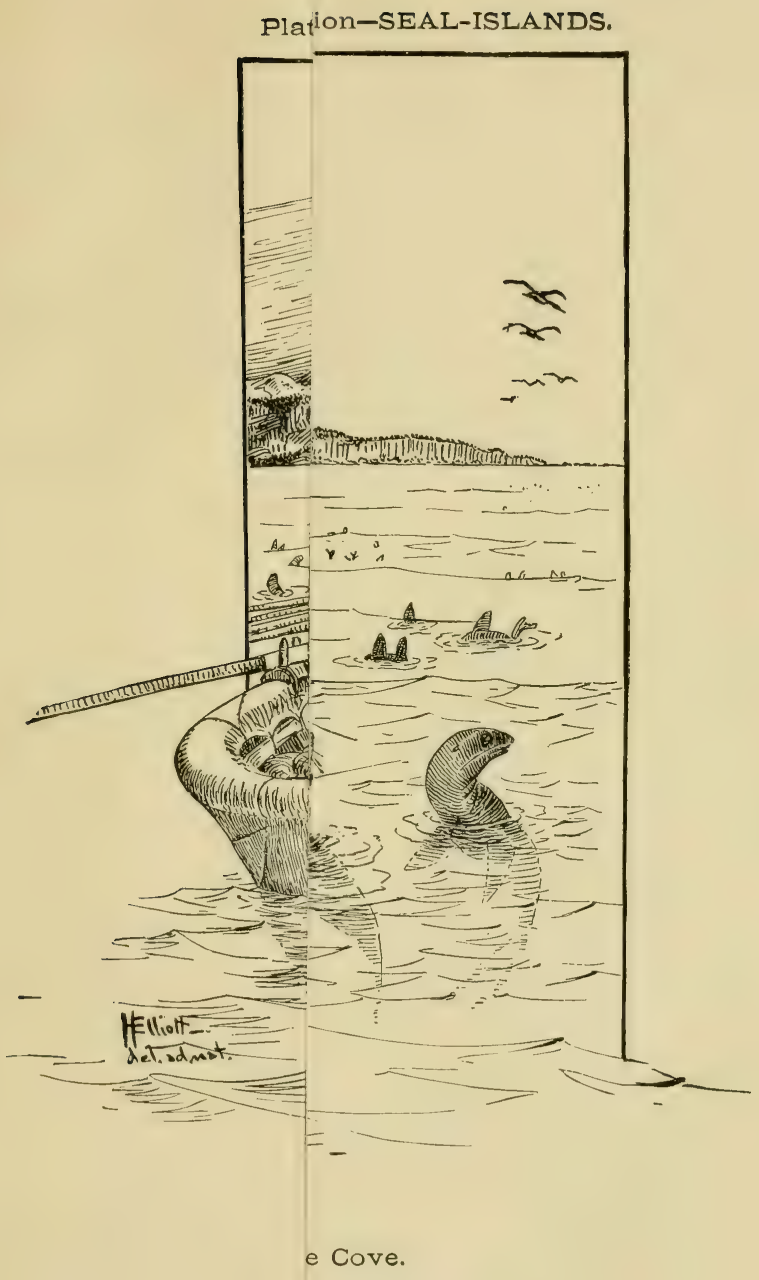



FUR-SEALS SPORTING AROUND THE BAIDAR.

Natives of St. Paul lightering off the bundled seal-skins to the ship from the Village Cove. View looking east over Zoltoi Bay on to "Gorbatch" of the great Reef Rookery. 





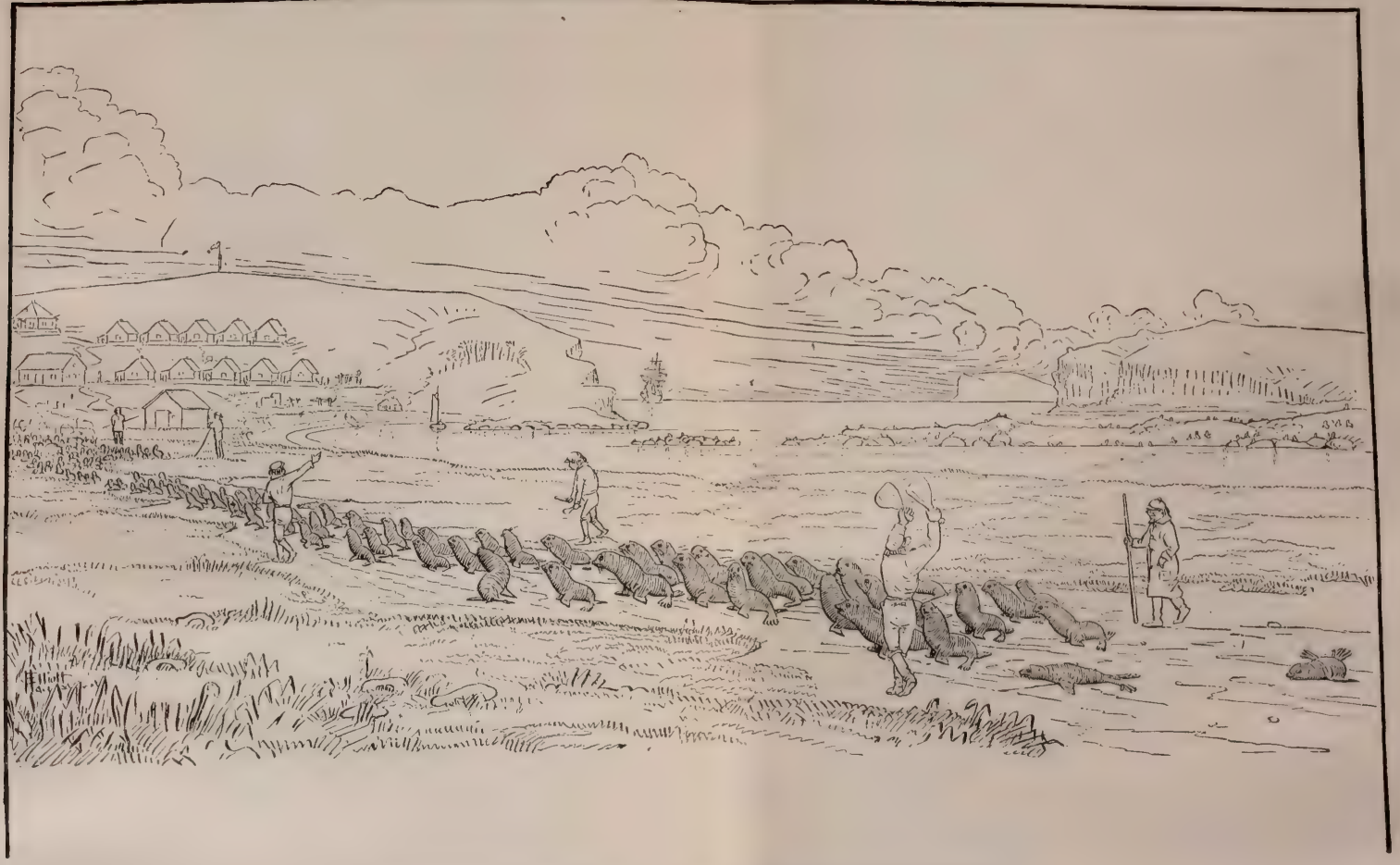

\section{NATIVES DRIVING THE "HOLLUSCHICKIE."}

The drove passing over the lagoon flats to the killing-grounds, under the village hill, St. Paul Island. Looking S. S. W, over the village cove and Lagoon Breeding Rookery, July 14, 1872. 

Plate 12.

ation--SEAL-ISLANDS.

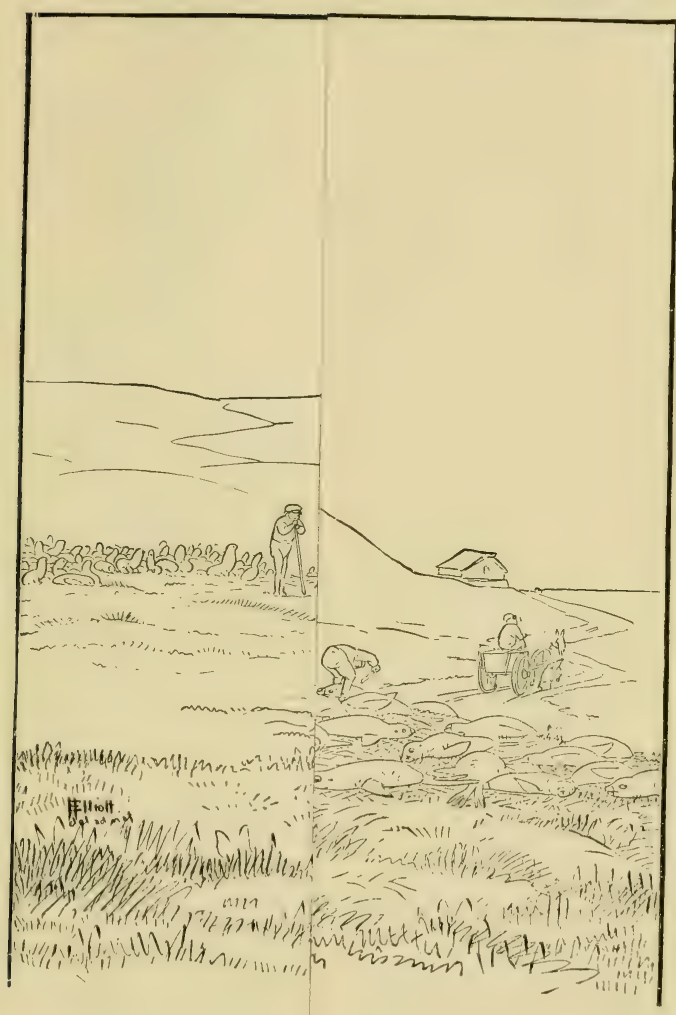

Misland.

The drove in waiting. ling. 





THE KILLING-GANG AT WORK.

Method of slaughtering Fur-seals on the grounds, near the village, St. Paul Island. 



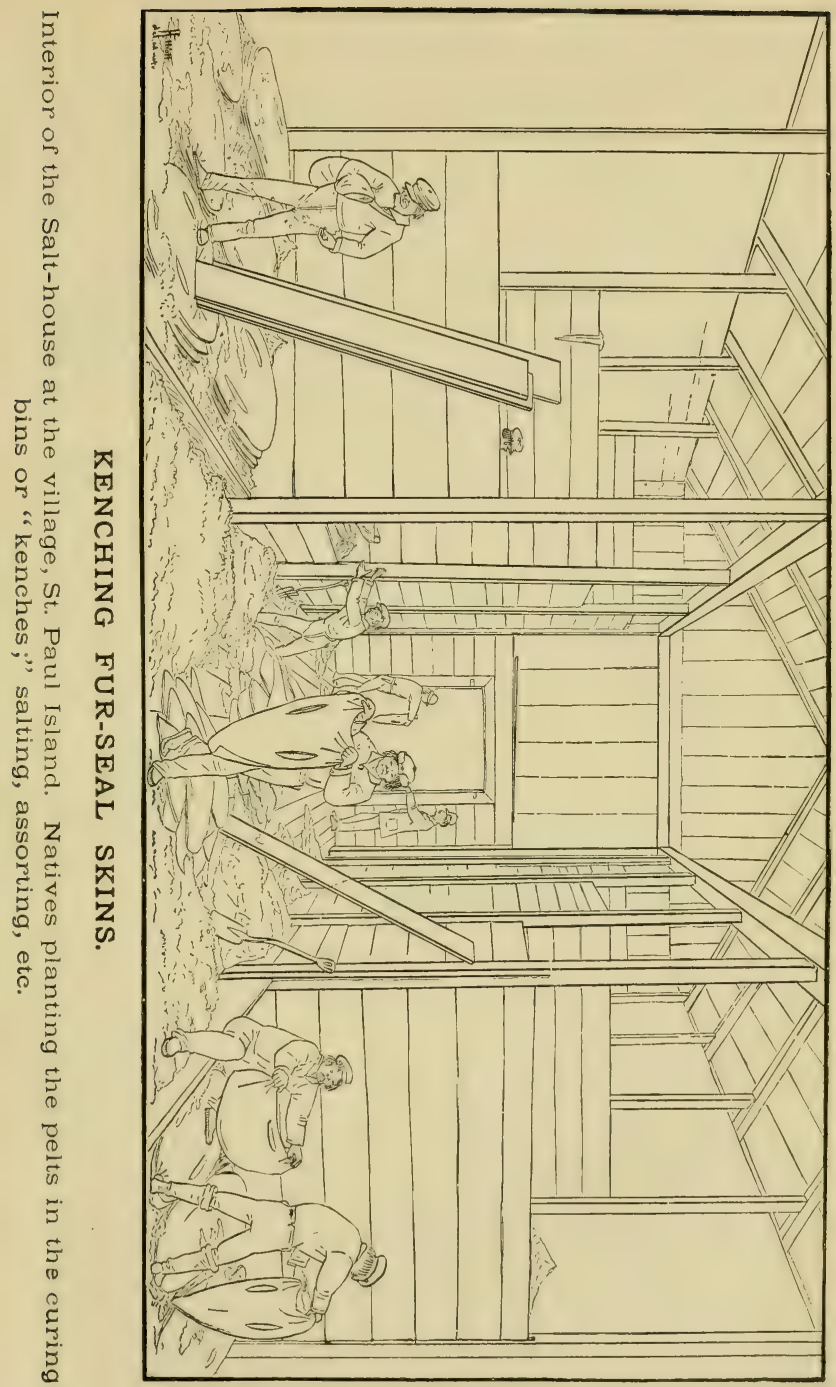





\title{
STATEMENT OF NR. GEORGE R. TINGLE.
}

\author{
W:ASHINGton, D. C., September 24, 1888.
}

GEORGE R. TINGLE, sworn and examined:

By the CHATRMAN :

Q. Please state your offi cial position.-A. I am the United States Treasury agent in charge of the fur-seal islauds of Alaska at the present time.

Q. You have visited those islands and discharged your official duties for what length of time?-A. I was appointed United States Treasury agent by this administration in April, 1885, and proceeded to the islands in May, 1885, arriving there on the 29th of May. I remained there continuously until August, 1886. I was there during the winter and continuously for fifteen mouths upon the islands. I came down to the States in August, 1886, and returned to the islands in May, 1887, and remained during the summer, attending to the duties of my office, overseeing the taking and shipment of seals, and came back in Angust, 1857. I returued to the islands in May, 188s, and remained during the last summer, attending to the duties of my office. After completing my report and shipment of the season's catch of seals I returned to San Francisco.

Q. You have just returned from the islands?-A. Yes, sir.

Q. State the nature and character of your official duties and generally what you are required to do?-A. I an the representative of the Govermment upon those islands, and hare three assistant agents. I am required to see that the lessees do not violate the law under their contract, and I am supposed to govern the natives, protect, them and regulate them. Practically the Government agents are the governors of the islands in connection with the management of the seal business. The agents have absolute control of the natives. The lessees have not anything to do with them or their management, other than to employ them as their operatives and pay them. The Gorermment agents are required to see that the natives are kept in subjection, and that they perform their duties toward the lessees, protect the seal rookeries particularly from any interference, either from the lessees, their employés, the natives, or any person visiting the islands. We guard and protect the seal rookeries.

Q. You supervise and overlook the taking of fur seals ?-A. I do.

Q. You see that it is done according to law ?-A. I go on the killing fields and see that the seals are properly driven and killed. I take a personal supervision over the business, see that the seals are driven and killed with the least possible loss of seal life. We are very particular as to that, and the Govermment agent frequently has occasion to reprimand the natives for hurrying the seals along too fast. When they become overheated they often die, and unless the skins are taken immediately afterward, when the weather is hot, the skins are not good. If it is a cold and wet day, the skins would be good for a day or two after the seal dies. I frequently walk over the driving ground to see that the natives are doing their work right, and I remain during the killing and skinning on the field to see that the work is going on satisfactorily. My assistants count the skins when they are taken into the salt-houses. The company's agent throws the skins ont of the pile and counts them, and the Government agent counts them with him. When the season's 
business is closed the skins are ready for shipment, and I count them out of the salt-houses for shipment, so that they are counted twice on the island. Those are the only counts. The natives do not count them or pay any attention to the counts. The Government agent counts them twice on the island, and when they arrive at San Franciseo they are counted out by the collector. At the islands the ship counts them while they are going aboard, and the ship also counts them at San Francisco.

Q. I wish you would state whether under that system there is a chance for any skins to be shipped direct to San Franciseo? $-\mathrm{A}$. It would be impossible for a slin to leave the island without the knowledge of the agents upon the islands, unless possibly a native might have a skin stowed away in his house, and had elandestinely got it aboard of a cutter or some other boat.

Q. Under the present system as adopted by the Gorernment is it at all practicable or reasonably possible that a ship could get any skins that the Government agents could not be aware of ?-A. It would not be practicable or possible. It could not be done. The company could not ship skins without the knowledge of the Gorernment agent. The company's ressel is the only one, except the vessels of the United States, that is permitted to land there. When the company's ressel arrives there it is for the purpose of discharging cargo or receiving the skins. Of course I am in and out of the salthouses at all times, and see and know everything that is going on between the ship and the shore. I count the skins out of the warehouses as they are loaded into the company's Bederahs and carried out to the ship. The company's agents take them right from the pile as I count them out, and they are taken direct to the ship. I do not allow any interference when I am counting, and so far my count has proven to be the most correct. It is impossible for any two counts to be alike. No person goes near the pile of skins where I am connting except my counters and myself. I have two good men to throw. They throw the bundles over in another part of the house and one calls out the odd number and the other the even number. They are counted ont in tallies of twenty. It would not be possible for the company, or anybody else, to ship any skins from those islands without the knowledge of the Government agents on the islands.

Q. Are there always Goverument agents there, either the principal or the assistants, while the seals are present?-A. Yes, sir; while the seals are present or not present. We have four agents, one in charge, and three assistants, and it has been the custom to have an agent remain on the islands at all times. While two agents are on the islands, two are down.

Q. So that all during the sealing season you have two on each island at all times?-A. Yes, sir ; the company commences killing the first of June, and continues until it gets its quota of 100,000 skins, which generally requires about forty days.

Q. What class of seals do you permit to be killed? - A. They are not permitted by law to kill seals under the age of one year. The company generally selects seals from two to five years old.

Q. Male or female?-A. They never kill anything but male seals; and we never drive up any but males. Males only are killed.

Q. They are nerer driven from the breeding grounds ?-A. No, sir; they are never driven from the breeding grounds, as there are no seals upon the breeding rookeries, except bulls, cows, aud pups. The young batchelor seals haul up by themselves. They are not permitted by the 
old bulls to go upon the breeding line. They would be torn to pieces if they attempted it. They would like to, but they can not possibly do it until they are about seven years old.

Q. So that these bachelor seals are the only seals that are driren and killed?-A. Yes, sir; they are obliged by the nature of things to haul ont by themselves. Drives are made from the hauling grounds of the bachelors, and females rarely get on these grounds. They are driven up to the killing grounds in front of the village, where they are killed and skimed. We keep a daily record of the number of seals killed. I do not know that sou desire it, lut I went up to the Treasury Department and got a statement of the daily killing, which shows the system of keeping our accounts.

Q. You keep that and return it to the Treasury Department as an account of your daily killing?-A. Yes, sir.

As an exhibit to my evidence, I will append copies of my annual statements of the killing of fur seals, with explanatory headings, showing total number killed of all kinds for 1887 and 18ss, which will illustrate the system.

Q. You say it has been found practically impossible to make the count upon the islands and at the custom-house correspond exactly?A. Certainly; it will vary a few skins every year.

Q. Is there found to be a material difference? - A. No, sir ; never a material difference.

Q. On which count does the company pay?-A. On my count at the islands. The law says that " the tax shall be paid on all fur-seal skins taken and shipped" from the islauds. Before I was appointed by this administration the Treasury Department had chauged the place of pay. ing the tax, and ordered that the tax be paid on the count at San Franeisco. The reason for loing it was that the discrepancies rumning through a term of years showed the San Francisco count to be a little more than the island count-a few skins more-and the company preferred paying on the greater amount, so that there might be no question of its receiving skins that it had not paid for. That is my understanding. I do not kuow that there was ever any question about it on account of the discrepaneies; they were slight and unavoidable. The law requires clearly that the tax shall be paid on the island count, and the administration so ordered. These counts have never varied more than thirty or forty skius between the island count and the San Francisco count.

Q. During your administration has the company faithfully performed its contract to the Goverument and the natives, and in the preservation of seal life, and in every other respect?-A. Yes, sir; it has performed all its obligations under the lease. I hare never had occasion to complain in any instance, except once or twice on a little difference that grew up between the general agent, Mr. Melntire, and myself about matters of poliey, and it was always adjusted very readily by the company always sustaining my views. They were matters of trivial importance-things not necessary to report to the Department, and which the company regulated themselves. The company has never failed to perform its duty since I have been on the islands. The truth is, they hare done too much for those natives. I have complained a little myseif of that. They have educated the natires and carried them along to expect more than they may receire hereafter from somebody else, and there may be trouble on that account.

Q. By doing more for them than the law requires?-A. Yes, sir; more than the law requires and more than is necessary for their com- 
fort and happiness. In other words, they are not treated by the company as employés in the States are treated. They are treated with too much cousideration and deference. They have never been accustomed to such treatment.

Q. What does the company do in excess? You say they do more than the contract and the law requires. What does the coutract require? $-\mathrm{A}$. The law requires that they shall furnish these natives with a maintenance. It does not require that the company shall pay them 40 cents per skin, but that they shall furnish them with a maintenance.

Q. You mean for killing and skinning seals ?-A. Yes, sir; for killing and skinning seals the natives every year receive $\$ 40,000$. They can not spend it all in their maintenance. It is not necessary ; $\$ 20,000$ would be ample each year. The company also carries them around on their vessels from island to island free.

Q. Are the natives not capable of purchasing and owning property and estates, if such were accessible ?-A. Some few are; very few.

Q. Is there any property on the island that they might buy?-A. There is property on the island, but they could not raise anything on it; absolutely nothing.

Q. Can they use money in business in any way?-A. No, sir. They can not raise ansthing on the island. It will not produce anything, except grass. They have attempted to raise vegetables, such as potatoes, and they never grew larger than the size of marbles. It is impossible to raise anything on those islands. The natives were expected, under their coutract, to do all the work for the 40 cents per skin pertaining to the business.

Q. The law forbids the company to employ other than natives?-A. Yes, sir; but the company have of late years brought from Oonalaska a considerable number of men-thirty or forty.

Q. Natives? - A. Yes, sir; natives of Oonalaska, and employed them on the islands to do the rough work, paying them extra from $\$ 30$ to $\$ 40$ per month each. They do almost balf of the work. They do all of the drudgery upon these islands, such as salting skins, loading boats, loading and discharging cargo, and work on the seal fields. The Oonalaska natives are paid extra by the company, whilst the island natives receive the full sum of $\$ 40,000$ each year. It is this indulgence that the company has granted these island natives that I most complain of. I think that they ought to be required by the company to do all the work. They are paid for it, and they should do it, instead of bringing other men there. Of course, by death, the natives on the islauds have been largely reduced, and as the company is anxious to get its catch within the time allowed by law, they employ extra help; they must get their quota before the 15th of August, because then the skins become stagey; so that, in order to facilitate matters, they have adopted this plan of bringing natives from Oonalaska to help do the work.

Q. The natires are unwilling to do it?-A. They will be now. They will growl like ererything if they are ever compelled to do it all.

Q. The natives are giad to be relieved from that rough work ?-A. Of course.

Q. All they do is to kill seals ?-A. All the natives do is to drive, kill, and skin the seals. They knock the seals in the head, stick, flipper, and skin them, and help to salt them in the salt-houses. They do not bundle or do any of the outside rough work. They are called on to salt skins in the salt-houses, and some of them think that a hardship. It only takes about an hour each day to salt the day's killing. 
Q. For this work they reveive the full 40 cents a skin ?-A. Yes, sir; for that they receive the full 40 cents a skin. I say it is an injustice to pay out $\$ 3,000$ or $\$ 4,000$ to other natives to do the work for the fnrseal island natives. It has demoralized the natives of the islands. Forty cents is more than a maintenance for them. Twenty cents would be a good maintenance, and ample.

Q. Forty thousand dollars a year is divided among how many? What is the population of the islaud ?-A. St. Paul has 237 and St. George 112 inhabitants.

\section{By Mr. Felton:}

Q. Are they all Alents?-A. Yes, sir; and I am counting males and females, young and old. The number of men and sealers in 1887 was 60 ; in 1872 ic was 71 , showing a falling off.

\section{By the Chatrman:}

Q. How do the uatives spend their money?-A. The company has a store upon each island well stockerl with all of the necessaries of life. They have all the articles found usually in a well-regulated country store. They do not go in to the fine goods quite as extensively, perhaps, but they have everything that any family, white or black, would require. The natives spend their money for dry goods and groceries only.

Q. Is there any intoxicatiug liquor's sold there?-A. Not a drop. There is not a drop landed, except for medicinal purposes, and small quantity is taken up by some of the officials. They keep drugs and a doctor on each island, and carry up liquors for medicinal purposes ouly. Not a drop of liquor is sold to the natives, and they can not get it. Somo years ago the natires became very intemperate by the use of a villainous beer called "quass," and my predecessor, Mr. Glidden, stopped the issuing of sugar to the natives, and they were prevented thereby from making this quass.

Q. The sugar is the principal ingredient, is it? -A. Yes, sir; sugar is the necessary ingredient, and they mix a little flour in it. Mr. Glidden stopped the issuing of sugar, and I have followed the same course since I have been there, and the result is that there is no intemperance among the natives at all. The company is very particular not to carry any intoxicating liquors upon their vessels.

Q. What rates does the company charge for goods?-A. Upon the two islands about 25 per cent. over the wholesale cost in San Francisco. The invoices are free for my examiuation. I am free to go into the store and see the prices charged to the people. They mark all their goods in figures, and I go through the invoices and regulate the prices if there is any necessity, which does not often arise.

Q. Do you compare those invoices with the San Francisco prices to satisfy yourself ?-A. Yes, sir. I have gone to stores in San Franciseo where the company deals. I did not carry any of these invoices with me to compare them with the books, but I took measures to satisfy myself that the prices charged were the wholesale prices in San Francisco and 25 per cent. added. I have been a merchant inyself and am fimiliar with the handling of goods, and I am also familiar with the the prices of goods at retail. My wife, who was on the island with me the winter I remained there, wąs astonished that goods in the company's store were always as cheap as she could buy them at retail in San Francisco. As to the prices charged the uatives upon the islands, there is no question but that they are lower than the retail prices in San Franciseo.

Q. Do you think that these people buy goods cheaper than laborers 
in our cities?-A. Yes, sir. Their condition is very much better than that of the laboring classes in any city of the United States to.day.

Q. Is there any suffering or pauperism among them ?-A. There is not a pauper upon the island. They all partake of this distribution fund.

Q. Men, women, and children?-A. No, not the children. Last season six men died and left widows, who were paid $\$ 250$ each out of the native fund.

Q. You are now reading from a statement accompanying your report to the Secretary of the Treasury?-A. Yes, sir; which will appear in this written statement that I have already promised to furnish the committee. Widows whose husbands had not died during the killing season are supported by the company out of their store. They go to the store twice a week and draw groceries and other necessaries of life just as though they had money to pay for them. The company give to them groceries and other supplies. They did not pay anything for them.

Q. How long does that continue?-A. As long as they live and remain widows.

Q. Do you mean that the widows of the natives after the deaths of their husbands are provided by the company, instead of having an allowance set apart from the earuings of the takers of the seals?-A. I do; they are provided with the necessaries of life only, free of cost.

Q. I thought it was in evidence here that a certain percentage of this $\$ 40,000$ was set apart for the support of the widows? $-\mathrm{A}$. That is a fact. Widows who lose their husbands, say since the last sealing season began, are paid ont of the distribution an amount that the Government agent, company's agent, and the chief may agree on, out of the $\$ 40,000$.

Q. They get seal meat free, do they not?-A. Yes, sir; seal meat is free, of course, to all.

Q. It is free to all the natives ?-A. It is as long as the seals remain there, and after the company closes the taking of its 100,000 seal skins, every week they make a little drive of seals for food.

Q. What class of seals ?-A. They kill only such as the company will accept the skins of. They kill for food and save the skins. They only kill what they will require for three, four, or five days, so that it will be fresh, until towards the end of December, when the seals are likely to leave, they drive up and kill largely of the killable seals, so that the natives may accumulate a stock to last them as long as possible into the winter. These skins are accepted by the company's agent, are counted into the salt-houses, and charged up in the daily record to the company. The food skins go into the next year's quota.

Q. Are there any methods adopted to preserve seal meat for the natives ?-A. There has nerer been any method adopted. Last year we talked the matter over, and this year Dr. McIntire and myself agreed upon a plan for building meat-houses.

Q. Cold storage?-A. Yes, sir; where we have a quantity of these carcasses, and preserve them during the season when the skins are stagey.

Q. If you do that, can you not preserve from the one hundred thousand sufficient meat? - A. That would not be asaving, because when we take seals for food after the company closes its catch, the more acceptable seals we can kill the more we have on the next year's quota.

Q. Then they are destroyed merely for food?-A. No, sir: as the seals are still there upon the islaud, it is a saving to secure their skins before they go to sea, as some are killed by their natural enemies in the water and do not return. 
Q. Does the company pay for those skins?-A. Of course. They go into the quota, and are charged against the company every day, becoming a part of the quota for the coming year. This is the ideal While these seals are there the more we can save of them the better it is, for this reason, that when they go into the water a large percentage of them will not returu next year, but while we hare them and we ean take acceptable skins, and use the meat as foor for the natires, we have got that much of a start on the next year's quota, for which the company pays the same as if they were killed next year.

Q. If you build this cold storage warehouse, it is possible to preserve a large amount of the meat of the one hundred thousand killed each year for other natives on the Aleutian Islands?-A. Yes, sir; it could be done if there was any way of transportation to those natives.

Q. The papers attached to your annual reports give the number of seals killed for food and the number killed for other purposes? - A. Yes, sir ; it is all there in detail.

I was goiug to tell you what this company does for these natives. They furnish a physician and medicines free to the natives, and their physician is always in atteuclance. The natives, however, are rery hard to manage when they are sick. They say to die is good, and when they get right bad and wake up their minds to die they geverally do so, the priest and doctor and everyboly to the contrary notwithstanding. The mortality is considerable each year, caused by carelessuess and general imprudence. They go out in the spring of the year after being shut in their hot houses, kept at a fearful heat by the use of blubber and other finel. They sit down on the damp, wet gronnd, and often get themselves wet up to their knees going through the grass. The result is that colds take them off, the mortality is very great among the natives. All of the efforts of the compan y's physician to change their mode of liring have proved, I was about to say a fainure, but there has beeu some improrement in them during several years past. But they are dying off so fast that the islands will have to have a new infusion of blood from sonie quarter pretty soon. I have mentioned that in my reports for the last year or two, and called the Secretary's attention to the fact that he would have to give the company permission to import additional labor to these islands. I think it is clearly within the power of the Secretary under the law to make an order at any time.

These islands were originally peopled from Oonalaska, about one hundred sears ago, and I think it would be perfectly proper to allow an accession of jopulation to these fur.seal islands to be made from Oonalaska or Attoo, where the natives are poorly off. It seems to me it is unfair toward the natives of Oonalaskin to take them up there and require them to do half of the drudgery and only get $\$ 70$ or $\$ 80$ each, while the natires of St. Paul get $\$ 500$ or $\$ 600$. They are the same people, and if there is a necessity for taking them up there (and I claim that there is), the point of difference between the company and myself has been that these natives should all go into the distribution together.

Q. Would the natiress of Attoo be willing to bes moved there?-A. I do not know whether they would or not, but whether they are or not they should be. The natires slo not know what is for their best interests. They are like children. I have had at times to peremptorily do things they did not want done. But it was for their interest, and it, almays turned out best. At $A$ tton the uatives do not have anything to live upon except fish and geese ; a few mackerel are packed in barrels there and shipped. They onght to be taken off there and brought to the fur-seal islands, in my judgment, becanse their women would furnish 
wives for the men of the seal islands and would sare them from going off. They go away looking for wives for the reason the regulations of the Greek Church forbicls the marriage of parties who are even very remotely related, as remotely as that of godfather and godmother. It is a very ridiculous thing, but can not be helped. If the natives of Attoo should be brought there they would make good sealers and would get a good living. It would reduce the income, of course, on St. Paul Island, perhaps $\$ 100$ to each inhabitant, but they would still have an ample income, and the other poor natives would receive a comfortable living.

Q. If the Government should take the vatives from Attoo to the furseal islauds it would avoid the probable necessity of having to support the natives of Attoo? - A. If they were all taken away there would not be any to support. It would be cheaper to move them to the fur-seal islands than to support them at Attoo.

Q. Do you think it is mobable that if the Government does not move them it will have to support them?-A. This company has for years had trading stations at most of the islands, but in former years they receired profits from these stations. They got more furs than they get now, but things are changed. They do not get a profit from all of these stations, and the people do not derire as much from the sale of their furs as formerly. Now if this company should drop out of that Territory, the Government wonld be compelled to take care of the people; or if this company should see proper to withdraw their care of the natives, the Government would have it to do.

Q. Is there auy law compelling the company to proride for those natires?-A. No, sir; it has no connection with their contract. Outside of the seal islauds the natives have no claims upon the company; they are free to deal with whom they please.

Q. It is simply gratuitous on their part?-A. Yes, sir; I think the lessees, whoever they may be, or whatever may be the disposition of this property by the Government-additional population for the islands must be provided-the lessee shonld have the privilege of selecting the additional men in connection with the Government officer. The Gorernment officer and the company's agent should be empowered to select such additional population and move them to the seal islands, with the view of getting the rery best men, those somud and healthy. The Alents are nearly all diseased; they have scrofula, and the selection made, as I stated, would secure better men than by taking an entire community and transplanting them.

Q. How are the natives of the seal islands housed?-A. They have comfortable frame houses. Each family has a house to itself of from two to four rooms. These houses were built by the lessees and are giren to the natives, rent free. They receive 40 tons of coal annually on St. Paul Island, and 20 tons on St. George Island. They receire all the salt salmon required for their use on both islands, generally 20 barrels on St. George Island and 40 or 50 on St. Paul Island, as may be required.

Q. Is that free of charge?-A. Yes, sir; free. The children get eight months' schooling free, and they are compelled to attend school after they are six years of age. They are very dull, however, and a child at seventeen or eighteen can scarcely more than read aud write, and know a little geography and spelling. They are rather averse to learuing English. The old people will not speak the "Americanska," as they call it.

Q. Do they teach English in the schools?-A. Altogether. 
Q. How is their condition as compared to what it was before the cession of the territory to the United States by Russia?-A. I can only speak from what I have read, and from the records and conversations with the old natives of the islauds. I hare of course inrestigated the subject, as far as I could. Old Kerrick Booterin, the most intelligent native of the islands, told me that under Pussian rule he was the highest salaried man on the islands, reeeived the highest par. That he was the head carpenter and the highest he ever received from Russia in one year was $\$ 60$. That man now receives about $\$ 600$, or a little orer, in cash. He has charge of the boats, and is one of the first-class men. That is a firir comparison betreen the Russian and the American rule. He told me that the pay of the natives for taking and delivering skins to the sirle of the vessel was 10 cents a skin. They were not supplierl by liussia to auy great extent in those days. There was a rery seanty stiply of tea ; about 45 pounds of flom per annum was furnisher each head of a family. They lived in what they call "barrabkies" and "barrakoons," large buildings made of earth in which they spent the winter. A large number would get into a building, so as to keep) warm, and save fuel. They built but one fire. Others wonld live in these sumken houses, 3 or 4 feet under ground and \pm feet, abovo grom ered with sorl. When this eompany took charge of tho islands it took these people up' out of the dirt houses and put them in comfortable frame cottages, and they have furnished them erer since, without cost to the natives.

\section{By Mr. FeltoN :}

Q. You say that under the lam thes are required to count the skins at the island?-it. Yes, sir.

(?. That would seem to bu the proper place for it?-A. Yes, sir.

Q. Then there mas a time when they took the count at San Francisco?A. Yes, sir; under Secretary Shermau.

Q. And now they take the count at the islands?-A. Yes, sir.

?. Jo you know any discrepancy between the count taken at the islands and that taken at San Francisco at the time the San Francisco count was used?-A. Nothing that would indicate fraud.

Q. I do not want to put it in that shape. In other words, did the count at Sair Francisco ever turn out to be less than the count at the islands?-A. Very often.

Q. The comt at San Fraucisco was sometimes less and very often more?-A. I few slins both ways. That change was not made on accomnt of any suspected fraud or any material discrepancy. It was fomme, after figuring it up, that there was an excess of a few skins by this San Franciseo count over the island count, and the Treasury made an order to talie the San Francisco cennt, because it was a few slims more in the angregate, and they thought possibly it might be better or the most nearly correct; lut I imagine that the real reason was that the Alaslia Commereial Company desired to pray on the greatest number of skias that was comnterl, in orider that there might be no runestion.

?. 'Then the achereate of the comnts as taken at San Francisco fincerel a few more, and upon that the company paid? - A. Tes, sir; the company pair on that. At the time I made the recommendation for the change, so that the eount upon which the tax is pairl should be the 'Treasury agent's comnt on the islands as the law requires, my reason was that the company, if it lost a carco of skins by the sinking of its ressel, would be obligerl to pay the tax mpon those skins loaderi at the islands, and moler the old order of things there might be a question, if $9951-11$ 
the skins did not land at San Francisco, that the company was not lia ble for any tax. My idea was that they would be obliged under the law to pay the tax, altiongh the skins might have been lost, and if lost they could secure relief through a bill in Congress.

Q. Referring to your testimony in relation to the prices charged by the company's store $u$, there, I understood you to say that the Grovern. ment ageut regulated the prices, or was permitted to regulate them ?-. A. Yes, sir; he does, if he fiuds they require it.

Q. By what right does he rlo that?-A. There is no question of law about it; but it has been the rule of the company to invite the agent to look orer their gools, prices, and invoices and see if there is any. thing in the line of gools that the agent thinks they charge too much for'; if so, they want him to regulate the price. He is asked to make suggestions. I hal occasion once to call the attention of Mr. Arm. strong, the company agent, to the item of canned mill. The price had been reduced, and he had not observed it, and I called his attention to it, and he reduced it at once.

Q. It is the desire and courtesy of the companr. and they are not compelled to do it by law?-A. It is the courtesy of the company. They want the Goverument agent to familiarize himself with the prices charget. The company furuish the uatives ali the salt they require to salt their blubber away for winter fuel and salt to salt their pup meat free, which amounts to many tons every year.

Q. What is your observation as to the number of seals resorting to the islands ammally; are they diminishing or increasing?-A. Upon that subject, if it is in orler, I would like to answer the question by reading from wy report to the Treasury. May I inquire if it is in Mr. Elliott's evidence that he makle his statements as to the seal life upon the islands from personal observation?

The CHAIRIINN. Yes; and estimates.

The Witxess. Was it shown that Mr. Elliott had not been on the fur-seal islands for fonrteen years?

The Cmarrand. His eviclence was that he was last there in 1876, twelve years ago.

The iVITness. He made a statement that there was no greater number of seals upon the islands now than at the time he measmed the reokeries. Since I have been on the islancls I have observed very closely the breeding rookeries. I have visited them daily, remaining around and observing them for hours at a time. I gave them very close attention. The reasun I diul so was that I desired to be able to place the Departmant in possession of the rery best information I conld in regard to this seal property; whather it was increasing or diminishing. I foumd on the islands this book of Mr. Elliott's, giving his measurements of the seal rookeries, and I conceived the idea of making some measurements myself ou the Elliote basis to find out if the seals were increasing. Mr. Elliott's measmements of the fur-seal islands showed an area. of $6,021,900$ squale feet, and he says that upou that basis there are 3,010,950 seals. Taking Mr. Elliot t's basis, I made measurements fourteen years after his, and they showed an increase of $\$, 234$ feet in sea margins of the rookeries, and an increase of $4,275,100$ feet of superficial area oceupied by breeding seals, showing upon St. Pau! Island, at the time I made my measurement, $5,1+5,500$ seals, or an increase of 2,137,500. I think the space estimated for each seal by Mr. Elliott is not large enongh, and a reduction of one-fomth will represent moro nearly the actmal number of seals. I believe it to be a fact that Mr. Elliott gave too small space, and a reduction of oue-fourth from my. 
figures and Mr. Elliott's would be more nearly correct. Of course I adopted his basis of measurement.

\section{By the Chairman:}

Q. Taking Mr. Llliott's field-notes and measurements, you estimate an increased area oecupied by the seals ? $-A$. The area has largely increased. I can not say when they increased, of course, but the increase must have been gradual during the past fourteen years.

Q. Do your observations satisfy you that more ground was oceupied by the seals on the breeding rookeries when you made your measurements than when Mr. Elliott made his?-A. Yes, sir.

Q. What was the amount of the increased area ocempied ?--A. I took some men that Mr. Elliott used when he made his measurements, and they showed me where Mr. Elliott's lines of measurement were. Mrr. Elliott's measurements were matle in July, 187.", when the breeding rookeries were at their fullest. I made mine in the spring when there were no lunls or other seals npon the rookeries, in iss6, so that when we went over the rookeries we got the actual measurements. It is impossible to go upon the grounds in July of any year.

The Cin IRMAN. I will state this, that he took his observation of the ground ocenpied in July and made his measurements and field-notes after the seals left.

The WI'Ness. I had nothing to go by except his reports, which show that he made his measurements July 10 to 18.

By Mr. FELTON:

Q. I understand yon to say that there is more territory covered by the seals now than there was when Mr. Elliott made his report? - A. Yes, sir ; that my reports show and there is no doubt about it.

$\mathrm{Q}$. Was there any increase in the breeding rookeries?-A. Yes, sir; that I have stated. It was the breeding rookeries that were measured. There is no doubt but that the number of seals as staterl were on the islands both in 1872 and 1886. From Mr. Elliott's statement I understand he says that there are no more seals now than there were in 1572. I am at a loss to know how Mr. Elliott got his information, as he had not been on the islauds for fourteen years.

Q. You are now speaking of what?-A. The breeding rookeries. Some of the rookeries have filled out their lines. On some of the rookeries the seals are less in number, while on others they have exteuderl their limits. There are more killable seals at Northeast Poiut this year than there has been since I have been upon the islands, but the seals this year upon the breeding grounds I do not think have increased. I do not think this year shows any increase at all. The seals were very late in coming this year, some fiften or twenty days late, aud we became somewhat alarmed. MIr. MrcIntire and I talked it over every das. I attributed the delay of their arrisal to their having been harassed in the sea by the maranders, at large number being killed and wotnded as they eame up along the coast and passed through into Bering sea. I think it is safe to state that there is a tendency from some sonree to check the landing of seals upon the islands, for this year I am quite certain the seals have not increased.

By the Ciramiran:

Q. It is Mr. MeIntire's opinion that they have not only not increased, but have decreased. - A. There has been a slight diminution of seals, probably.

Q. To what do you at tribute that ?- - I, I think there have been more 
seals killed in the sea than ever before by marauders. I estimated that they secured 30,000 slims in 1587 , and in orter to secure that number of skins they would have had to kill half a million seals, while this company in taking 100,000 on shore destroyed only 31 seals. Those were lifiled by accirlent. Some times a young seal, or one not intended to be killed, yops up his head and ge:s a blow muintentionally.

Q. The waste of seal life was only 53 in 1837 ? - A. Yes, sir; in securing 100,000 skius, while these maraders did not kill last year less than 500,000 . The logs of marauding schooners have fallen into my hauds, and they have conrinced me that they do not secure more than one seal ont of every teu that they mortally wound and kill, for the reason that the seals sink very quickly in the water. Allowing one out of ten, there would be 300,0 it that they would kill in getting 30,000 skins. Two hundred thousand of those killed would be females having 200,000 pups on shore. Those pups would die by reason of the death of their mothers, which, added to the 300,000 , makes half a million destroyed. I am inclined to think, because the seals show they are not increasing, or rather that they are at a stand-still, that more than 300,000 are killed by marauders.

Q. You are of the opinion then, that the marauders are killing more seals than the Alaska Commercial Company ?-A. At least five or six times as many as the Alaska Commercial Company ate killing.

Q. IVhat will be the effect if morestringent measures are not taken to protect the scals by the Government?-_. It more stringent measures are not taken, it is only a question of time when these seals will be driven ultimately to seek some other home where they will not be molested. They will not continue to be harassed; and if this marauding is continued, they will, in my opinion, either be gralually exterminated or will leave the islands permanently and land at some other place. They may go on the Russian side.

Q. Will maraulingr increase if the froverument does not take steps to prevent it?-A. I thiuk so.

Q. Is it practicable to prevent it?-A. Ies, sir. If we dirl not allow these cheeky, persistent, iusolent, British Uolumbia seamen to ogo there, and defy the United States and its authorities, it would very soon be stopped. When our revenue cuttersinize the British schooner's, the cap). taius are very msolent and defant aud chaim that they have a stroug Goverument at their backs. I am now referring particularly to Captain Warmer, of the Dolphin. He said in $158 \%$, whencapturer, "Wo have got a strong govermment at our batek and we will fight jou ou this yuestion." "Very well," says caj)tain Shepherd, "I have got a strong Govermment at my back aud I am goiug to lomy duty. My Govermment seuds me to protect these seal roolieries. I am charged by this administration to enforce the law, and I will seize all marauders."

When I took charge of the islatids they were practically without protection. The Government had one cutter to cruise in Bering Sea and the Arctic Ocean. She merely ("alled at the fur seal islands, took a look at us, cruised aromul us and then went on up) to the Arctic, remained there all summer and came down in the fall, calling at the seal islands, took another look at us, and then left for San Francisco. In my first report I made an aplecal to the Secretary of the Treasury for ail additional cutter, showing the interest the Government had in protecting this seal business, and the next spring they sent a cutter uy for duty in Bering Sea. The remained armmd the islands and made seizures. A cutter was also sent to the Aretic; a larese number of captures were made in liss; and 1587. 'Lhe two seasons' eaptures have paralyzed 
the marauding very much. So that this spring I got information that there would be no sehooners in Bering Sea this year; that they conld not get crews. The Indians would not ship, as they were afraid of being calptured. When I eame out of Bering Sea on the Alaska Commercial Com. pany's steamer, leaving the islauds on the 15 th of August, we had not seen a single vessel in Bering Sea. When we got to Oonalaska it was rumored that Captain Shepherd had seen a British and an American schooner, but I do not know whether he did or not. I could not get any anthentic information in regard to it. It has been stated that from the fact of our not seizing them there was a backing down on the part of the administration.

Mr. Felton. That is mere newspaper rumor.

The WITnEss. That is nere newspaper rumor. I have seen no eridence of any backing down on the part of the administration on the question of our rights in the Beriug sea, and I do not believe there has been any backing down.

Q. Do you think that the interest in those rookeries, in an ecoriomic point of view, are of sufficient value to justify the Government in adopting striugent measures for their protection?-A. I most unquestionably do. The property is of immense value.

Q. Can it be increased by protection?-A. Certainly. It is of great value to the people of the comitry and of the world. The seal is the only fur-bearing animal now extant that furnishes a valuable garment, and to perpetuate them will be to supply a want of the people which is of more value than the mere matter of income to the Government.

Q. Do you think that the Government conld increase the revenue from that source?-A. Unquestiouably it could, if it will adopt such measures as will protect the seals.

Q. What additional measures would jou suggest?-A. I think it is a very small matter to inar gurate some plan. I think the enactment of sometbing like a game law that will reach and protect the seals wherever they are, and which would be agreed to by England and Russia, would be advisable.

Q. This Goverument might come to an agreement between those countries to protect the seal whererer they are found within and without the jurisdiction of the United States?-A. I think those countries would agree to that; I have not any doubt of that.

Q. Do you think they are sufficiently valuabie to the Government to attempt to secure such a privilege?-A. Yes, sir; the only income we get from Alaska is derived from the fur seals; speaking of it merely as a commercial transaction and as a property, our fur-seal islands alone are worth a sum equal to the sum we paid for the entire territors, $\$ 7,200,000$. I think they are worth that. Now, if the Govermment loses this income it had better try to get Russia to take back the conntry, becanse it is not worth anything ontside of the seal business, except for a fer salmon and codtish they are catching now, which business is still in its infuncy. The fishing interest will ultimately be very extensive.

Q. You would extend protection to the seals in Bering Sea and also to the North Pacific?-A. Yes, sir; orer Bering Sea and the North Pacific. I would certainly claim juriscliction orer our half of Bering Sea. It is also very important to do it in the North P'acifie Ocean. The canning of fish has increased rery largely in Alaskir. Last year it was $187,500$ cases, and this year it is over 400,000$)$. But, without the fur seal, Alaska would be very expensive for our Goverument to guard and protect, and the loss of the fur seal to the people of the world would 
be a very serious loss indeed. I think we are in duty bound to preserve them.

Q. Do you think there is any difficulty in protecting the seals while they are within the juriscliction of the United States?-A. None whatever.

Q. That can be done simply by a rigorous assertion of power, and prompt execution of the law ?-A. By a vigorous execution of the law, and having it uaderstood that the Government is going to do it every year. There would then be no killing of seals in Bering Sea. From the fact that the Government las enforced the law so vigorously for the past three years and from positive notice having been published at San Francisco that seizures would be made, those people hat come to expect it, and were stopped from going up there this year.

Q. It is necessary to back up that notice by seizing them if they went in there?-A. Yes, sir; if you eatch one in there handle him as rough as you can. I do not believe in this thing of letting them go and making a compromise of it. The Russiaus do not treat them that way. When they eapture a schooner they take the crew off and sink the schooner. This is the way to do.

Q. They do not go about briuging them before an admiralty court?A. No; they do not.

Q. What additional measures would you suggest? Some of the witnesses have suggested that it would be a very valuable and important regulation to require all vessels entering Bering Sea to tonch at Oonalaska and take out a license, or at least make a report of their business and what they propose to do.-A. That would be rery well for all vessels except the whaler's going to the Aretic on legitimate business. They all pass throngh Seventy-Two Pass. To require them to come by the way of Oonalaska and report would be a great hardship to them, and would bring down on us the anathemas of the whalers.

Q. These wituesses refer to ressels going into Bering Sea for the purpose of hunting? $-\Lambda$. Well, vessels going into Bering Sea northeast of Seventy.Tro Pass should be required to enter at Oonalaska. That would enable us to catch the marauding schooners and fishermen, and that regulation ought certainly to be adopted. Let the Government deputy collector attend to that matter, as he has nothing to do except to draw his salary. He has not five miuutes' work a day. He is idle for months at a time. $\quad$ s $\mathrm{s}$ long as we are maintaining a deputy collector at Oonalaska these ressels should be required to enter there, and let him overhaul them and learn something about them.

Q. Would that be practicable? - A. It would be perfectly feasible.

Q. Do you think it would be practicable to keep a steam-launch at the disposal of the Treasury agent on those islands?-A. It would bo at St. Paul Island. There is no way of landing one at St. George Island, and there is not is much necessity for it there as there would be at St. Paul, where we take 85,000 seals a year. Last year, after the company's steamer departed for San Francisco, a marauding schooner went up and laid off the reef rookeries, and proceeded to kill seals. She was represented to have secured 4,300 seals, which were sold in Vietoria. If we had had a steam-launch there, the Goverument could have secured that schooner, or could have overhanled her, and prevented her killing those 4,300 seals. But it was not safe to go ont in a row-boat. I have recommended the purchase of a steam-launch for St. Paul Island, and it could be maintained there in safety. We could run it up into the lagoon, one that would not draw over 4 or 5 feet, and we could winter it there, or could haul it out. But we could not do that at St. 
Georgè. I am required to go orer to Otter Island, 6 miles a way, where there are some seals. Sometimes these schooners go in there and lill seals. If we harl a steam-launch we conld go orer there and capture them. A stean-launch of 20 tons would be a very valuable aequisition to the islands.

Q. From your observation of the Gorermment's interest there, would you recommend a change in the present policy of the Goverument as to leasing the islands or operating them directly by the Goverument's own agents? - A. It ronld be best for the Government to operate the islands, if it would always employ the same help for years right along. But it would be entirely impracticable for the Government to rum the business if they are going to change their ofticers with every administration. Every time they got on a new force the business would arindle. It would not be very creditable or profitable to the Government. If they wonld keep the same set of men, year in and year out, the Govermment might conduct the property profitably. This business must be run as a monopoly, whether by the Government or by a cor. poration, in order to preserve seal life. The lessees talie just as much interest in preserving seal life upon those islands as the Goremment does, and if I am to be asked what my opinion is on the question, I would say that the better plan would be for the Gorernment to lease the property.

Q. Should it be leased to one compans, or should it be divided ?-A. It should never be divided. The best way to do is to give it to one person, one corporation, or one set of men, and not have couflicting interests upon the islands. Of comrse there are those who would like to have the contract. There are a number of people who speak disparagingly of the fur-seal business and berate this company. I am not the champion of anybody except the Govermment. I would like to see the Government get ont of it all there is in it. More than anything, I would like to see our rights in Bering Sea maintained for all time, that the fur seal may be preserved for the benefit of the people of the world. The amount of money concerned is nothing at all in comparison with the economy of the fur seal, and the thing, in my judgment, to do is to let this property to the best bidder for at term of years, with absolute protection guarantied.

Q. Do you think the revenues of the Gorernment can be increased without serious detriment to seal life?-A. Certainly; there is no question about it. I do not think that the company now operating the islands ean cause auy detriment in taking its quota of 100,000 every year.

Q. Do you think the number of killable seals would increase if the protection is increased?-A. The number of killahle seals can be increased, and possibly thereby cheapen the price. There is no question but they will increase if given additional protection.

\section{By Mr. FeltoN :}

Q. Would not the policy of authorizing an increase of the killing tepend very much upon the commercial value of the skins?-A. The lessees would regulate that, and I think it would.

\section{By the CHzIRMAN :}

Q. The lessees look after the price, and the Government after the reveuue and seal life? - $\mathrm{A}$. There is but one way to run the property, I think, with the least seandal and the least objection and the greatest profit, and that is by this contract system.

Q. From your observations, do you think it likely, if the Gorernment were to attempt to operate the rookeries and take the skins, it might 
be a source of scauda! and corruption? - i. It might, in the hands of some agents. The Govermment may be very careful in the selection of its ageuts, as careful as it is jossible to be, but I have kum of cases, and so have you, where the Gorerument has been terribly imposed upon. It often gets the wrong men. It would be liable to get the wrong men in this case. If that were done, there wonld be sume scandal. If it got good, straight, honest men in charge of the business, with some knowlerlge of it, and paid them money enough to justify them and keep them in the business, then the Government conlil run it just as well as not.

Q. Uuder the present sfstem, then, you think that the Govermment maintains a vigilant match orer seal life, and that the company maintains a rigilant watch over its private interests, and that the present system constitutes the greatest ultimate safety to the public interest? A. Unquestionably; they both work in harmony.

Q. Eatch taking care of its own interest?-A. Tes; each taking care of its own interest, and doing its dnty. The company gives no trouble to the Gorernment officer. After it concludes the taling of its catch it ships the skins, and they leave a man to look after things on the island. The Government officer remains, and he has sole charge of everything, except the matters of the company. Each attend to their respective duties. There is no clashing.

Q. Have you had occasion to obserre and judge of the general effect that this lease has on the natives, and whether this lease enables the Alaska Commercial Company to exercise orer the business interests and general prosperity of the natives any influence?-A. Yes, sir; it enables them to exercise a very large infuence throughout Alaska.

Q. Is it injurions?-A. The basis of their business is the fur-seal industry. Without this contract, it would not be there. This contract euables the company to maintain stations in other portions of the Territory where there are natives congregated, and where they collect more or less land furs. This business they could not maintain without the fur seal contract, because a number of these stations are non-paying.

Q. Yon mean unprofitable?-A. I mean unprofitable, maintained at an actual eash loss annually. Most of their stations pay something. The most raluable fur that they have heretofore gotten has been the sea-otter, but of late years the sea otter has been hunted so vigorously by white hunters and others that the supply of that fur is very largely reduced.

Q. By competition?-A. Yes; by competition. Their business in Alaska is principally on the fur-seal islauds, and their business elsewhere has no connection with that, and does not lieep people out of the Territory at all. Since I have been there, their ressels have been at the service of any person wishing to travel up to Alaska. It carried missionaries, traders, and their fumilies, miners and others who happen to be at the stations. Such almays got passage. I have never known an instance where they refused passage to any one who unclertook the establishment of a store or tradling post at any point in Alaska. The company has its stations at all points where it is at all probable they will have a profit, and it does all the business it can; but it is in competition with many others.

Q. Is their influence in any respect, in your opinion, deleterious to the public interest? - A. Not to the natives. If it were not for this company I believe the natires in many portions of Alaska would be in a starving condition. If this company did not go there and carry pro. visions to them and take what few furs they have the natives would 
have to go some place else, for they would be in a half-started condition, and no better than they were under Russian rule, which was certainly deplorable. The presence of the Alaska Commercial Company in Alaska has been, in my judgment, a greater civilizer to the people of Alaska and has been of more benefit to them than all the Rer. Sheldon Jackson's crowd of missionaries has ever been.

Q. Have you read the last amual report of the governor of Alaska?-A. Yes, sir.

Q. Do you agree with him in his conclusions? -A. No, sir.

Q. Is it your opinion that he is not justified in his conclusions? - A. He does not agree with them himself now, because since he has mate that report he has visited the islands on the man-of-war Thetis. He made an extended tour along the coast, including the fur-seal islands, clear up to the Aretic. He visited me on the fur-seal islands, and I took him all through the rookeries, and shower him through my books. These paper's are merely copies of my books, and they show our system of keeping the accounts. I took him to the company's office, and the book-keeper showed him through their hooks and explained their system of keeping accounts with the natives. The company's local agent showed him the prices charged the natives in selling goods to them, and he examined into everything very thoroughly. He spent two days ou the island, and on leaving expressed himself to mo as entirely satisfied ; that he had been misled, and was entirely satisfied with everything he saw, very agreeably so, and would take pleasture in making the amende honorable.

\section{By Mr. Felton:}

Q. What was the source from which he obtained his information?A. The basis was information receiver from a man named Auderson, a carpenter, who had been recommended by the Alaska Commercial Company, and was appointed United States marshal. The Government oflicials asked the company to name some one for the place, ant it named this man Auderson. He fell out with the company's local agent and employés because he did not have everything his own way. He got to be a very ugly, bad man. I know of my own knowledgo that Anderson's statements are false from beginning to end. I think he ought to be the last man to make any complaints.

Q. Was that the governor's only' source of information ?-A. Yes, sir.

Q. Is that the Anderson who makes the affidavit attached to the governor's report?-A. Yes, sir.

Q. How many days' work in the conrse of a year do the natives put in on the seal islands? - A. That would be pretty hard for me to saly. It took, I think, forty days last year, and the year before thirty-uine days were required to take the skins, but they work for the company by the hour at all other irork, except taking the skins. The company pays them 10 cents an hour for other labor. They are employed at loading and discharging eargo, and loading skins on board the vessel. I have never reckoned it into days; but I would say seventy-five days a year would cover erery day they work. The balance of the time they have nothing in the world to do. At the close of business last year they had $\$ 65,0$ !n to their credit in the hands of the empany bearing 4 per cent. interest.

Q. You said something a little while ago about the importance of some additional labor, with the consent of the Secretary of the Treasury. I suppose the object of the company in getting the additional population, and paying them additional, was to facilitate its own business? $-\Lambda$. 
Certainly; they preferred to hurry up and get their number of skins within the time allowed by law.

Q. I suppose it would be necessary, in order to complete the business in the limited time, for the company to be allowed in the future to take such a number of additional laborers there as they desired?-A. Yes, sir; and in doing so, I think they onght to be placed upon an equality with the island natives. The imported labor gets a small pittance, while the island native gets the bulk.

- Q. I listened carefully to what you have said with regard to preserving the seal and the course the Gorernment ought to take. Do you know what instructions have been given to the revenue-cutters in regard to the preservation of those seals?-A. The instructions this year were the same as last year.

Q. What were they?-A. That the law should be vigorously enforced. The law is contained in section 1956 of the Revised Statutes. The Secretary told me the same orders would be issued this year that were issued last year.

Q. I do not recollect what that order was; can you tell me?-A. The order referred to the section of the law, and directed its enforcement.

Q. That is, taking of any schooners that may be found there?-A. Certainly.

Q. On what ground are sehooners taken?-A. Any caught sealing in Bering Sea are liable to seizure under the law, I suppose. Such has been the Departments view and practice.

Q. No matter what flag they carry?-A. The lines are defined in the law. If they are canght any where within those lines, they are liable to seizure, no matter what flag they sail under.

Q. That applies to any ship, does it?-A. It applies to ships of any nationality. I have seen no eridence that this administration Io:s changed that order. I have no knowledge that it has been changed. I have never seen any modification of it whatever.

\section{By Mr. JEFFRIES :}

Q. Who was Secretary of the Treasury when you were appointed to your present position?-A. Daniel Manning.

Q. You were speaking a while ago in regard to the amount of seal life destroyed by maranders, and that a captain had given the number of seals destroyed. Have you seen any of the log-books of those ressels ?-A. Yes, sir.

Q. Will you state what you remember with regard to the number of seals lost or captured by those vessels?-A. I remember reading the log-book of the Angel Dolly, which I captured. There was an entry in that log-book that read as foliows: "Issued to day to my boats three hundred rounds of ammunition. At night they came in with the ammunition all expended, and one seal skin."

Q. They had shot three huudred rounds of ammunition?-A. Yes, sir. Another entry I saw was: "Seren seals shot from the deck, but only secured one." All lost but one. Another entry: "It is very discouraging to issue a large quantity of ammunition to your boats, and have so few seals returned." An entry was made in another place where he gare it as his opinion that he did not secure one seal skin out of erery fifty seals wounded and killed.

Q. Hare you seen seal skins upon the island that had ben shot?A. Very often. We gather handfuls of shot every season.

Q. Does that injure the market value of the skins?-A. Undoubtedly. Any hole is an injury to the skin. 
Q. I hardly need ask yon whether these riolators pay any tax to the United States?-A. No, sir; they do not pay any tax, and sell the skins wherever they can do the best. Generally large firms ship the skius and they come in competition with the skins that have paid the tax.

Q. Where are these seals born?-A. On St. George and St. I'aul Islands.

Q. To what comntry do those islands belong?-A. To the United States of America.

Q. Have the United States leased the right to take these seals there?-A. Yes, sir; in 1870, to the Alaska Commercial Company.

Q. When the seals leare the islands, do they do so with the intention of returning?-A. We can only judge from the fact that they do return to the islands.

Q. They go upon substantially the same rookeries every year, do they not?-A. I have reason to believe that they go upon exactly the same rookeries. Year hefore last I killed an old bull that old George Buterin, a native, said was one of Mr. Bryau's bulls. Mr. Bryan canght a number of young pup seals, and cut oif the right ear, and then let them go. I had this bull killed and fomm that he was one of the bulls that Mr. Bryan harl elipped fonrteen years before, and that during the whole time he had returned regularly to the island and reef rookery.

Q. Do you regard these seals as the property of the United States?A. They are the property of the United States just as much as this table is.

Q. Yon have read the treaty of cession by which this territory was cerled to the United States by Iiussia, I sujpose?-A. Yes, sir.

Q. Where is the western boundary of Alaska Territory located? - 1 . It is an imaginary line drawn through the middle of Bering Sea and throngh the middle of Bering Strait, westward of St. Lawrence Island, and St. Matthew's Islant, bearing west and passing between the Island of Attoo and the Copper and Bering Islands.

Q. To whom does the western half belong?-A. It belongs to Russia.

Q. Are there any seal rookeries there?-A. Yes, sir; there are sereral places where they haul up.

Q. Are they protected by Russia?-A. Yes, sir.

Q. Do any interloper's interfere with the seals there?-A. They do not, sir.

Q. What would happen if they undertook to kill seals in Russian waters?-A. Well, sir, if they should go there once they would nerer be in a condition to kill seals another season.

Q. They have been burned, I understand?-A. Yes, sir. The crews have been taken off, and the vessel burned, in one instance at least.

Q. So far as their halt is concerned, it is a closed sea?- $\mathrm{A}$. Yes, sir. Russia exereises absolute jurisdiction over it.

Q. 'Then if the Euglish view be true, it presents the anomaly of onehalt being a closed sea and the other half an open one?-A. Yes, sir; that is correct.

Q. How long would seals exist on those islands if Bering Sea should be declared an open one, and if everybody is permitted to go there and kill seals? $-\mathrm{A}$. The first year there would probably be a liundred vessels there, and the next year there would be more. I think that in five years there would be very few ressels there, from the fact that the seals would be practically exterminated. These vessels can take seals just as well beyond the 3 -mile limit as they could a half a mile from shore, because the seals go out to feed and exereise in the water, and often a dense fog settles around these islauds. These marauders 
can come in upon the rookeries in a fog, go ashore, kill seals, and get in their boats and go off' before a cutter could overhaul them. The cutter might be on the other side. The marander's could load up and get off.

Q. As a matter of fact, the sea's do go out beyond 3 miles ? $-\Lambda$. They probably go 20 miles out in some cases. It takes $12,000,000$ or $15,000,000$ of fish every day to feed these seals. It is immense, and they have to go a great distance to get them. These marauders would want nothing better than a 3-mile limit, because they could kill a boat-load and get away and never be overhauled or canght at all. The practical extermination of the seals would be assured, and the only question would be as to the time it would take, whether three, four, or five sears; and I certainly think in five years the last seal would be gone.

By Mr. Felton :

Q. You believe it is indispensable that they be preserven at Behring Sea ? - A. Absolutely. Protection should be extended to the North P'a. citic Oceau, if possible, also, as a large number are killed en route to the Bering Sea.

\section{By Mr. JefFries :}

Q. Will you state whether or not the United States own the seal islands of Alaska?-A. They do, certainly.

Q. Aside from the revenue derived from the seal islands, does the Treasury receive any other income?-A. Not a dollar, except a little customs revenue.

Q. Does it receire as much as it costs to collect it?-1. No, sir; not one-fourth as much.

Q. If we withdraw this protection and declare these waters a high sea and allow the fur seals to be destroyed, to what extent would the United States be affected? - A. She would be affected to the extent of an absolute loss of all the revenue from the seal business.

Q. Do you know how much that has been under the present lease?A. 'The Government receives $\$ 317,500$ annually from the Alaska Commercial Company.

Q. How abont the duties paicl on seal skins when they return to the country? -A. The duty is 20 per cent. ad valorem.

Q. What is the total amount of that duty?-A. I understand that the entire amount is something over $\$ 3,000,000$ from duties alone.

Q. In regard to the management of the business by Treasury agents, would not that be an unusual thing? - $\Lambda$. Yes, sir ; it would be very unusual, but it could be done. It would be feasible.

Q. Are there not certain incidentals that the Govermment could not safely manage ; for instance, stimulating fashions, and expeuding money in European capitals ? - A. Of conrse there are a great many questions that might arise that wonld be difficult for the Government to handle, and therefore I say that while it is possible for the Government to manage it in the way I have suggested, I should decidedly recommend the present plan.

Q. You think the Gorermment had better not?-A. I think it had better not, because I do not believe that any one administration is going to remain in power always, and therefore they would change superintendents too often.

By Mr. FeltoN :

$\dot{Q}$. I take it that the Government could be induced to gire the power 
to a corporation to disburse moneys, enter into commercial operations, and so on?-A. Ob, yes; I think they could do that.

\section{By Mr. JLFFRIES:}

Q. I have seen it suggested in some newspapers that a treaty might be made with. England which, while not asserting our dominion over Bering Sea, would protect the seals in that sea. Would there be any. thing to prevent any British vessel or San Francisco schooner from registering from ofher comntries and, therefore, would that be of any value?-A. That would he of no value. Some Americans might go up to Victoria, sail out under the British flag, and if they got injured would put in a claim against the Government for four or five times the value of the schooner, or enough to put ler in hetter condition than she was before.

Q. When you estimate the ralue of the seal islands at $\$ 7,200,000$, of course you estimate that the seals will always remain there?-A. IVithout protection to the seals the seal islands hare no money or enmmercial value. With protection they are, in my judgment, cheap at $\$ 7,200,000$.

\section{By Mr. FELTON :}

Q. The seal islands have not, but has not Alaska some mines of value-has it not some successful miniug property?-A. Yes, sir; ¿ fer. The Treadwell mine is a paying one; but as for the interior of Alaska the mining interest is rery problematical. They brought down last year $\$ 50,000$ worth of gold, washed from the Xiklon River, but the sererity of the winter will preclurle the possibility of prosecuting any mining business in Alaska.

Q. Do you regard the fisheries as rery valuable?-A. Tes, sir; the salmon fisheries are very valuable, but they do not return any revenus to the Treasury. I say that, if we are to have this fur.seal businestaken from us, we had better try and get Rnssia to take back the comntry she sold us.

Q. Do sou happen to know about how many Secretaries of the Treas. ury have been in office since the islands were leased?-A. No, sir; I do not.

Q. I think nine or ten. Have you ever looked over the reports of those Secretaries to see what recommendatious they made in regard to this business?-A. I can not say that I have.

Q. The question I wanted to ask you was, whether they had not all, so far as they alluded to it at all, reported that the company had fulfilled its contract in every respect?-A. I have looked over the reports made by the Goverument agents on the island, who have generally reported to the Secretary that the company has fathfully performerl its contract under the law.

Q. Has it, so far as sou have observed ?- A. I have reported that the company has complied strictly with the law.

Q. You think there is no donbt about it?-A. I think there is no dombt about it, or I would not have so reported it to the Department.

\section{By the CHAIRILN:}

Q. Do yon know Chester Seeher, who was formerly Luited States commissioner at Uonalaska?-A. Yes, sir; I do.

Q. Inave you seen a letter addresserl by him to the chairman of this committee about the matters before it?-A. I salw in a newspaper a day or two ago a letter, or rather it was an Associated Press dispatch from Washington, which spolie of a letter that he had addressed to the committee, 
Q. Have you read that letter?-A. I read this synopsis of it.

(. Do you concur in the statements made by Mir. Seeber, or do you know anything about it? - A. I know that the matters abont which he speaks in that dispatch are not true. The statements are not true. I think that Mr. Seeber ought to be the last man living to bring any accusation against this company.

Q. Hare you any reason for that opinion?-A. Yes, sir.

\section{By Mr. FeltoN:}

Q. Of course you have some reasons. Whre you any objections to giving us those reasons? - A. I do not know that I have, beciuse right wrongs no man. This gentleman was commissioner up there, which office corresponds to that of justice of the peace in the states, and his salary was $\$ 1,000$. He was there several years; I do not know how long; two or three years, probably. He not only spent his salary (at a place where a man can not legitimately spend any more than it costs for board and clothing), while he kept drawing upon this company until he owed it some 81,700 , when they shut down on him and wonld not give him any more, and he left the comntry. At the time he left he owed the company some \$1,700. When he landerl in San Francisco he didn't promise to pay them, and did not go to their office even. He sent a boy un to the oflice, and ordered then to forward his mail to some other point for him. This is all they ever got for their $\$ 1,000$.

Q. I'robably it the company had expended a little more on him we wonld not have gotten this?-A. Probably not. I was very much astonished on reading that dispateh, hecause the matters of which he speaks are all untrue. His statements are absolntely filse.

I will submit as part of my testimony the iollowing extract from my report of 1856 :

THE BIREDING IROOKERIES.

Mr. Elliott embracel in his report of 1874 a measurement by him of the breeding rookeries on this island made July 10 to $18,187 \%$, since which tme no measurement has been made so far as the records of this office show. Deeming itof great importance that the Department should be in possession of the best information as to 1 he present coudition of the rookeries, I made a thorough measurement of all on this island, commencing on the 3 d day of May, before the bulls hauled up on the land, when an absolutely correct measurement could be made.

In makiug my measurements I was assisted by Dr. L. A. Noyes (Captain Loud, assistant 'Treasury arent, not laving returned to the islands), and four of the best informed natives. Is to the boundaries of the breeding rookeries in July, when the rookeries were fullest, we veritied our work by observation, and fomm the gromul included within onr lines fully covered sone of the rookeries, viz, Northeast Point, Tolstoi Gerbuteh Polivena, were densely packed, covering more area than my statement shows, while others were not so closely packed. I do not agree with Mr. Elliott in his assignment of 2 feet square to each seal; at this date it is not enough.

I inclosemy statement, marked E, as comparei with Mr. Elliott's, which on his basis gives us now on the breeding rookeries $5,148,500$ seals, an increase since 1872 ot $\stackrel{2}{2} 137,550$. I think the calculation of 1872 , as well as 1886 , would stand a reduction of one-fourth in agregate number of seals, and be nearer the true number than omr figures show. Statements at best are merely approximate estimates, but in the absence of any absolutely correct methorl of arriviug at the count they serve as a guide. Frequent inspection of the rookeries during last season and this shows a decided increase of cows, with an ample supply of bulls. The same report is also made by the assistant Treasury agent in charre of St. George, on which island I was not able to obtain measurements of the rookeries this spring, but will do so next, and forwarl the result with my next report.

So far this season we have sighted but one schooner off this island, supposed to bo sealing; she did not, however, come in close enough to disclose her real character.

At St. George an attempt was made by a nurauder to land for the purpose of killing seals on a rookery, but were driven off by shots fired at them by order of the officer in charge, as directed by me.

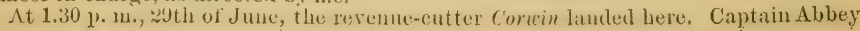


reported baving boarded the sehooners Tanderbilt, Captain Myers, Sierra, Captain Lee, and City of San Diego, the first two about :0) miles from Oonalaska, and the last 40 miles from St. George Island. He took from the Nierwa 4 ritles and 1, 100 rounds fixed ammunition, and from the City of San Diego 6 rifles and 500 rounds of ammunition. The last-named vessels had seal skins aboard, salted, aud plenty of salt and seal clulss, showing clearly they inteuded, if opportunity offered, to land on the rookeries. Captain Abbey notitied the captains of the trading schooners that if again causht in the waters with additional seal skins on board he would seize the vessel aud cargoes. On his arrival here, 26th instint, he reported having seized the schooner San Diero not far from Oonalaska, sealing, having some fresh-skinned seal skins on board, and 574 in salt, 175 of which hat been clubbed, and among the skins were some suall pups, this year's, showing eonclusively the marauder had landed on a rookery on St. George, as the pups had not yet gove in the water. 'The San Diego is an old oftender, aud was captured once on Otter 1sland sealing. Captain Abbey proposes to hand her over to the civil authorities. She is at present in custody of tho deputy marshal at Oonalaska.

This commencement of eaptures will do much toward breaking up the maraucling business about the islands this season; indeed the Corwin's presence here bas undoubtedy kept, off quite a fleet of schooners and destroyed their unlawful business hereabouts. With the entter Bear to remain until fall, after coming ont of the Aretic, seal life will be protected from pirates this season. It is the only means by which good can bo accomplished in that direction. I do earnestly hope the Department will see the necessity of keeping a cutter around the fur seal islauls every season from the 1st of June to the lst of November.

\section{Mr. Chairman, with your permission, I desire to real as part of $m y$ testimony extracts from my reports of 1887 , as follows:}

The time has come wheu, in my judgment, the lessees should be anthorized by the Secretary of the Treasury to employ additional natives, and teach them the business of sealiug in all its branches, as death has played sad havoe with the sealers of the islands. The mortality among the men since 1870 has heen fearful, and the smallness of the effective furce of able men and boys in 1887 to do the work of taking 45,000 seal skins on St. Panl Islaud during the time allowed by law is insufficient. Were it not for the fact that owe-latf the work pertaining to the taking, saltiug, bundling, ete., of the skius is done ly Oomalaska natives, brouglit up by the lesseets for the sealing season and returned to their homes at the close of the season's busi ness, and eight white men, employés of the lessees, the work would not be done on St. Paul Island without continuing the killing in the fill. About forty natives of Ooualaska, the same tribe of people who inhabit the fur-seal islands, are brought annually to the slands, and paid by the lessees for salting, bookingr, bundling, otc., in order to advance the work.

The island natives recenving the finll sum of 40 cents per skin, it would be entirely just to take this extra expense from the sum total of the native fund and distribute the remainder to the sealers, as the work performed by the extra help is a part of the duty imposed on the islamil natives muler the contratet and in consicleration of the 40 cents per skin paid them. Experience has demonstrated that the system of payment to the natives is not the best for their own intrest, for the reason that when the season's sealing ends and they each get their proportion of the community fund entered up to their crestit in their pass-books, they feel the sear's work is ended. If ealled upon to work on a roat over which they travel and wheel their water, meat, and fuel, or asked to laumeh a boat to board the vessel in the spring. they are paid by the hour; or when called out by the Treasury argeut in the spring to clean up the filth they have accumulated durmg the winter rombl their houses they are paid for their labor. 'They earn their year's salary or pay in six weeks, and for the remainder of the year feel they are free. If called on to do any work, oven though it may be as much for the benefit of the watives as the lessees, they must bo paid by the hour for it. 'The system of payment by the piece or skin was adopted im. mediately after the transfer of the conntry, as an iuduement for the uatives to secures the skins, rival companies oecupying the islands sealing at the time. In my opinion it is not the best way to compensate the island natives, and is vory unjust to then brothers who are brought from Oonalaska to help them.

The average pay of the St. Paul native sealer this year is a little over 8500 , whilst the Oonalaskans receive on an average gico each. This small sum is the main sulpurt of their families for the year, whilst the st. Paul man has, besides his \$500 cash, all the fresh seal meat he can eat, and salt, fuel, fish, house, medicines, pliysician, and schooling free. It would be a simple act of justice to place the natives of Oomalaska. employed to assist in sealing on the same footing with the St. Panl natives in lhes distribution of the sum earned, as one set of men are just as essential to the work as the other, I would suggest as in meh better plan the payment of a sum equal to 
40 ceuts per skin, divided into annual salaries in proportion to the value of each man and hoy's labor, payahle weekly or monthly, with the understanding that in considcration of this salary their time and lahor are subject to the orders of the lessees and 'ívasury agents at an and all times. For nine months or more every year the lessees liave nothing for them to do; hut the system of paywent, as suggested, I am sure, would prove more beneficial to the matives, and make no difference whatever to the lessees, except it would subject the natives to their orders at all times for any work necessury to be done.

I would respectfully reconmend that any adlitional force of natives you may see proper to authorize to assist in sealing be paid by the year and not by the skin, and such sum so paid be deducted from the community funds of 40 cents per skin beforo the division is male, and the remainder divided, as heretofore, among the old sealers, provided that none of the lessee's agents or white employés are paid ont of the native funds. It is evident the rapid decrease of native adult males on the islands will necessitate an increase in the outsicle force of natives, or the quota of 100,000 skins per annum can not be taken.

The Oonalaskan is paid by the lessees for doing the rork which under their contract the islanders are bound to do, and whilst the wages paid them by the Alaskia Commercial Company (\$40 per month) is very good, the timo employed (two months) is very short, lasting only through the killing season.

In view of the facts stated, it would seem but just that some more equitahle division of the funds be made among those natives who do the work, as they are all of oue tribe, the fur-sea islands having been first peopled a hundred years ago by trausplanting Aleuts from Oonalaska.

T'lo condition of the natives on the two islands is quite as good as usual after a long wuter of idleness, during which time they shut themserves up in their close houses, withont permitting any ventilation whatever, keeping the house warmenl up to an unhealthy temperature, taking only such outcloor exereiso as is required of them in attendance on their church service, emerging in the spring in time to clean 11p and prepare for the arrival of the vessel. When it is damp and cold they are as imprudent and careless as duriug tho winter, conseguently take cold easily, resulting in uany cases fatally. Bronchitis and pmeumonia are the spring diseases. This year has been an unusually fatal one, there having been seventeen deatlis in June and up to the 1:th of July. When once an Alent makes up his mind to die, having no recuperative powers, he baffles the skill of the physician and calmly awaits the inevitable. With proper care they would be much longer lived, as thero is nothing in the climate or sanitary condition of the islands to invite disease.

The white population on both islauds, some of whom have remained continnously for five years, are always remarkably healthy. It is a notable fact that not a single leat h from disease has occurred amoug them since the transfor of Alaska to the Uuited States, whilst the percentrgo of mortality among the ratives is much greater than can be found in any State or country of which we havo statistics. It is only a question of time when the Aleuts will become extinct.

The consus taken January 1,1887 , is as follows:

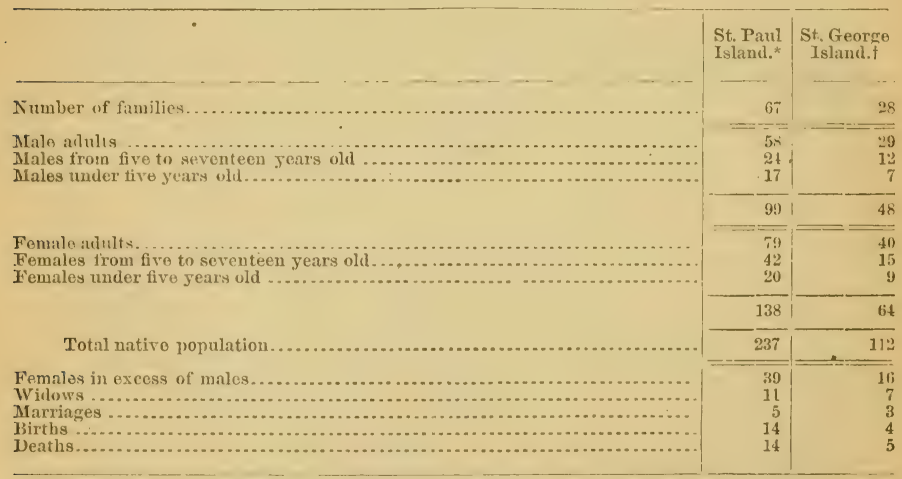

* Seventeen deatlis from Juno 1 to July 12, inclucling 5 sealers-almost 7 per cent. in forty-tiro datss.

t One death since June 1. 
The canse of the excess of females on the islaucls is owing to a regulation of the Greek Church which forlsids the marriage of parties wheres the most distant relationship exists; it even extends to the relatives of the contracting parties' godmothers and godfathers. This alisurd obstacle makes it aluost ont of the question for residents of the island to marry. The priest cont rols ali marriages; his permission is alsolutely required lefore a marriago can taks place. 'This rule of tho church ferces the men to go to Oonalaska or other islands for wives, and every year pilgrimages are male for that purpose. The priest first bring applienl to tells the wife-seeker whom he may marry. Whilst aceessions of females are made to the population in this way, no athitt males aro allowed to eome from other islands and herome citizens of the furseal islands without special pernission of the Secretary of the Treasury.

\section{THE BREFDING ROOKERIES.}

As I was unable to accompany my report of last year with a statement showing the number of seals on the brerding rookeries of St. George Island, I mado arrangements with the acting assistant Treasury agent, Dr. L. A. Nopes, in eharge, to make a complete measurement of all the rookeries on the island, which he did, and the result is here given:

Measurement of treeding rookeries by $\mathrm{Dr}$. L. A. Noyes, acting assistant Treasury agent, of St. George Island, January 4, Mareh 1, and dpril 22, 1887.

Namo of rookery. Sea margin. Depth. Square feet. Seals.

\begin{tabular}{|c|c|c|c|c|}
\hline $\begin{array}{l}\text { East } \\
\text { Zapadni } \\
\text { Littlo East } \\
\text { Starry A teel. } \\
\text { Near and North }\end{array}$ & $\begin{array}{r}2,200 \\
2,100 \\
600 \\
900 \\
3,500\end{array}$ & $\begin{array}{l}200 \\
160 \\
125 \\
575 \\
200\end{array}$ & $\begin{array}{r}440,000 \\
336,010 \\
75,000 \\
517,500 \\
1,050,000\end{array}$ & $\begin{array}{r}220,000 \\
168,100 \\
37,500 \\
258,750 \\
525,000\end{array}$ \\
\hline 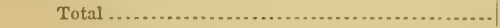 & 9,300 & & $2,418,500$ & $1,209,250$ \\
\hline
\end{tabular}

RECAPITULATION.-(Seventeen rookeries.)

St. Paul Island, 1886

St. George Island, 1887

Grand total of breeding seals only $\overline{6,357}, \overline{750}$

Notw- - I think that a cleduction of one-foncth from the above would show more nearly correct the true number of seals on the islands. In my judgment Mr. Elliot does not allow them space enough.

The breeding gromuls on St. George Island, survered July 12 and 15, 1s73, gave the following figures (H. IV. Elliot's "Condition of Atiatis in Alaska, 1874," 1. 70):

\begin{tabular}{|c|c|c|c|c|}
\hline Nane of rookery. & $\begin{array}{c}\text { Sea } \\
\text { margin. }\end{array}$ & Depth. & $\begin{array}{l}\text { Square } \\
\text { feet. }\end{array}$ & Seals. \\
\hline $\begin{array}{l}\text { Eastern } \\
\text { Little Eastern } \\
\text { North } \\
\text { Near } \\
\text { Starry A teel }{ }^{2} \\
\text { Zapadine }\end{array}$ & $\begin{array}{r}900 \\
750 \\
2,000 \\
750 \\
500 \\
600\end{array}$ & $\begin{array}{r}60 \\
40 \\
25 \\
150 \\
125 \\
60\end{array}$ & $\begin{array}{r}54,000 \\
30,600 \\
50,000 \\
112,500 \\
62,500 \\
36,000\end{array}$ & $\begin{array}{l}27,000 \\
15,000 \\
25,000 \\
56,250 \\
31,250 \\
18,000\end{array}$ \\
\hline Total ........... & 5,500 & ............. & 315,000 & 172,500 \\
\hline
\end{tabular}

The information furnished hạ tho estimates of seal life are very valuable, though of course not absolutely correct.

The measurement ou St. George Island is undonbtedly as near correct as it is possible to make it, and differmor sn widely from the estimate made by Mr. H. W, Elliot, July 12 and 15, 18i3, I am forced to conclnde that that gentieman, so uniformly correct in his voluminons and interesting history of the fur seal and his home, has made a great mistake somehow in his work of measuring the rookeries at that time. It is nuite evident snch is the ease, as the number of seals he makes on the breeling rookries, vi\%, $1,2,500$, is ont of all proportion to the number of males killed in 187: and 18:3. heing 25, (i00 each year, whilst on St. Panl Island, with $3,030,250$ seals on the roukeries, only 75,000 males wero talien cach year, or three timeg $9984-12$ 
as many as were taken on St. George; while St. Paul, according to Mr. Elliot, harl eighteen times as many seals on the rookeries. For $1879,18 \times 0$, and $1831,20,000$ wero taken anuually on St. George. Since that time the lessees have nut been ab:e to take conveuiently more thau 15,000 anuually, notwithstanding the rookeries have receiver large arecessions of cows aud bulls each year since 1873 , and now have seven tiunes tho number estimated by Mr. Elliot to have been there when they took 25,000 seals. The number of seals at present shown to be on the breeding rookeries of the two islands is as follows:

St Paul Island . ................................................. 5, 148, 500

St. George Island ......................................... 1, 209, 250

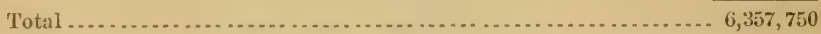

The poung malo seals haul out separately from breeders, and no estimate of their numbers has ever been made or attempted, so far as I know. It is certain one-balf the pups born are males, and that pups equal to 90 per cent. of cows on the rookcries go into the water; that is, exchusive of the young cows which eome upon the jookeries for the first time to meet the mules. The estimated loss of 10 per eent. is cansed by bulls in preserving vigid diseipline, and administering uecessary correction in the munagement of their domestie attits. Their silea of a temale's duty does not arlmit of any little indiseretions, and at the sliwhtest sign of deviatiou, regardless of ronsequences, they quickly pounce upon the ofiending fimale and shake ber by the neek. A number of pups aro also lost by being washed oft the rocks by the surf aud drowned, before they bave learmed to sivim. Fully one-balf the pups which go to sea in the fall return as yearlings the following spriug, the absent ones having furnisher foot for their natiral enemies in the water. As they grow older the percentago of loss by this eanse decreases larrely. I have made frequent aud close inspections of the rookeries this year, aud find the liues of occupancy exteuded beroud those of last year, and the cows quite as deusely packed on tho groumbl on nust of the rookeries. Whilst on two rookeries there is some fallug off, it is certain, however, this vast number of animals so valuable to the Governmeut are still ou the increase. The condition of all the rookeries conld not be better, and the seals, undisturlsed when ashore, seem to take great comfort out of their seatson of rest, after a long winter vosage at sea. The Department can not place too high an estivate on tho value of this seal property, aud the Govermment, I am sure, will not yield to auy demands which would nake it possible to accomplish the destruction of her seal rookeries and seal life, which, under jndicions mauagement and protected by law, may bo perpetuated indefinitely.

\section{DESTRUCTION OH SEALS.}

I am now convineed from what I gather, in questioning the men belougring to captured schooners and liom rialing the logs of the vessels, that not mote than one seal in ten killed and mortally wounded is lamed id ou the boas and skimned; thus you will see the wauton destruction of seal lifo withont any heuefil whatever. I thuk 30,000 skius taken this pear by the maranders is a low estimato on this basis; $300,000 \mathrm{fur}$ seals were killed to secure that number, or thres twoes as many as the Alaska Conmercial Company aro allowed by law to kill. You can readily see that this great slaughter of seals will in a fow years mako it impossible for 100,000 skins to be takeu on the islands by the lessees. I earnestiy hope more vigorons measures will be adopted by the Government in dealing with these destructive law-breakers.

\section{THE MARA UDERS.}

Last fill, after tho steamer had departed for San Francisco, a umuber of maraudiug sehooners were sighted from St. Paul Island. Oue, a steam-sehoover, laid off the reef rookery several ditys from $81 \mathrm{~h}$ of August, with boats dowu killing seals in the water. Owiug to the distance from land (thongh in full view) and the uncertainty of the weather, it was not deemed sale by Captain Loud, assistant Treasury agent in charge, to go out to her in small boats. Sho was rewarded by securiug a cargo of 4,300 seal slius for her British owners, which were delivered and sold in Victoria.

The Departmeut's attention is respeetfully ealled to the operatious of the cutter Rusth, Capt. J. D. Sheppard, sent to protect tho seal islands aud scal lifo this season. the has been indelatigable in bis effints, auel will no doubt adel at least six more to the list of his captures before he leaves the waters, as therearo at this time double that number of srehooners arnuml the islands. The Briti-h sehooner Dolphin had on board a very large lot of tino rifles and ab ton of fised ammunition. Iler commander, J. D. Warren, hat five vessels sealing; four of them are among the captured. Ho is one of the

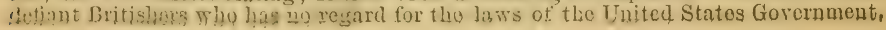


While the Rush was busy taking care of the marauders around St. Georwe, three schooners were killing seals near st. Paul, frequently in sight but beyond the reach of the Treasury agent, as we havo no facilities for going out to sea so far to board vessels.

What we should have on St. Paul Island is a 20-ton steam-yacht, to draw not over 5 feet of water, provided with ono small rifled gun. Such a steamer wo could ruu $\mathrm{up}$ in the lacroon at the village for gooul harbor where she wonld be perfectly safo against all kinds of weather. There is almays an engineer on the islaud competent to run a small steamer, and natives for crew always at hand, willing to serve the Treasury agent when called on. In this way it would not cost tho Government a dollar to run the yacht. She could cruise all round the island doing the work of a cutter withont any expense for erew. It is impossible for one entter to guard the two islauls successfully-as, for example, tho liush loft this island the niegt of the 15th instant, and bad not returned when wo left on August 3 , at 8 \%. $m$. She harl all she conlel do around St. Gerorge and to the eastwaril. Euring her absence three schooners operatiug at St. Paul's must havo seenred large catelies of seals. For the next month I have no donbt the marauders will concentrate near the islands. If the condition of the cutter Brar, on her return from the Aretie, will admit of it, Captain Healey will remain at the islants until the sea is eleared of the sealing vessels. The Bear was leaking badly when I boarded her at St. Paul, on her way north, and, indeed, the eaptain thought he wonkd have to return from St. Michicel's and proceed direct to San Francisco. If such should prove to be the case Captain Shepard will have more than he can do during the month of Angust.

As shown by my report to the Department, there was kilied for the year ending July 31, 1S57, a total of fur seals on the two islands of 104,S29, divided as follows:

Young pups for native food.

For uative food cluring the stacrey season when the skin is not menchantabe.

Small poung seals killed by natives during food killing ....................

Small young seals killed by the Alaska Commereial Company through accident while taking their catch .....................................

Alaska Commercial Company under contract............................ 100,000

4,110

As shown by my report to the Department, there was killed for the rear ending July 31, 1858, a total of lir seals on the two islands of 103,920, divided as follows:

Young pups for native food.

For native food during the starey season when the skin is not merchintable

Small young seals killed by natives during food killing ....................

Small young seals killed by the Alaska Commereial Company throngh acei-

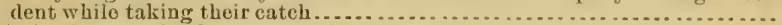

Alaska Commercial Company under contract........................... 100, 000

103,920

Wednesd 4 Y, December 19, $188 S$.

\section{TESTIMONY OF WILLIAXI GAVITT.}

\section{Villiaßi GAVitT, sworn and examined.}

By the CuAmman:

Q. Mr. Gavitt, are you ocenpying any offeial position now, and if so, what ?- 1 . Yes, sir ; I am a special agent of the Treasury Department at the seal islands.

The chairman here reald to the witness the resolution under which the committee aeted.

(2. You said that your are a special agent of the Treasury Department. To which island were jouassigned for dut y ?-1, To St, George Island. 
Q. Will you state the location and condition of the fur-seal rookeries on that island and so far as they came under your observation on both of those islands? - A. The location, you mean?

Q. Yes, sir. You may state as uear as you can when you went there and how long yon were there.-A. I landed there May 30, 1887, and left there August 9, 1888.

Q. You were there continually during that time ?-A. Yes, sir.

Q. You can now go and state the location and condition of the rookeries there and your administration of public aflairs there and your ob. serration upon such affairs.-A. In just my own language?

Q. Certaiuly, sir; in your own language.-A. Well, the rookeries were near the building. As far as concerned comparison with other years as to the seal increase or decrease, I kuow nothing, because I was only there the time mentioned. They commenced the killing on the 1 st of Jume and finished about the 1st of August. They take 15,000 scals on St. George aumually. The company have a store, school, and furnish 20 tons of coal to the natives, and during the winter I was there they had five men there.

Q. Well, did they conform to the requirements of the law and the contract; did they perform that contract-the Alaska Commercial Company, I mean?-A. The company used every endearor to perform their part of the contract. I had a difference with a man on the island in reference to the school which $I$ wonld call, in justice to the company, a local difference- a conflict of authority.

Q. By whom do you mean a man on the island?-A. The local agent, Mr. TVebster.

Q. The company's agent?-A. Yes; the company's agent. He closed the school in spite of a written protest from the Government officer, which I did not like and which I did not think was right. I do not consider that the company was any party to that, because I do not think the company would ever have approved of it. It is merely a case of obstinacy on the part of that agent. The company's intentions. I consider, were honest and upright, and they were endearoring to fulfill their contract with the Govermment. The company's iutentions, I believe, are honest and upright, but in regard to their men employed on the island I can not use severe language sufficient to corer their case. The men with whom I have dealt, that is, myself and my wife, did not respect the laws of God or man or my wife's presence or my position. I am referring to MIr. Webster, I)r. Lutz, John Kirk, and a man uamed John Hall. This administration expected a Government officer to take his wife there, and I took my wife from the altar to the St. George Island, and I have regretted it ever sinee. I wish a distiuction to be understood between the lonest intention of the gentlemen in San Francisco and that crowd of wen that they have intrusted with their business on that island. I wish for that to be distinctly understood. I believe that the company itself is homest and upright in its intentions.

Q. Do yon refer to those men in the execntion of their duties under the operation of the law or simply their moral deportment as men aud eitizens? - A. I refer to their powers to antagonize a sworn officer of the lat and to make him miserable aud crucify him.

Q. What particular case do you refer to. Mr. Gavitt? Can you specify acts on their part and name the individnals and how it affected the public interest?-A. Nir. Chairman, I went there without instructionsthat seems to be an opening that a Government officer does not know his dut - I went there without instructions whaterer, with the excep. 
tion of what Senator Voorhees gave me: "Determine to do your whole duty." That was all my instruetion.

Mr. Feltow. Did rou get any from the Department?-A. None what. ever. The surrounding circumstances would dictate what a man's duty would be-to protect the natives and see the latw enforced, and he hats no power to do so.

The Cmamrinan. Did fou read the laws in reference to that reservation?-A. Yes, sir ; and the company's rules, and those rules are good enough for anything, but they are violated.

Q. By whom?-A. Br the company's men; by their interference with the government of the natives, and by everything being dowe to antagonize law and order.

Q. Can yon specify any acts on their part which were in violation of the laws of congress in reference to reservation or the regulations of the Treasury Department? $-\mathbf{A}$. The regulations of the Treasury Department, no; but if my knowledge is correct in regard to a Government reservation, I have seen the flag insulted on St. George Island by its being hoisted and by their making sport of it-Mr. Webster and Dr. Lutz-and I have my wife here to prove it.

Q. Can sou specify any violation of the law on their part?-A. As to the taking of the fur seal?

Q. As to taking the fur seal and the general administration of the laws of the Gorerument on that reservation?-A. I know of no law, Mr. Chairman, with the exception of the taking of the fur seal, that they did not violate.

Q. I understood you to say awhile ago rou read the statutes creating the reservation of these islands of the Prybilov gronp, the islands of St. Paul aud St. Georgo and the others of that group. I beliere there is a little rock or two besides which are included in that reservation. Now, for instane, ron understand that no one is permitted to hunt there and to take the fur seals there except the lessees of the island. The islands are leased to this Alaski Commercial Company, and I suppose rou are familiar with the law governing that lease and the terms of the lease. You know what they are required to do under the operation of that law. You know under the operation of that law, or you should know as a Govermment agent, who are permitted to go there and what acts they are probibited from doing there. Now, I ask you if you know of any acts that were done in riolation of law in reference to that reserration, or any violatious of the contract by the lessees under that lease. I would like for yon to specify just what it is, whether by the compauy or its agents, because rou linow the agents there represent the com. pany, as the company can not be personally present. It is only present through the presence of its ageuts. The acts of its ageuts there the company is responsible for under the operation of the contract and the law.-A. The law as pertaining to the Alaska Commercial Company was carried out.

Q. By the agents of the company ?-A. By the agents of the compauy, with the exception of that school being closed.

Q. To what extent did that violate their duty there?-A. I will have to refer to my memorandum.

Q. Certainly; do so if sou wish to.-A. Uncler the 30th of April is this entry:

To-day at noon Mr. Clark infurms me that he intended elosing school to-rlay. I told him that he bat better not, and that the school onght to be contimued unfil the timo preseribed and in accordance with the contract, and that. ho harl not tanght eight months. Ho suggested that I seo Mr. Webster. I replied that I thought Mr. 
Webster knew his business and that I certain]y knew mine. He said that unless Mr. Webster told him differently he would close school to-rlas. I said that I had no way of compelling him or forcing him to keep school, but if it was closed I rould enter a protest against such illegal action. I told him that he and others should want to do their cluty.

\section{Then I made the following memorandum:}

These men are liable to do anything, and it would not surprise me if they should close the school. He commenced the school September 5, 1887, aud I kunw of 110 method by which he can figure eight months out of it.

That is my memorandum of $\Lambda$ pril 30 .

Q. Did he close the school?-A. I am coming to that.

May 1. $-\Lambda$ t breakfast this morning I told Mr. Clark that he should not close the school, and that I again protested against it. No school this morning, and all the hooks removed from the school-house. At 12.10 I handed to Daniel Webster, agent of the Alaska Commercial Company, the following:

"ST. GEORGE IsLand, MIay 1, 1888.

"SIr: I write this and serve on you as a protest against the stopping of the school and as a demand that the school be contiuned in accordance with the law and the contract with the Alaska Commercial Company and the United States Government. If the school is longer stopped I will cousider such action ou your part a positive violation of the company's contract with the Government.

"Respectfully, yours,

WILLIAM GAVITT,

"Special Agent of the U. S. Treasury Depariment, "In charge of St. George Island."

"Agent of the Alaska Commercial Company, "St. George Island."

Q. He closed the school then?-A. Yes, sir.

Q. How much did you lack of having completed the term required by law of the school? You say the school commenced in September.-A. It commenced September 5 .

Q. When should it have terminated?-A. It should have closed May 5.

Q. And he closed it when?-A. May 1.

Mr. FelTox. Making a difference of four days? - A. The point was not so much the four days, but it would have been just the same if it was four months, as the question was who was in anthority there.

The Ciramuran. Do jon know of any other acts of riolation of eontract or law? -A. No, sir; nothing pertaining to the contract of the Government and the Alaska Commercial Company. That is the only thing, and that would not have been done if any other man than Mr. Webster had been there.

Q. Did the company furnish the natires on that island the amount of fooll (the dried fish) the law required?-A. Yes, sir. did.

Q. Did they furnish the amount required by law ?-A. Yes, sir; they sir.

Q. Did they furnish the amount of fuel required by law?-A. Yes,

Q. Did they furnish medical atteudance and medicine to the natives on that island ? $-\Lambda$. Well, in a way.

Q. Well, sir, state what it is. Is that required by law, howerer?-A. No, sir.

Q. What did they do abont a doctor and medicine?-A. They have a physician on the island; of course I mean a medical man. But I do not approre of their way of doetoring the natives.

Q. Do they charge the natires for medieal attendance?-A. No, sir.

Q. Do they charge them for medicine?-A. No, sir. 
Q. Is there any other phrsician living there except the one maintained by the company? $-\Lambda$. No, sir.

Q. There is none there by the Government?-A. No, sir; I am somy to say.

Q. None resides there?-A. No, sir.

Q. What kincl of louses do they furuish to the natives? - They are pretty good.

Q. Are they comfortable?-A. They are good enough, sir.

Q. What rent do they charge?-A. None at all; as I understand it.

Q. If they charged any rent, you fatled to find it ont?--1. les, sir; but in my case there was a knife in erery hant.

Q. Does the law require them to furnish them houses free of rent?A. I do not know that it does.

Q. Did they furnish any lingor to the matives on the isiand? - 1. Not openly in any way.

Q. Did they in any other way ?-A. Yes, sir; and the abandoned prostitutes on the island, as I have reason to believe.

Q. Can you name iustances iu which it was furnished, and by whom ?A. No, sir; I conld not tell. Mars Oustigofi, a prostitute, aud her hus. band, were drunk there- -

Q. Do you know what they were drunk on? - A. Xo, sir; I can not tell.

Q. Were you able to discorer the introduction of intoxieating liquors by any one?-A. No, sir.

Q. The evidence, I think, discloses the fact that the natives mann. factured themselves an intoxicant? - $A$. It is true they mannfactured quass, which they manufactured from sugar.

Q. Sugar and dried fruit?-A. Yes, sir, and the way is that a fitrored fer get the sugar, and those who are not in good standing with the administration of the company there are licpt ont of not only lnxuries, but even the necessities of life.

Q. Were fou able to discover whether those two particularpersons were drunk by reason of their manufacture of intoxicating diuks in this way? - 1 . I searehed their house, but could find no quass.

Q. Did you find any other liquor ?-A. No, sir; but whisty might be colored with lieorice and

Q. Did rou make ailigent search there aud try to break up the manufacture of this intoxieating liquor?-A. Yes, sir.

Q. Did you aseertain who was supplying them?-A. Only by the constant visits (1) the compauy's house-that is, Mary Oustagofi' and her husband.

Q. Were any intoxicating liquors kept on sale in the company"s store?-A. No, sir; nothing like that; they would not have permitterl it.

Q. Wias any other person intoxieated habitually there excent those two persons? - A. Yes, sir.

Q. Who mere they? - A. Mr. Webster. Spealkingabont intoxicants, Mr. Webster told me he would give the native's liquor whenerer he salw fit to do so, and he said so in the presence of my wife.

Q. Did he?-i. I do not linow whether he did or not, but that is what he said.

Q. What is the law about the mannfacture or sale of intoxicating liquors mon these islands ? - A. I know that the natives me not allowet intoxicants.

Q. They are not allowed to the natives non to be sold to the natives?A. No, sir. 
Q. There is no law prohibiting any citizen of the United States who goes there from carrying and using it himself?-A. I think there is a law pertaining to the custom-house in San Francisco.

Q. A custom-house regulation?-A. I think so.

Q. Can you identify in particular any act in the introduction, sale, or use of intoxicating drinks in violation of the law or the regulatious of the Treasury Department, including the custom-house at San Francisco? Can jou specify any particular act or name au iudividual?A. I have seen wine brought in by Gorernment officers.

Q. In violation of law?-A. You see there is the tronble-we do not understand. Some say wine is not included in the law.

Q. The statute specifies intoxicating liquors.-A. I do not linow; I am very ignorant pertaining to that.

Q. I think the sum of it is that they are prohibited from selling intoxicating liquors and so on.-A. I saw Mr. Manchester give a drink to a woman named Merculiff. He gare her a glass of wine on the th of July, 1887.

Q. For what purpose?-A. Just for a drink; she was a nurse girl.

Q. He was a Government agent?-A. Yes, sir.

Q. Did she become intoxicated?-A. Oh, no. And he gave the priest a glass too.

Q. Will you state what are the general character and habits of these natires of that islaud in general ?-A. Their character is peaceable aud apparently, as I found, litw-abiding people. The disposition is to do as told, but they are greatly dissatisfied at their present condition.

Q. What is the source of their dissatisfaction? - A. As I found their treatment during the winter-time by the employés of the compant.

Q. Do you mean dissatisfied mith the execution of the law, or just a personal disagreement betreen them aud the govermment?- $\mathbf{A}$. It is pertaining to their general condition; the condition of things is wrong.

Q. Is their condition worse than it was before the cession of the islands to the United States? Have you any knomledge on that subject? - A. I suppose it is better now than it was.

Q. Is it your opinion that the condition is better?-A. I should judge so; but that is only from hearsas. Of course I lnow nothing of that. Q. Are they better clothed or worse clothed; do they earn more or less money than in their former state?-A. I can not auswer that.

Q. You hare no knowledge of their earnings under the Russian system there?-A. No, sir.

Q. Yon do not know what their habits of life and coudition were under the Russian system?-A. No, sir.

Q. You state that your general conclusion is that their condition is better from what you have heard as to what took place?-A. lrom a letter that one of the natires wrote, they were not treated any worse under the Russians. This letter can be rearl.

Q. Iu what does that bad treatment consist; can you specify acts?A. Yes, sir; I can. For instauce, one case: A native was reported for punishing his wife. I tried him, and found the man was innocent. He ranted to prevent his wife from going to the company house for immoral purposes. I lectured him and dismissed him. When I dismissed him, Mr. Webster ealled bim and told him that if he did not permit his wife to come to his room he would break his head. I hare here an affidarit from the man covering that. Another ilstance: $\Lambda$ native wished to marry a girl on St. George Island, and the marriage was preventerl in order to keep that girl for a prostitute. I have an affidavit corering that. 
Q. Prerented by whom?-A. Dr. Noyes and Mr. Clark. Mr. Clark told this man-gare him to understand-that there wonld be no more work tor him if he married that girl.

Q. Hare you other iustances within your knowlerlge?-A. If it comes nnder the head of whipping a Government oflicer or anything in that line, why I was threatened to be whipped.

Q. Fias the company's agent an opportunity to intimislate the action of an officer, and to prevent him from performing his duty under the law or under the lease?-A. They not only intimidated a Goverument officer, but abused him shamefully.

Q. Stato the actsconstituting this and the instances, please, sir.-A. Mr. Kirk told me five different times that he would whip any Government officer who interferer with his business. I asked him what he meaut by his business, and he said "With the women."

Q. His business or the company's business? $-\Lambda$. His private business.

Q. With the females ?-A. Yes, sir; anything that would tend to stop it. Mr. Webster has also talked shamefully to me.

Q. Did he attempt at any time or in auy way to prerent you from performing your public dnties in execution of the law and the contracts of the Government with that company?-A. Well, if the government of the natives is concerned, yes, sir.

Q. Towhat extent? - $\Lambda$. In regard to the natives, and making it so disagreeable for a Government, ollicer and his wife as that he almost wished ho was dead rather than go through such an experience. My wife would be whistled at and ridiculed whenerer she stepped out of the house. We pulled down the curtains between the goverument house and the commany house to prevent her from seeing things a decent lady onght not to ser. It is a Gorermment house of prostitution from one end to the other.

Q. Yon mean the Gorernment honse ?-A. No, the whole island; the way it is run. Every rule that is passed by the Government oflicer the company's agent there endearored to undermine it. Mr. Clark weut to a natire there and offered him inducements to make quass on the island.

Q. Who is Mr. Clark?-A. The school teacher on the island.

Q. Where is he now ?- $\Lambda$. On St. George Island. If a man conflicts with that crowl-I have not the descriptive ability to give you an idea of how they can persecute him and barass him day by day. The suggestion I have, as far as this is concerned, is that if you had a Gorernment officer there elothed with sufficient power there would be no complaints of this lind, but until that day comes the natires ean not expect any help.

Q. Mr. Gavitt, did you report these facts?-A. Yes, sir.

Q. To whom did you report? $-\Lambda$. I reported them to Mr. Tingle.

Q. Did you revort this condition of aflairs to Mr. Tingie?-A. Yes, sir. The rerenue entter Bear came up there, and a sort of a courtmartial inquired into tho facts. It continned its session from 7 o'clock in the erening until, I think, half past 11 o'elock at night, and the eridence was so shocking and disgraceful, that the cantain came to me and said, "Yon had better not let this thing go, as this thing is like a divorce court." I demanded the papers, and he told me he would give them. He told my wife that he would give them to me, but he did not, because he was afraid I wonld gire them to the newspapers.

Q. Who was the captain ?- A. Captain Healy, of the Dear.

Q. Mr. JeFrnies. I beliere this testimony is allomed a pretty wide latitude, but I do not object to that. 
The Cnumnuns. By what authority was that eourt-martial held; what was the court-martial doiug there?- $\mathrm{A}$. He told me he had power-

Q. Who was he trying? $-\Lambda$. The condition of things on the island of St. George.

Q. So he was simply inrestigating; it was not a court-martial proper ; it was not a trial of anybody?-A. I know Captain Healy sent his men on the island to inquire.

Q. It was just to inquire into the general condition of things there; was that it?-A. Yes, sir.

Q. He was making a general iuvestigation, auil no person was put upon trial, and so it was not a court-martial, was it?- $\Lambda$. No.

Q. Can you specify any other acts?- $-\Lambda$. Nothing, except afildavits of the natives-that is, covering the point.

By Mr. FELTON:

Q. You spoke of a Gorerument house; what do jou mean ly that? $\Lambda$. We have a Government house on the island.

Q. You did not mean the company honse? $-\Lambda$. There are two.

Q. You used the expression "Government house." Did you mean the compauy house or the Government house?-A. I do not remember the counection in which I used it. In the Goverument house were my wife and myself, and the company house was the headquarters of the company men.

Q. I understood you to speak of certain improper acts going on in the Government house; you mean the company house? - $\Lambda$. Yes, sir.

Q. Do you know of any importations of liquor by anybody there?A. No, sir. There was one case I remember. $\Lambda$ man came there from Oonalaska and brought a bottle of perfumery and a preparation what he called medicine for his father, the priest. I told him he could not have it until he saw the doctor, and the doctor gave him permission to keep it for his father and to use it for medical purposes.

Q. You do not know that the company imported any or sold it, or attempted to do it ? $-\Lambda$. They never sold it. If they had any they gavo it away to their favorites there.

Q. Do you know of any imported for that purpose?-A. No; I vever searehed the men's baggage-that is, the employ e's' baggage.

Q. I suppose liquor could be smuggled in by a sailor or any one who stolped there by taking a bottle in his pocket? - A. Very likely. No doubt of that. There is no direct law to corer anything. The Government officer does not know what to do; he is at a loss. The company does not approve of this condition of affairs, but it has been going on so long it is a terrible punishment to ask a man to go to that island with his wife and to live with the company's prople and eat at 1 beir table and to sail on the same ressels and all that sort of thing. The condition of things there was so bad that if I owe the Government an apology it would be for not having Webster shot on that island, as there is a high law in view of this condition of things.

Q. I suppose the Gorernment could bardly indorse that?-A. I hardly think so; but they would take their chances of indorsement rather than go through the abuse my wife and I have receired.

Q. Is it not a fact that the general character of the native women in a moral sense is what we mould call rery loose? Is not that the character with them?-A. Yes.

Q. Is not that their past history as far as you know and as far as you hare heard of it? Are not their social relations very peculiar?-A. I suppose so. 'There is oue woman who has never been married, but who 
h as had trelve children, and one of her danghters who has never been married I think has four.

Q. There is nothing very sacred?-A. I should not think so. As I said, it is a house of prostitution. 'The coudition of things is this: A Govermment ofticer goes there alone; if he conflicts with the wishes of these men they can not only make him wish he was dearl, but blackmail him when he comes away fiom there, becatise they have the preponderance of evidence on their side. Mr. Horgan told me once in resard to Mr. Webster, "He is all right if you get ahong with him, but he is a rery devil if you do not." They ean male you wish you were in hell with ten sackis of powder on your back it they get after you. 'They arucify everylhing. They destroy erery comfort, and those were the nime longest months I ever speut. I was ju Jeflerson Penitentiary the other day, and withont exaggeration I should prefer it for my wife and myself to what I have gone through on that island.

Q. Has there been any attempt to blackmail you?-A. Xes, sir; I have a letter in my pocket which 1 consider nothing but blackmail.

The letter was here produced and read. It is as follows:

\section{Cambridge, Ohio, December 2, 1888.}

Sin: I see by the Cincimnati Enquirer of 30 th that you and Mr. Ryau have had a meeting in Indianapolis. How far responsible you are for the article published $\mathrm{I}$ am able to judge by its tone. While in IVashington your petition, signed by Peter Rezansolf and other natives was received and filed; also your letter to the Department, asking that you and your wife be ordered to Washington to tell the Department what you know, ete. That letter was duly filed and when tho Department want you they wil! send for yon. Now, in view of the troubles you had on the island and in view of your record there, which from the afildavity of John Hau, D. Webster, Dr. Lutz, Kirk, Dr. Noyes, Clark, Mr. Manebester, Captain Loud, ete., which I have in my possession and which I tolel you en routo home should be suppressed if you did not force me to bring them to light.

So far I have kept my prouise to you, having no desire to iujure you with the Department or your people; but if it is sour purpose, as it would seem by the Euquirer article, to open uy your trouble, you must suffer the exposure of your conduct, as set forth in the papers $I$ hare, which wonli not, if published, elevate you in tho minds of respectable people. I am en route for San Francisco, where I will winter. My poor wite is yet uualle to be about. My address will bo Special Agrent's Otfice, Appraisers' Builıling, San Franciseo. Mr. Ryan is an applicant for my position. I will, of course, take 110 part for or against any one, but gracefully bow to the inevitable. I will go iu some business, a California or Puget Sound. I helieve General IIarrison will try hard to give the country a good administration. With regards to your wife aud self, I am,

Respectfully,

WiLliam GavitT, Esq.,

Evansville, Ind.

Geo. R. TiNgle.

Q. Do you consider that letter an attempt to blackmail?-A. I consider it in that light, for it states that if 1 will say nothing detrimental in any way to these mon that anything they have to say against me will be sijploressed, aud that if I say auything detrimental to these men on the islaud that evidence blackening my character will be produced from men at whose merey I was placed.

\section{By Mr. M ICDONALD :}

Q. State brefly in substance what you understood those gentlemen objected to; what you first complainer of:- - . In the tirst place, when I went on the island they were mad at the priest.

Q. The priest of the (ireek church?-A. Yes, sir. Mr. IVebster wanted me to keep the priest ont of pirps and coal, and I would not do it.

Q. Out of what?-A. Seal pups for their food. I told him I wonld not do that. 
Q. I say, what do you understaud was the first reason for wanting you to keep this priest out of pups and coal?-A. Because they hat a disagreement and ill-feeling existed between them.

Q. A personal enmity?-A. Yes, sir.

Q. Go on, now.-A. Previous to my arrival there had been some trouble abont the killing of pups, and it had been settled, and I told the natives that any one who made quass or killed pups I would have them sent from the island.

Q. What is quass?-A. It is a Russian intoxicating drink. Mr. Webster said he would get even with l'eter Rezanzoff if he had to kill the pups and put them in his house.

Q. For what?-A. Unly to get him in trouble aud persecute him. I said I should not permit that sfstem of persecution; that my belief was that the company was there to keep the store open and to fulfill their part of the contract, and that they must let the natives alone. That is all the natives want, to be let alone, hut they will not do it.

Q. Was there anything else? Why did you understand the employés of the company were unfriendly to you?-A. Because they could not make me do as they wanted me to do.

Q. In general terms, because you would not do as they wanted sou to do?-A. Because I would not be a tool of these men, and because I could not be whipped in. They conld not starre me in, and now they try to blacken my character.

By the CHatrmaN :

Q. Now, Mr. Garitt, will you state as to the selling of goods to the natires by the company? What prices do you charge the natives for the goods they sell to them ?-A. They are smpposed to charge 25 per ceut. abore the San Francisco prices, and, as far as I know positively, that law is obeyer with the exception-I have some samples.

Q. That is not a matter of law.-A. That is an agreement between the Government and the company, to chirge 25 per cent. profit.

By Mr. JEFFrTes:

Q. You do not know auything abont that?-A. It was my understauding of it, sir.

Q. You had better understand what you are talking about.-A. Well, I will try. Thank you for your interruption.

Q. You are welcome.

\section{By the CHAirmaN :}

Q. I will state to you that the committee is inquiring into this matter simply to ascertain whether any abuses are indulged in by the company towards the uative in habitants, who are stated to be a rery simple-minded class of people; and I do not know myself of auythiug in the law requiring the compauy, or rather regulating the sale of goods to the natires, except the laws prohibiting the sale of intoxicating drinks. I do not remember any regulation, but as the committee is iuquiring into that question I will ask you if you have any evidence of unreasouable extortion in the price of goods?-A. I have not, in reference to charg. ing one person more thau another; but in refusing to sell to one person and selling to another, I have. You see a favored few can go and buy luxuries, that are taken out of the store and put in the company's house, when those who are not farored can barely get the necessaries of life.

Q. On what account are they favored aud not farored ?-A. They are prostitutes. They can buy luxuries, while those who are not prostitutes can hardly get necessities. 
Q. Does the company authorize such things as that?-A. No, sir; I do not think those geutlemen in San Francisco would be gruilty of such a thing.

Q. Those are merely the acts of the agents?-A. Those are the acts of the employés out there in the winter time. I am willing to defend the Alaska Commeraial Company, aud I would tight for them as quick as I would condemn this rery system. I believe that they are gentlemen as far as $I$ linow. They do not approve of this business; $1 \mathrm{am}$ persuaded so.

Q. You mean then that this is simply the moral conduct of these emplosés?-A. Yes, sir; the compauy's emplosés. That is a point I want distinetly understood.

Q. How are thr natives employed? What are they employed to do by the company ?-A. To kill seal.

Q. To take the skins?-A. Yes, and salt them.

Q. What are they paid for that?-A. I hare forgotten, but the first payment is about $\$ 8,500$.

Q. How much per skin?-A. I understand it was 40 cents a slin. It is placed in shares and the men get it by shares.

Q. Is that paid in money

By Mr. MACDONALD:

Q. When did you know of your own knowledge of the compauy having been notified of the conduct of their employés on the island? I mean when was notice first given to the company?-A. I do not know. I wrote Dr. MeIntyre a letter, and I have copies of these letters I wrote to him. If you like it, I will read them.

Q. When was it?-A. As far as my recollection goes, it was the $3 d$ of June, 1888. That is as far as my administration weut.

Q. Is that the company's first knowledge, and was that notice tho first one given by any one that you know of?-A. If rumor is to be believed, no. It seems that every Government officer who wiutered at St. George's Island, I think, with the exception of one, had had a bitter experience.

Q. My question is, when did the company, to your knowledge, first have notice of this misconduct on the part of their employés?-A. i have no knowledge in respect to that.

Q. The first notice, to your knowlenge, you sent on June 3?-A. As far as I am concerned.

Q. How loug did you remaiu on that island ?-A. I landed there May 30, 1887, aud left there August 9, 1888.

Q. How soou could ycu get notice to the company; was the general manager there?-A. As soon as he came back.

Q. When did he return?-A. June 3.

Q. That is the time yon gave the motice?-A. Yes, sir; June 3, $18 S 9$.

Q. Was anything rlone after his retun aud receipt of your notice in the way of au attempt to reform those abuses you complained of?-A. No; nothing.

Q. You nerer saw anything up to the time you left on his part to correct them ?-A. No, I did not.

Q. What was done by him or anybody else after he receired your notice?-A. I know nothing that he did.

Q. Nothing was done by any member of the company at the time rou left?-A. Nothing at all.

By the CHAIRIINN:

Q. Have you any linowledge of any trespassing upon the herd of seal-any unlarful killing of the seal?-A. No, sir. 
Q. Did you hare any means of takiug observations on this subject?A. Yes, sir.

Q. Have you any knowledge of auy violation of the law prohibiting the killiug of seal by other persons than the lessees?-A. No, sir; nothing of that kind.

Q. As a result of 5our observations, luare any suggestions occurreal to you as to the wisdom of taking more stringent measures of protecting the seal?-A. Yes, six. To protect the seal it should be left to the intelligence of the Government officer on those islands, with a limit on him. For instance, 100,000 seal on the two islands; now if the agent oir St. George Islaud sees that 15,000 seal are too many to take that season, it should be left to lim and not to a man at Washington, who is uot on the ground.

Q. The observation of the agent, in your opinion, onght to gorern the taking of the seal?- $\Delta$. Yes, sir ; with a limit on him.

Q. I refer more particularly to the trespassing by unauthorized per. sons in the open sea-unanthorized hunters.-1. A revenue cutter should be kept there.

Q. You thiuk they should be kept there?-A. Yes, sir.

Q. A naval officer should cruise there all the time?-A. Yes, sir.

Q. Do you think the herd of seal of sufficient ralue to justify the Government in keeping up the policy of protecting it against destruction?A. Beyond all doubt.

Q. If it was thrown open to general hunting and everybody and auy. bouly could hunt there, how long would the seal be there; rould they be destroyed :-A. They would be destroyed.

Q. You think the methou of protecting them is to maintain the reserration?-A. Yes, sir; to maintain it and have revenue-cutters there to capture pirates.

Q. Is it your opiuion that the herd of seal if carefully protected will grow in numbers and value and that the Government may increase its revenue from that source if this bo protected? - i. 'That would be the only way to have the seal, to protect them.

Q. The only object to increase the revenue anri extend the revemue is to strictly protect the herd against mularful depredation and indiscriminate killing?-A. IVhen killing them on the islaud we often find them with bullets in them, showing where they were shot by bullets.

Q. Now, as a result of your general observation, do I understand your opinion to be that the best policy for tho Goverument would be to rigidly and strictly protect the herd, and maintain a reservation and police that interest carefully and strictly?-A. Yes; with rereune-cutters.

Q. With all the agencies of the Government, reremue-cutters and naval vessels, your idea would be to hold the reservation and protect

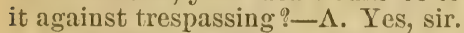

Q. And the point you desire to call particular attention to is for a better moral discipline to be extended on the islands themselves ?-A. Yes; and permit me to go further and say that this Government, deriv. ing such a revenue, should furnish the physician and school-teacher.

Q. You think it is safer and better?-A. Yes; a physician and schoolteacher. Send the Gorermment officer aud let him eat in his orm house so as to place him above these unjust criticisms, and then clothe him with anthority so he can do what is just and right.

Q. There are no magistrates or any civil officers; no such thing as a constable or sheriff or anything of that kind ?-1. No, sir; no such thing. 
Mr. MACDONALD. I understood thint you have to eat at the same table with the employés of the company?

The Witness. Yes, sir, and subject to their iusults, which no decent woman should bear.

Mr. FeLTON. Was anything compulsory in your eating with them?

The WITNESS. I attempted to get a cook-stove so that we could cook our own food, and they refused to sell that. I did not want to subject my wife to those insults, and so I wanted a stove so we could cook for ourselves.

\section{By Mr. MACDONALD:}

Q. What was the result of your observations and opinion that you feem reliable in respect to the unlawful killing of seal anuually?-A. We have no means of knowing that.

Q. It is a mere matter of estimate, of course, but I wish it based upon as reliable information as yon have.-A. I thiuk the first season the reveuue-cutters captured 15,000 stolen seal skins. At Jonalaska there was killiug of seal by the natives, and I so reported it to Washington.

Q. Who killed them?-A. Natives. These skins were sold to the Alaska Commercial Compans, who have a station there.

\section{By the CHATRMan :}

(2. Do yon know whether these seals are killed in the Bering Sea or in the Pacific?-A. I understand the Bering Sea.

Q. Where the law prohibits the killing in Bering Sea?-A. It is a question whether they aie killed in passing on the side of the Bering Sea or passing on the side of the Pacific Ocean.

Q. Is it, in your opinion, necessary that Government protection shonld be extended over the herd in the Pacific as well as the Bering Sea to preserve them?-A. Beyond question, as by that time these pirates all lie right at the pass in the Pacific Ocean and kill the seal as they come through.

Q. 'They go throngh this pass as they alpproach the Pribilov Istands?-A. Yes, sir.

Q. They travel on the surfice of the water, so they can be taken anannually as they return to the islands?-A. Yes, sir. If the schoolteacher is furnisher by the Goverument; if the doctor is furnished by the Government, and the Govermment oflicer has facilities to do his own cooking and travels in the Government ships, and the Gorernment offi. cer is clothed by law with the power to enforce everything on the island, as it should be, there will be none of these complaints. These men do not respect the positions of the Government officer, and since the Department insists upon a man taking his wife there they lo not respect the man's wife, which is distasteful and disagreeable. These things, gentlemen, that I speak of aro what I have seen; if you gentlemen go there, this is no guaranty of what yon will see, but this is what I have seen myself. Mr. Webster told me, "Mr. Gavitt, when a Grovermment officer comes here and gets along with us, it is prolitable, lout a good man never comes back here." It is worth a man's reputation to go in that country.

Mr. FeLTox. A good man nerer went back. What do you mean by that?

The Witness. I do not know. He said a man could draw two salaries like Mr. Falkner and Judge Glidden.

The Chairuan. Two salaries from who'

The WiTNEss. One from the company. 
Q. Webster said so?-A. Webster said a good many things I will not charge up to the company.

By Mr. Feltion :

Q. Did I understand you to say the Gorernment compelled a man to take his wife along with him?-A. I understood so.

Q. Could not a man occupy that position without a wife? - A. Not under this administration, I understand.

Q. Is that a law or a regulation of the Department?-A. It is a regulation of the Department, I understand.

Q. Then a man has to be married and has to take his wife with him ? -A. He has to go there and take his wile with him for the example which his wife will set to the ladies in order to elevate them. There are a good many thiugs that the women can do ; they ean copy a lauly's dress by a glance of the eye. These people are capable of sometining much better. They are not such a bad people. All they want is an example set for them, and they have not had it, I guess.

The CrramiraN. Do you think it better that there shonld be a commissioner or a magistrate placed there to execute the laws; say a commissioner and a deputy marshal to enforce the law?

The Witness: Yes, sir.

\section{By Mr. MaCdonald :}

Q. Are you speaking of what you have testified here partieularly in reference to the Islaed of St. George or the condition of things in general? $-\Lambda$. Of St. George Island in particular, as my knowlenge is limited to that island. I would freely give the benefit of the donbt to St. Paul, as it is a better island, I think. They have had none of this outbreak.

Q. You bave no personal linowledge of it?-A. No, sir. If it comes under the jurisdiction of this committee, I would say that as I nurlerstand it these peopje are Americau citizens here; and that a man wanted to go down and state his own story, and I gave him permission to go to Oonalaska with the chance of thus getting to Washington and telling his story; but he was sent to a remote part of the islaud until the steamer departed

\section{By the CHAIRMAN:}

Q. Who sent him?-A. He was sent at the instigation of Dr. Noyes.

Q. Was he s:nt against his will ?-A. He wats a single man, and he was eompelled to go.

Q. Who compelled him? $-\Lambda$. Dr. Noses.

Mir. MACDONALD. State the particulars, if it is anything, as to how it was done. $-A$. At Zappany rookery there is a watehman, or supposed to be one. Peter liezanzoff had bern very sick; he had fallen near the house with fits. Wr. Noves sent him to Zappany as watehman. This man was not fit to go, but because for the simple reason that this man had my permission to go to Washington to tell his own story, they sent him orer there and liept him 6 miles from the village, so the man could not get here to tell his own story.

\section{By the CHAIRMan :}

Q. What power compelled the man to go?-A. This compulsory power they have.

Q. Was he taken in custody and earried orer there?-A. No, sir; he knew better than to disobey. They have been taught that lesson long before. 
Q. What did the man want to tell?-A. We wanter to ask that tho natives have some rights and bo protected in them. They have asked me, "Does your Grover'ument approve of this ?" I said, "No," and they said, "If not, why do they not stop it?"

Q. What particular thing was he complaining of"? These immoral habits of these individuals?-A. They wanted some protection for their wives and children.

\section{By Mr. Macdonald :}

Q. This general misdemeanor you refer to?-A. Yes, sir.

Q. Well, if I understand you rightly, you are the only Government officer on the islaud? - A. I am the only one during the winter when all this trouble comes up.

Q. And practically the company goverus and controls the natives on the island? -A. The Government officer, both.

Q. It is a fact in reference to the natives? Practically, $I$ am speaking.-A. Yes, sir.

Q. And you while there were powerless to exercise any authority or control?-A. Yes, sir. I am like a whipped dog. You are aothing, and if son try it, they will teach you a lesson you will remember the balance of sour life. I was afraid of my life, aud my wife was, too.

Q. Was austhing said or done to cause you to be atraid of your life?A. Dr. Lutz tried to strike we with a file in his band in the eompany's house, when mo wife dragged me away.

Q. Anything else?-A. Kirk was a pugilist from San Franciseo, a big-fisted man-

Q. What did he do or saty?-A. He said he would lick any Govern. ment officer who interfered or reported him.

Q. Did you quarrel with him ?-A. No; he wanted to gire me to understand what he would do if I interfered with him.

Q. We would like to understand what you said. Tell us how it was.A. Kirk was telling about MIr. Ryan, who was there, and he satd Mr. Ryan did not interfere with him, but he would whip him or any Goverument officer that interfered with him, and in his presence I said, "What do jou call jour business?" and he said, "With women here on the island."

Q. Can yon state when you had this first trouble with the company's employés in that respect, and what it was about?-A. I want to see the exact late. I think it was November 1, when I gave the priest pups, seal pups, for food-all the natives are entitled to them-regardless of their protests that he should not have them.

Q. Whose protests?-A. Webster's-all of them.

Q. Just please answer my questiou. When was this?-A. November 1 .

Q. There was nothing connected.with the women, or protests about them?-d. No, sir.

Q. When did you have your next tronble with him or any other of the employés of the company?-A. This all continued.

Q. Yon meau this was the beginning, aud it continued right along: after that?-A. Then war was declared aud they kept it up.

\section{By the Chamrinan:}

Q. Just to continue Judge Maconald's inquiry further, the point he was driving at was, the disagreement between you and these persons was an accomnt of the execufion of your ollicial duties in enforciug the laws of the Enited States, or was it on accomt of their immoral iabits in connection with the deut women-them persoual habits? - $d$. It wats 
on account of the enforcing of the legal laws on the island and their habits.

Q. They objected to any interference on your part with their personal habits?-A. Yes, sir.

Q. And it was in connection with these things that you had a disagreement with them?-A. Yes, sir.

By Mr. FELTON:

Q. You spoke about a shoulder striker who was sent up there; who sent him?-A. He was \& man implicated in stabbing horses-

Q. How do you know ?-A. By his own confession.

Q. What did they send him up there for-to intimidate you?-A. No; I suppose not.

Q. They just hired him to go there?-A. He was just a workman aur 'an einployé of the company.

Q. When he got there he wanted to use the manly art and threatcred to do so ?-A. He came pretty near doing it.

Q. Did you have auy arms ?-A. I did not in the Gorerument huuse until I weut and got a gun to protect myself. This thing was going pretty far and I did not expect to get back alive. I told you that. 'Tinat is honest, I did not. That was a nice wedding trip for me.

\section{By Mr. Macdonald :}

Q. You stated before I came in, I understand now, but if not I mouli like to have you briefly state when you first arrived tirero what you attempted to do in the performance of your duties that was iuterferei with and prevented by the employés of the compauy?-A. Weli, I should say-

Q. Now please confine yourself to my question as closely as possi. ble.-A. For instance, in the local government-

Q. Just state what you attempted to do that the employés provented you from doing or interfored with you in any way.- 1 . The goverument of the natives; in the discharge of my duties-

Q. What did you wish to do in reference to the government of tho natives?-A. I wanted each man to carry up his orru coal firom the coal house and not to put it on the shoulders of some young boy. Alexa Oustigoff was drunk on the island; he was the hasband of the noturious ivomau, Mary Oustigoff. I told the boy that came with the sitck to get his coal that ho could not havo it unless Alexa Oustigolf camo him. self. He did not come the next time after the coal, so I refiused to griv. it to this boy, iu order to keep Oustigoff from making a slare out of this boy.

\section{By Mr. FELTON :}

Q. IVas this his own boy?-A. No, sir. Mr. Webster then, mather than permit Mary Onstigoff to be subject to the anthority of the Gorernment officer, took and bitched up tho bull and seut this very bos, who I told not to carry up the coal, and made him go there-made him gu down aurl bring the bull, and made this boy take this coal and carry it over to Oustigoff's house.

Q. It was carried up by the bull?-A. Until he got to the Govern. ment house gate, so as to make it plain he would not be interfered with by a Government officer.

Q. I uuderstand you to say that when tho ball arriven there with the coa! Mr. Webster made this boy carry it into justigofi"s Louse?-A. Yes, sir.

Q. And you understood that was done for the purpose of showing 
you that they would not permit your interference with that arrangement?-A. That they would not permit any interference in one way or another.

Q. What quantity of coal was it?-A. One huudred pounds.

Q. How old was the boy?-A. I do not know.

Q. How big was he; was he a young man or a boy ?-A. He was a young man.

Q. How old? - A. I really could not tell jou, but I suppose he was eighteen rears old.

Q. How large was he?-A. I shonld not say exactly, sir; he was a thin-chested fellow.

Q. He was pretty healthy to be able to handle a huudred pounds of coal? - A. He was.

\section{By Mr. MACDONALD :}

Q. How old was that boy, did you say ? - A. He was about serenteen or eighteen years old.

Q. Was he able to haudle that coal ?-A. Ho had to carry it for his father, too.

Q. Did the boy object to carrying it there, or was he perfectly willing to do se?-A. Yes, sir.

Q. What was the next thing you sas jou attempterl to do in the way of performing your duty as a Gorernment officer that was interfered with? - A. Well, the natives were intimidated.

Q. That is, generally. We want you to state a specific act, if you can. What was the something which you attempted to do in the performance of your duty which you were prevented or interfered with by the company's employés? I simply want this to the best of your recollection. What was the next difterence that you can remember to bave occurred after that? If you cam not gire the nest, give any you think of.-A. For instance, with the sehool. I instructed the scholars to be prompt in attending the school. Mr. Clark, the teacher, has been known to send them back to walk from the residences to the school-house building and had them walk in an unusual way. For iustance, they would walk like this [illustrating]. Walk two short steps and then look up at the Government house, so as to ridicule the Goverument ofticer.

Q. Why did you give instructions in regard to the attendance of the school ?-A. Because I wanted the scholars to attend with some system.

Q. How was the school conducted before you made that rule?-A. It was a humbug.

Q. That is only your conclusion. Give us some facts.-A. I should say it was becanse of the boisterous conduct there and the examination I made of the scholars.

Q. How was it about the attendance before you gave orders?-A. The atteudance was not prompt. They would straggie in to suit themselves.

Q. There is more or less of that in this comntry?-A. I kuow one girl, who they eall up there a "slave," who would be occupied thirty mimutes at the wash-tub by this famous Mary Oustigofí, doing her washing, after the sehool-bell had rumg. I wanted this girl to quit work aud go to school and learn something.

Q. Now, what was the result in her case?-1. The result was, the school children-

Q. No; in the case of this girl ?-A. She would be prompt for a short time and then stop. I found out that the more I sand the worse it was, because they could beat me at erery point.

$9984-14$ 
By Mr. Felton :

Q. Was that girl a servant of Mary ?-A. Yes, sir; what we call there a slave.

Q. I suppose there is no slavery there?-A. No, sir.

Q. She was a servant of this woman?-A. Yes, sir.

Q. She lived there?-A. Yes, sir.

Q. Aud got her eating and clothing ?-A. I suppose so.

Q. And sometimes Mary kept her at work rather than go to school?A. Yes, sir; kept her washing there.

Q. You spoke about 5,000 seal skins having been taken. As near as you ean recollect, were those taken in the open sea?-A. Really, I do not know. The first I heard of those 5,000 seal was whe. I landed at Oonalaska. There were boxes marked 800 pup skins. '. Tingle said, "What are these?" Mr. Newman, the agent, said, "If you do not like it, Mr. Tiugle, report it." Overhearing this conversation, I reported it to Washington. Then I was told that the $\check{, 000}$ seal skins were taken by the natives in the Alentian chain-I do not know how for-and that they were sold to the company. I reported the facts to Washington. I told Mr. Morgan at the time that I was going to report it.

Q. You do not know where they were taken, but the probability is that the most of them were taken in the Bering Sea by some maraudder's ?-A. By natives in the vieinity of Oonalaska, I suppose.

Q. Was there anything to prevent your making arrangements to have kept house by yourself if you had chosen to have done it?-A. After I was on the isiand?

Q. No one prohibited you; I mean, no Gorermment regulation or any other regulation?-A. I know of no other regulation.

Q. If you had had a stove and provisions you cond have lived by yourselves; that is, if the comlitions were right?-A. If the conditionswere right, yes, sir; but I was refused a stove. They refused to sell me a stove and food, and my wife is here to swear to it. If I could have obtained a stove and food I could have lived in the Government house.

By Mr. Maddonald :

Q. Did they have a stove?-A. They did.

Q. They refused to sell it on what ground?-A. Just stubbornness. I can not explain.

Q. Did you offer money for the stove?-A. A Gorernment officer's credit is good, because the Gorernment drafts come to the Alaska Commereial Company in San Franciseo, and they deduet his bill and settle? with him. When I found I could not get a stove, I was afraid to go down and eat day in and day out. Then I wanted-

Q. Let us inquire about the store. Do you mean to say that they absolutely refused to sell you a stove?-A. I do.

Q. What reason was given when they refused?-A. Me would not give me a reason except that he would not sell any.

Q. Did you get a store afterward?-A. Then, when I talked about food, he said he would not even sell food.

Q. So you had to eat there with them until you left?-A. Yes, sir.

By Mr. Felton:

Q. Did you ofter money for food or provisions? - A. Yes, sir. I de. manded food.

Q. Did you offer to pay for it?-A. Certainly; I would not expect to get it without money. 
Q. Did you, though ?-A. I did not count the money out. I did not expect-

\section{By Mr. MaCdonaLd:}

Q. Was there any question raised about the payment for the store?A. No, sir.

Q. Were they certain of getting their pay if thes sold that stove to you on credit?-A. Yes, sir.

Q. What security would they hare?-A. Why, the drafts sent to them at San Fraucisco. I could not get it until wy aceount was settled with the company.

Q. They had a lien on that, then?-A. Yes, sir.

The Cmamman. Does the Government give a draft on the company or to the company?

The WrTness. They send the Treasury draft to the company.

Mr. MACDONALD. But it was payable to your order; they conld not get the money on it?

The Witness. They presented the account when they presented the draft.

\section{By FeLTON :}

Q. Did they keep stoves for sale ?-A. Yes, sir,

Q. How many had they when they refused you?-A. I lo not know but I saw one, a range, down in the magaziue. I saw it witl: my own eyes.

Q. Did you see more than one?-A. No sir; but they certainly had one there.

Q. I suppose the draft is sent to you in care of the company, but they have no control over the drafts. They are sent through the company as a matter of convenience. Is that the idea?-A. No, sir; the Alaska Commercial Company gets my draft before I get itso.

Q. For the purpose of sendiug it to you?-A. I do not understand it

Q. Is it not sent that way because it is the most convenient and quickest way for you to get it? You have no mail, have you ?-A. No, sir.

Q. Now I will ask you oue question. Does the Gorernment give the Alaska Commercial Company the authority to pay the Goverument debts? Does it gire the Alaska Company a lien on your pay or any control over it whatsoever?-A. Not that I know of.

Cross-examination by Mr. JEFFries:

Q. You have nerer been on St. Paul Island?-A. No, sir; but I hare been at anchor there.

Q. During all these months you have spoken of, you were on St. George Island?-A. Yes, sir.

Q. The old bull seals stay on the rookeries?-A. Yes. sir.

Q. And the young bachelor seals, they remain down on the banks in and about the water?-A. Yes, sir.

Q. And the female seals, after they hare delisered their young, which are delivered after they land on the rocks, say within a few days?-A. Yes, sir.

Q. Now, in a short time they begin to go into the water to seareh for food, going out and returning again? - A. Yes, sir.

Q. Do you know where they go ?-A. To the feeding ground, towards Oonalaska. 
Q. About 50 or 60 or 80 miles south ?-A. Yes, sir.

Q. That is the point where these illicit seal hunters shoot these female seals?-A. Yes; that is where they kill them.

Q. They go there for the purpose of getting food to sustain themselves and their young?-A. Yes, sir.

Q. How long are they generally gone on that experition?-A. 'That is impossible to state.

Q. They are pretty swift swimmers?-A. Yes, sir.

Q. Now, will you please tell me who these gentlemen were on St. George Island that you had diffienties with, and please give me the names of the agents and employés of the Alaska Commercial Company on the island during the time you were there? Just a list of them. I think you named most of them, but I would like to take them in a list.A. I am glad you mentioned that, beeause I would not-

Q. Who was the chief man?-A. Webster.

Q. What did he do; what was his business?-A. He was the agent.

Q. He was the chief man?-A. In winter time; not during killing season.

Q. Where was he during the summer?-A. He goes to St. Paul.

Q. You had a quarrel, then, with the ehief man?-A. Yes, sir.

Q. Who was the next man?-A. He was Kirk.

Q. What was his first name?-A. Eugene.

Q. What was his business ?-A. He was assistant agent, I believe.

Q. Now, who was the next man?-A. That was Clark.

Q. What did he do?-A. He was a school-teacher during the winter.

Q. Who was the next man?-A. Dr. Lutz.

Q. He was a physician?-A. Yes, sir.

Q. Who was the next? - A. Dr. Noyes.

Q. The next?-A. John Hall.

Q. What was he doing ?-A. He was the cook.

(Q. Who else?-A. That is all.

Q. These are all the men there during the summer and winter; was there anybody else?-A. That is this last summer and during the winter. The first summer Mr. Morgan was there.

Q. He was an agent of the company?-A. Yes, sir.

Q. That is the gentleman sitting here?-A. Yes, sir.

Q. He was not there last summer?-A. No, sir.

Q. Now, that is a list of the names of all the persons employed by the company ou St. George Island during the period of your service as a Government agent?-A. Yes, sir.

Q. Now I will have to request you to go orer a little ground that you hare already gone over on your examination, to get at the particulars. With the exception of Mr. IIorgan, I think you state that you have been abused by all the people on this list?-A. Yes, sir. I had differences with every one.

Q. They were always wrong and you were always right; that is what you want to say.-A. I have not made that assertion, I think.

Q. I am asking you that gnestion. They were always wrong and you were always right; these six men. They were always in the wrong and you were always in the right. Just answer the question one way or the other.-A. I hatdly know-

Q. You can auswer yes or no.-A. I hardly know how to answer that. I do not know that I claim to be infallible.

Q. I want to know if these men were all wrong and you were right; as to whether these six men were wrong aud you right in these quarrels you had. 
Mr. MACDONALD. Let him answer it as he sees proper. This is a sweeping question. I should olject to it if I was defending him in court.

Mr. Jefrries. He can answer it as he pleases.

$\Lambda$. In all cases of contict between these men and myself they were wrong

Q. And you were right; that follows. Did you have any trouble with Mr. Morgan?-A. No, sir.

Q. Do you know how long irr. Webster has been employed by the company on this island?-A. I think he has been there pretty nearly twenty years.

Q. Have you ever heard of his having any troulle with any other Gorermment agent before you? --ג. If there is one he has not had tronble writh I do not know it.

Q. Yon swear that he had tronble with all of them?--A. I did not make that assertion.

Q. Youstated that if there was one there he did not bave trouble with you did not know it. So fim as you know he did have trouble?A. Yes, sir. ler.

Q. Who did he have trouble with?-A. He had trouble with Mr. Fow-

Q. That was one.-A. And a man named Marston.

Q. That is tiro. Who else?-A. And myself.

Q. That is three.-A. That is all I kuow.

Q. Do you know how many Gorernment agents have been there in the past nineteen or twenty years?-A. I do not know.

O. Has there been a dozen?-A. I do not know how many years it is, nor how many have been on the island.

Q. Do not you know there has been more than a dozen on that island in the past seventeen or eighteen years?-A. I know also that Mr. Webster has never wintered all the time on the island.

Q. I am not talking about that, sir. Do not you know that there have been more than a dozen Government agents on St. P'aul Island during Webster's administration?-A. I believe there has been.

Q. And of that dozen there are three that have had difficulty with Webster. Now, what trouble dicl Fowler have with Webster? -A. I do not know.

Q. How do yon know, then, there was any diffieults? from some records on the books.

Q. What do the records show ?-A. That there was a difficulty about issuing sugar br Mr. Webster.

Q. You say the records show that?-A. Yes, sir.

Q. Whose fiult was it? - A. That is for somebody else to say.

Q. You do not know?-A. No, sir.

Q. What was the trouble with Mir. Marston?-A. I do not know about that.

Q. How do you know that there was trouble? Who told you?-A. Mr. Webster.

Q. He told you he had trouble with Mr. Marston?-A. Yes, sir.

Q. Did he tell you who was in the right or wrong?-I. I do not know.

Q. You do not know but what Webster was right?-A. I do not.

Q. That is all you know about that? Now, we will commence with your tronble. How did your troilule begin with Webster? - A. I would not let him use me as a tool: because I would not keep the priest out of the pups and coal to gratify him. 
Q. I.et me ask a question about the priest and the pups. The priest is reguried as a natire. Does he come under the law and is he entitled to pups aud coal as a native"-A. Yes, sir.

(8) 10 you know that to be so ?-A. That is my understanding.

() Where is rour authority ?-A. My predecessor's action in the matter: custom.

Q. What was that trouble?-A. He manted to gratify his spite.

Q. As general agent what did he do?-A. What did he do?

Q. IV chister; in reference to the priest and the pups?-A. He did not want me to give the priest pups.

Q. Was that all there was of it? Did you give the priest pups after he said that?-A. Yes, sir; he got them.

Q. Now. what was the next quarrel hetween you and Webster ?-A. TY il, about two native women being drunk in the company's house.

Q. What was there abont that ?-A. I lid not think it was right that they should permit such things as that.

Q. Did you speak to him about it ?-A. Yes, sir.

(2. What did he say ?-A. He said he would give the natives drink whenever he wanted to.

Q. Thit was all of that controversy :-A. He said that we would see if the natives did not cut my throat.

Q. He did not do it ?-A. No; I will not say that. He said, "We will see if the natives will not cut jour throat."

Q. They dia not?-A. No, sir.

Q. That ended that. Let me ask you now, was any assault made upon you he any company agent? Wiere you ever wounded or injured in any way?-A. No; mental agony was about all.

Q. That mental agony grew out of the priest and the pups? What was the next thing Webster did?-A. The next thing was the hoisting of the flag and insulting the flag on the island.

Q. What flag?-A The United States flag.

Q. What dir they do to it?-A. They hoisted it in front of the Govermuent house.

(2. 'They hoister? the American flag in frout of the Gorermment house ?-A. Yes, sir; and insulted it.

Q. What did fou do to them?-A. I could not do auything.

Q. What was the next thing he did? - A. After hoisting the flag?

Mix. Mi CDONALD. That is not specific at all. You say he insulted the flag. Fow ?-A. He hoisted the Hag up aud got the men around and they put their hauds to their mouth aud laughed at it and ridiculed it so that the natives saw it.

By Mr. FELTON :

Q. What day was this; a public day?-A. I do not know; I can not tell you.

Q. Was it the Fourth of July or any celebration or special oceasion?A. No.

Q. What was the occasion of the raising of the flag?-A. I suppose to insult it, and to make me ont sometbing ridiculous when I got back here; to make me make some mistake that would be fatal. I do not know; it is hard to tell what they were up to.

\section{By Mr. JEHFRIES :}

Q. What was the next difficulty sou had with Webster?-A. We quit speaking to each other entirely.

Q. That enderl it ? Then these difficulties that I have enumerated are all that occurred between jou and Mr. Webster? Was there any- 
thing rone by him after that which you took exception to?-A. Certainly.

Q. Stute what they were.-A. He would get drunk and go through the village at 3 o'clock in the morning.

Q. Webster did ?-A. Yes, sir, and his men; and they refused to issue medicine.

Q. Who were his men?-A. Kirk, Clark, and Hall, I suppose.

Q. What did he do?-A. They threw some rocks one night against the Government house; but I do not know who that was.

Q. Did you see them?-A. No, sir; i.t was 3 o'slock in the morning.

Q. How did you know that it was Webster if you did not see him?A. I heard his voice, and the natives reported that it was Webster.

Q. Was there anything else that he did? I want to get it all if I can.-A. He abused me when I refused to let him kill seal this spring.

Q. Was that after you quit speakiug?-A. He followed me up and abused me.

Q. Why did you refuse to let him kill seal?-A. Because I did not think that the contract for the school was carried out and I refused to let them kill seal.

Q. You declared the lease forfeited ?-A. No, sir.

Q. Did not you declare the lease forleited and notify the company that they should not kill any seal because they did not keep sehool eight months lacking four days?-A. I had no authority to deciare the lease forfeited, but $i$ thought it was a direct violation of the contract.

Q. You swear that you did not forbid them to take seal on the ground that the lease was forfeited?-A. I say that I wonld not permit them to kill seal until my superior eame to see whether they would continue the school eight months.

Q. The school commenced on Monday instead of Thursday on this occasion. It always commenced the first Monday in September. Is not that an explanation of why it fell short four days?

\section{By Mr. FELTON :}

Q. What did you figure a month ?-A. A School month?

Q. Yes.-A. If school commenced on the first of one month then it would end the last of the month.

Q. Some months it would be much less days than others, as some months have thirty-one days. Do not they usually count a month as thirty days?-A. Yes, sir.

Q. In the payment of men who labor and everybody of that kind ?A. Yes, sir.

Q. At the rate of thirty days, would not this thing figure out with no lapse; if they figure thirty days in taking the months, there would be no lapse of time?-A. I think there were one hundred and six and one-half days.

\section{By the CHAIRMAN :}

Q. You stated that it commenced on the first Monday of September?-A. I think it commenced on the 5th.

Q. And terminated the 1st of May?

Mr. JEFFrims. Instead of that, the Jth came on Thursday, and they commenced on Monday.

Q. Was there any other diffenlties you had with Webster that you remember, other than you statenl?-A. He slaimed that his men would injure me, and that I must come to him, and when I would come to Mr. Webster with complaints he wonk ignore them; consequently I could not come in direct contact with his men. 
Q. Just give one instance in which that happened.-A. For instance, therloctor had notified a girl with consmmption that she must come to him, and this girl was uot ahle. It was reported to him that she was not able to walk there. She afterwarls died. I went to Mr. Wrebster, and he said it was a dammed lie. That settled it. He would not permit me to come in direct coutact with his men. If I made complaints, Ifr. Webster would ignore them.

Q. I want to ask yon in relation to the difficulties in regard to Mr. Kirk. What was the trouble betweeen fou and Kirk?-A. Mr. Kirk did not respect Mrs. Gavitt's presence on the island.

Q. Did you say Kirk was assistant agent?-A. I understand so.

Q. Was he not a mule driver?-A. Not the year I was there.

Q. You are sure about that?-A. Yes, sir.

Q. Who did then!-A. Mostly one Alex Lugubill.

Q. Give us some specific act on the part of Kirk.-A. In reference to what?

Q. In reference to any outrage upon yon or violation of law and regulation.-A. He gave me plainl, to molerstand that he would iick me.

Q. Give us what he did.-A. That is what I am trying to do. He gave me plaiuly to understand-

Q. Siate what he did; state what he said.-A. That he would lick me or any other Grovermment officer.

Q. What for?-A. 'That interfered with him.

Q. He told you that?-A. Yes, sir.

(2. Was there anything else between you and him at any time?-A. No, sir; exeept he did not respect Mrs. Gavitt's presence.

Q. Was there any other personal difuculty or any violation of law or rewulation, or auy outrage on the part of Mr. Kirk?-A. Nothing at all.

(2. Now we will take nj) Clark, the school teacher. Did you have any trouble with Clark?-A. With the exception of the way he did not comply with my wishes in reference to the school.

(¿. He did not keep) school as long as you thought he ought to ?-A. Ife would go to the priests and have them aly) ly for a holiday.

(3. Did it become a persomal rhfficulty between you and him?-A. No.

Q. You differed with regard to that subject?-A. He did not respont my position or recognize my anthority. He considererl that I was nothing.

Q. Just tell me what he said about that. Did he say you had no anthority he would reeggnize?-A. He told me my case was powerless because of the preponderance of evidence against me.

Q. Who did he tell-A. A native.

Q. How did you know that?-A. Pecause Demetreus said so.

Q. I am asking fou what he said to you? You had no personal difficulty?-A. None.

Q. But there was a difference as to bow the school should be kept aud how loug it should be liept. That is all there was of it?-A. Yes, sir. Let me think about Clark. No, I do not think Olark conflicted with me as an officer outside of that.

Q. Now we will take up Dr. Lutz. Did you have any persoual difficulty with him:-A. Yes, sir.

Q. What was that?-A. He threatened to strike me.

(?. Did he do it?-A. No, sir; because my wife dragged me array.

Q. What alid he threaten to strike you for?-A. In reierence to an investigation in which $I$ dismissed a native.

Q. Now he did not threaten to strike jou because there was an in- 
restigation? Why was it?-A. Becanse I would not condemu a man he was angry with.

Q. Who was the man-A. Andrian Philemanoff.

By Mr. Macdonald:

Q. What do you mean by condemn?-A. Because I wouk not fine him.

Q. Explain it a little clearer. Condemn him for what?-A. He was charged with whipping his wife, and the ease was brought before me. I saw it was a malicions persecution, because he would not permit his wife to visit the company house.

Q. Yon foum him not guilty, and he was angry hecause you so decided? $-\Lambda$. Yes; and he threatened to strike me after'wards.

By Mr. FELTON :

Q. It developed that he did not whip his wife?-A. No, sir; he did not. Ile refused to permit his wife to risit the company house.

Q. He did not whip her?-A. He did not.

Q. You mean to go to the company house?-A. Yes; for immoral purposes.

\section{By Mr. Jeffries :}

Q. He was charged with whippiug his wife?-A. Yes, sir.

Q. Who charged him?-A. Dr. Lutz.

Q. He was the doctor in charge?-A. Yes, sir.

Q. There were witnesses, were there nor? Dir Dr. Lutz testify?A. No; he said he was told so, and brought a witness. sir.

Q. Did the witness testify that the man whipped his wife?-A. No,

Q. Was there any proof that he did?-A. No, sir.

Q. Then what happened?

Q. Was Dr. Lutz present at the trial and heard the wituess swear that the man did not whip his wife and heard the evidence that showed the man was innocent, and then he threatened to strike you for dis. charging him?-A. Ife said that his witness did criminate this man and I said that he did not, and so it was a conflict of opinion.

Q. And there was a difference in judgment between you and Dr. Lutz as to whether the testimony coudemmed the min or not and you got into a dispute orer it? - $A$. Yes, sir. Then after I dismissed this man Mr. Webster ealled the man in and said if he did not permit his wife to come down there he wonld break his head.

Q. This dispute between you and Dr. Lutz was about the case of this man and you grew warm over it?-A. He grew warm.

Q. You were perfectly cool. I cim readily milderstand that, aud lie was very angry and he was going to strike yon, but he did not strike you?-A. No, sir; but he shook a poker in my face.

Q. He could not strike jou?-A. I do not know.

Q. You do not know whether he could or not. Was he within reach of you?

The Witress. I think, Mr. Chairman, if there is to be a lawyer here, that the witness should be permitted to bring a lawyer. This man seems to be going over the ground as if he was there, and I do not think, sir, that he has this right.

Mr. JeFFrues. The commiter will protect you if I ask any questions that should not be asked. He clid not strike you?

The Witness. No, sir. 
By Mr. Felton:

Q. You stated that there was a difference of opinion between you and the doctor in regard to the evidence given at that tıme?-A. Yes, sir.

Q. Of course you held the court, and he seems to have been an interested party on the other side, and you both heard the testimony? Now, what was the character of the testimony; that the man shoved his wife out of the house or against the door, or what; what was the character of the testimony ?-A. The character of the testimony was that he did not strike his wife.

Q. Well, what did he do?-A. Nothing, except to scold his wife and forbil her from going to the company house.

Mr. IIACDONALD. Was there anj record male of the eridence; did jou write it down?

The Witness. No, sir.

Mr. FELTON. That being the case, it would be rery singular that the question of a conflict over so plain a case should arise between yon.

The Witness. It should nerer have arisen, as I was the judge of the case. It was a put-up job.

Q. He did scold the woman?-A. Certainly, and he forbid her from going to the company house, and then after I discharged the man-

Mr. MACDONALD, I am not elear abont the matter, and have not time to look it up. Where did rou get anthority to try these parties? You were not a magistrate by authority of law ?

The Witness. No, but it has been the custom on the island erer since the Government took charge.

Q. You do not understand that there is any other anthority tian custom there?-A. No, sir.

Q. Are any instructions given by the Treasury that you shall do that or not do it?-A. No, sir.

The CHAIRMAN. The committee will now take a recess until 2 o'clock. Accordingly the committee at 12.40 arljourned until 2 o'clock p. m.

\section{AFTER THE RECESS.}

By Mr. JeFfries:

Q. The next person with whom you had some difficulty was Dr. Noyes. Will you state was that was? -A. Dr. Noyes interfered with the marriage of a girl.

Q. What were the facts? - A. The facts were that a man named Logan from Oonalaska wanted to marry her, and I could see no reason why any one shonld prohibit the marriage, and he used his authority there over this girl to prevent the marrage and to keep this girl from marrying this man, who, I understand, would have made her a good husband. She was what is termed a slave to Mary Onstagoff. I think it was the best thing for the girl, and I did not see why Dr. Noyes should prevent the marriage, but he and Mr. Clark did.

Q. Dirl you have any other diffienlty with Dr. Noyes?-A. No other that I call to mind.

Q. Did the girl marry the man?-A. No, sir; the man was forbidden and prevented from marrying her.

Q. The next is John Hall. What diffienlty did ron have with him?A. Well there were continnal complaints heing brought in about Hall. Q. Just state some one act of IIall. Let us have something substautial.-A. Well, his notorious conduct with the natives. 
Q. Well, give us instances. I do not want geueralities. I want facts.-A. I am trying to think first. I can not give the facts as if it was yesterday. One was he threatened to whip Andronic Philamoiff for not paying some monev he owed.

Q. Did he whip him?-A. No, sir.

Q. Was there any other trouble with Hall?-A. With the exception of his conduct with the women.

Q. Well, give us something. What was that?-ג. WVell his notorious conduct with the native women.

Q. Well, what did he do?-A. He kept two native women on the islant.

Q. Was that John Hall, the cook?-A. Yes, sir.

Q. Was there anything else?-A. Well, his conduct was disgusting in the presence of a white lady.

Q. What did he do?-For instance, he would come into the diningroom with his pants improperly arranged and acted indecently near the Government house.

Q. Dirl you have any personal diffienlty with him?-A. Yo, sir.

Q. He was a man of bad and vulgar habits ?-A. Yes, sir.

Q. That finishes the list. You had no trouble with Mr. Morgan?A. No, sir.

Q. Where did you get your authority for regulating the internal affairs on that island?-A. You mean as to the govermment of the natives?

Q. Yes, sir. You said that you had no instructions except what you got from Seuator Voorhees.- $\dot{A}$. Nothing, except the precedent on the island.

Q. I want to know where you got authority from the United States to disturb boys and prevent them from handling a hundred pounds of coal.-A. By custom. Because right would dictate it.

Q. Where were your instructions?-A. I have none, sir.

Q. Now we have got through the employés and we will take up the Government agents. How many Govermme.ıt agents were there on St Paul Island having control of St. George?-A. How many agents on St. Paul having control of St. George?

Q. Yes. Who was your superior officer?-A. Mr. Tingle.

Q. Where was he staying?-A. On St. Paul.

Q. What other Government agents were on St. Paul during your administration?-A. Mr. Manchester and Captain Loud.

Q. Was Mr. Manchester the Government agent that caused the difficulty in regard to the nurse maid?-A. Yes, sir.

Q. Did you have any trouble with him?-A. No, sir.

Q. No difference? $-\Lambda$. No difference. He was my superior in the summer. of.

Q. Did you have any trouble with Mr. Tingle?-A. Not that I know

Q. Was he on good terms with son?-A. I can not say we were.

Q. Were you ou good terms with Captain Loud?-A. No, sir.

Q. Did you have a quarrel?-A. Yes, sir.

Q. And he was wrong aud you were right?-A. I do not think that is pertinent to this question. I do not think these questions should be asked of me, and if I had a lawyer here he would object.

Q. Jut of the seren agents and employés of the company you quarreled with six; and ont of the three Government agents your inarreled with two; is that it?- $-\Lambda$. I do not admit quarreling with two.

Q. Did not you and Captain Loud have a fisticuff or something of that kind one day?-A. No, sir. 
Q. What was the difficulty between rou and Captain Loud?-A There was something in reference to how the company men blackened the Government agents' character, and Mr's. Gavitt and myself told Mr. Tingle what they had said about Mirs. Tingle taking a trip on the reveme cutter, and Captain Lond spoke out, in the presence of my wife, and called me a foul name.

Q. Were yon not abusing Dr. Noyes, and did not Captain Loud say he would not allow that, as he was a friend? - A. No, sir.

Q. Now, I want to call your attention to the insulting of the United States fiag which you testified to. Do you happen to know that that flag was raised ou Decoration Day ? - A. Possibly it was.

Q. You did not know it theu?-A. I might at that time.

Q. Do you remember it was raised at half mast ont of respect to the dead soldiers; do you remember that? - A. No, sir. It was not iu respect to the dead soldiers.

Q. Do you not know yon came out and ordered it hoisted to the top of the mast aud that the natires laughed at you, aud that was the whole tronble?-A. No, sir; I never gare such an order or heard of such au order until just now.

\section{By Mr. Felton :}

Q. As I understood yon some time ago, jou did not know which day it was? -A. I sail at the time possibly I might have known what day it was.

Q. When I askerl you some time ago?-A. I did not remember it. Possibly it was Decoration Day.

\section{By Mr. JEFFRIES :}

Q. When you receiced your appointment and made your preparations to go to Alaska, how did you expect to live ont there?-A. I was very ignorant about anything.

Q. Did you expect to live on the company?-A. No, sir; I did not know anything about it.

Q. Did you make any preparations; prepare yoursclf for honse-keeping or anything of that kind? - A. I had no idea of how I was to live.

Q. Yon took your wife direct from the altar to the woods? - A. I did not say auy such thing. Mr. Morgan gave me some information in San Francisco. I supposed there wonld be a place for the Government ofticer.

Q. You provided yourself in no way and rou had no information with the exception of what Mr. Morgan told you in Sau Francisco. He is a company man, Mr. Morgan ?-A. Yes, sir.

Q. Did you expect the company to support you?-A. Furnish food? Yes, sir.

Q. Did you pay anything for it?-A. No, sir.

Q. You lived on the company; you and your wife?-A. Yes, sir.

Q. Did yon lire in the Government house or in the company house?A. In the Government house and ate in the company house.

Q. Who was it that refused to sell you a stove?-A. Mr. Webster.

Q. How old is Mr. Webster?-A. He is an old man.

Q. Is be sevents years old? What is your judgment?-A. I hare no idea. He may be sixty or seventy years old, but I think probably between sixty and sixty-five.

Q. Did sou take any furniture there at all ?-A. No, sir; the Gorernment honse is furnished by the Goyerument. 
Q. Except a stove. Did you crer make any requisition on the Government, for a stove? $-\Lambda$. No, sir.

(. i) fel you apply to auy Gurernment ofiecer for a stove?-A. No, sir.

(Q. Fou irent to the company ? $-\mathbf{A}$. How conld I apply to the Government when there was no Govermment officer on the island?

Q. Where was your superior officer?-A. In the States; back here.

Q. Were yon required to make an oflicial report?-A. Yes; to Mr. Tingle.

Q Did you make it?-A. Yes, sir.

Q. Did you set forth these matters?-A. Yes, sir.

(2. When was that report mate to Mr. Tingle?-A. It was verbally reported to him. I can tell you by looking.

Q. Well, about when?-ג. When he came there between June and August, 1888.

(2. So far as eoneerns this prostitution you speak of, do you know of anl instance in which there was force used by any white man ou St. Gecige to outrage a native woman?-A. That would eome under the liead of rape; no sir.

Q. It was simply a criminal communieation between bad men and bad women, that inight happen in any community? -A. Yes, but only in a degree $I$ could not approve of.

Q. You do not approve of it here?-A. I did not approve of the adrantage they had to secure these things.

Q. Were there any outrages committed by white men on Alente women on St. George that you have knuwledge of? What I mean by that is, was there any evil comnection between men and women withont the consent of the women? -A. I do not see how anything of that kind conld be without its being rape. I know of no rape being committed on the seal islands.

\section{TESTIMONY OF GEORGE WARDMAN.}

\section{GEORGE WARDMAN sworn and examined.}

\section{By the CHAIRMAN :}

Q. During what perioul of time were you on St. George Island, and in what eapacity ?-A. I was stationed upon the island of St. George from the latter part of Iay, $1 \mathrm{ss} 1$, until I was relieved in the spring of 1885, when Captain Loud and Mr. Ryan came there. I was present two winters upon the island. The alternating winters I was in California and the liast. I was there four years.

Q. I have summoned you again, Mr. Wardman, to re-examine ron, or, rather, examine you in regard to statements recently publisher in New York papers, which you have doubtless reat.-A. I can not saly that 1 have.

(? Well, it goes to the question of the moral conduct of the agents of the Alaska Commercial Company there and the ontrage of native women ant a had state of affurs in general. Will you just state now what your observations were during the period you were there in that respect?-A. I nerer knew a woman or girl to be ontraged nipon the island while I was there, nor a man or boy to be abused hy an agent or any one else.

Q. Either Govermment agent or company agent ?-A. No, sir ; I never knew of a native woman living in the Gorerument or company house while I was upon the island, nor diel I ever know of an agent " maintaining" a woman in that sense of the word, any where. There was free 
intercourse between the natives and the ompany house; but I never hearl of auy outrages or anything of that kivul. Women went to the company honse freely. I would ses them in there and the men also canc and weut into the company house as they pleased ; but I nerer heard of any tronbles. Nothing was brought to my attention in that respect.

Q. Were any complaints made by the native fathers and husbands?A. The only complaint that was ever inade to me was by a native woman. She came to the Government house and compliained that a native's son, a young fellow about sixteen or eighteen years, had been trying to get her danghter to go out in the grass for, as she intimated, iusmoral purposes. I told her the only remedy I knew for that was to watch her daughter as the other people had to lo; that 1 had mothiug to do with it. That is the only complaint that ever came to me in that direction.

Q. Do you know Mr. Webster?-A. Yes, sir.

Q. He is a company's agent?-A. Yes, sir.

Q. What is his age, and how long has he been there? Do you know?A. Well, I bave knowu him ever since I began going up there. I first saw him on St. Paul in 1879, when I was in the steaner riush; I made a ernise up there in that year and I saw him then. I saw him afterwards on St. Paul, and he wintered on St. George one winter. The next winter Mr. Redpath was agent. Mr. IVebster is an old "shellback," a white-headed old mau. He was an old whaler. He was up there before the Alaska Commereial Company. He had been whaling up 11 the Ochotsk Sea and in the Aretic Sea bifore the United States acquired Alaska. I think lie was in the Aretic Sea in 185̇ ; but Iam not sure about the date. He was a querulons old man. He was dyspeptic and the winter he was upon St. George when I was there he was confined to bed a great part of the time, in fact, it was shought he would never staud another winter on the island; the doctor thought he would not, but he insisted on sticking to it. I never had any tronble with Mr. Webster. If I found him growling, I would turn him and give him a "bluff." Whenever I wanted anything done, I would go to him and tell him what I wanted and he would do it. I think if I had wanted to buy a stove he would have sold me one without any words or controversy.

I believe I never asked or ordered anything done but what he expressed his willnguess to do it, except once. That was when I wanted to seize the schooner Alexander, and hat left Mr. Kirk aboard till I talked with Webster. I would not seize her formally unless Webster would take her, because I did not want her to go on the rocks there. There was no havior there. I went ashore and told Mr. Webster that if he would take her over to the other island or down to San Francisco aud deliver her to the United States marshal, I would seize her. Ho said he would see the Government damned first. He said he had bad one experience of that kind and that one was sufficient. He said he never got anything from the Gorernment for his time or services on that trip, and that he never would take another schooner down. Then I asked him to let Mr. Kirk go and he said 1.o, that Mr. Kirk was the only assistant there and he could not spare him; so I concluded to let the schooner go. That is the only instance in which I had any controversy with him that I recall now. We did not have any words about that; he simply said he would not go.

Q. Was there any act on the part of Webster or other company employes in the way of obstructing the authority of the Gorernment 
there and to intimidate the Govermment agent?-A. No. Whenever I orlered anything to be done, Webster would say; "You are the Government ; go ahead on your own responsibility."

During the winter there was a good deal of "chaffing" and joking going on between Dr. Noyes and Webster. I never took ans part in ir myself, because I did not want to become involved in such things. I kept my side of the house pretty well. Dr. Noyes used to put hair nets and garters and such things in old min Webster's bed-he used to slip in there when Webster was vut-so that the woman who made up the beds would see them, and she wonld tell all over the village that an woman har been sleeping with Mr. Webster. They had great sport ont of that. That is what Dr. Loyes told me. Then they would talk and joke and "run" Webster ahout it for a day or two, and then they would go on to something else. They used to have uative women come to the house during breakfast to make nu the beds and to sweep out the rooms, and such things as that. They used to play a good many of these tricks and one thing and another. But I never heard of anything being done out of the way.

Q. Did anything come within four observation that they were using the Gorermment house or the company honse as a honse of ill-fame or prostitution!-1. No, sir. I think I know of one ease, the case of a girl there. She was "mashet" on a company's empleye who cante up there as a teacher. Well, she was rery badly treated by her people, and she would slip into the company house and stow herself away in a closet aud stay there two or three days, and the professor would feed her, and the old woman would eome there and hunt her nu). Mr. Morgan generalls stood the brunt of that. He told her she olght to keep the girl at home. Hedid not want her in the company house. She did the same thing in other houses there, native houses, and would stow herself among them as long as the natives wonld keep her. She is married now, and living very bappils, I have no doubt, with a man on St. Panl. I do not know what were the relations between the girl and the professor.

Mr. Feltor. He was a sort of natural protector at that time?

The WITnfss. I don't know. He left there before I dir, and I understand he is teaching a seminary now somewhere down Last.

The CHAIRMAN. They both seem to have gotten over it.

The Witness. Yes, sir; the girl is married. A man came orer from St. Paul and married her. The St. George girls are in great demand. I do not know whether it is on aecount of their goot housebeeping or what it is.

\section{Cross-examination by Mr. JefFries:}

Q. You are extitor of the Pittsumroh Press, are you not ?- A. Yes, sir.

Q. How long did you say you had been on st. George Island?-A. I was stationed there four years; that was my station.

Q. Subsequent to that you had heen over the entire Territory of Alaska?-A. Prerious to that, in 1879.

Q. You have written a book on Alaska?-ג. Yes, sir.

Q. I want to ask you now how the natives of st. Genroge Island compare with the other natis of Alaskat-i mean the different parts of Alaska?-A. Well, the natives of St. I'aul and St. Gerorge rank about alike, and they are considered the native arisiocracy of the lemritory. There is one of the st. George girls, Latalia Alereuliti, who hath several offers of marriage from Onnalaska men; but she would not matry them. She said she would rather live single all her life than marry them. She 
conld not marry anyboly on St. George or St. Paul because she was commecterl by ties of consanguiuity, some remote to the forty-seveuth degree, with about everyboly on the two islauds. The Russian chureh does not permit the marriage of such relations. She had the reputation of being a very nice and lecent girl-the best of the lot, the general in'port went. The real facts in the case I do not know.

Q. You have been on the Aleutian Islands?-A. Yes, sir.

Q. I want to ask you now, from your own observation, what do you say as to the condition of the natives of Alaska before aud since ilse transfer of the Territory to the United States, whether it has been improved or not?-A. You mean uatives generally?

Q. Yes, sir.-A. When I male that cruise in the Rush, in 1879, down about Fort Wrangel and sitha they had some mission schools, and the general reputation of the native women there was exceedingly ban?; that is, they would send girls to the mission schools until they learned to wash and clean themselres, and then sell them to the miners. Thit was common report, but I nerer linew anything like that on the Aleutian Islands. The women at Athka were considered the haudsomest and neatest women in the Territory, and I think they were the best looking women I saw except on the Seal Islands.

Q. IVhat do you say in regard to the natires of Alaska who have come in contact with the Alaska Commercial Company, as to whether they are better or worse in those localities where the company has stations?-A. I think they are improved considerably, particularly at Oonalaska, where the company aloo maintains a school.

Q. Did the company build houses?-A. They built houses. They took ont the old barabacas and made frame houses.

Q. That you know has nothing to do with the lease.-A. Nothing whatever. The Alaska Commereial Compauy has no monopoly at Oonalaska. Anybody that wants to cau go there and do business.

Q. That is so any where in the Territory exeept on the Seal Islands?A. Yes, sir. As I stated when I was here last summer, there was competition for the fur trade at various points-Kodiak, Unga, Ooualaska, St. Michael's and other trading points.

Q. What were Mr. Webster's habits as to drinking? Was he a man that got drmk aud ran through the village at 3 o'clock in the morning while you were there?-A. I never hearl of it. He was generally the first man to bed and the first $11 \%$. He was up and moring around sometimes at 6 in the morniug, hearing rocks at the Govermment house to get me up.

Q. Was he a man in the habit of getting drunk ?-A. No, sir; he was not. I "set them up" for him mrself on Washington's birthday. Ho took a drink with Dr. Foyes and myself. I had some whisky on tho 2ad of February which I had taken up in wy trunk in May. We took a drink out of that bottle.

Q. Was Kirk there when you were there?-A. Xes, sir.

Q. What sort of a man was Kirk?-A. I never had auy trouble with him.

Q. What is his business?-A. He went up there as assistant in the store. He was always in the store on store days, and he also drove the mule, hauling the skins, and the bull also at times. He was the general assistant. As Mr. Webster said when I wanted hm to go down on that vessel, he was the only assistant that he had and he would have to keep him there.

Q. Was Dr. Lutz there, and Dr. Noyes?-A. Yes, both rere there, 
Q. What sort of a man was Dr. Lutz ?-A. Dr. Lutz was a peculiar little fellow; he was what I would call a "cranky" German.

Q. Was he a bat man or a good man? - A. Me was what I would call an innocent kind of a fellow.

Q. Was John Hall there, the cook?-A. No; we had a miserable German cook, named Gus. That is the one thing for which I "had it in " for the Alaska Commercial Company-that cook, Gus.

Q. You have lived some years in Alaska and traveled extensively over it; now I want to ask you your judgment as to the relative value of the products of Bering sea and the jroducts of the balauce of the Territory. I include in the products the seal, the sea-otter, the whale, the salmon, the walrus, the halibut, the collfish, in short all the produets of those waters. I want your opinion as to the comparative value of those products with everything else in Alaskit.-A. I think the prorlucts of Bering Sea are much more valuable than those of the remaining part of the Territory of Alaska-that is, Bering Sea and what comes out of it.

Mr. JEFFRIES. I wanted to show why we bought it.

\section{TESTIMONY OF T. F. RYAN.}

\section{T. F. RYAN, sworn and examined.}

\section{By the Chatriran :}

Q. Will you please state if you were at any time a special agent of the Treasury Department on the seal islands of Alaska, and when.A. I was, sir; from April, 1885, until April, 1887.

Q. Will you state about the location of these islands and the condition of the seal ronkeries while you were there-A. St. George Island is in Bering Sea, 180 miles to the northwest of Oomalaska, one of the Aleutian ehain of islands. It is an island about 6 miles wide and 10 miles long, to which 175,000 to 200,000 seals come annually-male, female, and pup.

Q. Were you the chief agent, or an assistant?-A. I was first assistant.

Q. On which island?-A. On St. George.

Q. Will you give $n$ s an account of your occupation there?-A. On my landing at St. George and looking around, 1 reported direct to the Secretary of the Treasury that I fomnd the interests of the Goverument all right, and that they were well taken care of from the fact that it took care of itself, and that the slanders and stories that were then heard in Washington about frauds upon the seal interests that rere committed by the Alaska Company were false, as far as I could see; that it was not to their interest to do anything except what was right and correct as far as the seals were concerned. Matters continned very pleasant for that section of the world. I thought that I was placed there to see to the wants of the people, and to advance them in civilization, and to correct their morals, ete.. as best I could; and I considered it was also my duty as well to do that as to count the seal skins. I went slow, not abrupt, in auy move in that direction, and waited until 1 saw for my'self.

I had a great deal of trouble in looking after and protecting the rookeries from what we call there pirates. Schooners go up there and go on land and take seals, and also kill seals in the water. Those they kill in the water are so far away that we could not reach them. We soon run them off-the company people and myself and the natires. $9981-15$ 
One moruing we got, I believe, 112 seal skins, kuives, and hatchets, and things of that kind, with which tho seal hunters had come to hunt and slatughter seals, cspecially the cows, leaving their pups to be destroyet. There were instauces of that lind, and I wrote a very stroug letter to the Dartment, stating that somebody should be held responsible for this, and I thonght the Department in Washington, whose duty it was to luok after the Grovernment interests, should have a revenue cutter come there and cruise abont, for heretofore the revenue cutter came up there and passed up and beyond, and it was not snffieient protec: tion of Government interests. I reported this to Mr. Tingle, the bead ofticer. His reply stated that my report was of such importance that he haul sent it to Washington with his own. The next year I got a revremue cutter, aud they took some six or seven of what we call pirate ships and seal hunter's that come over from Victoria and San Francisco, both English and American ships. The revenue cutter took them to Oonalaskin and the skins also, aud took some men prisoners to Sitka, which was all very satisfactory as far as that was concerned. But the Secretary of State decided that our seizure of vessels and taking the skins away was illegal, and that they had a right to fish within 3 miles of shore. I was impressed with the idea that he thought they were codfishing instead of sealing at the time.

It was my place to write to the head officer. I wrote to the Secretary of the Treasury, stating that if that was the position in the matterif that was to be the rule in the futme-that the seal interest could not last rery long. I have my letter here, which will give you some information on that question if you wish to read it. The newspapers said that the letter was laid before the Cabinet, and that that was the first information that they had upou this matter. That is, it was before the Cabinet, and it was decided then that it was legal, and Mr. Bayard, I molerstood, issued an order that the ships should be taken, and they took quite a number the next year. But from some cause, after my letter was laid before the Cabinet on that question and they seemed to gain some information from it by their action-I was asked for my resiguation. I was dismissed from the service.

Q. Dicl yon ascribe your removal to the fact of your writing that letter?-A. No.

Q. You can put your letter as being eridence bearing upon the question of jurisdiction and law.

(See letter appended in answer to another question.)

Q. On that subject of the depredations of seals, do you think the regulations of the Goremment sufficieutly stringent and strict to protect the herd of seal?-A. I think it conlid be made so; Jes. That is, with a revenue cutter with the right kind of an officer who will do his duty. $\bar{i}$ understaud they have them, and whenever they want to do a thing they can do it.

(Q. Do you think that one revenue cutter would protect the herd entirely?-A. I think so.

Q. And let it be known that erery ressel engaged in this business would be subject to capture?-A. There shonli be one ressel for St. Panl and St. (reorge Islauds, lying between St. P'aul and Oonalaska. The hunters will soon get tired of him if he does his duty.

Q. Was the contract with the company strictly aud faithfully carried out while you were there?-A. Yes; outside of some little minor things that wonld not be of much imporlance in regard to the seals. The natives will go down on the rookeries sometimes and take a seal pup, aud you wonld have to call their attention to it. Mr. Morgan and the 
men under him were somewhat spoilen. The great tronble, Mr. Chairman, there is that the Government officers have not been doing their duty, and they have spoiled the eompany, so much so that they seem to think that they not only own the seals but that they own the whole island.

Q. The company's employés?-A. Yes, sir. They gradually drop into that way, from the Govermment officers not doing their duty, and its being simply left open to men who have no oath to regard. When I got on the island, for instance, I found one oflicer-you know you will have to take a goor deal from hearsay gossip-1 fomd one officer there would hardly speak to another officer. One was the father of a child by a chambermaid, and the other had a woman for his mistress, the wife of one of the best men.

Of eourse, with that example set, it's hard to eriticise the company's people. I foumd this state of affairs there. In fact, one of these officers on the day he left-he left in a hurry-and he had $\$ 50$ or $\$ 60$ worth of goods that he wanted left to his woman, and he asked me to give it to her or some one of her relations.

Q. Was that a Government oflicer, an agent of the Treasury Department? - A. Yes, sir; both were sworn officers of the Govermment

Q. Who were they ?-A. I would not like to give their names. If it is necessary, I will do so, but I would not like to do it.

Q. Unless it is a matter affecting the atministration of their office.A. They are not in office now and I do not think it would do any goord.

Q. That is a matter rather of barl morais than affecting the administration of their office.-A. [ only felt it my duty to tel] these facts to show that if people are bad and immorally inclined, they have been directed that way as much, or more so, as it rule, by the Government officers, considering their high position, than by the company men. If Govermment officers will work together and do their duty in keeping within their oaths and set good example, the company people will be kept in reasonable bounds of decency.

Q. While you were there did you observe any such dissolutenessfor instance, tmrning the company's house and Government houseA. No, not while I was there. If anything of that kind wats going on while I was there, I would not speak of this subject. I would not bring it up here.

Q. Was any such condition of things at the company honse under your observation?-A. No, sir; nothing direct. Only reports of illegitimate children being born and things of that kind. While I was on the island I believe there was only one act of disohedience on the part of the natives, which I punished. That was, they wanted a killing of seal, and I ordered them to talie no seal moler 7 pounds and they took some 5-pound skins. My requests to the company they met promptly except in one or two small instances. To show you how officers up there will differ-it is very far away and some people want to show their little anthority and in not digest well the thought of not being around showing their authority-I wrote my superior ofticer I could not congratulate the people on their adrancement in speaking English. That is all I said about it, and that I had reduested the company not to be talking Alent to them unless it was necessary. II wrote there was no law compelling the company people to speak Engish to the natires. I wrote back to him that I did not say there was a law for it, but I had made the request upon the eompany not to be talking Alent all the time and not to use it exeept when necessary, aud that the oficers of the company hat most politely complied with my request. 
Mr. Morgan was at that time, I beliere, on the island, and when I told him there was some objections to my move in that direction; that if it was understood on the inside, that is, the States, that the compauy people were not teaching the people English, but instearl of that they were retarding them, that the people on the inside might say that they refused talking English to them that they might not be able to tell something they did not want told. I called his attention to it in that way, and he said I was right abont it and that he would do what he conld. The next day I met a littie boy going to the rookery and he said to me, "Good morning, captain," knowing that would please me. I said to him, "Good morning, my boy ;" but almost immediately behind was a man of the company coming close by, and he said, "Drester" (the boy's words in Aleut). He knew the order was given the day before, and this was only the next day. In that way some of the company people have been so spoiled that they think they own ererything that belong's to the Government. The officers have not done their duty in showing them that the Goverument owns and governs that island.

Q. Whike you were there did the company perform its contract faithfully with the Government aud natives in regard to supplying the natives with food?-A. Yes; they supplied coal, salt, and schooling, as far as it goes. I do not think it was a very good school, and that what was tanght them at school in the day-time was forgotten at night. I have copied the reports sent my superior, which reports show for themselves. My reports were objected to by my superior, for some reason, but they are here. They are hearing Alent too much at the company's house, and at the store, and at the dance, and what they learn in the day-time they forget very soon by not hearing English. There are but few on the island who talk any English; one or two fairly. You can not hold much of a conversation excent with a man named Peter Rezanzoff. He tallis English rery well. I will gire you an instance how one offecer will try to show his authority and iuterfiere with another officer trying to do his duty. Whenerer $i$ had occasion to have conversation with them or lecture them, I would have to call this man Rezanzoff in. He was rery obedient to me. I male him chief, but when my back was turned away from the island he was remored. The agent and company people found some excuse to remove him.

Q. Were there any rapes committed there while you were on the island that came under your observation?-A. Not that I know of. The people are very timid and cowardly, and the Government officer and the company people can push them orer and do just about as they please. Shortly after I got there-several monthis-I called up the priest and the men and told them the state of affairs was very bad and they must correct it or that the Government would send them to the Alentian Islands to live on codfish; that this Goverument could not afford to have such a black spot in existence. Laving chuch ten times a month and then have such a state of affairs in morals was disgustiug to contemplate. The people hare not courage to resist anything done against them. It is something that should be corrected. He said he had been doing his duty, but cond not get any help from the Government officers. There was only one officer that I found recorded as trying to help, and that was Mr. Marston. He makes a record here. He says here:

It is vers evident that unfit and selfish men have heen in charge here, pandering to the people at times that they might be ahle at other times to have the people under their control for selfish purposes. I hope the end of such is at hand. 
This was written by Treasury $\Lambda$ gent George Marston May 18, 1877 I found that in 1877 , recorils of the opinion of the Grovermment officer as to the conduct of affairs by him in the Govermment house. Mr. Chairman, you must take into consideration that these ofticers are there mmler oath, iudorsed by what are supposed to be the first men of the land. The company's men are sailors and men they can pick up as hest they can, and, as I have sair before, they have been taught by the Goverment agents not only that everything belongs to them, not ouly the seal, but the rocks the seal are on. It comes to this by the ofticers not doing their luty, and one cause of that is that the system is treatinc officers the same as if they were in the State of New York, when they do not see them for a year or fifteen mouths. The reports are pigeon-holed and no attention is paid to them.

Ulere are two reports showing a conflict between mysulf and a superior officer. While some agents of the company people, on the island, might be pleased with this state of affairs, I can not bring myselt to believe that Mr. Sloss and the other gentlemen of the company with wives and daughters, would object to a man for trying his best to correct this miserable state of affairs which I fomm on the island. Well, this man Tingle has dowe that and is only doing what other ofticers have done before him.

Q. What were the particular conditions you were trying to correct?A. When I got on the island there were no rules at all. You harl to find out everything to be done from the company people.

Q. Did you have any instructions from the Treasury Department?A. No, sir; I had none. When I left, I had some ideat of matter's in) there and asked the Secretary about instructions, and he asked me to write my own instructions. I did not do so. I went on up there and found not a seratch of a pen anywhere except a recoml from day to day. Merely when it rained and when the sun shone and the state of the thermometer and things of that kind, but as to the government of the people, there was nothing. You had to learn for pourself. I arlopted some rules, as I wanted in teach the people a lesson. Here are some mules I wrote. They were set asir?e when my back was turued, by Tingle and Manchester. They said I had no law, and fou will ses they are marked roid. I was very slow in doing this, and day by day I talked to the people because I ilid not want to give any sudden shock to the company men. I thought I could win them to my way of thinking.

Q. A gentleman swore here to-day that Mr. Kirk tolit him he would

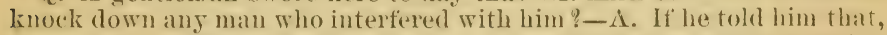
it was a lie; but I will take that back. It must have been exaggeration of his; he nerer said such words to me. If the Goverument agents, I repeat, would do their conscejous duty aud not place themselives so much under obligation to the company, by aceepting free transportation, etc., and swearing afterwards that they paid their way, they would be much belp to the poor natives.

The witness here appended the following paper:

liules and regulations goterning the Island of St. Georye, as mepared by T. F. Iiyan.

ORDER No. 1.

The nse of fire-arms is forlidlden between May 1 and December 1, except as permitted by the Government officer.

No. 2.

The driving and killing of seals for food, exeept pups, will not be permitted between Angust 20 and November 15 (then report to the Treasury for orders as you ciid in regard to bulls) - [ Foid. Conform to the law.] 
No. 3.

No "drive," or killing of seals or sea-lious for food, without permission of the Government officer.

No. 4.

All "drives" in the sealing season will be ordered by the agent of the Alaska Commercial Company- [N. G. Under the law. $]$

\section{No. 5.}

The natives are forbidden to go on board, or to go out to any vessel not belonging to the Alaska Commereial Comprany, visiting the island for the purpose of trading, without permission from Government oflicer.

\section{No. 6.}

No native will be permitted to leave the village without a pass from Goverument officer. They can leave the village whenever they wish.

\section{No. 7.}

No one will be excused from his share of rookery watching, or any work required by the Government officer, that may be for the benefit of the natives, except on account of sickness, which must be certified to by the company physician.

No. 8.

No scholar will he permitted to remain away from sehool withont permission of the Govermment ofticer, on request of teacher and excuse from doctor-[Correct.]

No. 9.

All females are forbidden to visit the Government house or company house after 5 o'clock p. m. - [ Foid. $]$

$$
\text { No. } 10 .
$$

All females over the age of fifteen years are forbidden to visit the Government house without company-[Void.]

\section{No. 11.}

All females over the age of fifteen years are forbidlen to visit the upstairs of the compauy house at any time, chamberwaid and washerwomen excepted-[ I oid.]

No. 12.

All females wver the age of fifteen years are forbidden to visit the down stairs of the company homse without company, except for mediciue or on business to the conipany agent-[Void.]

\section{No. 13.}

The making of quass liquor by the natires, out of sugar, sweet crackers, ete., is forbidden hy an order from the Treasur. Department, and auy one disolseying the order will be severely punished-[Old order covers.]

Read to the natives through Peter Rasonzoff, January 31, 1886.

These are all marked roir by this man Tingle. He wrote back to me that I had no anthority of law, and in my next report he said that I had no anthority for these rules, so this report was made to him about the 1st of June. I went over to St. Paul and he did not say a word abont it; but there were some other influences bought to bear on him, as I do not thiuk he could have ohjected to such rules unless some undue influence was brought to bear ou him. I replied to him as fol- 


\section{lows ; a portion of it goes to give a report of the seal interest and their} authority:

\section{Treasury Departuent, St. George Island, July $: 6,1886$.}

Dedr SIR: Inclosed you will find statement of season's quota of 15,000 seals taken from this islaul, and also stowing the losses from perisbiug, stagy, and muler-size, in all 118, 29 of which number yerished by filling into a pit near the village last August; 29 stagy were taken by watchmen during watehing season on 1 hes other sicles of the island; and 13 under-size, taken by the natives in a killing for food, contrary to orders, were charged up to them as a small lesson in discipline.

The rejection of skins weighing from $4 \frac{1}{3}$ to 6 pozuds, in my opinion, shonld not be allowed. Where the company get so many thousands weighing from $] 2$ to 20 joumb, it seems but reasonable that they should be required to accept the very few small ones that are unavoidably killed in driving to the killing grounds.

If the Government ever expects to increase its revenue from seal islands by an increase in the number to be taken in each year, would advise the taking (under the next lease) of skins weighing 5 pounds aud upwards and at so much per pound.

One of the reasous, I thiuk, why attimes seals of an acceptable size aro scarce, is that the demand for larger skins has lowen gradnally on the increase. For instauce. seven or eight years aun, as I understand it, baml 8 pound skins were taken fieely. as mow they are avoided. The more of this size that are taken by the Govermment or the lessees, the less number of that size will be left to be taken by the prowlers of the sea.

From close observation, aud some measmements of rookeries, with estimates made in varions ways, I am satisied that the estimates made heretofore of the number of seals hauling up on this island have been overestimated. Mr. Elliot's estimate of 160,000 cows, bulls, and pups, I think the nearest, and he is certainly over the mark, at even this date, when the rookeries are larger than when he measured them. I think this island but a resting spotfor many thousands of seal born ou St. Panl.

The set of rules sent you in my last report (withont calling any atteution to them) were inclosed werely as a memoraudum that you might see that your assistaut was, at least, making an effort to create a little system in this office, and on this islaud, which was very much needed. My report did not say that there was a law, that we conld puforce, repniring the Alaska Commercial Company to transact their business with the natives in the English language. I merely stated what seemed to me to be the fact, that I could wot complimest the people on their alvancement (afrer fifteen jears of sehool) in spealing onr language; that they were hearing ton much of their own jargon from the employés of the company to retain very long what they learned at sehoul, and have lately requested the agent of the Alaska Commercial Company, in writing, to please instruct their English-speaking belp to avoid conversing with the natires in the Alent only when absolutely necessary, which reguest was most cheerfully complied with.

Orders No.9, 10,11 , and 12 , which yon say "there is no anthorit s of law for," were issued in the interest of decency, and to bring about, if possible, a better stateof morals among the women of this island, and to impress all classes that the Government would not tolerate with impunity whol'sale prostitution and hastardy on Government property. I can easily find ample authority for such rules, especially when they are very acceptiable to all the male portion of the native pounlation, from the priest down. We would not disagree on this point, or the rnles referred to, I think, if you had asked me for the cause for such rules when on a visit to you in June.

With the exception of a few women, the couduct of the natives is and has been both obedient and respectful.

Seals of good size were plentiful for the first fifteen days of sealing, but from then on till the close it was something of a strain to fund them of sufticient size to fill the season's quota of 15,000 .

As the report will show, we killed but fow bulls, though the company was anthorizen to knock ilown all old troublesone fellows coming in their way to the number of thirty, the skins of which the natives wanted for door mats. 'Thes surplus of old bulls expected to be found did not make their appearance in the drives or on the rookerjes this season; and, I think now, nor last season either. One has to be very eareful in the first season here to keep from seeing too little or too much.

The Alaska Commercial Company have complied with all the requirements of their leaso up to ciate.

The company made their last drive of the season yesteriay, and, from appearance, suppose a few more thousand conld be taken between now and $A u$ gust 1 st, if wauted. I inclose you a small orler for furniture, which the Government houso here is very much in neerl of.

With kind regards, I am, very respectfully,

T. F. RYAN,

Treasury Agent.

Mr. G. R. TINGLe,

Treasury dgent, Seal Islands. 

sir.

Mr. MACDONALD. Is that letter addressed to Mr. Tingle?-A. Yes,

\section{By the Chatruan:}

Q. Mr. Ryan, did you observe that spirituous liquors mere carried there and delivered to the natives in violation of the law--intoxicating liquor's?-A. No, sir. The Alaska Commercial Company has liquor in its drug store but sparingly; they give a small quantity of it to the natives as merlieine. If they have given it otherwise while I was there I did not see it, except on one occasion the chief was made drumk by Dr. Lutz and one Clark, by giving him Perry Davis's pain killer reduced with water. They had a little work there and be went into the seal house and laid down; but in that case I oredoolied it. That is the first sign of !iquor I saw in the thirteen months. Once I yermitted the chief and the priest, anii the chief's danghters, and the priest's daughter to go to a reveune cutter commanded by Captain $\Lambda$ bbey. When they returned the chief gave some signs of being in liquor. That is all the signs of liquor that I know of by drunkenness on the island except myself. I hare been accused of beiug drunk, as I am informed-

Mr. Jefrries. We have heard nothing of that kind here.-A. IV eil, I was giving the whole history. I was hismissed the service on accomt of being drunk, as reported loy Tom Morgan, of the company, and one Dr. Lutz. It is an absolute lie, and I would like for the committee to hear my statement.

The CHAIRM $\Lambda$. That is not the question we are inrestigating.

MIr. JeFFries. I do not think we have ever heard of that before.

The Chammin. No, I do not think I liave ever heard of it. I want to assure you that you are not uncler inrestication in this matter.

The Wi'Ness. I was out at the rookery one day with Mr. Morgan, and came in and took a drink on an empty stomach. They wanted to build a house muder the cliff, and the men would not go there. I latughed and said to him aftermards that I must have been drunli on that one drink. That is the ouly drink taken by me while on the islaud that could be construed into drunkenness.

By the Chatrinan:

Q. How does the company pay the natives for their work ?-A. They pay them 40 cents a skin and for all extra work that is done, as well as bringing the provisions to shore belonging to the company and for improving the company's property or anything that is done for the company, which cover the amount of $\$ 500 \mathrm{or} \$ 600$ a year to the people of St. George; I do not know exactly the amount, but they always have some little for them to do even in the winter, in getting ready for the spring, and they treat them well in that way.

Q. They are well paid for their work?-A. Yes; they draw those wages. They furnish them coal free, free reut, free doctor's, free schools, free fish. They get so much salmon and coal and schooling by law and contract.

Q. The doctor and the medicine and so on is a voluntary act on the part of the company?-A. I thiuk so.

Q. Did you make any obserrations of the conditions of the natires through parts of Alaskin so as to enable you to make a comparison between those on the island and those in the other parts of Alaska?A. Only at Oonalaska. Some of the Oonalaska natires are brougit up to help in the sealing season, and being at Oonalaska a few days I had formed an opinion as to the people.

Q. What was your judgment as to that?-A. In appearance, I think, 
the people of St. George were more intelligent and more eirilized than those of Uonalaska.

Q. Dirl they seem to be in a more comfortable position?-A. Yes, sir. I found this, however, of the people at Oonalaskit; there more of them spoke English than on the island, on aceount of then coming in contalet with English-speaking people at Oonalaska and being compelled to talk English.

Q. From your observation there, do you conclude that the herd of seals are worth taking care of as the Government is now doing; worthy of preservation and keeping? - $\mathrm{A}$. I certainly do; I think it is one of the most interesting spots in the wordh, Niagara Falls not excepted.

Q. Can that herd of seals be preserved in a beter manuer than the

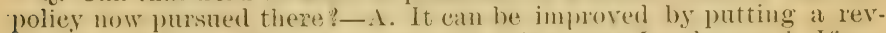
enne cutter there. There was none there this seanson, I understand. If you keep it revenue cutter to go there for that business, I think the interest can be protected.

Q. Strictly, so as to prohibit depredations?-A. Yes, sir.

Q. Is it your opinion that the revenue, by keeping up a strict protection over' the the seals and rookeries, may be increased under that policy?-A. Yes, sir; I think so; I think this present company will ibid more for it next time.

Q. The whole pay amounts to about $\$ 3.17 \frac{1}{2}$ per skin?-A. It pays the Government over $\$ 300,000$ net, I think, and I think the company will be willing to pay tnore next time.

Q. Do you think the Gorernment would be justified in expecting some more revenue next lease? - $d$. That will depend upou the bidder's that will be in the field.

Q. And also on the price of skins and the number?-A. Yes; I think there will be more skins taken next lease than are now taken; that is, if the officer's that hare been at St. Paul have not greatly exaggerated the number going there. There are 150,000 to 160,000 seal going to St. George, which at 1 in per cent. would give a number of $1.5,0: 10$ to be taken. They claim that the seals going to st. Paul will rise far orer a million. Now, if they are right and they pay the same percentage as on St. George it will take a great many more skins. In regard to the taking of skins by weight there, you will understand that at 7 -pound skin is worth \$2.62, while a 10-pouml skin is the same; but a 14 poumd skin is not only worth twice as much, but three times as much, as I understand it.

Q. You think it is better to regulate the price by weight?-A. Yes; by the pouml. I do not know whether it would be advisable, without injury to the seal interest, to take orer a humberl thousand. I have not been to St. Paul and I have only formed an idea from what was told me.

\section{By Mr. MaCdonatd:}

Q. Have you been there long enough to feel justified in givmg your opinion as to the effect of the present course pursued as to these seal fisheries, whether they will be maintained in the present condition or will it result in exterminating them?-A. Yes, sir.

Q. Please state what your opronion is as to the practice that has been pursued.-A. It has been in the main good. I do think that it can be improved upon, and I would suggest that a revenue-cutter be kept there constantly in the sealing season.

Q. Well, continning as it has been in the past year or so, will the supply of seal be kept up? - A. I think so. 
Q. Would it result in lessening the number?-A. I think not. Here is this letter which I referred to before. This answers this question. It the revenue-cutters will protect the seal life, they have got to protect the feeding grounds, and by protecting the feeding grounds and the cows, yon will have an increase in the seal, and if you do not you will have a decrease:

\section{Hon. C. S. Fairchild, Secrelary of the Treasury:}

INDIANAPOLIS, March 3; 1887.

Dear Sir. The Governuent having decided, as I learn throngh public press, that the seizure of vessels canght in the act of killing seals in the vicinity of seal islauds, at a distance of over 3 miles from shore, to be illegal, as one of the Govermment ofticers to seal islands I feel it to be my duty to inform you that, if the Government has beeu madle to understand that by protecting seal islauds to a distance of 3 miles from shore will be sufficient protection, or any real protection at all to seal life, will, in my juigment, prove to be a great mistake.

While the food of the seal (fish) may be in abundance throughout Bering Sea, the main feeding gronnds of the seal, during the summer stay upon the islands, and to which the cows are constantly going and coming, are to be found from 40 to 70 miley sonth of St. George Island. It's but reasonable to suppose that fish would be a little scarce in the near vicinity of the home of a million or more seals.

The number of seals taken by maranders from seal islands or in the waters near by are very few in comparison to the great numbers taken in the 50 or 60 miles south of the islauds. Old seal-hunters seldom bother the islands, and from the information to be had, 95 per cent. of seals taken by seal-hunters in Beriug Sea are taken at a distance of from 40 to 75 miles south of st. George Islaud, aud 90 per ceut. of those taken are cows, the producers.

The male seal-the bachelor, as they are callerl (the class taken by the Alaska Commercial Company for their skins) - are lazy, and stick close to the islauds during their summer stay, and but for heary rains or a hot sun would selilom leave the island at all, while the cows are constantly on the gor to the feedling grounds, leaving their youth to the watchful care of the old bull seal. While the female seals (cows) are protected by law from being killed, within the past seventeen years the lessees have taken about $1,700,060$ male seals, and yet the increase of female seals upon the breeding grounds is not very perceptible, showing, I think, that they have been taken as I bave indicated, by being more at the merey of the hunters than the male seal.

The number of seal-hunters hunting in Bering Sea (in the vicinity of seal islands) in past years have been numerons gnongh, but few in comparison to the number that will swarm around seal islands this coming season, if there is no law to prevent them. For what has been clone heretofore in a limited way and by stealth will now be done openly and extensively, to the extent of extermination within ten, or at the furthest, twenty years.

Very respectfully,

\section{T. F. RYAN.}

Mr. MACDONALD. Then, I understand your answer to be that if this is done that this is the oniy way to keep) off these maranders, from whom there is dituges of exterminatiug the seal?-A. That is all. It is not to the interest of any merchaut who has a contract, certainly, to destroy them.

The CHaIRMan. If the Govermment makes this system of protection rigid and complete throughout the Bering Sea and limits the killing to the number stated in the lease and the law, would the herd increase or diminish?-A. I think it would increase. I wish you would add right there that if you ever wish for the morals of the natires to be corrected, that you should see that Government officers do their duty, and iusist on their rights on the island.

Mr. FELTON. What is the law on that subject at the present time?A. The laws of Uregon corer Alaska, and I think it also inchudes those islands.

The Chambuan. There is an act of Congress extending the laws throughout the Territory. 
By Mr. Feuton:

Q. That being the case, there is no officer under the statute of Oregon to carry them out?-A. No, sir.

Q. The authority you assume there, of course, for the best purpose in the world, was rather arbitrary?-A. Yes, sir.

Q. But there should be a law giring some such authority ?-A. Yes, sir.

The Chatranan. By the passage of the Territorial act 1 think that is repealed, but that is a question we will have to look up.

By Mr. MaCdonald:

Q. Who is this Mr. Tingle?-A. He is head agent there.

Q. Is he the agent with headquarters at San Frauciseo?-A. I don't know.

Q I find here this provision $\mathrm{m}$ the contract, in referring to a copy of the contract between the company and the Government. Reference is made to rules and regulations, and one of the provisos is as follows:

And the said lessees further covenant and agree that this lease is accepted, subject to all needful rules and regulations which shall at any time or times herealter be made by the Secretary of the Treasury for the collection and payment of the reutals herein agreed to he paid by said lessees; for the comfort, maintenance, education, and protection of the natives of said islands and for carrying into effect all the provisions of the act aforesaid, aud will abide by aud conform to said rules and regulations.

Have you ever been furnished with regulations by the Secretary of the Treasury ?-A. Yes, sir. The ouly instructions that I had while I was there was that of Secretary Bontwell, calling attention to the quass business and to stop giving the natives sugar. They finally decided to stop giving sugar to any one.

The Cinarman. That is, you mean to say the company refused to sell to the natives the material out of which quass could be made?-A. Yes, sir, except as a medicine; they treated the innocent and guilty alike.

Mr. Macdonald. This lease was entered into on the 3d day of Angust, 1870, and I understood you to say rou hare no knowledge of any such rules or regulations made by the Secretary of the Treasury haviug been furnished?-A. No, sir; the rule is supposed to be made by his ageuts; he has never made any. They sent up a man there by the name of Manchester, who is mp there now, and he refused to stay his pait of the time, and he objected to doing many things I asked him to do, and he finally pulled a dispatch on me and told me that here was his authority; that his only business there was to count seal skins; as much as to say, I veed not ask him to bother himself abont the people.

Q. Was he a Government agent?-A. He wonld not stay on the island lis portiou of the time and came on lome. He said his wife was sick. When he got to Oonalaska he found his wife well and hearty, but he would not go back to the island. The head agent appointed a physician of the company as agent there. I protested against the proceeding, as it was wrong, and said that he should make this man star there or return. He said it made no difference; that he was going to do it; that if the Gorernmeut did not pay, the company wonld. "Well, I have heard that the company has paid him, and he has got a bill now before the Honse for his pay as an agent made by another agent.

\section{By the CHatrinan :}

For pay as a Government agent?-A. Yes, sir.

Q. Did the Treasury agent refuse to pay him?-A. Me put in a bill.

Q. Was he appointed by the Secretary of the Treasury ?-A. No, sir; this agent assumed Tingle to be the Secretary of the Treasury. 
Q. Which agent was that?-A. Mr: Tingle. He swore him in as an officer of the Government while he was a jhysicinn of the company on the island of St, George instean of making the man who was appointed by the Secretary of the Treasury, and sent there to do his duty as a Government agent, do his duty.

Q. Who was that man?-A. Manchester.

Q. He had been appointed by the Secretary of the Treasury ? $-A$. Yes, sir.

Q. And he bas put in a bill for pay?-A. Yes, sir; a physician of the company, Dr. Noyes, has.

Q. For performing Manchester's duties?-A. Yes, sir.

Q. Manchester has been paid by the Gorermment?-A. Yes, sir; of conrse he draws his pay as a regular officer. The law provides for four and MIr. 'Tingle made a fifth ofthicer withont authority of law.

\section{By Mr. MaCdonald:}

Q. What does Mr. Noyes claim jay for? For performing what duties?-A. For being there during the winter time.

Q. He is both physician and agent?-A. Yes; he is a physician of the company.

Q. Does he claim pay for that?-A: He is employed by the company and paid by them.

Q. What actual service does heclaim pay for from the Government?A. For acting as special agent of the Treasury on St. George Island, under authority of another agent, which was given him.

Q. He is a deputy of Tingle?-A. Yes, sir.

Cross-examination by Mr. JEFFries:

Q. You were spealking of one revenue entter policing these waters. I would ask you whether there would not be some difficulty in disposing of the captured crews?-A. Yes, sir.

Q. What would you suggest 10 remedy that?-A. I know when we captured sereral in 185.5 it was very embarrassing to take charge of the men, and there would lave to be a ship of some kiud stationed at Oonalaskit or a prison to put them in ontsirle of the revenue-cutter. I spolie of one rerenue-cutter as being sulficient protection to seal islands if she done lier duty.

Mr. MACDonaLd. The Gorerument should provide a place for keeping the prisoners?

The Witness. Yes; at Onnalaska, to take charge of the men. Oonalaska is the ouly place where the ship or prisou conld conveniently be.

Q. I would like to have you, in this connection, while it is in your mind, state specifically what you think the Government onght to do in addition to what is now being done to suitably protect the seal fisheries.A. Ontside of a revenue-cutter in these waters, whose dnty it shonld be to protect the islands, there should be a person of some kind at Uonalaska to take charge of the crews that the revenne cutter might seize, and I suggest that it be a prison, because it would be something to punish them. They would not like to go back again when they were locked up in a prison.

The Chamran. Let me suggest. Several witnesses who have been examined before have suggested and urged the policy of reguiring all vessels who enter Bering Sea to touch at Oonalaskal and take there fiom a Goremment official, a customs officer, a permit to euter the sea, stating for what purpose they are going there, and then require them to report before coming out. Would you think that a wise policy? You may just go on, however, without regard to that aud finish your state- 
ment.-A. I had finished ry statement. It would be a question of judgment whether there should be a ship stationed there-a large - wipl, or a prison. A ship probably would be the most practical, because it miglit be used in sending prisoner's to Sitkal, and it could be moved any time back and forth. Besides, if it becomes generally linown that the revenue-cutter is doing her full duts, stealing seals will soon cease.

\section{By Mr. Fexton:}

Q. Now, in resard to the question the chairman asked about ressels reporting there. They could run in and ont and avoid it if they chose to do it? -A. What was that?

Q. The rquestion asked by the chairman was to make all the ships report at Uomalaska going into Bering Sea. Suppose a pirate should go there, he could go in and come out without reporting, it he chose, and talie the chances? - A. He would not be apt to ask for papers. He woule! not go in unless to steal, and he would not want any paner's. The parpers that a captain of a revemue cutter would be looking for would be seal skins.

The ('IALRMIN. If re'ssels went in without a permit required by law it would authorize the revenue cutter to seize them at once.

The WITNess. He might take a permit out and then slipout another way. I think it would be merely another officer to corrupt.

By Mr. MACDONALD :

Q. Confining ourse'ives to what I started ont to get information on-if I mulerstand it, the Goverument has a revemue cutter the enow part of the time or all the time ?- 1 . During the summer. It goes up in Maly and comes back in September or Uctober.

Q. Is that long enough ?-A. Yes, sir.

Q. What I wanted to ask you in that connection was whether one of these revenue cutters was sufficient to protect notonly these islands but the others; in other words, the Alaska seal fisheries?-A. The other islands and their interests are taken care of by auother revente cutter.

Q. You are confining your answer to St. George?-A. To St. George and St. Paul Islandis. The other vessel goes up hunting traders and everything of that kind.

Q. This revenue-cutter, I understand you to say. is confined to watching the seal tisheries and does not have anything to do with any uther business ?-A. It should not.

Q. That one is snfticient?-A. I should think one would be sufficient if it is done properly to protect seal islauds.

Q. There is nothing more you wothld suggest? - A. Tes, sir. I would also suggest that the Government require its oflicers to insist upon being treated like oflicers on other reservations in the United States ; and there shond be special attention paid to the agent. They should not be treated as the azent of a custom-house in New York; they should insist that they must report and that their reports shonld be read. In that way theresan be some improvement made. Now, there is one mistake I will call your attention to to show the weakness of the rnles under the Treatsury. It silys one agent and three assistants. One agentin chief has sio per day, the next ss per day, and the next two geet $\$ 6$ per day. When I went to the island one of the reasons the genthemen 1 fomil there diel not agree, besides their quareding about the women, was, hoih were paid the simme amount, 86 pere day. When a man came to asisist me, Mr. Manchester, he insisted the next day that 
he was in authority just as much as I was, and I told him I would not have it; that there must be a head.

He went to Mr. Morgan and Mr. Morgan jnformed him that the company would have to look to somebody as a head and that they would look to me for orders. If the commission would read, "Agent-in-chief and his tirst, second, and third assistants," the authority would not be defied. 'This is on accomt of the islands being far apart-40 miles, over a rough sea. An assistant agent can't see the chief once a year. The goveruorship of aflairs on the island of St. George should not be interfered with unless it should be submitted to the Secretary of the Treasury.

Mr. Felton. I understand you to say there are two agents on the island at one time?

The Wirness. Yes; from the 1st of Jume until about the 10th of August.

Q. Was there any necessity for them?-A. They are sent there for this reason: To assist duriug the sealing season and to stay the follow. ing winter. It has been the rule for an agent to stay one winter and the other the uext. If you go there in June you are there during the sealing season. The company's ship does not take the other agent oft until the end of the sealing season.

Q. There is no necessity for but one being there?-A. But you could not send the other away.

Q. Why not?-A. Becanse the Goverument ship goes up about the 1st of May and don't return until September.

Q. But I am tilkiug about a Government matter.-A. The Government could not send up unless it sent a special revenue-cutter in August, and that would be an expensive matter, to send a cutter for two agents. Besides, there are ouly sixty days between the coming and going of the company's ship.

Q. Then why should he have any authority until the other man has left? It should be arrainged that way; for instance, you are in charge and a man comes to relieve you, and until you left the authority is with you, and after you left the authority is with him - A. Yes, sir; but where there are tro on the island it makes a difference and should be regulated by makiug the agents agent-in-chief, first, second, and third assistants.

The committee here adjourned until Friday at 10 o'clock.

\section{Commttee on Merchant MARINe aND Fisheries,} Washington, D. C., December 21, 1888.

\section{TESTIMONY OF H. A. GLIDDEN.}

\section{By the CHAIRMAN :}

Q. We have recalled you for the purpose of taking your evidence as to the charges amd statements made in recent publications in the New York patper's (which 1 presume you have read) in reference to the moral condition of affuirs in Alaska. I desire you to state again, if you please, what length of time you were there as special agent, and what truth there may be in these reports as affecting st. Paul and Sst. George Islands, and how far the Govermment arents and the agents of the Alaska Commercial Company are respousible?-A. I was there from 1582 to 
1855, about three years. I was the chief agent and had two assistants. I do not know how I can answer the question except in a general way.

Q. State whether you have real those charges?-A. Tes, sir.

Q. Is there any truth in those statements as to the islancls of St. George and Si. Paul?-A. I do not think there is. Of conrse the morals of the natives are not of as high a character as that of civinized peronle, but so far as geueral character is concerned I think it is equal to the average community of that size anywhere. There is no doubt that now aurl then in man and a woman may desire to have a little "fun," and when they are acquainted and would like to have it they frequently do have it; that is all there is about it. I do not know whether the agents are implicated or not.

Q. So far as your obserration has extended, has the conduct of the ageuts of the Alaska Commercial Compray teuded to the depravity or demoralization of the natives or the contrairy ?-A. I think the conduct and teachings of the company have tended to the elevation and civilization of the natives.

Q. Has it bettered their condition generally ?-A. Tery much.

Q. Morally and materially?-A. I never heard of its doing anything that I thought would deteriorate the morals of the community. The church is the ruling power, aud the priest has almost perfect control of the people. Whatever he tells them to do they do.

Q. Did you hear of any cases of rape of female natires of the islands while you were there?-A. No, sir; I nerer heard any complaint from the natives.

Q. Was there any complaint made by native fathers or husbands as to abuses of their wives or daughters by white men?-A. Never; and they knew that I was the persou to come to to adjust any difficulties between them and the company. Whenerer they had auy little troubles or complaints they would come to me with them.

Q. Will you state to what extent the laws and regulations of the Treasury Department empower its agents to exereise authority there?A. The agents of the Goverument make the law and enforce it. If any complaint is made, either by the company's agents or by the natives, the Government agent determines the question as to which of the parties is entitled to redress. I really did not see any difference in the morals of that community and any other that I have ever been in, except that $I$ do not think they are as particular about some things as civilized people. They are not so among themselves.

Q. What is the extent of your observation as to the general influence of the operations of the Alaska Commereial Company in Alaska? - A. Only so far as those two islands are concerned.

Q. Your observations did not extend elsewhere?-A. No, sir; I never was on the main-land.

Q. Do you have any reason to think the influence of that company is detrimental to the public good and the public welfare?-A. No, sir.

Q. What is the character of the men it employs as agents on those islands? $-\mathrm{A}$. They are all gentlemen, so far as I know, and they are very kind to the natives.

Q. Do you know of any instance of resistance or repudiation of the regulations and authority of the Government?-A. None at all. They never refuse, or argne a question. If I made an order they complied with it without question always.

By Mr. JeFfries:

Q. Where do you lire?-A. Albion, N. Y. 
Q. What is your present business?-A. None at present. I am a lawyer, but am not practiciug now. sir.

Q. Were sou subperuacd to be here on the 7 th of Januarr ?-A. Tes,

Q. How does it happen that you are here now ?-A. I am going to Florida and could not come at that time.

The Chamman. State the circumstances, please.-A. I telegraphed to Judge Sawyer that I could be here on the 20th of this month, and he arranged it so that I could be heard to-day.

By Mr. JeFFRIES :

Q. Were you three years on the seal islands?-A. I risited St. George once a sear. My headquarters were at St. Paul.

The CHAIRMAN. When the committee adjourned the other das I forgot to state that I had arranged to have Judge Glidden appear on the 20 th.

\section{BY Mr. JEFFRIES :}

Q. Have you ever had any personal connection with the Alaska Commercial Company"-A. No, sir.

Q. You have had no interest in this matter except as a Treasury agent?-A. None. I have never seen any of the company since I left Sau Francisco in July, 1885.

Q. About how many of the company's agents are there that remain on either or both of these islands during the winter?-A. I think there are fire, including the cook. do.

Q. Do they have their wires with them usually?-A. Several of them

Q. About how many married ladies?-A. There were five at one time, including the wife of the captain of the revenue cutter.

Q. What was the social urder during the summer?-A. White people and the natives have no social intercourse at all. It is business entirely. Once in a while I would go to see MIrs. Molovedoff, who is really a queen in that section.

Q. During the three years preceding 1885 did you ever know of any married lady being insulted on those islands ?-A. Never. The natives are always gentlemauly, and the white men are particularly so.

Q. How do you regaril the true condition of the natives, not as to the houses they live in, but as to their social and moral condition? What do you say as to the effect on those people of the company opera tious ?A. I think the condition of the people is improving all the time, and with some rapidity, too. Of course the natives came to see me and visited my wife, and we were glad to have them do so. Although they could not talk English, they could use pantomime.

Q. Did you have an opportunity of knowing what the instructions of the company were as to the manner of doing business?-A. Yes, sir.

Q. What were the instructions so far as the uatives were concerned?A. To treat the natives well and observe the conditions of the contract all the time. I talked to the president of the Alaska Commercial Company in San Francisco, and he said he wanted the contract obserred strietly.

Q. Who did the natives and other people regard as supreme authority?-A. The chief Goverument agent and his assistants.

Q. During the time you were there was your authority ever resisted by the company's employés or agents ?-A. Never.

Q. Do you know Mr. Webster, an agent of the company ?-A. Tery well. He was in St. Paul all the time I was there. 
Q What kind of a man is he; an old man, and white-haired?-A. He is an older man than I am and has white hair.

Q. What sort of a man is he morally and socially ?-A. I never saw anything in Mr. Webster but what was perfectly gentlemanly.

Q. What are his habits as to temperance or intemperance?-A. I never saw him drunk in my life.

Q. How long did you know him ?-A. Three years.

Q. It was testified to here yesterday by a gentleman named Gavitt that on at least one occasion-I do not know but it was more-Mr. Webster, at St. George Island, was running through the streets of the village at 3 o'clock in the morning, yelling and whooping, and rery drunk. If that had not been sworn to on oath what would be your belief about it?-A. I should not believe it.

The Chairman. Of course the witness has no personal knowledge about this.

Mr. JEFFries. No; the question contemplates that.

The IVITNESS. I lived there three years, and of course there being but few white people on the island, whatever pleasure or pastime we got we had to get it together. We used to have card parties.

Q. I wish you wonld state to the committee, if you please, what you know in reference to the Church, the Greek Ohurch, to which these natives belong, and what the habits of the people are with regard to the Church ?-A. The Greek Church is the only church there, and the only religion attempted to be promulgated on the islands. Every native is a member of the Church. They are baptized into it when they are children, and they all attend regularly.

Q. Do they appear to believe in their Church ?-A. I never saw but few but what did. Some few do not.

Q. Does the bishop ever visit those two islands?-A. The bishop weut up with us the first time I went up.

Q. What was his name?-A. I do not recall his name.

Q. Where is his official residence?-A. San Fraucisco. He went up to st. Michaels, and on his return jumped overboard and was drowned.

Q. Do you know what the company's instructions are in regard to non interference in religious matters?-A. When I went up there I talked that over with Dr. MeIntyre, who said his iustructions were never to interfere in church matters. In the Greek Church they have a great many holidays, and when they hare a holiday ther must attend church. It appeared to me sometimes as if they had a holiday almost every day, and it interfered with the sealing during the season. We had a conference with the priests, and arranged the matter so that the workers in the seal fields need not attend.

Q. Who did that?-A. The company.

Q. Was it amicable?-A. Yes, sir.

Q. Do the priests have much influence over the people?-A. They have complete control over them.

Q. They do not have a priest at St. George Island ?-A. Yes, sir ; when I first went there they did not have any at St. George, and the chief carried on church matters.

Q. Are there any regulations by the Treasury Department for the guidance of the Government agents on those islands?-A. Ido not think there are. I never saw any.

Q. Are there any instructions to the agents by the Treasury Department?-A. Tes, sir; one was a prohibition of the manufacture of "quoss."

$9984-16$ 
Q. Do you happen to remember whether as late as 1882 there was a collation made of all the Treasury letter's, circulars, and decisions, which was eompiled by Mr. Otis, and sent to the Treasury Department?-A. I think there was. Otis was a martinet in some respects. He collated the letters and circulars issued by the Government to its agents iu Alaska.

Q. Hare you read the articles which appeared in the New York Sun of December 12, which purports to be an interview with ex-Special Agent Kimmel in relation to the seal islands of Alaska?-A. Tes, sir.

Q. Please state to the committee whether that statement, purporting to be made by Mr. Kimmel, is a true one.-A. Some parts of it is true. He says the Alaska Commercial Company is the lessee of the seal islauds. That is true.

Q. Is there anything in the statement that is not true?-A. Ies, sir.

Q. Please point out those portions of the statement which are not true.-A. He says that the Government agent is supposed to see that the terms of the contract are properiy enforced and carried out, the natives fairly treated, and to see other things done, but that he has no power to enforce his orders. That is not true; he has complete porrer to enforce his orders. He says, "The worst thing about the natives is their complete helplessness." That is not true. He says, "The natires have no rights except such as the company's employés choose to allow them." That is not true. He never reported to me anything about the teacher's being drunk.

\section{By the Chatrman:}

Q. I think there was an intimation or statement to the effect that the company intimidated the natives, or they were afraid to make complaints. Did you observe anything of that sort?-A. No, sir; I never knew of anything of the kind. I will say in relation to the school, that his report to me was that it was not kept the required length of time, aud he reported it to me as I reporter it to the Government. He never said anything about the teachers being drunk. He did report that a man wanted to go down to Oonalaska and I would not let him go.

\section{By Mr. JEFFRIES :}

Q. Is there anything else in that intervier which you wish to explain, or which is not true?-A. No, sir. I do not know anything about an attempt to blacken his character.

Q. What would happen if an agent or employé of the company would refuse to obey the orders of the Government agent?-A. I should report him to the Department at once.

Q. Talke St. George Island-supposing Mr. Kimmel in charge of St. George Islaud-was it his duty to report to you if an agent of the company would refuse to obey any order of the subagent?-A. Yes, sir.

Q. Hare yon ever known of an instance of such refusal ?-A. Nerer.

Q. Was this report that was spoken of in this interview that is referred to a written or a verbal report?-A. It was a verbal report.

Q. When he made it was there any complaint made as to the conduct of the company's agents on St. George Island or anything about the demoralization of the natives ?-A. Nothing at all.

Q. What did he say to you in that report as to how things were going on in St. George Island?-A. I do not remember. Mr. Wardmau usid to make a report to me once a year.

Q. From what he said to you in that report what were you led to believe as to the condition of affairs on St. George Island during his. 
alministration? - A. I could draw no inference from it except that there was nothing wrong. His complaint was that I would not let a man go down to Oonalaska. The natives were in the habit of making applications to go to Oonalaska to see their friends or spend the winter, and every time the steamer went down there would be a certain number to so. The agents of the company generally agreed upon a number to go, and when I got this particular application I refused it because the applicant was too late.

Q. If such a state of facts existed on St. George Island as Mr. Kimmel in the interview is made to say existed, would it or not have been his duty to have reported those facts to you as his superior officer?A. I certainly think it would.

Q. Did he make any such report?-A. He did not. I went to St. George once a year, and he never made any such complaint to me.

Q. How mauy Government emplosés were there on eacu island ?-A. Two, except during the winter, when one on each island came down.

(2. Exelusive of the Goverument agents, what was the entire num. ber of white males on the island?-A. Five white males.

The committee adjourned to meet on January 7, 1889.

\section{Committee on Merchant Marine and Fismeries, January 7, 1889.}

\section{TESTIUONY OF CAPT. L. G. SEEPARD.}

\section{Capt. L. G. SHEPARD sworn and examined.}

The Uharrmax. The subject under investigation by this committee is the contract and lease made by the United States Government with the Alaska Commereial Company for the purpose of taking fur seals in A laskia, and the extent to which this has been enforced or complied with, etc., by that company at any time.

Q. State what position you oceupy ? A. I am captain of the United States reveuue-cutter Richurd Rush, and made two cruises to Alaska in the summers of 1887 and 1888.

Q. Will you state to the committee the result of jour observations in the discharge of your duties. I suppose you were instructed to look after the violations of law in reference to prohibiting the killing of tur seals ou those islands. State your observations in regard to that.-A. That was the purpose of our eruise. I hardly know what particular line you wish to pursue.

(Q. You might as well gire simply a brief statement of your uruise and whether you observed any riolations of the laws in reference to the taking of fur seals by unanthorized persons and the extent to which it was carried, ete.-A. During the summer of 1887 we sailed from San Franciseo (June 4) on a eruise for about four months, and two and onehalf months were spent in Bering Sea, and during that time I seized twelve ressels which were found taking fur seal iu Bering Sea. These vessels were afterwards taken to Sitka and condemned in comrt. Xine rere condemned and three failed to report at Sitka. Their skins and arms were confiscated, but the three ressels, one British and two American, did not come within the jurisdiction of the court.

Q. In what localities did you find those ressels when you seized them ?-A. In distances varring from 20 miles north of Oonalaska Island, to about 60 miles sontheast of St. George Island, a distance of 
about 100 miles. About 60 or 75 miles southeast of St. George aprears to be the principal reudezvous of vessels cruising in Bering Sea for the purpose of taking seals in the water.

Q. In what manner do they take them?-A. They are furnished with boats, the number varying according to the size of the vessel and the number of the crew. In most of the British vessels the crew consists of about thirty or thirty-five men. There are about five white men on each vessel and the remainder of the crew are Indians. The Indians go out in the canoes, two Indiaus in each canoe. They shoot the seals with shot-guns or spear them. They sometimes go quite a distance from the vessel. I have seen canoes s or 10 miles from their vessel. They go out in different directions and thus corer a large surface of the sea. A vessel with fifteen canoes cau cover a surface of the sea pretty well for 12 miles in every direction from the vessel, and any seal coming within that surface stauds a pretty poor chance of getting away, as the Indians are very expert in taking them.

Q. Why do they go to that particular locality? Is that the feedingground?-A. They pass this locality in going to the feeding-ground nearer the Aleutian Islands. I understand the seal lives on fish.

Q. The hunters intercept the seals constantly as they go to and from the islands ?-A. Yes, sir ; that is what I understaud.

Q. Do you have any opinion as to the probable extent of the destruc. tion of seals by these unlawful hunters?-A. During the season of 1887 I estimated that they killed about 40,000 seals and would have taken 20,000 more had no seizures beeu made. We captured fifteen ressels on board of which we found about 12,000 skins. Some of the ressels captured early in the season harl taken only a few skins. The number varied from 150 to 1,500 skins on each vessel.

Q. You estimate the destruction of seals, then, at 40,000?-A. Yes, sir; for tha: season.

Q. From the number of skins taken you estimated the number killed?-A. That season I know there were thirty-five vessels in the sea, and we captured tifteen ressels. The catches of the vessels were published in the papers when they arrived home and averaged from 1,000 to 2,500 skins each.

Q. You estimate, then, that during the season, 40,000 skins were taken? In killing them in the open sea they do not recover every seal they kill? -A. No, sir; I do not think they do. In fact, I know they do not, judging from the amount of shot and lead taken from the seals that are afterwards killed on St. Paul and St. George Islands.

Q. So that the destruction of the seals in the open sea would be much in excess of the number taken, probably ?-A. I have no very accurate information on which to base an opinion, but I should judge that they lost from 40 to 60 per cent. of them. I saw a good many shot from the boats as I was approaching, and thiuk they lost two or three out of five or six that I saw them shoot at.

Q. From your observations have you any recommendations or suggestious to offer, the arloption of which would lead to the better preserva tion of seal life in these waters than is now provided by law? - A. There is a difference of opinion as to the construction of the law. I firmly believe that the Government should either protect the islands and water in the eastern half of Bering Sea or throw up their interest there. If the Bering Sea is to be regarded as open for vessels to go in and capture seals in the water, they wonld be exterminated in a short time.

Q. You think the mere protection of the rookeries upon the islands will fail to preserve the seal unless protection is extended to Bering 
Sea?-A. Yes, sir. To look at it in another light, I think it would be cheaper to take them in the water than to make a contract, or pay a tax to the Government, for the privilege of taking them on the islands ; and that no company would be willing to enter into a contract with the Government unless guarantied protection on water as well as on the islands.

\section{By Mr. MaCDONALD :}

Q. You are now speaking of what the Government ought to do, regardless of the present law? - A. I think the business should be either wholly protected or throwu up, one or the other. I do not see any halfway course to take in the matter.

\section{By the CHAIRMAN :}

Q. Did you observe any violations of the law on the part of the Alaska Commercial Compauy in the course of your cruise there?-A. No, sir ; I do not remember seeing any thing of the kind.

Q. Did any violations of the law by the company come under your observation while there?-A. I thought they were very careful to observe the contract and carry it out to the letter.

Q. How often did you visit the islands of St. George and St. Paul?A. Probably ten times each summer. I have no special record of it, but whenever I was in that vicinity I landed to cousult with the special agents.

Q. Did you look into the subject of the faithful execution of the law? -A. Yes, sir.

Q. Did you hear of auy riolations of the law on the part of the company or its agents, or on the part of the Treasury agents ?-A. No, sir. The particular object of my visits was to learn if any marauding vessels had been seen about the islands.

Q. Did you have an opportunity to observe the character and manner of the uatires upon those islapds, and their condition?-A. Yes, sir; I went about their villages and looked at their houses.

Q. Did you talk to the natives?-A. No, sir; not much.

Q. What was your observation of their condition?-A. I think they are as well provided for and as well taken care of as possible under the circumstances. They are certainly very much better off than the laboring classes are elsewhere; at least, they obtain a living with much less labor.

Q. They were in a comfortable condition, and had good houses to live in?-A. Yes, sir; good mooden houses.

Q. They were well rlothed?-A. Yes, sir.

Q. Had plenty of food?-A. They all looked to be in a fat and healthy condition.

Q. Of course you know something of the former condition of the natives before the Territory was cerled to the United States. How does their condition now compare with their condition prior to the cession?-A. I understand that before the country was ceded to the United States the natives lived in hovels or barrabaras, houses built half under and half above ground, and lired principally on seal meat. Their elothing consisted prineipally of skins of seals, and the seal was almost their whole means of sustenance. This is what I understand by concersations with people who visited the country early. The natives now live in woorlen houses, which I understand have been built by the Alaska Commercial Company, and they have been moved up on higher eround than they formerly ocenpied. They are higher and drier, and should be healthier. 
Q. Hare the natives better clothing than formerly?-A. Ther wear woolens of the best class. The company keeps a store which is furvished with everything usually found in a conntry store.

Q. The natives wear the same class of clothing as cirilized people?A. Yes, sir.

Q. Did you observe whether or not alcoholic drinks are used by them or furnished to them ?-A. I did not observe any. I do not think there is any on the islands except what is necessary for medicinal purposes.

Q. You are aware that the law prohibits it?-A. Yes, sir.

Q. Is there any violation of the law in this respect?-A. No, sir; not on the seal islands.

Q. There have been a great many accusatious published in sereral papers as to a wholesale coudition of moral depravity amongst the women; that rapes have been committed and the chastity of the young as well as middele-aged women indiscriminately violated by a great many people. Have you had an opportunity to make observations of those couditions? - A. My visits to the islands were made during the day. I was not in a position to see ansthing of the kind. I nerer heard of anything of the kind when I was there. If such abuses had occurred, the natives could have appealed to me for assistance if ther wasanted to.

Q. Did you observe the condition of the natives in other parts of Alaska to any great extent?-A. Yes, sir ; along the Aleutian Islauds. Q. How did the natives of St. Panl and St. George compare with those of other parts of Alaska ?-A. They are better clothed aud better cared for on those islauds, hare much better houses to live in than those living in other settlements, excepting at Oonalaska. In a number of other places, the houses are partly undergromud. In Oonalaska the company has made abont the same provisions as have been made on the islands; has built at least forty houses which they allow the natives to occupy free of rent.

Q. The condition of the natives on St. Paul and St. George is better than the natires elsewhere in that Territory? -A. Yes, sir. I understand the natives of those islands cousider themselves the aristocracy of western Alaska; it is looked upon as a privilege to be allowed to live there.

Q. Did rou make the acquaintance of many of the agents and employés of the Alaska Commercial Company on the islands of St. Faul and St. George?-A. Yes, sir; I know them personally and had short conversations with most of them.

Q. Are you acquainted with Mr. Webster, one of the agents on the island of St. George? - A. Yes, sir; I know Mr. Webster.

Q. What character of a man is he?-A. Nr. Webster is a man of about sixty-five jears of age, perhaps seventy, and is rather quiet.

By Mr. Macdonald :

Q. Is he a man that is cross and overbearing ?-A. Here is a photograph of Mr. Webster, [exhibiting photograph]. I had very little to say to Mr. Webster, as he was located on the uortheast point of St. Paul during both summers. He was in charge of the working force. I have not seen as much of him as of the other employés, but I should judge he was a very peaceable and harmless kind of a man and quiet.

By the Chairinan :

Q. Did you learn whether or not he was a habitual drunkard ?-A. No, sir ; he has not the appearance of a man who drinks; he has a pecu- 
liar disposition, however, as he prefers living on those islands to living down in civilization.

Q. Did you learn whether he was a man of good or bad moral character? - A. I never heard anything detrimental to his character while I was on the islands.

Q. The other agents of the company were men of fairly good moral character-not bad men?-A. I should judge that they were men of as good character as can be found anywhere of that elass of employés.

By Mr. Macdonald :

Q. You speak now of what you heard of their reputation?-A. Yes, sir; I uever heard anything detrimental to them. I nover heard their moral character questioned.

\section{By the ChaIRMAN :}

Q. It has been testified to here that they were meu who had no regard for the ehastity of the native females there. Have you heard any stories of outrages of females by any of the agents there?-A. I never heard anything of the kind. I do not know anything of it. I do not think it would be tolerated by the company if it should be known. Some of the employés of the company hare been there serenteen or eighteen Jears, aud if they were guilty of any such thing they would have been discharged and sent away.

Q Is it your opinion that the Alaska Commercial Company, by reason of having this lease for the exclusive taking of fur seals, exerts a general influence over the Territory that is detrimental to the public interests ?-A. I have not observed anything of the kind.

Q. Hare you visited most of the tradiug stations?-A. I visited four of them.

Q. Is it your opinion that the operations of the company have a misehierons or a detrimental influence?-A. No, sir; I never heard anything of the kind.

Q. What is the general opinion of good people as to whether it is misehierous ? -A. People who know from personal observation generally speak well of the company. The company have no exchusive business escept on the seal islands. All other places are free to auy man or company to go there and open stations.

\section{By Mr. Macdonald :}

Q. How long have you been engaged by the Government in that country ?-A. Two seasons; $18 \times 7$ and 1885. I was ordered there in 1887 on the revenue steamer Rush.

Q. As the result of your observations, and the information fou gathered while there, what is your opinion as to the finture effect or result with reference to the taking and killing of fur seals? If the present condition of things is allowed to continue, will it result in the extermination of the seals, or will the supply continue or diminish?-A. If ressels are allowed to go into the sea and eapture seals in the water it is only a matter of a very short time when they must beeome extinet.

Q. Assuming for the moment that there is no contract, with the present conlition of thing's continuing, what is your opinion as to the ultimate effect upon the seal fisheries, and have you any suggestions to make? - A. I do not see how the business can be conducted in any bet. ter way than it has been since the eompany has harl this lease.

Q. I was not asking the question for the purpose of criticising the company.-A. I mean if a new lease be made, or one similar to the one which has been in effeet for the last twenty years. 
Q. If seals are continued to be killed in as large numbers as they have been while you have been there, what is your opinion as to the future effect upon the busiuess?-A. If they are protected on the islands and hunters excluded from the Bering Sea, I do not think there is any danger of extermination.

Q. You think the supply would continue about as it is now ?-A. Yes, sir; I should judge so.

Q. Could an increased number be taken ?-A. Certaiuly, if thes are protected in the water.

Q. What would be a fair estimate of the number taken during the past sear by these trespassers?-A. The number, I think, varies considerably. In 1887 I estimated the number to be abont 40,000 . This last season the numbur was about 25,000 or 26,000 . There were not as many vessels there as during the previous year. I understand that a large number of vessels are being fitted out at the present time with the intention of going into the sea next season unless some measures are taken by the Government to prevent it.

Q. What do you suggest that the Gorerument should do to protect these seal fisheries from these outrages?-A. If the President or the Secretary of the Treasury should issue a proclamation prohibiting the taking of fur seals in Bering Sea, aud enforce the law as it was enforced in 1887, I think that would be sufficient.

Q. What is the necessity of issuing a proclamation? Is it not generally understood that it is unlarful?-A. It is not so almitterl. Many claim that Bering Sea is an open sea, and say that the United States hare no jurisdiction there.

Q. Noexclusive juriseliction?-A. Noexclusive juriscliction, and many of the captains of the ressels said that if they had kuown it was unlaw. ful thes would not have gone into the sea.

Q. You believe that if this proclamation were issued a great many would respect it, and would not go there?-A. Yes, sir; it would be necessary to issue a proclamation, and send a vessel there, aud make it dangerous for vessels to go there for the purpose of taking fur seits.

Q. Allowing that to be the case, and supposing the Secretary would issue such a proclamation, would it be uecessary to have a revenuecutter there?-A. Yes, sir; one cutter wonld be sufficient.

Q. One for the entire islands? - A. One in the sea would be sufficient. It has been customary to send two ressels each year. One starts in May and remains until the second one arrives, about the middle of Jume, and then the first one goes into Arctic Ucean to look after the whalers. They returu to Sau Franciseo about the first of October.

Q. Were any of these vessels that were taken foreign ressels?-A. Yes, sir ; five of the vessels that I captured were British ressels.

Q. Were they coudemned in court?-A. Yes, sir; they were condemned in court at Sitka.

Q. Were you there?-A. Yes, sir.

Q. Was there any question raised by them as to their right to go into Bering Sea on the ground that it was au open sea?-A. Yes, sir ; there was a lawyer from Victoria, B. C., who eutered a protest against the proceedings.

Q. And the claim was orerruled ?-A. Yes, sir.

Q. When did this ocenr?-A. First in 1s86, I think. Captain Abbey made those seizures. Aud again in 1687.

Q. You think a proclamation should be issued anually ?-A. Yes, sir; I think it advisable to keep it before the eyes of the public and give them to understand that it will be enforced. 
By Mr. FELTON :

Q. You think one revenue-cutter would be sufficient for that purpose? - A. Yes, sir; one cutter, I think, would protect our interests pretty well.

By Mr. Macdonald :

Q. If it was not required to perform any other duty ? - A. Yes, sir; it should not be required to perform any other duty.

By Mr. FELTON :

Q. I understand you to say-for instance, taking 1887 or 185 i - that the 100,000 seals taken upon the islauds and the 40,000 takeu and killed in the water, if no greater amount was taken, that there would be no perceptible diminution in the number of seal; that by the natural increase the company might take 40,000 more than now, if it were not for the depredations?-A. I bad in mind an average between 25,000 killed in 1858 and about 40,010 in 1887.

Q. What I want to know is this: Is it your opinion that the number taken in the sea, when they are on the way firm the islands to the feeding grounds, have a tendency to demoralize the seal and to break up their habits, their confidence, etc.?-A. It wonld be likely to to it. They are very easily frightened, and the discharge of fire-arms has a tendency to frighten them away.

By Mr. MaCdONALD:

Q. No seals are killed by the company in this way?-A. No, sir; they are all killed on the islands with clubs.

By Mr. FeLton:

Q. Including seals in the water, is not a large number of those killed females?-A. Yes, sir; all ages, sizes, and sexes.

Q. When they kill them, are the females usually with pup ?-A. Many are.

Q. In that case it would be a loss of two ?-A. I have seen a great many skins of unborn pup seals taken from females. Those skins are not marketable and the crew usually take them for their own use.

By the Chatriran:

Q. While you were upon the islands of St. George and St. Paul did you observe or inquire as to whether or not the natives accorded a ready and respectful compliance with the requirements of the Government agents there?-A. I think they do, willingly. The Govermment officer is there for the goverument of the natives as well as to look after the general interests of the Goverument.

Q. Would they repudiate the authority of the Gorernment ofticer in any conflicts of a serious nature?-A. Not in any serious manner. I do not know any particular instance, but I understood that they objected sometimes to rules made by the Gorernment agents, hut how serious they were I can not say. They asked that they should be allowed certain privileges and the Gorernment objected.

(2. Did you inquire just what they were?-1. Yo, sir; I do not remember anything especially.

Q. What are your observations as to the conduct of the agents of the company in that respect? Did fou observe any confliets between the agents and employés of the comprany upon those islands and the Treasury agents?-A. No, sir; I have heard nothinge except that Mr. Garitt stated here the other day. I hearl of some tromble he had at St. George last winter. 
Q. You heard what he testified to here?-A. Yes, sir; I heard something regarding the trouble thes had last winter about his peculiar ideas, etc.

Q. Did you hear of any other disagreements or conflicts between the company's employés and the Goverument agents?-A. Other Government agents? No, sir; I do not think there were any other. I do not remember ans other agent having trouble with any of the employés.

By Mr. Macdonald :

Q. State what you heard about Mr. Gavitt's trouble.-A. I heard it in a general way from the employés of the company in their conversation about it.

Q. Did they complain about his conduct?-A. They did not make any formal complaint about it. They said he was a rather peculiar man and acted as if he was not in his right mind at all times. For instance, on Decoration Day, they hoisted the flag at half-mast and that he objected and said it was an insnlt to the flag and was done to annoy him.

(2. Is that the only incident you heard there abont the tronble between him and them ?-A. I understood that he declared the lease of the company forfeited becanse they closed the school too soon. He would not allow them to commence taking seal until Colonel Tingle and Dr. MeIntyre arrived uron the islands in the spring.

Q. Did you have any personal knowledge of those facts?-A. No, sir; only hearsay.

Q. Did you ever have any conversation with Mr. Gavitt?-A. Yes, sir; I talked with him whenever I risited the islands.

Q. I)id you see much of him while he was there?-A. Yes, sir; I hat several conversations with him.

Q. How did he impress your as to the kind of a man he was? -A. I thought he was rather light and peculiar, and not by any means competent to hold so responsible a position. He seemed to be afraid that somebody was going to kill him. I did not see any one make auy at tempts of that kind.

\section{By the Chairiran:}

Q. Did he hare anything like a reasouable foundation for such an apprehension?-A. Certainly not. I would not have been afraid to be there. I think Mr. Gavitt is not at all times of sound mind.

Q. Did you hear anything that yon thought wonld be sufficient to give him surh an impression as that, or that would lead him to think that he was likely to be killerl? - A. No, sir; I do not really think he believed it himself. Mr. Redpath here is a fair sample of the employés. Mrr. Morgau aud Dr. McIntyre are also fair samples, the latter being superintendent of the islands.

Q. Did you see this Mr. Gavitt soon after he arrired? - A. Yes, sir; probably two or three weeks afterwards. He went up to the islauc? of St. George about a month before I went to Alaska.

\section{By Mr. JEFFries :}

Q. Ton are familiar with the habits of the fur seal, I suppose, to some extent?-A. Yes, sir.

Q. Is it a fitct that the old bull seals remain on the rookeries luring the whule summer season?-A. Yes, sir; I understand so.

Q. And what you eall the bachelor seals stay down near the water and near the shore?-A. Yes, sir ; they herd by themselves on separate rookeries.

Q. Shortly after the female seals arrive they bring forth their young? A. Yes, sir; I understand it is so. 
Q. After they have bromght forth their young do you know whether or not it is their habit to leare the roolieries and go itown for food and stay sometimes for days at a time before coming back to nurse their young ?-A. Yes, sir; I understand that is one of their habits.

Q. And that when they are killer while with young two seals are lost?-A. Yes, sir.

Q. If after they bring forth their young they go down for fool and are killed, then what becomes of the young seals on the rookery ?-A. I suppose they would starve to death.

Q. In that event two seals are wasted?-A. Yes, sir.

Q. Did you happen to observe, amoug the skins that rou captured in Bering Sea, whether or not a large majority of those skins were the skins of female seals?-A. I lookerl over the captured skins as they were passed out of the ressels, and I estimated that 75 per cent. of them were skins of female seal.

\section{By Mr. MACDONALD:}

Q. I want to ask you whether, in statng that if the present condition of things contiuues the seals would not be exterminated, you took into consicleration the fact that 7.5 per cent. of these were females? - $\mathrm{d}$. That did not enter my mind at the time.

Q. That being the ease, it would largely increase the liability of their being exterminated?-A. Yes, sir.

By Mr. FELTON :

Q. Was it not jour idea that if the prosent state of things continued that the seals would continue to increase?-A. Yes, sir; with protection.

Q. You eliminated from your idea this killing in the open sea ?-A. Tot wholly. Of course the more there are taken the more liability there is that the seals will decrease.

Q. If there were no depredations more seals could be taken on the islaud by the compans?-A. More could be killed on the island if there mere none at all killed in the water.

Q. And those killed on the islands are of a better grade?-A. Yes, sir; they are the best of the seals.

By Mr. JEFFRIES:

Q. Do you happen to know whether the company kill any female seals ?-A. They are very careful not to do so.

Q. They are not permitted to by law?-A. No, sir.

$Q$. It has been stated in testimony here that not one out of fire, six, or sereu of the seals wounded in the water are recorered. I think yon put the estimate a little lower than that. Have you any knowledge on that sulject?-A. I think they recover about one-half.

Q. In 1887 you say there were 40,000 skins taken by these marauders?-A. Yes, sir; according to the best information I have.

Q. If they recorer only one-half that wonld be a loss of $\$ 0,000$ seals? A. Yes, sir.

Q. And if one-half of those were females with pup it would add to that number very much?-A. Yes, sir.

Q. And it would also deprive them of a capacity for further proluction?-A. Yes, sir.

Q. From all these considerations, if Gorernment protection were withdrawn from Bering Sea how long; in your judgment, would it take to exterminate the fur-seal rookeries of Alaska?-A. It is a difficult ques- 
tion to answer, but I think they would be pretty nearly destroyed in three to five years.

Q. You have stated that a revenue-cutter, policing Bering Sea, would protect the seal interests. Would it be advisable to have a man-of-war or relief ship down at Oonalaska with which to trunsport persons eaptured when marauding?-A. Yes, sir; it would be an excellent idea to have a larger force than the usual crew of one cutter near at hand.

Q. IIave you some trouble in disposing of captured erews?-A. Yes, sir; it is rather more tronble to dispose of them after eapture than to find them.

\section{By Mr. M $\triangle$ CDONALD:}

Q. Right in that connection stare what, in your opinion, is the best method for the Govermment to carry out in regard to police regulations and taking care of the prisoners?-A. If there was a vessel located at Oonalaska to take charye of the captured vessels and crews, so that they could be sent to Sitka, it would facilitate matters a great deal. In the summer of 1887 , when I made the seizures, I had not sufficient force. My method was to place a man on board and send the ressel to Sitka. Of course he was but one man, while the crew consisterl of thirty or forty, and they could have gone to Victoria or San Francisco, if they desired. Oonalaska is about 1,250 miles from Sitka, the capital, where the court is held. It is a long distance and there is no communication between the two places. It depends wholly upon the disposition of the captain to go and stand his trial in court.

\section{By Mr. JEFFRIES :}

Q. What is your opinion as to the number of vessels that will enter Bering Sea next season for the purpose of killing seals?-A. My information, which I have obtained through the newspapers, is that from fifty to sixty vessels are now fitting out for that purpose.

$\dot{Q}$. What is usually a fair catch for a vessel of the description of those now being fitted out?-A. It raries very much, according to the size of the crest, but from 1,000 to $2, \tilde{0} 00$ seals.

Q. Say 2,000 , would that be a fair arerage?-A. I would say 1,800 .

Q. There are about fifty such vessels now being fitted out?-A. Yes, sir.

Q. You spoke with reference to some complaint that the natives made about some regulations. Was it against the Goverument's agent or the company's agent?-A. The Treasury agent.

Q. Do you happen to know whether it related to the making of quass, an intoxicant that they produce; was that perhaps the cause of the complaint?-A. I have understood that they complained that they were not allowed to have any aleoholic liquor of any kind, but I do not know what special objections they made.

Q. Do you happen to know what effect intoxicating liquors have upon that people? - A. It is certaiuly very demoralizing, as it is to all other people. I understood the agents required the natives to ask permission before going out in boats to fish. That they thought they should hare a right to go out in boats as much as they pleased without going first to ask the agent's permission. That may be necessary or not; I do not know.

Q. Would it be possible for the Alaska Commereial Company to take its catch of seals if intoxicating liquors were giren to the natives?A. Not with those that now do the work.

Q. The Treasury Department has been in the habit of issuing a notice prohibiting the killing of seal in Bering Sea.-A. Yes, sir. 
Q. It so happened last year that there were no seizures made ?-A. No, sir.

Mr. II $\triangle$ CDONALD. Suppose you get him to state why?

Mr. Jeffries. I do not care to go into that. The committee can if it chooses.

By Mr. Dingley:

Q. Why were no seizures made last season? - A. I found no vessels violating the law according to the instructions I received from the Treasury Department in regard to the raking of fur seals up there.

Q. There were instructious issued by the Treasury Department in regard to vessels catching seals unlawfully ?-A. I found no ressels liable to seizure under the instructions I received.

Q. Do you mean to say there were no illegal catchings?-A. No, sir; I do not say that.

Q. There were vessels catching seals illegally? - A. I saw ressels in Bering Sea apparently for the purpose of taking seals.

Q. But under your instrnctions jou conld not seize them?-A. No, sir.

Q. Will you state to the committee how those instructions varied from the instructions previously given How were they different from the instructions of last season?-A. I received confidential instructions from the Treasury Department, a copy of which is on file in the De. partment, and which were returned to the Department by their orders. If it is all the same to the committee, I would ask that it apply to the Secretary of the Treasury for a copy of those instructions, rather than ask me to divulge them

Mr. Dingley. We will ask the Treasury for them.

\section{By Mr. JEFFRIES :}

Q. What I was about to ask you was whether there is a large number of residents of the United States who are determined to enter Bering Sea this next summer if they have an opportunity?-A. I think those vessels are about equally divided between American and British.

Q. There were no American vessels taking seals in 1888, were there?A. I heard of two American vessels, but did not see any.

Q. Who was it that took seals unlaw fully in 1885-what nationality?A. The ressels I "spoke" hailed from Victoria, British Columbia.

Q. Were they American or British ?-British.

Q. If the Goverument had been firm and had exhibited a determination to protect these seals would there have been any danger from these marauders? - A. It would be necessary al ways to keep a vessel there to enforce the law. I think the issuing of a proclamation would be a great assistance. They would then certainly have no excuse for going there.

\section{By Mr. Dingley:}

Q. I will ask you, in order to be certain upon one point, this question; I understand you to say that there were no American ressels catching seals, but if there had been you would have seized them ?-A. I said I did not see any, but heard of two or three.

Q. As a matter of fact there were none?

Mr. Dunn. He said he saw none, but there were one or two.

\section{By Mr. DINGLEY :}

Q. If you had discovered an American ressel catching seals there would you have seized her? 
Mr. Denn. There is no discriminatiug between an American and a British vessel. One would hare been seized under precisely the same circumstances as the other? - A. The law makes a little distinction between an American and a British vessel in regard to the killing of female seals and seals under one year of age.

Mr. Dinglex. The law makes a distiuction or the Treasury Depart. ment; which?

The Witness. I understand the construction the Treasury Department puts on the law is that they can prohibit the killing of female seals or seals less than one year old by an American ressel anyichere, but they could not enforce that regulation on a foreign ressel.

\section{By Mr. Dunn :}

Q. You understand the Treasury Department puts that construction upon the law. Is there a different construction embodied in the orders given officers of rerenue ressels? - A. Yes, sir ; they prohibit the killing of female seals and seals less than one year old by American ves. sels anywhere.

Ir. DINGLEY. If I understand you correctly British vessels were allowed to do certain things that American ressels were not allowed to do.

Mr. Dunn: He states the Treasury Department places a construction mpon the statute which does discriminate between an American and a British vessel.

By Mr. MaCdonald :

Q. Here is a pamplulet containing the rules and regulations and order's relating to lease of the seal islands to the Alaska Commercial Company and the regulations governing the Government agents in charge of the seal fishernes, published by the Gorernment. Does that contain what yon refer to ?-A. This defines the Territory of Alaska more particularly. I understand the Treasury Department claims the right to prohibit Americau vessels auywhere in the Pacific or elsewhere from killing female seals or seals less than one year old, but the Govern. went can not enforce this regulation against foreigners in neutral waters.

Mr. Duns. The distinction does not apply to Bering Sea?-A. To, sir. The Gorernment simply claims the right over American ressels which they can not elaim over British ressels.

Mr. Dingley. Has there been any attempt or necessity for enforcing these laws as to vessels otherwise than in Bering Sea, or in the waters where the United States, under the cession from the Russian Gorernment, claim exclusive jurisdiction over?

The Witness. I would say that a seizure made in 1887 was thrown out of court by Judge Dawson, as he claimed the United States had no jurisdietion over American vessels outside of American waters.

Mr. Dunn. In the Pacifie?-A. Yes, sir.

Mr. Dingley. Does not that decision run counter to the claims this Government has put forth, that Bering Sea is a closed sea?

The Witness. This decision did not relate to exelusive jurisdiction over Bering Sea. It was simply a question as to the extent of jurisdiction that the United States might exercise over an American vessel outside of American waters.

Mr. Dingley. The whole controversy lies in the question as to whether Bering Sea are closed waters.

Mr. MACDONALD. Or whether the ressels were in there or not.

Mr. DunN. My information is that there have been some steps taken by the administration, or the executire department of the Goverument, 
looking to securing the consent of some of the maritime powers to the extension of our protection to the herds of seals in the waters in the Pacitic Ocean, as well as in those of Bering Sea.

Mr. MACDONALD. In that pamphlet that I have mentioned is a letter sigued by H. F. Freveh, Acting Secretary of the Treasury, dated March 12,1851 , construing the law relating to the lilling of these fur-bearing animals upon the islands of St. George and St. Panl. State whether this letter is the instructions or constructions of the Treasury Department that you refer to as a basis of reference.

Tine Wriness. They republish that letter each year, with a proclamation stating the claims of the United States, abd it has never been changed.

Q. This letter contains the con struction of the Department upon the law ?-A. Yes, sir.

Treasury Department, Office of the Secretary, "Washington, D. C., March 12, $18 \varepsilon 1$.

Sin: Your letter of the 19 th ultimo, requesting certain information in regard to the meaning placed by this Department upon the law regulating the killing of furhearing animals in the Territory of Alaska was duly received. The law prohibits the killing of any fur-bearing animals, except as of herwise therein provided, within the linits of Alaska Territory or in the waters thereof, and also prohibits the killing of any fur semls on the islands of St. Panl and St. George, or in the waters adjacent thereto, excopt during certain months.

You inquire in regard to the interpretation of the terms "waters thereot" and "waters adjacent thereto," as used in the law, and how far the jurisliction of the United States is to be understood as extending.

Presuming your inquiry to relate uore especially to the waters of western Alaska, yon are informed that the treaty with Russia, of IIarch 30,1867 , by which the Territory of Alaska was ceded to the United States, defines the houndary of the territory so ceded. This treaty is found on pages ó 1 to 673 of the volume of treaties of the Revised Statutes. It will he seen therefrom that the limit of the cession extends from a line starting from the Arctic Ocean and ruming through Bering Strait to the north of St. Lawrence Islands. The line runs thence in a southwesteriy direction, so as to pass midway between the island of Attoo and Copper Island of the Kromanboski complet, or gromp, in the North Pacific Ocean, to meridian of 193 degrees of west longitude. All the waters within that boundary, to the western end of the Aleutian Archipelago and chain of islands, are considered as comprised within the waters of Alaska 'Territory.

All the penalties preserilied by law against the killing of fur-hearing animals womld therefore attach against any violation of law within the limits before de. seriberl.

Very respectfully,

Mr. D. $\Lambda$. ANCONA,

H. F. Frencir, deting Secretary.

No. 717 O'Farrell. Strcet, San Francisco, Cal.

Commtted on Merchant Marine and Fismeries, Washington, D. C., January $8,1889$.

\section{TESTIMONY OF LIEUT. HENRY E. NICHOLS.}

\section{By the CHAIRMAN :}

Q. I'lease state your full name, four place of resiclence, and your business?-A. IIeny W. Nichols, commanding a naval vessel, at present on duty in Sau Francisco.

Q. State whetherin the past you have in any mauner been cugaged ju eruising or had any comection with any of the (xovermment vessels o! revenue cutters cruising about St, I'aul or St. George Islauds ?-A. 
No, sir; I have nad no connection with such ressels, but I have been there the past summer.

Q. State your duties.-A. I was collecting information for compiling the "Coast Pilot" and Alaska coast survey.

Q. How long were you there?-A. From the 1st to the latter part of August.

Q. How much of that time were you on the islands?-A. More than half of it, I guess. I was on the islauds two weeks or more altogether. Q. How much time were you on the mainland?-A. I was on the islaud of St. Michaels and over the Bering Sea wherever I could get information.

Q. State what, if anything, you have learned with reference to depredations by persons unlawfuliy engaged in the killing of seals?-A. I vever saw anything myself. My duties did not take me where I could see that.

Q. Have you any information of the character elicited from the last witurs and others as to what has occurred on those islands?-A. No, sir ; except from general conversation.

Q. How long were you on St. George?-A. I was on St. George but a few hours, but $I$ was around the island for sereral days.

Q. Were you on the island of St. Paul?-A. Yes, sir; several times, and spent ten days there.

Q. Did you notice anything with reference to the treatment of the natives by the employés of the Alaska Commercial Company that you would regard as a subject of adverse criticism ?-A. No, sir.

Q. Did eversthing appear to be conducted in a satisfactory manner, so lar as you could judge?-A. Yes, sir.

Q. Were the natives contented ?-A. Absolutely so.

Q. You understand what the law is in reference to the company and its contract?-A. Yes, sir; I have read it.

Q. State whether, in your opinion, the company has, so far as jou can judge, been performing its part of the contract in every respect.-A. Yes, sir; so far as I have heard or seew, it has performed it faithfully.

By Mr. JEFFRIES:

Q. You are are an officer of the Navy ?-A. Yes, sir.

Q. IIave you ever been to other parts of Alaska?-A. Yes, sir.

Q. Have you been up as far as St. Nichaels?-A. Yes, sir.

Q. You have been pretty well over the Territory, so far as you could go with a ship?-A. Yes, sir.

Q. You have had some opportunities for seeing the native inhabitants of all parts of Alaska?-A. Yes, sir.

Q. What do you say as to how the natives of St. George and St. Paul compare with the natives of other portions of Alaska? I mean socially, morally, physically, and every other way? - A. Their condition is very much better than the natives of other portions of Alaska ; have more money, etc.

Q. Do they show the benefits of civilization more?-A. I think they do.

Q. Are they well elothed and housed on both islands?-A. I think they are.

Q. How are they dressed?-A. They wear European clothing.

Q. They are comfortable?-A. A bsolutely so.

Q. Both men and women?-A. Yes, sir.

Q. Hare they comfortable houses?-A. I should think they were comtortable. 
By Mr. MaCdonald :

Q. I understand you to say that you spent considerable time in other parts of Alaska, on other islands, and on the mainland. Have you been up to Sitka?-A. Yes, sir; I visited all the inhabited islands and the Aleutian group.

Q. Have you paid any particular attention, so as to be able to form any judgment of the general condition of the natives on the other islinds of Alaska as well as on the mainland?-A. Yes, sir.

Q. How does the condition of the natives on the seal islands compare with those in other parts of Alaska? - A. It is much better than in other parts.

Q. Did I understand you to say they are better contented ?-A. Yes, sir; so far as I know. I only staid there during the working season

Q. You do not speak their language?-A. No, sir.

Q. Were you there long enough to become acquainted with the agents and employés of the Alaska Commereal Company on those islands as well as the Government agents?-A. Yes, sir.

Q. State what is your opinion as to the class of men the company has there. In the first place, are their habits good and are they temperate?A. Yes, sir.

Q. Did you see any evidence of intemperance among them ?--A. No, sir. I juige from the fact that the men have been there a good many years they are held in esteem by the company.

Q. Have you seen these articles in the newspapers with reference to the loose morals of the natives?-A. I have seen some of the statements.

Q. State whether you have seen anything to justify any such criticisms as that?-A. No, sir; I have seen nothing to justify such critieism.

\section{By Mr. Dunn:}

Q. Do you know anything about the raping of native women by white men ?-A. There was a good deal of talk there by one or two people. Mr. Garitt, I was told, said something of that kind.

Q. Did you observe from other sources anything to support those rumors?-A. Every one I talked to said there was no truth in them.

Q. Did you bear any complaints from the natives of the islands against the Government agents or the agents of the company?-A. No, sir; I had no opportunities of kuowing.

Q. Did you make the personal acquaintance of $\mathrm{Mr}$. Webster, an agent of the Alaska Commercial Company, there?-A. Yes, sir.

Q. What kind of a man did you conclude he was?-A. I thought he was a very nice gentleman.

Q. Was he an habitual drunkard or a man of bad and dissolute habits?-A. No, sir.

Q. What was his general reputation there?-A. Very good. They were all very fond of him.

Q. Ilis general reputation there is fair?-A. I think so.

By Mr. MaCdonald :

Q. What was Mr. Gavitt's reputation?-A. There was more or less hard feeling there.

Q. I mean his official administration ; as to his manner of performing his oficial duties? $-\Lambda$. I was hardly long enough on St. George to say is to that. They were all in hot water,

$9984 \sim-17$ 


\section{TESTIMONY OF CAPT. CHARLES A. ABBEY.}

\section{Capt. Charles A. ABBEy, sworn and examined.}

By the Chamrin:

Q. Do jou oceupy any official position under the Govermment?-A. Yes, sir.

Q. Please state what it is.-A. Captain of the reveute steamer Gallatin, at Boston.

Q. In the discharge of your duties as the officer in command of a revenue-cutter, have you at any time been in the waters of Alaska?A. I have.

Q. State what time you were there aud what your obserrations were.- $-\Lambda$. From June, 1S86, until the latter part of August, 1S86, I was in charge of the revenue-steamer Cortcin for the protection of seal life and the fur-seal industry and the Goverument interests in Alaska generally.

Q. In that connection gire the committee an account of your observations in the exercise of your duties.-A. Well, I was ordered from New York to the west coast to take comma d of the Corvin, without any knowledge of where I was to go. Arriving at San Franciseo, 1 proceeded to Astoria, Oregon, and there took ehirgo of her, received my instructions, and learued her destimation. It was to the seal islands for the protection of the fur seal on those islands. I had a chance to sturly my instructions on the way across. I linew rery little about what was to be done, except what i had read in the reports of the officers who preceded me, and I had never looked up the law previously. In looking the matter up) I found I was clothed with suflicient porrer to do aluost anything that I might be called upon to do. I fonnd that the law protected all fur-beariug animals in Alaska and the waters thereof. I stopped at Oonalaska for a week and then proceeded towari the seal islauds. I fell in with two vessels, I think the first day ont from Oonalaska, in the Bering Sea. Both of them were sealing, but the first one had no boats down when I first saw her. She had a permit for her arms and ammunition. She had a number of seal skms in her hold, but I could not claim that she had killed those seals in the Bering Sea; consequently I was obliged to let her go.

During this time I sighted another vessel, with her boats in the water; they were sealing, but hefore I reached her they took the boat in. They also had seal skins. I iuquired if she had a permit for arms and ammunition, and as she had not I disarned her, to which the master ob. jected rery stremuonsly. That mate no difference, however. He then suggested that he rould go over on the Rnssian side and pursue his avoration there if I would let him have his arms; but I would not do that. The next day I found a ressel within perhaps 20 miles of the southeastern end of St. George Island. He confessed he was sealing, but said he harl takeu no seai in tho Bering Sea. He had no permit for his arms and ammmnition, so I disarmed him, which was all I conld ro. I think this fellow afterwards snececled in getting guus from here and there from other vessels and managed to make some sort of a cargo. I then stopped at the islands aud eruisenl ahout there for some days and heard of no vessels. I did hear that some of the Aleuts on the rookeries lad reported that some one ham landed there, probahly from the vessel I had spoken; then I hearl that the sealers were oft sonthwest of St. George and I went there. I ricl not find any and so cruised down 
to westward among Aleutian chain and back towards Oonalaska, and as I approached Oonalaska I fell in with tho sehooner San Diego. Je had, I think, several hundred seal skius on board. I have forgotten tho exact number. He confessed he was sealing, but the seals he had thero laad been taken in the Pacific. But the officer sent on board being rather sharp, saw fourteen skins with fiesh blood inpon them ; so I seized her and took her in. I turned her over to the deputy marshal of Oonalaska and proceeded cruising. The captain of that vessel mado a great complaint that the Government was very strict in the Bering Sea as fir as American vessels were concerned, bit did not attempt to touch Euglish vessels.

Q. Did you have any orlers to make any distinction between English and Ämericau ressels?-A. Noue whatever.

Q. You harl no orders to treat them differently?-A. No, sir; I had simply the law, with orders to seize auy one violating those laws. Some time after that, 60 miles sontheast of St. Greorge, we ran right upon a nest of sealer's.

Mr. MACDONALD. What did you say you did with those men whom you captured? - $\Delta$. I turned them over to the marshal at Oonalaska and proceeded towards the islands again. Hearing of nothing in that vicinity I struck in towards the main-land, towarls the Oonimak Pass 60 miles. After leaving St. George I met a boat which was plainly sealing. She hat two sitters and a rower. I ranged up and asked what they were doing. Meantime I sighted a vessel some miles away; so I took up the boat aud went after tho vessel. An hour or so after that I saw another vessel. I captured those two vessels. One was called the Thornton and the other the Carolina.

The CHamaran. These were British vessels?-A. Yes, sir; aud they were taken in the act. Of course they liwew what I would do. I took them and started on. I) uring the night that tollowed I saw auother vessel. I think it was the Chullenge. We passed her, aud as it was blowing very fresh and the water was rough she quickly passerl out of sight. Encumbered as I was I could not talie her. The officer on watch sighted her and called my attention to her, but by that time we had got b5. In the early morning we fell in with another schooner, the Omward. I sent an officer on board; lie said he was sealing, but not taking any seals in the Bering Seal but unfortunately there were fourteen or fifteen dead ones on the forward deck that they had not had time to skin. So I took her into campalso. Thus I had three. Then the day was pretty fine and I was getting towards Oonalaska. I had taken all the arms and ammunition out of them and put an officer and a couple of men ou each eapture. I think I sighted four more. I ran right through a covey, but they all spread their sails and passed out of sight and I saw no more of them. I conld not abandon the others and stop for these. I went to Oonalaska with these prizes and disposed of them; and that wound up my eruise, as I had abont seventy prisoners and only forty men to take care of them. I then proceeded towards Sitka and brought my cases up before the court there, convicted the prisoners, condemned tho ressels, and came home.

Q. Did you form any estimate as to the number of seals destroyed by these depredators, by the unlawful hunters during that season ? $-\Lambda$. Well, I made an estimate of my own, a rough one, perhans, of what damage they had done. I should judge that there were thirteen or fourteen vessels and I heard of five or six ofhers who reported at Victoria afterwards what they had done or takeu in the Bering Sea. The Department, I know, sent me a list of thirty who were prepared to go 11 , and 
perhaps more were outside of the Bering Sea. These resseis cleared from Victoria, San Francisco, aud various places that those people clear from. I do not know, of course, how much, but there were about 30,000 skins which went into the market that season presumably all taken unlawfully up there.

Q. Did yon form any opinion as the proportion of seals killed and wounded in the open sea by hunters ?-A. Yes, sir.

Q. What was your opinion about that?-A. In the earlier days they shot them with bullets and with rifles, and when they are shot: with a bullet the seal sinks and probably out of half a dozen they would not get more than one. If the seals are not killed but simply wounded that leaves a chance to get them into a boat. They were very expert hunters who hired for that purpose, but I judge that they killed about three for every one they got. I got that from the conversation with the hunters themselves.

Q. What kind of seals de they take-any and all?-A. Any one that shows his head above the water.

Q. Were these seals found in their feeding ground cruising for food? Did you learn that? - $\Lambda$. I do not know where the fur-seal feeding ground is ; 1 do not think it is known.

Q. From your observation there was it your opinion that it was important to the preservation of seal life to make the Government protection rigid? -A. It is imperative, I think.

Q. You think the herd of seals visiting these rookeries might be destroyed in the open sea as well as on the island?-A. Without doubt, and at no very distant day.

Q. It would be useless, then, to protect the rookeries and herd without protecting the Bering Sea and elsewhere?-A. Quite so, sir, in my opinion.

Q. Do son think that protection ean be made so that depredations might be practically prevented ?-A. Yes, sir.

Q. By what means?-A. By the Goverument maintaining its jurisdiction orer that sea aud prohibiting seal killing in the water.

Q. Is it necessary to keep more than one ressel to patrol the sea? ?A. It would be better to have two or even more, as seals are also killed on the outside, in the Pacific Ocean, near the land or in the passes.

If we prevent them from hunting on the inside they will go outsicle to the sea-otter grounds and kill seal there, and they will kill sea-otter and frighten them away. The whole coast around there needs, in my opinion, better protection than it is practicable to give now. We proteeted it with the Corrin as well as we could, but more ships are needed in those waters, as their extent is too great for one or two to effectively protect them.

Q. Have these islands of St. Paul and St. George aud the Alentian Islauds any other importance except that derived from taking fur-bearing animals in accordance with the lease of the Government?-A. I do not think there is any other of importance. I do not think there is anything that the natives could live upon except fish ; they can not grow anything there.

Q. Fishing and sealing?-A. Are the ouly indnstries except, possibly, mining. .

Q. Did you land upon the islands of St. George and St. Paul?-A. Yes; frequently.

Q. Did you find the laws of the United States faithfully executed and the contract of the company fath fully lived up to while there?-A. Yes, sir; very faithfully. 
Q. Did you observe or hear anything that led you to believe that the Government was being defrauded in any way by the Alaska Commercial Company, its agents, or other persons?-A. No, sir.

Q. Except these lawless hunters you have spoken of ?-A. That is all, sir.

Q. What is the condition of the natives on the islands of St. George and St. Paul ?-A. I should say excellent, as compared to the natives where the company have no statious aud do not exercise any anthority or protection.

Q. Has the condition of the natives under that administration become improved ? - A. They used to live in barrabaras or mud huts, and were clothed with skins and ate seal meat aud blubber. Now they are comfortably elothed aud live in good houses as the artisans do here.

Q. What was rour observation of the moral condition among the natives as compared with the former?-A. Their condition now will compare favorably with the lower elasses of any other nation. There is a strong inclination on the part of the Aleut to drink. He wants alcohol as the Indian does and he will get it any way, shape, or manner and stupefy himself with it.

Q. The laws of the Government prohibit the sale or giving of intoxicants. Did you find any violation of that law?-A. No, sir; I saw no violation of it at all while I was there. They make quass, and they do sometimes distili a little liquor; I do not know what it is. For instance, they might get hold of a couple of kerosene caus and make a little distillery out of those. They will get drunk if they can.

Q. You are satisfied the compauy does not sell or give any to them?A. I feel thoroughly satisfied of that, sir. It is against their interest to do anything of the kind.

Q. Did you observe whether or not the natives seem to be fairly well contented with the arlministration of the affairs by the Government and by the company's agents there?-A. They seemed to be highly so.

Q. Contented and satisfied?-A. Oh, yes. I conversed with everyone that talked any English there and I heard no complaints.

Q. Did you get acquainted with the agents of the company and the Government at that time there?-A. Yes, sir.

Q. What was the general character and reputation of the employés and agents of the Alaska company there-good or bad?-A. Excellent, in my opinion.

Q. Were the agents dissatisfied with their treatment by the company's agents?-A. I heard of no dissatisfaction at all.

Q. Did you get acquainterl with Mr. Webster; was Mr. Webster an employé of the company there at that time?-A. He was there, but I never saw him.

Q. Did you hear much about his character and repution for sobriety and morality?-A. I never heard auything particular about him any more than that everybody knew Mr. Webster and that they all liked him. I nerer had the pleasure of meeting him as it happened. I certainly never heard anything against his character in any way.

Q. You have seen recent publications in the New York papers as to the moral condition of the people of those islands, and the rery low state of depravity on the part of the natives. Did you see or observe anything that would justify accusations of this kind?-A. No, sir; I did not, certainly not.

Q. Did you see or hear of anything that would seem to indicate that the company's store-house and Government house was a sort of house 
of iil-fame and debauchery for Aleut women and bad men?-A. I nerod heard anything of that kind, and I never saw anything of that kind.

Q. Did you form any conclusion as to the moral habits of the native women and the whites who are living there amongst tnem in that re. spect?-A. No, sir; but I presume it is much the same as in any other semi-civilized nation where the women are probably approachable at proper times and in proper ways. You hear a great deal of talk but I saw nothing that led me to think that they were-well, their morals are equal to those of the Chinese aud Japanese and that sort of people.

Q. Dirl you hear of any rapes being committed?-A. No, sir.

Uross-examination by Mr. JEFFRIEs:

Q. When you visited those islands you were in command of the Corwin?-A. Yes, sir.

Q. You were there in your official capacity?-A. Yes, sir.

Q. You carried the United States flag aud represented the Governernment of the nation. Did the natives on these islands have an opportunity to communicate with you freely and lay before you freely any grievances they had if they liat any?-A. Yes, sir.

Q. Was any complaint of any sort made to you by any native as to the treatment by the company or Govermment agents on the island ?A. No, sir; I do not recolleet of a single instance. If there was, it was very trifliug and it has escaped my memory, but I do not think there was anything.

Q. Are you acquainted with a native by the name of Peter Rezauzotf, on the island of St. George?- $\Lambda$. I do not know, but I may be.

Q. Do you happen to know whether the number of seals killed during the time of your cruise, say a larger or large proportion of them, were females?- $\Lambda$. I do not know about that. I know there were a great many, but I do not know what proportion.

Q. Do you know about the habit of the female seals leaving the roolieries aud going south into the water for food and then returning to the rookeries?-A. I know they leave their rookeries and go away, but what for I do not know.

Q. What do you say as to having another vessel stationed at Oonalaska, a sort of man of-war and prison-ship, on which to stow away the er'ivs of the eustured ressels?-A. That is highly necessary, and somethiug of the sort should be had if these seizures should continue to bo made.

Q. How far is it from the seal islands to Sitla, where the United States officers aurl comrt are?-A. Fifteen humdred miles.

Q. Therefore, if you capture one or two ressels and take their craws to Sitka, that leaves the whole waters of the Bering Sea open to depredatious while you are going to Sitka aud back?-A. Certainly.

Mr. MACDONALD. How long would it take you to go to Sitka and re. tuin?

The Witness. It would take the Comoin about three weeks.

\section{By Mr. JEFFRIES:}

Q. So the depredator's mould have that time to operate in between your leaving and returning? $-\Lambda$. It mould take at least three weeks to go and come.

Q. Then, necessarily, there should be one to remain and cruise around while the other was moving these persons?-A. I think that at Oonalaska there should be a strong force kept to guard against danger, as there are only half a dozen white perple there, and durmg this time most of the dlents are alliy. There is no reason why the catch at the 
seal islands ean not be stolen any day, if anyborly is disposed to. I believe I conld take a vessel with twenty good men and go there and steal the whole catch and go away with it. There is more than a million dollars' worth of seal skins at the mercy of any marauder, and has been for years.

\section{By Mr. MaCdonald :}

Q. As a result of your observations while there, in regard to the management of affair's by the Government agents and company agents of those islands, what would you suggest in the nature of an improvement which the Goverumeut should adopt? Now I have heard it stated by witnesses here that these Government agents are stationed at St. George and St. Paul, and that they have very little an thority any more than a mere supervision, which hardly appears satisfactory.-A. Certainly the Government agent, in case of a contentiou with the employés, could overrule them. There has never arisen, I guess, any question, as the interests of the company are identical with those of the Government.

Q. Suppose one of these natives should be charged with having committed an offense, by whom conld he be tried ? - A. There is a United States commissioner at Oonalaska.

Q. There is no officer on St. Paul and St. George?-A. No, sir; except Mr. Tingle, with such power as he is clothed with.

Q. He has not juclicial power; it is limited.-A. I to not know about that. I do not remember.

Mr. MACDONALD. Why I wanted to ask you the question was that this committee may be able to report on that as well as other questions in regard to any thing jou might suggest.

Ir. JeFFries. While you are on that point, ask him whether there is not a good deal of tribal goverument by chiefs of their own selection with which the company has nothing to do.

The Witness. There is; though how far it extends, and what can be done under it, I do not, know. I do not recall any case that came up. They are an inoffensive lot, and do not fight or quarrel except when they get drunk.

\section{By Mr. JEFFRIES:}

Q. That is a Gorernment reservation and it is placed under the Treasury Department?-A. Yes; the company furnishes them with medical assistance, and does that as well as can be expected. They have their surgeons and doctors and send them about in the various steamers. The condition of the Aleuts is such, with serofula and syphilitic tronbles, that in my opinion there will be no Aleuts in a few years if they are not looked after medically. There should be some hospital of some sort where the doctors could risit and examine them. I met a case, for instance, at a little place called Neckolovski, in 1856. The company has no station there, and there is nothing much there but the harbor and a few houses and miserable Alents. I went through there with the doctor and found a few rotten barrabaras and a little church, and I found my way to the chief's house. He had one of his arms bound down to his side. He was a joung man about thirty-five or forty years old, and lived comfortably for an Aleut, but he could talk little or no English.

I had an interpreter but I could not get much intelligence between then. That was the worst place I saw. There was no company supervision or government supervision. Ile had his arm bound up bocause the scirofulat haul eaten it finll of holes. The loctor looked at 
it. He had a bottle of wash there that he seemed to pin his faith to, some sort of carbolic wash. The doctor said that he would probably' live about six months and that the arm ought to come off. It is necessary for the preservation of the company that the people should have a rigid melical supervision and some preparation in that way should be made. The first thing to be done is to get them in good physical condition, as they are full of scrofula.

Q. That sort of information is as important to the committee as any we could get. Does any such condition exist among the natives of these islands?-A. The seal islands? No; their eondition is greatly improved. 'They have doctors there and they furnish them with medical assistance and do as well as could be expected, but there is a great deal to do.

Q. Does the company provide sufficient medical assistance?-A. I think they do, sir. I do not know definitely whether they do or not, and I have no complaint to make of what the company does about it. 'They have a doctor at each place and they do what they ean. I think there are two on St. Paul, and they send them abont in the steamers, and if the company exercised a better medieal supervision it. would re. quire more physicians.

Mr. MACDONAI.D. I would call attention to the fact that there is no provision in the contract for furnishing physicians and medicine. The contract is only for St. Panl and st. George, and, if I understand you correctly, the company does all they are required, and probably more than they contracted for.

The Cmamman. The company is not required to furnish medical attendance. 'That is not a part of the contract. The law does not require that.

The WITNEss. I believe you are right about that.

Mr. MACDONALD. You give it as your opinion that the Government should sumply a fixed medical attendance?

The Witness. My opinion is that they should have better medical attendance, whoever furnishes it.

\section{TESTIMONY OF JACOB H. MOULTON.}

\section{JACOB H. MouLToN, recalled and examined.}

\section{By the Chatrman:}

Q. Will you please state if at any time you have oceupied an official position under the Govermment in connection with the arministration of the lease of the seal islands of Alaska, and at what time.-A. I was special agent of the Treasury Department at the seal islands from 1877 until 1885 , eight years.

Q. State what your duties were there-A. My duties were to see that the law in regard to the killing of seals was complied with and to take general charge of the native population of the island.

Q. Did you find the laws faithfully executed and the eontrat faithfully complied with on the part of the Alaska Commercial Company ?A. Yes, sir; always.

Q. What number of seal did they take annmally?- $\Lambda$. The first year I was there they took 75,000. 'That was in 1577. P'erhaps more-a few over-but it was aboui 75,000. And another year, I do not remem. ber whether it was the next year or not, they took 80,000 . With that exception of two years they took 100,000 annually for eight years. 
Q. Did it in any case exceed 100,000 a year ?-A. No ; occasionally there would be a mistake of a dozen skins, but that would be the fault of the Goverument agent who counted them.

Q. What kind of seal were killed and how were they killed? - $\mathrm{A}$. From two to six years old, and they are killed with clubs.

Q. Are they males or females ?-A. All males.

Q. Where were they taken from?-A. They were taken from the different rookeries on the two islands, 15,000 on St. George, and the remainder on St. Paul.

Q. Were the breeding rookeries disturbed whilo these were being killed?-A. The killable seals hauled out by themselves. They do not han on the rookeries because they are not allowed to by the large male? seals, so they have to haul in some other place. Never any cows haul out with them. Sometimes there might be a few large seals who might be driven from the breeding rookeries by the stronger bulls.

Q. Are these driven up to the killing gromnd?- $\Lambda$. They are driven to the killing ground. The salting house is near to the shipping point. These seals are driven by the natives from the hauling grombls 10 the killing grounds without disturbing the breeding rookeries. The driving is all done by natives, as a white man ean not get niall a rookery without flisturbing the seal, as they are so sensitive to the seent. The natives can go there, as their clothes and everything is saturated with the olor of the seal so they can get close where a white man can not go.

Q. Is that driving and killing observed and inspected by the Government agent?-A. Yes, sir; the superintendent of the company is on St. Paul. That is his place.

Q. Is there any considerable destruction of seal life in the process of taking, driving, and killing in excess of the number taken for skins?A. Yes, sir; there are a fiew.

Q. What are they? Is it necessarily so and unavoidable?-A. Yes, sir; it is unaroidable.

Q. Is it considerable?-A. No, sir; it is not. It is very little compared with the number of seal killed.

Q. I think one superintendent testified here that the destruction of seal in excess of the number intentionally killed for their skins was about 52 in one season.-A. Well, it is more than that.

(2. It would exceed that?-A. Yes, sir; perhaps 150 , but it depends a great deal on the weather. In driving the seal there may he a large drive and the sun may come out, and they can not stand the heat although the thermometer may not go above 60, so they will take to the water and it is impossible to hold them from the water. All the natives on the island could not prevent them from going into the water if the sun came out. That is where the great loss is in the killing.

Q. You think the unintentional destruction would be $150 \mathrm{in}$ a year ?A. Yes, I think so.

Q. That is a very small percentage. Is great care taken to avoid unneressary killing of them?-A. Yes, sir; the agents of the eompany are there and have the killing in charge. The killing is done by the natires, and the agents have charge necessarily.

Q. How do they count the skins?-A. They are hauled to the salthouse. This killing ground is somewhat a little distant from the salthouse. There they are connted and tally is kept by the Govermment officer. The leeps the tally of the count. That is the first time they are counted. They are then salted, and after being salted thes are taken and bumbled, two skins in a lumble. After they have gone 
through the process of salting, they are taken out of the salt-honse, an the shipping is not done wntil they are killed and ready for shipping. Then they are loaded on barges for shipment and brought ont to the ship, which runs in about a mile, and bronght there by natives ami ('m. pioyés of the company. A tally of them is then kept.

(Q. Does the Govermment officer observe that count also?-A. He oversees the count and keeps the tally.

Q. Where are they shipped to?-A. San Francisco.

(2. Are they again comnted there?-A. They are comnted over by tho custom-house officer-some inspector of eustoms.

Q. And the Govermment tax upon them is there paid?-A. As I moderstand it, that is the final count.

Q. What diserepancies did you observe in your ardministration between the island and the San Francisco count? $-\Lambda$. Very little. Some seasons there would be very little, not more than one or two bundles; and sometimes it would be as ligh as twenty:

Q. Nothing eonsiderable?-A. No, sir.

(2. How long was your administration?-A. Eight years.

Q. What was the condition of the natives on the island while you were there?-A. I do not know exactly how to get at that.

(2. How did they live and dress? $-\Lambda$. They had comfortalle woolen houses, two or three rooms. They were claphourded, warm houses, marle as comfortable and warm as possible. They dressed the same as our laboring people do and some of them much better.

(2. Do they wear the same clothes as civilized communities?-A. Yes, sir.

Q. Have plenty of fuel ?-A. Yes, sir.

Q. By whom was that furnished?-A. The Alaska Commercial Company furnishes 60 tons of coal annually.

Q. Is that sufficient to keep them comfortable?-A. That is, in atdition to the drift-wood; but they are allowed to buy coal, provided the company has a supply on liand.

Q. Did the company always furnish the amount required by law ?-$\Lambda$. Yes, sir; they furnished salt and salt salmon. They had more than required, and sometimes several barrels wonld be left over.

By Mr. MACDONALD:

Q. What is their food \%-A. Seal meat.

Q. How about breadstuffis and vegetables? $-\Lambda$. They have very fow vegetables, and the company serve them flom and crackers. They use more crackers than flour. Perhajs there are some few families that make bread, but the majority can not bake bread and prefer to buy erackers.

The Ciramman. The company is required by law, I believe, to furnish a stated amount of coal and a certain amount of salt fish and lieep a school a certain length of time. Were these conditions always complied with? -A. Yes, sir.

(Q. Always? -A. Yes, sir; school was kept eight months during the year.

Q. Did they obtain good teachers ?-A. Yes, sir; good teachers.

Q. What was the attendance at school?-A. The first season I was there there was a very small attendance. There were no instructions there when I went there in regard to compelling the people to send their children to school. They sent them or not as they liked, and some seasons there would not be an avorage of more than ten ont of forty. The eourse pursued hy us was to compel the parents of the children to 
send them to school. Then, the arerage aftendance was much greater, because it was a small village and we could control them.

Q. Did the childen seem to learn reasonahly ?-A. Well, for that class of people.

Q. Were they taught in the English language?-A. They are taught in English altogether by the company, but at the request of the priests they were allowed to teach liussian; that is, outsicle of the eight months' school.

Q. The eight months' sehooling by the company's teachers was in the English language?-A. Ies, sir; and the other time they were taught by the priests or some one selected by the priests.

Q. The company charged no rent for the houses?-A. No, sir.

(. Did the eompany furnish the houses?-A. They belong to the eom. pany, with two or three exceptions. There are two or three houses belonging to men there.

(2. Did the natives pay anything for the seal meat they ate?-A. No, sir; they helped themselves.

Q. Does the company keep a store there?-A. Yes, sir.

Q. What sort of rates do they eharge natives for what they sell to them? - A. The intention is to eharese 25 pere cent. rifference on the wholesale price in san Francisco, hut provisions and articles of that kind are sold for less than that. Flom has heen sold there for less than it would cost in San Franeisco when flon was high there.

Q. You satisfied youself that the company did not extort from the natives?-A. Yes, sir.

Q. How were the natives paid for the work they do for the company? A. They are paid 40 cents for every skin they take from a seal.

Q. Are they pain in money or orvlers on the store?-A. In money.

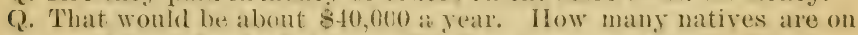
those two islands?--A. I think on St. Laul there are about $2: 35$ Indians when I laft there and perhaps 112 on St. George. That is less than when I went there, as the population has been reduced since I went there by sickness, etc.

Q. Who gets paid for the killing and skinning of seals?-A. All tho population on the islands derive benefit from it in this way: They lieep a recorch of all the killing that is done, the company agent and superintendent, and at the end of the sealing season a division is mate. 'They keep a record of the amomit of work every man does.

Q. Who keeps that record? - A. That record is kept by the company agent and is overlooked and seen every day by the Goverument agents iu regard to what is done.

Q. Do the natives have any say in that?-A. No, sir; none at all. That system was changed when I was there and was done with the sanction of the Gorermment agents there. That is the only system by which they condel be dealt with justly. Before that the division was always made by the chiefs and priests and some of the leading men of the chureh, and they are very mujust towards each other; the most unjust people towards each othex. A few would get all the money if they could and the others would not have any.

Q. The fovernment agents and company agents try, then, to arrange a just system of compensation?-A. They changed the system of making division so the distribution combl be made by the (iovernment agents, and this record is kept by the eompany agent. They keep) a record of the work each man does.

(?. The skinmers worle was highere?-A. The division is made on merit; just lyy the work elone. The man that alid the most work and 
the best work got the most money; but there was provision made for boys. Of' course boys could earn but little. The division gave them really more than they earued.

Q. Were widows and orphans provided for?-A. Yes, sir; the company provides for the widows and orphans.

Q. Ont of this fund?-A. No, sir; they furnish them clothing and provisions out of the store.

Q. The company supports them without sharing this fund anong them?-A. Yes; while I was thère. I do not hnow about it since.

Q. Was there any suffering from starvation or freezing among the natices from want of provisions? - A. I never heard of such a thing.

Q. What is the moral condition among the natives?-A. Of course from my own observation I conld not say anything in regard to that any more than any community, but among themselves they talked outside and talked to me and the company's agents, and it was stated in their conversation that there was adultery going on among them and very vicious habits. I know that from conversatious, but as far as I know personally, I know nothing of it. They appeared as honest as any people can of that class.

Q. What is the effect of their association with the agents of the company and the agents of the Government in that respect? Does it tend to degrade and make them more demoralized, or do you think it is beneficial ?-A. I think it is in a beneficial direction. It can not be otherwise, as far as I know.

Q. You have seen, $\mathrm{I}$ presume, the recent publications in the New York papers of some wholesale debauchery of native womeu by whites among the Government agents and the Alaska company's agents there. What have you to say as to the islands of St. George and St. Panl in that connection?--A. I nerer knew anything of the kind on the island. I know nothing of the kind conld occur on the island withont $\mathrm{my}$ knowledge. If anything of that kind occurred between the natives and any one of the company the Government officers would know at once, because they would report to him.

Q. Has the company honse and salt-house been made a sort of rendezvous of lewd-women and bad ıen?-A. No, sir.

Q. Or the Goverument house?-A. No, sir.

Mr. MacdonaLd. When were you there last?

The Witness. I left St. Paul Island in 18S4, and arrived in San Francisco in August.

Q. Then you speak of the condition of things existing while you were there?-A. Yes, sir.

The CHAIRMAN. Have they churches there?

The Witness. Yes, sir; on each island; the Greek Catholic Church.

Q. Have they good church buildings?-A. They have a very fine building on St. Paul.

Q. Who built that?-A. The money was furnished by the natives, but the company sent up mechanics to do the work for them.

Q. Are priests stationed there all the time?-A. Now there is a prlest on St. George, but the first year I was there there was no priest there.

Mr. MACDONALD. The priest would hare to visit them?

The Witness. A priest from Kodiak was sent there. Now they have one residing there when I left.

Q. What was the native population of St. Paul and St. George when you left ?-A. I think abont 235 on St. Panl and perhaps 112 on st. George. 
Q. What proportion in either case would be adults, males, females, and children?-A. The majority were females, largely.

Q. On St. Paul and St. George?-d. Yes, sir; but I can not say now in regard to the adults.

Q. What is your estimate of the number of grown people?-A. The families were about the ordinary size, three or four children.

The CHamman. On the subject of the preservation of seal life, you are familiar with the laws and regulations of the Goverument and its policy. Do you think that seal life conld be better preserved or the revenues of the Govermment increased by auy other policy than that now pursued?

The WrTnEss. No, sir; the ouly system of conducting the business on those two islands is, I think, the present system.

Q. A. Government reservation and a lease?-A. Yes, sir.

Q. Protecting it and taking it under Govermment supervision?-A. I do not see any other way that seal life can be preserved.

Q. Was it your opinion, that the number of seal hauling on those islands increased or decreased during your observation?-A. I think during the first five years I was there there was an increase, and cluring the last three years there was no increase.

Q. To what do you attribute that fact?-A. To the marauding vessels, etc. There are a great many seal killed in the Pacific in the spring of the year. Perhaps that can not be prevented by the Government.

Q. You think it should be prevented if it can be?-A. Yes, sir. At that time there were from 10,000 to 20,000 killed every spring in the Pacific along the British Columbia coast while they were going up to the seal islands. By some law or natural other reason they follow the coasts II); the majority are females. It is said by those who buy the skins that the majority were females.

Q. Do you think it essential to the preservation of seal life to protect the seal in the waters of Alaska and the Pacific?-A. There is no doubt about it.

Q. The herd could be exterminated without taking them upon the islands?-A. They could be exterminated by a system of maraudng in the Bering Sea, but I think the number killed along the British Colum. bia coast did not affect the number we were killing on the islands at that time, because there was apparently an increase during these years. There had been for fire or six years up to that time. Since that time in Bering Sea the seal have been gradually decreasing.

Q. You think their decrease is attributable to unlawful hunting in Beriug Sea?-A. There is no doubt of that.

Q. As a result of your observation there, could jou suggest any better methou of preserring seal life in Bering Sea than that now arlopted?-A. Not unless they furnished more revenue vessels and men-of-war.

Q. So as to patrol the sea closely?-A. I think so. I do not think the seals scatter much through any great distance during the summer season, allhough very late in the summer the smaller seals arrive. The females, after giving birth to their young, scatter out in Bering Sea for food. We know they leave the islands to go into the water, be. cause they are coming and going. They suckle their young the same as most animals.

Q. Lawless hunters kill everything they finci, I believe, females or not?-A. Yes, sir.

Q. When a female is nursing her young and goes out for food and is killed of wommled, that results also in the death of her young?-A. Yes, 
sir. As her young does not go into the water, it does not do anything for some time, and can uot swim and has to be taught.

Q. The seals are born upon those islauds?-A. Yes, sir; they come there for that purpose. They come there expressly to breed, because if they dropped their young in the water the pup would drown.

Q. Do fon think the ralue of the seals justifies the poliey that the Government pursues for their preservation and protection?-A. Yes, sir; I do.

Q. And under a rigidly enforcerl system protecting seal life in the waters of these seas, do you think the herd conld be materially increased? - $A$. I think it would. I think there is no doubt but what it would.

Q. And the amount of rerenue to the Gorernment might be increased correspondingly?-A. Yes, sir; but as it is now they are decreasing, there is no doubt.

Q. You think that the decrease is at tributable altogether to the unlawful hunting? - A. Yes, sir.

Q. You think the numbers taken bs the Government under the con. tract could be continued if there is no unlawful depredation?-A. If there is no unlawiul depredation the same number could be killed every season.

Q. Is it your opinion that the poliey pursued by the Gorernment in making a reservation of this-of these islands and leasing the exclusive privilege of taking to a person or a company, has a deleterions effect upon the public interests of the other parts of Alaska?-A. No, sir; I do not see how it ean.

Q. Does it tend to prevent the settlement and occupation of the Territory?-A. I ean not see how it could tend that way.

Q. Does it tend to discourage trade in business of other people in Alaska?-A. I think not.

Q. Does it lead to oppressious and injustice by the company and its agents, have you any observation on that point?-A. No, sir; I never heard anything of the kind.

Q. You saw nothing to justify such an opinion?-A. No, sir.

Q. Is it jour opinion that the administration of that lease is deleterious or beneficial to the interests of the people there?-A. I think it is beneficial.

\section{Cross-examination by Mr. JEFFRIES :}

Q. What do you say, Mr. Moulton, as to the condition of the natives who have come in contact with the Alaska Commercial Company as compared with the other people of Alaska who have not come in contact with that company or with its agents?-A. I know the people very well in Oonalaska, as we always visiterl there going aud coming. That is the only point of Alaska I ever visited except one spring I went to Kodiak. The condition of the natives of St. Paul is much superior to the natires of Oonalaska, while the condition of the matives of Oonalaska is much superior to the natives of Korliak. That is as far as I observed. I know of nothing outside of those three points-the seal islands, Oonalaska, and Kodiak.

Q. Do you know whether the company has done anything in regard to ameliorating the condition of the people of Onalaska? - A. Yes, sir.

Q. What have they done? -A. They have built houses there.

Q. Have they furnished a doctor?-A. Yes; a doctor aud a schoolhouse.

Q. Is that included in the contract with the seal islauds?-A. No, sir. 
Mr. Felton. Has the company a tradiug store there?

The WITNESS. Yes, sir.

Mr. JefFries. It has beeu stated to the committee by an assistant Treasury agent by the name of Gavitt that he went to Alaskia without any instruetion from the Treasury Department, and, in fact, that he had never seen any. Here is a pamphlet- $[$ do not know where it comes from-

Mr. MACDONALD. I think I brought that there.

Mr. JEFFRIES (continuiug). I understand this is introdnced here by the committee and is entitled "Laws aud executive order's relating to Alaska, the leasing of the islands of St. George and St. Paul, and regulations goveruing agents of the 'Treasury Department in charge of the seal fisheries." This is printed in 1SS3. I ask you to look at this and state if you ever saw it before.-A. These regulations are on the island and I have seen them before. I was there at the time this was compiled.

Q. Was that on the islands of St. Panl and St. George?-A. I took a copy to St. George myself.

Q. When was that?-A. That was-

Q. Before Mr. Gavitt went there?-A. Yes, sir; in 1880.

Q. That was earlier than this date. This was printed in 18S2.

Mr. MaCdonald. Where have you been since 18s4?

The Witness. Bowdoinham, Me.

Q. You are not in Government employ now ?-A. No, sir.

Q. Nor have been since?-A. No, sir.

Q And have nothing to do with the Alaska Commercial Company ?A. No, sir.

Mr. JefFries. Do you know a native on St. George by the name of Peter Rezanzofi'?-A. Yes, sir.

Q. Hare you seen a letter purporting to have been written by Peter Rezanzoff, published in New York City and other Lastern paper's?-A. Yes, sir.

Q. Do you know Rezanzoff well enongh to know whether he could write such a letter? -A. He might write it, but he could not compose it. He can write a very fair hand, but he eould not compose a letter in English.

Q. What sort of a man is Peter Rezanzoft? How does he staml in the community in which he lives?-A. I am afraid $f$ can not give him a very good reputation. He can talk a little English, and he thinks himself smarter than any native there, but he is a notorious liar. That's the plain English of it. You can not believe anything he says. When I first went there I used him as an interpreter letween myself and the natives, and I found I could not depend upon anything he told the nattives from me or anything he told me from the natives.

Q. Do you know anșthing about his having been caught stealing from the store?-A. I heard he had, but that was while I was away, but I have no doubt it was so from the character of the man.

Q. Do you know he had violated the law in regard to the killing of seals ?-A. No, sir.

Q. What is his reputation for truth and veracity in the community?A. The natives do not believe him.

Q. Do the whites believe him?-A. No, sir; I think no one.

By the CH$\Delta$ IRMAN:

Q. I will ask you some questions partienlarly about the standing of the agents of the Alaskal Company there. What is the character of 
the people there as to morals?-A. I have always found them of good morals.

Q. Of good moral deportment and habits?-A. Yes, sir.

Q. Do you know Mr. Webster?-A. Yes, sir.

Q. Is lie a man of sober habits, or is he given to dissipation ?-A. I never knew him to be dissipated. Everyborly liked him. The ladies up there always thought a great deal of inr. Webster.

Q. Was he a man dissolute among women?-A. No, sir; he is an old mau. He is a man nearly seventy years old. I know he is over sixty. He is not that kind of a man at all.

Q. Did you have any trouble with him there in performing your duties as agent of the Government; did you find any resistance or ob. struetion in any way?-A. Not at all.

Q. Did he co-opperate cheerfully with yon?-A. Yes, sir.

Q. Was he a violeut, bad-tempered man?-A. No, sir; he was one of the most quiet men on the island. I never saw him angry while I was there, nor any sign of it.

Q. I believe you have stated there was no instance of fraud or violation of the laivs of the United States on the part of the company or its agents ?-A. Nû, sir.

Q. Is there any doctor or medical attendance on the seal islands?A. Yes, sir; there is a doctor on each island.

Q. Who supports the doctors there?-A. The company, I suppose. I know the Government does not. It is in the interest of the company.

Q. Are natives charged for medical attendance or drugs?-A. No, sir.

Q. Does the company furnish them free, at their own expense?-A. Yes, sir.

By Mr. JEFFRIES:

Q. Does the company supply liquor on the island so persons may get drunk who want to"-A. Nó, sir.

Q. How about liquor kept there and who keeps it?-A. Liquor is brought there for medicinal purposes.

Q. Who has charge of it?-A. Sometimes the doctor and sometimes the agent, but I think generally the doetor.

Q. Do you know anything about the efforts made by the company to suppress the manufacture of quass ?-A. Yes, sir. sir.

Q. Did they take measures to prevent the making of it?-A. Yes,

Q. What did they do?-A. In this way. When I first went on the island there was a great deal of drunkenness from quass that is manufactured from sugar aud flour, a sort of beer. The company at that time was selling so mnch sugar a week, perhaps half a pound to an adult and one-quarter of a pound to a child. This sugar was used by the natives for manufacturing quass instead of using it for their tea and colfee. The attempt was malle by the Government agents to suppress the manufacture of quass without stopping the sale of sugar but they fuund they could not do it, and at my own request the sale of sugar was stopped altogether.

Mr. MACDONALD. That stopped the quass?

The Witness. Yes, sir.

Mr. JEFFries. The company could not carry on business if the natives were allowed to drink?

The W'ITNEss. No, sir; they conld not do any business there.

Q. Let me ask you whether, at your request, the company superintend- 
ent discharged one or two men to whom you objected?-A. The superintendent discharged the doctor. The first winter I was there I had, not an official difficulty, but a personal dificulty with the cioctor seut there by the company, but in fact $I$ did not request his removal.

Q. Did you report the fact?-A. Never. I reported to the agent stationed on the island, aud he reported to the general agent the facts of the case, and the general agent asked me if that was the case, and I said it was, and then he promptly discharged the doctor.

Q. There was never any contlict between you and the agents of the company?-A. Never.

Q. Did they do all that you asked them to do, or asked to be done ?A. Yes, sir.

Q. Cheerfully?-A. Yes, sir.

Q. For eight years ?- A. Yes.

Here the committee took a recess until 2 p. m.

AF'TER 'THE RECESS.

\section{TESTIMONY OF JOSEPH B. JOHNSTON.}

JosEPII B. JoHNSToN, sworn and examined.

By the CHATRMAN :

Q. State to the reporter your name and place of residence, and the ofticial position that you occupy, if any--A. My name is Joseph B. Johnston, United States commissioner, stationed at Oonalaska. I reside there, and I have resided there for the last two years.

Q. Have you veenpied that official position duriug those two years?A. Yes, sir.

Q. Have you risited the islands of St. Paul and St. George during your residence there?-A. Yes, sir.

Q. Have you familiarized yourself to any extent with the character and habits of the white and native population there?-A. I was only there for a short time-only four days I think at St. George and two days at St. Paul; but I know a number of the natives of those places who come to Oonalaska, and I have talked frequently with them.

$\mathrm{Q}$. What was your observation as to the condition of the natives upon those two islands?-A. I thought it was excellent.

Q. Do yon know something of the former history of their former condition before the Territory was ceded to the United States? How does their present condition compare with their former condition? -A. Most favorably.

Q. Have they advanced and improved?-A. Yes, sir; both morally and physically.

Q. Have they improved in education?-A. Yes, sir.

Q. Were they living comfortably and well provided for?-A. They were comfortably housed and comfortably clothed.

Q. From your observations, from what yon saw and heard, what do you think of the moral condition of the natives there, as to-in other worls, you have read the recent reports in the newspatpers?-A. Yes, sir.

Q. Abont their loose moral condition and a sort of wholesale debanchery of women, aud so on; were any of those reports correct, do $998 \pm$ $-18$ 
you think, in regard to the people of those two islands ?- $-\Lambda$. I do not think so.

Q. Yeu say you heard uothing ?-A. I never heard of anything of the kind.

Q. Were there any rapes or wholesale debanchery of the native women there?-A. No, sir.

Q. Were the natives contented and satisfied with the condition they were in?-A. Apparently they were.

Q. Was there any appearance of oppression or wroug or injustice inflicted by the agents of the Alaska Commercial Company there?-A. No, sir ; I never heard of anything of the kind.

Q. Did you get acquainted with Mr. Webster there, the agent of the company?-A. Yes, sir; I kuew Mr. Webster.

Q. Did you learn anything of his reputation for peace and morality in the neighborhood?-A. His reputation is good. I know Mr. Webster quite well and I never heard anything to the contrary.

Q. Was he a sober man or a drunkard?-A. He Was a sober matl.

Q. Was he a man of violent and bad temper, or good deportment?A. He was not of bad temper; to the contrary.

Q. Was he a peaceful citizen?-A. Very.

Q. From your observations during your official residence there, is it your opinion that the lease of the seal islands aud their administration by the Government under the present policy exercises a deleterious influence to public interests in Alaska generally?-A. I think not; I know to the contrary.

Q. Do you know anything in their operations there which leads you to conclude that therr inflnence is unfavorable to immigration and the settlement of the country?-A. I know nothing of that kind.

Q. Do you know of any act of the company or its agents which would tend to prevent and ciiscourage other people from engaging in trade and commerce in that Territory ? - A. I do not, and I never heard of auy.

Q. I will be glad if you will state to the committee in a general way the result of your observation as relating to the administration of that interest there and the interests of the company in the Territory ?-A. In the Territory in general or simply in regand to those islands?

Q. Their general influence and conduct?-A. I think the influence is good. I have traveled considerably over the Aleutian Islands; in fact everywhere except at Attoo and Athka. I have always found the company exerted a very good influence amongst all the natives.

Q. Do they treat them humanely and kindly ?-A. Yes, sir.

Q. Is it your opinion that the seal islands conld be better and more protitably administered under any other policy than that now operated by the Goverument?-A. I do not believe it could, sir.

Q. Can the seal life or the herd of seals be preserved without a rigid governmental protection over it?-A. No, sir.

Q. That is absolutely essential to the preservation of the seal life?A. Yes, sir.

Q. Do you think it is necessary to protect them in the waters of the Bering Sea and the North Pacific as well as upon the rookeries?-A. I think they need more protection there than at the rookeries.

Q. Could you make any suggestion of a better method of enforcing that protection than is now adopted by the Govermment?-A. Nothing, except an increase of force. I think it is necessary to do that, and I think you might make Oonalaska a port of entry, and require every ship going into Buring Sea to enter there, except the whaling ships. Last 
summer, during the time that Captain Shepherd was making these seizures, Oonalaska was entirely unprotected. Some of the crews of the sehooners seized were desperate men. One of the vessels taken was the Dolphin, placed in charge of Lieutenant Dunwoody, and threats weri made by some of the crew of that vessel to bum the village. There were no men there at the time; a majority of the natires were out at work, some on the seal islands and some hunting. There were only five white men at Oonalaska.

Q. You think it requires more ressels than one to protect seal life there?-A. Yes, sir.

Q. Have you read the report that the governor of Alaska made to the Secretary of the Interior in 1887?-A. Yes, sir.

Q. Are you the Johnston mentioned in that report?-A. Yes, sir.

Q. A commissioner of the Government there?-A. Yes, sir.

Q. Do you desire to make a statement in answer to that?-A. The governor was at Oonalaska this summer and made an inrestigation of those charges, and he wrote a letter to the Departmeut of Justice, in which he exonerated me from the charges which had been brought by Anderson. That letter is on file in the Department of Justice.

Q. Have you a copy of that?-A. No; I have not, sir.

Q. So it was not true that the Alaska Commercial Company exercised any such influence over you and your administration as was stated by Aulerson?--A. Not at all. The agents of the company there nerer attempted anything of the kind and never would.

Q. Do you know of any instance of that company exereising any such inthence in the Territory over Government officers upon the islands or elsewhere?-A. I do not. I never heard of it, except through this affidavit of Anderson.

\section{Cross-examination by Mr. JEFFrIES:}

Q. How long have you been a United States commissioner of Alaska?-A. Since the 13 th of September, 1856.

Q. Are you the son of ex-Senator Johnston, of Virginia?-A. Yes, sir.

Q. Where do you make your headquarters?-A. At Oonalaska.

Q. How many other eommissioners are there for Alaska?-A. Three.

Q. Where are they ?-A. One is at Sitka, one at Juneau, and the third at Fort Wrangel.

Q. Have you traveled pretty extensively orer Alaska?-A. I have over the Aleutian Islands and sontheastem Alaska, near Sitka.

Q. Then you have some idea of the comparative condition of the natives on the seal islands with the other parts of Alaska which you have visited ?-A. Yes, sir.

Q. What do you say as to their condition? $-A$. It is much superior to any other part of Alaska that $I$ have been in.

Q. What do you say as to the conditions of the natives of Oonalaska since the Alaska Commereial Company commenced business there compared with what it was formerly ?-A. I think it has improved wonderfully.

Q. What have they done for them?-A. They have given them honses to live in free of rent, and have furnished them a doctor and medical attendance free of charge.

Q. Tou are familiar with the law gorerning the lease of the seal islands generally?-A. Yes, sir.

Q. Are they required to do anything for the people of Oonalaska under their contract?-A. No, sir. 
Q. That was a gratuity; why dicl they do it?-A. To improre the natives.

Q. It is to the interest of the company to have them well cared for and comfortable, and to keep them from intoxicants as much as possi. sible? - A. Yes, sir.

Q. At Oonalaska there are a good many ressels of different nationalities which come there?-A. Yes, sir; quite a number come there from March until November.

Q. What do they come for?-A. They simply touch there, as there is no trade; but they always come in, and some of them stay as long as a month.

Q. Do not trading schoouers?-A. Yes, sir.

Q. Trading in the sea-otter and fox. Do thes introduce spiritnous liquors?-A. I think not, sir; I do not think they ever attempted it there, but it is done on Unga Islands.

Q. Have the company built any houses on any of the other of the Aleutian Islands ?-A. Yes, sir.

Q. Where?-A. At Belkorski, at Unga, at Wozensinski, Mozuvia, and at other places.

Q. At these points the company have trading stations?-A. Yes, sir.

Q. Is it wherever the company have trabling stations that they make accommodations for the natives in regard to houses and furnish them medicines and dress? Is that the rule of the company? - A. That is the rule.

Q. Now, what do you say as to whether or not the condition of the natives of Alaska-I am speaking now outside of the seal islands-is improved wherever they have come in contact with the Alaska Commercial Company? - A. I believe their condition has been very unch improved. that.

Q. Do you know Mr. Webster? But I believe you lase testified to

\section{By Mr. FeLton:}

Q. Do I understand they are better elothed and better housed than they were before"-A. Yes, sir.

Q. And a restraint is kept upon the selling of intoxicating liquors?A. There is no sale of intoxicating liquors.

Q. Because these things are for the advantage of the company as well as for the natives of the islands?-A. Yes, sir.

\section{By Mr. JEFFRIES:}

Q. I want to ask you about Mr. Webster; is he a suitable man for the position he holds with the company ?-A. I believe him to be. I believe him to be a very reliable man.

Q. Do yon know Mr. Newman, general agent at Oonalaska?-A. Yes, sir.

Q. What sort of a man is he?-A. I know him to be a man of high character and an honorable gentleman.

Q. Well respected?-A. Yes; a man of very higb character.

Q. He has charge at Oonalaska?-A. Yes; at Yonalaska and the principal stations in the Alentian Islands west of Kodiak.

Q. Is he well liked and of good repute there?-A. Yes; he is liked by everybody.

Q. How long has he been there? $-\Lambda$. I think about seven years.

Q. Do you kuow how long Webster has been in the employ of the Alaska Commercial Company at the seal islands? - A. J do not know; but $I$ know it has been a number of years. 
Q. Now, while you were on the seal islands as a Govermment officer, a law officer, did the natives on those islauds have an opportunity to communicate to you any grierances that they had, if they had any ?A. Yes, sir.

Q. Was any complaint made to you by any native on either of the seal islands?-A. None whatever.

Q. I wish you to state to the committee what is the practice of the Alaska Commercial Company as to affording facilities for the carrying of passengers and freight to all parts of Alaska to which their vessels run and with regard to their bringing back emigrants and miners and anybody else and the taking of them in either direction gratuitonsly? A. I have seen it frequently done. They were taken gratuitously. They have rendered every service in their power always, and they seemed anxious to promote the welfare of everyboly. While I was at Oonalaska quite a number of miners came from the Yulion, who were bronght down on the Bear and taken from there to San Franciseo on the company's ressel. Some of them who had no money were taken down free.

Q. Do you remember how many were takeu down?-A. I think probably there were abont thirty-five. Last summer there were sume brought down, and some of those who wished to go to Unga and had no money, were sent free of charge.

Q. Do you know whether the price eharged those who condd pay was reasonable or not?-A. I think it was very reasonable.

\section{By Mr. MACDONALD:}

Q. You mean the transportation? The transportation in some cases was free?-A. Yes, sir.

Q. What did they charge for carrying passengers?-A. From Sam Francisco to Oonalaska, a first-class passage I think, is $\$ 68$; that is $m y$ recollection.

\section{By Mr. FeLton:}

Q. How many miles?-A. Two thousand one hundrenl and firty miles. It takes about eleven days to make the trip.

Q. That includes everything?-A. Yes, sir.

The CII IRMAN. How do their rates compare with the regular rates on the steamers running to Sitka?

The Wirness. I think they are less.

\section{By Mr. Magdonald :}

Q. Are the accommodations equal?-A. Yes, sir; on the steamers and the schooners also.

Q. That is, you mean they are as goon? - $\mathrm{A}$. Yes, sir; as good. When I was at Oonalaska acting in my official capacity, I receired a good many applications from native hunters and at other points also to be allowed to go to the seal islands to work, and not only to work, but to live continuously. I told them I had not anthority to give them permission. The idea was they received better pay for less work. The hardships they undergo in hunting are very great and there are many dangers connected with it. And then the very best of hunters fail sometimes to make anything during the year, and they thought their life would be easier there. That was not becanse they received any ill treatment at the places where they belonged, but that they would prefer to go there.

Mr JefFries (laughing). Thes wanted to go there and be oppressed?

The WiTnESS. Exactly. 


\section{TESTIMONY OF SIMEON MELOVIDOFF.}

STMEon Melovidoff, sworn and examined.

By the Chamrian :

Q. Where do you live ?-A. St. Paul Island.

Q. Are you a native of the island?-A. Yes.

Q. Were you born there?-A. No, sir; I was not boru there. I was born at Sitka but have been on St. Paul Island since I was three months old.

Q. How old are you now ?-A. Twenty. one years.

Q. You have resided on St. Paul Island since you were three months old ? - A. Yes, sir.

Q. Do you know the agents of the Alaska Commercial Company there, all of them ?-A. Yes, sir.

Q. How have they treated the natives of the island"-A. They have treated them very nicely.

Q. Have the people living there had occasion to complain of them in any way-the agents ?-A. They never have.

Q. How old were you when the Commercial Company took possession? You were quite a child?-A. Yes, sir.

Q. A very little fellow, and you do not know much about what was going on ?-A. Only from what I heard.

Q. What do the people say about their courlition between now and then?-A. They say it is greatly improved since the Alaskat Commercial Company came there.

Q. Do they like to live under that arrangement better than the Russian system? Are they better treated?-A. Yes, sir.

Q. iv hat sort of improvement was it and in what respect are they better off? - A. The Alaska Commercial Company has supplied houses there.

Q. They live in better houses than before?-A. Oh, yes.

Q. Pay any reut for their houses?-A. No, sir.

Q. Furnished to them free?-A. Yes, sir.

Q. Are they elothed different from what they had before?-A. Tes, sir; they are elothed better.

Q. How are the schools now? Does the company keep sehools for the children?-A. Yes, sir.

Q. You were educated there?-A. Partly.

Q. Do they have school every year?-A. Erery year, sir.

Q. Teach English and Alent both? - A. No, sir ; the Russian language. They teach English four days in the reek, and on the fifth day they have Russian tanght.

Q. They teach school eight months in the year?-A. Yes, sir.

Q. Do you know Mr. Webster, the company agent?-A. Yes, sir.

Q. Is be an especially bad man?-A. No, sir; he is a very good man. He is liked by every one up there on the island.

Q. Do the natives all like him?-A. Yes, sir.

Q. Is he a bad fighting man?-A. No, sir.

Q. liet drunk?-A. I never saw him get drunk; they have got nothing to get drunk on.

Q. You can not get any intoxicant?-A. No, sir.

Q. Why?-A. Because I believe the company does not allow an thing there.

Do not the emmany furnish it? -A. Yos, sir; but the doetors have charge of it. 
Q. It is only used for medieal purposes then?--A. Yes, sir.

Q. Wouid the natives like for the present arrangement and policy of the Government to be broken up there and get rid of the company's men?-A. No, sir; I guess not.

Q. You think they would not like that?-A. I think not.

Q. Did you know some Government agents who have been there for some few years past?-A. Yes, sir.

Q. When did you leave there; when were you there last?-A. I spent last winter there.

Q. And came down this summer?-A. Yes, sir; last August.

Q. Were you on St. George Island last winter?-A. No, sir ; St. Paul Island.

Q. Were there any controversies or disagreements between the Goverument agents and the comprany agents last winter?-A. None on St. Paul.

Q. Did you know anything of what was going on at St. George last winter? - A. Only what I heard.

Q. What did you hear about it?-A. Ther said they had little diffieulties. It was a disagreement between Mr. Garitt and Mr. Webster.

Q. Some little disagreement. Did you see Mr. Webster any last winter?-A. No, sir; I saw him last summer,

Mr. FELTON. Did you get the most of your edncation upon the island? - A. Yes, sir.

Q. You learned English there?-A. Yes, sir ; I did.

Q. Did you learn arithmetic there?-A. Yes, sir.

Q. Aud a little geograyhy, history, and writing?-A. Yes, sir.

Cross-examination by Mr. JeFfries :

Q. You have, I suppose, often talked with the people on the island and heard them talk to each other, comparing their present condition with what it was in former times when the Russians had it?-A. Yes, sir.

Q. From what you have heard them say, how do they live-but I will ask you particular questions, so you cau answer them. How did they live under the Russian régime; what did they have to eat?-A. They lived on seal meat, 1 believe.

Q. Un seal meat and blubber?-A. Yes, sir.

Q. There was then no store at which they conld buy crackers and necessaries in those days?-A. No, sir; I believe not.

Q. What kind of houses did they live in ?-A. Barribakis.

Q. Which were virtually undergromd and had no floors?-A. No, sir; no floors.

Q. And no chimneys?-A. No, sir.

Q. The fire was built on the ground floor inside the house?-A. Tes, sir ; in the middle of the house.

Q. What kind of elothing did they have in those days ?-A. Calico.

Q. Under the Russians?-A. Yes, sir.

Q. How did the men dress ?-A. Well, I conld not tell you abont that; 1 do not know.

Q. Now, what pay did they get in those days for a summer's work; how much ?-A. Ten dollars.

Q. An able-bodied man got $\$ 10$ ? - A. Yes, sir; a first-class man.

Q. And others got less?-A. Yes, sir.

Q. That was for a whole season's work? -A. 'Tes, sir.

Q. How loug did you go to school at the eommany's school on the 
island and what did you learn at that school?-A. I went to school when I was five years old.

Q. And continued until you were- A. Fifteen years.

Q. Now, what did you learn at that school during that time?-A. I learned to write and read and spell.

Q. Did you learn any arithmetic?-Yes, sir.

Q. Geography?-A. Yes, sir.

Q. So you learned spelling, rearding, writing, arithmetic, and geography at a school maintained by the Alaska Commercial Company ? A. Yes, sir.

Q. Were other children attending school at the same time that learned these branches?-A. Yes, sir.

Q. Now what do you say as to the majority of the young men of your age resident on the island; have they learned to read and write, or not?-A. Yes, sir; they have learned to read and write. sil'.

Q. And know something about arithmetic aud geography?-A. Yes,

Q. A majority of the men on the island, which they have learned at the company's school ?-A. Yes, sir.

Q. After you quit going to school there, you went to San Francisco; the company sent you there and you went to school-the high school at San Francisco?-A. No ; I went to school at Napa.

Q. Have you been in the habit since then of going back to engage in work: $\mathrm{A}$. Yes, sir.

Q. What do you do?-A. Flipped the seals; cut them open.

Q. You were a sealer on the islauds, working like auy other common hand? -A. Yes, sir.

Q. Do you get your share of the pay?-A. Yes, sir.

Q. How much pay do you get?-A. Five hundred and sixty-odd dollars last year.

Q. Now, what did it cost you to live there, or would cost any man liv. ing on the island who works for the company; there is no rent?-A. No, sir.

Q. He does not pay for salt meat ?-A. No, sir.

Q. He does not eat any other kind of meat?-A. Yes, sir.

Q. What does he eat?-A. They have salt beef.

Q. That he can buy from the company?-A. Yes, sir.

Q. Do you know what they pay for the beef"? -A. I do not.

Q. They do not eat much of that?-A. No, sir.

Q. Then, under their contract, the eompany is obliged to furnish them with dried salmon, dried fish ?-A. No; salt fish.

Q. Does the eompany supply that; all they want?-A. Yes, sir.

Q. Aside then from what beef they buy there is nothing else they neel to buy except groceries and such luxuries as they want?-A. No, sir; some of them are cheaper than I have seen in San Francisco.

Q. Have a good many natives of St. Paul and St. George got money on deposit at San Francisco, do you know?-A. I believe there wre quite a ferw on St. Paul Island.

Q. Have you got any on deposit?-A. No, sir; I have not.

Q. You spend your money ?-A. Yes, sir.

Q. You must not do that. You must save it. Now with regard to the Russian school, where they teach Russian, that is under the management of the Church?-A. Yes, sir.

Q. You have a priest at each island ?-A. Yes, sir.

Q. Your people are a very religious people?-A. Yes, sir.

Q. And have a good many feasts and fasts and all that?-A. Tes, sir. 
Q. Does the bishop come there once in a while?-A. Yes, sir.

Q. Where are his headquarter's?-A. San Franciseo.

Q. Bishop of the Greek Church ?-A. Yes, sir.

Q. Does the priest and any leadin 2 man, or anybody else on these islands, liave an opportunity of sending from the islatid any letters and communications down with the ship?-A. Yes, sir.

Q. Is the priest in the habit of sending down to the bishop to-what do they call it?-A. Consistory.

Q. To the consistory, reports and packages and papers you want to send?-A. Yes, sir.

Q. You know they do do it?-A. Yes, sir.

Q. Is it not put up in a box by itself and closed up?-A. Yes, sir.

Q. And put on board the vessel and delivered to the consistory ?A. Yes, sir.

Q. So if you had a grievance against anyborly or the company which you wanted to send, jou could jut it up with the other papers?-A. Yes, sir; you could.

Q. Mave you been at Oonalaska?-A. Ies, sir; I was lown there.

Q. What becomes of the widows and orphans and the sick and poor people who ean not work on the island, who takes care or them, if anybody?-A. The company.

Q. Do they provide for them well and make them comfortable?-A. Yes, sir.

Q. You know that to be true?-A. Yes, sir.

\section{TESTIMONY OF LOUIS KIMMEL.}

\section{Lou1s KIMnEL, sworn and examined.}

Q. What is your residence? - A. My residence is La Fayette, Ind.

Q. Have you at any time been an official of the Government, anci if so, in what capacity and where?-A. Yes, sir ; I was assistant Treasury agent at the seal islands, stationed on St. Creorce Island.

Q. When ?-A. From 1SS2 to 1583 . Arriver there in the latter part of Mar, 1S8:, and left there in the early part of August, 1853.

Q. What were yom duties there?-A. Well, to see that the contract that the Govermment had with the Alaska Commereial Company was carried out faithfully, that the natives were treated well, and to oversee the sealing business.

Q. To see that the laws of the Gorermment were enforced ?-A. Yes, sir.

Q. Will you give the committee a statement of your observations and administration of that office there; what you did and what transpired, and the condition of things there during that time? $-\Lambda$. Wenl, the seal business commenced in the latter part of June and continued until the latter part of July.

Q. That is the taking of seal skins there allowed by law ?-A. Tes, sir.

Q. What number were taken upon that island?-A. I think there were 15,000 taken.

Q. What kind of seal were taken? - A. Only the male seals from two to tive pears old; perhaps older than five; but I do not thmk there were any taken over five years old.

Q. Were any temale seals killed?-A. No, sir.

Q. None under a year old ?- $\Lambda$. No, sir. 
Q. Was there any in excess of the allowance by law taken there?-A. Not that I know of.

Q. Were any considerable number killed except those that were intentionally killed for their skius? -A. No, sir ; only what the natives userl for their food, and their skins were all taken and counted in the quota.

Q. Did any riolations of law in any respect oceur while ron were there, on the part of the company's agents or other persons?-A. Not to my knowledge.

Q. Who was there for the company upon the island while you were there?-A. Mr. Rerlpath.

Q. Did you have any diffieulty or disagreement with the agents and officers of the company while you were there-find any resistance?-A. No, sir, not the least. Only one man made rather a disrespectful expression, it was one Dr. Kelley.

Q. The company's doctor?-A. I'es, sir. He made a remark to me that the Government had been in the habit of sending up nothing but ignoramuses. He insulted me in that way, and he harl done that before, I understand. I reported that to my superior offieer, to Mr. Glidden, verbally, and when the ressel came up there the doctor went down with the same vessel, so I judged from that he was diseharged. That is the only case.

Q. The company kept a school while yon were there?-A. Tes, sir.

Q. How long?-A. Eight months in the year.

Q. What was the attendance on the part of the native children?A. It was fair. I should judge three-fourths of the children on an average, sometimes more. But in extreme winter weather, there was less than three fourths of them, which was an obstacle that the company could not overcone. The natives I do not know actually object to sending their children to the English school there, but they do not like it, and I had to force them several times to send their chilitren.

Q. Dill the company officers and the Govermment officers use what influence they conld to get the children to school?-A. Yes, sir.

Q. Does the company furnish fuel to the natives in compliance to contract?-A. Yes, sir; in fact they furnish more than what the contract requires them to do.

Q. Do they furnish a sufficient quantity to keep them comfortable?A. Yes, sir; but they mostly use blubber for fuel. Only in extreme weather they take and burn coal. The company issued more to them than they were entitled to.

Q. Did the company issue the amount of salt fish and dried salmon required?-A. Yes, sir; they had more than what they wanted. It seemed to me while I was there they did not like salt beef and salted fish; they rather prefer seal meat and fresh fish.

Q. They have always a plenty of food ?-A. Yes, sir.

Q. Is there a physician there?-A. Yes, sir.

Q. Maintained by the company ?-A. Yes, sir.

Q. At the company's expense?-A. Yes, sir.

Q. Are the natives charged for medical attendance and drugs?-A. No. sir.

Q. Any rent charged for their houses ?-A. No, sir.

Q. According to your observation, was the influence of the company's agents there over the natives beneficial or demoralizing?-A. I think it was beneficial.

Q. Have you seen recent publications in the newspapers as to a sort of wholesale depravity of the native women? -A. No, sir; I have not.

Q. You have not seen those publications? $-\Lambda$. No, sir. 
Q. There were statements made that agents of the Alaska Commercial Company and their white people committed rapes and violated the chastity and sanctity of single and married women, and invaded the sanctity of the family circle, and all that sort of thing. Did you observo any tendency to acts of that sort while you were there?-A. There was nothing that came to my knowledge. I never heard of any such tuing.

Q. Did you know Mr. Webster?-A. Only for a few days. He came to St. George Islaud I think when I left there.

Q. Do you know anything about his character and standing and reputation for morality ?-A. I do not think that there is any donbt that it is high. It seemed to me he was a gentleman, from the two days I saw him. I could not see anything to the contrary.

Q. Did you see anything on either of these islands to lead you to believe that the agents of the companr; were debanching in any way the native population and demoralizing them ?-A. No, sir.

Q. Have you seen a publication recently of what purports to be an interriew with you in a New York paper?-A. I never saw it until about an hour ago.

The CHAIRNAN. Is that the slip?

The Witness. Yes, sir.

Q. Have you read it?-A. Yes, sir.

THE WRONGS OF THE ALEUTS-EX-MAYOR KIMMEL CORROBORATES THE SHAMEFUL, STORY-IL WAS A GOVEIRMENT AGENT ANU AN FYE-WITNESS OF THE OUTRAGES UPON WOMEN AND MEN-UNPRINCIPLED WHITE AGENTS.

La Farite, Ind, Dec. 11.-Ex-Mayor Louis Kimmol, of La Fayette, has come forward to corroborate the wretched story of oppression and ontrage in Alaska, which was given to the public by the Sun recently. Mr. Kimmel has been three times mayor of La liayette, and is well known as a man of high standing. He was special Treasury agent at the seal islands in $180^{\circ}$ and 188:3, aud resigned his place in the Department service rather than go back to the islands again.

"No momey could have hired mo," he said to-day, "to spend another year in that place, and have to witness the treatment indicted upon the innocent natives without being able to prevent it. I was there through owo season, and I had enough of it."

Asked as to the truth of the story of the situation as told in the Sun, he said :

"So far as my personal knowledge conld extend, the story is true, and is not in the least exagucrated. It couldn't be, Of course there were details of it which I knew nuthing about, because I have been on only one of the two islands, and that was five vears aro; but, so far as it dealt with the greneral treatment of the natives, the abuse of the women, aud the ahominable oppressions practiced upon the natives by the employés of the Alaska Company, it agreed perfeetly with wy knowledge of what was the situation when I was thero."

"Dil you make any rejort of these matters when you returned from Alaska?"

"I did to my superior, Judge Glidilen. It was a verbal report, and he said he would take the matter into consicleration. 'That was all that ever came of it. I was assigned to duty at the Chicago eustom-house mil the noxt summer and spring, and then I found that they were going to send me back to that place again, and I resigned.

"The lease platces the two seal islands absolutely in the hands of the company. No vessel hut theirs can land there, and no supplies can be obtained bat at their stores. The Government arent is smprosed to see that the terms of the contract are poperly enforced and carried ont, the natives fairly treated, and other things done as they should be. But he has no power to enforce his orders. All he can do is to report to his superior. The whole timo I was there all that I saw of the United States frovernment was once when a revenue-cutter passing near the island sent a small boat atsoro and asked if I were still alive. They found I was all right, and went away.

"The worst thing about it is that the natives are alisolutely helpless ev'n to make an appeal for the righting of their wromgs. When I came array the chief of the people wanted to come with me to San Franciseo to make a petition to the people in "the land where the sun shines' to relieve his people of some of their aftlictions. Ho begred me to take him with me, but all I comhl do was to ask my superior, Judge Gililden, for permission for the chief to leave the island. Glidrlen said: 'Oh, no; we can't let him get down there. He cau't have the permit, and that was all there was about it. 'ho man bad to stay. 
"I know this Peter Rezanoff, whose letter was printed in the Sun. When I was arrent he was the brightest and most intelligent man of the natives on the island. He call even talk Euglish. I used to talk with him when I conld, but the company employés prevented it whenever they had a chance, and warned me not to talk to him. They said he was treacherons, but $I$ believe him to be as honest a man as lives. If he were in this comutry I should not hesitate for a moment to make an equal of him.

"These natives are all far abovesavages in intelligence. They are half-civilizerl at least, and would make grood citizens if they had a chance. As it is they have no rights, except what the company emplojés choose to allow them. The school, which the company's contract obliged them to keep up, was nothing but a humbug. The teacher was drunk all the time. An agent can clo nothing for the natives. If he doesn't act to suit the company's employés his life is made miserable. They attempted to blacken my character while I was there by inventiug a lot of stories about me. I sent for Gus Samer, the company's steward, who was responsible for them, and told him I wonld shoot him on sight if I heard any more of them. After that they let me alone.

"That is the method with all the Goverument officers who do not act to suit them. They attempt to blacken the agent's character, and with the kind of men they have got $u$, there it is easy to get them to tell most any story about a man they don't like. I don't say anything alout the company itself, for I understaud that the men interested in it are honest and reputalle men; but the employés who do their work are a horde of rascals, who ought to be cleaned out.

"The exact number of inbabitants on the two seal islands is less than 350, but the possession of these two islauds gives the Alaska Company the key to the whole commercial business of the Territory, affording it a monopoly, by the profits of which it can carry on the whole business of the conntry on terms with which no other company can hope to compete. 'This power is particularly complete over the Alentian Islands, with a native population of about 4,000 ; and, besides these direct victins of the company's oppression, there is a great body of natives on the main-land who are to a less extent under the thumb of the monopoly.

Q. Is that true?-A. No, sir; that is perverted greatly.

Q. From an interview that rou had with a corresponclent?-A. Yes, sir. I did not know he was a correspondent. Duriug our conversation it turned out that he was a correspondent. That was at Indianapolis. I see that it is dated La Fayette, Ind. Mr. Gavitt wrote we several letters that if I wanted to hear any news of the St. George Islauds to come to Evansville to see him. I thought it would not pay me to go to Evansville to hear the news. He then wrote me a letter to come up to Indianapolis, and he stated in it that he would go to Washington in a few days; that if I wanted to see him and hear the news of St. George Island to come up there, and he gave the number of the street where I conld find him. 'That is, if you wish me to tell you how I got there. So I went to Indianapolis the next day and found him at the number of the house where he wrote me. WV commenced talking over who had died there, and who were still liriug, and then he said, "Let us go down to the new Dennison House and see 'Tom Ryan, who has been Treasury agent there." I never knew him before. So we went down to the new Denuison House, and we could not find Ryan there, and then Gavitt said, "Let us go to the Bates House ; perhaps we will find him there."

We went to the Bates House and sat down there, and he introduced me to one Mr. Chamberlain and we talked about the seal islands, and talkingaiong we discussed and talked about St. George Island, and during the conversation he said, "Mr. Chamberlain is a correspondent of the New York Sum." I dirl not know what was up until then. If 1 had known it I would not have said-as you talk freely to a man, perhaps something slips trom your lips you ought not to have said, but something has been laid in my mouth that I nerer uttered and never mado any such remarks.

Q. Did you ever hear of any cases of rape there?-A. No, sir; I never hend of any such thing.

Q. Did jon observe any unusual amount of debauchery amoug women there?-A. Not to my linowledge. IVhat inas been going on among the natives I could not observe very closely. 
Q. Nothing came under your observation to lead you to believe that the agents of the company and other white people there were debanching the native women?- $\mathrm{A}$. No, sir. I was acquainted there with Mr. Redpath, who was there while I was there, and during the sealing season Mr. Morgan and some others, and they were all gentlemen, every one of them.

Q. Did the agents of the company there accord ready obedience and execute the laws and orders of the agents of the Govermment?-A. It seemed to me they were just as much conversant with law and the requirements of the law as we were. We never had auy difficulty in car. rying out the law.

Q. Is it your opinion that the herd of seals are of sufficient value and importance to justify the Government in making a reservation of these islands and protecting them at the great expense it incurs ?-A. I think so, especially the seals ought to be more protected in the water.

Q. You think a very rigid protection should be extended in the waters of the sea away from the islands?-A. Yes, sir.

Q. Do you think the herd could be increased over the number the Government takes now, 100,000 a year, if they were thoroughly protected in the waters of Bering Sea? Do you think it could be increased in numbers?-A. If there be $n 0$ depredations outside of the seal islands, I think they will be increased in number. But they are slaughtered recklessly outside, which will undoubtedly decrease the number.

Q. I think that you have stated before that you have no knowledge of any violation of law in any respect. What do you say of the unauthorized hunting of seal; was there any?-A. I have no experience about that. Only in one case the chief reported to me he had seen a ressel, so $I$, together with the agent of the company, went out to the place, East Rookery, they called it, about 3 miles distant. After we got there we found that a vessel had been there, as we found some ropes aud cartridges and such things that they left there. That is the only time I recollect any pirates being around.

Q. Do you think seal life could be better preserved by any policy than the one now pursued by the Government"-A. I do not know what method is pursued now.

Q. It is the same now as it was when you were there.-A. It ought to le more protected by having revenue-cutters.

Q. Against the killing of seals?-A. Yes. At that time there was only one revenue-cutter only there once a year.

Q. What would be the result if the Government should withdraw this protection and abolish the reservation?-A. They would be exterminated.

Q. Is it your opinion, from your observation there, that the effect of having control of those islands by the lease enables the Commercial Company to dominate the business interests of the Territory generally?-A. I think it does.

Q. To what extent and how?-A. Well, when I went there there was competition there. The Western Fur Company had a station at different islands, but did not interfere with the seal islands, only on the otter islands, and at that time they consolidated the two together.

Q. The evidence here is that the Alaska Commereial Company bought the Western Company out.-A. They either consolidated or bonght them out, as I say. There is no competition any more in compensating the natives of the different islands for their furs and skins.

Q. I)id furs go down or up? - A. ( the general market, but up there on the islands for the hunters. 
Q. Well, anybody has a right to go and trade that wants to?-A. I think so.

Q. Do you think the company exercises an influence on that Territory that prevents the occupation and settlement by emigrants? $\mathbf{A}$. I do not think they interfere with that in the least.

Q. You do not think their influence has interfered with anything of that sort?-A. No, sir.

(Q. Has their influence on the natives been deleterious or beneficial ?A. Beneficial.

Q. You are satisfied the inflnence has been beneficial to the natives generally ? - A. Their condition has improved considerably.

Cross-examiuation by Mr. Jenfries:

Q. You reside at La Fayette, Ind.?-A. Yes, sir.

Q. You are a former mayor of the city?-A. Yes, sir.

Q. How many times?-A. Three times.

Q. What official position do you hold now in that city, if any ?-A. I an a presiding officer of the school board.

Q. I understood you to say you had not seen any of these communications going the round abont the Alaska Commercial Company?-A. No, sir; only the other day I received a copy of the San Franciseo Ex. aminer, which my son sent me.

Q. At the time of this interview that Mr. Gavitu coolsed up, in the way you know, sou had not read any of these publications at that time?-A. No, sir.

Q. You harl never seen an article previously published in the Sun?A. No, sir; never beard of it.

Q. They mak you say in this interview you approve of everything in that paper, when you had not seen it?-A. I never saw it.

Q. You are made to say in this paper-

No money conld ever hire me to spend another year in that place and have to witness the treatment inflieted mpon the immocent natives without heing able to prevent t. I was there one season and had enongh of it.

Did you say that?-A. No, sir.

Aslied as to the truth of the situation as told in tho Sun, he said "So far as my personal knowledgo could extend, the story is true."

\section{Q. Did you say that?-A. No, sir.}

And is not in the least exargerated. It could not be. Of course there were detanls of which I knew nothing about, hecause I have been on one or two islands and that was five years ago, hut so far as it told of the generabl treatment of the natives, the aluse of the women, and the abominable oppressions practiced on the natives by the employés of the Alaska Commercial Company, it agreed perfectly with my knowiedge of what was the situation when I was there.

Q. Did you ever say that?-A. Never.

Q. That is all a lie?-A. Yes, sir.

Q. That is the English way of expressing it. There is a good deal of stuff here I do not eare anything about, but I just want to call your attention to two or three paragraphs. Now, it goes on to say:

The worst thing about it is that the natives are absolutely helpless even to make an appeal for the righting of their wrongs. When I came awas the chief of the people wauted to como with mo to San Francisco to mako a petition to the peoplo in the "land where the sim shines" to relieve his people of some of their aftlietions. He beuged me to take him with me, but all I could do was to ask my superior, Judge: Glidden, for permission for the chiet' to leave the island. Glichen said, "Oh, no; I can not let him go down there; he can not have the permission," and that was an! there was about it. 'The man had to stay, 
Did you say that?-A. I only heard one complaint, and that was the chief told me there was some money coming to the natires from some former year for some seal skins which remained at the salt-house at the time I was there, and he wanted to go to San Franciseo and settle. I told him that as far as I was concerned I had no objection to it, but I had to report to my superior ofticer, aud if he had no objection to it he could go. I reported to MIr. Glidden at the time aud he said that he could not give him any permission then, as he would have to report to the Treasury Department and get the permit.

Q. That is all of that?-d. Yes, sir; I never heard any other complaint.

Q. What sort of a man is Peter Reyanzoff? - A. I know him.

Q. What sort of a man is he?-A. He seemed to me to be a little more educated than the balance of the natires there and talked with more fluent English.

Q. What is his character aud reputation ?-A. It seems to me that he always tried to stir up a little strife.

Q. A mischief-maker?-A. Yes; you can say that.

Q. Was he a truthful man?-A. I did not have much conversation with him.

Q. Did you ever tell the reporter of the New York Sun or anybody else this : "I believe him to be as honest a mau as lires?" Did you make that remark? - A. I nerer made that remark or any such thing.

Q. You are made to say:

The school which the company's contract pledges them to keep up was nothing but a humbug.

A. That never came into my mouth.

Q. And "the teacher was drunk all the time." Did you say that?A. No, sir.

An agent eau do nothing for the natives. If he rloes not act to suit the company's employés his life is made miserable.

Q. Did you say that?-A. No, sir. I said in regard to the company's schools that I thought in this country the children could be better educated than up there.

Q. That is not the fault of the company ?-A. No, sir ; they try their best.

Q. This interview goes on to state that you said:

They attempted to blacken my cbaracter while I was there, and invented a lot of stories about me.

Did you say that?-A. There is some truth about that. There was a man there by the name of Gus. Laner, who was a porter of the company, told some things derogatory to me, and I tolit him if I heard of anytbing of the kiud that I would defend my honor and character, which I will do to-day, at the risk of my life.

Q. Anything more come of it?-A. That settled it.

Q. Now, you are made to say:

That is a method with all the company officers who do not act to suit them. They attempt to blacken the arents' characters, and with the kiud of men they have up there it is easy to get them to tell almost any story abont a man they do not like.

I do not say anythiug about the company itself, for I uuderstand that the men interested in it aro honest and repritablo mos; but the einployés who do their work are a lierd of rascals aud ought to be cleaued out.

A. In ovner words, that is what Mr. Gavitt said, and not me.

Q. Did Mr. Gavitt disclose to you his object in making up, this attack upon the Alaska Commereial Company?-A. No, sir; only I heard him $9984-18$ 
make one remark on the sidewalk. I met General Harrison, who was an old acquaintance of mine. I am personally acquainted with.him. When General Harrison saw me there, he said, "Mr. Kimmel, how do you do? How is your health?" I heard Gavitt make use of the expression while shaking hands, "I am going to push that Alaska business through." I did not know what he meant by it. He said that to General Harrison. That is the only intimation I had from which I inferred what he wanted to do.

Q. Did he ever tell you he borrowed $\$ 1,000$ from the company which they made him pay back unexpectedly? -A. No, sir.

\section{TESTIMONY OF GEORGE R. TINGLE.}

\section{George R. TINGLe, sworn and examined.}

The Chairman. Mr. Tingle has been heretofore examined. He is at present Treasury agent in charge of the islands of St. George and St. Paul. I hare recalled you, Mr. Tingle, in consequence of publication s that have been made in the newspapers since you testified before, representing a very bad moral condition existing in some parts of Alaska, and principally on St. George and St. Paul Islands, which consequently exert a demoralizing influence towards the natives on the part of the Alaska Commercial Company and its agents, as well as other white persous. Have you read those publications?-A. Yes, sir; I hare read all that has come to my notice, and hare read quite a large number.

Q. I wish you would state to the committee generally whether there is any foundation for these reports as to the islands of St. George and St. Paul.-A. Well, sir, I can state positively from my experience upon those islands as the Treasury agent in charge that the published stories are absolutely false. That there is some immorality upon the islands of St. Paul and St. George among the natives there is no doubt. It is under cover, as it is in the civilized cities of the United States. It is not preceptible to the naked eye. I do not know a community of the size of 'St. Paul and St. George Islands in any part of the United States where there is less immorality appearing. They are all quiet and peaceable, well-behaved citizens upon those islands. They look upon a Government officer in charge as a representative of the Government and the only law and authority they know any obing about, and his authority is implicitly obeyed. They are careful nut to do anything that will bring reproach upon them and censure of the Government oficer. The stories as published in these communications I have read and, as far as they app!y to the natives of the fur-seal islands, are absolutely false.

Q. You are the general agent in charge of these islands at this time?A. $1 \mathrm{am}$.

Q. Did you have any instructions from the Treasury Department about your duties there? - A. Yes, sir; when I was appointed I went there with instructions, verbal as well as in writing, and I was directed to instruct my assistants, which I did, and assigned them to duty, which was the language of the Department ordered to me.

Q. Who were your assistants there?-A. Capt. A. P. Loud, J. P. Manchester, and William Gavitt.

Q. Did soll give Mr. Gavitt instructions when he entered upon his duties? - A. He was assigned by the Department to St. George Island, and I was ordered to place him there and instruct him in his duties. 
I instructed him as far as he was cajable of receiving instructions, went ashore with him, and showed him the books in the office aud how he was to keep them. I placed a copy of the law and executive orders in the office there and gave him instructions as to the discharge of his duties.

Q, Have you a copy of those?-A. I have, sir. I have not a copy of the Department instructions, but this pamphlet contains the law and the lease of the company and the executive orders. Then the Secretary said, "You will see that this law is faithfully carried out and the instructions as here given will be your guide. Mr. Gavitt must have the same that are here presented to you." This contaius the ruling of the Treasury Department as to the jurisdiction :

\section{LAWS AND EXECUTIVE ORDERS}

RELATING TO ALASKA.

LEASE OF THE ISLANDS OF ST. PAUL AND ST. GEORGE TO THE ALASKA COMMERCIAL COMPANY, AND REGULATIONS GOVERNING AGENT'S OW THE TREASURY IN CHARGE OF THE SEAL EISHERIES.

\section{Treasury Department,} April 13, 1882.

The following compilation of the laws and Executive orders relating to Alaska, the lease of the Seal Islandsoof St. Paul and St. George to the Alaska Commereial Company, and regulations govermug the seal fisheries is published for the information of the officers of the Depurtment, and others interested.

Chas. J. Folger, Secretary.

\section{REVISED STATUTES.}

SEc. 1954. The laws of the United States relating to customs, commerce, and navigation are extended to and over all the main-land, islands, and waters of the territory cerled to the United States by the Emperor of Russia by treaty concluded at Washington on the thirtieth day of March, anno Domini eighteen hundred and sixty -seven, so far as the same may be applicable thereto.

Skc. 1955. The President shall have power to restrict and regulate or to prohibit the importation and use of fire-arms, ammunition, and distilled spirits into and within the Territory of Alaska. The exportation of the same from any other port or place in the United States when destined to any port or place in that Territory, and all such arms, ammunition, and distilled spirits, exported or attempted to be exported from any port or place in the United States, and destined to such Territory, in violation of any regulations that may be preseribed under this section, 'and all such arms, ammunition, and distilled spirits landed or attempted to be landed or nsed at any port or place in the Territory, in violation of snch regulations, shall be forfeited; and if the value of the same exceeds four hundred dollars, the vessel upon which the same is found, or from which they have been landed, together with her tackle, apparel, aud furniture, and cargo, shall be forfeited; and any person willfully violating such regulations shall be fined not more than five hundred dollars, or imprisonedi not more than six months. Bonds may be required for a faithful observance of such regulations from the master or owners of any vessels departing from any port in the United States having on board fire-arms, ammunition, or distilled spirits, when such vessel is destined to any place in the Territory, or if not so destined, when there is reasnnalile ground of suspicion that such articles are intended to be landed therem in violation of law ; and similar bonds may also be required on the landing of any such articles in the Territory from the person to whom the same may be consigned.

SEC. 1956. No person shall kill any otter, mink, marten, sable, or fur-seal, or other fur-bearing animal within the limits of Alaska Territory, or in the waters thereof; and every person guilty thereof shall, for each oflense, be fined not less than two hundreel nor more than one thousand dollars, or imprisoned not more than six months, or both; and all vessels, their tackle, apparel, furuiture, and cargo, found engaged in 
violation of this section shall be forfeited; but the Secretary of the Treasury shall have power to authorize the killing of auy such mink, marten, sable, or other furbearing animal, except fur-seals, under such regulation as he may preseribe; and it shall be the duty of the Secretary to prevent the killing of any fur-seal, and to provide for the execution of the provisions of this section until it is otherwise provided by law; nor sbali be grant any special privileges under this section.

SEc. 195\%. Until otherwise provided by law, all violations of this chapter, and of the several laws hereby exteuded to the Territory of Alaska and the waters thereof, comsitted within the limits of the same, shall be prosecuted in any district court of the United States in California or Oregon, or in the district court.s of Washington ; and the collector and deputy collectors appointed for Alaskia Territory, and anj person anthorized in writing by either of them, or by the Secretary of the Treasury, shall have power to arrest persons and seize vessels and merchandise liable to fiues, penalties, or forfeitures under this and the other laws extended over the Territors, and to keep and deliver the same to the marshal of some one of such enurts; and such courts shall have original jurisdiction, and may take cognizance of ail cases arising under this act and the several laws herebr extended over the Territors, and shall proceed therein in the same manner and with the like effect as if such cases had arisen within the district or territory where the proceedings are brought.

SEC. 1958. In all cases of tine, penalt., , or forfeiture, embraced in the act approved March 3, 1797, ch. 13, or mentioned in any act in addition to or amendatory of such act, that have oecurred or may occur in the collection district of Alaska, the Secretary of the Treasury is autborized, if in his opinion the fine, penalty, or forfeiture was incurred without wilful negligence or intention of fraud, to ascertain the facts in such manner and under such regulations as he may deem proper without regard to the provisions of the act above referred to, aud upon the facts so to be ascertained, he may exercise all the power of remission conferred upon him by that act, as fully as he might have done lad such facts been ascertained under and according to the provisions of that act. (Secs. 5292, 5293.)

SEc. 1959. The islands of Saint Panl and Saint George, in Alaska, are declared a special reservation for Goverument purposes; aud until otherwise provided by law it shall be unlawful for ans person to land or remain on either of those islands, except by the authority of the Secretary of the Treasury; and any person found on either of those islands contrary to the provisions hereof shall be summarily removed; and it shall be the duty of the Secretary of War to earry this section into effect.

SEC. 1960. It shall be unlawful to kill auy fur-seal upon the islands of Saint Paul and Saint George, or in the waters adjacent thereto, except during the months of June, Julf, September, and October of each year; and it shall be unlawfinl to kill such seals at any time by the use of fire-arms, or by other meaus tending to drive the seals away from those islauds; but the natives of the islands shall have the privilege of killing such young seals as may be necessary for their own food and clothing during other months, and also such old seals as may be rerruired for their own clothing, and for the manufacture of boats for their own use: and the killing in such cases shall be limited and controlled by such regulations as may be preseribed by the Secretary of the Treasury.

SEC. 1961. It shall be unlawful to kill any female seals, or any seals less than one jear old, at any season of the year, except as above provided; and it shall also be unlawful to kili any seal in the waters adjacent to the islands of Saint Paul and Saint Gearge, or on the beaches, eliffs, or rocks where they haul up from the sea to remain; and every person who violates the provisions of this or the preceding section shall be punished for each offense by a fine of not less than two hundred dollars nor more than one thousand dollars, or by imprisonment not more than six months, or by both such fine and imprisomment; and all vessels, their tackle, apparel, aud firniture, whose crews are found engaged in the violation of either this or the preceling section, shall be forfeited to the United States.

SEc. 1962. For the period of twenty years from the first of Julj, eighteen hundred and seventy, the number of fur-seals which may be killed for their skins upon the island of Saint Paul is limited to seventy-five thonsand per annum; and the uumber of fur-seals which may be killed for their skins upon the island of Saint George is limited to twenty-five thousand per annum; but the Secretary of the Treasury may limit the right of killing, if it liecomes necessary for the preservation of such seals, with such proportionate reduction of the rents reserved to the Government as may be proper; and every person who knowingly violates either of the provisions of this section shall be punished as provided in the preceding section.

SEc. 1963. Wheu the lease heretofore made by the Secretary of the Treasury to "The Alaska Commercial Compans," of the right to engage in taking fur-seals on the islauds of Saint Paul and Saint George, pursuant to the act of July 1, 1870, ehapter 189, or when any future similar lease expires, or is surrendered, forfeited, or terminated, the Secretary shall lease to proper and responsible parties, for the best advantage of the United States, having due regard to the interesta of the fovernment, the 
native inhabitants, their comfort, maintenance, and erlucation, as well as to the interests of the parties heretofore t'ngaged in trade aud the protection of the fisheries, the right of taking fur-seals on the islandis herein uamed, and of sending a vessel or vessels to the islands for the skins of such seals, for the term of twenty years, at an annual rental of not less than tifty thousand dollars, to be reserved in such lease and secured by a deposit of United states bonds to that amount; and every such leaso shall be duly executed in duplicate, and shall not be transferable.

SEc. 1964. The Secretary of the Treasury shall take from the lessees of such islands in all cases a bond, with securities, in a sum not less than five hundred thousand dollars, conditioned for the faithful observance of all the laws and requirements of Congress, and the regulations of the Secretary of Treasury, touching the taking of fur seals and the disposing of the same, and for the payment of all taxes aud dues accruing to the ['nited States connected therewith.

SEc. 1965. No persons other than American citizens shall be permitted, by lease or otherwise, to occupy the islands of St. Paul and St. George, or either of them, for the purpose of taking the skins of fur-seals therefrom, nor shall auy foreign vessels be engaged in taking such skins; and the Secretary of the T'reasury shall vacate and declare any lease forfeited if the same be held or operated for the use, benefit, or adrantage, directly or indirectly, of any persons other than American citizens.

SEC. 1966. Every lease shall coutain a coveuant on the part of the lessee that he will not keep, sell, furnish, give, or dispose of any distilled spirits or spirituous liquors on either of those islands to any of the natives thereof, such person lot being a plissician and furnishing the same for use as medicine; and every revenue officer, ofticially acting as such, on either of the islands, sball seize and destroy any distilled or spirituous liquors found thereon; but such officer shall make detailed reports of his doings in that matter to the collector of the port.

SEc. 1967. Every person who kills any fur-seal on either of those islands, or in the waters adjacent thereto, without anthority of the lessees thereof, and every person who molests, listurbs, or interferes with the lessees, or either of them, or their agents or employés, in the lawful prosecntion of their business, nuder the provisions of this chapter, shall for each offense be punished as prescribed in section nineteen hundred and sixty-ove; and all vessels, their tackle, apparel, appurtenances, and cargo, whose crews are found engaged in any violation of the provisions of sections nineteen hundred and sixty-five to nineteen hundred and sixty-eight, inclusive, shall be forfeited to the United States.

SEC. 1968. If any person or company, under any lease herein authorized, knowingly kills, or pervits to be killed, any number of seals exceeding the number for each island in this chapter preseribed, such person or company shall, in addition to the penalties and forfeitures herein provided, forfeit the whole number of the skins of seals killed in that year, or, in case the same may have been disposed of, then such person or company shall forfeit the value of the same.

SEc. 1969. In addition to the anmual rental required to be reserved in every lease, as provided in section nineteen hundred aud sixty-three, a reveuue tax or duty of two dollars is laid upon each fur-seal skin taken and shipped from the islauds of St. Paul and St. George, during the continuance of any lease, to be paid into the Treasury of the United States; and the Secretary of the Treasury is empowered to make all needful regulations for the collection and payment of the same, and to secure the comfort, maintenance, education, aud protection of the natives of those islands, and also to carry into full eflect all the provisions of this chapter except as otherwise preseribed.

SEc. 1970. The Secretary of the Treasury may terminate any lease given to any person, company, or corporation on full and satisfactory proof of the violation of any of the provisions of this chapter or the regulations established by him.

SEC. 1971. The lessees shall furnish to the several masters of vessels employed by them certified copies of the lease held by them respectively, which shall be presented to the Govermment reveune officer for the time being who may be in charge at the islands as the authority of the party for landing and taking skins.

Sic. 197:. Congress may at any time hereafter alter, ameud, or repeal sectious from nineteen hmolred and sixty to nimeteen hundred and seventy-one, both inclusive, of this chapter.

SEc. 1973. The Secretary of the Treasury is authorized to appoint one ageut and three assistant agents, who shall he charged with the management of the seal fisheries in Alaska, and the performance of such other duties as may be assigned to them by the Secretary of the Treasury.

SEC. 1974. The agent shall receive the sum of ten dollars each dar, one assistant agent the sum of eight dollars each day, and two assistaut agents the sum of six dollars each day while so emploved; and they shall also be aliowed their necessary traveling expenses in going to and returning from Alaska, for which expenses rouchers shall be presented to the proper acemuting officers of the Treasury; and such expenses shall not exceed in the aggregate six hundred dollars each in auy one year. 
SEC. 1975. Such agents shall never be interested, directly or indircetly, in ang lease of the right to take seals, nor in any proceeds or profits thereof, either as owner, agent, partner, or otherwise.

SEC. 1976. Such agents are empowered to administer oaths in all cases relating to the service of the United States, and to take testimony in Alaska for the nse of the Govermment in any matter concerning the public revenues.

SEc. 2591 . There shall be in the Territory of Alaska one collection district, as follows: The district of Alaska ; to eomprise all the Territory of Alaska; in which Sitka shall be the port of entry.

SEC. 2592. There shall be in the collection district of Alaska a collector, who shall reside at Sitka.

SEc. 4140. The Secretary of the Treasury may make such regulations as he may deem expedient for the nationalization of all vessels owneri by actual residents of the Territory of Alaska, on the twentieth das of June, eighteen hundred and sixty-seven, and which continmed to be so owned up to the date of such nationalization.

CirAl. 64.- $\mathrm{AN}$ ACT to amend the act entitled "An act to prevent the extermination of fur-bearing animals in Alaska," approved July first, eighteen hundred and seventy.

Be it enacted by the Senate and House of Representatires of the United States of America in Congress assembled, That the act entitled "Au act to prevent the extermination of fur-bearing animals in Alaska," approved July first, eighteen hundred and seventy, is hereby anemiled so as to anthorize the Secretary of the Treasury, and he is hereby authorized, to designate the months in which fur-seals may be taken for their skins on the islands of St. Panl and St. George, in Alaska, and in the waters adjacent thereto, and the number to be taken ou or about each island respectively.

\section{Treasurt Departarent, February 8, 1870.}

The attention of collectors and uther ofticers of the customs is directed to the following Executive order:

\section{Executive Mansion,}

Tashington, D. C., February 4, 1870.

Under and in pursuance of the authority rested in we by the provisions of the second section of the act of Congress, approved on the 27th day of July, 1868, entitled "An act to extend the laws of the United States relating to enstoms, commerce, and navigation over the territory cederl to the United States ly Russia; to establish a collection district therein, anil for other purposes," the importation of distilled spirits into and within the distriet of Alaska is hereby probibited, and the importation and use of fire-arms and ammunition into and within the islands of St. Paul and St. George, in said district, are also hereby prohibited, under the pains and penalties of law.

U. S. Grant, President.

In conformity with the foregoing order of the President, and to insure its faithful execution, collectors of customs are bereby instructed to refuse clearance to ail vessels baving on board distilled spirits for ports, places, or islands within the territory and collection district of Alaska.

Vessels clearing for any port or place intenling to touch, trade, or pass within the waters of Alaska, with distillet spirits or fire-arms and ammunition on board, will be required to execute and deliver to the collector of customs, at the port of clearance, a good and sufficient bond in double the value of the articles so laden, conditioned that said spirits, or any part thereof, shall not be landed unon or disposed of within the Territory of Alaska, or that said arms aud ammunition, or any part thereof, shall not be landed, disposed of, or used upon either of the islands of St. Paul or St. George, in said district. 
Treasury Department, September 10, $18 \% 0$.

The following executive order relating to the importation of arms into the islands of St. Paul and St. George, within the District of Alaska, is published for the information of officers of the customs :

\section{Executive Mansion,}

Wrashington, D. C., September 9, 1870.

So mueh of executive order of February 4, 1870, as prohibits the importation and nse of fire-arms and ammunition into and within the islands of St. Panl and St. George, Alaska, is hereby modified so as to permit the Alaska Commercial Company to take a limited quantity of fire-arms and ammunition to said islands, subject to the directions of the reveune officers there and such regulations as the Secretary of the Treasury may prescribe.

\section{U. S. Grant,}

\section{President.}

The instructions issued by this Department in its eircular of February 8, 1870, are accordingly modified so as to adjust them to the above order. Revenue officers will, however, see that the privilege granted to the said company is not abused; that no fire-arms of auy kind are ever used by said compauy in the killing of seals or other fur-bearing animals on or near sair islands or near the haunts of seals or sea-otters in the District, nor for any purpose whatever, during the months of June, July, Angust, September, and October of each year, nor after the arrival of seals in the spring or before their departure in the fall, excepting for necessary protection and defense against maranders or public enemies who may unlawfully attempt to land upon the islands.

In all other respects the instructions of February 8, 1870 , will remain in force.

WM. A. RICIIARDSON, Acting secretary.

\section{EXECUTIVE ORDERS.}

\section{To Collectors of Customs :}

Treasury Departaent, Washington, D. C., July $3,1875$.

The importation of breech-loading rifles, and fixed ammunition snitable therefor, into the Territory of Alaska, and the shipment of such rifles or anmunition to any port or place in the Territory of Alaska, are hereby forbudden, and collectors of customs are instructed to refuse clearance of any vessel having on board any such arms or ammunition destined for any port or place in said Territory.

If, however, any vessel intends to tonch or trade at any port in Alaska Territory, or to pass within the waters thereof, but shall be ultimately destined for some port or place not withiu the limits of said Territory, and shall have on board any such firearms or ammunition, the master or chief oflicer thereof will be required to execute and deliver to the collector of customs at the port of clearance a good and sufficient bond, with two sureties, in double the value of snch merchandise, conditioned rhat such arms or ammunition, or any part thereof, shall not be landed or disposed of within the Territory of Alaska.

Such hond shall be taken for such time as the collector shall deem proper, and may be satisfied npon proof's similar to those required to satisfy ordinary export bouds, showing that such arms have been landed at some foreign port; or, if such merchandise is laudecl at any port of the United States not within the limits of the Territory of Alaska, the bond may be satisfier upon production of a certificate to that effeet from the collector of the port where it is so landed.

Approved :

Ohas. F. Conant, Acting Secretary.

U. S. Grant, President.

NOTICE.

Treasury DepartMent,

Washington, D. C., April $21,1879$.

Section 1956 of the Revised Statutes of the United States provides that no person shall, withont the consent of the Secretary of the Treasury, kill any otter, mink, marten, sable, or fur seal, or other fur-bearing animal within tho limits of Alaska Territory, or in the waters thereof, and that any person convicted of a violation of 
that section shall, for each offense, be fined not less than two hundred nor more than one thousand dollars, or be imprisoned not more than six months, or both; and that all vessels, with their tackle, apparel, furniture, and cargo, found engaged in violation of that section shall be forfeited.

No fur-bearing animals will, therefore, be allowed to be killed by persons other than the natives within the limits of Alaska Territory, or in the waters thereof, except fur seals taken by the Alaska Commercial Company, in pursuance of their lease. The use of fire-arms by the natives in killing otter during the months of May, June, July, August, and September is hereby prohibited. No vessel will be allowed to anchor in the well-known otter killing grounds, except those which may carry parties of natives to or from such killing grounds; and it will be the duty of the officers of the United States, who may be in that locality, to take all proper measures to enforce all the pains and penalties of the law against persons found guilty of a violation thereof. White men lawfully married to natives and residing within the Territory are considered natives within the meaning of this order.

JoHi SHerman, Secretary of the Treasury.

\section{WINE AND BEER.}

The Treasury Department, in a letter to the collector of customs at Sitka, Alaskadated October 7, 1881, held that section 1955, Revised Statutes, which prohibits ship ments of distilled spirits to Alaska, does not include wine; and also by letter dated December 5,1881 , to the collector of customs at Port Townsepd, Wash., that said section does not include beer, which is a fermented liquor and not a distilled spirit.

Previous instructions were modified accordingly.

COPY OF LEASE FROM THE UNITED STATES TO THE ALASKA COMMERCIAL COMPANY OF THE RIGHT TO TAKE FUR SEALS IN ALASKA.-DELIVERED AUGUST 31, 1870.

This indenture, in duplicate, made this third day of August, A. D. eighteen hundred and seventy, by and between William A. Richardson, Acting Secretary of the Treasury, in pursuance of an act of Congress approved July 1st, 1870, entitled "An act to prevent the extermination of fur-bearing animals in Alaska," and the Alaska Commercial Company, a corporation duly established under the laws of the State of California, acting by John F. Miller, its president and agent, in accordance with a resolution of said corporation duly adopted at a meeting of its board of trustees held January 31st, 1870, witnesseth:

That the said Secretary hereby leases to the said Alaska Commercial Company, without power of transfer, for the term of twenty years from the first day of Mas, 1870, the right to engage in the bnsiness of taking fur seals on the islands of St. George and St. Paul within the Territory of Alaska, and to send a vessel or vessels to said islands for the skins of such seals.

And the said Alaska Commercial Company, in consideration of their right under this lease, hereby covenant and agree to pay for each year during said term, and in proportion during any part thereof, the sum of fifty-five thousand dollars iuto the Treasury of the United States, in accordance with the regulations of the Secretary to be made for this purpose under said act, which pasment shall be secured by deposit of United States bonds to that amount; and also covenant and agree to pay anmually into the Treasury of the United States under said rules aud regulations a revenue tax or duty of two dollars upon each fur-seal skin taken and shipped by them in accordance with the prorisions of the act aforesaid; and also the sum of sixty-two and one-half cents for each fur-seal skin taken and shipped, and tifty-five cents per gallon for each gallon of oil obtained from said seals for sale on said islands or elsewhere and sold by said company. And also covenant and agree, in accordance with said rules and regulations, to furnish, free of charge, the inhabitants of the islands of St. Panl and St. George annually, during said term, twenty-five thousaud dried salmon, sixty cords fire-wood, a sufticient quantity of salt, and a sufticient number of barrels for preserving the necessary supply of meat.

And the said lessees also hereby covenant and agree, during the term aforesaid, to maintain a school on each island in accordance with said rules and regulations, and suitable for the education of the natives of said islands, for a period of not less than eight months in each year.

And the said lessees further covenant and agree not to kill upon said island of St. Paul more than seventy-five thousand fur seals, and upon the island of St. George not more than twenty-five thousand fur seals per annum; not to kill any fur seal upon the islauds aforesaid in any other month except the months of June, July, Sep- 
tember, and Octoher of each year; not to kill such seals at any time by the use of fire-arms or other means teuding to drive the seals from said islands; not to kill any female seal or any seal less than one year old; not to kill any seal in the waters atjacent to said islands or on the beaches, clitis, or rocks where they haul up from thu sea to romain.

And the said lessees further covenant and agree to abide by any restriction or linitation upon the right to kill seals under this lease that the act prescribes, or that the Secretary of the Treasury shall judge necessary for the preservation of such seals.

And the said lessees hereby arree that they will not in any way sell, transfer, or assign this lease; and that any transfer, sale, or assigmment of the same shall be void and of no effect.

Aud the said lessees further covenaut aud agree to furnish to the several masters of the vessels employed by them certified copies of this lease, to be presented to the Government revenue officers for the time being in charge of said islands, as the anthority of said lessees for the landing and taking said skins.

And the said lessees further corenant and agree that they or their agents shall not keep, sell, furnish, give, or dispose of any distilled spirits or spirituons linuors on either of said islands to any of the natives thereof, such person not being a physician and furnishing the samo for use as medicine.

And the said lessees further covenant and agree that this lease is accepted subject to all needful rules aud regulations which shall at any time or times hereafter be made by the Secretary of the Treasury for the collection and payment of the rentals herein agreed to be paid by said lessees; for the comfort, maintmance, education, and protection of the natives of said islands, and for carrying into effect all the provisions of the act aforesaid, and will abide by and conform to said rules and regulations.

And the said lessees, accepting this lease with a full knowledge of the provisions of the aforesaid act of Congress, further covenant aud agree that they will fulfill all the provisions, reguirements, and limitations of said act, whether herein specifically set out or not.

In witness whereof the parties aforesaid have hereunto set their hauds and seals the day and year above written.

William A. Richardson, [SEAL.] Acting Secretary of the Treasury. Alaska Commercial Com
By Jno. F. Millir, President.

Executed in presence of-

\section{J. H. SAVILLE.}

\section{Treasury Department, Office of the Shcretary,}

Washington, D. C., March 12, 1881.

SIR: Your letter of the 19th ultimo, requesting certain information in regard to the meaning placed by this Department upon the law regulatiug the killing of tur-bearing animals in the Territory of Alaska, was duly received. The law jrohibits the killing of auy fur-bsing animals, except as otherwise therein provided, within the limits of Alaska Territory or in the waters thereof, and also prohibits the killing of any fur seals on the islands of St. Paul and St. George or in tine waters adjacent thereto, except during certain months.

You inquire in regard to the interpretation of the terms "waters thereof" and "waters adjacent thereto," as used in the law, and how fir the jurisiliction of the United States is to be understood as extending.

Presuming your inquiry to relate more especially to the waters of western Alaska, you are informed that the treaty with Russia, of March 30, 1870, by which the Territory of Alaska was eerled to the United States, defines the bomilary of the Territory so celed. This troaty is found on pages 671 to 673 of the volume of treaties of the Revised statutes. It will be seen therefrom that the limit of the cession extends from a line starting from the Arctic Oeean and rumuing through Bering Strait to the north of St. Lawrence Islands. The liue runs thence in a southwesterly direction, so as to pass midway between the island of Attoo aud Copper Island of tho Kromanboski conplet or gromp, in the North Pacific Ocean, to meridian of 19:3 desrees of west longitude. All the waters within that boundary, to the western end of the Alentian Archipelano and chain of islands, are considered as comprised within the waters of Alaska Territory.

All the penalties preseribed by law against the killing of fur-bearing animals would therefore attach against any violation of law within tho limits before described. Very respectfully,

Mr. D. A. ANCONA, Acting Secretary.

No. 717 O'Farrell street, San Francisco, Cal. 
REGULATIONS GOVERNING THE SEAL FISHERIES IN ALASIKA.

The law limits the number of seals which may be killed for their skins on the islands of St. Paul and St. George to one hundred thousand $(100,000)$ per aumum. At present the quota is fixed at eighty thousand $(80,000)$ for St. Paul Isiaud and twenty thousand $(: 0,000)$ for St. George Island. This proportion may be: varied from time to time by the Secretary of the Treasury, as facts may seem to demand.

The skins will be counted by 'Treasury agents as they are placed in the salt houses, and again as they are placed on board the vessel; and a daily record of the count will be kept. This record will be filed, and from it will be entered, in a ledger, a proper report of the season's catch. At the close of each season a report to the Treasury Department will be marle by the principal agent, showing the number of skins taken and shipped, which will inclule the skins of any seals killed for food and accepted by the company as part of its quota. The report will also show to what extent the company has performed the other conditions of the lease, with respect to furnishing supplies to the natives, keeping the school, etc., and generally embracing a review for the year of the condition of affairs at the islands. The natives are expected to perform the work assigned them in an orderly and proper manner, and the making or the use of "quass" or other intoxicating driuks will be discouraged by the officers of the compauy and of the Government, and, when necessars, the issuance of supplies from which sueh beverages can be made may be refused. To do the coarser kind of work, such as salting the skius, etc., the company is authorized to take from other parts of the Territory a proper number of men who may be used to do the work of killing or flayiug, sliould the natives of the islands fail or refuse to do their work or to perform it in a satisfactory manner.

The Treasury agents are expected to maintain order, require the attendance of the children at the school, and lend their best efforts to regulate the condition of affairs so as to promote the welfare of the natives and advance them in civilization.

Occasional visits will be made by the Government ofticers to Otter Island, situate about six miles from St. Paul Island, where large numbers of seals congregate, in order to keep off marauders aud prevent the unlaw ful killing of seals. On shipment of the skins from the seal islands, a certificate, signed by the Treasurs ageut and by the captain of the vessel, of the number of skius laden on board, will be marle out in duplicate, one copy to be given to the captain and one to be retained by the agent. The captain will, on arrival, deliver his copy to the collector of custons at San Francisco. The skins will be then counted by officers detailed by the collector for that purpose, and a record of each day's count made. Temporary payment of tax will be accepted on the count of skins made at San Francisco, and a report will, upon pasment of such tax, be made by the collector to the Treasury, showing the number of skins embraced in the certificate presented by the captain, the number ascertained by the San Francisco count, and the sum paidas tax. Should ant considerable variance be shown by these reports between the count of the sliws made at the islands aud that made at San Frauciseo the Department will take such action in regard thereto as the facts may appear to demand.

Mr. Manchester, the assistant agent, who had been upon the islands the fear before, landed the same spring with Mr. Gavitt, and having had one year's experience upon the island; I said to Mr. Gavitt, "Mr. Gavitt, Mr. Manchester knows all about this business, and is fully posted and fully instructed, and that you may get along smoothly when you are left here aloue at the close of the season, and Mr. Manchester goes over to St. Paul, I will leave Mr. Manchester in charge of the islands for the summer. You will be instructed by Mr. Manchester. You will observe bow he conducts the business, learn it, and be better equipped for going through the winter alone." He did not seem to like it, and was very much displeased with it, in fact. From that time on he was hostile and displeased with me for making him subject to Mr. Manchester. Mr. Manchester instructed him as far as he would receive any instructions from him, but he was not disposed to take it from Manchester; in fact, he treated him rery disrespectfully and unkindly.

Mr. Gavitt was left in charge in August and Mr. Manchester was placed in charge of St. Paul Island. I returned, by authority of the Department, a cops of which anthority I have here, back to San Francisco and spent the winter. On my return to the islands in the spring 
the steamer was not able to land at St. George Island, owing to rough weather, and we went on to St. Paul, so that I did not have an opportunity to see Mr. Gavitt until some time after I arrived in the country. However, he had an opportunity of writing to me after I lauded and told his story about the winter's troubles. Ife wrote several letters to me under date of Jume 3, making complaints agaiust the Alaska Commereial Company's agents who were with him on St. George. He seemed to have quarreled with everybody. There was not a single good man on the island, not one. I, of course, investigated the matter thoroughly, and in reply to these letters I wrote this official letter, a copy of which I would like to read as part of $\mathrm{my}$ evidence.

The letter was reat as follows:

\section{Office of Special Agent Treasury Departunent,}

St. Paul, June 8, 1888.

Sir : Your various letters of $J$ tune 3 received by the return of the steamer St. I'aul.

Yon will restore Eustin Swetzoff, whor: I leprived of his privilege as sealer last year as punishment for his refusing to obey Dr. Noyes, acting assistaut Treasury agent, and for inciting a riot; tell him he goes to work by my order.

From your own showing, the school was kept eight school months from september 5 to April 30 , and you will so enter on the account aud report to mo when you send me your report of the season.

Your recommendation as to senting the Austeggoffs from the island will remain for my action when I come over to the island.

As to the old broken furniture you speak of in the house, you and Captain Loud can disposo of as you may deem best; if there is auything the captain wishes to repair and keep for his use, let him do so.

Your order preventing the company from killing seals on the 1st day of June was wrong, the law fixes that absolutely; during the killing season, commencing lst day of June, they have charge of the seal killing.

Your order served on the company's local agent vacating the compauy's lease was, as you must know, irregular. You or I have no power under the law to say when they have violated their contract with the Government and forfeited their lease. I am expected to report all facts, ineluding violations of law, and it is your duts to report to me, and no one else, all facts and violations of law that I mily report to the Department. You did wrong in makiug a report to the Alaska Commercial Com. pany's general agent in writing of matters pertaining to the island under your charge. You are, under the regulations and the law, required to report to tho Treasury agent in charge only.

As to the matters personal to myself, of which I have been informed fully, I will speak to you in person.

I will come over when I can to close the business of the season. Should the Thetis arrive and land on St. George with the governor and ofticers of the Territory on board, and they should wish any information regarding the fun-seal islands, jou will refer them to me as the proper personto give them full information, as the books and papers are all kept here by me. You will pursue the same course as to the Concressional committee, shonld they arrive. Treat the governor and lis party with tho courtesy their positions entitle them to.

I am, very respectiully,

William GavitT, Esq., Assistant Treasury Agent, St. George Tsland.

GEO. R. TINGLE, Treasury Agent.

I heard nothing more from Mr. Gavitt until I went over there to continue the investigation. I made a full investigation of the matter com plained of, and before I left the island I wrote to Captain Loud, who was in charge, this letter.

The letter was read as follows:

Office of Special Agent Treasury Department, St. Paul Island, Alaska, August 10, 1888.

Sin: In the matter of the charges and emmlaints of William Gavitt, assistaut Treasury agent, against the Alaska Commercial Company's emplosés on St. George Island, as spreat on the journal in the Treasury agent's oflice, and as set forth to mo in his letters of the $\therefore$. June, on file in the oftice, I have to say that I male an ox- 
haustive investigation into the whole matter complained of, taking the sworn statements of those persons who had wintered on the island with Mr. Gavitt, as well as his own statement.

The affidavit of Dr. C. A. Lutz, Daniel Webster, and Eugene Kirk disprove wholly all the charges made by Mr. Gavitt, whilst the recital to me by Mr. Gavitt himself on the oceasion of my visit to St. George Island on 30th ultimo only strengthened the statements of others, and leaves him in the unenviable position of having been the main canse of disturbing the harmony and persoual friendly relations which existed among the white people of the station when I left him in charge one year ago. Many of the things complained of and recorded by Mr. Gavitt in the publie journal, improperly, are of a trivial nature, not proper to be written in the journal.

I can only excuse Mr. Gavitt's conduct in many things on the ground of ill health. In taking this extremely charitable view, I must, in justice, say that he manifested a disposition of ineuborlination to his superior officer, aud was cuarrelsome to a degree which became unbearalble.

Many of the entries in bis journal are absolutely falso and rlisgraceful, so much so that I can not refrain from placing on record in the journal this letter, and therefore ask you to spread it in full upon the jourual, with such additional iudorsements by you which jour association and knowledge of Mr. Gavitt would warrant.

I am, very respectfully,

Capt. A. P. Loud,

Geo. R. Tingle, Treasury Agent.

Assistant Treasuriy Agent, St. George Istand.

Mr. Jeffries. Q. Is this official correspondence?-A. Tes, sir.

The Cmamran. Are you acquaintel with Mr. Webster, agent of the company?-A. Yes, sir; rery well, for the last three rears past.

Q. You read Mr. Gavitt's testiu ony in relation to Mir. Webster?-A. Yes, sir.

Q. In which he says that he (Mr. W'ebster) was habitually intoxicated. What do you think of Mr. Webster in regard to his hahitual propriety and moral conduct?-A. I know Mr. IVebster intimately; in that respect he is grossly misrepresented. There is not, iu fact, a shadow of truth in the statement of Mr. Gavitt in regard to Mr. Webster. He is an old sailor, and went around the Horn when he was ten years old, as I have said, and has been in that country ever since, and, of course, has not had the advantage persons have in being educated. But I consider lim very much of a gentleman; he is thoroughly honest and true to the interests of his employers and is a good citizen, as respectable as you will find in any place; as to being habitually drumk, there is not one word of truth in it. I am told that Mr. Webster when iu San Francisco will occasionally take a drink. Beyond that I hare never heard Mr. Webster was a drinking man at all. The truth is, I have uffered him liquor myself in my house on St. Paul and he has refused it. I have never known him to take a drink there. I keep a little there for medicinal purposes, and not knowing when we may be risited by a Congressional committee or the goremor of Alaska I am always prepared for them, and this summer when the goreruor risited me on St. Paul Island I am sure my forethought was duly appreciated.

Q. Or ju case a sea-serpent bit you?-A. I had occasion for it this summer, when the gorernor risited me. Mr. W'ebster has persistently refused to drink anything in my house. The story of his being habitually drunk is absolntely false.

Q. Is Mr. Webster disposed to resist the authority of the Government agents?-A. On the contrary, he is very careful to obey the orders. He has been trained in that kind of a school, and he knows the importance of obeying orders and law. He is the last man I know of in the company's employ to be charged with anything thrt would reflect upon a gentleman.

Q. What do you say as to whether or not the uatires on the seal isl- 
ands are satisfied with their condition and treatment by the agents and employés of the company? Mr. Gavitt said that they were dissatistied, you remember, in his evidence.-A. I can not say that they are entirely and perfectly satisfied. I do not think that would be just exactly the truth, because they are a restless people. They will ask the new ageut representing the Goverument if there has been any change in the laws, and will possibly ask him who the seals belong to, and if they did not belong to them. They are hoping all the time there will be something turn up by which their condition will be changed a little, not that it will be for the better or that they have aus clear idea as to what ther want. You take any one of them who has any complaints to make and say, "All right, if yon are dissatified I will send you to Oonalaska," and he will say, "Oh, no; do not seud me away from here; I do not want to go awas from here," that is not the idea at all. When you talk of giving them a residence any place but these islands they are perfectly satisfied; they would not for any consideration be removed from those islands.

Q. Do you mean to convey the idea that they would iike to have the seals turned over to them?-A. Yes, sir; they asked me the question when I went up on the island. The next complaint is, that they are not allowed sugar. They would say, "TVe have no sugar for our tea and coffee." The truth is, you ean not trust them with sugar or anything else of which intoxicants can be madle. They will swear to you that they will not use it for that purpose, but they can not help it. They will do it and lie to you. No matter under what condition they would get 5 pounds of sugar they would go and use that sugar for making quass. For this reason we can not trust them with sugar, and they are not allowed to have it at all. Their condition since sugar has been kept from them has vastly improved, and is improving all the time.

Mr. JefFries. Mr. Chairman, would sou ask him whether that was done by authority and by the consent of the Gorernment agents-that stopping of the issuing of sugar?

The Witness. The matter was represented to the Secretary of the Treasury before I went there. I found this a matter of record, and my immediate predecessors, Captain Moulton and Mr. Glidden, carried out this recommeudation. They recommended to the Secretary that sugar should be kepr away from them, and the Secretary authorized that it should not be issued to them. It was by authority of the Treasury Department that the sugar was taken from them. The Alaska Commercial Company had no choice in the matter. If they issue sugar to the natives the Government officer would hanl them orer the coals for it and thes would not presume to do it withont his order. They do not do anything ou those islands in violation of the Treasury regulations or the law, if they know it.

The Chairian. What do you say about the treatment of the natires by the company's agents?

The WITNESS. It has always been my opinion that the treatment of the natives is entirely too goou. They spoil them for anyborly else who may come after them. They expect more than they will ever receive again from any other company. Thes treat them with a great deal of care and consideration, and allow them a great many things gratuitously they are not bound by the contract or under the law to give, and it would be hard for the natives to understand why the same treatment was not continnes to them. I kunt of no lahoring class of people in this country at any place who receive as much money, consideration, and comfort for so little work. Their work, all told, in taking the seal 
skins and doing outside work for the eompany is not orer ninety work. ing days out of three hundred and sixty-fire. I think that ninety days would give the average, and they get an average of $\$ 500$ to a family in cash annually besides gratuities.

Q. As to the moral condition of the natives on those islands, to what extent, if any, does prostitution exist there, and who is engaged in it? Is it the habit of the company's agents there or other white persons there to debauch and demoralize the females?-A. If there is any prostitution going ou there, I do not know it. I nerer had buc one case brought to my attentiou officially, and that was a case of Metrophan Shutygean, who complained to me that a native oy the name of Popoff was sleeping with his wife, and he wanted that bușiness stopped if it could be done, and that it was inconrenient for him to get up early in the morning; get his own breakfast before going to work on the sealfield.

Q. Who was Popoff?-A. He was one of the natives of the island. He at that time did not have any wife.

Q. He was not one of the company's agents?-A. No, sir ; ther were both uatives. I said, "MIetrophan, what do you want me to do?" He saicl, "I want you to stop him and to bring him up for trial." All these little offenses are brought before the Gorermment agent. We had a trial, and Martin Popoff was summoned, ?ud Metrophan and Olita, his wife, with the necessary wituesses, etc. He testified he had gone to Popoff's honse at 3 o'clock in the morning and saw his wife in bed with Martiu Popoff. Olita admitted the fact, but claimed that she was to blame and not Martin, as she had gone to him, and that she did not think Martin onght to be punished. But still, atter hearing the evidence, I fined him $\$ 10$ in the interest of morality. They all promised to hehave themselves after that and be decent people. As far as I lnnow, Olita has behared herself and stayed at howe with Metrophan. Martin Popoff has since died. That had a very good effect on the community. It was the first and only instance where parties had been hanled up for that, and being on the complaint of a husband, I took the opportunity to talk to the natives alout it, and deliver them a lecture. There were quite a number of persous present on whom it had quite a beneficial effect. There is less immorality on the seal islands than any community of semi-civilized people $I$ erer saw, I think. IVithout donbt the natives are immoral to some extent, or at least they are said to be among themselves.

Q. Is it your opinion that the white men there to any extent were responsible for that immorality ?-A. No, sir; I think the natires upon both islauds are improved by association with them, since we have owner and earried on affairs there; my own observation is that they are gradualls improving in morals aud gradually adopting our customs and habits and becoming reconciled to their citizenship of the United States. It was very hard for them to break off their old association and connections with Russia.

Q. Did you observe the company's agents there extended special privileges to any particular females, the natire females, in consideration of immoraiities of any kind?-A. No, sir; there is no truth at all in that. I do not think there is any consideration of that kind extencied by any of the company's employés to any female upon the islands.

Q. It has been stated that Miry Onstagoff was a notorions prostitute and was known to be such, and was permitted around the company house and received favors that others could not get?-A. I think I can tell about that. She is dead now, poor old woman. She was a prosti- 
tute; everybody understood and knew that Mary Oustagoff was a prostitute. Of course it was only hearsay as far as that is concerned, but it was developed in the investigation of the Gavitt business that Mr. Gavitt wanted to use her for his own purposes and she declined; she said, "No, Mr. Gavitt, you have your wife, your bride here, and I do not want any trouble between you and your wife, aud I will not come to you." She refused absolutely. Then Gavitt got up this scheme to send them off the island, and said that they were all drunk; that they had quass under the floor. In my investigation of Mr. Gavitt's troubles I inquired into that, and Mr. Gavitt himself explained to me that he found the story of the quass under the floor was not true, by going to the house and tearing up the carpet and opening up the trap-door where it was supposed to be stored, and he found there was none secreted there. There are several witnesses in the room who can tell you more than I ean about it; at any rate, $I$ found the story of their being drunk was not true. I did not go there until after Mary died, but she sent me word she would like to make a statement to me before she died. I could not get there. Howerer, she sent me a statement that Mr. Gavitt tried to entice her into the Government house when his wife was absent, and she refused to go ; that was the cause of Mr. Gavitt's enmity, and his reason for wanting to send them oft the island. Mary Oustayoff was a good woman to work-one of the company's best working women-very clean and nice abont the house, although she was a prostitute. I was in her house when I was on the island making the investigation. Mary kept a clean, nice house, the best on the island.

Q. What was it about the girl he wanted to be married? Mr. Gavitt's statement was, the company's physician prevented the marriage.

Mr. MACDONALD. What is the basis of your knowledge as to Gavitt's having endeavored to entice this Mary Oustagoff to submit to his desires? How did you get the information?

The Witness. She sent me word herself.

Q. You got it from her?-A. Yes, sir; I heard it outside, and I sent word to know. I asked Dr. Noyes to inquire if it was true and she was willing to make a statement under oath and send it to me. The evidence of his immorality is abundant, if you want to go into anything of that kind; the witnesses are here who can prove it.

By the Chatritan:

Q. Anything connected with official conduct is all right; but what I wanted to direct your attention to was- you have testified, or rather spoken about, the company's physician preventing a native girl from marrying. State in relation to that.-A. Gavitt wanted a native girl to marry a man named Logan, of Oonalaska, and the girl did not want to marry him. He wanted to force her to marry him. This girl lived with Mary Onstagoff. The girl did not want to leave the Onstagoff family, where she was very well treated, and she did not want to be married.

Gavitt got the idea in his head that he wanted to make this match. When I eame over there he wanted me to take his view of the case and I went to see the girl and ascertained whether she desired to marry this man. She said she did not wish to marry him and she wanted to live with Alexa, who is Mary's husband. I asked her if there was any one she was interested in. I told her if there was not I knew a young man who wonld make her a nice husband and I recommended her to see him. She dinl not mary Logan, and when I left there she was not married at all and dirl not want to marry. The young man I spoke of was Neon Tetolf. He has since married, and my last reports from Captain Loud are 
that the girl was still unmarried. Mr. Gavitt speaks in his testimony of Dr. Noyes having sent the native, Peter Resanzoff, to Zopodine. With your permission, MIr. Chairman, I have an official letter here from my agent on St. George, Captain Loud, upon that subject. I would like to put it in evidence. Peter was the friend and companion of both Ryan and Gavitt and ranks among whites and natires as the worst man on the island.

Here the letter was read as follows:

\section{Office of Special Agent Treasury Departinent,}

St. George Island, dugust 10, 1888 .

My Dear Sin: The steam-ship St. Paul arrived here yesterday at $4.30 \mathrm{p} . \mathrm{m}$.; we immediately commenced loading skins; we got all on board at midnight. Mr. G. aud wife they were afraid to go on board, Gavitt told Clark, and wanted to buy the revolver in company's oftice for his ow use. Mr. Clark told him no, he could not sell it, and that he would be treated kindly aud as a gentleman ou board of the steamer; be got a native rifle, and I found it in his room loaded last night after he left; he has lone many strange things on this island which does no erentit to himself. I au afraid that he is a good sulject for a lunatic mansion. His jourual I never saw it until after he left last vight, as he always had it carefully in his room. I was surprised to fiud that he had so far disgraced the name of a Democrat as to write such base fabrications in a Government jourmal, and then has so disfigured urany of the pages by scratehing and interlining.

He acenses me of seuding his friend Peter Resanzoff to Zopodine for punishment. Peter was sent to Zopodine the day yon were here to relieve Huestou, who was sick. Last Sunday he (Gavitt) sent for Peter by a hoy, Joseph Mocoloff. I told the chief that I conld not trust any boy to watch a rookyn so far away; that I must have a man for that work. He told me that Peter wonld return to Zopodiue in the morning, as he only came in to see Gavitt on business. In the morning I found that Peter had returned to Zopodine of his own will, and is there yet. He calls down the curse of God upon me for punishing Peter, of which I had vo intention to do. Yesterdary he made a drive of seals for food; killed thirty-nine, of which seven were rejectedsmall. He maile an awful bad job of seal killing. He would point out the seals and order the natives to knock down. I have been informed that the first seal killed was a female.

Very sincerely, yours,

A. P. Loud.

That is all in regard to that matter; the balance is unimportant.

Now, in relation to Mr. VVebster, here is a letter dated August 30, 1Sss, after I left the country, which is an official report to me at San Francisco. When we left the island of St. Paul we carried Mr. Webster and the girl, Arclosia Popoff, past St. George, because of rough weather we could not land them there; and so they went to Oonalaska, and returned later to St. George Island. In this letter Captain Loud tells how Captain Webster was received by the natives.

The letter was read, as follows:

Office of Special Agent 'Treasury Department,

St. George, August 30, 1888.

MY DEar SIR: I take this opportunity of writug rou as the United States revenue steamer Rush is now here, and the captain thinks that he will leave for San Franciso as suon as the Thetis gets down from the north. Captain Sheppard reports not having seen any schooners on his last cruise, and none bas been seen from this island, and as it is getting late in the season I don't think we shall be troubled with them this fall.

Your letter, of Angust 10 and $1 R$ I received lyy the Alaska Commercial Companj's steamer Dork, that arrivel here on Sumlar, Angust 97, from San Francisco August 6, via Oonalaska Angust 24. All of them have my careful attention and your instructions will be carefulls attended to. Mr. Webster, Alaska Commercial Company's local agent for thisisland, and Avdosia Popoff also arrived by the Dora. All of the natives seemed pleased to see Mr. Webster on his arrival here. They didn't appear to be afraid of him, as represented li, Mr. Gavitt, but on the contrary they all gathered around. 
him and seemed to be awful pleased to see him. There was a great change in the natives for the better after Mr. Gavitt left the islaud. They all seem to be cheerful and happy now, and wo are getting along nicely now, with overy prospect for a pleasant and happy time for all this winter.

I was sorry to have you leave without haviug seen you again as I very much wanted to have a talk with you, and I wanted you to have examined Mr. Gavitt's journal after he had made so many erasures; it is not a journal that a sane man would write and be proud of his writing. Mrs. Loud joins me in love and kind wishes to yourself and all of your family, hoping this will fiad you arrived at your home and find all well. I will write you again the next opportunity offering. I wrote you to St. Paul, but as you did not connect with the Kush you will receive it, no doubt, at San Francisco. Hoping to hear from you by last vessel,

I am, very respectfully,

A. P. Loud, Assistant Treasury Agent, in charge St. George Island.

Hon. George R. Tingle, Special Treasury Agent, in charge of Seal Islands in Alaska, care of Alaska Commercial Company, San Francisco, Cal.

Q. Are there any other facts and circumstances within your knowledge bearing upon these subjects that you remember now?-A. Here is the letter of Captain Loud, of July, which is in regard to Mr. Gavitt and his conduct there.

Q. Is it in relation to anything Mr. Gavitt has testified to here?-A. It speaks of his bad conduct on the island and particularly as to his character.

The CHAIRmaN. That is personal, and I have no desire to go into an examination of his private habits.

Mr. JeFfries. On behalf of the company we do not desire to make an attack upon Mr. Gavitt or anybody else.

The CHAIRMAN. We ouly want to get your evidence bearing on the points to which Mr. Gavitt has testified.

The WiTnEss. The condition of the natives on those islands, as compared with other parts of Alaska I touched at, is certainly very much superior, and I attribute it wholly to their contact with the Alaska Commercial Company's men and the Goverumentagents who did their duty.

Q. Mr. Gavitt states that a native was reported to him for punishing his wife. He says:

Then I tried him and found him innocent. He wanted to prevent his wife from going to the company house for immoral purposes. I lectured him and dismissed him. Webster called him (the native) aud told him that if he did not permit his wife to come to his room he would break his head.

Was that circumstance brought to your attention?-A. No, sir. Not at all. I am perfectly satisfied that Mr. Webster made use of no such language. He is not that kind of a man.

Q. Have you ever knowu any instance of Webster or the company's agents intimidating Govermment officers there?-A. No, sir; the compauy agents are very careful not to run counter to the Government agents. Their instructions from the compauy's home office are very strict upou that point. They do not want any conflict with the Government in any way, shape, or form; they simply want them to go ahead and perform their work under the law, which they do as far as I know.

Q. In a portion of his (Gavitt's) testimony he says that the islandI suppose he meaus the whole island-is a sort of Government house of prostitution, from one end of the island to the other, and that he reported this to Mr. Tingle. What do you know about that?-A. He reported to me by letter dated June 3 , upon which I made an investi$9984-19$ 
gation, and I found his statements not sustained by the facts. I.knew them to be absolutely false. The evidence I obtained showed, so far as he could make it a place of prostitution himself, he did it, both in the Goverument house and the company's house and elsewhere. He stole a march in the company's house when they were all absent, and had women in there, which can be proven. He had John Hall, the cook, to take his wife ont boating. During her absence Gavitt had Polixenia, a native woman prostitute, to come to him at the Government house, as testified to betore me by Daniel Webster.

Q. He spoke of an inrestigation being made there of these matters by the oflicers of the revenue cutter Bear. Were you there at that time?-A. I was on St. Paul Island at the time the revenue-cutter went there and made this investigation. She came over to St. Paul Island and the captain reported to me through his lientenant, that he had made the investigation.

Q. Is that the report made by the officers [handing same to witness]. That report was transwitted to me at my request from the Secretary of the Treasury. Is that the report referred to?-A. I must say, Mr. Chairman, that I never read the report of Captain Healy.

Q. This is the investigation referred to?-A. I took the lientenant's statement of the investigation, and what they elicited, which was afterwards confirmed by the captain. I never saw his papers. The truth is I did not like their making an investigation upon that islaud. I thought it was an infriugement on my prerogative. I did not think they had the right to go ashore there and make an investigation unless I was first applied to. I never saw the report, but the captain talked over the matter, telling me what it contained.

I consider, under the law and instructions of the Treasury Department, that I had exelusive jurisdiction over those islands, and that if a revenue vessel is there policing the seas and be within hailing distance of the Treasury agent, they should reuder him any assistance he may require of them. I consider they are there for the express purpose of capturing the maranding vessels and to aid him in the execution of the laws. I do not understand that their duties would warrant them in going ashore and making an investigation of this character without first applying to the agent in charge and seeing whether he desires them to do so. How they came to go there exactly I do not know, but they made the investigation, and $\mathrm{I}$ presume this is the report. The Treasury agent is the sole anthority on the fur-seal islands.

Mr. JEFFRIEs. I will ask you to read that report and tell the committee whether the conclusions were the same you came to when fou in restigated this state of facts.-A. Substantially the same, sir.

The witness here read the report, as follows :

\section{U. S. Revenuw-Marine Steanier Bear,}

San Francisco, Cal., December 20, 1 है88.

SiR: In pursuance of your order of June 14, 18 - , a court, composed of Lieutenants Buhner, Dunwoody, Engineers Churchill, Cutchin, and Surgeon Bratton, was conrened at the Government house, on St. George Islaud, to inquire into the nature of the charges preferred br Mr. William Gavitt, special agent of the Treasury for that island, against the Alaska Commercial Company and its agents, and we respectfully submit the following report:

We regard the charges in the main frivolous and of a merely personal nature.

As regards the charges of a really serious nature, the evideuce in support was not satisfactory, while no evidence in rebuttil was introduced.

It appears to $n$ s that Mr. Gavitt hat nursed his personal troubles and pestty grievances, many of them no doubt imaninary, until he had wrought himself into a state 
of nervous irritability, such as to render himself alınost irresponsible, and we think that under the circumstances his charges do not merit serious consideration.

Very respectfully,

Capt. M. A. Healy, U. S. R. M.

\author{
A. BuHNer, \\ First Lieutenant. \\ F. M. DUNWOODX, \\ Second Lieutenant. \\ A. L. Churchill, \\ Chief Engineer. \\ W. D. Bratton, \\ Past Assistant Surgeon, M. H. S.
} Commanding Revenue Steamer Bear.

U. S. Revenue-Marine Steamer Bear, San Francisco, Cal., Deccmber 21, 1888.

Srk : During the recent cruise of the Bear in Alaskan waters, while at St. Georre Island, Mr. William Gavitt, special agent of the Treasury, visited this vessel, aud made a number of statements relative to some irregularities which occurred on the island since our last visit. I deemed it my duty to inquire into the matter, aud accordiugly directed Lieutenants Buhner and Dunwoody, Chief Engineer Churchill, Second Assistant Engineer Cutchin, and Pased Assistant Surgeon Bratton to investigate the charges.

The board convened at the Government house, and, after hearing the charges and questioning a number of the natives, arrived at the conclusion that they were in the main frivolous aud of a personal nature, and as regards those of a serious nature, the evidence in support was not satisfactory. They were of the opinion that that Mr. Gavitt had worked himself into such a state of nervous excitement as to render him almost irresponsible, and that under the circumstances his charges did not merit serious cousideration. A verbal report to this effect was made to me by the board. I did not consider the matter of sufficient importance to make a note of it in my report on my return to San Franciseo; but now that there is being so much published in the newspapers relative to the treatment of the natives in Alaska and on the seal islands by the Alaska Commercial Company aud its agents, I herewith trausmit, for the information of the Department, a written report, signed by all the members of the board, with the exception of Mr. Cutchin, who is now in Port Townsend.

Very respectfully, your obebient servant,

The Secretary of the Treasury,

M. A. Healy, Captain, U.S.R. M.

Washington, D. C.

By Mr. Felton:

Q. In Mr. Gavitt's testimony, as I recollect, he stated there was a Government house there provided for the agent.-A. Yes, sir; one on each island, furnished by the Government.

Q. And that he was compelled to eat with the employés of the Alaska Commercial Company, and that under the circumstances was very dis. agreeable; they could do nothing else but accept that. Now is there anything in the law that compels them to that sort of living?-A. No, sir.

Q. I asked him the question, and he said he applied to them and they refused to sell him a stove.-A. He told me the same story, but the truth is they did not have a suitable stove. They only had one, and that was a range. If he desired it, and there had been any necessity, he could have gotten a stove. They would have supplied him with the necessaries.

The Chalruan. Did you hear any complaints made by him to yourself or others that he was eompelled to eat at the table in the company house, and that his wife had to eat with him, and submit to hearing improper language used by the emplorés, and that the conduet was generally discourteous? 
The Witness. Yes, sir; I heard that from Gavitt.

Q. He stated so here?-A. He so stated to me at the time I was making the investigation.

Q. The investigation was in reference to that?-A. Yes, sir, and all his complaints ; there was not a word of truth in it. The cook at that time always waited on the table, and he assured me positively there was no truth in that statement; and that he had instructions from the agent of the company, when they wanted it, to carry Mr. and Mrs. Gavitt's meals up to the house, and for a month or two before we landed in the spring Mrs. Gavitt ate her meals in the Goverument house, or for a while at least. There were no indignities offered Mr. Gavitt or his wife in the company house at all; at least in my investigation I failed to find anybody who could testify to any indignities being offered to him. He made it very disagreeable for Captain Loud and his wife, and worried his owu wife, who was a very innocent, clever lady.

Mr. MACDONALD. Did any person testify to anything of that kind except Mr. Garitt?

The Wirness. No, sir; no one but Mr. Gavitt.

Cross-examination by Mr. JeFfries :

Q. On the branch of inquiry to which your attention is just now being called, I want to ask you in regard to the cook. Mr. Gavitt testified that he insulted Mrs. Gavitt by coming into her presence with his clothes disarranged?-A. How?

Q. I do not know. In some way; indecent acts, by his pantaloons being open. Do you know anything about that?-A. My knowledge of John Hall and association with him upon the island has always been in the dining room. I have been there taking meals when he would be waitiug on the table. If I am correct in my recollection I do not think I ever saw him in the dining-room when he was not very neatly and cleanly dressed, and wore an apron, as servants do, tied around his waist, and if his pants had been open there would have been no exposure.

Q. Did the apron go all around him?-A. I think so. I know it was a white apron.

Q. Did he wear them habitually in the dining-room?-A. Yes, sir.

Q. Have you taken meals in that room with those people?-A. Frequently.

Q. Was Mrs. Gavitt present?-A. Yes, sir; and Mr. Gavitt.

Q. Were a number of ladies on the island?-A. No, sir; there was Captain and Mrs. Loud and Mrs. Gavitit.

Q. Now I want to ask you who the natives ou the seal islauds regard as paramount authority on those islands? - A. The Goverument agent in charge; for as soon as new agents land the first inquiry is, "Who is the agent in charge." They do not consider the assistant Goverument agent as anthority except when he is there by himself. When there are two on the island together, the agent in charge and the assistant, they look up to the agent in charge; and when the assistant is in charge, of the island they look up to him.

Q. What I want to make plain to the committee is, do they regard the Government agent or the company people as paramount authority ? - A. They regard the Treasury agent all the time as the paramount authority there on the islands?

Q. Do.they understand that thoroughly?-A. Perfectly so. They are reeognized as steh, and obeyed implicitly. The company's employés all look upon the Treasury agent in the same way. 
Q. Mr. Garitt testified here that there was a regulation of the Treasury Department that the special 'Treasury agent had to be a married man, and should take his wife there; did you ever hear of such a regulation?-A. That is not true, sir; he does not have to be. There is no law or regulation of the Treasury Department requiring it. After my experience with Mr. Ryan, I suggestet to the Secretary that it would be well to send a man in his stead with his wife.

Q. How far from the island was this Zapadni rookery, where the man Peter Resanzoff was sent?-A. Zapadni is on St. George, 6 miles from the village.

Q. Now the business which requires the talsing care of is Government business?-A. Entirely.

Q. Would Dr. Noyes, who was an employé of the company, have any authority to detail men to watch a rookery ?-A. None whatever. it would have to be dene by the Government agent.

Q. Would it have to be Captain Loud, or Mr. Gavitt, or you?-A. Whoever was in charge.

Q. So, then, it could not be true that Dr. Noyes forced Peter Resan zoff to go to Zapadni; that would be impossible?-A. Entirely impossible. It is not true, of course, and is absolutely false.

Q. Was Mrs. Tingle, during her lifetime, on the Island of St. Paul witb you ?-A. My wife, daughter, and little boy went up in the spring of 1885 , and remained with me for fifteen months; my wife was also with we the second year.

Q. Were they ever insulted by anybody ?-A. Never in any way while on the islands; always treated by natives and whites with marked courtesy and respect.

Q. Were they ever on St. George Island?-A. They were not. The natives were very respectful and treated them with a great deal of consideration. The fact is they came down to the wharf to see my wife off; when she left the island, we left half the village standing upon the wharf shedding tears; men and women both.

\section{TESTIMONY OF THOMAS WILKINSON.}

\section{Thomas Wilkinson, sworn and examined.}

By Mr. JeFFries:

Q. Where do you live?-A. San Francisco.

Q. How long have you heen living there?-A. I have lived at San Franciseo two years; at Oakland ten years.

Q. What is your present business?-A. Mining business in Alaska.

Q. What part?-A. Uuga Island.

(2. Where is that?-A. East from Oonalaska about 250 miles.

Q. That is one of the Aleutian Islands ?-A. Yes, sir.

Q. Do you know Lonis Schloss, of San Franciseo?-A. I do, sir.

Q. He is president of the Alaska Commercial Company?-A. Yes, sir.

Q. What sort of man is he?-A. I think he is a very fine gentleman; one of high integrity and honor.

Q. Do you know Louis Gerstle?-A. Yes, sir.

Q. What sort of a man is he?-A. He also is a fine man.

Q. Do you know Captain Niebaum?-A. Yes, sir.

Q. What kind of a man is he ?-A. He belongs to the same company, and there is no tiner gentleman than Captain Niebaum. 
Q. These three gentlemen, in connection with Mr. Williams, who sits at the head of the table there, are the men who control the Alaska Commercial Company? - A. I believe so, sir. sir.

Q. Have you visited many parts of Alaska?-A. Nost of it, I think,

Q. Been pretty nearly all over the whole Territory ?-A. Yes, sir.

Q. Have you been on the seal islands?-A. On St. Paul only.

Q. I would like for you to state with regard to the condition of the natives of St. Panl Island as compared to the natives in the other parts of Alaska that you have visited.-A. I think they are much more inproved on St. Panl Island than in some other parts of Alaska.

Q. What do you know as to what the company has done for the na. tives in Oonalaska?-A. Well, they have built houses and given them free of rent good schools and churches.

Q. What do you say as to the different natives at such points as they come in contact with the Alaska Commercial Company as compared with the natires of other parts of the Territory where they do not come in contact with the company?-A. I think thes are much farther advanced than in the Territory where they are not reached by the company.

Q. Then you would say that the influence of the company has wrought good for the natives of Alaska; is that your judgment?-A. Yes, sir; decidedly.

Q. What portion of Alaska is it that is most densely populated with white people?-A. Unga Island, Jumeau, and Douglas Island, and up the Yulion, to which immigration tends, and mining to the business portion. There are many miners at the Yukon River, more than at any other part of the Territors.

Q. How about southeastern Alaska?-A. I have not traveled a great deal through there.

Q. Sitka?-A. I stopped there and was at Sitka about a week. Oonalaska is far ahead of sitka in regard to the natives there.

Q. How about Kodiak?-A. I was there twice. They all looked contented there, about the same as in Oonalaska.

Q. Has the company a station there?-A. Yes, sir; schools and churches; and they seem to be well contented.

$\mathrm{Q}$. As well treated as elsewhere?-A. About the same, I think.

Q. Are you acquainted with Mr. Webster, the company's agent?-A. No, sir; I never met him.

Q. Are you acquainted with any of the company's people on St. George Island?-A. I am with Mr. Morgan and Mr. Redpath. I think that is about all the gentlemen I know.

Q. Mr. Wilkinson, what business relation do you occupy towards this company?-A. Noue.

Q. YGu are not in any way connected in business nor interested in their affair's in any way?-A. No, sir.

\section{By the Chatrman :}

Q. You have business interests in Alaska?-A. Yes, sir.

Q. Is it your opinion that the position of this lease for taking seal skins, exclusive right to which this company enjoys, enables that com. pany to dominate the business of the Territory in a damaging way, so as to push out competition?-A. Not at all. I beliere they invite immigration. I know they did when we started in ; they did everything they could; carried freights at fair rates when they had their own to carry. And I think they do so for every one who wants to go there. I never had any trouble. 
Q. Have you observed any policy on the part of the company that you thought opposed to the public interests of that Territory?-A. No, sir; on the contrary, I think they have done more for Alaska than any other company could, and I believe more than was required by the Government.

Q. Do you think that the Government could make any other disposition of the seal islands that would be more in the public interests than it is now ?-A. I do not.

Q. Have you any information connected with the killing of seals in the waters of Bering Sea and the North Pacific? - A. Not much. I was on the island one day when they were killing seal, and I was kindly shown around by Mr. Tingle and Dr. McIntyre.

Q. You know nothing in regard to the killing in the Bering Sea and Pacific?-A. Only that many seals have been taken by the marauders, and mostly the female seal.

Q. Do you cousider the fur-seal interest, the berd of fur seals, of sufficient importance to justify rigid measures on the part of the Government to protect them?-A. Certainly I do, sir. If an order were issued and signed by the President, it would have good effect.

Mr. FELTON. Have you ever given any thought or had any opinion as to the policy of the Govermment taking charge of these islands and killing the seal, etc.?

The Witness. I do not believe it would be a good policy. I think it is iu better hands now than the Government hands. They get more money out of it if properly protected.

The CHatrman. You think it is better polies for the Govermment to lease it than to undertake the business itself?

The Witness. Yes, sir.

Q. Mr. Wilkinson, the only question is whether the Gorernment gets all they ought to out of it?-A. I do not know. The Territory, I believe, cost about $\$ 7,000,000$ and they have got over $\$ 8,000,000$ out of it to date, so they could not be much out on this showing.

\section{CoMMITTEe on MERChant Marine and Fismeries, Washington, D. C., Tuesday, January 8, 1889.}

The Charrian (to the attorney of the Alaska Commercial Company). I will pass this morning upon your application, contained in your written communication to the committee of January 7 , in relation to the matters to be covered by this investigation.

The chairman read the communication, and also the resolution under which the committee are acting, as follows:

\section{Washington, D. C., January 7, 1889.}

SIR: Before ealling witnesses in behalf of the Alaska Commercial Company, is to the manner in which it has performed its eontract with the United States, I beg to submit to the honorable committee as statement, which I dern important, as to the course to be pursued by the eompany in reference to the preuding in estigation.

The committee is doubtless aware of the charges which have appeared in certain nowspapers, aceusing sitd company with oppressing and ontraging the native inlabitants of Alaska Territory; and in an oftecial report by its governor the company is charged with opposing inmgration and settlement, and with driving out competition in its trade, monopolizing its business, and oppressing the natives.

The object of this communication is to respectfully ask the committee to allow me, on behalf of said company, to show, by sworn testimony, that said publications and official statements are unfounded:

1. I desire to prove that the only business in which sait company is engaged in Alaska-outside of the seal islauds-is the purchase of laud furs and sea-otter skins from the hunters and natives, who bring their peltry to its trading stations, and the sale of such goods and provisions as these people wish to buy. 
2. In its entire business in Alaska-outside of the seal islands-the company is an independent trader, like all others who choose to engage in that or any other business in the Territory. It was so engaged at the date of tis contract. It has no relation to or connection with the Government in reference to this business, and of course no special advantage or privilege from the United States concerning it. The only portion of Alaska Territory in which this eompany has any connection with the Unnited States Government is the Pribylov Islands, in Bering Sea, nearly 2,000 miles from Sitka and 200 miles from the nearest land.

3. In the purchase of land furs and sea-otter skins it competes with the other traders, but with the other branches of industry in the Territory it has nothing whatever to do. It takes no part in, and has no connection with, or interest in the business of salmon fishing, cod fishing, herring fishing, salmon canning, whaling, or mining, all of which is carried on throughout the Territory and gives employment to a large number of persons.

4. Within the entire Territory of Alaska-outside of the seal islands-the Alaska Commercial Company has in its service forty-tbree men, covering a range of over 2,700 miles, embracing the entire chain of Aleutian Islands ; the eastern coast of Bering Sea; the island of Kodiak, and the coast of the North Pacific Ocean.

In all of southeastern Alaska, in which the capital, Sitka, the town of Junean, and other white settlements are located, this company has no trading station, agent, or employé.

5. I am now prepared to prove that whatever outrage or oppression exists in Alaska, if there be any, will be found in a section of the country far remote from the operations of the company; that wherever the Alaska Commercial Company has come in contact with the native inhabitants the condition of the latter is improved, both morally and physically; and that the natives who deal and have intercourse with the company are far in advance of those in other sections of the Territory.

6. I ain prepared to disprove all these charges against the company by reputable and credible wituesses, including the bishop of Alaska, officers of the Navy aud of the Merchant and Revenue Marine and of the Signal-Service; Territorial officers, officers of the U. S. Commission of Fish and Fisheries; the United States agent of education in Alaska; the Catholic, Moraviau, and other missionaries, and by leading eitizens of Alaska and elsewhere doing business in the Territory.

I respectfully request that $I$ be permitted to prove the facts herein stated.

Respectfully submitted.

\section{Hon. Poindexter Dunn, Chairman, etc., Investigating Affairs of the Attorney for Alaska Commercial Company. Alaska Conmercial Company.}

Resolved, That tho Committee on Merchant Marine and Fisheries be anthorized and directed to fully and thoroughly investigate the fur-seal fisheries of Alaska, and all contracts or leases made by the Govermment with any persons or companies for the taking of fur seals or other fur-bearing animals in Alaska; the character, duration, and conditions of such contracts or leases, and whether and to what extent the same have been enforced and complied with or violated; the receipts therefrom and the expenses incurred by the Govermment on account of any such contracts or leases ; and to fully investigate and report upon the nature and extent of the rights and interests of the United States in the fur-seal and other fisheries in the Bering Sea, in Alaska; whether and to what extent the same have been violated, and by whom; and what, if any, legislation is necessary for the better protection and preservation of the same; that said committee be authorized to sit during the sessious of the House, send for persons and papers and administer oaths, employ a messeuger if found necessary, and that all expenses of such investigation shall be paid out of the contingent fund of the House.

The Chatrman. The subjects which the committee are directed to investigate are specified and definitely stated in the resolution, and there is no authority to deal with any other subject. I have heretofore held, in the course of this investigation, that so much of the accusations as have been made in publications and otherwise, of a state of a moral depravity existing in Alaska, and of the immoral and bad conduet of people who are doing business or visiting there or hunting, etc., were vutside of the scope of this investigation. This committee will confine itself to the investigation of the general subjects incident to or connected. with the administration of the lease of the Alaska Commercial Company. I have also ruled heretofore that any general question might be asked 
as to the condition of the natives, or the effect which the possession of this lease by the eompany might have upon them, and what power it might enable the company to exert upou the public interests in that Territory, and whether its influence was beneficial or deleterious; but to go into the details, as stated here in your letter, would exceed the committee's authority. You may prove the geueral proposition in relation to the purchase of furs from hunters aud natives, etc., and you may gire the number of persons who are employed there as agents and their location, and the opportunities wbich the company may have by reason of the possession of this iease to exert an influence over the natives and over the public interests and the trade ofthe Territory. I see no objection to making that proof.

Mr. JEFFRIES. The committee will not allow us to disprove the accusations made by Governor Srvineford or those made by the newspapers.

The Chairman. These go into the details of the moral depravity existing or said to exist there, and that is a question pertaining to the Territorial government, and is a subject which this committee is not directed to investigate. The general question, showing the efiect of this lease on the development of the Territory, may be asked, but further than that the committee has no authority to go.

Mr. JEFFRIES. There seems to be an impression throughout the country that the Alaska Commercial Company occupies a large portion of the Territory of Alaska, and practically dominates the whole Territory.

Mr. Dunn. For that reason I am willing that yon may give a list of the employés and their location.

Mr. JeFFries. Any one who will take the trouble to look at the map will see that the only parts of the Territory which we have any control over or relation to are those two volcauic rocks known as St. George and St. Paul Islands. That is all our contract covers. The whole of the rest of the Territory is as open to everybody else as it is to us. It is true we have a few trading stations ou the Aleutiau Islands. So far as the poptilated portion of the Territory, Junean and Sitka, and the white settle. ments are concerned, we have no trading stations there and no employés within 300 miles of them. We hare one tradiug station about 300 miles from Sitka, at which we have one white man; the next is 700 miles off, and that is our whole relation to the mainland, except down at Kodiak. So far as the region of country is concerned to which immigration is tending, and where millions are said to be anxious to go, it is a veritable terra incognita to the Alaska Commercial Compauy, and a place with which it has nothing whaterer to do. We hare rescned from that sterile country miners and others who have gone there and met with disaster. At one time we brought down thirty-five, and at another time serenty-nine, and took them on our ships to Oonalaska.

\section{TESTIMONY OF T. F. IKORGAN-Piecalled.}

\section{T. F. MorgaN, recalled.}

\section{By Mr. JEFFRIES :}

Q. What are the facilities of communication between the natires of the seal islands and San Francisco, and other places in the United States? - A. The uatives hare the same opportunities for communicating with San Francisco, or the world in general, as do the employés of tine company or the officials of the Greek Chureh. 
Q. Are you an employé of the Alaska Commercial Company ?-A. I am.

Q. On the islands of St. George and St. Paul?-A. Tes, sir.

Q. How long has it been since you went there?-A. Seventeen years.

Q. Are you perfectly familiar with the operations of the company on both islands ?-A. I am.

Q. Go on and state, in detail, what opportunity a native would have, if he had been ill treated by the company or any of its a gents or employés, of sending a letter stating his grievances to San Francisco or any other part of the United States without interference.-A. If a native has a grievance, the first place he would tell it would be to the Government agent. He conld make his complaint in writing, or he could send it direct to the Treasury Department at Washington, and if he doubted its arrival here by the usual course of mail, he could put it in the church box of what we call the Russian Consistory at San Francisco, which is sent down every time a mail goes. We have a revenue-cutter about the island, and he could send the mail by that when it goes down.

Q. In what way are papers or letters receired for the consistory, and by whom ?-A. The priest prepares the documents and mail matter, and has it ready and brings it to the company's office. It is generally in a box about 2 feet long, 12 inches wide, and 4 or 5 iuches thick. It is pasted around with paper and sealed with the seal of the church, and generally one or two large envelopes are with the box, sealed with wax. That is brought to the company's office and put in the mail.bag and sent to San Francisco.

Q. Is that mail ever molested in any way?-A. There is not as much chance for its being molested as there would be in the United States.

Q. Is that taken on the company's vessels or on the revenue-cutter?A. When they come to me they always go on the company's vessel.

Q. If a native were badly treated by an employé of the compans, would he be likely to go to the priest with his complaint?-A. He would go direct to the Goverument officer, and if he had a complaint against the Government officer he would probably come to the compauy's agent. He would come to the company's agent for sympathy.

Q. What do you say as to his having abundant ofportunity to communicate any grievances he might have?-A. 'There is no question but that any man can communicate his grievance either to the Gorernment agent or to the Department iu Washingtou. They send money to their firiends elsewhere, and they send letters to their friends over on the Commander Islands.

Q. The Commander Islands is the Russian seal islands which our company controls?-A. Yes, sir.

Q. Was the governor up there during the last season?-A. I was not on St. George last season. I heard the goremor was there.

Q. Was he at St. Paul?-A. I heard that he was.

Q. What do you say in regard to the coudition of the natives as compared with the vatives in other parts of Alaska?-A. They are rery much better provided with clothing, food, necessities, and lusuries.

Q. Hare you been in different parts of Alaska?-A. I hare.

Q. You have seen the natives in other parts?-A. Those of Sitka, Kodiak and Oonalaska.

Q. What do you say as to the condition of the natires on those islands. Are they satisfied or dissatisfied?-A. I consider that they are well satisfied with the condition of affairs there, if jou except their complaint that the company deprives them of sugar with which to make 
an intoxicant. That is one of their grievances, for under the Russians they had sugar with which to make quass. They have been deprired of sugar now for that purpose.

Q. Were you up there before the lease went into operation?-A. Yes, sir; I was up there in 1868.

Q. What was the condition of the natives then? How were they clothed, etc., under the Russian règime?-A. They were clothed in very rough clothes, not too many, and wore some skins. Their food was coarse bread, seal meat, dried salmon, aud seal oil. The houses were filthy (they could not be any other way), they had open fires and no floor.

Q. Were they half underground ?-A. Yes, sir.

Q. Did they have any chimueys?-A. They had a hole in the roof.

Q. How do they live now?-A. They have good comfortable frame houses with good floors; the houses are papered aud some are carpeted. They hare stores and are as comfortable as any people could be.

Q. What does the company keep) in this store?-A. A supply of canned meats, jellies, jams, condensed milk, rice, dried fruits, crackers, bread, flour, and general provisions.

Q. Is it good tlour?-A. We use it.

Q. It is the same as the company has for its own use?-A. Yes, sir; just the same.

Q. Have the natives all they want?-A. Yes, sir.

Q. Pleniy of money?-A. Yes, sir; they have a sufficiency, aud enough left to play poker with.

Q. Have they money on deposit in San Francisco?-A. Some of them have.

Q. Do you know what amount ?-A. No, sir; I do not, exactly.

Mr. JEFFRIES. I will submit here a pamphlet which contains a state. ment showing the amount of money to their credit and the names of the persons that own it.

Q. Whe do the natives regard as of paramount anthority on the seal islands?-A. The special agents of the Treasury Department. do.

Q. They represent the Goverument of the United States ?-A. They

Q. What do they call Mr. Tingle?-A. They call him the Government.

Q. He is generally known as the Govermment?-A. Yes, sir.

Q. He is regarled as the representative anthority of the United States?-A. Yes, sir. These people understand this, and whenever there are two Government agents they will invariably ask who is the head man of the two Government officers.

Q. Has there been ever any attempt by any of the company's officers, so far as jou know, to make the uatives beliere that the company's authority was paramomnt?-A. No, sir. Rather the opposite has always been the policy of the company's agent, to instruct those people to look to the Govermment officer, and that, right or wrong, they must obey lim, and the company must obey him; that the Government oflicer would be held accountable for his mistakes. Eren if he was in the wrong they would not be justified in resisting him.

Q. During the seventeen years you have been an agent or an emplocé of the Alaska Commercial Company have you ever at any time hearr the paramount anthority of the Goverument officer resisted or questioned by any one connected with the company?-A. It has nerer been to my knowledge. 
Q. You would be likely to know it if it had ?-A. If it occurred where I was.

Q. Has there been any outrages by the agents or employés of the company on the native women of the islands, that you ever heard mentioned?-A. No, sir.

Q. A witness has a made a statement here that tine island of St. George was a Government house of prostiution. What do you say as to that? A. That is a libel on the people of St. George Island. The people there are not that kind of people. There are some women there that are just as virtuous as they are elsewhere, and men the same way.

Q. Do you happen to know that that is peeuliar to that class of people?-A. People not only there but elsewhere are abont the same as the people of the United States or the people of the Sandwich Islands or any other place that $\mathrm{I}$ ever visited.

Q. Do you know a native by the name of Peter Resanzoff?-A. I do.

Q. What kind of a man is Peter Resanzoff?-A. He has been pretty well described here by a witness as a misehierous man. He is unreliable, and is the willing tool of any white man that comes to the island, whether from the Treasury or as an employé of the company.

Q. How long have you known Peter Resanzoff?-A. Erer since 1874.

Q. What is his reputation for truth and veracity?-A. I would not believe him.

Q. Would you believe him under oath ?-A. I would not.

\section{By the Chatrman:}

Q. What is his general reputation among the people?-A. He is not respected by the people. When they divided the protits of the season's work, Peter received a second-class share, although he was an own brother to the head chief, and when the division of that money was made by the Treasury agents, the company's agent, and the chiefs. The first jear Peter receiverl a first-class share, because he knew that unless he worked he would not get his money, as a record was kept of the time employed and the class of work done by each man. He was discharged from the employ of the Alaska Commercial Company as clerk for dishonesty.

\section{By Mr. JEFFries:}

Q. What kind of a man is Mr. Webster, the company's agent there? -A. He is a first-class officer of a ressel. I served on two vessels with him. Mr. Webster is a gentleman of high character and rery good judgment.

Q. How long hare you known him?-A. I hare known him for the last twenty-two or twenty-three years. I mas associated on St. Paul Island with him in 1869, and in 187't at Northeast Point, and 1 have been associated with him more or less ever since.

Q. What do yon say as to his cheracter and habits?-A. Пе is an honest and a truthful man. I never heard a charge made about Mr. Webster being drunk; I never saw him drunk.

Q. Have you ever heard of any such charges being made, exeept by Mr. Gavitt?-A. No, sir; Mr. Webster will not drink liquor when he has the least responsibility resting upou him. IIr. Tingle told me he would not take liquor in his house; he would not even take a social drink.

Q. Suppose he was on the island and wanted to get a drink, how would he get it?-A. He would have to get it from the company's physician. 
Q. He has charge of the liquor?-A. He has charge of the liquor.

Q. The company's agents keep no liquor?-A. No, sir; the company will not allow it.

By Mr. Felton:

Q. Is that a rule of the company ?-A. Yes, sir ; I saw two employés discharged for being intoxicated. They were both physicians.

Q. Is one the man that insulter Mr. Kimmel?-A. Yes, sir. Mr. Ryan appointed Peter Resanzoff ehief while he, Ryan, was Goverument agent; the natives were discorered going out in the night and killing pup seal, bringing the meat to the village, and throwing the offal over the cliffs. Mr. Manchester and Mr. Gavitt har an investigation about it, and Peter testified in the investigation of the matter that he knew nothing about it, although the priest and every man and boy over twelve years old confessed to the fact or to knowledge of the killing, with the exception of three; and sereral testified that Resanzoff had a share of the pup-seal meat.

By Mr. JEFFRIES :

Q. Was he fined? -A. Peter and several of the first-class men were fined $\$ 10$, and some of the natives were sentenced to work on the roads.

By Mr. Felton:

Q. Why was the law changed which allowed the people to elect their chief ?-A. I do not know the reason why. The Treasury agents thought it was the best.

The CHamman. There was evideuce that whenever the distribution of the compensation for taking the seals was made, they found that favoritism prevailed which was unjust. The priest had his favorites and they generally had the chief with them, and it was foumd that this favoritism worked great injustice to a great many of the natives; and therefore the Government agent determined to take eharge of the matter of the classification of this distribution, and it is now made in accordance with a classification by the Government agent, the company's agent, and the chief, whoever he may be.

\section{TESTIMONY OF DR. CHARLES A. LUTZ.}

Charles A. Lutz, sworn and examined.

By Mr. Jeffries:

Q. What is your profession ?-A. Physician.

Q. Are you a graduate of medicine?-A. I am a graduate of the University of Penusylvania.

Q. Where have you practiced in formertimes?-A. I have been mostly connected with the St. Luke's Hospital, South Bethlehem, Pa., and Mercy Hospital, in Pittsburgh. I also practiced a short time in Phila. delphia.

Q. Have you been stationed in Alaska recently?-A. Since $185 t$.

Q. Whereabouts in Alaska?-A. I was most of the time on St. George's Island, and during the summer I visited some of the other stations.

Q. How long have you been at St. George and when did you leave the island? - A. I have been at St. George Island during the fall and winter since 1884, and also spent the summer there while Mr. Redpath was agent, and this lat time while Mr. Gavitt was agent. 
Q. In whose employ are you?-1. The Alaska Commereial Company.

Q. Are you still in their service?-A. No, sir; I resigned when I left this last time. sir.

Q. As a matter of fact, you are not now in their service?-A. No,

Q. When did you say you left St. George Island?-A. I left the island on the 3d of June, 188s, and traveled on the company's steamer, arriving in San Francisco August 29.

Q. Do you know Mr. Webster?-A. Yes, sir ; right well.

Q. What sort of a man is he ?-A. Vary excellent, so far as I know.

Q. What were his habits?-A. Very good, so far as I could see.

Q. What were his habits as to temperance while on the island?-A. Well, he uever conld have gotten any liquor except from me, and I know that many times during this last winter he refused liquor when I thought it was necessary for him to have it.

Q. You, as a physician, thought he ought to hare it, and he refused to take it?-A. Yes, sir.

Q. Who has charge of the liquor on St. George Island?-A. I have charge of it.

Q. Could Mr. Webster or anybody else get any liquor unless he got it from you?-A. I think that would have been almost impossible.

Q. Unless he took it by force?-A. Yes, sir.

Q. Llare you ever seen Mr. Webster intoxicated on St. George Islaud?-A. No, sir.

Q. Do you know a gentleman by the name of Gavitt?-A. Yes, sir.

Q. Mr. Garitt, as a witness here, testified that rou attempted to strike him with a poker on one occasion. Is that true?-A. No, sir; I nerer struck him or threatened him by word of mouth or in any other way.

Q. Then his statement is not true?-A. No, sir.

Q. He also stated that the whole island was a Government house of prostitution. What do you say as to that statement?-A. So far as the company's people are concerued, I should say that is untrue.

Q. So far as they participated in the business, you never heard that statement marle except by Mr. Garitt?-A. That is all.

Q. Was Mrs. Gavitt with him during the time of his stay?-A. Yes, sir.

Q. How was she treated by the employés of the company, so far as you observed ?-A. Always with marked respect.

Q. Was there a man there by the name of Hall, who was the cook?A. Yes, sir.

Q. Did you ever see anything in his conduct in the presence of Mirs. Garitt that was wroug?-A. I always thought that MIr. Hall treated both Mr. and Mrs. Garitt with extraordinary respect on all occasions.

Q. Did you all eat together at the same table?-A. Yes, sir.

Q. Did you erer hear Mr. Garitt raise any objection to his or his wife's treatment at the table? - A. No, sir.

Q. He made no complaint that you heard?-A. No, sir.

Q. Do you happen to know whether he applied to the company's ageuts for a stove?-A. I only heard it at the time. I was not present.

Q. Did the company have an assortment of stoves on hand at the time?-A. I believe not.

Q. What did they have?-A. I do not remember that they had any stores. I remember that there fas a range there. It would not have been suitable.

Q. Do you know whether or not Mr. Weloster told Mr. Garitt that 
he could have a separate table in the dining-room, or if that did not suit him, he could have his meals sent to him ?-A. Yes, sir; I remember the time that occurred. Of course, I was not present, but I understood they said that Mr. Gavitt could have his meals sent to him or have a separate table if he wished.

Q. How was Mr. Hall dressed usually, when in the dining-room?A. Mr. Hall always dressed with rery great neatuess. He used an enormous amount of stuff to make his aprons. He has at least four dozen.

Q. Who furnished those aprons?-A. The company.

Q. How long are they?-A. They reached far below his knees and extended almost entirely around his body.

Q. Would it be possible to see whether his pantaloons were disarranged if he had one of those aprons on?-A. It would have been impossible.

Q. Did he always wear them at meal-times ?-A. I think he always did. I am sure I never saw him without them at meal-times.

Q. What do you say as to the condition of the inhabitants of the seal islands? How are they cared for?-A. I think they are treated with a great deal of kinduess and their wants are liberally attended to.

Q. Are they a religious people? - A. They are a rery religious people.

Q. They are members of the Greek Church?-A. They have absolute faith in that.

Q. Are they influenced, or not, by the priests to any extent?-A. I suppose they could be; I have no doubt they are.

Q. Does the bishop vist those islands?-A. I so understand. I remember the priest has been there while I was there.

Q. If the company's employés or any one else were to mistreat those natires, would they be likely to look to the priests?-A. I think they would go to the Government officer first.

Q. Who is regarded as paramount in authority there?-A. The Government officer.

Q. Is there any question about that ?-A. No, sir; there is no question about that.

Q. The authority of the United States is represented by the Government agents and his authority is paramount?-A. Yes, sir.

Q. Have you known of any conflict of authority between the Government agents and the company's agents ?-A. No, sir.

Q. Do the company's agents aud employés obey the directions of the Government agent in every respect?-A. Yes, sir.

Q. What do they call Mr. Tingle?-A. They call him " the governor." Some of the people speak of him as "father." [Laughter.] They were adults.

Q. Have jou been around to other portions of Alaska ?-A. I visited St. Michaels and two or three other places.

Q. St. Michaels is up ou Beriug Sea 700 or 800 miles north. How do the natives of St. Michaels compare with the natires of St. George?-A. I think the natives of St. George are very much superior.

Q. What do you say as to the influence of the Alaska Commercial Company upon the natives of the section of the country where it is brought in contact with the people? Is it good or bad?-A. It is very beneficial to them.

Q. What do you say as to the morals of the natives of those islands as compared with that of those in other portious of the Territory?-A. I am quite sure it is better; it is better on St. George Island, at least. Q. During the time you have been on St. George Islaud do you know 
of any ottrages having been committed on any native women by any of the Alaska Commercial Company people?-A. No, sir; I never knew or heard of any outrages committed by the company's people.

Q. Do you know of any having been committed anywhere on any natives of Alaska?-A. I have heard of attempted outrages, but not by the employés of the company.

\section{By Mr. FeLToN :}

Q. What was the reason for the difficulty or the coolness, or rather the feeling, between the agent, Mr. Gavitt, and yourself? From his testimony it is very evident he had no very great cause of complaint.A. The difficulty came from his side. I never had any hard words with him myself. He was very angry witli me at one time because I would not sign a paper to the effect that I had permitted a native to land a bottle of whisky on the island.

Q. Because you would not sign a paper stating that you had authorized a native to bring whisky through ?-A. Yes, sir.

$\dot{Q}$. Did you?-A. He came to me one day and told me that a native had just arrived with a bottle of whisky, and that as they were making something for him in the way of presents he wanted some excuse for the native to keep the liquor. He wanted me to tell him that he should use the liquor for medicinal purposes. I told him all right. I would be pleased to do any faror for him. He said he wonld send the native around, and some time after that-the ressel had gone-the native came to me aud I happened to be very busy, and I said, "Demetrie, you are here to see me about a bottle of whisky?" He says, "Yes." "Well," I sairl, "that is all right; be careful liow you use it. Use it only when you are sick and be sure sou do not drink too much at one time. Will you do that"? He says, "Yes," and so he went away I had forgotten the circumstance, when one day Mr. Gavitt eame down in a great rage and wanted me to sign the paper to the effect that I had authorized the landing of a bottle of whisky. I told him that I would see about it. I was busy and asked him to call later. He came afterwards and $I$ told him $I$ had no right to do that; that it did not matter to me who had whisky. I could uot stop it and was not anthorized to. He got very angry and called me a liar and was off like a shot.

Q. What did Mir. Webster say abont it?-A. Mr. Webster agreed with me that I had nothing to do with the landing of whisky and that I should not indorse it.

\section{By Mr. Dingley :}

Q. Are you authorized as the physician to give permission for the landing of intoxicating liquors on the island?-A. We have some whisky coming up as medical stores. We get that on the requisition that is signed by me and the Government officer.

Q. That comes in regularly as stores?-A. Yes, sir.

Q. Are you in the habit of giving permission to bring intoxicants to the island ?-A. No, sir. He wanted to get some excuse for himself to permit it. He said a native wanted it for medicinal purposes, to use when he was sick. I nerer saw the bottle and do not know whether it was a large or a small bottle.

Q. I understand you to say that no intoxicating liquors can be bronght upon the island except as company stores, to be dispensed by you or the surgeon for medical purposes?-A. No liquor is brought for medical purposes except through the company's requisition.

Q. As a matter of fact, are there any intoxicating liquors brought to 
the island except for medical purposes?-A. Not that I know of. I eertainly never heard of auy one bringing any liquor there.

Q. Do I understand you to say that it is brought in pursuance of a requisition or order signed by the Gorernment agent and the physician?-A. Yes, sir.

Q. In pursuance of that requisition the company brings it in?-A. We make a requisition for a certain amount.

By Mr. FeLton :

Q. It is brought by the company through the officer in charge?-A. Yes, sir.

Q. In any other way ?-A. No, sir.

Q. Can you state how much is brought to the islands for medical purposes?-A. Last year I had eighteen bottles of whisky and I think about a gallon of braudy. I had very little.

Q. How many inhabitants are there on the island?-A. About 111. I had a very small amount of liquor for the entire winter.

Q. As I understand you, no permission is ever given to individuals to briug intoxicating liquors to the islands. It must all come in as sup. plies?-A. Yes, sir.

By Mr. JeFFries:

Q. You make the requisition for what liquor you think is necessary for medical purposes for the season; yon take that to the Gorernment agent and he approves it?-A. Yes, sir.

Q. That is sent down to San Francisco and the liquor is forwarded, consigned to you? -A. Not to me directly. It is sent up to the island among the company's supplies, and of course I put it away.

Q. It is delivered to jou ?-A. Yes, sir.

Q. The whole of it?-A. Yes, sir; and I examine it to see if it is the quantity applied for in the requisition.

By Mr. Dingley :

Q. Do the natives obtain any intoxicating liquors upon the islands?A. Never, unless ther are sick. They might get it from time to time as medicine.

Q. Then intoxication is rare?-A. Yes, sir; very rare. Sometimes they might make some themselves in some way by preparing it from something sweet.

Mr. DiNGLEy. As I understand it, Mr. Chairman, this company have stations upon the main-land, where they carry on business that has been authorized by contract with the Government. Now, under the ruling that you have made, could we inquire as to the treatment of the natives and their condition at these several stations?

The ChaIRMAN. I think so.

MIr. Dingley. Of course the only islands exclusively occupied by this company are the seal islands.

The Chamman. In the decisions I hare made I hare stated that they may show the number and location of these trading stations, as tending to show whether or not the possession of the lease of the fur-seal islands enables the compauy to maintain in Alaska an establishment which would dominate the Territory and affect its trade and commerce. I have stated that they might show the number and location of these stations, but that we could not go into an inrestigation of the abuse of the natives at those stations. The general question has been put as to the condition of the natires there, and it runs clear through the eridence.

$9981-20$ 
Mr. Felton. The object of this investigation is for the benefit of the Gorerument, in order to enable it to determine in future what is the correct policy to he pursned in regard to the seal islands.

The Cirarranan. 'That was the object which the committee had in view, and that was the provision of the resolution authorizing the inrestigation, but the question of the treatment of the natives outside of the seal islauds is a governmental one and the committee has no anthority to go into it.

Mr. JEFFRIEs. There has been an intimation during the proceedings of the investigation that the committee would be likely to hold as the chairman has decided, and I deemed it proper to submit this letter in order that the question might be submitted, as I did not wish the committee to go to the expense and inconvenience of summoning wituesses without knowing whether I could put them on the stand. You are faniliar with the fact that a great deal has been published in the newspapers which does the company great injustice, by imputing to it acts with which it could have nothing to do; could not possibly have. We have in our employ to-day forty three men, mostly white men. At the island of Attoo, as far west from San Fraucisco as Maine is east of it, we have one man. Go 430 miles and we have another white man; 200 or 300 miles from that we have another; another hundred miles to Oonalaska we have four or six men. On Kodiak Island we sometimes have two. From Kodiak to Nutchic is a great distance, the latter being 300 miles west of sitka. On St. Michaels we have another station. It is charged in the newspapers and officially reported br the gorernor that we exert such an influence over the Territory as to drive out trade and monopolize the business of the Territory. We have no interest in Alaska except on those two seal islands. We bave no connection with any other business or manufacture, with no canning business, mining, or anything else. We do not attempt to resist the teeming millions that Governor Swineford talks about who are desirous of occupsing that Territors. I can show these facts, but I want to make it overwhelming, so that there can be no mistaking the facts.

\section{By Mr. JEFFRIES :}

Q. Did you erer have any conversation with Mr. Garitt, on the islands or elsewhere, as to what he could do or would do, or had influence to do, against the Alaska Commercial Company?-A. I had several conversations with him on the steamer on the way down to San Francisco from Oonalaska.

Q. When was that?-A. On the trip up. I started on the 14th of May. It was on the trip up, and occurred about half way on the pas. sage up to the islands.

Q. State that conversation.-A. He stated that the Alaska Commercial Company could not afford to have any quarrel with him. That he knew that the company had given special instructious to erery one of their employés to let him have anything he wauted, and that the company was rery anxious to retain his good will because of the rery great aid that he could be to the company, since this lease was so near its termination; that this was a very critical perion in the history of the compans, and that he knew that any thing said about the company, whether true or fals anything published in the papers at this time especially, would be very prejudicial to the interests of the compans, and rery much a gainst its chance of getting a renewal of its lease. He said that the next Presilent most likely would be a Democrat, and that as the probable Democratic nominee would be Dan Voorhees or Joe McDonala, 
and as those gentlemen were his backers, why of course he would have a great deal of influence through those gentlemen; and that consequently the Alaska Commereial Company would be ouly too glad to do anything to retain his good-will. That was about the substance of it.

By Mr. Dunn :

Q. Where did that conversation occur?-A. On the steamer. He referred to it afterwards on the steamer as he $r$ ent up; but then he remained in his room most of the time.

Q. Was any one else present when that conrersation took place?-A. No, sir.

By Mr. Felton:

Q. What year did you say that was?-A. In May, 1887.

Q. And he used the words "whether true or false?"-A. Yes, sir.

Q. You are quite sure about that?-A. Yes, sir.

Q. He said becanse the lease was expiring?-A. Yes, sir; because the lease was expiring and the company were thinking of getting a renewal. And he intimated that if they gave him any trouble they would suffer; tbat he was a man that came from a fighting family, and that most of his people hat died with their boots on. That if they made him any trouble, he would get even with them if he had to go to hell with ten sacks of gunpowder on his back.

By Mr. Dunn:

Q. Have you mentioned that conversation to any one else?-ג. Yes, sir ; I spoke about it.

Q. To whom ?-A. First to Mr. Clark. I had goue to see Mr. Morgan about it, but he would not listen to me. He was certain that Gavitt would turn out all right.

Q. What dicl he mean by "turn out all right?" $-\mathrm{A}$. He meant that Gavitt might be agreeable and pleasant, and not antagonistic toward the company's people on the islands.

Q. Did you report that couversation to the Govermment agents?-A. Yes, sir. I believe that I told him about the same story, or may be not quite all ; pretty much in substance, I think.

Q. Did you report it to Mr. Tingle?-A. Yes, sir.

Q. When did you report it to him?-A. When I left the islands. I reported it to him on St. Paul Island.

Q. How soon after the conrersation?-A. After the winter had passed. Of course I did not see Mr. Tingle any more until the following summer.

Q. Did you report it to Mr. Tingle the first time you saw him after the conversation occurred ?-A. I do not remember.

Q. Did you report it to him before Mr. Gavitt turned out all right or all wrong?-A. After he turned out all wrong.

Q. Why did you not report it to him before?-A. Because I thought Gavitt was merely talking.

Q. Did you not know at the time that a Government official that talked to you that way was not a fit man to hold such a position?-A. Yes, sir.

Q. Why did not you report it to the agent the first time you saw him? -A. (Hesitating) I do not know but it was the first time.

Q. Do you know whether it was the first time or not? State why fou did not report it to him the first time; do you know ? $-A$. I believe I previously saicl that I was not quite sure but it was the first time.

Q. But you did not seek an opportunity to inform him of this until 
after Gavitt had the difficulties?-A. No, sir; I understood that Mr. Garitt entertained a very antagonistic feeling towards Mr. Tingle, and I did not think it would be proper to mention it to him because it might lead to trouble between the Treasury agents.

Mr. JeFFries. We will say that the witness reported it to his superior officer.

Mr. Dunn. He states that he undertook to report it to Mr. Morgan, anci that Mr. Morgan declined to hear it.

The WITNEss. Mr. Morgan did not get a ehance to hear it all. I wanted to talk about it to him, but he would not listen.

By Mr. JeFFries :

Q. You did report it to your superior officer ?-A. Yes, sir. gle.

Q. You did report it to Mr. Tiugle?-A. I did report it to Mr. Tin-

\section{TESTIMONY OF J. EUGENE KIRK.}

J. EUGENE KIRK, sworn and examined.

By Mr. JeFFries :

Q. When did you leare St. George Islaud?-A. On the 3d of June, last.

Q. Are you an emplojé of the Alaska Commercial Company ?-A. Yes, sir.

Q. How long hare you been so employed?-A. Since May, 1852.

Q. Have you been ou St. George Island since 188? ?-A. Y'es, sir.

Q. Do you know Mr. Webster?-A. Vers well, sir.

Q. What sort of a man is Mr. Webster?-A. As nice a man as I ever met in my life.

Q. What are his habits?-A. I nerer saw him under the influence of liquor, sir.

Q. What is the condition of the natives of St. George Island as compared with the natives of other portions of Alaska that jou have been iil ?-A. They are very far ahead of the rest of them.

Q. Is their condition improving or retrograding?-A. Improring all the time.

Q. How do they dress?-A. The same as cirilized people.

Q. Are they well dressed ?-A. Very well.

Q. Do they have Sunday cìthes?-A. Yes, sir.

Q. Finery?-A. Yes, sir; men and women.

Q. Do they have carpets on the floor?-A. Yes, sir; some do.

Q. What kind of food do they have?-A. The company has ererything to sell in its store-flour, canned goods, prorisions, rice, etc.

Q. Are they in positiou to live as well as the companj's emplojés live?-A. Yes, sir.

Q. They use the same kind of flour?-A. Yes, sir.

Q. What do you say as to the condition of the people there as compared with laboring people elsewhere?-A. Thes are ahead of a good many laboring people I have seen, and more comfortable.

Q. Who built those houses they lire in ? -A. The company.

Q. Do the natives pay any rent?-A. No, sir.

Q. Did the company put stores in their houses?-A. They did.

Q. Are they furuished with fuel by the company?-A. They are.

Q. Are they furnished with dried fish?-A. Salt fish.

Q. Their principal meat is seal meat?-A. Yes, sir. 
Q. Are ther compelled to eat seal meat, or do they eat it because they prefer it?-A. They prefer it.

Q. Their living expenses are comparatirely trifling?-A. Yes, sir.

Q. About how many dollars each do the able-bodied men, ou au average, receire for thirty days' work ?-A. Close to $\$ 500$ each.

Q. Who has charge of the liquor on st. George Island?-A. The doctor on the island at the time.

Q. Can anybolly go to the doctor and get liquor on which to get drunk? -A. No, sir.

Q. You are sure of that?-A. Yes, sir.

Q. Did you erer know of any natives being intoxicated by liquor obtained from the doctor?-A. No, sir.

Q. It was testified to here by Mr. Gavitt that you threatened any Government officer that interfered with your business, and when he asked you what your business was you said it was with women?-A. It is a false statement, sir.

Q. Was there erer ansthing transpired that could be construed to mean any such thing as that?-A. No, sir.

Q. Then it is a lie, is it?-A. Yes, sir.

Q. Now, let us know something about your operations with women there; I do not mean in particular, but the company's employés. Mr. Gavitt states that the island is a Goverument house of prostitution?A. There is no truth in that.

Q. What do saly about the morals of the women on St. George Island? - A. They compare favorably with any place I have been in. I have been in a good many small places.

Q. Did the employés have their wives ?-A. The Government officers had; no employés Lad.

Q. How are they treated by the employes ?-A. With the greatest respect, sir.

Q. You saw Mrs. Gavitt?-A. Yes, sir.

Q. How was she treated?-A. Very well indeed, sir.

Q. Where did she take her meals?-A. At the company's mess table, with the rest of us.

Q. Who was the cook? -A. Mr. Hall.

Q. What was his deportment in the presence of Mrs. Gavitt?-A. Very respectful indeed.

Q. W'hat sort of a man is Mr. Hall; a respectable man?-A. He is, so far as I know.

Q. Well behaved?-A. Yes, sir.

Q. Did he erer have any trouble with anybody ?-A. I nerer heard of any.

Q. He is employed by the company as cook? - A. Yes, sir.

Q. Did he wait on the table?-A. Yes, sir.

Q. How was he dressed?-A. Very neatly.

Q. What kind of aprous did he wear?-A. He wore aprous that came below his knees.

Q. Did you ever discover anything wroug with his pantaloons?-d. No, sir. ways.

Q. Did he wear aprons habitualls in the dinning-room?-A. Al-

Q. Have you been about Alaska much?-A. I have been to Kodiak.

Q. What do you say as to the condition of the natives of St. George and St. Paul as compared with those of Kodiak and other places?A. The seal-island natires are very much ahead of them. 
Q. What do you attribute that to?-A. The conduct of the Alaska Commercial Company.

Q. So far as you were instructed by the company and its agents, what is the policy of the company as to the treatment of the natives? - A. We are supposed to treat them as well as we know how.

Q. What do you do at holiday times, Christmas or New Year's? Do you make them presents or risit them?-A. Wealways gave them a little spread.

Q. Who attends on those occasious ?-A. The men, women, and children.

Q. Is that spread made by the company ?-A. Yes, sir.

Q. Are presents generally given to the widows and orphans?-A. Yes, sir; they gire the widows pairs of shoes, stockings, dresses, handkerchiefs, etc.

Q. How do the widows, orphans, and old men live?-A. They are supported by the company.

Q. All supported?-A. Yes, sir; thes are furnished erersthing they need.

Q. Out of the company's funds?-A. Ont of the company's funds.

Q. It was testified to bere br Mr. Garitt that a prostitute could go to the company's store aud buy luxuries wlsen other people could not get them; how about that?-A. That is not true.

Q. You know that?-A. I know that.

Q. You are the assistant agent?-A. Yes, sir.

By Mr. Felton:

Q. What is the cause of the feeling between yourself and Mr. Garitt; what caused the uupleasantness which he talks about?-A. As far as I understand it, he came to me and ranted me to bring charges against the compans, and I refused. I told him I had no charges to make.

Q. Did he specify any that he wanted you to make?-A. No more than geueral charges.

Q. He was angry because you would not do that?-A. Tes, sir.

Q. Have you any reason to know why he was afraid of his life up there?-A. No, sir.

Q. Do you know of any demonstrations made against him by anybody there which would eause him to fear for his life?-A. Nothing of the kind happened, to my knowledge.

By Mr. Dingley:

Q. You said Gavitt came to you and desired you to ma e general charges against the company. Was that the language that he used?A. Yes, sir.

Q. Did he specify particular charges ?-A. No, sir.

Q. What kind of charges would general charges be?-A. I do not know. I asked him no questions. I do not know what he ranted.

Q. And he gave no explanation?-A. No more than that he expected the company to buy him.

By the Chatrian :

Q. Did he say that ? - A. He said to me he expected the company to buy him, and he was a high-priced man.

Q. Do I understand rou to sar that he said to sou that he expected the eompany to buy hin? Dirl he use those words?-A. He did.

Q. And lie also said he was a high-priced man?-A. Yes, sir; that they could not buy him low.

Q. When was that? -A. Along in the winter of 1857 and $158 s$. 
Q. Did he say that more than once?-A. He spoke about wanting his price two or three times-quite a number of times.

\section{By Mr. Dingley :}

Q. Price for what?-A. I do not know. He wanted to be bought.

Q. Bought for doiug what ?-A. To keep from making charges agaiust the company.

Q. And he did not tell jou what charges he had to make against the company? -A. He never told me what the charges were.

Q. Did you know any charges that he might make against the company? - A. No, sir. I told him I had no eharges to make, and knew nothing against the company whatever.

By Mr. Felton:

Q. Did he ever give you any reason why he wanted to prefer any charges? - A. No, sir.

Q. Did he ever make any statement of ansthing that the company had clone that was wrong?-A. He never gave me auy particulars at all.

Q. It is very evident that there was not a very good feeling ou his part toward the company's employés nor on their part towards him ; what was the eanse of it?-A. Nothing more than that he was trying always to create trouble and mischief among them and between them and him.

The Chairiran. I do not think Mr. Gavitt's eridence showed any particular complaiut against the company. He was particular to dis. claim any thing against the compauy, but had reference to the treatment he received at the hands of the officer's and men of the company. It was personal between them and him at St. George, and that formed the burden of his testimony-the moral conduct and general deport. ment of the employés.

\section{Bj Mr. Dingley :}

Q. Mr. Jeftries asked you if the doctor who had charge of the intoxicating liquors ever furnished them to the agents, officers, or employés of the company for the purpose of getting drunk. I ask you if he ever furnished it to them for use as a bererage ?-A. The ouly time we got liquor was on holidays, one drink each.

Q. On each of the holidays-low many are there ?-A. Thanksgiring, Christmas, and New Year's.

Q. Those were the only times that intoxicating liquors were furnished iby the doctor for use as a bererage?-A. Yes, sir.

Mr. Jeffries. As I said yesterdar, Mr. Chairman, we do not want to go into any personal controversy with Mr. Gavitt, aud therefore I did not call ont these facts from this witness, but now I would like to ask a few questions to get at the bottom of it so far as this witness is concerned.

The Chairuan. To get at the bottom of what?

Mr. JEFFries. What he knows about Gavitt wanting to be bought.

By Mr. JEFFRIES :

Q. Where did this conversation occur?-A. In the company's storeroom.

Q. During the day-time or at night?-A. Day-time.

Q. What led up to the conrersation-how did he happen to say this, and what did jou say in reply?-A. He came to the store to get some fox skins that was promised to him or that he wanted. He came up and 
started the conversation. He started in crying at first, and claimed that he had been insulted at the table.

Q. Who had insulted him?-A. I asked him that question; he said it was Mr. Clark aud Dr. Lutz; that at the table insulting remarks were continually passing back and forth. I said, "Why don't you report them." He said he had. He said it had got so bad that his wife could not come to the table. I said, "That has got to be stopped." He told me the rest of the employés were down on me, and that he and his wife both were willing to take up for me; that they were both satisfied that I was a good man.

1 Q. He said that all the others were down on you?-A. Yes, sir; and that if I would bring in charges against the company he would see that: I lost nothing by it. I said that I had no charges to make against the company.

By Mr. Dunn :

Q. Was anybody else present at that couversation?-A. No, sir.

\section{TESTIMONY OF JOHN HALL.}

\section{JOHN HALL, sworn and examined.}

By Mr. JeFFries:

Q. Are you an emplosé of the Alaska Commercial Company?-A. No, sir; not at the present time.

Q. You have been?-A. Yes, sir.

Q. Where were you stationed?-A. On St. George Island.

Q. In what business?-A. Cook.

Q. Did you as cook wait upon the table at the company's house?A. Yes, sir.

Q. Were there any ladies boarding there?-A. Mrs. Gavitt.

Q. How was she treated by the emplojés and by jou in particular?A. With the greatest respect.

Q. Did you erer find any fault with her or she with you?-A. No, sir; not that I am aware of.

Q. Did you treat her with respect?-A. Always.

Q. Mr. Gavitt testified that you came in to the dining-room with your pantaloons disarranged in the presence of Mrs. Gavitt.-A. The agent would not allow me to go into the dining-room withont an apron on.

Q. Are they nice and clean?-A. Yes, sir; the agent would not allow me to go without a clean one.

Q. Who furnished those aprons?-A. The company.

Q. How far do they come down?-A. Below my knees.

Q. How far behind :-A. Nearly clear around.

Q. Did you wear them habitually in the dining.room?-A. Yes, sir.

Q. How are the natives treated on the island of St. George? - A. Very good.

Q. Do they appear to be satisfied with their condition?-A. Perfectly satisfied.

Q. Have you been orer Alaska pretty well?-A. I have been to (Oonalaska; that is all.

Q. How do the emplorés of the Alaska Commercial Company generally treat the natives? - A. Always with the greatest kindness.

Q. Were you there on Decoration Day when they hoisted the flag?-A. Yes, sir. 
Q. State whether there was any insult offered the United States flag.-A. No, sir; not that I am aware of. day.

Q. It was out of respect to the dead soldiers?-A. Yes, sir.

Q. Did Mr. Gavitt find fault with it?-A. That I could not say. I was inside.

Q. Do you know Mr. Webster?-A. Perfectly.

Q. What sort of a man is lie?-A. The best man I ever worked for.

Q. Did you ever know him to be drunk on st. George Island?-A. No, sir.

Q. Do fou know whether he was drunk on the island?-A. Never. to my knowledge.

Q. Were you there all the time?-A. Yes, sir.

Q. Who keeps the liquor?-A. The doctor.

Q. If he got any he had to get it from the doctor?-A. We got a drink on holidays, Christmas, New Year's, and Thanksgiving. full.

Q. How much liquor did sou get on holidays?-A. Half a wine-glass

Q. Each person?-A. Yes, sir.

Q. Did you ever know of auybody being drunk from liquor obtained from the doctor? -A. No, sir.

By Mr. Felton:

Q. Were you present when the flag was raised? -A. I was in the kitchen.

Q. You did not sce the flag raised?-A. Not until after it was hoisted.

Q. Then you do not know what occurred?-A. No, sir.

\section{TESTIMONY OF JARES C. REDPATH.}

JAMES C. ReDPATH sworn and examined.

By Mr. JeFFRIES :

Q. Have you been an agent of the Alaska Commercial Company in Alaska?-A. Yes, sir.

Q. On which of the islands?-A. I have been located on both islands.

Q. I will call jour attention to St. George more particularly. When did you leave St. George Island ?-A. In 188t, the last time.

Q. How many years have you spent on the seal islands?-A. I have spent fourteen summers and ten winters on the seal islands.

Q. Have you been in other parts of Alaska?-A. I was in Oonalaska only, on the American side, and Kanchatka on the Russian side.

Q. When did you first go to Alaska?-A. April, 1875.

Q. What do you say as to the progress made by the native inhabitants of the seal islands during that time, from 1875 to 1884 ? - A. I cousider that wonderful progress has been made.

Q. Did you pay any attention to the schools?-A. Yes, sir; it was my duty to see that everything was propesly kept on the part of the company.

Q. Was Mr. Clark there as the school teacher?-A. One winter.

Q. What sort of a teacher is Mir. Clark?-A. A very good man and quite capable of taking charge of any school.

(Q. Mr. Garitt states that Mr. Claik was a man that was drunk all 
the time.-A. I never knew him to be in that condition; on the con. trary he was a very temperate man.

Q. State, if you please, all about the company's school on St. George Island? $-\Lambda$. I can not see where there can be any reason for complaint in regard to the company's school. It is conducted like schools in most country villages. It is kept eight mouths in the year, and the teachers are usually first-class teachers; in fact always while $I$ have been stationed there they have had capable men as teachers-men who have been teachers in institutes here in this country, and who are well educated in the art of teaching. The school-houses are kept in first-class order always.

Q. Has this a familiar look to fon (exhibiting a photograph)?-A. Yes, sir; this is a picture of the sehool-house and the school children taken on the island last winter.

Q. Does it correctly represent the children?-A. Yes, sir; just about as they appeared in school every day.

Q. What branches are they taught?-A. Spelling, reading, writing, arithmetic, geography, and some few other exercises.

Q. There is still a prejudice against the teaching of English only on the part of the Greek Church ?-A. Yes, sir.

Q. It is the only difficulty the company has to contend with? -A. That feeling always existed on the part of the Church.

Q. Why is that?-A. They seem to think that it has a tendency to alienate the children from the Church service.

Q. The Greek Church is a close corporation ?--A. Exactly.

Q. Is that because of the failure of some of the chuldren to attend regularly?-A. It is, without doubt.

Q. What efforts do the company make to induce the children to go to school?-A. The company's agent does what he ean and the Gov. erument agent gires it his special attention. If a child is absent the teacher reports it and the Govermment agent will send for the chief, or go to where the child lives, and ascertain the reason why the child does not go to school.

Q. As the results of the teaching, are they leaming to read and write and to speak English?-A. They are, without donbt.

Q. Did yon hear this young man that testified here?-A. Yes, sir; I am well acquainted with him, and have been erer since he was eight year's of age. When I first saw him as a child he could not talk any English, and you see what progress he has made.

Q. What proportion of young men and women of eighteen or trenty fears of age can read and write and know something of geography and arithmetic? - A. I consider all of that age on the islands can read and write and know more or less abont geograply aud can master figures to some extent. They go to the store and buy things, and they know what amount of change they want back and exactly when they hare the correct amount.

Q. The books are kept in English ?-A. Yes, sir.

Q. There is a school on each island? $\mathrm{A}$. Yes, sir; there is a school on each island.

Q. What do you say as to the condition generally of the natives of those islauds and their treatment by the company?-A. I consider the natires in very comfortable condition. As good as I have found in any working community that I ever came across. ing.

Q. How are they clothed?-A. They dress well; wear good cloth-

Q. Both men aud women ?-A. The women always wear good clothes as good as you generally see in any city. 
Q. Do they hare finery ?-A. Yes, sir.

Q. What kind of dresses have they for Sunday and for visiting ?-A. They hare dresses of nice woolen material, and frequently silk.

Q. You allude to the women ?-A. Yes, sir; the native women, and they also decorate thenselves with jewelry which they order throngh the company from San Francisco.

Q. Do you know anything in regard to the morals of the natives, and the women in particular?-A. I can not siy that their morals are bad in any respeet. Of course there is more or less immorality amongst those people, the same as people in any other community.

Q. Do jou know of any outrages upon them by the employés of the Alaska Commercial Company ?-A. I never heard of any such thing.

Q. If there had been you would have known of it?-A. I would have known all about it.

Q. Yon are employed by the Alaska Commercial Company?-A. Yes, sir.

Q. Do you know Daniel Webster, the ageut of the company?-A. Yes, sir; I am very well acquainted with Mr. Webster.

Q. What kind of a man is Mr. Webster ?-A. I cousider he is a very good and kind-hearted old gentleman.

Q. How old a man is he?-A. He is abont sixty; prossibly a little more or less; I do not exactly know what his age is.

Q. What are his habits as to intoxication ?-A. I nerer knew of Mr. Webster being drunk in my life.

Q. How long have you known him ?-A. Fourteen years.

Q. Do you know whether he has ever been drunk?-A. I know Mr. Webster absolutely refused to drink whisky at times wheu he really neerled it.

Q. Do you know Peter Resanzoff, a native of St. George Island?-A. Yes, sir. He is a man that has no standing amoug his people; none whaterer.

Q. What is his reputation for truth and reracits?-A. He has none.

Q. Would you believe him under oath ?-A. I would not.

Q. Do you know him well?-A. Very well.

Q. Did fou see a letter purporting to be written by him published in the New York Sun or some other newspaper?-A. Tes, sir.

Q. What do you say about that letter?-A. I hardly think that that is his composition. If it was written by Peter, the probability is somebody dietated that letter to him. He talks English; he can read and write, but I know that he can not compose such a letter as that. That is not his composition by any means.

Q. What would become of the people of the seal islands or the people of Oonalaska if the fur-seal industry should be abandoned, or the rookeries should be abandoned by the seal for any cause?-A. It would be utterly impossible for them to live on those islands.

Q. Explain to the eommittee why that is so.-A. In the first place the seal is the ouly source of revenue whaterer that thes hare. There is nothing there except that and it constitutes their meat and their food, and if the seal were exterminated they would have to be remored from there. It would be a great calamity to the whole Territory if such a thing should oceur.

Q. What is it necessary, in rour judgment, for the (iovermment of the United States to do in order to jreserve the seal rookeries?-A. I beliere if the laws now in existence are executed it would be all that is necessary.

Q. Do you regard the rookeries in dauger of being destroyed ?-1. Fes, sir. 
Q. Why?-A. From marauders killing so many seals in the water. I understand 75 to 80 per ceut. of those killed are females.

Q. How do you account for so great a number of females being killed?A. It is usual for the females to leave the beach and go out to feed in the sea and leave the pups on shore.

Q. The males remain on shore, do they ?-A. The breeding males remain on shore. The males do not require as much food as the females, because the latter have the pups to nurse.

Q. The female soon after she arrives on the rookeries brings forth her young and some days after that she goes out into the sea in search of food ?-A. Yes, sir; and often remains a day or two.

Q. And it is during that time that these hunters intercept them?A. Yes, sir.

Q. If they kill females are they not apt to kill the pup as well ?-A. Yes, sir.

Q. And if they wound a seal in the water, the seal is likely to sink before they can recover it?-A. There is no doubt about that.

Q. What proportion do they recover of those that are killed bs firearms in the water?-A. Very few, I should suppose. I have never seen a seal shot in the water. I have known of sea-lions that if wounded in the water conld be recovered, but if shot and killed they will sink.

Q. In your judgment, what proportion of seals that are shot in the water are recovered?-A. It is hardly possible to ricorer one-half of them.

Q. Do you happen to know the extent of the depredations for the last three or four years in those waters?-A. Yes, sir; I have been familiar with that, more or less.

Q. How many skins were taken surreptitiously and marketed since 1886 , as far as you know?-A. It is, of course, simply newspaper reports that I am familiar with. I know of some instances where Tictoria ressels made a catch of 12,000 or 15,000 ; I have not paid particular attention to it.

Q. Do you bappen to know that the law limits the number to be taken br the Alaska Commercial Company to 100,000 skins a year?-A. Yes, sir.

Q. That, in the judgment of Congress, was as much as the business would stand? -A. Yes, sir.

Q. If they kill, say 30,000 a year surreptitiously in addition to that many skins, and kili mostly females, and in adlition kill pups, what effect would it have upon the rookeries in time?-A. No doubt the rookeries wonld diminish rery perceptibly in the first or the second year.

Q. Do jou happen to know if any efforts are being made for the outfitting of ressels for the purpose of killing seal during the coming year?-A. Yes, sir; I left San Francisco a week or two ago, and I learned from some friends that there were preparations being made there to hare a large number of ressels go out from San Francisco in the spring.

Q. Why are they encouraged to go out next spring?-A. I presume in consequence of the non-seizure of ressels last season.

Q. Do you know anything about what they are doing up in British Columbia?-A. No, sir, I do not; I have no present kuowledge. There is no doubt there will be a large number fitted out from there and eren from the Japan and Chinese side also.

Q. Is it jour judgment that if the lars enforced in the United States 
were executed the rookeries would be safe?-A. Yes, sir; I think they would be.

Q. How many cutters ought the Gorerument to have in those waters in view of what is expected next summer?-A. I should think two vessels of the elass that have been plying in these waters for the last two years would be all that is really necessary.

Q. That is, two eutters to patrol Bering Sea?-A. Yes, sir.

Q. If forty or fifty ressels should be captured, what would they do with the crews?-A. It would be necessary to send the captured vessels, with an officer in charge of each, to Sitka, or wherever they might be sent. That is the way they have been doing.

Q. What do you say as to the propriety of haring a man-of-war or some ressel at Oonalaska on which to transfer these erews and send them to Sitka and go back and patrol the seal islands?-A. It would be a great expense, but no doubt it is a pretty good idea.

\section{By Mr. Dingley:}

Q. You alluded once or twice to a non-enforcement of the law during the last season. Do I understand from that that there was a particular laxity in regard to the enforcement of the laws last season in comparison with previous seasons ?-A. I know of no ressels haring been captured last season, though there were some in the waters. I am not familiar with the reason why or anything about it.

Q. There was seizures before this last season, but this last season there were none? - A. There were no seizures last season.

Q. Not of any kind of vessels ?-A. No, sir; not that I know of.

Q. You do not know the reason?-A. No, sir.

Q. Are you familiar with the execution of the law before this last season? - A. Yes, sir; it was pretty thoroughly carried out, and they were sncessful in breaking up this marauding. That summer fourteen vessels were captured, and there was also quite a number that were not captured, as there was only one revenue-cutter at a time in the waters.

Q. There was the same number, howerer, this season as the previous : seasons?-A. Yes, sir.

Q. There were the same rerenue-cutters one season as another?-A. One at a time were stationed there.

Q. And in 1857 there were a number of seizures made, and the Bering: Sea was successfully protected?-A. Yes, sir.

Q. In $18>8$ there were no seizures?-A. None that I know of.

Q. Do you know there were no seizures?-A. No, sir; I do not know of any seizures having been made.

\section{TESTIMONY OF C. A. WILLIAMS-Recalled.}

\section{A. WILLIAJIS, recalled.}

\section{By Mr. JeFFries:}

Q. Will you please state to the committee what information sou may have as to the number of illicit sealers that are expected in Bering Sea next season, either from the United States or British Columbia, from the reports you may have heard or from your own knomledge?-A. Such information as 1 have is derived from correspondence from San Franciseo and Victoria. Letters from San Francisco inform me that by reason of the non-seizure of ressels in Bering Sea last year the uumber that are now being outfitted preparatory to going there is very 
much in excess of that of any previous year, and that the probability is there will be frum thirty-fire to forty vessels that will go from that port. Information from Victoria, derived from the house of Martin Bates \& Co., of New York, states that their purchaser writes that; owing to the lack of seizmre of British ressels and others in Bering Sua last year, some 22,500 skius were lauded and put on the market in Victoria, that the result would be in his expectation that at least 50,000 or 60,000 skins would be put on the market in Victoria the comiug year, and that vessels are preparing for that purpose to go out early in the spring. 'That is all the information I have on the subject.

Q. As you have been engaged in this business since jou were a young man, and your father and grandfather before you, from your knowlerge of the business, what would you say would be the effect upon seal life of the taking of 50,000 or 60,000 skins by these unlawful marauders?A. The waste rould be rery great, rers much larger than the number of skins represented, for this reason: Most of the skins which are taken by these so-called marauders are those of females. These females that are killed usually have a pup, which they have left on shore while they hare gone off the islands to feed. When the female is killed the pup dies on shore from the lack of sustenance, aud that destroys the possibility of further production. 'The record shows that of the number of seals that are killed or wounded but a small proportion are recorered. From my own estimates, from my experience in the matter, I am inclined to. think that it would be at the very lowest one-half. I think 60,000 slius certainly represent over 130,000 seals that have been shot, wounded, or killed.

Q. You are one of the principal shareholders and managers of the Alaska Commercial Company?-A. Yes, sir.

Q. Does the company know from its agents or otherwise that the number of seals on the rookeries lately, within the last year or two, is diminishing? - A. It does.

Q: It has such reports from the agents on the islands?-A. Yes, sir.

Q. What do you say as to the compauy haviug been unable to get its full quota of proper marketable skins last year?-A. It was unable to get its full quota.

Q. For what reason ?-A. By reason of the interference of marauding vessels in Bering Sea.

Q. What will be the result if that continues ?-A. Extermination of seal life on the rookeries. That means the extermination of the native population.

Q. Prior to 1855 were there any depredations ?-A. There were so fer as to hardly be noticeable.

Q. The Government had taken a stand?-A. Up to that time it was not considered safe for a vessel to venture in there.

Q. What do you say would be the result if the existing law prohibiting seal lilling in Alaskan waters and Bering Sea were properly enforced?-A. The suppression of illicit killing.

Q. Would the rookeries then yield 100,000 skins annually without depreciating ?-A. After a year or two. It would take some little time for them to recover.

Q. Do you know Mr. Webster?-A. I do.

Q. How long bave you known him?-A. Forty years, and upwards.

Q. Was he ever in jour employ?-d. Yes, sur; a great many years.

Q. What doing?-A. He sailed in $m y$ ressels in almost erery position from a boy to first mate of a ship.

Q. How long?-A. Fifteen or twenty jears. 
Q. And how long has he been in the employ of the Alaska Commercial Company?-A. Siuce the formation of the company.

Q. How old a man is he?-A. He is a man sisty-three to sixty-fire years of age.

Q. What are his habits?-A. Temperate.

Q. What is bis character?-A. Very good.

Q. How as to temperance?-A. He is a thoroughly temperate man. At times of responsibility, or when he is ou duty, he is to be relied upon in every respect. I suppose at times that he may inclulge in a social glass when he is off duty. I have never seen him under the influence of liquor.

\section{By the Chatritan :}

Q. I believe I will ask sou a question which Dr. Meintyre was not prepared to answer, as to the aggregate probable value of jour trade in Alaska outside of the seal islands? - A. That has varied some in past years. When sea-otter were plentiful their hunting was a fairly good trade to pursue. Under the present condition of the diminution of seaotter trade, the competition in prices which the company has to meet from other parties engaged in the trade-and they are very many-the value of what is called the land business of the company, which includes sea otter and land furs, is so inconsiderable as hardly to be remunerative, and if I am permitted I will say that if it were not for the humanitarian aspect of the matter-if it were not necessary to sustain the natives of Attoo-the company would withdraw their vessels from the prosecution of that trade. But the natires on the islands of Attoo and Athka, and other of the Aleutian chain, depend almost entirely for sustenance on sea-otter hunting, and the returns from it are so little that the compauy does not receive sufficient uoney to pay coal bills for steaming to Attoo and back again; but if we did not go there and supply the natires I really think they would starve. During the past three jears we have followed that business at a loss.

Q. Would the natives be able to reach a market for their furs themselves if your ressels and trading stations were not there?-A. The natives on the extreme islands of the Aleutian chain would have no opportunity whatever, especially these natives at Attoo. They would have no possible opportuuity of reaching a market unless, perhaps, a transient ressel should pass, hunting trade. But they would be quite unable themselves to get to a market.

There is one point I would like to call the attention of the committee to if permitted to do so-not in the interest of the company, but simply in the interest of the Alent population of the Aleutian chain of islands. That is, that whereas in former years the result of the sea otter hunting of those islands was sufficient to direct attention to them and induce traders and our company aud other parties to go to them for the purpose of secming skins and taking them supplies, the people were in the way of getting a sufficient living in a rery respectable way. The diminution of sea-otter life has been rery rapid, owing to the large increase of hunters, and insteal of $5,1100,6,000$, or 7,000 being secured, as in some jears, it has run down to 2,200 or 2,000 , and even less than that, and if the same ratio of decrease continuts it will be but a rery few years before the sea-otter will be extinct, or at least be taken in such small quantities that the expenditure would not pay tratlers to seek for them. If that source of sustenance is lost to these natives it is going to be a rery important and pressing question as to how they are to live. The islands furnish absolutely no means of sustenance; no agricultural 
products. They might live in a half-barbarous way upon fisb. No traders would go near them, and their condition would be rers wretched indeed.

In that connection it is well for the Govermment, and whosoever may have the lease of the seal islands, to consider what will be the condition of the people of the Alentian chain proper, apart from the Pribrlor Islands ; whether or not certain consideration should not be given them in any future arrangement that mas be marle looking to the support of the people of those and other islands in comnection with the working of the Pribylor group. Unless one has had his attention called to this subject earefully, by association of past years, he would hardly realize the condition of things. These people may be reduced to starration, because when the sea-otter business is gone there is nothing else on any one of those islands. From the seal islands proper it is demonstrated there could be derived a suficient amount of seal meat to feed this Aleutian population. The question is not one of production, but it is one of distribution, and it should be taken into account by the Gorermment that the possibilities of those people in the future should be considered and the distribution made from the seal islands of the seal meat which now goes to waste and which would sustain these people. It would involve, possibly, the necessity of erecting, br whaterer compauy may have the business, cold storage on the island in which to keep this seal meat. It is something which is worthy of consileration in this connection, and the future of the natires of the Aleutian chain will depend very cousiderably upon tie action that the future lessees of the seal islands may be inclined to take with regard to these people.

Q. Can the nieat be preserved and distributed in any other form that would make it edible except by means of cold storage?-A. Cold storage suggests itself to me as the simplest method, but Dr. McIntyre thinks he kuows a great deal better war. Vast quantities of seal meat go to Taste. The time will come rery shortly when the natires of the Alentian chain must be assisted in some way, and if they should be assisted by the company that may have the lease of the seal islauds or by the Gor. ermment, by a proper distribution of this food, and at the same time if there conld be some way of employing them-I can not at this time say That-some kind of occupation which would gire them nominal responsibility and make them feel that they were labores rather than paupers, it would vastly belp them. The Alaska Commercial Compauy has always endearored, as far as possible, to notice those peoplo and look after them.

Q. One wituess testified-perhaps more; Mr. Tingle, I am sure, rererrerl to it-as to the condition of the iubabitants of Attoo as being already almost destitute, without sufficient game to support them, and suggested the idea of a permit being giren for the removal of the population, or a portion of it, to the Pribylov Islands, where they could be emplosed by the company, as it felt the necessity for a little more labor than the native population of the islands can give, and thereby extending them relief in that way. What do you say as to that?-A. That is one point that I had in my mind. For the past three years the com. pauy visited that island aud distributed supplies there, and they have not receired any returus from that station sufficient to pay eren the cost of the coal used in steaming up and back.

At the beginning of this lease the natires of St. Panl who were arail. able for working must have been 130 to 140 , I should think, and if I am wrong Mr. IIorgan or some other gentleman can correct me-and now they are reduced to somewhere about $S 0$ bs natural processes. If I 
were asked in that connection why the ratio of birth is not equal to the ratio of death, I would state that the laws of comsanguinity in the Greek Churel are such as to retard marriage between the population, and there is on the islauds a surplus of women who are not able to find husbands. There are men in this Aleutian chaiu who would be glad to marry these women if they could become members of the sealling force and share in the distribution. The people on the seal islands hold their position as one of great value, and are nuwilling to have additional men brought there. It is necessary for the company to employ, by permission of the Secretary, people taken from the Aleutian chain as laborers to do the rougher work. I think a better portion of the people of the Aleutian chain should be permitted to go there aud gain settlements on St. George aud St. Paul Islands by marriage or importation. It would infuse new blood into the iulabitants. It would promote marriage between them and the women. A woman of St. Paul will not marry an Gomalaskan native and return to Oonalaska with him and thereby lose hex proportion of this fund. I think it would be well to introduce the young men and restock the islands.

The CHAIRJIAN. I think that is a very good suggestion and a very important one.

\section{By Mr. JEFFRIES:}

Q. The seal island natives get the $\$ 40,000$ fund and you have to hire other people and pay them extra.?-A. Yes, sir; the whole fund is distributed among the natives of St. George and St. Panl. All the extra labor is brought mp from the Alentian chain and is paid for extra, and they are boarded, lodged, and supported by the company.

Q. Is that by reason of a Gorermment regulation - - A. No, sir; the only Gorermment regulation in the matter is simply that they may be taken up there as laborers.

Mr. Dunx. The law giving the natires of St. George and St. Paul the exclusive privilege of doing that sealing work, is it a statute or a Treasury regulation?-A. It is a Treasury regulation.

Mr. FELTON. If the Aleutian chain of islauds are incapable of sustaining the people, would it not be better policy to remove them to some place where they could be made self-sustahing, rather than seurimg them supplies aud supporting them with nothing to do?-A. The question has a good many sicles to it and is one I could not answer immediately. These places are far apart, and you could not remove these people to any place where they would be self-sustaining except on the main territory. On the islands they are supported entirely by fishing and hunting animals of the sea, and by placing them on the main-land $\mathrm{my}$ impression is they would fall into evil ways and habits and they would depreciate, and perhaps fall into the condition of roving Indians in their llabits.

Mr. Felton. You think they conld not live in enforced idleness ?

The WiTnEss. It would be well to introduce some kind of work amoug them. They might learn to do certain linds of basket-work or net-work. I thiuk it would be jossible to derise some occupation for these people which would relieve them from the irlea that they were simply paupers sustamed at the expense of the Goverument.

By Mr. FeLton :

Q. Do these islands produce any grass?-A. Yes; during the short summer.

Q. Sumething would have to be importer ? -1 . They can alwars fish, $9984-21$ 
and if ther could get a certain amount of flesh meat or seal meat, and conld be offered encouragement, they might get along.

Q. I infer that morally and intellectually these natives are superior to the natives of the seal islands?-A. I do not speak from personal obserration, but only from such information as I have been able to get from reports in Congressional documents and from travelers. I think they are a docile race, capable of elevation and guidance, and a race capable of being elevated above the tendencies of savage life and deuse immorality.

Q. You think one valuable factor in that problem would be to allow the women on the Pribylov Islands to marry these Aleuts and let the Aleuts thereby acquire a domicile on the islands and a participation in the benefits of the seal business?-A. I consider that these men would be clesirable inhabitants to introduce upon the seal islauds, and they should be permitted to marry there and have a share in those benefits. This fund of 40 cents per skin was fixed by the company with the sauction of the Treasury Department. If the seal business and the sea-otter traffic should both disappear, that would be the end of the race.

\section{TESTIMONY OF DR. H. H. MCINTYRE.}

\section{Dr. H. H. McIntyre, called and examined.}

Q. Please state your full name and oecupation.-A. H. H. McIntyre; I am superintendent of the seal-fisheries for the Alaska Commercial Company.

Q. Where do jou make your headquarters?-A. On St. Paul Island during the sealing season.

Q. How long have you been connected with the Alaska Commercial Company ? - A. Since the beginning of the lease in 1870.

Q. How mauy of those years or seasons have you spent upon those islands ?-A. I have spent one entire year and erery sealing season, with the exception of three, during that time.

Q. Had you ever been to Alaska before you went into the employ of the Alaska Commercial Company?-A. Yes, sir; I went there in the summer of 1868.

Q. In what capacity?-A. As special Treasury agent.

Q. What parts of Alaska have you visited?-A. Nearly erery part, from the most southerly to Bering sea, and up as far as St. Michaels; and also to the mouth of the Yukon River.

Q. Have you been as far as Attoo?-A. I was there in the summer of 1869 .

Q. Have you visited many of the Aleutian Islands, or any them?A. I have touched at many of them.

Q. Have you been at Kodiak?-A. Repeatedly.

Q. Have you been in sontheastern Alaska?-A. Yes; but not since the sprivg of 1870 .

Q. Dici you have an oplortunity to examine the condition of the natives in other parts of Alaska?-A. Yes, sir; it was a part of my duty, under my instructions from the Treasury Department, to examine into and report upon their condition.

Q. What do you say as to the difference in the condition of those people then and now? - A. I think their condition has vastly improved at all poiuts, and particularly at the seal islands, whese the company has had exclusive control. When I first went to these islands I found them living half underground, in a semi-barbarous condition. At present 
they are living, in every respect, the same as civilized people in other parts of the world. The simme may be said of places other than the seal islands, but in a less degree. WV have not done as much for the people of other places, but wherever the posts of the Alaska Commercial Company are located the condition of the natives is improved.

Q. W hat has the company done at other stations, or at other islands, for the people?-A. It has supplied them with improved facilities for hunting and tishing, and with the necessaries of life pertaining to civilization.

Q. When hunters have not the means for fitting out expeditions, do you you furnish them the meaus?-A. It is customary for us to do so, when they are going upon their annual hunts.

Q. What do you do for them to enable their families to live while they are on these expeditions?-A. Wre furnish thein supplies for their hunting parties, and, to such an extent as is possible, take our pay from the procteds of the season's catch. They are not al ways able to pay in full. We furnish them transportation to and from the hunting grounds, and provide for their families while they are gone.

Q. How many assistants have you usualiy on the seal islands, taking the summer and winter separately"-A. I have six men who are called agents of the company. All are on duty during the sealing season, and a part of them remain at the islands through the winter. 'Then we have, in addition, physicians, storekeepers, teachers, teamsters, cooks, etc., numbering in all about fifteen or twenty men during the summer, besides the native seal-hunters.

Q. From the spring of 1887, in May or the 1st of June, up to August, 18s8, being the period of Mr. Gavitt's administration, who did you have on St.George Island, where he was stationed chring that time?-A. Mr. Webster was the agent in charge; and he was helped by Mr. Kirk, storekeeper; Dr. Lutz, the physician; Mr. Clark, the teacher; and John Hall, the cook.

Q. All these gentlemen testified here to-day, except Mr. Webster and Mr. Clark?-A. Yes, sir.

Q. What sort of a man is Mr. Webster?-A. Mr. Webster has been in our service as long as I, and was in the same business during the summer of 1869 and 1570 , under the predecessors of our company.

Q. Do you happen to know whether he was an officer on Mr. Williams's vessels for twelve or fifteen years previous to that?-A. I know he has been following the sea nearly all his life. We regard him as one of our very best men. He is a very intelligent man-without book education, but efficient, houest, and thoroughly reliable.

Q. Have you heard any complaint as to how he managed the business?-A. None whatever. On the contrary, the people of the islands are very fond of him, while the Government agents on St. George have never made any complaint until Mr. Gavitt came in contact with him.

Q. What are his habits as to temperance?-A. He is strictly temperate when on duty. I presume that in San Francisco, if he were off diuty, he might take a social glass.

Q. Did you ever know of his getting intoxicated on the seal islands? A. No, sir; while he is on duty he can be relied upon.

Q. I understand that during the holidays whisky or brandy is giren to the employés as a beverage?-A. I clid not know that that practice prevailed. I never heard of it until it was mentioned here to-day; but it is quite likely that a glass is set out sometimes on holiciay occasions. It certainly is not allowed under the instructions. 
Q. Have you known any intoxication among the employés on St. George Island?-A. None whaterer among the present employés. It has happened, however, heretofore, and those who were found in that condition at times were promptly discharged when the matter came to our notice.

(2. There were but two, I believe?-A. I think only two, and those were both physicians and had access to the liquors.

Q. Where did Mr. and Mrs. Gavitt take their meals while on St. George Island?-A. At the company's mess table.

Q. Did they pay anything?-A. Nothing whatever. We hare never demanded anything from any Goverument officer for board.

Q. Did Mr. Gavitt go there prepared to take eare of himself and wife?-A. No, sir; he had made no provisions. I would like to say in regard to Mr. Webster, that he reported to me, when I arrived at the islaud, that he had had trouble with Mrr. Gavitt; that Mr. Gavitt had been absent from the mess-room for sereral days, perhaps for weeks, and that he had proposed to Mr. Gavitt to send his meals to his house, if he chose to have them, and in that way to provicle for him. He told me that Gavitt asked him to furuish him with facilities for taking care of himself in the Government house. Mr. Webster replied that the supplies were not in such shape that he could conveniently do so, but that his meals shonld be cooked in the company's kitchen and sent to the Government house. The two buildiugs are but a few steps apart.

Q. What about the stove? Gavitt says he tried to buy a stove?A. We had no suitable stove on hand. I understand there was no kind of a stove in stock except a large range, and this was not thought suitable for his purposes.

Q. Do I uncierstand you to say that Mr. Gavitt, on his own part, had made no provision for living in Alaska?-A. None whaterer.

Q. How much time did you spend on St. George Island while Mr. Garitt was there?-A. My headquarters being at St. Panl's, I staid at St. George only while the vessel remained there, a day or two at a time, on several different occasions.

Q. You have heard these statements in regard to the immorality ou St. Paul and St. George Islands. What have you to say about them?A. I think there is no foundation in fact for them. I believe there is no more immorality on those islands at present than there is in the average civilized community; but in this respect they have greatly improved. When I first went there it was eustomary for any one who chose to do so to ask a native woman to accompany him, and she would do so. But now the social evil has been restricted, as in other orderly villages.

Q. That evil has been corrected?-A. The good example set by the agents of the company and the Government has inculcated a seuse of decency that has decidedly improved matters in this respect.

\section{AFTER RECESS.}

\section{By Mr. JeFFries :}

Q. I would like to call your attention to these photographs aud ask you whether these are correct representations? - A. Yes, sir. This [incating] shows the school as it was taught last winter. Here [indicating] are the scinolars, amanged by the side of the school-house. I would say in regard to the interior of the building, that it is fitten up with modern school-room desks and seats and is kept in far better order than the average country school-house. 


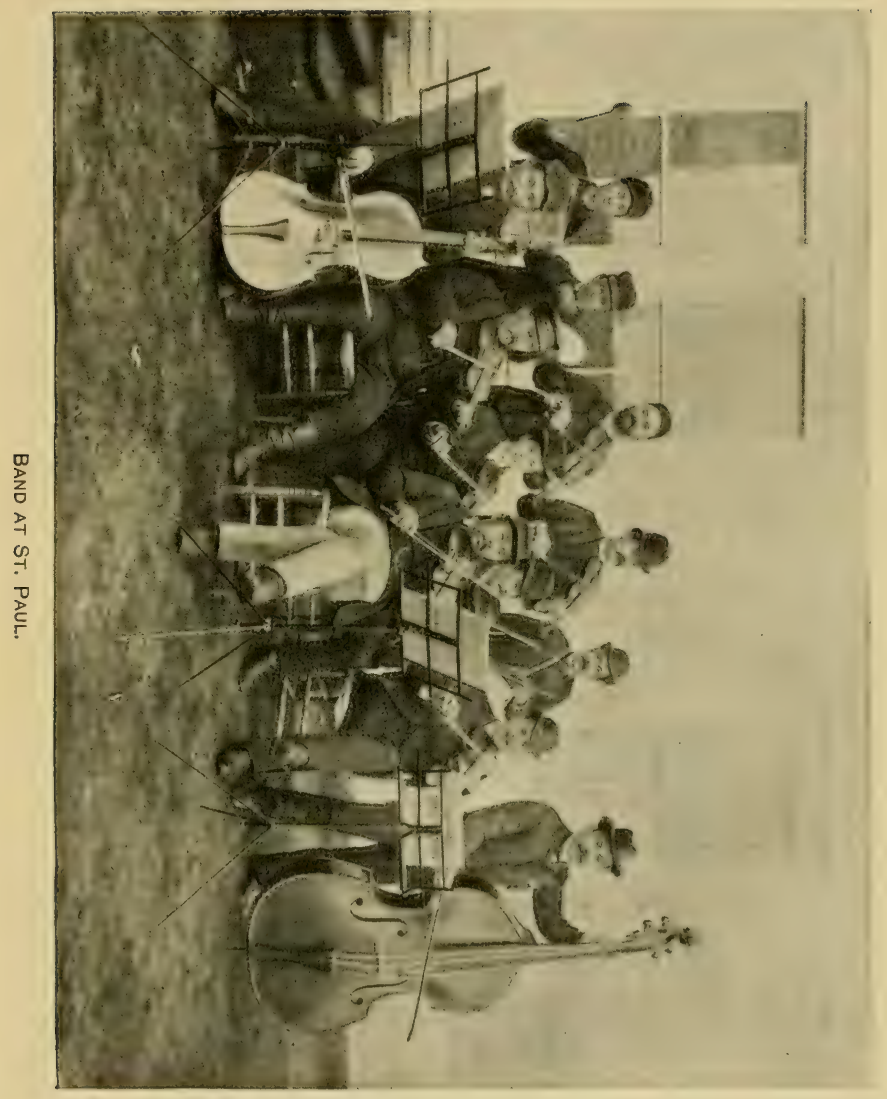







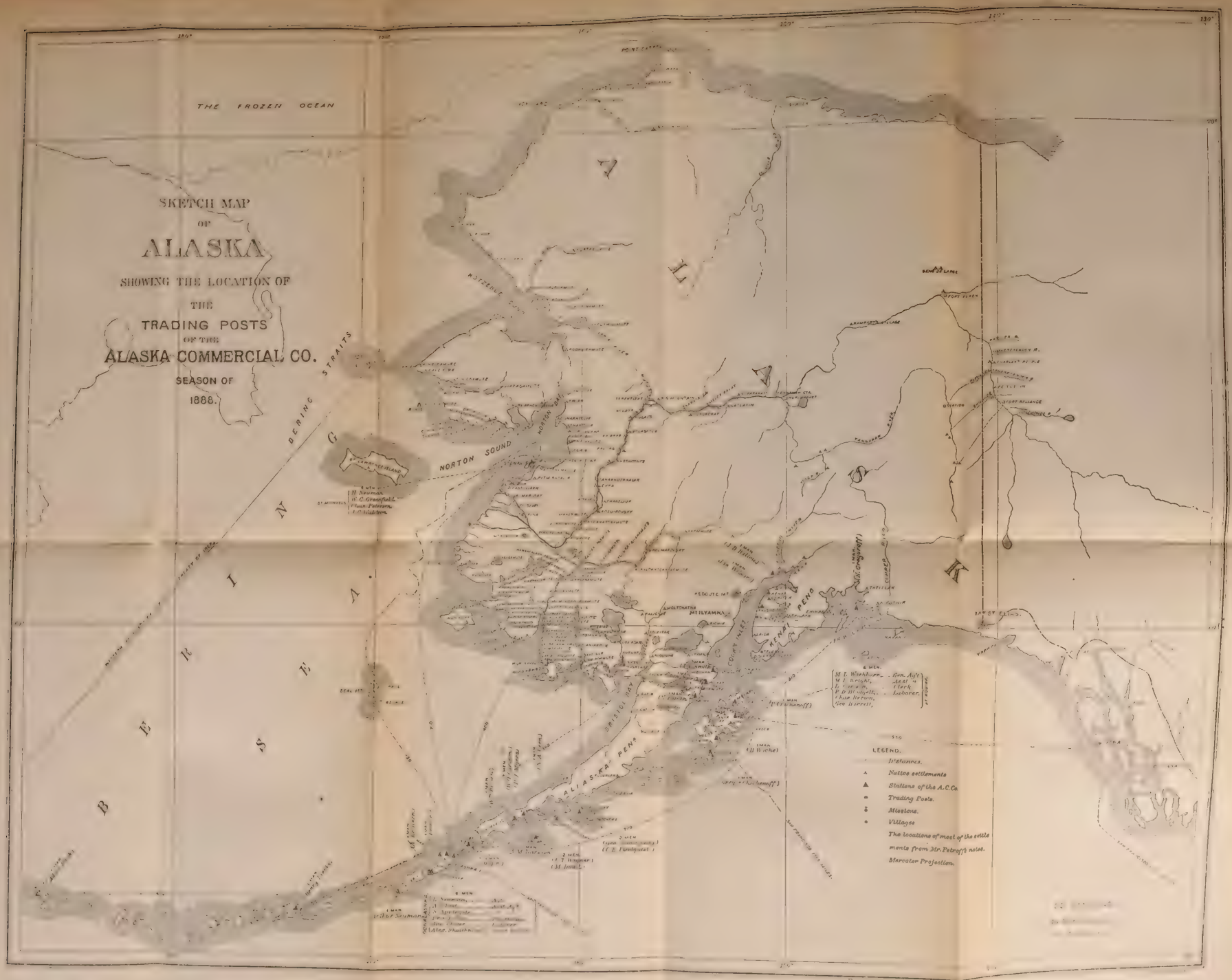



Q. What does this photograph represent [handing the witness a photograph]?-A. This is the orchestral at St. Paul Island, composed of emplores of the company and natives in about equal uumbers.

Q. Who furnished the instruments for that band?-A. They were purchased with funds subseribed by agents of the company, the agents of the Government, and the natives. Mr. Tingle, the Treasury agent in charge, subscribed largely to that fund.

Q. Have you had any conversation with MIrs. Gavitt since you have been here?-A. Yes, sir.

Q. Who was in company with you? - A. Mr. Morgan.

Q. How did that happen?-d. We went to call upon Mrs. Gavitt, after Mr. Gavitt's examination before this committee on the 19th of December last, at his request.

Q. Disl you have any conversation with Mrs. Gavitt in reference to Mr. Webster?-A. Yes, sir.

Q. What was it?-A. She stated, in substance, that Mr. WVebster was a nice old gentleman and always treated her with a great deal of respeet and that she liked him very much. She said, "he would always do ansthing for me that I asked of him." And, further, that he was acenstomed to go frequently to the Government hotise during the winter; that he did not talk to Mr. Gavitt much, becanse he did not like him, but, she added, "he would sit and talk and play cards with me all the erening."

Q. That was said in the presence of Mr. Morgan?-A. Yes, sir.

Q. Did she make any complaint as to the other employés?-A. No, sir; not to me. I heard of her having made complaints, but they were of a trivial nature, and grew out of the quarrels between Mr. Gavitt and the company's employés.

(Q. I will ask you to look at this map of Alaska, and state to the committes where the most western station of the company is located ?-A. At Attoo, the most westerly of the Alentian chain of islands.

List of employés of the Alaska Commercial Company in Alaska.

IN OONALASKA DISTRICT:

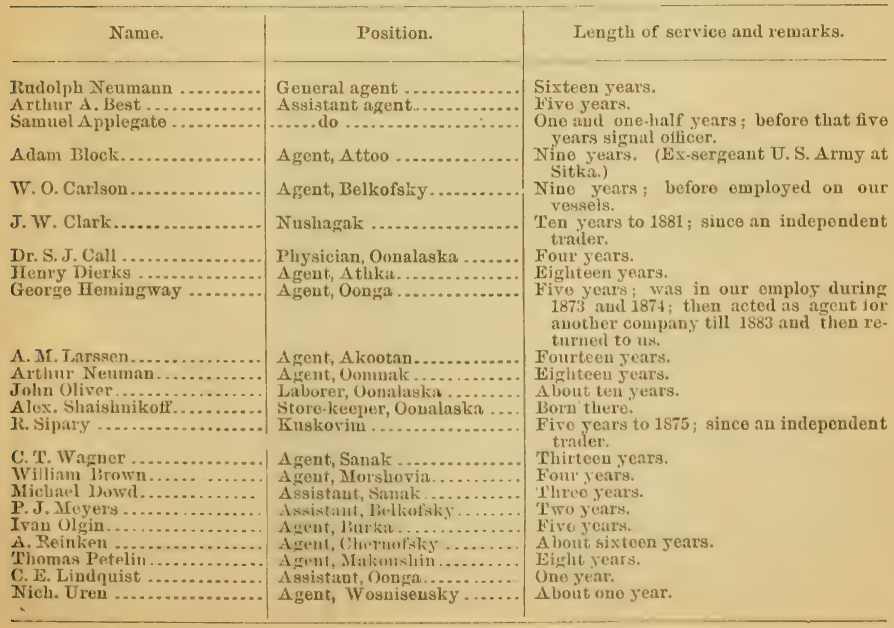


List of employés of the Alaska Commercial Company in Alaska-Continued.

KODIAK DISTRICT.

\begin{tabular}{|c|c|c|}
\hline Name. & Position. & Length of serrice and remarks. \\
\hline 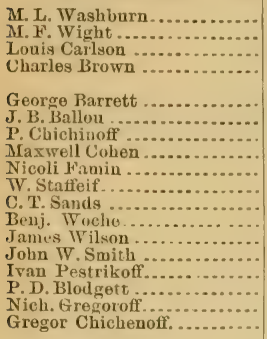 & 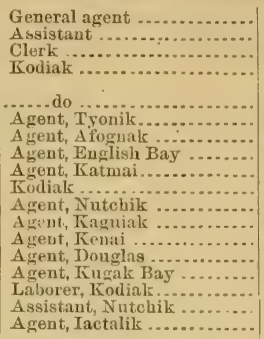 & $\begin{array}{l}\text { Ten years. } \\
\text { Two years. } \\
\text { Two years. } \\
\text { In various capacities for about thirteen } \\
\text { years. } \\
\text { About four years. } \\
\text { About five years. } \\
\text { Thirteen years. } \\
\text { Eightoen years. } \\
\text { Seventeen years. } \\
\text { Eighteen years. } \\
\text { Seven years. } \\
\text { Eirhteen years. } \\
\text { Sixteen years. } \\
\text { Six years. } \\
\text { Five years. } \\
\text { Fourteen years. } \\
\text { Four years. }\end{array}$ \\
\hline
\end{tabular}

ST. MICHAEL DISTRICT.

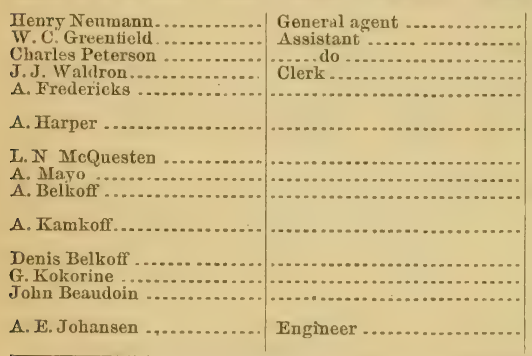

Eleven vears.

Two years. .

Eighteen years.

Fourteen years.

Six years to 1880 ; since an independent trinler.

Eight Jears to 1882 ; since an independent tradex.

$$
\begin{aligned}
& \text { Do. } \\
& \text { Do. }
\end{aligned}
$$

Thirteen réars to 1886 ; since an independ. - ent trader.

Threo years to 1886 ; since an independent trader.

$$
\text { Do. }
$$

About three years; since an independent trader.

About two years.

All these independent traders have now no further connection with the company, except to buy their goods from us.

\section{State of California,}

City and County of San Francisco:

Max Heilbromer, secretary of the Alaska Commercial Company, being first duly sworn, deposes as follows: That the within list of employes of the company aud their terms of services, consisting of three pares, is taken from the books of the company and other avanlable sources, and is, to the best of his linowledgo aud helief, true aud correct.

[SEAL.]

MAX HEILBRonNer, Secretary.

Subserined and sworn to before me this 11th day of December, 1888.

[SEAL.]

JAMES L. KING, Notary P'ublic.

Q. Here is a list of the employés of the Alaska Commercial Company upon and ontside of the main-land, with the names of the statious where they are loeated. This is prepared and verified by Mr. Heilbromer, secretary of the company, and bears the olficial sfal of the company I will ask you whether this is a correct statement, so far as you know?A. Yes, sir; it is a correct statement of the names and locations of these persons in Alaska, the number of years of service of each under 
the employ of the Alaska Commercial Company, and, in addition, the names of several who are traler's in Alaskia, who latve no connection with the company, except as they purchase their goods from us as wholesale dealers.

$\mathrm{Q}$. How many men has the company stationed on the island of $\Lambda$ ttoo? -A. One, Mr. Block.

Q. Where is the next station?-A. The next station is Athka, about 450 miles to the eastward of Attoo.

Q. How many men are there?-A. One.

Q. Where is the next?-A. At Oomnak.

Q. How far is that from the last-named station?-A. It is about 200 miles.

Q. Now continue with the next station, $-\Lambda$. The next station is Oonalaska, and there are on Oonalaska Island three other small stations, at each of which one man is stationed.

Q. How large an island is Oonalaska? - $\Lambda$. About 80 miles long.

Q. How far are these small stations apart?-A. The most distant one is about 80 miles from Oonalaska village.

Q. How many are there at Oonalaska?-A. Six.

Q. Oonalaskia is a kind of a supply station for the company ?-A. Yes, sir; it is a supply depot for all the western part of Alaska, and the place at which all vessels tonch when going into Bering Sea.

Q. You have four men there?-A. We have six. One is a native.

Q. Five white men?-A. Yes, sir.

Q. Go on to the next station.-A. The next station is on Akootan Island.

Q. What is the next?-A. The next is Sanak.

Q. How far is that from the last station ?-A. About 120 miles.

Q. How many men have you there?-A. Two.

Q. What is the next one?-A. The next two stations are on the west end of the Alaska peninsula.

Q. How far is that from the last-named station ?-A. About 20 or 30 miles.

Q. How many men are there ?-A. One at each place.

Q. What is next?-A. The next is Oonga, about 100 miles east of Sanak.

Q. Where is the next?-A. The next is in Kodiak district, on Kodiak Island.

Q. How far is that from the other stations named? $-\lambda$. It is about midway between Sitka and Oonalaska-about 500 miles from either place.

Q. What is the name of the next?-A. The next to the eastward is Nutchik.

Q. How far is that from Kodliak?-A. Two hundred and twenty miles.

Q. How many stations are there on Kodlak Island ?-A. Three.

Q. How far are they separated from each other? - $\lambda$. They are from 20 to 50 miles apart.

Q. How many men have you on Kodiak Island?-A. At each of these smaller stations we hare one man. At Kíoliak, headquarter station, we have five men altogether.

Q. Now where is the next?-A. We have three men stationed at as many places about Cook's Inlet.

Q. How far is that from any of the other stations?-A. About 100 miles north of Kodiak lslaud. We have a station on Prunce William's 
Sound, nearly 300 miles northwest from Sitka. That is the nearest station to Sitka.

Q. Your nearest station is, then, about 300 miles from Sitka?-A. Yes, sir.

Q. Where have you other men located?-A. The next are in the St. Michaels district, bordering on Bering Sea.

Q. How many men have you there?-A. We have stations in this district at St. Michaels and at the mouth of the Nushagak and Kuskovim Rivers, and one or tro men at each place.

Q. How far is St. Michaels from the seal islands?-A. Abont 450 miles.

Q. And how far from Oonalaska?-A. Six hundred miles.

Q. How far from Sitka?-A. It is nearly 2,000 miles.

Q. Have rou any inland stations anywlere in Alaska?-A. No, sir.

Q. They are all on the coast?-A. Yes, sir.

Q. Hare cou any stations in southeastern Alaska?-A. No, sir; none at all.

Q. How near is the nearest one to southeastern Alaska?-A. The nearest one is Nutchik on Prince Williams Sound, 300 miles northrest of Sitka.

Q. Have you named all the stations of the Alaska Commercial Company in Alaska?-A. Yes, sir; except the seal island.

Q. How many are there altogether, how many men and how many stations?-A. Twenty-two stations and forty-three men. But I think we hare included in this some m?n that ongint not to be included, for they are independent traders.

Q. And all these forty-three men are located upon the coast or upon the islands of Alaska?-A. Yes, sir; we have no men iu the interior of the Territory.

Q. About what range of distance do these ranges cover, beginning at Attoo and going to St. Michaels, and on to Kodials and Nutehili?A. They cover a distance in longitude of over 2,700 miles, and of latitude a distance of 800 miles. I should have to compute it to be exact.

Q. From your knowledge of Alaska, to what portion of the Territory is immigration tendiug?-A. Chiefly, at present, to the mining districts in southeastern Alaska, and, also, considerably within the last two years, to the salmon-producing regious about Bristol Bay, on Kodiak Island, and Cook's Iulet.

Q. Is there much salmon-canuing in Alaska?-A. It is increasing, and I understand that preparations are being made to seud several new cauneries to Alaska next summer, besides those projected by persons comnected with the Alaska Commercial Company. I thiuk there are already twelve or fifteen canneries in Alaska.

Q. Have you any stations anywhere near the region that was visited by Mrs. Voorhees, who has written up the conntry?-A. I have not seen her letters, but I understand that she visited only the sontheastern part of Alaska, as far north as Sitka.

Q. Hare Jou examined the official report of the commissioner of education in Alaska for 1856 ?-A. Yes, sir ; I have read it.

Q. What do you say in regard to the statements in regard to the, Alaska Commercial Company contained in that book?-A. I think they are, in the main, correct.

\section{By the CHATRMAN :}

Q. Will you mark the paragraphs you wonld like to insert in your testimony, and let them go into the record ?- $\mathrm{A}$. I will. 
OONALASKA.

This village has a population of fourteen white men and three hundred and ninetytwo Aleuts aud Creoles. They have a church, priest's residence, the stores, residences, warehonses, and wharves of the Alaskia Commercial Company, eighteen trame residences, and fifty barrabaras. One-half the population can read the Aleutian langnage. It is the most important settlement in western Alaska, and the commercial center of all the trade now in that region or that shall slevelop in the future. It is the natural ontfitting station for vessels passing between the Pacific and Aretic Oceans.

\section{MORAT TRAINING.}

The training of the schools should be extended to the heart as well as the mind and hand. In sections of Alaska the uncivilized natives are accustomed to herd in large houses, with several families ocenpying thesame room and cooking around a common fire. Amoug some of these families polygamy prevails, and sometimes, not often, a woman is found with two or more husbands. The children grow up amid filth aud uncleanliness, accustomed to impure sights and conversation, and systematically tanght to lie and steal. To them there is no wrong or disgrace in it. It is only disgraceful in being canght, as that seems to be a reflection ou their skill; they should have been smarter. Nephews inherit their uncles' wives and his property as well, so that many a boy is married to a toothless old aunt. In these samo houses are tanght, aud sometimes even yet practiced, the horrible cruelties of witcheraft.

\section{EXTRACTS FROM DIARY OF REV. J. A. H. HARTMANN.}

May 2.-Through the Lord's merey I was clirected by Captain Healy to the Alaska Commercial Company. I told Mr. Sloss, one of the partwers, that the object of our visit to Alaska is to prepare the way for preaching the Gospel to the Eskimos. Ho seemed favorably impressed with the undertaking, and we felt hissymparhy was with us. The compauy gave us a letter of introduction to Mr. Newman, of Oonalaska, asking him to assist us.

May 16 to 30.-Our letter of introduction from the company at San Francisco proved very useful. We were received kindly by the friendly and polite agents of the Alaska Commercial Company, with whom we had pleasint intereourse during our whole stay in the island. Our baggage was put into one of the store-houses. The quartery given us in the office of the defunet Western Fur Tradiug Company consisted of two comfortable rooms warmed by a stove, and contained bedding, furniture, and fuel. Thither we conveyed our most necessary articles, including the photographie apparatus. Wo called our lodgings "Providence;" they were only a few minntes' walk from the eompany's loarding-house where we took our meals with the agents and employés, but we little dreamed that wo were being entertained gratis, whilst wo had pleasant converse with those who had visitud and could tell us a good deal about the places and people most interesting to us.

\section{INTOXICATING LIQUORS.}

The Eskimos of the Kuskovim River know nothing as yet of intoxicating liquors, and as long as the Alaska Commercial Company maintains its supremacy in these waters, we have a guaranty that they will not be introduced amongst them. Should spirituons liquors once be imported into the comntry the destruction of the Eskimo wonld speedily follow, and a serious hindrance would be opposed to the preaching of the Gospel.

\section{By Mr. JefFries :}

Q. Here is a letter of instructions of the company to an agent, Mr. Lorenz. I wish you would examine it and see if you are familiar with it, and whether that indicates the poliey of the company on the subject mentioned in it?-A. Yes, sir. This letter was written by the president of the Alaska Commercial Company, and I saw it on file in the company's office.

Q. Was that submitted to you by the president of the company?A. Yes, sir; before it was sent to Mr. Lorenz.

San Francisco, May 7, 1886.

Dear Sir: We have been informed that a large number of miners have alrealy started to the Yukon and Stewart River Nines, and it is probable that many others 
will be attracted to that section of the Territory, in consequence of the supposed existence of rich cliggiugs in that district. Considering that the company's station at st. Michaels is the nearest source of supply, an extra anount of groceries and provisions has been sent to you to meet the possible demands likely to be made upon you during the coming winter.

It must not be understood, however, that the shipment referred to is made for the purpose of realiziug profits beyond the regular schedule of prices heretofore established. Our object is to simply avoid any possible suffering which the large iverease of population insulticiently provided with articles of food might occasion. Hence, yon are directed to store these supplies as a reserve to meet the probable contingency herein indicated, and in that case to dispose of the same to actual consumers only, and in such quantities as will enable you to relieve the wants and necessities of each and every person that may have occasion to ask for it.

In this connection we deen it particularly necessary to say to you, that traders in the employ of the compauy, or such others as draw their supplies from the stores of the company, doing business on their own account, must not be permitted to charge excessive profits, otherwise all business relations with such parties must cease, as the company can not permit itself to be made au instrument of oppression towards any one that they may come in contact with.

it is useless to add that in case of absolute poverty and want, the person or persons placed in that unfortunate position should be promptly furuished with the means of subsistence without pay, simply reporting such facts at your earliest convenience to the bome office.

Asking your strict compliance with the foregoing instructions, which we hope will be carried out with due discretion on your jart, I am, with kiud regards to yourself and Mrs. Lorenz.

Yours, truly,

Mr. M. LORENZ,

Lewls Gerstle, President.

Agent, St. Michaels, Alaska.

Q. Was that letter sent?-A. Yes, sir; and received by Mr. Lorenz.

Q. What do you say as to that being the policy of the company?A. That is the policy of the compauy in regard to the matters touched upou.

Q. Do you know whether or not the company has been in the habit of carrying miners and missionaries, or anybody else, free of charge ?A. It was formerly the custom to carry all missionaries and all who were destitute free of charge.

Q. Is that the present practice?-A. That is the present practice towards those who are destitute, but the missionaries became so numerous that we had to charge them a small fee.

Q. What is the policy of the company in reference to the transportation of goods and passengers; or does it refuse to carry them ?-A. No, sir, it does not refuse; and has carried them in some cases to its own detriment, to the exclusion of the company's freight.

Q. How are its charges; reasouable?-A. Very reasonable, compared with other liues.

Q. You said something about the company's taking care of the families of the hunters; how long are these men usually huntiug?-A. From a few days to several weeks, depending upon the distance they have to go.

Q. Their families are provided for by the company?-A. It has been our custom to give sutficient funds to those men to purchase their outfit, and to issue provislons to their families while they are gone, taking the chances of their return with a sufficient catch to balance the debt.

Q. When the hunter returns with his catch is he bound to sell it to the Alaska Commercial Company?-A. No, sir; there is no obligation to do so.

Q. As a matter of fact, he sells it to whoerer will give him the most?A. He often sells to the other traders and leares the company entirely in the lurch. 
Q. There is no contract abont it-no obligation that they shall sell the eatch to the company ? - A. None, except the moral obligation.

Q. Have sou noticed within the last few years any diminution of the quantity of seals upon the rookeries?-A. Yes, sir; in my testimony in regard to that matter, which is now on file, I have gone over it as fully as I could do now.

Q. How do you account for that?-A. I think it is due to the marauders who trespass upon the business.

Q. Is that diminution quite perceptible?-A. So much so that we are in doubt whether we can get our full quota of skins next season.

Q. Do you have any tronble to get the full number?-A. We were nnable to get the kind of skins we wanted. We take smaller skins now than formerly.

Q. Do the seals approach the islands in the same way that they formerly did? - A. They seem to be coming later than they formerly did, especially that class of animals that we desire to kill.

Q. How do you account for that?-A. I think they are intimidated by the marauders shooting them in the water on the grounds where they are accustomed to feed. I know of no other reason why they should be late.

Q. What do you say as to the remedy ?-A. I think a strict enforcement of the law, as it stands, will be a complete remedy.

Q. Existing law ?-A. Yes, sir.

Q. IIow would you do it?-A. By patroling the feeding grounds and capturing any vessel that might be found taking seals.

Q. In other words, prohibiting the unlawful killing of fur seals in Alaska waters?-A. Yes, sir.

Q. Hare you any estimate as to the number of seals that have been unlawfully killed during the last two years?-A. We know the number that are sent into market, and we estimate the number of animals that are killed to obtain one skin.

Q. What is your estimate as to the destruction of seal life compared with the number of skins recovered ?-A. I think that not more than one in five of those wounded can be captured, but how many of the wounded actually die, it is difficult to say.

Q. Do not seals go to the rookeries that have been shot?-A. Very often lead is found imbedded in the blubber, under the skin, of those killed on the islands.

Q. Are the skins taken by these marauders put on the market in com. petition with those on which a tax of $\$ 3.17 \frac{1}{2}$ is paid ?-A. Yes, sir; they are sold to the same purchasers.

Q. Where are they sold ?-A. In London.

Q. Sold by. Lamson \& Co. at anetion?-A. Yes, sir.

Q. How many rexenue-cutters should be sent to Bering Sea?-A. I think one cutter constantly patroling the feeding grounds about the islands would be sufficient. If the Goverument vessel was there the marauders would keep out of Bering Sea.

Q. I suppose that the presence of the cutter would not be of much benefit unless it was understood they were going to seize illicit sealers?-A. A single cutter, unsupported by a proclanation from the proper source, wonld be mable to maintain itself against them. I think perhaps they would have rather more respect for a proclamation firom the Chief Executive than for that from the Treasury Department.

Q. You advise a proclamation hy the President?-A. It would be much more effective than one hy the Secretary, becanse there was an actual failure to enforce the orders of the Treasury Department during 
last summer, and the marauders would have every reason to suppose that they could violate them again with impunity.

Q. You think that abont one in five is the extent of the seal that are captured after being shot in the water?-A. I think so.

Q. Look at that paper and tell the committee what it is [giving the witness the following paper]:

Extracts from the log of the schooner Anget Dolly, kept by Capt. Alfred N. Tulles, who wus accidcutally killed by his own hand on the 2oth of July, 1887, near Olter Island.

July 4, 1887.-Hove to 30 miles southwest of St. George Island. At 1.30 out boats. Got 5 seals.

July 5, 1887 .-Out boats at 6.30 a. m. Returned at 11.15 p. m. with 11 seals, one boat getting 6 .

July 9, 1857.-I am now on the hunting-ground, but keep sail on the vessel as we may pick up a sleeping seal.

July 11, 1887.-Caught 7 seals.

fuly 13,1887 . - Caught 12 seals ; they were around the vessel as thick as bees (the seal). Had it been clear we would have canght 100 east.

July 16, 1887.-Saw :3 sleeping seals from the vessel. Got boat over and got them. I havo not seen the sun for nine days, thereforo I have had no observations, yet I know that I am not over 14 miles from St. George Island.

July 17, 1887. - Ont boats at $10.30 \mathrm{a} . \mathrm{m}$. The seals were arouud the vessel in humdreds. The boats would not go any distance from the vessel. Harl they gone away they conld have caught 200 or 300 seals. They were afraid of the fog, yet i told them that it would clear up, which it did at $3.30 \mathrm{p}$. m., and continued thus all the rest of the day. They are the hardest set of hunters that were ever in Bering Sea, who canght 20 seals and used 250 rounds of ammunition. They get 1 out of every 10 they fire at. Well, I will never be caught with such a crowd again. The hearl hunter fireil 100 shells and got 6 seals. The vessel is lying between the Islands of St. Panl and St. George. Just as soon as the fog clears off the land I will have to more, as I might have the cutter after me. I came here to get a load of seals, and, by God, if I had any men with me, I would get them, too. They are all a set of eurs; genuine ones, too,

July $21,188 \pi$.-Ont boats at $6.30 \mathrm{a} . \mathrm{m}$. coming back to the vessel at $9 \mathrm{p} . \mathrm{m}$. One boat returned at $7 \mathrm{p} . \mathrm{m}$. This was the head hunter. He is last ont and first back always; caught 30 seals; one boat got 14 . 'This is the hest day's work we have done yet. From the amount of growling among the boat-pullers, I conclurle that they fired at and missed nearly 200 seals. They hat 100 loaded shell each when they left the ship, and when they came back all were emptied, so they did some tall firing.

July 23, 1887. - To-day I asked Daniel MeCue, boat-puller for Charles Lorlerstrom, how it was that his boat got only 9 seals. I told him that I had seen do sleeping seals from the vessel, and that he must have scen more as he was pulling about. His answer was that if he had a man that knew how to shoot that the boat conld not carry all the seals that were missed. Why captain, said he, it is enongh to disconrage a man. You pull up to a sleeping seal to within 10 feet, fire at him and see the shor go 6 feet the other side of hini. I then asked J. Linquist, puller for hoat two. He said, captain, don't ask me how many we have seen, but ask me how many we missed, and I will tell you. I asked him the abovequestion; he said 100. I now asked Joe Spooner the same questions as above; his answer was, we only want hunters, and we would be going home now with 1,500 skins at the very least.

July 24, 1887. - As fine a day as was ever seen in San Franeisco. A flat ealm with the sea as smooth as glass. (rot out the hoats at $6.30 \mathrm{a} . \mathrm{m}$.; coming back at 7.30 with 14 seals. Why! One boat with an orlinary hunter conld get that many withont going 100 yards from the ship. I lilled two inside of ten miuntes, and it was then nearly dark.

July 25,1887 . - Nice weather. Ont boats at 7 p. m. Came back with 4 seals. Irig catch.

July 26, 1887.-There were thousands of seals aronud the vessel. I shot and killed 7 from the vessel, but only got 1 , through the tardiness of the lumters. At 4.30 I put the boats ont; came back at 7.30 with 1 seal. The water was fairly covered with seals, yet they only caught 1 .

The loy eloses on the ¿sth of July, 188\%, on which day the captain was killed and his vessel seized for violation of the revenne laws.

His signals were: (1) Come back to the vessel; (2) want a boat for dead seal; (3) keep near vessel. Bad weather or fog; (4) cutter in sight.

A. This paper is a transeript of the log-book of the schooner Angel Dolly, captured by Mr. Tingle in July, 1887. 
Q. Did you make that copy?-A. Yes, sir; this is a copy from the transcript made by me.

Q. Do you know of any large number of illieit sealers that are expected in Bering Sea from the United States or British Columbia next season? - A. Only from hearsay. We estimate there were, diming the last three years, from twenty to thirty such vessels engaged in illicit sealing, and it is credibly reported that the number will be largely increased during next season.

Q. Do you know anything of those that are being fitted out in British Columbia?-A. Nothing specific.

Q. From whom do you receive instructions as to the general policy to be pursued by the company on the islands?-A. The instructions issued by the late Senator John F. Miller, who was at that time president of the company, continue to this day to be the basis of the poliey for the gnidance of the company's agents on the islands. They are on file on the islands, and the agents are told to be guided by them. The letter in which the most of these instructions are found coutains about 30 pages, but I have here with me, and am able to produce at this time, extracts relating to only a few of the subjects treated upon by General Miller.

Extrac's from the letter of John $F$. Miller, president of the Alasta Commercial Company, to the superintendent of the scul fisheries, dated March $29,157: 2$, the tenor of which is still followed on the islands, June, 1888.

Prices of goods.-It is the policy of the eompauy to not attempt to make any profit in the sillo of provisions and merchandise at the islands. It is desired that all articles bes sold at prices rather below original eost and trausportation than above the same, but never above ordinary retail prices at San Francisco for like articles. An addition of 25 per cent. above invoice prices will probably cover transportation, aud hence that rulo has been adopted; but in case of light fabries or small articles it may be that the application of the rule would bring such articles abovo San Francisco retail prices. In such cases you will mark such articlesdown. It makes no difference if prices were higher. The company desires prices adjusted on the principles above stated, but does not desire that the price of any article be raised above former prices, even though it be sold at a loss.

Tages. - The payment of 10 cents eoin for the labor of taking each skin and carrying it to the salt-house is deomed sufficient compensation, and this will be continued until the Secretary of the Treasury makes a different regulation. In respeet to other labor the company desires to pay tiair, liberal compensation. It will probably be well to fix the maximum wares for a day's work of the hest laborers at 81 , and the winimum at 50 cents, making always the wages a matter of contract with the persons employed. The chargo has been published that the company held these native inlabitants in a condition of peonage of quasi-slavery. This charge, thongh filse, is a serious one. Snch a condition is ahhorrent to the sense of every man interested in the company. The natives are the laborexs of the company, not by compulsion, but by free choice, and all labor is performed under contract. You will be eareful that no act is eommitted or word sad by any agent of the company which can he eoustrued as inclicating a purpose on the part of the company to arlopt or carry on a srstem of compulsory labor. If the inhabitants choose not to work it will be a misfortuno greater to them than to the company.

Treatment of the people.-Complaints of the most extravagant character, and false in overy particular, concerning the treatment of the native people by the arent of tho company have been published in this city by the blackmail sheet called the Alaska Ifuald, and in some instances have been copied into Eastern newspapers. No great harm has been done by these publications, for they have, for tho most. part, been so extravagant and evidently malicions that they carried their own refutation. Nevertheless, it has heen a source of congratulation that we have been able to truthfully controvert all these damaging statements. It is important that the utmost care be taken to see that the natives are kindly and liberally treated; that friendly relations between them aud all our employes eonstantly exist, and that no injustice, even in the smallest degree, be done them; that free selools are maintainer; that mo interference with their local governmont or religion be practiced, and that they are constantly treated as peoples having tho sime rights, privileges, and immmnities as nll citizens of tho United States onjoy, All eflorts to olovate them in the seale: 04 
civilization should be encouraged. It is the desire and hope of the company to so elovate, civilize, and benefit these people as to make a good example before the world. You will see by the papers sent you herewith what libels have been published against the company, aud you will then see the propriety of so managing on the islands that such eharges ean not be truthfully made, even in the smallest matters.

Q. What amount of spirituous liquors are allowed upon the islands ?A. Only such au amount as is required for medical purposes, and that is obtained by a requisition of the physicians on the islands, approved by the Treasury agent. We generally send to St. Paul two cases of whisky (twenty-four bottles), about 5 gallous of port wine, and from 1 to 4 gal. lons of brandy, and sometimes a case or two of light wines for our table on bolidays.

Q. Who has charge of that on the islands?-A. The doctor, if he be reliable. For St. George the amount is abont one-half or two-thirds that for St. Paul. The ehurch has annually about 10 gallous of port wine at each island for sacramental purposes. Exactly what use is made of it all I do not know. That invariably goes to the priest, and we know rothing furtber of it. It is sent up there by the Russian consistory of Alaska from San Francisco.

Q. You say the liquor is all in charge of the physicians; are they worthy men? -A. On two occasions they have proved unworthy, and the liquor was taken from them by the agent until better men took their places.

Q. Something was stated here by a witness in relation to the company paying salaries to Goverument agents.-A. I suppose the witness referred to Dr. Noyes, who was appointed by Special Agent Tingle as his acting assistant agent until the place could be regularly supplied by the Treasury Department.

Q. It was stated by Mr. Gavitt that the company paid salaries to - Mr. Falconer, Mr. Glidelen, and others?-A. That is false. The only Government ofticer to whom we have paid any money was Mr. Falconer, when he was employed to do certain mechanical work. We had no one else present at the time who could do it, and he kiudly consented to help us. He was a mason by trade, and laid chimneys, foundations, etc., for us.

The Charrman. Mr. Gavitt said some one told him that that was the case. He did not testify of his own knowledge; he stated that he had hear such rumors.

\section{B. Mr. JEFFRIES:}

Q. It was stated by Mr. Gavitt that a man was sent by the company's agent to watch the rookeries. How is it as to that?-A. I do not know about that specific case, but it is the custom of the Goverument agent in charge to detail the native watchman. It is the business of the Government to take care of the rookeries. The company has nothing to do with it, except that our physician, when asked, certifies whether the man detailed is fit for duty.

Q. Who are the teachers on the island of St. George?-A. The teachers on the two islauds are, at St. Paul, Charles C. Mead, and at St. George, Harry N. Clark. They are both gratuates of the State Normal School of Vermont, and from that school hold certificates entitling them to teach in the schools of Vermont without examination at any time within five years after graduating.

Q. As a ma'ter of fact they are competent teachers?-A. Yes, sir. They were engaged in teaching in Vermont before going to the seal islands.

Q. Mr. Gavitt said that Mr. Clark was a drinking man.-A. That is 
not true. He is temperate, and I think very nearly a total abstainer from liquor.

Q. Have any complaints been made to you as superintendent by the natives as to their treatment by the employés?-A. No, sir; except in trivial matters, which were promptly righted at the time. They are invited to make complaint. They are also told to appeal from the com. pany's agents to the Government officer at any time when they are rissatisfied.

Q. They are told that the company considers him the highest authority on the islands?-A. Yes, sir; and we have bad occasion to appeal from them to him on one occasion, when they "struck" during the sealing seasou, on the ground that we withheld their supply of sugar, and they were thereby leprived of the material for making intoxicants. The appeal was made to Colonel Otis, and after considerable parleying, he told them they had better go to work, which they did.

Q. Will you state to the committee what facilities the natives have for sending written complaints to the United States?-A. There is no postmaster at the seal islands, but we have regular mail-pouches, and letters can bo put into them by any one who chooses to bring them to the company's office. The ponches are carried to and deposited in the company's office iu San Francisco. In addition to that, mail is also sent by the church in sealed packages to the consistory in San Francisco.

Q. Do you know whether the mail is ever tampered with by anyborly?-A. No, sir; no more than it is in any other part of the United States.

Q. Who appoints the chief? $-\Lambda$. The chief at the present time is appointed by the Goverument agent in charge. Formerly the people elected him; but such abuses arose under that system that the Govermment assumed the authority several years ago, and has since contimued to exercise it.

Q. Are you acquainted with Peter Resanzoff; what kind of a man is he?-A. Yes; I have known him erer since he was a boy; he is brighter than the average, but is less reliable than auy other man on St. George Island. I do not think he could be believed in any transaction where it was in his interest to misrepresent.

Q. What is his reputation for truth and veracity ?--A. I believe it is bad.

Q. Would you believe him under oath?-A. No, six; I would not.

Q. Do the awents of the company obey the Government ofticer?-A. The agents of the Alaska Commercial Company are instructed to co. operate with the agents of the Government in maintainug order, to assist them in preventing the manufacture of quass, and to comply with any reasonable request that the Government agont may make upon them in the conduct of the business. I think that every agent on the islands understands that.

By Mr. FELTON :

Q. Hare you any idea as to the amount of the trade of the Alaska Commercial Company at the stations other than tho seal islands?-A. I shall be unable to give any definite answer about that, becunse it is outside of my department. Although I have a general knowlerlge on the subject, I think it is not sufficient to be of any value to the committee.

By the CHAIRIIAN :

Q. Can you gire the probable aggregate valuo?-A. It has always 
been understood by the agents of the company that the business ontsicle of the seal islands paid very little profit. I know that has been the case at least in the st. Michaels district, where I was instructed a few years ago to examine into the matter. Suflicient slins were not obtainerl to pay (xpenses. In foriner years there was considerable profit derired from the sea-otter fisheries, but these animals have been hunted to such an extent lately that I douht if it continues to be profitable. The fur business in Alaska is in a very bad state, and fishing is suj)plantiug it.

Q. If the company would abaudon its trading stations in other parts of Alaska, except the seal islands, would other traders, in your judgment, occupy the ground?-A. I believe they would at but few places where we are now maintaining agents. The busiuess would not warrant it.

Q. If they did not, conld the natives reach a market?- $\Lambda$. They conld only through the small ressels which go there, and as these are geverally supplied with liquor, they would do the natives more harm than good.

Q. You mean that ressels would simply go up there selling them goods and supplies and purchasing their furs in return?-A. Yes, sir.

Q. Is that kind of trade conducted there now ?-A. Yes, sir; at every point where they think they can make a profitable venture.

Q. Your company does not interfere with them in any way ?-A. No, sir; we have no desire to do so, except that we would like to break up this illicit traftic in spirituous liquors if we could.

Q. Are seal skins sold by weight or by size?-A. By size. They are laid out in piles, assorted for size and quality, and buyers are invited to examine them.

Q. What is the per cent. of difference in the value of those of different qualities \% $-\mathrm{A}$. The difference is more than 50 per cent. between the best and the poorest. If we had a larger number of seals on the islands from which to choose we could make a better selection and take only those skius that were desirable, but the supply is growing less and less, and the range of difference between the best and poorest is widening.

If the committee will allow me, I would like to make a suggestion in regard to a matter that has been mentioned by other witnesses, in reference to having a prison-ship stationed at Oonalaska. I think a much better system would be to establish a court of competent jurisciction at Oomalaska, rather thau send prisoners 1,200 or 1,400 miles to sitka. We have now snch a court, competent to real with criminals from Buring Sea regions, only at Sitka for the entire Territory. The judge and marshal reside at Sitka.

We have at Oonalaska only a commissioner with the powers of a police magistrate or justice of the peace, and a deputy marshal. All seized vessels and arrested criminals must be sent to Sitka, and it is a great hardship for them as well as for the officers. If we had a competent court at Oonalaska I think matters would be greatly facilitated.

Q. What would be your opportunity to get a jury to try them ?-A. As good as it would be in Sitka. There are no more inhabitants at Sitka who are competent by intelligence or position to sit on a jury than in Oonalaska. In summer season, at least, an intelligent jury could be always found at Oonalaska.

Q. What is the population of the island of Oonalaska?-A. I can not 
give it now, but it is several hundred, inchuling natives. The population of Sitka, as I understand it, is much less than formerly.

Q. Would it answer the purpose if the judge who holds the court at Sitka should be authorized or required to hold a term of court once or twice a year at Oonalaska? - $\mathrm{A}$. The difficulty with that arramgement would bo in securing transportation between Sitkat and Oonalaskia. At present there is no regular transportation between the two places, and communication can be relied on only by way of San Francisco.

By Mr. JeFFRIES :

Q. Would it be well to hare a Government agent on each island clothed with the power of a magistrate? - A. I do not think there is any oceasion for it. The special Treasury agents now have the anthority of justices of the peace, not by law, but by direction of the Secretary of the Treasury. They try causes and impose penalties, and, so far, the system has given satisfaction.

THURSDAx, January 10.

The committee met at $2 \mathrm{p}$. m. for the purpose of recalling Mr. William Gavitt, who had been subpornaed by wire on Tuesdas, the sth. Mr. Gavitt not being present, the committeo adjourned until liriday at 11 o'elock.

FrIDay, Jamuary 11, 1889.

The eommittee met pursuant to adjurnment, and the chairman laid before the committee the following telegram, dated:

Evansvilux, Ixd, Jamuary 9, 1889.

To J. II. Lwedon, Sergeunt-at-Arms, IIouse of licpresentuties, Hashington, D. C.. :

Will arrive in Washington Sunday.

WiLliam GavitT.

The Charrman. The Cham will state to the committee that the summons to Mr. Gavitt to appear before the committee was for the sole purpose of giving him an opportunity to reply to the facts testified to by the witnesses, Dr. Lutz and Mr. Kirk, as to certain eonversations they had with him and which seemed to impreach his integrity as an oflicial of the Govermment. The Chair thought it was an act of justice that Mr. Gavitt should have an opportunity to plated upon record his denial of such conversations and such explanations as he desired to make of it. It is immaterial for the purposes of this investigation, for it is a subject for the action of the Secretary of the 'Treasury and not a subject for action by the Honse of Representatives; and while the facts testified to are important as reflecting upon the integrity of Covernment officials administering the subject under consicleration by this committee, it is a matter for the action of the secretary of the 'Treasury and not for the committee. Therefore, considering it in connection with this investigation, it is not of material conseguenee that we should detain witnesses here and keep this investigation ofen, for Mr. Gavitt can make his showing to the Secretary of the 'Treasury just as well as if he appeared here and testified.

It is also known to the (hatir that within a few hours after the summons was sent to Mr. Gavitt, on the Sth, he sent a personal telegram to $9984-22$ 
the cleak of this committee asking what it was that the committee desired him to testify about again, and that the clerk of the committee informed him or indicated to him in a personal dispatch what it was that he was desired to respond to, and the committee then adjourned from Tuesday till Thursday at 10 e'clock to give him an opportunity to appear here. He not being here on Thurstay the committeo adjourned over until to-day at 11 o'clock, and this telegram to the Sergeant-atArms is all the information of which tie Chair is in possession. It is for the committee to determine whether the investigation be liept open and a number of witnesses retained here until Mr. Gavitt cau arrive.

Now, Mr. Felton, have you any suggestions to make?

Mr. Felton. No; I do not know that I have any suggestions to make. I am of opinion that he has received all the courtesy and has been given every opportunity to come here that is necessary, aud that it is simply a question, not of justice or of right or wrong, but simply a question of policy whether this committee shall under the circumstances await this gentlemen's convenience for the purpose of giving him a chance to answer certain statements which have beeu given, and in which he is personally and his personal character are interested. That is all.

The CHamrinan. I will also state that I know of no other reason why the investigation should be longer kept open. The communication has been sent to the Secretary of the Treasury requesting him to transmit to the committee copies of all orders issued by the Treasury Department to officers in command of revenue, marine, and naval vessels, all United States vessels, which have been sent to the Bering Sea dluring the year's 18s6, 1887, and 18s8, for the purpose of protecting the seal rookeries and public interests in that comnection in Bering Sea. 'That communication can come in and be incorporated in the evidence, and it is not likely that it will require further action of the committee. It was sent at the instance of Governor Dingley, and he has intimated to the chairman that he will be content with that reply; but if that reply, at any rate, is not satisfactory, a resolution through the House of Representatives would aceomplish the purposes more fully than the action of the committee after'wards. Therefore it is a simple question of holding the investigation open further simply to enable Mr. Gavitt to say whether or not he held the conversations which these witnesses testified to, and to explain if he had those conversations or deny that he had such couversacions.

Mr. FELTON. I think, in view of the fact of the lateness, or rather in view of the little time remaining of the session for this committee to digest the evidence that has been before $i^{2}$, and to make a report in time to give the House time for action upon it, would hardly justify us for any delays that were not necessary, because if the delays extend too much, then this committee will have had all its labors in vain, and ii will be productire of no good.

The Chamman. Suppose, then, we close the investigation this morning with the privilege to IIr. Gavitt to place upou record his reply to the particular matter as to whether he had conversations with Dr. Lutz on the ressel which he testified to, and whethro he bad the conversation with Mr. Kirk upon the island which he testified to?

Mr. FELTon. If he confines himself to the facts as to whether he had these conversations, and whether the statements made by these witnesses are true or not, there will be no objection to it; but if, in the mean time, he shonld get new matter, as it were, and make ofher statements going to show that what he had said was true, why, it seems to 
me, then it places the other witnesses in a position where they would not have a fair chance to answer.

I suppose, as a matter of course, he would make a denial in toto of what they have said, because he has sworn directly to the contrary, and he could not be satisfied with anything more. He would have to do that. If he is content with that much, that is all right; but if in doing that he brings out, as it were, new matter in instances going to show, or throw a suspicion upon what they said, it seems to me, then, they ought to have a right to reply to it.

The Cirarrman. Then it is a question of holding this number of witnesses until he can come here, and keep the iuvestigation open for what may be developed, or of closing it. So far as I am concerned, as I stated before, the continuance here was purely and exclusively for Mr. Garitt's benefit, to enable him to have a thorough opportmuity to deny these statements. For the purposes of the committee and the conducting of this investigation it was not necessary nor material to continue it longer, nor is it now material. The chair is arlvised by a communication heretofore received from the printing-office that, in order to make certain plates and illustrations that will be included in the evidence, some time will be required, and we can not expect the printing of the evidence to be done as quickly as if there was nothing but the printing to do. There are some plates and illustrations to be gotten up. After the printing of the eridence it is to be considered by the committee and a report made.

'This report aud evidence is not printed for general use, but is for the use of the committee. If we use all possible speed and should close todiay, and deliver the evidence to the printing-office next week I am satisfied it will be some time in February before we can get the evidence and report it to the House. And, with the conrse the business of the House is taking now, there will be little opportunity for consideration aud action upon the report left.

Mr. FeLTON. How wonld this strike you: In view of the fact that anything here is not pertinent for the purposes for which this investigation was made, and in riew of the fact that the committee deemed it a simple matter of justice that Mr. Gavitt be given an opportunity to reply to matters personal to himself, and he having bad ample time to have done so and not having done so, and in view of the further fact that the commissioner in charge of these islands will place this matter before the Secretary of the Treasury, and there he will have a chance to vindieate himself, why not just close the investigation without anything further from him?

The CHAIRMAN. I see no objection:

Mr. Feltox. And in view of the fact that if he is allowed to answer that he might bring in such matter-relerant though it may be-which might reflect upon the character of other witnesses; and we would then feel compelled to extend to them an opportunity of denying.

The Cmaminan. Such action would simply be diverting this investigation into a contention personal to him and other witnesses, which is a channel into which the committee cau not suffer it to be carried. The committee is conducting this investigation for purposes for which the House ordered it, and not for the purpose of ventilating personal grievances between witnesses who have' been summoned here.

Mr. Felton. And the chair, as I molerstand it, is of the opinion that it will be good, just, and proper for us to close this investigation.

The Cramrisin. I do not see any public reason for holding the inves- 
tigation open, or any reason that appeals to the committee for continuing it longer. I know of no reason why it should be louger kept open. Mr. FELTON. I am quite with the chair in that respect.

The Chairman. Now, Mr. Tiugle has, by some newspaper paragraph, had his attention called to one statement of Mr. Gavitt's testimony to which he did not reply in his evidence the other day, and he desires now to make a single statement in regard to that.

Now you can make that statement, sir.

\section{TESTIMONY OF GEORGE R. TINGLE (continued).}

\section{GEorge R. TINGLE, recalled.}

The witness said:

Mr. UharRman. I find under date of December 19 a dispatch from Washington that Gavitt presented a letter from me, but I will read it as it is here:

The witness (Gavitt) presented a letter from the Treasury Agent Tingle which he regarded as a piece of black-mail intended to discount his published statement.

I desire to explain how I came to write that letter to Mr. Gavitt.

The Chamman. Well, sir, you may do so.

The Witness. Having made investigation upon the island of all the charges that Mr. Gavitt brought against the people there, I became satisfied that Mr. Gavitt was not at all times respousible for what he was doing; he had wrought himself into quite a fever with his imaginary grievances, and my treatment towards him was in pursuance of that feeling and belief. I advised him constantly to keep cool and suppress his wrath. He said he had quite a voluminous manuscript which he proposed to make public when he came down. I alvised him against that course, and he told me he would accept and act upou my advice; that he thought it was good.

Coming down on the vessel the subject was renewed again, and I said, "Gavitt, in view of your troubles on the island and the record which you have left behind you, you can not go back there again as a Treasury agent. That is impossible. My advice to you is to go lome, rest up and keep quiet until after the election, and not publish auy of your grievances to the public. It is unnecessary, and it will be contradieted. You would only force me to publish all the affidavits and evidence that I have in iny possession as a refutation entirely of all your statements that you would make in the papers; you would be placed in a very unenviable position before your people." He promised me he would not publish anything. I said I disliked very much for anpbody to read this stuff-even his wife and others there-his wife is a very estimable lacly, innocent and unsuspecting. He said, "I will take your adrice; I will do as you say. I will present my resignation after the election." The next thing I saw of Mr. Gavitt was the publication after he had made a visit to Indianapolis and conferred with T. F. Ryan, a former Treasury agent-his predecessor-who had been dismissed from the island by the Secretary of the Treasury at my request and on the showing of others that he was an improper man for the position. Then I wrote Mr. Gavitt the letter, which I am glad the committee have to print with their report, as it furnishes a complete refutation of the coustruction Gavitt put on it.

The CHAIRMAN. The letter he read here ?

The Witness. The letter which he placed on file. I hare read it in Gavitt's evidence, and it is the same. I identified it as my letter to him 
calling his attention to his promises to me to keep out of the nerspapers It was written with the hope that it might eall to his mind his promises, and, in his own interests, keep him from publishing anything further, which might force me to publish to the people of the world the facts as set forth in affidavits I have; as he had taken the public for his audience, I would necessarily have to go there with the refutation. I was in possession of affidavits, I have them here with me, which thoroughly disprores his statements. My letter was written to him wholly in his own interests, not that it made any difference to me, except so far as $I$ am responsible for the acts of $m y$ assistant. The letter I did not consider in any sense could be construed by auy person as a black-mailing letter.

The CHAIRMan. In connection with this letter was there any information or knowledge in the possession of Mr. Gavitt affecting the public interests or the administration of the officers and the affairs committed to your charge which you desired to prerent him from jublishing?

The WITNEss. None whaterer. He was not in possession of one scintilla of information that could reflect upon the integrity of any Govermment officer, either myself or any of my other assistants. No better men can be found than Captain Loud and J. P. Manchester, my other assistants. There was nothing, and there has not occurred anything, upou the islands that I would not be glad to have published to the world in commection with my official duties and my administration. I report to the Secretary of the Treasury fully eversthing that is of a public nature affecting the interests of the people or Goverument. I regret Garitt did not obey the summous of the committee and appear now that I might cross-examine him; he is a great coward.

The CHAIRALAN. So, in this letter you referred and intended to refer to these personal immoralities which he accused persons of?

The Witness. Yes.

The Chamrian. And then accusations which were purely personal to him you thought would be made by the persons whom he accused ?

The Wrtess. Certainly. It was entirely in his own interest I wrote the letter, and to prevent exposure of his immorality and unfitness to associate with gentlemen.

The CIIARMAN. All of that has been brought out in the evidence in this case.

'The WIINEss. Some things hare been brought out which I desired to suppress. I refused to be interviewed by auybody from San Frauciseo to Washington. Although newspaper men have had several inter. views with me upon this subject, I have positively refused to be interviewed, for the reason I expected to be before this committee, and whatever I had to say I llesired to say to the committee alone until they got through with their investigation, and after that, possibly, I might publish a statement of facts or extracts from the evidence after the report of the committee to Congress.

Mr. liyan, the assistant Treasury agent on the island, testified, according to this newspaper article, that-

He formulated rules forbidding females on the island visiting the company ard Govermment houses, but Mr. Tingle, his superior ofticer, had declared such a rule null. It was impossible to imagime what cansed him to do this, as the order was issued in the interest of law and deceney.

I desire to say in regard to Mr. Ryan that he was another Indiana crank. He issued a set of rules that were no improrement on the rules I established when I took charge of the islands. They were not any more in the interest of law and decency than the rules which I had 
promulgated for his guidance. On the contrary, one of his rules, and the one he laid most stress upon, was that the natives should be allowed to buy sugar, which, if it had been promulgated, would have demoralized the whole community.

The CHAIRIAN. State how?

The WrTnEss. Because that is an in grerlient ont of which quass is made, a native beer that is an intoxicant. He claimed that "these people were American citizens," and therefore should be allowed to buy sugar and use it. At the same time that he made this claim on the ground that they were American citizeus, his other rules forbid "these American citizens" from going to the Govermment house. If there is any place in the world an American citizen would have a right to go it wonld be to the Government house. Supposing a man wanted to bny something, he sends his wife or daughters or boys. Under these sweeping rules they could neither eall upon Mr. Ryan at the Government house or the agent at the company's house for anything they might require. His. rules were very foolish, as I considered the regulations I had established were all that was necessary, and I simply marked them void and declined to promulgate them, telling him that whenever it was necessary to amend the rules in force I would be glad to do so, if he would cail my attention to any imperfection, and I could be convinced they might be improved by the adoption of his suggestions. I conferred fully witls my assistants, Loud and Manchester, about all matters pertaining to the business; they co-operated with me cheerfully and pleasantly. I here bear testimony to their ability and faithfulness as officers. Mr. Ryan was watchful of the seal rookeries and even braved danger for their protection.

Mr. Chairman, before closing my testimony I wish to say that it has been my purpose throughout this investigation to avoid personalities, and confine my evidence within the scope of the resolution ordering your committee to proceed with the investigation. Being forced by the extraordinary character of evidence given by Willaam Gavitt to reply thereto, I conld not, in justice to the defenseless people uujustly assailed, do otherwise than ask the indulgence of the committee, that I might defend the distant, helpless, houest, virtuous communities under my charge, as the Goverument's representative, from the grossly wrong, wholesale charges of immorality marle by William Garitt. I assure you the islands of St. Panl and St. Greorge contain among their inhabitants many good Christian native people, honest and virtuous, who love their wires and fimilies devotedly, who will be shocked when they see, as they must, the base, foul, and false accusations against their character. I here wish recorded my defense of the white people on the islands, whether employés of the fur company, Gorernment officers (excepting William Gavitt), ofticer's of the revenue marine, or visitors, as gentlemen worthy to fill positions of responsibility, as incapable of the outrages imputed to them in the sweeping charges of the witness, who alone of the great number giving evidence under oath is found to possess the knowledge of the astounding state of immorality represented by him.

Mr. Chairman, his evidence is an insult and outrage on the good. people of the community I have known personally more than twice as long as he has; and as their chief officer, sent by this Government to look after their welfare and interests, I make this defeuse as is my bounden duty, and ask that it be received as part of my erideuce.

Mr. Chairman, there is one thing in the interests of the native people and the Govermment to which I would like to refer; that is, the subject taken up by Mr. Willnams when he was last on the stand. 
The Cinatranan. The subject of permitting the Aleutes to marry?

The WITnEss. Yes; and what might be their condition in the future. Mr. Williams very ably and properly, I think, presented the matter; but I would like to adi a few suggestions. The income of the people on the fur seal islands of St. George and St. Paul is sufficiently large to support an additional population. They have an accumulation of their earvings on deposit with the Alaska Commercial Company-a considerable amount- which shows there is a surplus beyond what is required for their maintenance. Now, they are all Aleuts. They were brought originally from Oonalaska and others of the Aleutian chain of islands. They are all the same people upon these islauds that are uot sparsely inhabited; where the sea otter hunting has ceased to afford them a liv. ing otters are no more to be found, and the people live on fish and what the fur company bring them. I think these people-the best of the men-should be taken to the fur seal islands and allowed to marry the surplus women we have upon the fur seal islands and become sealers.

The population of the islands is very rapidly decreasing. Some of our best sealers die off every spring. Of course their places, to some extent, are taken by the young boys growing up, but there is a very perceptible decrease of the good working force upon the islands. It is absolutely necessary that additional help should be placed upon those islands, and the question is, where shall it come from? I think from Attoo, and a great many islands where the people are very poor and get a poor liring. We could furnish the seal islands with a very considerable addition to the population without doing any injury whatever to the present citizens of those islands. They have enongh and to spare. TVe do not propose to decrease their income, but when you decrease the numbers the income of the families left increases every year. As a matter of fact, 20 cents a skin would furnish these natives a maintenauce; whereas the amount they receive ammually is 40 ceuts a skiu. Now, why not increase the population from these poorer communities in Oona. laska district, put them upon the fur seal islands, and make sealers of them? If you do not do that they will ultimately become a charge upon the Government, or starve; because I do not believe there is any corporation or company in the world that is going to continue to maintain a lot of natives on remote islands when they ilo not get some return from them. There is meat-the seal meat-which would furnish food for thousands of them, for that matter, and at the present time this company operating the islands pack off in their vessels every year at thousand seal carcasses and earry them to Oonalaska, and from that point distribute them to the natives along the Alentian chain gratuitously.

Q. Do jou know any authority of law to prevent women on St. Paul and St. George Islands marrying whom they wish?-A. No, sir. It is only the regulation of the Greek Church.

Q. They are permitted now to marry as they please, are they not, by the laws of the United States?-A. Certainly.

Q. There is no restraint by law or regulation of the Treasury Department; what is it that interferes with these marriages that you speak of ?-A. That regulation of the Department wheh prohibits anyone else going in there: natives or auy other person landing on the islands, participating in that work, and becoming a citizen. I think it is clearly within the power of the Secretary of the T'reasury under the law to regulate the matter by his orier or Department regulatious.

Q. Which would reliere them in regard to the matter you speak of?A. Yes. sir. 
Q. As I understand, the regulation now is if any woman marries a man from the dleutian Islands, that man has to take her to his home ?A. Yes, sir.

Q. Because the regnlation prohibits him from acquiring a domicile upon either St. Paul or St. George Islands and participating in the seal work?-A. Yes, sir.

Q. That can be accomplished by a slight modification of the regulations of the Treasury Department?-A. Yes, sir; it can.

Mr. Felton. The result of the change would have two effects: It would prevent these people from starving who are on the rerge of starvation, and give them something to do.

The Chamman. And relieve those people for whom the company transports the seal meat to the Aleutian Islands.

Mr. Felton. Andit would also prevent-which must ultimately occur if they are not looked after-the final degeneration of the people by intermarriage.

The Witness. Yes, sir.

Q. So it would have two effects?-A. Yes; two beneficial effects: Infuse new blood into the inhabitants, and make them stronger and better people, and furnish them a good living without injury to the sealers on the islands.

Q. And further than that, it will gire them labor?-A. Yes, sir; and on that these people could live.

Q. As I understand it now, dming the sealing season they have to send people up there for a short time and then they are sent home?A. The company take thirty, forty, or fifty there from Oonalaska and pay them outside of this community fund from $\$ 60$ to $\$ 80$ each for two months' work, besides their keep and transportation, and each one of them takes home to bis family barrels of choice cuts of seal meat.

Q. And the women will not marry ontside now, from the fact that they prefer to live on the islands; they do not eare to go aud starve on some other island?-A. They would not go off the island to starre with any man, as they are maintained on the islauds by this company when they are widows, free; besides, they do a great deal of work for which they are paid in cash, and lire well.

The Chairman. General Jeffries, do you desire to submit an argument or brief to be printed and submitted to the committee?

General Jeffries. So far as the testimony relates to the charges-if there are charges-I do not deem it worth while to submit anythiug on that question; but so far as the question as to the jurisdiction of the United States over the Bering Sea and the ownership of these waters, I desire to present a brief.

The CHamman. Will you please prepare it, and will you have it printed?

General Jeffries. I will have it printed and furnish a cops to each member of the committee.

The CHAIRMAN. I will be very glad to have a copy printed with the general report-not with the eridence-but I would like to have a copy of the brief printed with the general report.

General JEFFRIEs. Very well. I regard the testimony as all one way so far as the company is concerned, and I do not consider it necessary to argue that question, but will leare that to the committee.

The Chamman. In the absence of any objection the inrestigation is at a close. I will hare the eridence printed and furnished to the members of the committee, and I will notify the committee as soon as it is, so that all may be present and we can consider our report. 


\title{
APPENDICES.
}

\author{
Treasury Departurent, \\ OFFICE OF THE SICRETARY, \\ Washington, D. C., July 6,1888.
}

SiR: Your letter of the 11th nltimo, in which you recuest to be furnished with an itemized statement of all sums received by the United states from the Alaska Commercial Company as rent, tax, or duty for the privilege of taking fur seals on the seal islands of Bering Sea in Alaska, and of all expenditures made by the United States on account of the contract with said eompany and for the enforcement of the laws in relation thereto, was duly received, aud in reply I inclose herewith a statement compiled by the Register of the Treasury, sbowing salaries and traveling expenses paid a grents for each sear. A detailes statement of receipts has already been prepared and forwarled as Exhibit B in a letter addressed to Hon. J. G. Carlisle, House of Representatives, under date of May $3,1888$.

I also inclose copy of a letter from the acting Register of the Treasury, dated the 25th ultimo, explaining certain items in the statements above referred to.

The amount expended for the protection by the revenue mariue of the interests of the United States in the seal islands eau not be approximated for the reason that the revenue-cutters eruising in the waters of Alaska were dispatehed thither for varions purposes, and sailed many thousand miles on business in no way connected with the protection of seal life.

Respectfully, yours,

Hon. PoINDEXTER DuNs,
Chairman Committee on Merchant Marine and Fisheries,
House of Representatives.

\section{S. Fairchild,}

Secretary. House of Representatives.

\section{Treasury Department, RFGISTER'S OFFICE, June $25,1888$.}

Sir : The letter of Hon. Poindexter Dunn, dated June 11, in regard to receipts and expenditures on account of the Alaska Commercial Company, as rent, tax, or duty for the privilege of taking fur seals on the seal islands of Bering Sea, in Alaska, is herewith returned.

After much labor and research, I have tabulated, from the Comptroller's reports on file, a statement of the salaries and traveling expenses paid agents for each year, which is herewith transmitted.

I am unable to furnish any more detailed statement of the receipts than heretofore given. The reeeipts are entered on the book of this office from the covering warrants.

During the fears $1873,1876,187 \%, 1879$, and 1881 the warrants eovered the money into the Treasury as receipts from rents for taking seals in the islands of St. Panl and St. George, Alaska, hut in all other years under the title of "Tax on seal skins, rent for taking seals in the islands of St. Paul and St. George, Alaska."

This irregularity in the description expressed in the warrants neeessitated eonsolidating, in the former statement, the receipts from this source into the one title of "Tax on seal skins and rental for right of taking seal furs in Alaska," aud I can not separate them unless tho covering warrants are changed.

I ean, however, state from general information, with the exception of the jear 1871, that the amount of 855,000 was reeeived and covered into the Treasury for the years stated, from rental for taking seals, etc., and the remainder of the amount was from tax on seal skins.

The amounts appropriated for "protection of sea-otter hunting grounds and seal fisheries, Alaska," from 1878 to 1887 , were earried by counter warrants to tho "expenses of the revenue-cutier service." 
The books of this offec do not show what proportions of the appropriations for the "expenses of revenue-cutter service" were expended on accomnt of cruising in the waters of Alaska to protect the interest of the Government in the seal islands.

It is respectfully suggested that perhaps the dirision of revenue marine of your office may approximate the annual expenditures for that purpose.

Respectfully,

L. W. REID, Acting Register.

The Secretary of the Treasury.

Statement of amounts paid for salaries and traveling expenses, etc., for agents at the seal fisheries in Alaska.

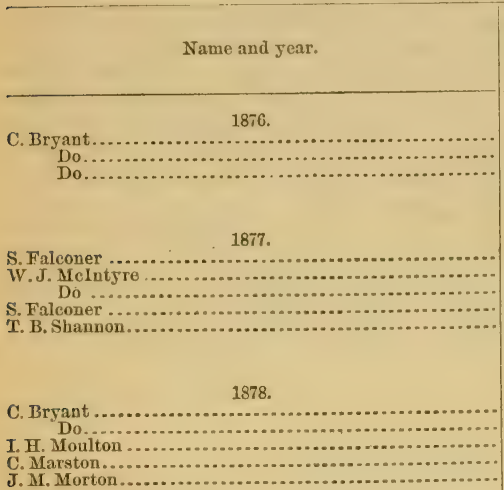

Disallowed J. M. Morton

\begin{tabular}{|c|c|c|c|}
\hline $\begin{array}{l}\text { No. of } \\
\text { report. }\end{array}$ & Salaries. & $\begin{array}{l}\text { Traveling } \\
\text { expenses, } \\
\text { etc. }\end{array}$ & Total. \\
\hline \multirow[t]{2}{*}{$\begin{array}{l}4761 \\
4991 \\
5014\end{array}$} & $\begin{array}{r}\$ 1,517.50 \\
618.35 \\
290.80\end{array}$ & $\begin{array}{r}\$ 325.53 \\
.25 \\
.25\end{array}$ & $\begin{array}{r}\$ 1,843.03 \\
618.60 \\
291.05\end{array}$ \\
\hline & $2,426.65$ & 326.03 & $2,752.68$ \\
\hline $\begin{array}{l}5969 \\
6047 \\
6428 \\
6489 \\
6819\end{array}$ & $\begin{array}{r}3,749.75 \\
2,600.52 \\
363.02 \\
500.00 \\
500.00\end{array}$ & \begin{tabular}{r}
366.95 \\
.25 \\
\hdashline .25 \\
\end{tabular} & $\begin{array}{r}3,749.75 \\
2,96747 \\
363.27 \\
500.00 \\
500.00\end{array}$ \\
\hline \multirow{4}{*}{$\begin{array}{l}7027 \\
7028 \\
7177 \\
7189 \\
7322\end{array}$} & $7,713.29$ & 367.20 & $8, \overline{080.49}$ \\
\hline & $\begin{array}{r}1,223.35 \\
3,178.71 \\
328.90 \\
4,598.60 \\
461.25\end{array}$ & $\begin{array}{c}273.97 \\
336.37 \\
371.31 \\
110.00\end{array}$ & $\begin{array}{r}1,497.32 \\
3,515.08 \\
328.90 \\
4,969.91 \\
571.25\end{array}$ \\
\hline & $\begin{array}{r}9,720.81 \\
10.04\end{array}$ & $1,091.65$ & $\begin{array}{r}10,882.46 \\
10.04\end{array}$ \\
\hline & $9,800.85$ & $1,091.65$ & $\overline{10,892.50}$ \\
\hline $\begin{array}{l}8460 \\
8458 \\
8544 \\
8724 \\
8750 \\
8818 \\
8910 \\
8923 \\
8954 \\
9009 \\
9011 \\
9085 \\
9099 \\
9104 \\
9112 \\
9186 \\
9214 \\
9251 \\
9321 \\
9401 \\
9408 \\
9758\end{array}$ & $\begin{array}{r}4,264.95 \\
95.22 \\
178.53 \\
184.48 \\
902.58 \\
178.53 \\
184.48 \\
916.45 \\
307.47 \\
188.58 \\
188.58 \\
170.33 \\
3,165.98 \\
170.33 \\
471.29 \\
598.20 \\
188.58 \\
188.59 \\
464.71 \\
200.55 \\
180.49 \\
547.50\end{array}$ & 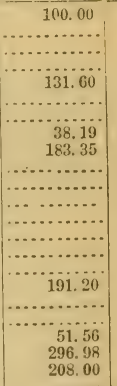 & $\begin{array}{r}1,364.95 \\
95.22 \\
178.53 \\
184.48 \\
1,034.18 \\
178.53 \\
184.48 \\
954.64 \\
490.82 \\
188.58 \\
188.58 \\
170.33 \\
3,165.98 \\
170.33 \\
471.29 \\
598.20 \\
379.78 \\
188.59 \\
464.71 \\
252.11 \\
477.47 \\
755.50\end{array}$ \\
\hline & $\begin{array}{r}13,936,40 \\
\ldots \ldots . . .\end{array}$ & $\begin{array}{r}1,200.88 \\
\ldots . .6 \\
\end{array}$ & $\begin{array}{r}15,137.28 \\
547.50 \\
697.00\end{array}$ \\
\hline & $13, \overline{936.40}$ & $1,200.88$ & $16,381.78$ \\
\hline \begin{tabular}{r|}
9762 \\
9755 \\
9776 \\
9771 \\
10735 \\
10018
\end{tabular} & $\begin{array}{r}3,165.98 \\
367.01 \\
1,067.16 \\
\ldots . .2 . \\
\ldots .57 .50\end{array}$ & $\begin{array}{r}1.00 \\
327.75 \\
721.98 \\
\ldots . . .2\end{array}$ & $\begin{array}{r}3,165.98 \\
368.01 \\
1,067.16 \\
327.75 \\
721.98 \\
547.50\end{array}$ \\
\hline
\end{tabular}

T. H. Moulton

1880.

H, G. Otis. . .

Do

1879.

J.M. Morton

Do.

J. M. Morton Do

Scribner

B. F. Scribuer

B. Beaman

J.M. Morton

S. Bryant

J. M. Morton.

J. WV. Beaman

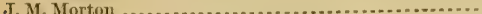

H. G. Otis ...

B. F. Seribner

Add repayment :

B. F. Seribner $(1880)$

B. F. Scribner

10018

547.50

547.50 
Siatement of amonnts paid for salaries and traveling expenses, etc.-Continued.

\begin{tabular}{|c|c|c|c|c|}
\hline Name and jear. & $\begin{array}{l}\text { No. of } \\
\text { report. }\end{array}$ & Salaries. & $\begin{array}{l}\text { Traveling } \\
\text { expenses, } \\
\text { ete. }\end{array}$ & Total. \\
\hline I. H. Moulton . . ........... & & & & \\
\hline $\begin{array}{l}\text { I. I. Moulton............ } \\
\text { II. G. Otis ............... }\end{array}$ & $\begin{array}{l}10091 \\
10166\end{array}$ & $\begin{array}{r}\$ 722.06 \\
694.29\end{array}$ & & $\begin{array}{r}\$ 722.06 \\
694.29\end{array}$ \\
\hline 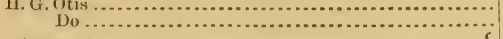 & $\begin{array}{r}10106 \\
9989\end{array}$ & ............ & $\$ 215.35$ & 215.35 \\
\hline I. H. Moulton ............ & $\left.\begin{array}{l}9747 \\
9848\end{array}\right\}$ & 221.75 & ... & 221.75 \\
\hline 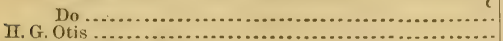 & 10314 & 494.66 & & 494. 66 \\
\hline 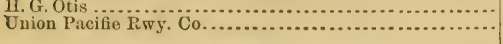 & $\begin{array}{l}10509 \\
10557\end{array}$ & $1,517.53$ & 54.50 & $\begin{array}{r}1,517.53 \\
54.50\end{array}$ \\
\hline \multirow{3}{*}{ 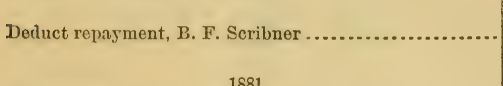 } & \multirow{11}{*}{$\begin{array}{l}10981 \\
11118 \\
11195 \\
11180 \\
11181 \\
11720 \\
11794 \\
11794 \\
12080 \\
12081\end{array}$} & $8,797.94$ & $1,320.58$ & $10,118.52$ \\
\hline & & …... & ………. & 547.20 \\
\hline & & $8,797.94$ & $1,320.58$ & $9,571.02$ \\
\hline $\begin{array}{l}\text { 73. F. Scribner } \\
\text { F. L. Sullivan }\end{array}$ & & $1,095.00$ & & $1,095.00$ \\
\hline $\begin{array}{l}\text { F. L. Sullivan ... } \\
\text { J. IV. Beaman }\end{array}$ & & & & $\begin{array}{r}499.89 \\
\end{array}$ \\
\hline $\begin{array}{l}\text { W. I } \\
\text { F.S }\end{array}$ & & 1,690 & & $1,690.11$ \\
\hline $\begin{array}{l}\text { F. Scribner } \ldots \ldots \ldots \ldots \\
\text { H. Monlton } \ldots \ldots \ldots \ldots\end{array}$ & & 547 & & $\begin{array}{l}547.50 \\
160.59\end{array}$ \\
\hline $\begin{array}{l}\text { H. Monlton } \\
\text { ntral Pacifie Rwy. Co. }\end{array}$ & & $\begin{array}{c}160.59 \\
\cdots\end{array}$ & 46.00 & 0.59 \\
\hline 1. Seribner ........... & & 329.10 & ......... & 329.10 \\
\hline $\begin{array}{l}\text { J. W. Beaman } . . . \ldots \ldots \\
\text { E. L. Sullivan ............ }\end{array}$ & & 277.10 & . & 277.10 \\
\hline $\begin{array}{l}\text { E. L. Sullivan } \ldots \ldots \ldots \\
\text { Do } \ldots \ldots \ldots \\
\end{array}$ & & (n)........ & $\begin{array}{r}123.80 \\
1.76\end{array}$ & $\begin{array}{l}123.80 \\
176.00\end{array}$ \\
\hline \multirow{3}{*}{ 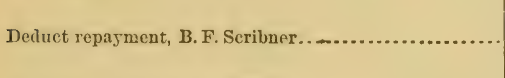 } & \multirow[b]{5}{*}{12388} & & 345.80 & \\
\hline & & 99.29 & 340.80 & $\begin{array}{r}4,945.09 \\
697.00\end{array}$ \\
\hline & & $4,599.29$ & 345.80 & $4,248,09$ \\
\hline Central Pacific Rwy. Co........ & & & & $4,248.09$ \\
\hline $\begin{array}{l}\text { Central Pacific Rwy. Co.... } \\
\text { I. H. Monlton ................ }\end{array}$ & & & 46.00 & 46.00 \\
\hline E. Wardman .............. & $\begin{array}{l}12520 \\
12547\end{array}$ & $\begin{array}{r}3,165.97 \\
367.00\end{array}$ & $\cdots \ldots \ldots$ & $3,165.97$ \\
\hline J. Go Otis & $\begin{array}{l}125+7 \\
125 \div 6\end{array}$ & & $\cdots \cdots \cdots$ & $\begin{array}{l}367,00 \\
156,42\end{array}$ \\
\hline . B. T & 12613 & 5,475 & 256.60 & $5,731.60$ \\
\hline $\begin{array}{l}\text { W. B. Taylor...... } \\
\text { E. Wariman..... }\end{array}$ & $\begin{array}{l}12682 \\
12701\end{array}$ & & 100.00 & 800.85 \\
\hline $\begin{array}{l}\text { E. Wariman...... } \\
\text { IV. B. T'aylor..... }\end{array}$ & $\begin{array}{l}12701 \\
12774\end{array}$ & $\begin{array}{l}5+7 \\
529\end{array}$ & $\because 37.25$ & 547. 50 \\
\hline Do........... & 12930 & $\begin{array}{l}529 \\
370\end{array}$ & $\begin{array}{r}137.25 \\
. \ldots \ldots\end{array}$ & $\begin{array}{l}666.89 \\
370.81\end{array}$ \\
\hline Do....... & 13100 & 273.75 & (n......... & 273.75 \\
\hline H. A. Glidden ........... & $\begin{array}{l}13670 \\
15501\end{array}$ & $\{\ldots \ldots \ldots$ & 399.00 & 399.00 \\
\hline W. B. Taylor............... & 13220 & 164.25 & 47.75 & 212.00 \\
\hline I. Kimmel. & $\begin{array}{l}13796 \\
152 \times 3\end{array}$ & & 94.40 & 94. 40 \\
\hline & i5605 & & 12() .10 & 120.10 \\
\hline 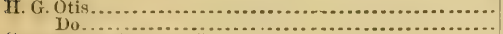 & 13247 & $1,825.00$ & (n)......... & $1,825.00$ \\
\hline Central Pacific Rwy. Co...... & $\begin{array}{l}133+4 \\
135+2\end{array}$ & 100.27 & & 100.27 \\
\hline Uniou Pacifie Rwy. Co..... & 13540 & & $\begin{array}{r}92.00 \\
109.00\end{array}$ & $\begin{array}{r}92.00 \\
109.00\end{array}$ \\
\hline \multirow{3}{*}{ 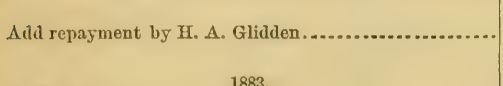 } & \multirow{22}{*}{$\begin{array}{l}12546 \\
12683 \\
13729 \\
13767 \\
13784 \\
13774 \\
13840 \\
12150 \\
13954 \\
14154 \\
14152 \\
14170 \\
14263 \\
14365 \\
14415 \\
14537 \\
14609 \\
14 \times 76 \\
14660 \\
14089\end{array}$} & $13,676.46$ & $1,402.10$ & 15,07 \\
\hline & & …............ & …......... & 184.50 \\
\hline & & $13,676.46$ & $1,40: 10$ & $15,263.06$ \\
\hline G. Wariman.... & & & 100.50 & 100.50 \\
\hline & & & 100.00 & 0.00 \\
\hline$\cdots$ & & 192.00 & & \\
\hline ten & & & & \\
\hline ten $\ldots \ldots \ldots \ldots \ldots$ & & & & 0.57 \\
\hline tom........... & & & 75 & \\
\hline R. R. Co. & & $3,165.97$ & & \\
\hline & & $i, 6 i$ & & $\begin{array}{r}54.50 \\
850\end{array}$ \\
\hline & & $\begin{array}{r}1,61 \\
51\end{array}$ & $\begin{array}{l}207.85 \\
\ldots \ldots \ldots\end{array}$ & $\begin{array}{r}1,850.35 \\
5+7.50\end{array}$ \\
\hline$\because 7 \%$ & & $\begin{array}{r}517.50 \\
\ldots . .2 . . .\end{array}$ & 60.50 & $\begin{array}{r}5+7.50 \\
60.50\end{array}$ \\
\hline I Pacific R. R. Co... & & & 46.00 & 46.00 \\
\hline H. Moulton.............. & & & ........ & \\
\hline & & & & 245.98 \\
\hline$\cdots$ & & 547.50 & & 547.50 \\
\hline & & $\cdots$ & $\begin{array}{l}63.75 \\
54.50\end{array}$ & $\begin{array}{l}63.75 \\
54.50\end{array}$ \\
\hline cific R. R. Co.... & & 965.95 & .50 & $\begin{array}{r}54.50 \\
965.95\end{array}$ \\
\hline 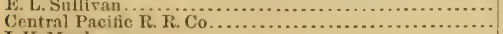 & & & 43.70 & $\begin{array}{r}\text { 700. } 93 \\
43.70\end{array}$ \\
\hline I. H. Moulton . . . . . . . . & & 484.04 & $16 \overline{7} .50$ & 651.54 \\
\hline & & 10,0 & $1,067.55$ & $11,090,32$ \\
\hline
\end{tabular}


Statement of amounts paid for saiaries and traveling expenses, etc.-Continued.

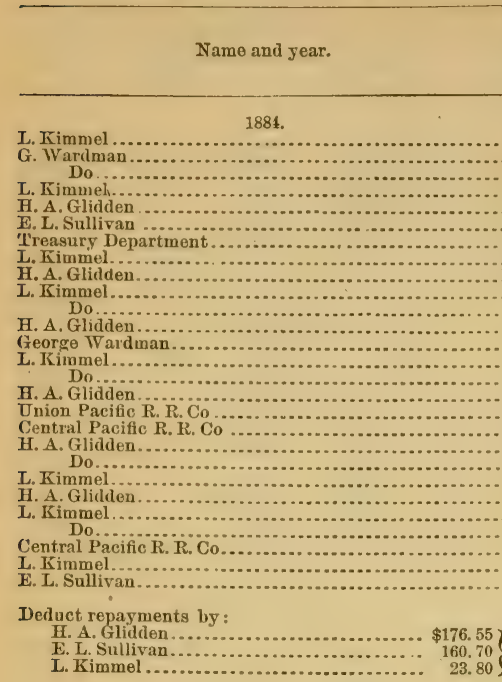

\begin{tabular}{|l|} 
No. of \\
report.
\end{tabular}

Salaries.

Traveling

E. L. Sullivan.

$\left.\begin{array}{l}60.70 \\ 23,80\end{array}\right\}$

1885.

J. H. Beaman

George Wardman

H. A. Glidden

H. Gliclden .

George Wardman

I. H, Moulton

$$
\text { Do }
$$

George Wardman

I. H. Moulton

H. G. Fowler

I. H. Monlton. .

George IVardman Do.

I. H. Moulton

Union Pacific R. R. Co

Central Pacific R. R. Co

I. H. Moulto

George Wardman.

$$
\text { Do }
$$

Union Pacific $\mathrm{R} . \mathrm{R}$.

Central Pacific R. R. Co

A. P. Loud

Central Pacific R. R. Co

George R. Tingle

Union Pacific R. R. Co

IV. H. Sears

Union Pacific R. R. Co

\section{6.}

H. G. Fowler

H. A. Glidden

$$
\text { Do. }
$$

G. Fowler ...

Union Pacific R. R. Co A. P. Lond

Do.

Do.
$13,429.31$

\begin{tabular}{c|c} 
& \multicolumn{1}{c}{$13,429.31$} \\
$\ldots \ldots \ldots \ldots$ & $\ldots \ldots \ldots \ldots$
\end{tabular}

$13,429.31$

17529

$16 \pm 49$

16450

16613

16617

16681

16626

16671

16776

16809

168:2

16907

16912

17010

17023

16910

16996

17147

17164

17320

17461

17490

18496.

17678

20426

18477

20165

17751

17812

18340

18888

$18 \pm 88$

18464

18517

18497

$186 \times 6$

18838

$=$

i, 095.00

521.40

919. 14

916. 50

$2,435.97$

245. 97

178. 50

238. 06

363. 02

245.98

184.50

178. 50

238. 04

245.98

18t. 50

188. 60

*600.00

${ }_{*} 600.00$

$+600.00$

$1,265.38$

1, 612.50

$2,858,03$

600.00

178.53

368.97

184.48

178. 54 expenses, etc.

$\$ 1,095.00$ 186.50

364.98

916.50

4, 066.58

$1,219.35$

728.00

297. 55

178. 50

181.48

307.47

363.02

178. 50

184.52

605. 03

..........

600.00

310.85

186.50

290. 80

174.50

186. 50

192.50

611. 68

Total.

$\$ 1,095.00$ 302.50

361. 98

916. 50

$\$ 116.00$

207.05

1, 919.35

728. 00

160. 70

318.28

178. 50

184. 48

307.47

363. 02

178. 50

184. 53

605. 03

108. 00

81.98

(600. 00

310.8 .5

386. 50

339. 25

174. 50

186. 50

.47

19.. 50

611. 68

14, $\overline{172.69}$

361. 05

$13,811,64$

743. 38

743. 38

8. 14

173. 32

277.80

167.50

247.60

88.50

...........

............

.

103.06

77. 88

...........

..........

51.53

38.94

38. 94

.........

51. 53

291.30

51. 53

$11,445.04$

$1,657.57$
8. 14

1,095. 00

173. 32

799. 20

919. 14

1, 074. 00

$2,435.97$

493. 57

267. 00

238. 06

363.02

245. 98

184. 50

178.50

238. 04

103. 06

77. 88

245. 98

184. 50

188.60

51. 53

38. 94

600.00

38. 94

600.00

600.00

51. 53

$1,556.68$

51.53

$13,10 \div 61$

1, 814. 25

2, $9.55,38$

600. 00

136. 75

51. 53

274. 28

479. 97

184. 48

178. 54 
Statement of amounts paid for salaries and traveling expenses, eto.-Continued.

G. R. Tingle

W. Garitt .

T. F. Ryan .........

G. R. Bartlett.

Deduct repayments :

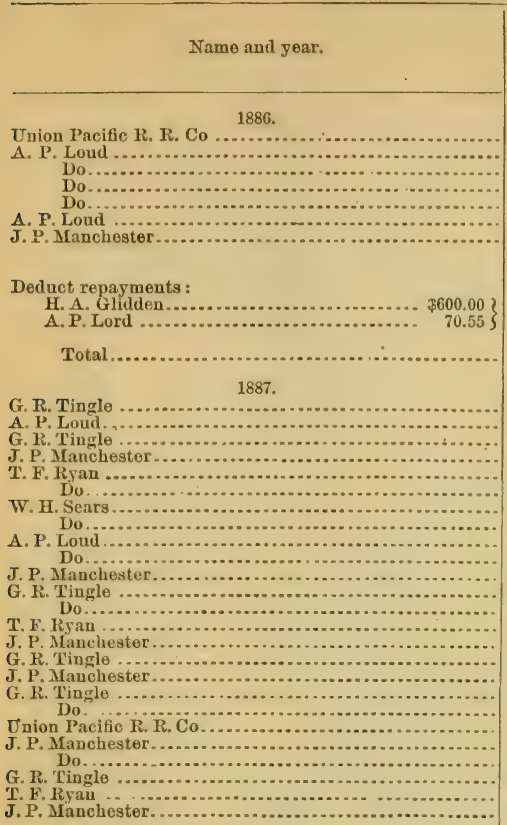

\section{Do}

G. R. Tingle ............................\$309. 25

T. E. Ryan. $600.00\}$

Total.

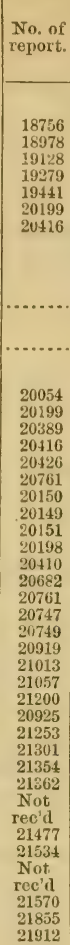

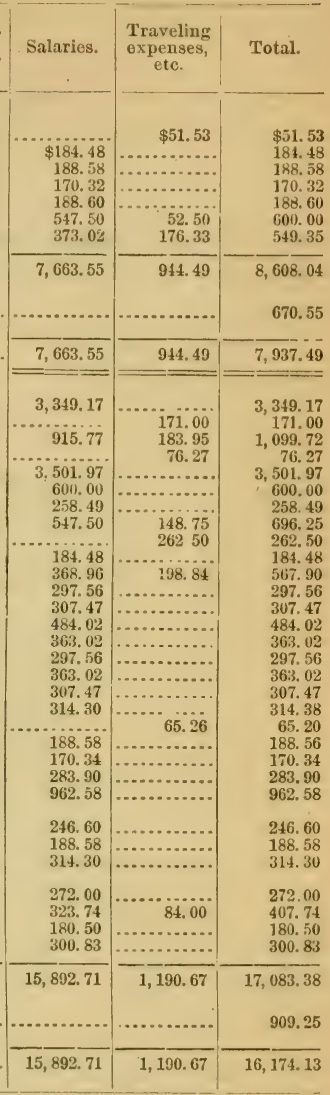

RECAPITULATION.

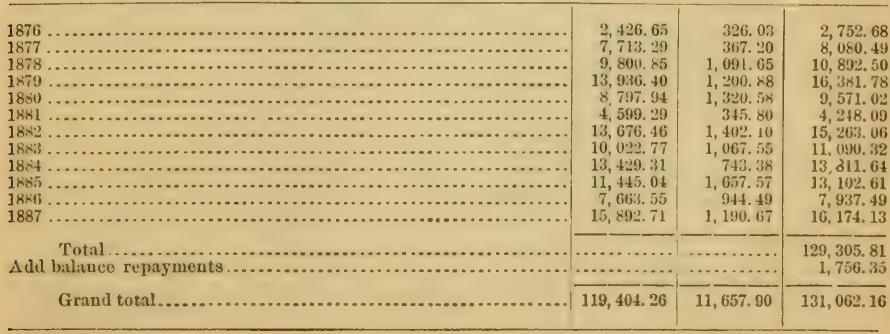


Consolidated annual report of fur seals killed at the seal islands of Alaska during the year ended July $31,1888$.

\begin{tabular}{|c|c|c|c|c|c|c|}
\hline \multirow{3}{*}{ When killed. } & \multirow{3}{*}{ Rookery. } & \multicolumn{5}{|c|}{ Killed for natives' food. } \\
\hline & & \multirow[b]{2}{*}{ Pups. } & \multirow{2}{*}{$\begin{array}{l}\text { Large } \\
\text { young } \\
\text { seals. }\end{array}$} & \multirow{2}{*}{$\begin{array}{l}\text { Skins } \\
\text { accepted } \\
\text { by lessees }\end{array}$} & \multicolumn{2}{|c|}{ Skins rejected. } \\
\hline & & & & & $\begin{array}{l}\text { Under } \\
\text { size. }\end{array}$ & Stagy. \\
\hline July 1887. & St. Paul Island .... & n...... & 39 & 39 & & \\
\hline A ugust ....... & ...... do .......... & ..... & 980 & 976 & 4 & \\
\hline September........... & . & & 1,051 & 1,020 & & $3 i$ \\
\hline October............... & ando do & $\ldots \ldots$ & 300 & 135 & .... & 165 \\
\hline November ............ & ...... do & 2,177 & 943 & 918 & 25 & (.......... \\
\hline $\begin{array}{l}\text { December.............. } \\
1888 .\end{array}$ & ..... do do & (n)............ & & & & .......... \\
\hline January ..... & ...... do ....... & & 545 & 532 & 13 & \\
\hline May ................... & ...... do do........................... & . & 408 & 398 & 10 & 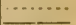 \\
\hline & Total ........................ & 2,177 & 4,885 & 4,630 & .59 & 196 \\
\hline 1887. & & & & & & \\
\hline $\begin{array}{l}\text { August ................. } \\
\text { September........... }\end{array}$ & $\begin{array}{l}\text { St. George Island } \ldots \\
\ldots\end{array}$ & & $\begin{array}{l}265 \\
113\end{array}$ & 264 & $\begin{array}{l}1 \\
\cdots\end{array}$ & 113 \\
\hline Octuber............... & 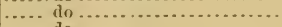 & & 126 & 126 & ... & \\
\hline Norember ............ & 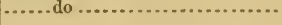 & 1,356 & 24 & 24 & $\cdots \cdots$ & ......... \\
\hline & Total ............................ & 1,356 & 528 & 414 & 1 & 113 \\
\hline & $\begin{array}{l}\text { RECAPITULATION. } \\
\text { St. Paul Island } \\
\text { St. George Island } \ldots \ldots \ldots \ldots . . . . . .\end{array}$ & $\begin{array}{l}2,177 \\
1,356\end{array}$ & $\begin{array}{r}4,885 \\
5: 8\end{array}$ & $\begin{array}{r}4,630 \\
414\end{array}$ & $\begin{array}{r}59 \\
1\end{array}$ & $\begin{array}{l}196 \\
113\end{array}$ \\
\hline & Total ... & 3,533 & 5,413 & 5,044 & 60 & 309 \\
\hline
\end{tabular}

\begin{tabular}{|c|c|c|c|c|c|c|c|}
\hline \multirow{3}{*}{ When killed. } & \multirow{3}{*}{ Rookery. } & \multicolumn{3}{|c|}{ Killed by the lessees for skins. } & \multicolumn{3}{|c|}{ A grgregates. } \\
\hline & & \multicolumn{2}{|c|}{ Skins accepted. } & \multirow{2}{*}{$\begin{array}{l}\text { Skins ro- } \\
\text { jected un- } \\
\text { der size. }\end{array}$} & \multirow{2}{*}{$\begin{array}{c}\text { Total num. } \\
\text { ber of skins } \\
\text { rejected. }\end{array}$} & \multirow{2}{*}{$\begin{array}{l}\text { Thtal uxm- } \\
\text { ber of skins } \\
\text { rectised by } \\
\text { lessees. }\end{array}$} & \multirow{2}{*}{$\begin{array}{l}\text { Total num- } \\
\text { ber of seals } \\
\text { billed dur- } \\
\text { ing the } \\
\text { rear. }\end{array}$} \\
\hline & & Yrime. & $\begin{array}{l}\text { Second } \\
\text { class. }\end{array}$ & & & & \\
\hline 1887. & & & & & & & \\
\hline July ..... & St. Paul Island .. & 39 & & & & 39 & 39 \\
\hline August ...... & .... do ............. & 56 & $i 5$ & & 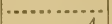 & 56 & 56 \\
\hline August ....... & ... do.............. & 961 & & ..... & 4 & 976 & .980 \\
\hline September ... & .... do.............. & 1,005 & 15 & $\cdots \cdot$ & 31 & 1,020 & $1,05 \mathrm{I}$ \\
\hline Oetober ....... & ....do.............. & 135 & 8 & $\cdots$ & $\begin{array}{r}165 \\
25\end{array}$ & 135 & $: 00$ \\
\hline Norember - . & .... do do................ & $\begin{array}{l}910 \\
603\end{array}$ & $\begin{array}{l}8 \\
9\end{array}$ & (n.......... & $\begin{array}{r}25 \\
7\end{array}$ & $\begin{array}{l}918 \\
61{ }^{2}\end{array}$ & 943 \\
\hline 1888. & 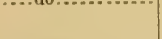 & & & & & & \\
\hline January ..... & .... do............. & 528 & 4 & $\cdots$ & 13 & 532 & 545 \\
\hline May ........ & ... do do............. & 394 & 4 & $\cdots$ & 10 & 398 & 408 \\
\hline June .......... & . . do do .............. & $\begin{array}{l}26,649 \\
52,830\end{array}$ & $\begin{array}{l}280 \\
555\end{array}$ & $\begin{array}{r}10 \\
6\end{array}$ & $\begin{array}{r}10 \\
6\end{array}$ & $\begin{array}{l}26,929 \\
53,385\end{array}$ & $\begin{array}{l}26,939 \\
53,391\end{array}$ \\
\hline gury..... & 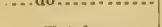 & 32,000 & & & & & 50,501 \\
\hline 1887. & Total........ & 84,110 & 890 & 16 & 271 & 85,000 & 85,271 \\
\hline July .......... & St. George Island & 4 & ..... & & & 4 & 4 \\
\hline August ....... & . . do do do.............. & 264 & & 1 & 1 & 264 & 265 \\
\hline $\begin{array}{l}\text { September ... } \\
\text { Oetober ...... }\end{array}$ & 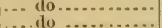 & 126 & ..... & 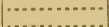 & 113 & 126 & $\begin{array}{l}113 \\
126\end{array}$ \\
\hline $\begin{array}{l}\text { Oetober...... } \\
\text { Norember ... }\end{array}$ & 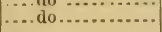 & $\begin{array}{r}120 \\
24\end{array}$ & (n... & (n) & (a... & 24 & 24 \\
\hline 1888. & & & & & & & \\
\hline \multirow{6}{*}{$\begin{array}{l}\text { June ........... } \\
\text { July .......... }\end{array}$} & ... do do .............. & 5,171 & ............... & 1 & 1 & 5,171 & 5,172 \\
\hline & .....do do.............. & 9,411 & & & & & \\
\hline & Total........ & 1,500 & .......... & 2 & 115 & 15,000 & 15,115 \\
\hline & RECAPITULATION. & & & & & & \\
\hline & $\begin{array}{l}\text { St. Paul Island } \\
\text { St. George Island }\end{array}$ & $\begin{array}{l}84,110 \\
15,000\end{array}$ & $\begin{array}{r}890 \\
\ldots\end{array}$ & $\begin{array}{r}16 \\
2\end{array}$ & $\begin{array}{l}271 \\
115\end{array}$ & $\begin{array}{l}85,000 \\
15,000\end{array}$ & $\begin{array}{l}85,271 \\
15,115 \\
\end{array}$ \\
\hline & Total......... & 99,110 & 890 & 18 & 386 & 100,000 & 100,386 \\
\hline
\end{tabular}


CIRCULAR.

Pcrmit required for hunting, trading, and fishing on Russian coasts of the Olihotsh and Bering Seas.

[1882.-Department No. 13.-Secretary's Othice.]

Treasury Department, Office of the Secretary,

To collectors of customs and others :

Washington, D. C., January 30, 1882.

The subjoined notice by the Russian consul at Yokohama, that American vessels are not allowed, without a special permit or license from the governor-general of Eastern Siberia, " to carry on luuting, trading, fishing, ete., on the Russian coasts, or islamels in the Okhotsk or Bering Seas, or on the northeastern const of Asia, or within the sea-boundary line," is published by the Department for the information of American ship-masters interester.

It will bo observed that the Russian order took effect on January 1, 188:.

CHAS. J. FOLGER,

Secretary.

\section{NOTICE.}

At the reyuest of the local authorities of Bering and other islands, the undersigned hereby notities that the Russian Imperial Government publishes, for general know Iedge, the following:

I. Without a special permit or license from the governor-general of Eastern Siberia, foreigu vessels are not allowed to carry on trading, hunting, fishing, ete., on the Russian coast or islands in the Okhotsk and Bering Seas, or on the northeastern coast of Asia, or within their sea-boundary line.

II. For such permits or liceuses, foreign vessels should apply to Vladivostock, oxclusively.

III. In the port of Petropaulovsk, though being the only port of entry in Kamchatka, such permits or licenses shall not be issued.

IV. No pernits or licenses whatever shall be issued for hunting, fishing, or trading at or on the Commodore and Robben Islands.

V. Foreign ressels foumd trading, fishing, hunting, etc., in Russian waters without a liceuse or permit from the governor-general, and also those possessing a license or permit who may infringe the existing by-laws ou hunting, shall be eoufiseated, both vessels aud cargoes, for the benefit of the Government. This enactment shall be enforced henceforth, eommencing with A. D. 1882.

VI. The enforcement of the above will be intrusted to Russian men-of-war, and also to Russian merehant vessels, which, for that purpose, will carry military detachments and be provided with proper instructions.

Үоконама, November 15, 1881.

A. Pelikan,

H. I. R. M. Consul.

\section{Office of Special Agent Treasury Department, \\ St. Paul Island, Alaska, July 31, 1888.}

Sin: I have the honor to trausmit herewith a report of the operations of the furseal islands of Alaska for the year ending July 31, 1888.

I inclose the Alaska Commercial Company's steamer st. I'aul's receipts for 100,000 fur-seal skins "taken aud shipped." Statement $\Lambda$ shows the daily killiug of seals, from which you will see the number of large seals killed after the close of the season of $18-7$, for native food, was 4,885 , of which 1 umber the Alaski: (iommercial Company accepted on the quota of 185 s 4,6330 ; there was 59 rejected, being under size, and 196 rejected stagy.

Two thonsaud oue hundred and seventy-seven small pups were killed in November for native food, being 6.47 less than were killed the previous year, whilst the stagy skins destroyed this year were 394 less than the year last preceding. This was owing to the fact of the Alaska Commercial Company accepting and silting all the stagy skins that were but slightly tonched, so as to save all that it is possible to pass as merchantable skins.

The large killing of seals in November, December, and January for food showed an munsmal number on the island at that season of the year. Mr. Manchesster, assistant Treasury agent in charge of St. Paul Island, had the natives salt, in the company's salt-house, it large portion of the meat, which gave them a better supply than they have had for soveral years in the winter, when the islands are depopulited of seal, 
Statement B shows the killing on St. Paul and St. George consolidated each month.

The extremely small number of seals rejeeted this year, viz, 27:3, attests the care which is exercised in killing the quota of 100,000 . This insiguificant loss is the more remarkable when it is considered that in the drives many large bulls and yearling seals are driven up to the killing grounds, which have to be separated in the pods when clubbing. The presence of these seals aung the killables is very embarrassing to the clubbers, as they can not be turned out to return to the sea until nearly or quite all the acceptable seals are knocked down, when they are driven off to the water unharmed.

The sealing throughout the season progressed without any serious interruptions, and was conchuled in a most satisfactory manner by the lessees on both islands.

There has been general good behavior among the natives on both islands during the past year, owing to the strict discipline and careful watchfulness of the Government officers in charge.

The natives have performed their work during this sealing season with alacrity, each one manifesting a disposition to do his whole duty.

The breeding rookeries were later filling this year than for several years past. I may say that, fully three-fourths of the cows and bulls were ten days later bauling out than usual, which at the time gave the impression there would be a shortage this season of killable seals as well as breeders.

I am happy to be able to report that although late landing the breeding rookeries are filled out to the lines of measurement heretofore made, and some of them much beyond those lines, showing conclusively that seal life is not being depleted, but is fully up to the estimates given in my report of 1887.

The marauders which infest the sea, shooting and harrassing the seals on their way to the islands, I am sure, is the main cause of their late landing this year, and if this unlawful slanghtering of the fur seal in Bering Sea is not in some way effectually stopped they will adopt some other route and make a home ou some other laud, most likely on the Russian side. The number hauling out on our islauds will each year grow rapidly less, when it would be inıpossible for auy lessee to secure the quota they may by contract be allowed to take, and your world-wide famous seal islauds would be in a short time reduced to the home of a ferw straggling seals and as a source of revenue be entirely destroyed. Although this question of unlawful killing of seals by schooners fitted out in British Columbia ports, as well as Anerican, has been referred to at leugth in previous reports, I again beg to call the Department's attention to it, in view of the termination of the present lessees' contruct on the 1st day of May, 1890, which grives them but one more season's killing. It is of the highest importance some definite and prompt action should be taken looking to the preservation of seal life, or the valuable seal property, which could be made to yield a larger revenue to the Govermment than it does now, will soon be of no value.

With absolute protection the seals will increase, so that a greater uumber could each year be taken to keep pace with the increased clemand, and the price cheapened to the people of the world, and particularly to those of moderate means in our own country who would be glad to enjoy the comforts of the beantiful seal garment.

On April 4 the steam-whaler Orca, Captain Baldras, touched at this island on her way to the Arctic Ocean. 'The captain very kindly sent on shore a file of Sau Francisco papers up to the 5th of March, together with a quantity of fresh fish and vegetables. In returu for his kindness the Treasury agent, Mr. Mauchester, aud the Alaska Commercial Company's agent, Mr. Redpath, sent him off some presents.

The weather last winter and spring was exceptioually mild. The lowest temperature in December was 14 degrees, Jauuary 8 degrees, and February 2 degrees above zero, and then only for one day in each of the nonths. The ice did not make its appearance aroumd either of the island, or even in sight, contrary to the usual custom. This is accounted for by the prevailing winds being east and southeast instead of north and northeast, as is generally the case.

The condition of the natives on the two islands remains about the same as heretofore reported; they are slowly becoming more Americanized, and are perfectly happy and contented; as they well may be, with the treatment they receive at the hands of the Alaska Commercial Company and the Government.

The usual number of deaths occurred this year, mostly the result of imprudent exposure, althongh the best medical treatment is furnished them, with medicines free, they fail to give that careful attention to mursing which is necessary to bring them throngh. When they are remoustrated with for exposing themselves unuecessarily in bad weather, the generally reply in Russian, "Never nind, to die is good." When once prepared for death by the priest of the Greek Church, they calmly aud happily await the eud. No tears are shed by the relatives of the deceased, and no sorrow is manifested in the household. If it is a wife, the husbaud, according to their custom, makes the coftiu; aud if a husband, then the nearest male relative makes the coffin. The body in all cases is taken to the chureh, where services are held, at the conclusion of which every man, woman, and child kisses tho corpse on the forehead and on 
the left cheek. The boty is then carried to the grave by the relatives and buried. $\Lambda$ fow days after the funeral a tea party is given at the house of the deceased, and is usually largely atteuded, mostly by the femitle portion of the population. After forty days' mourning and mrayers, the surriving wife or husband, as the case may be, is at liberty to marry agaiu.

The sauitary coudition of the villages on both islands could not bo better, and indeed will compare very favorably with the small towns in the States, if not put many of them to shame could they be compared.

On the 17th day of June at, noon, the United States man-of-war Thetis, LientenantCommander Emory, arrived at this island and anchored, having on board his excellency A. P. Swineford, governor of Alaska.

Commander Emory, with a number of his oflicers and the governor, came on shore and were met at the landing by the Treasury officials and Alaska Commercial Company's agent, Dr. H. H. McIntyre, by whom a cordial welcome was extented the distinguished visitors. Every facility was oftered the goveruor to further the object of his visit. He was placed in possession of the fullest information from the books and by personal observation, as well as inquiry among the natives as to the management of the fur-seal islands. The entire ship's party were taken to the rookeries by the Treasury agent, as woll as upon the seal fields, through the salt-houses, and store, school-house, and church, where the goveruor looked into everything critically. He took occasion to express himself as highly pleased with the condition of the natives and the management of the Government interests and the relation of the lessees therewith.

He was indeed quite profuse in his praise of the company's care and provision for the natives, as well as the correct methods of conducting the Government business. He thought it could not be improved on.

The governor's visit here can have but one result, as he is a fair man, viz, to give him the data gained by personal knowledge on which he will base a report correcting many of the errors into which he was led in his last report, by accepting as true the false statement of a man named Auderson.

The visitors were entertaiued at the Government bouse, and on the 18 th the Treasury agent returned their visit and was entertained at dinner on board the ship.

The United States revenue-cutter Bear, Capt. M. A. Healy, arrived and anchored at this island on the 16 th of June, the day before the arrival of the Thetis. She brought our mail and papers from San Franciseo up to May 25 . The two ships left on the 19 th at $3 \mathrm{p} . \mathrm{m}$. under sail for Oonalaska. The Bear, after eruising to the south and eastward retirned to the island on the 7th of July, departing again the morning of the 8th instant at daylight.

The U. S. revenue-cutter Rush, Captain Sheppard, arrived at the island on the 25th instant, bringing mail for the islands from San Fraveisco up to July 2 , and the first intelligence we had of the action of the two national conventions.

The cutter Bear anchored here on the 20 th instant, and left on the 21st for the Arctic Ocean; she had cruised quite extensively in the Bering Sea since she was last here. Captain Healy reported to me that he had not sighted any schooners, which indicates an unusual absence of marauders this year. In a letter from Captain Glover, of the U. S. cutter Walcott, by the liush, I am informed that the American sehooners had deeided not to enter Bering Sea this season to kill seals. Captain Glover's opportnnities in Puget Sound for obtaining correct information are good ; he is fully sustained by the reports from Captains Healy and Sheppard, who, up to the last of this mouth, have not sighted a single marauding vessel in Bering Sea.

The good work of the U. S. revenue-cutters last year, in seizing the vessels unlawfully engatred in sealing, has had a salutary effect.

Whilst the vessels havo kejt ont of Bering Sea up to this date, they have vigorously pursued the fur seals in the North Pacific Ocean en route to their home on the islands of St. Paul and St. George, killing and destroying a very large number.

All the obligations of the lessees were performed to the entire satisfaction of the Government officers, and in strict accordance with their contract.

Although the sehools are as well supplied with every facility for teaching that can be found in any easteru town, yet the native ehildren make but limited progress in their studies; they are extremely dull and indifierent abont learning, aud are not encouraged by their parents to study; they are particularly averse to iearning English.

I leave St. George Island in eharge of Captain Loud, assistant Treasury agent, and St. Paul Island with Mr. J. P. Manchester, assistant Treasury agent, in charge. Mr. William Garrett, assistant Treasury agent in charge of St. George Island during the past year, and myself return to our homes, as per Department letter of anthority March 5,1888 , A. F. 308 .

Respectfully submitted.

Hon. C. S. Faircimid, Secretary of the Treasury.

Geo. R. TrNGLe, Treasury Agent.

$9984-23$ 
Census January 1, 1888.

Number of families

ST. PAUL ISLAND.

Male adults .

Males five to seventeen years old

....................

Femalo adults

Females five to seventeen years olat.

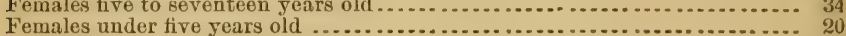

Total population .........................................

Deaths-

Male adults..................................................

Males five to seventeen years of age............................. 1

Males uuder five years old.................................... 3

Female adults............................................... 3

Females under five years .......................................... 6

Births-

Males.

Females

ST. GEORGE ISLAND,

Number of families...... .......................................... 30

Male adults..................................................... ${ }_{29}$

Males five to seventeen years old...................................... 13

Males under five years old ....................................... o

Fernale adults ..............................................

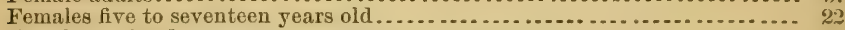

Females under five years ........................................ 10

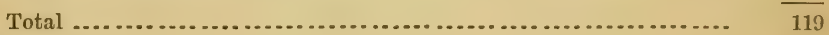

Deaths-

Males ............................................................ 5

Females ....................................................... 10

Births-

Males..................................................... 5

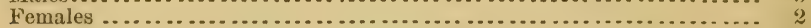

IsLAND OF ST. GEORGE, Bering Sea, Alaska, July 30, 1888.

This is to certify that nine thousand nine humdred and forty-eight $(9,9.4)$ fur-seal skins have this diay been shipped on board the Alaska Commercial Company's steamer St. Paul, whereof M. C. Erskin is master.

\section{C. ERskin. \\ WILLIAJI GavitT, Assistant Treasury Agent.}

ISLAND OF ST, GEORGE, Bering Sea, Alaska, Augrest 9, 1888.

This is to certify that five thonsaud and fifty-two $(5,052)$ fur-seal skins have this day been shipped on board the Alaska Commercial Company's steaner St. Poul, commanded by M. C. Erskin. 
ISt,AND OF ST. PAUL,

Bering Sea, Alaska, August $9,1888$.

This is to certify that righty-five thousand $(\$ 5,000)$ fur-seal skins have this day been shipped on board the Alaska Commeresal Company's steamer St. I'aul, whereof M. C. Erskin is master.

\author{
M. C. Ensizn. \\ GEO. R. TINGLE, \\ Treasury Agent.
}

\title{
Treasury Departinent, Office of the Secretary, Washington, D. C., September 27, 1888.
}

Sik: In complianco with the request contained in your letter of the 24 th instant, I inclose herewith Senate Document No. 31, containing the report of Special Agent George R. Tingle, relative to the administration of the fur-seal islands of Alaska for the year 1887, and also a copy of said officer's report dated July 31, 1885, and documents accompanying the same.

Respectfully, yours,

\section{Hon. Poindexter Dunn,}

Chairman Committee of Merchant Marine and Fisheries, House of Representatives.

\section{H. MAYNARD, Assistant Secretary.}

[Senate Ex. Doc. No. 31, Fiftieth Congress, first session.]

Letter from the Secretary of the Treasury, transmitting, in response to Senate resolution of December 13, 1587, Spccial Agent Tingle's report on the conduct of affairs in the seal islands of Alaska.

Treasury Departalent, December 16, $188 \%$.

Sir : In compliauce with the Senate resolution of the 13 th instant, 1 have the honor to inclose herewith copy of Special Agent George R. Tinglu's report, dated July 31, 1887, upon the condition of affairs in the seal islands of Alaska.

Respectfully, yours,

C. S. FAIRCHILD,

Secretary.

Hon. J. J. Ingalis,

President pro tempore, United States Senate.

\section{Office of Special Agent Treasury Department,}

\section{St. Paul Island, Alaska, July 31, 1887.}

Sin: I have the honor to transmit herewith my report for the year ending July 31 , 1887, with the steamers' receipts for 100,000 seal skins shipped

Statement A, inclosed, shows the daily killing of seals for food and by the lessees; Statement B, the killing on both islands consolidated. It is very gratifying to be able to report almost no loss from seals perishing on the drives; men are sent to follow up the seals and skin such as perish, and bring the skins to the salt-houses.

The loss in clubbing is also insignificant.

'This result is owing to greater care being exereised by the natives and lessees' men in handling the immense droves of seals, aud the saving in clubling small seals, which appear as rejected in the statement, is mainly owing to the presence on the field of the Treasnry agrent and the personal superintendence and strict orilers of the lessees' general agent, who reguires of his men the greatest care in killiner, so that nono but acceptable seal skins are taken; indeed, the unuecessary slanghter of seals whose skins are not merchantable is a thing of the past, as a comparison of this season's statement with former years will show.

The ice hume around St. Paul Island until the 1.3 th of IIay, the weatlue being very cold, which no doubt was the cause of the light supply of killable seals tirst part of June. By the 20th of the month they lambel in as great mumbers as usual. and more than conld be handled each day hy the deplested force of natives cntitled to participate in the work of skinning or sealing. No difliculty was experienced by the lessees 
in securing their quota of fine skins in thirty-nine working days-an average of 2,564 per day.

The time has come when in my judgment the lessees should be authorizer by tho Secretary of the Treasury to employ additional natives, and teach them the business of sealing in all its branches, as death has played sad havoc with the sealers of the islands, as shown by a statement I herewith inclose, marked C, compiled from the records by the Alaska Commercial Company's general agent, Dr. H. H. MeIntyre. From this list you will see the mortality among the men since 1870 has been fearful, aisd the smallness of the effective force of able men and boys in 1887 to do the work of taking 85,000 seal skins on St. Panl Island during the time allowed by law is insufficient. Were it not for the fact that one-half the work pertaining to the taking, salting, bundling, ete., of the skins is done by Oonalaska natives, brought up by the lessees for the sealing season and returned to their homes at the close of the season's business, and eight white men, employés of the lessees, the work would not be done on St. Paul Island without eontinuing the killiug in the fall. About forty natives of Oonalaska, the same tribe of people who inhabit the fur-seal islands, are brought annually to the islands and paid by the lessees for salting, booking, bundling, etc., in order to advance the work.

The islaud natives receiving the full sum of 40 cents per skin; it would be entirely just to take this extra expense from the sum total of the native fund and distribute the remaincler to the sealers, as the work performed by the extra help is a part of the duty imposed on the island natives under the eontract and in consideration of the 40 cents per skin paid them. Experience has demonstrated that the system of payment to the natives is not the best for their own interest, for the reason that when the season's sealing ends, and they each get their proportion of the community fund entered up to their credit in their pass-books, they feel the year's work is ended. If called upon to work on a road over which they travel and wheel their water, meat, and fuel, or asked to launch a boat to board the vessel in the spring, they are paid by the bour; or when called out by the Treasury arent in the spring to clean up the filth they have accumulated during the winter round their houses they are paid for their labor. They earn their year's salary or pay in six wceks, and for the remainder of the year feel they are free. If called on to do any work, even though it may be as much for the benefit of the natives as the lessees, they must be paid by the hour for it. The system of payment by the piece or skin was adopted immediately after the transfer of the comntry as an iuducement for the natives to secure the skins, rival companies occupying the islands sealing at the time. In my opinion it is not the best way to compensate the island natives, and is very nujust to their brothers who are hrought from Oonalaska to help them. The average pay of the St. Paul native sealer this year is a little over $\$ 500$, whilst the Oonalaskans receive on an average $\$ 80$ each. This small sum is the main support of their families for the year, whilst the St. Paul man has, besides his $\$ 500$ cash, all the fresh seal meat he can eat, and salt, fuel, tish, house, medicines, physician, and schooling free.

It would be a simple act of justice to place the natives of Oonalaska employed to assist in sealing on the same footing with the St. Paul natives in the distribution of the sum earned, as one set of men are just as essential to the work as the other. I would suggest as a much better plan the payment of a sum equal to 40 cents per skin divided into amnual salaries in proportion to the value of each man and boy's labor, payable weekly or mathly, with the understanding that in consideration of this salary their time and labor was subject to the orders of the lessees and Treasury agents at any and all times. For nine months or more every year the lessees have nothing for them to do, but the system of payment, as suggested, I am sure would prove more beneficial to the natives, and make no difference whatever to the lessees, except it would subject the natives to their orders at all times for any work necessary to be done.

I would respectfully recommend that any additional force of natives you may see proper to authorize to assist in sealing be paid by the year and not by the skin, and such sum so paid be deducted from the community funds of 40 cents per shin before the division is male, and the remainder divided as heretofore among the old sealers, provided that none of the lessee's agents or white employés are paid out of th9 native funds. It is evident the rapid decrease of native adult males on the islands will necessitate an increase in the outside force of natives, or the quota of 100,000 skins per anuum can not be taker.

The Oonalaskan is paid $b y$ the lessees for doing the work which under tneir contract the islanders are bound to do, and whilst the wages paid them by the Alaska Commercial Company ( $\$ 40$ per month) is very good, the time employed (two months) is very short, lasting only through the killung season.

In view of the facts stated, it would seem but just that some more equitable division of the funds be made among those natives who do the work, as they are all of one trive, the fur-seal islands having been first peopled a hundred years ago by transplanting Aleuts from Donalaska, 
The condition of the natives on the two islands is tquite as good as nsual after a long winter of idleness, duriug which time they shut themselves up in their close houses, withont permitting any ventilation whatever, keeping the lonse warmed np to an unhealthy temperature, taking only such outdoor exereise as is required of them in attendance on their church service, emerging in the spring in time to clean up and prepare for the arrival of the vessel. When it is damp and cold they are as imprudent and careless as during the winter, consernently take cold easily, resulting in many cases fatally. Brouchitis and pueumonia are the spring diseases. This year has been an unusually fatal one, there having been 17 deaths in June and up to 1isth of July. When ouce an Aleut makes up his mind to die, having no recuperative fowers, he baffles the skill of the physician and calmly awaits the inevitable. IVith proper care they would be nuch longer lived, as there is nothing in the climate or sanitary condition of the islands to invite disease.

The white population on both islands, some of whom have remained continuonsly for five years, are always remarkably healthy. It is a notable fact that not a single death from disease has occurred among them since the transfer of Alaska to the United States, whilst the percentage of mortality among the natives is much greater than can be found in any State or country of which we have statistics. It is only a question of time when the Aleuts will become extinct.

The census taken Jauuary 1, 1887, is as follows:

\section{St. Paul Island.}

Number of families

Male adults......................................................

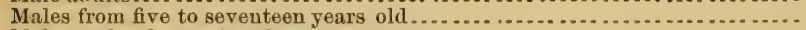

Males under five years of age......................................... 17

Female adults........................................ $7_{9}$

Females from five to seventeen years old .............................. 42

Females under five years old ......................................... 20

Total native population .................................. $\frac{138}{237}$

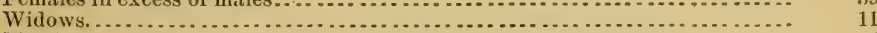

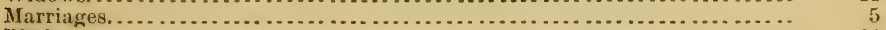

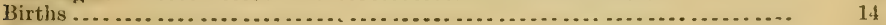

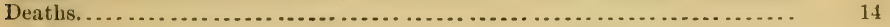

NotE.-Seventeen deaths from 1st of June to 12th of July, including five sealers. almost 7 per cent. in forty-two days.

St. George Island.

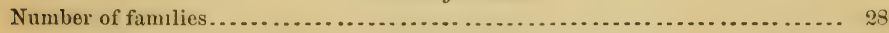

Male adults.................................................. 29

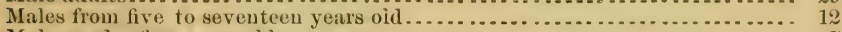

Males under five years olik..................................... 7

Female arlults ............................................. 40

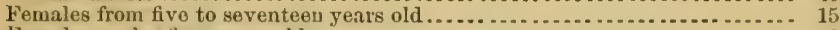

Females under five years old ............................................ 9

Total native population ....................................... $\overline{112}$

Yemales in excess of males........................................

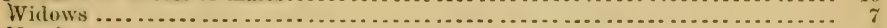

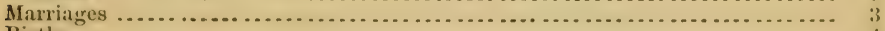

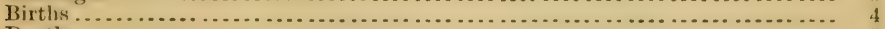

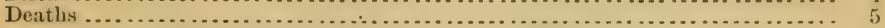

Note.-One death since June 1.

The cause of the excess of females on the islamis is owing to a regulation of the Greek Church which forbids the marriage of parties where the most distant relationship exists; it even extends to the relatives of the contraeting parties' focl-nuthers and god-fathers. This absurd obstacle makes it almost out of the question for resi- 
dents of the island to marry. The priest controls all marriages; his permussion is absolutely reouired before it marriage can take place. This rule of the church forces the men to go to Oonalaska or other islands for wives, and every year pilgrimages are made for that purpose. 'The priest first being applied to tells the wife-seeker whom he may marry. Whilst accessions of females are made to the population in this way, no adult males are allowed to come from other islands and becone citizens of the fur-seal islands without special permission of the Secretary of the Treasury. The usual eight months' school was conducted on both islands with about the usual results; 25 ehildren attended on St. George and 55 on St. Paul. The native children are stupidly dull, aud not encouraged by their parents to learn English. They wonld not send a child to school if not compelled by the Treasury agent to do so. The teachers on both islauds do their dity faithfully, but their work is not appreciated or rewarded with vèry brilliant results.

\section{THE BREEDING ROOKERIES.}

As I was unable to accompany my report of last year with a statement showing the number of seals on the breeding roolsertes of St. George Island, I made arrangements with acting assistant Treasury agent, Dr. L. A. Noyes, in charge, to make a complete measurement of all the rookeries on the island, which ho did, and the result is hero given :

Measurement of breeding rookeries by Dr. L. A. Noyes, actin! assistant Treasury agent, on St. George Island, January, 4, March 1, and April 22, 1887.

\begin{tabular}{|c|c|c|c|c|}
\hline Name of rookery. & Sea margin. & | Depth. & Square feet. & Seals. \\
\hline $\begin{array}{l}\text { East } \\
\text { Zapadni } \\
\text { Littlo East } \\
\text { Starry A teel } \\
\text { Near and North }\end{array}$ & $\begin{array}{r}2,200 \\
2,100 \\
600 \\
900 \\
3,500\end{array}$ & $\begin{array}{l}200 \\
160 \\
125 \\
575 \\
300\end{array}$ & $\begin{array}{r}440,000 \\
336,000 \\
75,000 \\
517,500 \\
1,050,000\end{array}$ & $\begin{array}{r}220,000 \\
168,000 \\
37,500 \\
258,750 \\
525,000\end{array}$ \\
\hline Total ........... & 9,300 & ......... & $2,418,500$ & $1,209,250$ \\
\hline
\end{tabular}

RECAPITULATION.-(Serenteen rookeries.)

St. Paul Island, 1886

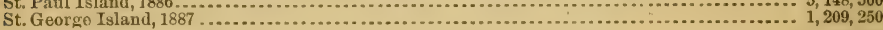

Grand total of breeding seals only

$6,357, \overline{750}$

NorE.-I think that a deduction of one-fourth from the above would show more nearly correct the true number of seals on the islands. In my judgment Mr. Elliot does not allow them space enough.

The breeding grounds on St. George Island, surveyed July 12 and 15, 1873, gave the following figures (H. W. Elliot's "Condition of Affairs in Alaska, 1874," page 78):

\begin{tabular}{|c|c|c|c|c|}
\hline Name of rookery. & $\begin{array}{c}\text { Sea } \\
\text { margin. }\end{array}$ & Depth. & $\begin{array}{c}\text { Square } \\
\text { feet. }\end{array}$ & Seals. \\
\hline 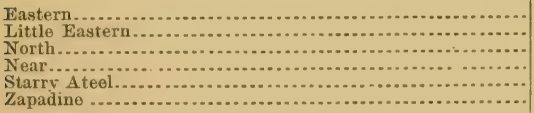 & $\begin{array}{r}900 \\
750 \\
2,000 \\
750 \\
500 \\
600\end{array}$ & $\begin{array}{r}60 \\
40 \\
25 \\
150 \\
125 \\
60\end{array}$ & $\begin{array}{r}54,000 \\
30,000 \\
50,000 \\
112,500 \\
62,500 \\
36,000\end{array}$ & $\begin{array}{l}27,000 \\
15,000 \\
25,000 \\
56,250 \\
31,250 \\
18,000\end{array}$ \\
\hline 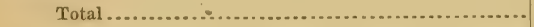 & 5,500 & 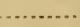 & 345,000 & 172,500 \\
\hline
\end{tabular}

The information furnished by the estimates of seal life are very valuable, though of course not absolutely correct.

The measurement on St. George Island is undoubtedly as near correct as it is possible to make it, and differing so wislely from the estimate made by Mr. H. W. Ellint, July 1: and 15, 187:3, I am forced to conclude that that gentleman, so uniformly correct in his voluminous and interesting history of the fur seal and his home, has mate a creat mistake somehow in his work of measuring the rookeries at that time. It is quite evident such is the case, as the number of seals he makes on the breeding rookeries, viz, 172,500, is out of all proportion to the number of males lilled in 1072 and 
1873, boing 25,000 each year, whilst on St. Paul Islaud, with $3,030,250$ seals on tho rookeries, only 75,000 males were taken each year, or three times as many as were taken on St. George; while St. Paul, accorling to Mr. Elliot, had eighteen times as many seals on the rookeries. For 1879, 1880, aud 1881, 20,000 were taken annually on St. George. Since that time the lessees have not been able to take conveniently more thau 15,000 awumally, notwithstanding tho rookeries have received largo accessions of eows and bulls each year since 1873, and now havo seven times the number estimated by Mr. Elliot to have heen there when they took 25,000 seals. 'The number of seals at present shown to be on the breeding rookeries of the two islauds is as follows:

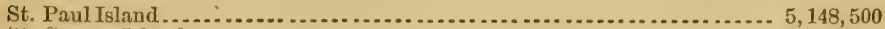

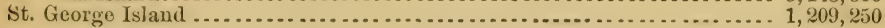

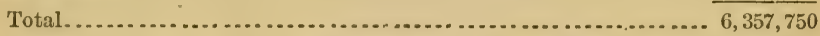

The young male seals haul out separately from breeders, and no estimate of their number's has ever been male or attempted, so far as I know. It is certain one-half the pups born are males, and that pups equal to 90 per cent. of cows on the rookeries go into the water, that is, exelusive of the joung cows which come upon the rookeries for the first time to meet the males. The estimated loss of 10 per cent. is caused by bulls in preserving rigid discipline, and administering necessary correction in the management of their domestic affairs. Their idea of a female's duty does not admit of any little indiscretions, and at the slightest sign of deviation, regardless of consequences, they quickly pounce upon the offendiug female and shake her by the neck. A number of pups are also lost by being washed off the rocks by the surf and drowned, before they have learned to swim. Fully one-half the pups which go to sea in the fall return as yearlings the following spriug, the absent ones having furnished food for their natural enemies in the water. As they grow older the percentage of loss by this cause decreases largely. I have made frequent and close inspections of the rookeries this year, and find the lines of oceupancy extended beyond those of last year, and the cows quite as densely packed on the ground on most of the rookeries. Whilst on two rookeries there is some falling off, it is certain, however, this vast number of animals so valuable to tho Government are still on the increase. The condition of all the rookeries could not be better, and the seals, undisturbed when ashore, seem to take great comfort ont of their season of rest, after a long winter voyage at sea. The Department can not place too high an estimate on the valne of this seal property, and the Govermment, I am sure, will not yield to any demands which would make it possible to accomplish the destruction of her seal rookeries and seal life, which, unler judicious management, and protected by law, may be perpetuated indefinitely.

\section{THE MARAUDERS.}

Last fall, after the steamer had departed for San Francisco, a number of maranding schooners were sighted from St. Panl Island. One, a steam sehooner, laid off the reef rookery several days from 8th of August, with boats down killing seals in tho water. Owing to the distance from laud (though in full view) and the uncertainty of the weather it was not deemed safe by Captain Loud, assistant Treasury agent in charge, to go out to her in small boats. She was rewarded by securing a cargo of 4,300 seal skins for her British owners, which were delivered and sold in Victoria.

Had Captain Abboy, with the rovenue-cutter Corvin, eruised around the seal islands until Aurnst 15, he no doubt would have captured several valuable prizes, which escaped with large catches of seal, owing to the absence of the cutter.

On St. George Island, in charge of actiug assistant Treasury agent Dr. L. A. Noyes, soon after the departure of the entter, a schooner was sighted. She sent her men in small boats direct to a rookery to kill seals. Under orders from Dr. Noyes, the natives watehing the rookery fired on the men as they landed, causing them to retreat to their boats and pull for their vessel. Two of the men were wounded, according to their own admission-one shot through the arm and the other in the foot. This warm reception aud impressive lesson was not without beneficial results, as it became grenorally known last fall and winter among the profession, and may serve to keep them a safe distance from the shore-line of the rookeries this season.

I understam the captains of British vessels had great difticulty this siring shipping their crems of Indian sealers, owing to the few eaptures of last year. A ther their experience of this season I am quite sure British Columbia Iudians will be hard to secure for Bering Sea sealing in the future.

So far this season four schooners have been operating around this island, at times within a mile or two of the land, their ritle shots being distunetly heard from the shore, a dense fog concealing the ressel from view. One schooner remained around North East River from 15 th imstant to $26 \mathrm{th}$, then camo down near the village. On 
the 28 th instant, at :3 p. wu., I sighted her near Otter Island, elose to the Iand. The Alaska Commereial Company's steamer st. Paul having arrived early the same morning, I, in company with their general agent, McIntyre, their physician, Dr. W. S. Hereford, and Captain Loud, assistant Treasury agent, boarded the steamer St. Paul. At iny earuest request her captain, M. E. Erskin, got under way and followed the schooner, which was then standing away from us; she changed her course suddenly and stoud directly for the steamer. When near enough to see with the glass we diseovered she was in distress, 11 yiug the Ameriean tlisg, Union down. When we came up to her she proved to be the schooner Angel Dolly, of San Francisco. I hailed her from the bridge of the steamer and was answered by the men on the schooner with calls for help, saying the captain was shot and dying, and one man wounded. I directed Capt. A. P. Loud, assistant 'Treasury agent, and an experienced navigator, to board the schooner in the boat towing astern of the steamer with the native crew, which he did, Dr. H. H. Mclntyre and Dr. Hereford accompanying him. A high cross sea with strong northwest wind made it dangerous to get to the vessel, which was at the wercy of the elements. All got safely on board, and Captain Lond took command of the schooner and bronght her to smooth auchorage east side of St. Paul Island, where I boarded her a few minutes after she anchored. Captain Loud was in charge with the revenue flag flying, he having seized the schooner and cargo for violation of section 1956 Revised Statutes.

The captmed schooner, Capt. Alfred N. Tulles, with three of his men, had been on Otter Islaud, 5 miles from St. Paul Islaud, during the aftermoon and killed four fur seals on the land. Returning to his vessel he picked up a ritle on the house of his calin and drew it towards him, when the hammer of the gun caught, discharging the contents through the body of the captain, killing him and wounding Joseph Spooner, one of the crew, who was at the wheel, behind the captain; the crew all agreeing in their statements to me that the firing of the gun in the hands of the captain was acciclental.

I had the body of Captain Tulles moved on shore, the Alaska Commercial Company's physician taking charge. The funeral took place the following day, Rev. Father Weschtomoff officiating. Joseph Spooner, the wounded man, was taken on the islaud and made comfortable in one of the company's houses, with one of his shipmates to attend him, and is doing well. I sent the schooner to Oonalaska, in command of Capt. Paul Porlofi, at an expense of \$25, which sum the agent of the Alaska Commercial Compauy paid him on my order; the captured crew remaining on the schooner to Oonalaski, where they are to be taken on board the steamer St. Paul for San Francisco at my request.

The sehooner Angel Dolly had on board 178 fur seals, 125 of them cow seals. At Oonalaska I turned over the schooner, cargo, and papers to Capt. L. D. Sheppard, of the United States revenne-cutter Rush; also furnished him with depositions of Capt. A. P. Loud, seiziug officer for the Government, aud the erew of the seized schooner, together with a full statement of the case by me, directerl to the United States district attoruey, Sitka, which will obviate the necessity of our going to Sitka. This makes the seventh eapture so far this season, the cutter Rush having taken six and sent them to Sitka for trial. Their cargoes of seal skins stored inere number 2,532, as follows:

Captured by Rush.

Skins.

American schooner Challenge, with ................................... 151

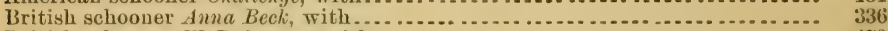

British schooner W. P. Sawyer, with................................... 479

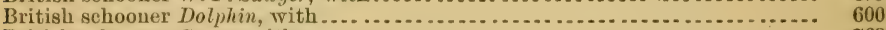

British sehooner Grace, with ........................................ 769

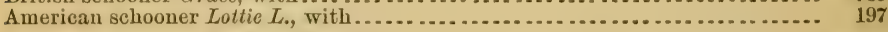

$2,53 i$

The Department's attention is respectfully called to the operations of the cutter Rush, Capt. L. D. Sheppard, sent to protect the seal islauds and seal life this season. He has been indefatigable in his efforts and will no doubt add at least six more to the list of his eaptures before he leaves the waters, as there are at this time double that number of schvoners aronud the islauds. The British schoouer Dolphin had on board a very large lot of fine rifles and a ton of fixed ammunition. Her commauder, J. D. Warren, hat five ressels sealing; four of them are among the captured. He is one of the defiant Britishers who hals no regard for the laws of the United States Government. While the Rush was busy taking care of the marauders around St. George, threo schooners were killing seals near St. Paul, frequently in sight but beyond the reach of the Treasury agent, as we have no facilities for going out to sea so far to board vessels. What we should have on St. Paul Island is a 20 -ton steam-yacht, to draw uot over 5 feet of water, provided with one small rifled grun. Such a steamer we could run up in the lagoon at the village for good harbor, where she would be per- 
fectly safe against all kinds of weather. There is always an engineer on the island competent to rum a small stemer, and natives for erew always at haud, willing to serve the Treasury agent when called on. In this way it would not cost the Government a dollar to run the yacht. She could cruise all around the island doing the work of a cutter without auy expense for erew. It is impossible for one cutter to guard the two islands successfully-as, for example, the Riush left this island the night of the 15th instant, and had not returned when we left ou August 3, at 8 p. m. She had all she could do around st. George and to the eastward. During her absence three sehooners operating at Saint Paul's must have secured large captures of seals. For the next wonth I have no doubt the marauders will concentrate near the islands. If the conclition of the cutter Bear, on her return from the Aretic, will admit of it, Captain Healey will remain at the islands nutil the sea is cleared of the sealing vessels. The Bear was leaking badly when I boarded her at St. Paul, on her way north, and, indeed, the captain thought he would have to return from St. Michaels and proceed direct to Sau Fraucisco. If such should prove to be the ease, Captain Sheppara will have more than he ean do during the month of August.

I desire to say in behalf of a faithful officer, that Captain Sheppard has displayed commendable zeal in the execution of his orders, and will make a record of seizures this season which will demoralize the marauding business.

\section{DESTRUCTION OF SEALS.}

I am now convinced from what I gather, in questioning the men belonging to captured schooners and from reading the logs of the vessels, that not more than one seal in ten killed and mortally wounded is landed on the boats aud skinned ; thus you will see the wantou destruction of seal life without any benefit whatever. I think 30,000 skins taken this year by the marauders is a low estimate on this basis; 300,000 fur seals were killed to secure that number, or three times as many as the Alaska Commercial Company are allowed by law to kill. You can readily see that this great slanghter of seals will in a few years make it impossible for 100,000 skins to be taken on the islands by the lessees. I earnestly hope more vigorous measures will be adopted by the Governnent in dealing with these destructive law-breakers.

Dr. L. A. Noyes, left last fall as aeting assistant Treasury agent on Saint George Islaud in place of J. P. Manchester, who returned on account of sickness in his fam$11 y$, performed the duties of the office faithfully until relieved May 30, 1887, by the return of Mr. Manchester. Dr. Noyes should be paid for the time he served the Goverument. If there is no fund out of which he can be compensated, I respectfully ask to recommend the passage of a bill for his relief" or include it in the "civil sundry bill" in accordance with his account rendered.

I left St. Georgo Island in charge of Assistant Treasury Agent William Gavitt, having fully instructed him in regard to his duties. Mr. J.P. Manchester, assistant Treasury agrent, is in charge of St. Paul Island, with full instructions; Captain A. P. Lond, assistant Treasury agent, and myself return by the steamer St. Paul to San Francisco, from which place we will report by telegraph and await your further orders.

\section{Hon. C. S. FaIrCHild,}

Geo. R. TIngle, Treasury dgent.

Secretary of the Treasury, Washington, D, C.

\section{Supplemental report.}

San Francisco, August 19, 1887.

SIR: We arrived from the islands Oonalaska August 5 ; the cutter Rush came in the same day, leaving early the morning of the 6th for the fur-seal islands. On the 17th the Americau schooner Anna, with 380 seal skins, was brought into port by a cutter officer, having been seized by Captain Sheppard. She reported the seizure of the British schooners Mary Ellen, 395 skins, and Alfred Adams, 1,400. The cutter also towk 400 skins landed on an island by the British schooler Lottie Fairfield, in the Bering Sea. This makes a total of 5,300 seal skins seized.

I can uot too highly commend Capt. L. D. Sheppard for the energy and correct business mothods he has displayed in the execution of his orders.

The owners of the Ingel Dolly, seized by me, told me last night they inteuded to make a fight before the court; lint they, least of all, have any grounds of defense, as they were on Otter Island killing seals when sighted by me.

I.am, very respectully,

George R. Tingle, Treasury Agent.

Hon. C. S. FAmcirild, Secretary of the Treasury, Washington, D. C. 
C.

Roll of natives of St. P'aul Island who shared in the seal catch of $18 \% 0$.

[Annotated July 1, 1887.]

\begin{tabular}{|c|c|c|}
\hline No. & Name. & Remarks. \\
\hline 1 & Artamanoff, Keriek. & Healthy, but getting oldi. \\
\hline $\begin{array}{l}2 \\
3\end{array}$ & Artamanott, Herman. & Dead. \\
\hline $\begin{array}{l}3 \\
4\end{array}$ & $\begin{array}{l}\text { Arkashotf, George .... } \\
\text { Anulenock, Eupheme. }\end{array}$ & $\begin{array}{l}\text { Dead. } \\
\text { Dearl. }\end{array}$ \\
\hline 5 & $\begin{array}{l}\text { Anulenock, Eupheme. } \\
\text { Avela, Marka.......... }\end{array}$ & $\begin{array}{l}\text { Deari. } \\
\text { Dearl. }\end{array}$ \\
\hline 6 & Butrin, Kerick.......... & Unable to do heary work. \\
\hline $\begin{array}{l}7 \\
8\end{array}$ & Butrin, Karp......... & Able man. \\
\hline $\begin{array}{l}8 \\
9\end{array}$ & $\begin{array}{l}\text { Bachotr, Michael } \\
\text { Bolockshin, Benedict (1st) }\end{array}$ & De:ul. \\
\hline 10 & $\begin{array}{l}\text { Bolockshin, Benedict (1st) } \ldots . \ldots \ldots \ldots . . \\
\text { Bolockshin, Benedict (2d) ............. }\end{array}$ & $\begin{array}{l}\text { Deall. } \\
\text { Dearl. }\end{array}$ \\
\hline 11 & $\begin{array}{l}\text { Bolockshin, Benedict (2d) ............... } \\
\text { Bezazihoff,'Joseph ................... }\end{array}$ & Healthy, but getting old. \\
\hline 12 & Bezazitioff, Yorlampia & Dearl. \\
\hline 13 & Belaglazotf, Stephen .. & Dead. \\
\hline $\begin{array}{l}14 \\
15\end{array}$ & $\begin{array}{l}\text { Evanoff, John } \\
\text { Evanoff, Tomothy...... }\end{array}$ & $\begin{array}{l}\text { Dead. } \\
\text { Dead. }\end{array}$ \\
\hline 16 & $\begin{array}{l}\text { Evanoff,' Tomothy .... } \\
\text { Evanoff, Gabriel...... }\end{array}$ & $\begin{array}{l}\text { Dead. } \\
\text { Dead. }\end{array}$ \\
\hline 17 & Glotoff, Timothy ..... & Dead. \\
\hline 18 & Hopoff, John, sr ...... & Dead. \\
\hline 19 & Kotchutin, Mark .... & Dead. \\
\hline $\begin{array}{l}20 \\
21\end{array}$ & Kotchutin, Eupheme .. & Not able to do heary work. \\
\hline $\begin{array}{l}21 \\
22\end{array}$ & $\begin{array}{l}\text { Kotchutin, John........ } \\
\text { Kotchutin, George .... }\end{array}$ & $\begin{array}{l}\text { Dead. } \\
\text { Able man. }\end{array}$ \\
\hline 23 & Kotehutin, Jacob...... & Able man. \\
\hline 24 & Krukoff, Stephen..... & Deac. \\
\hline $\begin{array}{l}25 \\
26\end{array}$ & Krukoff, Peter & Able man. \\
\hline $\begin{array}{l}26 \\
27\end{array}$ & $\begin{array}{l}\text { Kusbin, Yermoli } \ldots . . . \\
\text { Kotehurgin, Gabriel.. }\end{array}$ & $\begin{array}{l}\text { Dearl. } \\
\text { Dead. }\end{array}$ \\
\hline 28 & Kozeroff, Mis hiael..... & $\begin{array}{l}\text { Dead. } \\
\text { Dead. }\end{array}$ \\
\hline 29 & Kuzuitzoff, Pentra... & A ble man. \\
\hline 30 & Kosloff, John ......... & Deart. \\
\hline $\begin{array}{l}31 \\
32\end{array}$ & Kematchnock, Plilip. & Deal. \\
\hline $\begin{array}{l}32 \\
33\end{array}$ & & Dearl. \\
\hline 34 & $\begin{array}{l}\text { Mandregin, Erackleo. } \\
\text { Mandregiu, John..... }\end{array}$ & $\begin{array}{l}\text { Dead. } \\
\text { Deatl. }\end{array}$ \\
\hline 35 & Mandregin, Jacob .... & Dead. \\
\hline $\begin{array}{l}36 \\
37\end{array}$ & Meseekin, Perry .... & Dead. \\
\hline 37 & Nenarazoff, Alex ..... & $\begin{array}{l}\text { A confirmed invalid, very old (sixty-six } \\
\text { years), oldest man on St. Paul Island. }\end{array}$ \\
\hline $\begin{array}{l}38 \\
39\end{array}$ & Nocack, Myron........ & Dead. \\
\hline $\begin{array}{l}39 \\
40\end{array}$ & $\begin{array}{l}\text { Paranchin, John..... } \\
\text { Pohomoff, Joseph... }\end{array}$ & Dead. \\
\hline 41 & $\begin{array}{l}\text { Pohomoff, Joseph..... } \\
\text { Pancoff, Alexander... }\end{array}$ & $\begin{array}{l}\text { Dead. } \\
\text { Dead. }\end{array}$ \\
\hline 42 & $\begin{array}{l}\text { Pancoff, Alexander ... } \\
\text { Peeshenkoff, Peter ... }\end{array}$ & $\begin{array}{l}\text { Dead. } \\
\text { Healthy, but getting old. }\end{array}$ \\
\hline 43 & Sedick, Zachar ........ & $\begin{array}{l}\text { Healthy, but getting old. } \\
\text { Dead. }\end{array}$ \\
\hline 44 & Sedick, Keer.......... & Dearl. \\
\hline $\begin{array}{l}45 \\
46\end{array}$ & Sedick, Theodore...... & A ble man. \\
\hline $\begin{array}{l}46 \\
47\end{array}$ & Sedick, Dennis ........ & Dead. \\
\hline $\begin{array}{l}47 \\
48\end{array}$ & $\begin{array}{l}\text { Sedick, Philip ........... } \\
\text { Suaroft, Paul ........... }\end{array}$ & $\begin{array}{l}\text { Dead. } \\
\text { Dead. }\end{array}$ \\
\hline 49 & Sntyagin, Antone..... & Dead. \\
\hline 50 & Sutyagin, John ........ & Dead. \\
\hline 51 & Sutyagin, Jacob........ & Deadi. \\
\hline 52 & Squartzott, Stephen........ & Dead, \\
\hline 53 & Shabolin, Cresar........... & Healthy, but feeble-minded and old. \\
\hline 54 & $\begin{array}{l}\text { Sedule, Vicele } \\
\text { Tarakanoff, Platon......... }\end{array}$ & Healthy, but getting old. \\
\hline $\begin{array}{l}55 \\
56\end{array}$ & $\begin{array}{l}\text { Tarakanoff, Platon .... } \\
\text { Tetoff, Philat......... }\end{array}$ & $\begin{array}{l}\text { Dead. } \\
\text { Ablo man. }\end{array}$ \\
\hline 57 & 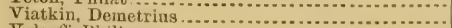 & $\begin{array}{l}\text { A } \\
\text { Dead. }\end{array}$ \\
\hline & 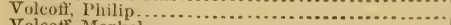 & Dead. \\
\hline 59 & 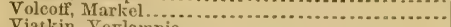 & Able man. \\
\hline $\begin{array}{l}60 \\
61\end{array}$ & 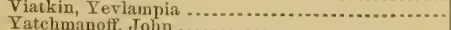 & A ble man. \\
\hline $\begin{array}{l}61 \\
62\end{array}$ & 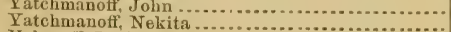 & $\begin{array}{l}\text { Able man. } \\
\text { Deart. }\end{array}$ \\
\hline 63 & 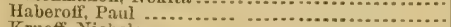 & Healthy, but not strong. \\
\hline 64 & 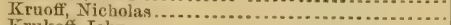 & A blo man. \\
\hline 65 & 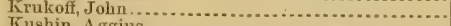 & Dead. \\
\hline $\begin{array}{l}66 \\
67\end{array}$ & 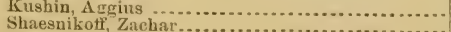 & Able man. \\
\hline 68 & 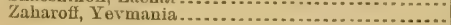 & $\begin{array}{l}\text { Dead. } \\
\text { Feeblo and worthless. }\end{array}$ \\
\hline
\end{tabular}

RECAPITULATION.

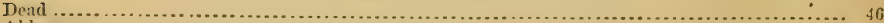

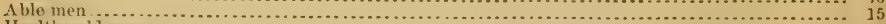

Healt hy old men . . .

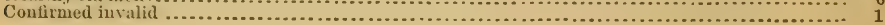


Additional names of those who share in the seal catch of 1887.

\begin{tabular}{|c|c|c|}
\hline No. & Name. & Remarks. \\
\hline 69 & Arkashoft, Arsenius . .. & Able boy, twenty years old. \\
\hline 70 & A ustagoft, Peter ....... & Able man. \\
\hline 71 & A kunsky, Dometay ... & Able man. \\
\hline 72 & Bordukottisky, A pollo.. & Ible man, from Oonalaska. \\
\hline 73 & Bogodanofi, Nicholas .. & Boy, fifteen years old. \\
\hline 74 & Emauoft, George........ & Alile boy, eighteen years old.' \\
\hline 75 & Fratis, John ......... & A ble mau, a Ladrone Islander. \\
\hline 76 & Gromoff, Nicholas... & Able man, from Oonalaska. \\
\hline 77 & Golkin, dkake...... & Dying of consumption. \\
\hline 78 & Golahteanoff, Alex. & Invalid boy, fitteen years old (Oonalaskan). \\
\hline $\begin{array}{r}79 \\
80\end{array}$ & Kopoff, John ....... & Able and stupid. \\
\hline $\begin{array}{l}80 \\
81\end{array}$ & Kotehutin, John ... & Boy, sixteen years old. \\
\hline $\begin{array}{l}81 \\
82\end{array}$ & Kozerotf, Stephen.. & A ble man. \\
\hline $\begin{array}{l}82 \\
83\end{array}$ & Kozeroff, traul ..... & Able man. \\
\hline $\begin{array}{l}83 \\
81\end{array}$ & Krukoff, Maximus ...... & Epileptic, unable to work. \\
\hline $8 t$ & Koshevnikoff, Eupheme & Able man, trom St. George. \\
\hline 85 & MIandregin, Neon ...... & Able man. \\
\hline 86 & Mandregin, Vicele........... & Boy, seventeen years old. \\
\hline $\begin{array}{l}87 \\
88\end{array}$ & Mollivedoffi, Simeon....... & An able boy, about twenty years old. \\
\hline 88 & Merculieff, Bosephay ... & Able wan. \\
\hline 89 & Nedarazotf, Martin..... & Abie man. \\
\hline 90 & Nedarazott, Stephen... & Able man. \\
\hline 91 & Paranchin, Daniel .... & Able man. \\
\hline 92 & Pancoff, Perfaria...... & A ble boy. \\
\hline 93 & 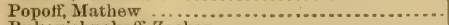 & Subject to aberration of mind. \\
\hline 91 & 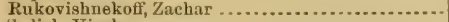 & Able man. \\
\hline 95 & Sedick, Vicele ............ & A ble man. Died July 11, 1887; pueumonia. \\
\hline 96 & Sutyagin, Metrophan .... & An invalid, feeble-minded boy. \\
\hline 97 & Shabolin, Necon ......... & An invalid, and feeble-minded. \\
\hline 98 & Stepetin, Elaria... & An able boy, about twenty years old. \\
\hline 99 & Stepetin, Dorofay. & A boy, about fifteen years old. \\
\hline 100 & Stepetin, Tarentia ........ & Able man (second chief). \\
\hline 101 & Shaposhnikoff, A gapius.. & A very stupid boy, tifteen years old. \\
\hline 102 & Tarakanoff, Kerick ....... & Able man. \\
\hline 103 & Tetoff, Peter............ & Able man. \\
\hline 104 & Tetotf, Neon ........ & A ble boy, sixteen years old. \\
\hline 105 & Mollivedoft, Antone..... & Able man (first chief). \\
\hline 106 & 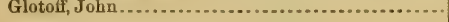 & A feeble boy. \\
\hline
\end{tabular}

\section{RECAPITULATION.}

Able men

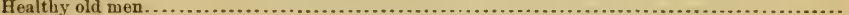

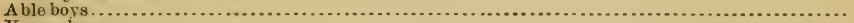

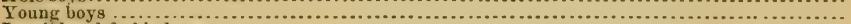

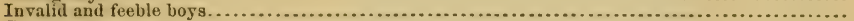

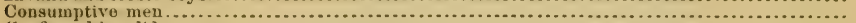

Confirmed invalid. . . . . . . . . . . . .

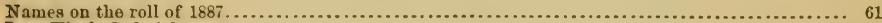

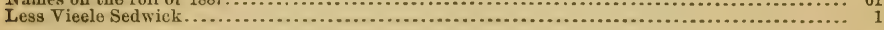

Nork.-These sixty-one natives do but little more than half the work of taking the skins and preparing them for shipment, the remainder being done by Americans and Ooualaskans, whose pay up to this time has not been deducted from the proceeds of the catch at 40 cents perskin, paid by tho Alaska Commercial Company to the community.

\section{U. S. Revenue Marine Steamer Bear,} San Francisco, December 20, 1888.

SIR : In pursuance of jour order of June 14, 1888, a court composed of Lieutenants Buhner, Dunwoody, Eugineer's Churehill and Hutchin, and Surgeon Bratton was convened at the Government house on St. George Islaud, to inquire into the nature of the charges preferred by Mr. William Gavitt, special agent of the Treasury for that island, against the Alaska Commercial Company and its agents, and we respectfully submit the following report:

We regard the charges in the main frivolons and of a meroly personal nature.

As regards the cbarges of a really serious nature, the evidence in suplort was not satisfactory, while no evidence in rebuttal was introduced. 
It appears to us that Mr. Gavitt had nursed his personal troubles and petty grievances, many of them no doubt imaginary, until he had wrought himself into a state of nervous irritability such as to render himself almost irrespousible, and we think that, under the circumstances, his charges do not merit serious consideration.

Very respectfully,

\section{A. Buhner,}

First Lieutenant.

F. M. DUNWOODY, Second Lieutenant.

A. L. Churchile, W. D. Bratton, Chief Engineer. Passed Assistant Surgeon M. H. S.

Capt. M. A. Healy, U. S. R. M., Commanding Revenue SteamerBear.

\section{Extract from the report of $A$. $P$. Swineford, governor of Alaska for 1887 , to the Secretary} of the Interior.

\section{CONDITION OF THE NATIVES.}

In southeastern Alaska the natives are largely employed by the white people in various kinds of work, and generally receive fair wages. They are not only a provident and self-sustaining people, but to a large extent ambitious of bettering their cundition by adopting civilized ways of living and providing for the education of their children. As fast as they can accumulate the means they tear down their old houses and build new ones of more modern style. One of these, recently completed by a native at Wrangell, is the finest and most pretentious private residence I have seen anywhere in the Territory. But for the chronic diseases prevalent among them, and for the eradication of which, in my opinion, some effective steps should be taken by the Government, they would be, generally, a happy, contented, and progressive people, not more than one or two generations distant from intelligent and useful citizenship.

1 regret very much the fact that I can not make a similar report concerning the condition of the native people in other parts of the Territory. The fur trade of Alaska is practically monopolized by the Alaska Commercial Company, a non-resident corporation, which does not confine its operations to the seal islauds leased to it by the Government, but holds and possesses most of the Aleutian chain and the greater part of the mainland as a principality of its own, over which it exercises undisputed sway and control. Clothed by the Government with a monopoly of the seal-fur trade, by which it has profited to the extent of many millions, it has, octopus-like, thrown out its great tentacles and gathered to itself about all there is of value in the fur trade of the whole Territory. It has, by the power of its great wealth, driven away all competition and reduced the uative population, wherever its operations are not supervised by Goverument officials, to a condition of helpless dependence, if not one of absolute and abject slavery. Unhampered by a healthy competition, it offers and compels acceptance by the natives, on pain of starvation, such beggarly prices for their peltry that it manages invariably to keep them in its debt and at its mercy. In order to more effectually monopolize the trade in furs, it at one time marked and mutilated the coin of the United States and refused to receive any other from the vatives in payment for goods necessary to their comfort and well-being. Its insatiable greed is such that it is not content with robbing the poor native in the price it sets upon the prodnet of his dangerous toil, but it robs him also in the exorbitant prices it exacts for the goods given in exchange. And there is no appeal; no alternative. There are no other trading stations in all that vast section, and the natives must pay the price asked and accept that which is offered-the first a hundred per cent. advanee on the amount at which the same goods are sold to the whites, and the last low enough to add still another hundred per cent. to the company's protit. As, for instance, there is no timber on the Alentian Islands, and the native who goes ont to hunt the sea-otter has no time to provide himself with fuel by gathering drift-wood from the shores, as many are able to do. He must have fnel for the winter, and the company generously takes his sea-otter skins at half their real cash value and pays him in coal at $\$ 40$ per ton-coal of the same quality as that which it sells to the fow white residents for $\$ 20$. The native who dares to seli his furs for eash to others than the agents of the company fuds that his money has no purchasing power at perhaps the only trading station within a distance of several hundred miles, and is thus starved into submission. 
While all this and much more is true concerning its treatment of the native people, iustances are not lacking where it has boyeotted and driven away from the islands Government officials who, intent upon the honest, faithful discharge of their duties, have incurred the displeasure or refused to do the bidding of its agents. In fact it possesses the power to compel compliance with its every exaction, and wherever it has obtained a foothold neither whiteman nor native can do more than eke ont a miserable existence, save by ita sufferance. Without mail communication other than that supplied by the corporation which is their master, the native people of the sections thus dominated are effectually walled in by the great waters which lie between them and the most advanced outskirts of trade and civilization, and in the absence of all competition are forced to sell their furs at whatever rates the agents of the company may be pleased to offer, and accept payment in goods at prices which no community of people not entirely belpless could or would telerate. Its paid agents and lobbyists are kept at the national capital to oppose any and every effort that may be made to pronote the welfare of Alaska through such legislation as will encourage immigration and the enlistment of capital in the development of the natural wealth hidden away in her forests, streams, and mountains; its every aim and effort is in the direction of prolonging its existence and strengthening its tyrannical hold by a blocking of the wheels of progress; and to its pernicious influence is due the fact that Alaska is not to-day largely populated avith an industrious, enterprising, prosperous people; that millions, where there are now only hundreds, have not long ere this been invested in the development of her many varied, and, as I bonestly bejieve, incomparably great uatural resuurces. I have positive information of flagrant violations of the law and executive orders in relation to the importation and sale of breechloading fire-arms by its agents; its oppression and robbery of the natives is notorious; the partial responsibility, at least, of the Government for the wrongs to which the inoffensive native people of the Aleutian Islands and the whole of northwestern Alaska have been and are still being subjected can not be ignored or denied.

If it can not legally be rescinded, the lease to and contract with this company ought not to be renewed. It is not, in my opinion, necessary to the preservation of seal life or the seal-fur industry that the islands on which the rookeries are located should be leased to any corporation or individual, but if it be held that I am wrong in that regard, then $I$ do not hesitate to aver that it would be better for Alaska, better for the Government, and, above all, far better for the enslaved Aleuts that every fur seal in Alaskan waters should be exterminated at one fell swoop than that such a blighting monopoly should be perpetuated. It is mauifestly the duty of the Government to protect the weak against the strong, to shield the poor and helpless from wrong and oppression; yet here we have thousands of the latter class, who by solemn treaty stipulation, were guarantied enjoyment of "all the rights, advantages, and immunities of citizens of the United States," practically enslaved, and a professedly free and liberal Government not only creating but actually protecting their oppressions, and that, too, against a restless spirit of enterprise which, unhindered, wonld people the best portions of Alaska with a thrifty population, and add untold millions to the wealth of the nation.

I have said that the leasing of the seal islanils is not necessary to the preservation of the industry; neither is it, as so persistently claimed, and as I was at first inclined to believe, essential that a fur-seal monopoly shonld be maintained in order to secure the largest revenue to the Government. Manifestly, the natives of the seal and adjoining islands have the first and best right to profit by an industry which may truly be said to have come to them by inheritance. They are not Indians, but a peacefui, bonest people of mueh uatural intelligence, and capable of transacting business for themselves. They cau nearly all read and write in their own or the Russian language, and if most of the younger mev and women on St. Panl and St. George are not fairly well educated? in Engrlish, the fact ean only be accounted for on the theory that the Alaskan Commercial Compauy has not complied faithfully with that provision of its contract which requires it to maintain schools on those islands for at least eight months in each year.

Instead of practically enslaving them by farming out to others that which is theirs by right of inheritance, it seems to me that the Government should secure to them at least a fair share of the profits, and that its duty is to protect and, if possible, perpetuate the seal fisheries for their benefit, and not in the almost exclusive interest of organized greed and corporate monopoly. To accomplish this it is ouly necessary that regulations be promulgated by the proper department prohibiting the killing of seals on the islands of St. Panl and St. George ly any but natives, preseribing the number that may bo killed each year, the mode of killing, and imposing all the other restrictions now in force. It would require no greater number of agents to supervise the killing hy natives thau are now employed to wateh and guard the interests of the Government, if as many. The skins could then be sold in open market by the natives themselves, in the presence of, or by a fovernment agent aeting in their behalf, and whose duty it should bo made to collect from purchasers a Government tax of not less 
than $\$ 5$ on each sikin sold. By such plan a much larger permanent revenue would be assured to the Government, the uatives secured in the free enjoyment of their rights, and a monopoly wholly inimical to the best interests of the Territory shorn of a large part of its tyrannical power. Conceived (as there is abundant evidence to show) in corruption, born in iniquity, and nurtured and grown strong and insolent on ill-gotten gaius wrung from a hapless aud helpless people, this giant monopoly, which rests like $a$ blighting curse upon the progress and welfare of this great Territory, should be shorn of its corruptly secured, much-abused franchise with no more delay than may be absolutely necessary.

The mortality rate as compared to the number of births furnished me by the authorities of the Greco-Russian Church iudicates the gradual extinction of the native people, particularly the Aleuts on Oonalaska Island, the population of which was 1,065 in 1082 ; 326 deaths have since been recorded, while there have been only 158 births. During the past summer an epidemic carried off a larger number of people at Belkofsky and on the Shumagin Islands; a very heavy rate of mortality is also reported from Kenai and Bristol Bay, occasioned by pulmonary diseases to which the natives, owing to exposure and want of proper precaution, are generally subject. In my opinion, if some effective measures are not taken to ameliorate their condition the complete extinction of the native inbabitants of the Alentian Islands and on some parts of the main-land will be a question of comparatively short time only. A removal of the disabilities imposed by the grinding monopoly which has destroyed their every ambition, and made them reckless of lives scarcely worth the living, would give them new bope, and tend to an indefinite prolongation of their existence as a people. The civil government is powerless in the prewises, having as yet been uuable by reason of the absence of mail communicatiou or means of transportation, to extend to them the poor protection of its qualified, limited, and altogether doubtful authority. To a higher governmental power, one they do not know in their present deplorable condition of abject dependence how to reach, and if they did would not dare appeal to, must they look for redress of wrongs which would not for so long a time have been quietly en. dured by any people anywhere in the slightest degree less patient and helpless.

\section{DEPARTMENT OF THE INTERIOR, EXeCUTIVE OFFICE, Sitka, Alaska, November 12, 1888.}

SIR : I most sincerely hope the investigation your committee has been making into the affairs of the Alaska Commercial Company has not been closed upon such evidence as you have been able to obtain, holding your sessions in Washington. I have lately returned from a protracted trip through the large section of country dominated by that corporation, and was not aware until my return that an investigation was in progress. I do not know what witnesses have been called or examined, but am perfectly well satisfied that you can not possibly have elicited the truth from such evidence as is within reach from Washington.

During the past summer I visiter nearly all the stations of that company on the Aleutian Islands, on the Pribylov Islands and the main-land, and can only say that nearly everywhero $I$ found abundant evidence to prove every assertion made by me against it in my official reports to the Secretary of the Interior and to Congress. These witnesses, and their name is legion, could not possibly lave been called to testify before your conmittee, since it is impossible that they could have responded to subponas, even had their names been known to you and such process been served upon them, owing to the great distance at which they reside from Washingtou and the utter absence of any mail communication or means of transportation save that supplied by the company itself.

It is not likely that $I$ will be able to visit Washington the coming winter. Were I there, however, and the case not closed, I would not hesitate about giving my statement under oath, especially could I have my ofticial interpreter with me who assisted in obtaining the facts. If ilesired, I will forward the names of ten or a dozen persons who will testify under oath to the truth of the charges I have made; but, iu iny opinion, a subeommitte ought to visit the scene of the company's operations in order nake a complete and thorough investigation, and if it could get by San Francisco in cog. its inquiries might be more effectively made.

Very respectfully,

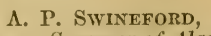
Governor of Alaska.

Hon. Porndexter DunN,

Chairman Committee on Merchant Marine and Fisheries, House of Representatives, Washington, D.C. 
TEPLY OF THE ALASTA COMMERCIAL COMPANY TO THE CHIRGES OF GOVERNOR ALFRED $P$. SWINEFORD, OF ALASFA, AGAINST THE COMPANY IN HIS ANNUAL REPORT FOR THE YEAR 1887.

San Francisco, December 13, 1887.

Hon. C. S. FAIRCHILD,

Secretary of the Treasury, Washington, D. C.:

Sir: By section 5 of the act of Congress of May 17, 1884, "providing a civil government for Alaska," it is provided that the governor "shall from time to time inquire into the operations of the Alaska Seal aud Fur Company, and shall annually report to Congress the result of such inquiries and any and all violations by said company of the agreement existing between the Uniter States and said company." Treating the name of the company as a mero misuomer and that the Alaska Commercial Company was intended (a fact we do not contest), the Hon. Alfred P. Swineford, goveruor of Alaska, has made two annual reports-one in the latter part of 1885 , and the other in the latter part of 1887.

In his first report, the honorable governor very frankly stated his belief "that no definite results can be attained through an inquiry into the operations of the Alaska Commercial Company directed from this quarter," meaning Sitka.

He further said :

"The seal islands are distant from the 'Territorial seat of government not less than 1,500 miles, and the nearest point at which that company maintains an establishment is some 300 miles to the westward of Sitka. As nearly as I can ascertain from this distance there is no just complaint against the Aliska Commercial Company in connection with its operations on the seal islauds, leased to it by the Government, and it would appear, from all I can learn, that its reputed monopoly of the fur trade on the main-land and islands not leased is only such as might be expected to follow the employment of a sufficient amount of capital to defeat any aud all attempts at competition. This is a conclusion arrived at from hearsay eviderce only, there being no means of transportation to enable me to institute the personal inquiry seemingly contemplated by the act referred to. *** Unless a Government vessel is detailed for the purpose of conveying him (the governor) to the seal islands and the various other points where the company maintains establishments, it will be impossible for hin to institute such inquiries as will enable him to make a report founded upon personal knowledge and investigation-unless, indeed, it be through the courtesy of the company itself, and even then he can only do so at the expense of a trip of many thousauds of miles by way of San Francisco. * * * To make the contemplated inquiry at all effective the person making it must necessarily visit the scenes of the company's operations. This he can not possibly do unless the Government provides transportation."

The report further proceeds to show that it was "impossible for the goveruor to have instituted the inquiries contemplated, or to have made any report based on facts secured through personal investigation of the company's operations," and he claimed that he could "not be beld responsiblo for failure to obey a law which, though mandatory, enjoins upon me [him] a duty the performance of which is, and has been, for the reason stated, and through no fault of my [his] own, alsolutely impossible of accomplishment." (Senate Ex. Doc. 115, Forty-ninth Congress, first session.)

That the act contemplated, as the governor contended, "a report founded upon personal knowledge and investigation," and that "to make the contemplated inquiry at all effective the person making it must necessarily visit the scenes of the company's operations," seem too obvious for discussion. It is equally elear as shown by him "that no definite results can be attained through an inquiry into the operations of the Alaska Commercial Company directed from this quarter"-Sitka.

The suggestion that a Government vessel be detailed to convey the governor "to the seal islands and the various other points where the company maiutains establishments" was not acted upon by the Government. The general conditions remained the same, and in the latter part of the year 1887 it was equally impossiblo as in tho year 1885 for the governor "to instituto such inquiries as will enablo him to make a report founded upon personal knowledgo and investigation." He did not visit any one of the stations or "establishments" of the company, or inquire of the Uniteil 
States agent, or any of the assistant agents, appointed by the honorable secretary of the Treasury (Section 1973, Revised Statutes United States, page 346). We are positively assured that he received no information from any of the United States commissioners or deputy collectors, situated in any part of the country where this company transacts business; nor from any of the officers of the Revenue or Signal Service, nor yet from any of the priests or missionaries qualified by location or travel to speak of the affairs of this.company.

No application was made to the company or ans of its agents for information as to its "operations;" no inquiry marle at its principal office in San Francisco or at any of its stations in Alaska; nor was any examination made of its books or papers, to ascertain whether it bad violated "the agreement existing between the United States aud said company." Notwithstanding the fact that the honorable governor did not, or could not, avail himself of any of these sources of information, his report, made in the latter part of the current year, charges upon this company a series of wrongful acts, some of which amount to actual crimes against the very letter and spirit of the statutes, commencing with the very inception of its agreement with the Government and continuing throughout the period of its operations until the present time. Having been afforded no opportunity for defense before the governor, having had no notice, except from the report itself, that any such complaints were seriously entertained, this company begs leave now to present to you a statement, verified by unquestionable evidence, which is deemerl a complete answer to any and all accusations presented-that is to say, every taugible charge; for mere denunciation, not being an assertion of issuable facts, can not form the basis of such a reply as comports with the dignity of the subject or the respect due the head of the Treasury Department.

\section{I.-The Charge that the lease was Fraudulently Secured.}

Beginning with the very initiative of this company's connection with the Government, it is charged in the governor's second report that the lease of the seal islancls from the Government was a " corruptly secured franchise." At the close of the year 1887 - more than seventeen years after the lease was signed-this charge may well be considered stale and moldy. More than eleven years ago it received its deathb-low at the hands of the Committee of Ways and Means of the House of Representatives after a full and complete examination of persons and papers. (H R., Forty-fourth Congress, first session, Report No. 623.)

The House itself adopted the report of the committee on the fth of June, 1876, fully exonerating the company and estabiishing the falsity of the charge. (Vol. IV, Part IV, Congressional Record, p. 3657.)

The matter, therefore, stands adjudged against the present complaint after a full, fair, and impartial hearing, and we respectfully submit that the company is relieved from any further answer to this accusation.

\section{II.-Lobbying at the National Capital.}

Another charge against the company in the second report is:

"Its paid agents and lobbyists are kept at the national eapital to oppose any aud every effort that may be made to promote the welfare of Alaska, through such legislation as will encourage immigration and the enlistment of capital in the development of the undeveloped wealth hidden away in her forests, streams, and mountains," etc.

It could hardly have been contemplated by Congress, in passing the "act providing a civil government for Alaska," or in that part of the same which requires the governor to inquire into the operations of this company and to ammually report to Congress the result of his inquiries, that his functions to be discharged at Sitka or elsewhere in Alaska, wonld make him a valuable medium through whom accurate information could be obtained as to transactions at the capital of the mation. Congress certainly did not intend to clothe the governor with the power of inquiry into offenses committed against itself at Washington or with the right to investigate the influence of the "lobby" upon proposed legislation for Alaska. Neither an accurato knowledge of the archives or state papers of Alaska nor a prolonged residence at Sitka would give special knowledge of the doings of "paid agents and lobbyists at the nationai capital." We may, therefore, reasonably claim that the governor's report on this topic is in excess of the jurisdiction and duty imposed upon him by the aet of Congress referred to. We, however, respectfully say that the charge is untrue in every respect; is not warranted by the facts in the slightest degree; but that, on the contrary, this company has never in any manner discouraged immigration or the investment of capital in any enterprise in Alaska, or interfered in any way with legislation looking to those ends, We will presently show how utterly groundless these charges are, 


\section{III.-Tine Generality of tire Cirarges Made.}

The report of the goveruor, so far as relates to the operations of this company in Alaska and its alleged violation of tho terms of the agreement with the Govermment, does not elearly distinguish between its course of business in different parts of tho country or discriminate between the "fur-seal islands," which alone are embraced in the lease from the United States, and thoso portions of Alaska in which this company has no greater rights or privileges than fuy other company or person. Varions charges of wrong aud oppression aro made to apply grenerally, and in comnection with the statement that the company "does not confine its operations to the seal islands leased to it by the Government, but holds and possesses most of the Alentian chain and the greater part of the main-land, as a principality of its own, over which it, exercises undisputed sway."

No intelligent or aceurate view can be taken, no sound or eulightened julgusent exereised, and no correct or rightful conclusion be reached without the discrimination referred to, and without considermar the charges separately and in relation to the natural divisions of the country. For these reasons we beg leave to present tho subjects treated of in the report under the following principal heads:

First. As to the "fur-seal islands" embraced in the lease from the United States to the company.

Second. As to the ofher portions of the conntry occupied by the Alents, that is to say, the Aleutian chain, and including therein the "Alaska Peninsula."

Third. As to the-main-land.

\section{IV.-AS TO THF: LEASED ISLANDS.}

\section{First. The preservation and protection of fur seals.}

The lease from the Government to the Alaska Commercial Company bears date the 3d August, 1870, and embraces the two ishonds of St. Panl and St. George in Bering Sea. The leasu contains specific terms, to be performed by the company, and these for seventeen jears last past have been practically construed by the parties and exactly performed. This lease was made by the Government in pursuance of a profound policy and general plan of action well considered by Cougress. It was well kuown in the light of the history of the past that unless Congress took eticiont steps towards the presorvation of the fur seals on these islands they would very soon be annililated, as had been the case in the South Pacific Ocean and elsewhere, except on a small island belonging to Peru and two small islands of Russia in Bering Soa. Of all the vast "rookeries" of the fur seals of the earth formerly existing there remaimed worthy of note only those upon the islauds of St. Paul and St. George and the Russiau islands mentioned. That of Perm is enmparatively insignitieant, while those of Russia are far inforior to St. Paul and St. George. Had no stews been taken by Congress for their preservation, the "restless spirit of enterprise, unlindered," roforred to by Goveruor Swincford, or, in other words, the invading aud aggressive spinit of the fur-seal hunter, muhecked by wholesome legislation, infent alone mpon immeriate and selfish gain and unrestrained by any wise or jrudential rules, befoxe this timo would have completely annibilated or driven off all the fur seals from these islamis.

This subject is very fully and ably treated by Mr. H. W. Elliott in a monograph writ. ten by him under thedirection of the Superintendent of the Census, aud his crieat reputation for profound research and scient ific attaimments in connection with the Sunthsonian Iustitution gives to all that he asserts the position of established fact. 'The value of the seal islands to-daty is due to the wisdom of the Russian Government, followed up by the legislation of Congress in the same line of policy, or, as Mr. Elliott says, to the wise "restrictions and wholesome direction which the Russians establisherl in tho morth seas, the benefits of which aceruo to us to-day, and will forever, as mattors are now conducted. Certainly it is surprising that the business thonght, the hard-hended sense, of those early Euglish navigators should not have been equal to that of the Russian Promyshleniks, who were renowned as the most unserupulous and tho greedies tof gain-getters." (Vol. VIII, Tenth Census United states, 1880, 1). 7, Elliott's Report.)

The treaty by which we obtained the cession of Alaska from Kussia was proclaimed by the P'resident on the 20th of Jume, 1867. Immediately thereafter the Pribylov Islands were invaded, and all restrictions being removerl, the slanghter of tho fur seals was carried on to such a trementons extent as to promise an carly extinction of the whole of the rookeries. It took some time for appropriate legislation to bo framed, hut Congress determined to adopt the old Russian polieg of protection and regulation.

At first the killing of the fur seals was entirely prohibited, and it was made tho special duty of the Secretary of the Treasury "to preveut tho killing of any fur seal $99 S 4-24$ 
and to provide for the execution of the provisions" of the statute for the punishment of the persons killing the same. (Vol. 15, U.S. Stat., p. 241.)

On the $31 \mathrm{l}$ March, 1869, by a joint resolution entitled "A resolution more efficiently to protect the fur seal in Alaska," the islands of St. Paul and St. George were "declared a special reservation for Government purposes," and it was further declared to be unlawful for any person to land or remain on either of those islands, except by the authority of the Secretary of the Trcasury. (Vol. 15, U.S. Stat., p. 348.) On July 1,1870 , Congress passed the further act " to prevent the extermiuation of fur-bearing animals in Alaska." (Vol.16, U.S. Stat., p. 180.) This is limited to the islands of St. Panl and St. George and "the waters adjacent thereto." The effective means of this policy, as determined by this act, was the leasing of the islands upon the terus aud conditions and under the restrictions prescribed in the act. We thus see that the great object and purpose of Congress and its established policy were the preservation of the fur seal.

In examining into the operations of this company it wonld therefore seem of yrimary importance to ascertain how far this established policy of the Governmentthis paramount and leading intent of Congress-has been inaintained by the company.

Upon this topic the report of Governor Swineford affords no light, though he is prouonnced against the wisclor of the act of Congress in adopting the leasing system as a means "necessary to the preservation of the fur-seal industry."

As for the scheme proposed by him as a substitute, we beg leave to make some suggestions at a later period in this paper, but it may he well now to state that so for the policy of the Goverument in leasing the islauds as a means of preserving the fur seal from diminution and extermination has been most triumphantly viudicated.

Mr. Elliott, before referred to, gave this subject his special attention under most favorable circumstances. He was, to use his own language, "by the joint action of Professor Baird and the Secretary of the 'Treasury, enabled to visit the Pribylov Islands for the purpose of studying the life and habits of these animals." His " notes, surveys, and hypotheses were" founded upon his own personal olsservations in the seal rookeries of St. Paul and St. George, during tho seasons of 1872 to 1874, inclusive, supplemented by his confirmatory inspection made in 1876. The wero obtained through long days and nights of consecutive observation, from the beginniug to the close of each seal season, and cover, by actual surveys, the entire gromnd oecmpied by these animals." Nothiug could have been more searching, thorough, and efficient. His views have been confirmed by the numerous agents of the Treasury Department sent to Alaska, and have been acted upon by the Govermment generally, if not universally. He states that:

"Provided matters are conducted on the seal islands in the future as they are to-day, 100,000 male seals under the age of five years and over one may be safely taken every year from the Pribylov Islands, withont the sligltest injury to the regular birth rates, or natural iucrease thereon; provided, also, that the fur seals are not visiter by any plague or pests, or any abnormal cause for their destruction, which might be beyond the control of men; and to which, like any other great borly of animal life, they night ever be subjected to the danger of. $*_{*}^{*}$. That these animals are preyed upon extensively by killer-whales (orca gladiator) in especial, and by sharks, and probably other submarine foes now unknown, is at once evident; for were ther not held in check by some such cause they would, as they exist to-dar on St. Paul, quickly multiply, by arithmetical progression, to so great an extent that the island, uay, Bering Sea itself, cuuld not coutan them. The present annual killing of 100,000 out of a yearly total of over a million uales does not in anappreciable degreo diminish the seal life, or interfere in the slightest with its regular, sure perpetuation on the breeding-gromuds every year. We may, therefore, properly look upon this ageriegate of four and five millions of fur-seals as we see them every season ou these Pribyfov Islands as the maximum limit of increase assigned to them by natural laws. The great equilibrium which nature holds in life upon this earth must be sustained at St. Paul as well as elsewhere." (Elliott's report, pp. 62, 64.)

When before the Committee of Ways and Meaus on the 17th of March, 1876, on the investigation before alluded to, Mr. Elliott made a similar statement, giving in somewhat greater detail the reasons for his conclusions. His eridence wiil be found annexed to the roport of the committeo. (Report No. 623, H. R., Forty-fourth Congress, first session.)

Capt. Charles Bryant was also called before that committee on the 20th March, 1576. He was then the Treasury agent stationed on the Islaud of St. Paul. Ho went there first in 1869 and remained there from that date, "every successive season of the sealing;" to 1876 , when he gave his evidence to the committee, and it will likewise bo found annexed to its report. He fully confirms the views of Mr. Elliott.

In support of the same conclusion will be foumd the report of Lient. Washburn Maynard, U. S. Navy, made to the Secretary of the Navy on the 30th November, 1874. His investigation was made pursuant to the act of Congress of April 22, 1874, 
and was made upon the uround itself. $\Lambda$ syuopsis of this report will be found in Vol. VIII of 'Tenth Census of United States, 1880, 1\%, 102, Elliott's Report.

Mr. Ivan Petrotr, as special agent of the Government, in his report to the Superintendent of Census, August 7, 188\%, referring to the seal islauds, says:

"The subject of the fur-seal industry aud its commercial and physical aspects has been fully discussed in a monograph written by Mr. H. WV. Elliott, under the direction of the Superintendent of Census, and it only remains to say here that the business has been so thoroughly worked 11 ' and systematized as to bring it to a par with a well-conducted cattle ranch on a large scale-with this difference, perhaps, that greater care is lavished upon the seals, and greater cantion with reference to their comfort than is generally bestowed by farmers upon their cattle." (Vol. VIII, Tenth Census United States, 1880, Petroff's Report, p. 22.)

Mr. George R. Tiugle, present agent, appointed by the honorable Seeretary of the Treasury, substautially confirms Mr. Elliott also in his above views, except that, upon a careful survey made by himself in $1-86$, he estimates that the fur seals in the two islands had increased in number about $2,000,000$ up to that time.

We likewise beg leave to refer to the amuual reports of the several agents of the Treasury Department now on file.

It must, therefore, we respectfully urge, be accepter as a fact beyond controversy, that the past management of the company being continned, the Government will find at the termination of the lease its intentious and policy in preserving the seal industry, fully maintained and vindicated. The number of seals existing in 1870 , at the commencement of the lease, will have been increased. The great primary object of the Goverument will have been fully conserved to its great advantage as the possessor of the tinest seal-rookeries of the world, with the promise of its perpetuity for all time, the same policy and good management being pursued.

As this part of the sulject hears upon the company's relation to the Government, we may be excused for here calling attention to the fact that the total anmual tax and rental paid by this company to the United States from .July 1, 1870, to August, 1857, amounts to $\$ 5,290,736.49$.

Calculating that the full number of fur seals for the next two years to be taken and and we will have paid the full sum of $\$ 5,925,736.49$, almost six-sevenths of the entire sum paid by the United States to Russia for the whole of Alaska.

The charges of "boycotting" and driving away from the islauds "Government officers who, intent upon the honest, faithful discharge of their duties, refused to do the bidding of its agents," could only have had foundation in some misrepresentation made to the governor, for this company has always treated all the ofticers and agents of the Goverument with the greatest respect and kindness, as their reports on file fully show.

\section{Second. The company in its relations to the inhabitants of the seal islands.}

The act of Congress in authorizing the Secretary of the Treasury to lease the seal islands expressly provides, among other things, that in making said lease the Secretary of the Treasury shall have due regard to the "comfort, maintenance, and elncacation of the natives" of said islands. The lease itself, as executed, contains a number of particulars preseribed by the secretary for the benefit of the natives, which the company covenants to fulfill.

The charges made by Goveruor Swineford against this company in relation to its treatment of the "natives" are comprehensive enough to include the inhabitants of the islands of St. George and St. Paul in many particnlars, and in some particulars they are especially referred to as being practically enslaved "by the farming ont that which is theirs by right of inheritance "by the company, whose "ill-gotten gaius" have been "wrung from a hapless and helpless people." "And it is also charged that "if the Alaska Commercial Company had kept its agreement with the Goverument most of the younger ones among them onght to be fairly well edneated in English."

We may, therefore, be parloned for meeting these charges here, leaving the consideration of the inbabitants of other points of Alaska for another part of this statement. These charges are in fact not at all new; they wero long ago uttered and circulated and have been heretofore malle the sulject of investigation by the Government more than once. They constitute in part the canse of the investigation made

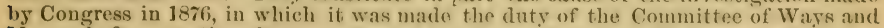
Means, before mentioned, to examine into and report whether this company hal complied with all its duties, and, amongr other things, in relation to the natives. A pamphlet purporting to have heen issued at San Franciseo by the "Anti-Monopoly Association of the Pacifie Coast." containing, we believe, most if not all of the charges made by Governor Swineford, Wats presented to the commitfes. General Mliller, linte Senator from California, and hefore then the presilent of this emmany, was ealled before the committee and examined under vath in relation to these charges. His 
answer made to the then pending charges can now be made to these charges of Gov. ernor Swiueford. General Miller was asked by the committee the following questions and made the following answers:

"Q. What have to say in reply to the charge of this pamphlet? [indicating pamphlet]; I believe it is anonymous.-A. Well, it purports to have been published by the Anti-Monopoly Association of the Pacific coast, Charles Leisch, secretary. I don't know of any such association on the Pacific coast. I could not find it. I tried to find it.

"Q. What have you to say in reply to that part of the pamphlet which professes to give an account of the condition of the people there; your selling them whisky, four oppressions, and your refusal or omission to carry out that portion of the law which requires you to look after those people, and to exercise a kind of paterual government for their moral improvement?-A. I say that those statements are entirely false from begimning to end ; that the compauy on the seal islands found those people burrowing in the ground, living in a sort of eaves in the ground, in their own filth and squalor and disease, and we began, as soon as we got this lease, the construction of dwelling-houses for them. We have gone on until we have constructerl a good, substantial, comfortable dwelling-house for every fumily on both islands. We have built on St. Paul Island sixty-four dwelling houses for the native families, and on St. George something over twenty. There is one for each family. They are all above grouud, and the houses are as good as the average houses that mechanics live in in your city. They are warm, lined inside, filled in between the lining and the weather-boarding. We give each one a stove.

We charge them no rent for those houses at all; we make no charge for keeping them in repair. We have taught these people all we could of the benefits of civilization; have tried to enlighten them; we have maintained schools on the islands regularly; we have hired teachers. We have kept a physician on each island, a regu' $r$ graduate of a medical college, all the time, with medicines free of charge; no charge for medical attendance upon the people; we forbid the doctors receiving any gratuity from the people whatever. They have surgical instruments of all kinds there, so that if a man is sick or hurt or injured be can have the best kind of medical attention at once. We sell as cheaj, as retailers sell them in San Francisco. Our instructions are, that in no case shall there be more than 25 per cent. added to the wholesale cost in San Francisco. We make nothing at all out of the goods that we sell them. Flour we sell actually on St. George Island cheaper than we buy it in San Francisco. The reason of that is that the price was establisher there a long time ago, and those people would think it was a sort of imposition if we changed the price. The price was established when flour was low, and we used to give them that black flour. We give them now excellent wheat flour, of good enough quality for anybody; as good as I want. The cloth, all that we send there, is of good quality. We have done this because it was to our interest to do it. They are our laborers, and we want them to be in a condition to labor. We desire to improve their condition in every way. They make better laborers and they are better satistied. It is our interest in every respect to do this, and we have done it; and all these stories about their being maltreated in any way are all false; there is not a word of truth in them. I challenge the whole world to show an example equal to this corporation in its humane treatment of its laborers.

"Q. What is the number of the native population on the islands ?-A. It is about 370. There are certain families there that have no male protector, no person to labor, and we support those people free of charge.

"Q. Has there been an increase or a decrease of the population since your contract went into existence? - A. I don't think it has increased or decreased. The total population of the two islands is put down here in Moore's report as 348. I suppose that is correct.

"Q. What other employments are there on the islands except what your company furnishes?-A. None.

"Q. You employ all the male population in your business?-A. Yes, sir; they work during the sealing season. For two months they work pretty well; they make good wages. They are quite prosperous; they have saved up a considerable amount of money. We taught them to save their earnings, and we act as a sort of savings bank for them. They do not know anything about the San Franciseo Savings Bank, although we explained the matter to them; and they prefer to deposit their savings with the company, and we consent to take them, and we are paying them interest. I believe this report of Mr. Moore's, on page 13, gives the amounts correctly. In St. Paul eighty natives are credited with $\$ 34,715.24$, and the church with $\$ 7,969.17$, making a total of $\$ 42,681.41$. In St. George twenty-four natives are credited with $\$ 6,623.96$, and the church with $\$ 2,006.91$, making a total of $\$ 8,630.87$.

"Q. Have they any religions worship on the islands?- $\mathrm{A}$. Yes; there is a church on each island, a Greek Catholic church, established there by the old Russian-American Company. 
"Q. Are there any other denominations?-A. No, sir.

"Q. There is no interforence by your company with their religious views?-A. No, sir; we do not interfere with their religious ceremonies or teachings at all; we have never attempted to change them or influence them in their religion. WVe have encouraged the church in overy possiblo way. We have assisted them in building the churches there.

"Q. You say you have established schools there; are those sehools taught in English?-A. Yes, sir.

"Q. Do the natives readily send their children to those schools?-A. At first they did, but they do not now. They have got an idea that by learning linglish they will lose the Russian; that is to say, they will not be able to perform tho rites and ceremonies of their church. They are an inteusely religious people, it is theirevhole life; and the ceremonies of the chirch are in the Russian language, and the older people are rather opposing the teaching of English on the islands for that reason, that it interferes with the performance of the church ceremonies; but a good many of them go to school, and some of them are learning something. But it is a bard job, our people say, to teach them anything. We have tried very hard. In one of those schools there was a Mrs. Fish teaching school; she was the wife of an ofticer of the Signal-Service Bureau; she is a very intelligent lady, highly educated, and we put the school in her charge. She tried it on this kindergarten system, which was found to be very good with the smaller children. We have done everything we could to make progress, I am informed." (Report No. 623, H. R., Forty-fourtl Cougress, first session, pp. 29-31.)

Mr. Ivan Petroff, the special agent of the Government, before referred to, who visited the islands in 1880 and 1881, makes the following statement as to the manner in which the natives are treated by the Alaska Commercial Company:

"The people now classed as natives of the islauds are in reality natives and rescendants of natives of the various islands of the Alentian division, a majority having sprung from Athka and Oonalaska. When the Russian navigator Pribylov discovered the islands, toward the end of the last century, he foumd them uninhabited, and in order to slay and skin the vast numbers of seals and sea-otters then found there it was necessary to import laborers from the more populous districts. Under the Russian régime, when these sealers were lodged in wretched subterranean hovels and were fed upon seal meat and blubber the year round, it was considered a hardship to be stationed there, and the managers of the fur compauy found it necessary to relieve their force from time to time. Since the islands have fallen under the direct management of the United States Government the condition of the people has been improved to such an extent as to stop all applications for removal from tho islands, and to create a great clemand on the part of the people of other islands to be transplanted there. Under the terms of the lease the lessees have erected comfortable cottages for all the families, and provide them throughout the year witb fuel and an abundant supply of salted salmon free of charge. In aldition to this, each family derives from tho compensatiou paid by the lessees for the labor of killing and skimning the seals, which is done upon a co-operative plan devised by the natives themselves, a cash income of from $\$ 350$ to $\$ 450$.

"Many other opportunities arise at various times during the vear for adding to their income by labor of various kinds at a good rite of wages. Whatever necessaries, comforts, and luxuries the sealers may desire to procure from the stores are sold to them at very reasonable rates. Were it not for the strong propensity for gambliug existing among them every sealer would have his bank account, but even now there is quite a respectable list of names upon the books of the company of those who draw annually interest from deposits in the saving bauks of San Francisco. A sehool ou each island, maintained by the lessees, under direct supervision of the special acrents of the Treasury Department stationed on the islands, exerts its beneficial influence among the younger members of these isolated communities. Many of the boys and girls ean oxhibit quite respectable specimens of peumanship, aud even composition, in the English language. Theso were produced at school, and under great pressure; but if tho visitor attempts to address one of these youngsters in English the reply will be a grin and a shake of the head. They havo not thus far learued to apply the knowleclge acquired. The average atteudance at the sehool on St. Paul is 69, and at that on St. Georue 23, out of a total population of '390." (Petroft's Report, pp. :2:, $2: 3$. )

We afîrm positively that what General Miller said in 18\%6, and what Mr. I'etroff said in 1832, is true as of to-day, and has been true during the whole interval of time since 1876. Our treatment of the natives bas been miform and consistent up to the present time, and the history of one year is the history of each other year.

Capt. Charles Bryant, the Troasury agent before referred to, who went to the islauds in 1869 and remained until after 1876 , in which latter year he testified before the Congressional committee, states in his testimony that it came directly withiu tho lime of his duty to observe the treatment which the natives received from the company; that tho latter observed to the fullest extent its obligations to the natives; 
"that tho relations between the natives and the Government officers have arvays been of the most friendly and trustworthy kind; " that he had never known a complaint from the natives or a failure on the part of the company to supply their wants or discharge their obligations to the matives; that the natives were more comfortable than they had over been umder auy previous coudition; that they never were compelled to work, but did so voluntarily and under the directious of their own chiefs; that their pay was cortain, rerular, and fair; that their whole compeusation was paid to their chiefs and distributed anong themselves according to their own rules and according to classes of theix own forming; that they were never charged extravagant or unreasouable prices, the company uniformly charuing 25 per cent. profit on the San Francisco wholesale prices; that the law and all regulations are published in the Russian language, which the natives understand, aud filed with the chiefs, so that they are constantly informed of all their rights; that they have a school eight mouths in the year; and that nany of the youngor chilkreu are reading simple sentences in English and leaming simple arithmetic.

He adils:

"Wo uncounter in the teaching of the English language some opposition from a portion of the natives; or rather a fear exists among them lest by teaching tho English language wo shall ontirely supersede the Russian language, aud thereby they shall lose their comnection with the Russian Church. ** * The old people ask us, with a good deal of reason, "Who, when wo are dead, will read the prayers over our graves, if our children can not read Russian?" (H. R. Report No. 623, Forty-fourth Congress, first session, p. 101.)

Mr. H. W. Elliott, before referred to, stated before the committee, under oath, that he was on the islamils of St. Paul and St. George from the 28th of April, 1872, until the 10 th of Angust, 1873 , continuously, and was again there on the 5 th of July, 1874, and left on the 4 th of August, 18\%4, and that whilst there he songht by inquiry and observation to inform himself as to the conclition of the uatives, and further adcls:

"And to more thoroughly do that, I studied the Russian language, and acquired sufficient knowlerge of it to converse with them, and to read and write it, and I am free to say that those people have talked to mo in a very independent, and, to my surprise, a very intelligent manner." (Report No. 623, p. 79.)

When asked by a member of the committee what was the feeling of the natives toward the lessees, he answered: "Their fooling, independent of their testimony to me, is one of gratitude and thaukfulness." (Page 79.)

Mr. Bristow, then Secretary of the Treasury, was also called before the same committeo to testify in regard to the affairs of the company, and, among other things, he stated the following:

"I ourht to add that Mr. Bryaut, the special agent, who was appointed by Mr. Boutwell at the time of the commencement of this contract, has been here during most of the winter (I think he has, perhaps, just left within the last fow days), and I have talked frequeutly and very freely with him on the subject, and he gives the most positive assurances that all these charges are false; that they are made in the interest of rivals and irrespousible persous. So that I have uot been able to discover, from any source at all, ofticial or unofficial, any responsible person who is willing even to father the charges that are made." (Page 69.)

The Committee on Ways and Means, as well as Congress itself, came to the conclusion, ou the evid nce before it, that there was no just ground of complaint arainst the Alaska Commercial Compauy or any of the ofticers of the Govermment intrusted under tho law with the power to make the lease or see to its performance. 'That was in 1876, after six year's had expired from the making of the lease, and when the whole system and mode of action of this company was completely established. The same methods and course of proceeding have since continued without change.

In Oeteber, 18ß4, Lientenaut Lutz, of the United States Marive Service, in obedience to orders from Capt. II. A. Healy, of the same service, commandiug the revenue steamer Corwin, male a report to the same effect, now on file in the Treasury Department, to which we beg leave to refer. In the appendix hereto wo present some extracts from the same. (No. 1 of Appendix.)

In the fill of 1885 , Captain Healy hinself made a report to the Hon. Daniel Manning, Secretary of the Treasurg, also to the same effect, giving his own personal experience aud linowledse. begiming in the sear $186^{2}$, extracts from which wo also append hereto. (No. Z of Appendix.) We also call attention to his several reports on file, and especially to one which we are informed has just been made to the Treas. ury Department.

Ve also respectfully and especially refer to our correspondence with Mr. George R. Tingle, the present agent of the Treasury Department, hereto annexed, which we feel assured will, from his high eharacter for integrity and intelligenee, command at the hamds of the Department the highest respect. (Nos. 3 and 4 of Appendix.)

It will thus be seen that our treatment of the uatives, from first to last, has been uniform and consistent. Probably as complete an auswer upon our part to any 
charge of ill-treatment or harsh usage of the natives of these islands is the fact that we now hold to their creslit the sum of $\$ 64,732.11$ as their surplus savings, the details of which appear in the stittement also contained in the appendix bereto. (No. 5 of Appendix.)

In this counection it is to be remembered that on the Islaud of St. Paul there are now eighty-seven families and eleven widows, and on St. George twenty-six families and six widows, the entire population on both islands, men, women, aud ehildren, consisting of 347 persons.

Wo claim that this company has fulfilled to the uttermost its entire contract with the Uniterl states, and has also faithfnlly performed all its obligations to the natives of the islands, as the above facts fully demonstrate.

\section{V.-As to the Aleutian Chain of Islands and the Peninsula of Aliaska.}

Were this company disposed to staud upon the letter of the act of Congress, or did its contract require a defense based on mere legal or technical propositions, it might well insist that the duties of the governor in reporting upon the "operations" of this company should be limited to its contract relations with the Government under the lease, and that independently of the obligations resting upon it by reason of the terms of the lease it has been free to trausact business in any part of Alaska outside of the islands of St. Georre and St. Yaul, "and the waters aljacent thereto," as any other company or person inight, being at all times, of course, liable for any violation of law, in the same manner, and in the same manner only, as other persons. The charges, however, are so entirely withont foundation, and all complaint so destitute of merit, that we ben leave to present the facts themselves to the honorable Department of the Treasury, that the truth may be known. It is mostly, we apprehend, in this part of Alaskat that the wrongful couduct and acts of oppression of the natives by the Alaska Commereial Company, as alleged by Governor Swineford, aro supposed to have occurred, Referring to the company, he says:

"It has, by the power of its great wealth, driven away all competition, and reduced the native population, wherever its operations are not supervised by Government agents, to a condition of helpless dependence, if not absolute slavery. Unhampered by a healthy competition, it offers and compels the acceptance by the natives, on the pain of starvation, such beggarly prices for their peltry that it manages invariably to keep them in its debt and at its mercy. * * * In fact, it possesses the power to compel compliance with its every exaction, and wherever it has obtained a foothold neither white man nor native can live in peace and comfort except by its sufferance. Without mail communication other thau that supplied by the compiny, which is their master, the natives are effectually walled in, and in the absence of all competition are forcel, of a necessity, to sell their furs to the company at whatever prices its agents may see fit to offer. * * * Its oppressiou and robbery of the natives is notorions. The partial responsibility, at least, of the Government for the wrongs to which the inoffensive people of the Alentian Islands and the whole of northwestern Alaska have been subjected can not be ignored or denied."

In the first place, this emprany has not driven away competition, but has always been, ard uow is, subjected to competition all along the coast of the Aleutian chain. The field is an open one for commercial enterprise and competition. It invites the tratler, the merchant, and all to its shores, but if we were the sole survivors of the contest, we might well claim it to be a case of the "survival of the fittest." Time and again expeditions fitted out in San Francisco and elsewhere have mvaded Bering Sea and tried to obtain the furs there, contrary to the acts of Congress and the regulations of the President and the Departments, and at the risk of criminal proseeutions and the furfeiture of valuable vessels. It would, therefore, be strange indeed if the "restless spirit of enterprise" had not availed it self of the fiold offered by the Aleutian chain, where it has been "uuhindered" all these years.

We annex hereto in the appendix a eops of the oflicial map of Alaska, ${ }^{*}$ with the natural divisions of the country, as made by Mr. Petroff. TVe may be understood as referring to these as we progress. We also annex a map of distances.*

Next in importance to the fur seal is the sea-otter. The Shumagin group of islauds of this chain is the great ceuter of the trade in its polts. Different vessels of clifferent companies and individuals go there every year to buy and trade, with a resultiug active competition. The fact is that there is a lasere aud valuable trade all alonir the Alentian ehain in peltris's other than the tracle of this company, at well as in fish and other commodities, in which this company does not at all participate. Vessels of persons and companies having mo comnection with the Alaska Commereial Company go every year to the coast, and buy, barter, and trade extensively. A large anount of eapital is resed by establishments draling in codtish and salmon, and the 
proprietors not only have stationary stores and smpplies on Kodiak and other islands, but they also own their own vessels used in the trade. These tradery are always ready, too, to buy any fiurs offered them. Small traders are always moving around these islands where there is any opportmity to buy pelts at fair prices. This company has always paid as much as any other or as the trade warrants.

The chief fur hunting along this shore, as alrealy stated, is that of the sea-otter, and many are engager in it. Not ouly do tho Aleuts participate in this, but many whito hunters. These white hunters havo mostly married native women, and not only claim all the rights and privileges of the uatives, but have been recornized from time to time by the various Departuents at Washington as possessing all the rights, privileges, and immunities of the native Aleuts. These white hunters are wholly in spmpathy with, aud in sentiment and marriage allied to, the natives; are quite independent, and cutirely capable of taking care of themselves and their allies. They seei the highest prices and hold their peltries up for the highest offer. At times prices have ranged so high that this company has been compelled to pay for the best sea-otter prices equal to that of the London market. At Kodiak alone there are about twenty of these white hunters who own their own schooners and sloops, and who principally liunt the sea-otter.

Mr. Petroff, in his report before referred to, says:

"As the northern portion of the 1slaud of Kodiak and the smaller islands to the northward are timbered, the people here have facilities for ship or boat building, of which they avail themselves to the fullest extent. One or more small crafts can always be found in process of construction, principally upon orders from the prosperons white sea-otter hunters of the Shumagin Islauds or for the trading firms and private traders. A cleputy collector of customs stationed at Korliak has quite a respectable list of small craits built aud registered in the district. Sea-otter parties are fitted out in nearis every village, and are frequently taken to distant hunting grounds in sloops and schooners." (Vol. VIII, Tenth Census, 1880, p. 25, Report of Ivan Petrofí.)

The sea-otter parties referred to often consist of teets of about fifty boats on doparture, but divide up into lesser uumbers as they proceed to different points. In their outfit they require considerable expense, and without substantial aid and assistance the natives would not be able to proceed, except upon a rery limited scale and with very inadequate supplies, for a somewhat protracted absence.

The Alaska Commercial Company oftentimes, therefore, furnishes the entire outfit and supplies, including the smaller vessels intended for use by the huuters at the immediate points which constitute the haunts of the sea-otter. The company virtually takes the risk of success. If the expedition is successful, the hunters get paid fair prices for their pelts, and are enabled to pay their share of the advauce for supplies. They are alwass well informer as to prices, for other purehasers stand ready to buy and thus afford ample protection against sacrifices. As these expeditions go to distant places, aud are ont for a considerable time, and the hunters are thus absent from their families, they are given a limited credit at the company's stores in antieipation of a successful result in the adventure. It is, of course, to the interest of the company to restrict this indebtedness as much as possible, but the eredit becomes inevitable where the family stands in want of necessary articles turing the absence of the hunter. In these transactious with the natives it has always been the aim of the company, and to its interest, to deal justly and fairly and to cultivate the most fiendly relations, for the company is more dependent on the hunters for a supply of the pelts of the sea-otter than the hunters are dependent on the company. In order to make the hunters satisfied and to induce them to act with greater energy in liuntiug, the company rewards the best hunters by buildiug houses for them to live in free of rent, and it constantly brings the salted carcasses of seals from St. Paul and St. George islands to the Alentian chain and distributes them to the natives who have no other supply of animal food, except fish. Besides the pelts of the sea-otter, this compauy gets nothing else from the Alentian chain except a few fox skins. The supplies from the company's stores in this part, as in all other parts of Alaska, are furnished to the hunters and to all persons, native or otherwise, at reasonable prices.

We have before alluded to the savings of the Alents upon the islands of St. Paul and St. George. We maty here also state that so prosperous are the hunters of tho Aleutian chain dealing with this company, that they are not only well elothed, but we now have on hand to their eredit, as the result of their savings, and upon which we pay thim interest at 4 per cent. per annmm, the sum of $\$ 29,396.17$. This amount is due to seventeen persons, as appears by the statement in the appendix horeto. (No. 5 of Appendix.) The number of persons and amomnts of money would be much larere, if extravagance, gambling, and love of liquor were not so prevalent. This company has always exercised its influence, as much as possible, for the suppression of these vices. It has eontributed largely to the church and to the schools, and has, pursuant to the wishes of the Government, declined, as well on the Pribylov Islands as elsewhere, to suplyly the natives with sugar, to prevent their manufacture of an intoxicating mixture called "quass," which they delight to drink, in the absence of 
other intoxicating liquids. (Seo "Regulations governing the Seal Fisheries in Aliska," issued by IIon. Charles J. Folger, Secretary of Treasury, April 13, 1832.)

Ilow this comprany, by earrying the United States mail upon its vessels, on their ronte to anl from its places of business, "wall in" the natives and compel them "to sell their furs to the company, at such prices as its agents see fit to offer," is somewhat obseure. The United States mails are as sacred when carried on the company's boats as elsewhere, and as much under the protection of the law. That this lawfinl act, apparently so convenient and useful to all concerned, should be a means of enslaving the Aleuts, we confess ourselves unable to comprehend.

Upon the subject of the treatment which the natives of the Aleutian chain sustain at the hands of the company, wo beg leavo to refer to their condition as shown by Mr. Ivan Potroff in his report to the Superintendent of the Census in 1882. (Vol. VIII, Tenth Consus United States, pages 18 aud following.)

The following is from the same anthority, the "trading firm" that he especially allules to being the Alaska Commercial Company. Speaking of Oonalaska (page $20)$, he says:

"A school, in which both English and Russian are taught, is maintained by one of trading firms, but the attendance is at best irregular. Nearly 50 per cent. of the adults of Iliuliuk, however, are able to read and write in the Alentian language and a fow in the Russian. The sime firm that maintains the school also employs a physician and keeps a well-stocked dispensary, where natives are treated free of charge."

We also refer to the statement of others on the same subject, likewise contained in the appendix.

This company has no disposition whatever to disparage any part of Alaska, but as it has been charged with hostility to its interests, as well as with attempts to prevent the influx of immigrants and the settlement of the country, reference in reply to this accusation may be made to the archives of the Census Department, so that a sound jud sment may be formed on this topic in relation to the Aleutian chain, as well to other parts of the Territory.

If the official reports be true (independently of any statement we may make), the Aleutian chain at present contains about as large a population as can there find means of subsistence. The settlements are necessarily confined to the narrow margius of the sea-coast, the greater part of the interior of the islands being inaccessible.

The natives confine themselves principally to hunting the sea-otter and fishing, and the reason why they do this is well ascertained from the nature of the country and the climate. It appears that the Russian missionary, Veniaminof, under the anspices of the Rnssian Government, kept and recorder a careful account of the weather for seven years. That record shows that during that time there were but 53 clear days, leaving 1,263 eloudy days and 1,230 days with snow, hail, or rain. Hay can be imported from San Francisco cheaper than it ean be raised on the islands, and even potatoes are a failure there. 'The necessary resort of the people, therefore, is to hunting and tishing, and the principal of these is sea-otter hunting. The small accession of white men, who having intermarried with the native women, has greatly changed the latter oceupation, the better vessels of the white hunters and their greater energy enabling them to hunt at times when the Aleuts are kept at home by gales and storms. The sea-otter seems thus destined to extermination at no remote period. What a clenser population on this chain of islands could resort to as a means of subsistence we are unable to suggest.

Upou this general subject much valuable information will be found in the report of Mr. Petroff to the Superiutendent of Census in 1882 (Vol. VIII of Tenth Census, 1880, pp. 18 and fol.).

\section{VI.-Traxsactions of thy Alaska Commercial Company upon tile main-land.}

The governor in his report states that this company "does not confine its operations to the seal islands leitsed to it by the Govermuent, but holds and possesses most of the Alentian chain and the greuter part of the main-land as a principality of its own, over which it exercises undisputed sucuy.". Ho then proceeds to charge upon the company a series of misdeeds and aets of oppression, as well as acts of hostility to the welfire of Alaska, and even crimes against the express letter of the statutes of the United States. Most of these charges impliedly refer to the acts and doings of the company on the main-land, as well as upon the Alentian chain. The report further alleges:

"To its pernicious intluence is clue the fact that Alaska is not to-tay largely populatnl with an industrious, enterprising, prosperous people; that millions, where there are now only humbeds, have not ere this been invested in the development of her many varied, and, as I believe, incomparably great natural resources."

It these statements be true it is the first time in American history that the elsewhere irresistible tide of emigration, seeking congenial fields, with "incomparably 
great natural resources" luring them on, has been turned aside from-its course hy any conpany, however great. The masses of immigrants that peopled, in turn, Inlnois, Iowa, Missouri, Kansas, California, and Oregon, would have run over and crushed ont any impecliment that stood in their way. In new territory west of the Mississippi wo have but recently seen the United States Army called out to keep immigrants from settling upon lands in advauce of the Goverument's wishes, even where the country only possessed " natural resources" quite "comparable" with those of other States and Territories. It therefore becomes a uatter of great historieal interest, as well as of vast importance in the seience of grovermment to ascertain how a sinlge corporation, with a capital of s.2,000,000, had acpuired such " sway" over the greater part of a territory of 541,409 square miles, mate it a "principality of its own," and turned aside and overcame the vast inass of "industrious and enterprising people," who, with their millions, have tricel in vain to reach its shores, rich in the pronise of a great future, and who have unsuccessfully sought to invest in her "incomparably great natural resources."

The inguirer will learn with astonishment that the only natural resouces of the country in which the Alaska Conmercial Compauy deals are furs and the pelts of animals, with the exception of fish to a very limited decree beyoud its supply to the natives under the terms of lease. It has nothing to do with mines, either of coal or precious metals, forests, quarries, grain, fruits, or vegetables, and make uo iuvestment in the "incomparably great resources" refered to, save only in furs and the skins of will animals. It in no wise competes with the cod and salmon fisheries or auy of the canneries. Its vessels are intended primarily for its own use, in its own business, lut it freely carries the mails and offers to all who desiro it the full aceommodation which any cau obtain from a conmon carrier. Tet it competes with no lines of steamers or other vessels for the earrying trade and leaves the field open to auy who seck it.

\section{First. Southeastern Alaskia.}

The company does no business at all of any kind with southeastern Alaska ; that is, the portion lying south and east of Monnt St. Elias, called the Southeasteru division. It is here that Sitka, the seat of government, is situated, and where the greater part of the white population of Alaskia resides. It extends from Momnt St. Elias to Portland Canal and contains 28,980 square miles, beiug larger in area than eitber Connecticut, Delaware, Maryland, Massachusetts, New jersey, Vermont, or West Virginia, and is nearly as large as Indiana. Compared with this large district the Pribylov Islands leased to this company are very insiguificant in area. St. Paul is 15 miles long and less than 6 miles in point of greatest width, and contains about 33 square miles, a large part being rock, rugged cones of volcanic rock, whilst a great deal of the remainder is drifting sand dunes. St. Cieorge Islaud is about 10 miles in extreme length and about $4 \frac{1}{4}$ miles in greatest width, aud contains about 27 squaro miles. Its greatest elevation is 920 feet above the sea.

None of the vessels of this company tonch at any port in sontheasteru Alaska, and as Governor Swineford says, in his first report (that of 1885): "The seal islands are distant from the Territorial seat of govermment mot less than 1,500 miles, and the nearest point at which that compauy maintains an establishment is some 300 miles to the westward of Sitha." The goveruor also shows that the only communication between Sitka and "the scenes of the company's operations" is by "a trip of many thousands of miles by way of San Francisco." So far as sontheastern Aliska is coneerned, the "pernicious influence" of the Alaska Commercial Company must be a myth, and the mers creature of an excited imagination.

As to southeastern Alaska, its great natural resomrees and general merits, we have no personal knowledge. We do not in the least desire to underrate it, or say auything that may reflect upon it as a country wortby of everything good that has been or may be said of it. This company ouly says that it has not had any business intercourse with southeastern Alaska, or its peojle; that it has no possilile motive to interfere with it, or any projects for its beuefit, and that the business onterprises and operations of this company are too remote to have the slightest eflect upon this part of Alaska for goorl or ill. As well might the Sandwich Islands or Oregron complain of this company as southeastern Alaska.

\section{Second. Kodiak division.-Main-land.}

If we go northward and westwarl from sontheastern Alaska we pass beyond Mount St. Elias, aud into what Mr. Petroff̈ calls the Konliak division, the eastern limit of which is the eastern boundary of Alasks, north of Momnt St. Flias. The main Alaskan ran:20 bounds this division on the north and west. In this he embaces a part of the Aliaska Peninsula and the islaud of Kodiak already mentioned. WV are now, however, speaking of the main-land.

Upon the main-land of this hivision the company has five substations, including the peninsula of Aliaslia, two on Couk's Inlet, one on English Bay, one on the peninsula, 
and one on Prince William's Somul. The latter is called Nonehek, and is the "estabblishment" referred to by (iovernor swineford as beiug "3ou miles to tho westward of Sitka," and the nearest station to it. At this place this company has one white man as a subagent aud a fow Alents as employés. The popnlation is ail Indian, and the only people with whom the company trades are Indians. The Indians are the only hunters and they bring to the company chiefly the skins of the marten and mink, with a few others. The company has a small store of supplies for the Indian traders, and its boats go there generally twice a year. The entire business is only between $\$ 3,000$ and $\$ 4,000$ a year. This station is not at all remmerative, and its abandonment has been contemplated for some time. There is no nining in the neighborhood, no fish industry, no canneries, and no white population.

Of this station Mr. Petroff says:

"'The number of sea-otter's sold at the Nuchek stores every year aes not exceed one hundred and fifty, and aro all killed between the islands Nushagak and Kaiak. The whole Eskimo population of this secluded district is only about 500 , and, as they are poor, they will probably remain in this sechusion, which is broken but once or twice a year by the arrival of the trading schooner." (''etroff's Report, p. 28.)

The two statious of the company on Cook's Inlet are 'Toyonok and Kenai; that on English Bay is Alexaudrovsk, and that on the peniusula is Katmai. At Toyonok, the company has one subagent, who is a white man, and also has a small store. 'There are no white or Aleutian hunters there, only Indians and but fow of them. They bring in mink, marten, bear, and deer skins ouly. The trade is very small. There is no town there, and but very little surromeling population. An occasional ship comes in and tho Indians freely avail themselves of tho best offer for their peltries.

Kenai was once a station of the old Russian-American Commercial Company. It now has only one subagent and a small store. The hunters are likewise Indiaus, there being no white hunters or Aleutians there. The tracio with this company is very small. At this place the Arctic Fishiug Company does considerable business in salmon-to the extent, probably, of upwards of $\$ 6,060$ per annum, and has its own vessels and imports its own supplies for its employés and those with whom it trades. The Indians also do the fishing.

Alexandrovsk, situated on Euglish Bay, contains about eighty-eight people. Of these, one is a white man, twelve are creoles or half-breeds, and the remaibder are Aleutians. The white man is the agent of the Alaska Commercial Company, who alone and without any employés manages the business, including one small store of supplies. The trade is quite small and is principally confined to the sea otter, hunted exclusively by the Aleuts and creoles. Occasionally vessels of others visit this point and compete for pelts, which are readily obtained by the offer of contraband articles by way of barter.

Katmai, on the peninsula of Aliaska, is a sulstation of very small importance, and one man only with a small store is kept there at occasional intervals. It is practically abandoned. The trade is insignificant.

We have now presented the entire operatious of the company on the main-laud in the Kodiak division. This division contains 70,881 square miles, and how much of that large territory is afiected by the Alaska Commercial Coupany's operations can thus be seen at a glance. If so little business, at such fow iusignificant points, on the mere margin of the country, has such a "pernicious inllnence" on that main-land and is such a blight to its general prosperity, its whole vitality and ivherent strength must be very susceptible indeed.

The greater portion of this division lies between Prince Williams's Sonnd and Mount St. Elias. Those who have visited it describe it as an "Alpine region," the whole eoast "deeply indented with eoves and tiords, and towering peaks rise abruptly from the sea. Nearly every valley and ravine has its glacier, some of the latter being among the most extensive in tho world. In Port Valdez, at the northern extrenity of the sound, a glacier exists with a face 15 miles in length at the seashore, while its downward trick ean be traced almost to the summit of the Alps." (Vol. VIII, Tenth Census, 1880, p. 27, Petroff's Report.)

The same author gives the entire population of the Kodiak division in 1-82 at 4,352, of which 34 are whites, 917 ereole or half-breeds, and the rest Iudians. It is donbtful if there has beeri any increase by immigration since.

Whether the prospects in the Kodiak division on the main line are vers inviting for immigration, or its prospects have been marred by this company, can be judged of by the facts submitted.

\section{Third. The Aretic division.}

This is described by Mr. Petroff as follows:

"The Aretic division, containing 12.5,245 square miles, aud composing all that portion of the North American continent between the oue humdred and forty-first meridian in the east, and Cape Prince of Wales, or Bering strait, in the west, the Aretic 
Ocean in the north, and having for its sonthern boundary a line indicating the watershed between the Yukon River system and the streams emptying into the Arctic and impinging upon the coast of Bering Sea just north of Port Clarence."

With this vast tract this company has uothing whatever to do. The interior is virtually an unknown and unexplored region. As to the coast trade, we have no knowledge or sources of information not possessed by the public at large. We believe that the fucts, as stated by Mr. Petroff, are correct. He says:

"It is impossible to obtain statistics of the provisions, manufactured goods, arms, and ammunition shipped to the Arctic coast of Alaska, and disposed of among the natives there, ehietly beeanse the bulk of this trade has fallen into the hands of illegitimate traders, who clear from American ports for the coast of Siberia, then touch at the Saudwich Islands to lay in a supply of spirituous liquors, and finally eruise along the Alaskan coast, purchasing all the furs, fossils, and walrus ivory in the hands of the Arctic Innuits with rum, breech-loading arms, and ammunition. This traftic, though quite extensive in volume, lies at present altogether without the pale of official investigation, and ouly the continuous presence of one or two vessels of the revenue marine in these waters could reduce the trade of the Arctic division to a legitimate basis."

This company may, therefore, be excused from any defense as to the Arctic division.

\section{Fourth. The Yukon division.}

This division lies immediately to the sonth of the Aretic division, contains 176,715 square miles, and comprises the valley of the Yukon River as far as it lies in Alaska, and its tributaries north and south. It extends east and west from Bering Sea to the British Possessions, and is bounded south, in part, by the Kodiak division, already reviewed, and the Koskokvim division, shortly to be referred to. No State or Territory in the United States at all approaches in area this vast Yukon division, excepting only Texas. Yet, within its wide domaiu, the Alaska Commercial Company has but one station or trading post, and that is at Saint Michael or Michaelovski, situated on Norton Sound, which its vessels visit once a year only. At this place the company has a store aud an agent and assistant agent. A captain and engineer to each of two small river steamers, a carpenter, and a laborer. Its business is with the tracters who number about a dozen. It nerer comes in contact with the natives or hunters, but obtains all the commodities it purchases from the traders at agreed rates, and in turn sells its supplies to the traders at fair prices.

The company also runs two small steamers from St. Michael up the river in summer to carry supplies to the traders, and to bring down the peltries there purchased. It also at times receives orders or commissions for articles to be purchased at San Francisco, which it always fulfills at fair and reasonable rates, and delivers the articles at St. Michael or on the river. The traders referred to also have two small steamers of their own runuing from St. Michael to carry supplies up to their stations on the river and return with pelts. These traders also have stations at various places on the river where they lieep supplies, with which to barter with the hunters for peltries. There are eight of these statious on the river-Fort Reliance, Tananab, Novikakat, Nulato, Anvik, Mission, Andreivsky, and Kotlik. The entire busiuess of the Alaska Commereial Company in this division amonnts to about $\$ 30,000$ per anumm.

Vessels eau but rarely, aud for short periods, approach the auchorage, or very near the anchorage, at St. Michael, and never before the latter part of June, on accomut of large bodies of ice that drift in the waters of Norton Sonud and the straits between the delta of the Yukon and St. Lawrence Islaud. The river is not open for navigation uutil July, and closes at the end of September. Sea-groing vessels cau not enter the river, and all supplies for the interior are transferred neeessarily at St. Michael to the sinaller crafts that ascend the river. The vessels of the traders are usually frozen in near their upper trading stations in winter, and return in the following summer, whilst the small steamers of the Alaska Commercial Company make return trips and winter at St. Michael.

The mountains are covered with forests almost impenetrable, and the great plains are alwost all swamps and covered with snow for seven aud eight months of the year. Mfiuing has not proved a success, or sufficiently promising to indnce a large influx of miners. Some mines have been found on the Tenuanah, paying little more than laburers' wages, for the seasou is too brief to warrant any expectation of greater rewards. We respectfully refer to the statement of Mr. Schieffelin, an energetic and experienced miner, found in the appendix. (No. 6 of Appendix.)

Whilst the river is abnadant in fish and the forests in game, the food supply from these sources is not greater than the demands of the Indians, for in the fishing season the concentration of tribes on the river banks is so great as practically to depopnlate the greater part of the adjacent territory. The better authority and most reliable explorers of this region state that there can be no well-grounded expectation of this ever being an agricultural country. 
"The whole valley of the Yukon lies within a few degrees of the Aretic Circle; the soil, where it is level, is always swampy, and even the slopes of the hills and monntains are never drained of their superabundant moisture. The heat of smmuer has no effect beyond an astonishingly rapid growth of native grasses and weeds, and the bringing in to life of dense clouds of mosquitoes all over the country. * * * For hundreds of miles from the sea the Yukon River flows through low, level tundras, or mossy morasses, resting upon a foundation of clay.

The shifting current of the river eats away the shores on either side with astonishing rapidity; the dull thud of the caving banks is constantly heard by the traveler, and whole reaches change their aspect entirely within a single season. Stepping upon the shore the explorer must jump from hummock to hummock or wade aroumd from kneo to waist deep. In many places the ieo never disappears within a few inches of the surface, being protected from the rays of the sun by a non-conductive carpet of sphagnum. * * * The temperature, as exhibited in the above table (tables of mean temperature at St. Michael, Greek Church Mission, Nulato, and Fort Yukon), would not seem to afford much encouragement to the agricultural immigrant, even withont reference to the existence of frozen soil thronghout the year within a short distance of the surface as mentioned above. (Vol. VIII, Tenth Ceusus, 1880, Petrofi's Report, pp. 6 and 9.)

These statemeuts are corroborated by Mr. E. W. Nelson, ehief signal officer, in his report on the meteorology of St. Michaels and vicinity, and by Mr. W. H. Dall in his report upon the agricultural resources of Alaska. (See same volume, pp. 7 and 9.)

From the foregoing facts it will be readily seen that no "pernicious influence" of this company has kept that portion of Alaska from being "to-day largely populated with an industrious, enterprising, prosperous people," or prevented "inillions where there are now hundreds" from being invested in its "natural resources." Such language applied to this part of Alaska clearly aftords a striking instauce of remarkable exaggeration or want of accurato information.

\section{Fifth. Koskokvim division.}

This lies durectly sonth of the Yukon division; northwest of the Kodiak division ; extends to Bering Sea, and includes theKoskokvim Bay, River, and Valley, and Bristol Bay, with the Nushagak River and Valles. It contains 114,975 square miles, and is larger than the whole Territory of Arizona.

The Alaska Commercial Company has not a single station in this division. It had one formerly at Kalmakoveki, hut it was abandoned about ten years ago. Wo send a vessel once a year to the Koskokvin River, to a point 15 or 20 miles ahove the mouth, to meet and trade with a single trader, Mr. Sipary, who accumulates during the year in the interior and neighborhood the pelts of mink, marten, bear, and other cheaper skins, and gets his supplies from our company. The trade amounts to about $\$ 10,000$ per annum. Mr. Sipary is a principal in the business, and does his own trading with the hunters. Wo also send a ressel once, and sometimes twice, a year to Nushagak, on the river of that name, where we trade with a single trader, Mr. John W. Clark, from whom we buy peltries, and to whom we furnish supplies. The business covers about $\$ 10,000$ per annmm. Mr. Clark has about eight employes, and has established stores of his own at Nushagak, Togiak, aud Illamna. The Alaska Commercial Company does not come in contact with the hunters or auy other trader than Mr. Clark. At this point, Nushagak, there are several companies doing a large business in salmon canneries. These are the Arctic Packing Company, Bristol Bay Canning Company, and the Alaska Packing Company. This is one of the finest salmon fisheries on the coast, the salmon heing found in immeuse numbers on the Nushagak and other streams emptying into Bristol Bay. The American fisherman have been established here for many years and do a very large business.

Two of these fishing companies are of California and one of Oregon. The Alaska Commercial Company has nothing whatever to do with this business.

The total population of the Koskokvim division by the last census was 8,911 , mostly Eskinios. The number of whites and ereoles togrether only amounted to 114 . Thero has been no obstruction to immigration except such as the natural condition of the country presents. Between the Koskokvim and the Nushagrak Rivers the villages of the Indians are so very numerous, and they are so very poor, that they could not exist were it not for tho abundant supply of salmon in the summer, when they lay in a supply for themselves and dogs. They ahsorb the whole or nearly all the salmon of the Koskokvim River, in connection with the other natives, who also go there from the delta of the Yukon River. This leaves nothing in the salmon line for traders. This dense Indian population extends from Kinskokvim Bay far up the river.

The headwaters of the Koskokvim is an unknown and unexplored region.

The country between Koskokvin Bay and Bristol Bay, on the River Togiak, sometimes ealled the Togiak division, is so poor in natural products songht by white men, that it is not visited by whites, and has no trade. The natives there are poor in the extreme. They live in a state of nature of the most primitive character. 
The whole of this division between the Kroskokvim and the Nushagak, including the valleys of those rivers all along the coast of Bering Sea and extending far inland, is so invested in summer with mosquitoes and small poisonous black flies, that their "pernicious inflnence" alone will, nntil some great deliverance comes, forever exclude the white population from that region. Writers on the subject describe these as prodncing "a most terrible and poignant infliction," not only producing the greatest distress, but also fever. Mosquitos torture the Indian dogs to death, and "even drive the bear and deer into the water." The Indiaus protect themselves by annointing their bodies with rancid oil and by wrapping mosquito nets and cloths aronnd their heads and wearing mittens in midsummer. (Vol. VIII, 10th Census United States, 1880 , p. 14, Petroff's Report.)

As to these portions of Alaska we present simple facts, with no desire to underrate any part of the country; but as the Alaska Commercial Company does a small business here, we may rightfully show that its operations have not the slightest influence for good or ill, but that nature has placed here barriers beyond human power.

At all times we have offered facilities to all miners, scientists, explorers, excursionists, traders, missionaries, or immigrants, visiting any part of the country. We have in uumerons instances written to our agents to extend to them every courtesy. We have carried them and their haggage and freight to and from ali points to which our vessels rum; and it has been a pleasure to assist unfortuuate miners on their way home from remote regions to which they have been tempted by overdrawn pictures of promising bonanzas. We present in the appendix (No. 7) a letter of Mr. Lewis Gerstle, when president of this company, written in 1886 , as a specimen of orders given to our agents from time to time, and as evidence of our general treatment of our fellow-citizens who visit any portions of Alaska where we have business and agents.

We have furnished supplies at fair prices, and filled orters and commissions on reasonable terms, acting at times in the character not only of common carriers, but as expressmen. Our business with all persons has heen on a legitimate basis, resting on the establisherl proposition that commercial transactions may be condueted in such a manner as to be of profit and advantage to all engaged.

\section{VII.-Mutilation of Uniten States Coin.}

Governor Swineford, in his report, states of this company :

"In order to more effectually monopolize the trade it has marked and mutilated the coin of the United States, and refused to receive any other from the natives in payment for goods sold them."

As this is made a felony under section 5459, Revised Statutes United States, it should not have been charged except upon the most reliable evidence and after the greatest consideration; yet it is not only utterly and wholly untrue, but this company has done no act in reference to United States coin which its bitterest enemy could distort in to the semblance of this erime. On the contrary, the company has for several years past taken all the mutilated and defaced coin received by it, and from time to time sold it as bullion by weight in San Francisco, at its own loss, for the purpose of getting it out of circulation in Alaska.

If an effectual monopoly of traile in territory of the United States can be effected, and all competition. overcome by defacing and mutilating United States coin, and refusing to receive in business transactions auything except coin so mutilated, it involves a principle of trade and political economy too profound for the comprehension of this company. Certain it is that such a scheme has never been pursued in any country ever heard of till now.

VIII.-As to violations of THE LAw AND Executive ORDers in RELATION TO THE IMPORTATION AND SALE OF BREECH-LOADING FIRE-ARMS BY THE COMPANY'S AGENTS.

If the governor has positive information on the subject of such "flagrant violations," it is his duty to see that the offenders are prosecnter in due course of the criminal law. A conviction in such a case would most satisfactorily establish the fact. As yet, however, no such offense has been charged on the oath of any prosecuting witness, nor have auy proceedings to rindicate the law been initiated. We apprehend that noue will be, for it will be found, in the future as in the past, that when responsibility attaches to the making of charges, and verification is required uuder oath, none will be seen so reckless as to conform to the riecessary forms of law in making accusations.

On a similar charge heretofore made, this company was heard hy this honorable De. partment and honorably acquitted. The papers of the Departmeut will verify this statement. The charge now made is merely a reproduction of the old eharge, without any foundation whatever. 
This company has not, nor has any of its agents, violated the law or any of the oxecutive orders, in relation to the importation or sale of breech-loading fire-arms, or any other fire-arms.

Under the Revised Statutes of the United States, section 1955, this matter is entirely within the control of the President. President Grant, on the 4th February, 18\%0, prohibited the importation and use of fire-arms and ammunition into the islands of St. Paul and St. George, and his order was promnlgated by tho then Secretary of tho Treasury on the 8th February, 18;0. But on the 9th September, 1870, the President modified that order "so as to permit the Alaska Commercial Company to tako a limited quantity of fire-arms and ammunition to said islands, subject to the directions of the revenne officers there and such regulations as tho Secretary may prescribe." On the 10th Soptember, 1870, the Acting Secretary of the Treasury announced the President's order and prescribed the regulations. Theso pertained to the islands of St. Paul and St. Georgo alone.

On the 3d day of July, 1875, the Acting Secretary of the Treasury, with the approval of the President, issued a circular to the collectors of customs, prohibiting the importation of breech-loading rifles and fixed ammunition suitable therefor, into the Torritory of Alaska.

On the 21st of April, 1879, Mr. Sherman, then Secrefary of the Treasury, issued a notice announcing the effect of scetion 1956 of the Revised Statutes, relating to the killing of otter, fur seal, etc., and prohibiting the killing of fur-bearing animals by persons other than natives in Alaska, except those taken by the Alaska Commercial Company under its lease, and jrohibiting the use of fire-arms by the natives in killing otter in the months of May, June, July, August, and September. Ho expressly announced that "whito men, lawfully married to natives and residing in tho Territery, aro considered natives within the meaning of this order."

On the 30 th March, 188:, the Treasury Department, with the approval of the Presillent, issued a further circular to the collectors of eustoms, amending and modifying so much of the instructions of July 3,1875 , as prohibited the importation of breechloadivg rifles, and suitable ammunition therefor, so as to permit "each adult emirrant" who intends to becomo an actual bona-iide settler on the main-land, to ship to the cure of the collector of customs at Sitka, for his own personal protectiou and for hunting game, a rifle and suitable ammunition; also to each actual bona-fide resident of the main-land of Alaska (not including Indians and traders), upon application to the collector and with his approval, to order and ship for personal use such arms and ammunition to his care, not exeeeding one riflo for each such person together with proper ammunition.

On the 21st of March, 1885, the collector of custorns at Sitka addressed the honorablo Secretary of the Treasury a letter npon the subject, requesting an extension of the provisions of the eircular of the 30 th of March, 1852, and recommending, in view of the increasing population aud needs of the Territory, that such authority bo extended so as to permit actual settlers aud residents, not traders or Indians, to import for their own use breech-loading arms and suitable ammunition into all parts of Alaska, including its islands, except tho leased Pribylov islands, aud that the collectors of customs at San Francisco, Port Townsend, and Sitka, respectirely, be empowered to graut the requisite permits. The Hon. Daniel Manning, then Secretary, granted the request, and made the order accordingly in his official letter to the collector at Sitka, dated May 8,1885 , sending and directing circulars to that effect to the respective collectors named. These letters bear date the 12th May, 1885.

On the 4th May, 1887, further regulations were issued by the present honorable Secretary of the Treasury, prohibiting "the importation into said Territory of breechloading rifles and suitablo ammunition therefor, except for the personal use of white settlers or temporary visitors, not traders."

All these orders were approved by the President.

This company has never in the slightest degree violated these several regulations, a fact that wo stand ready to verify and sustain, whenever required by tho Department, by Congress, or by any judicial tribunal.

IX.-As to the Rescission of the Lease; the Abandonuext of tue Leasing Systeit, axd Substitution of a New Plan for the Maxagement of the Islaxds of St. Paul and St. George, Proposed bY Goverxor Swineford.

This recommendation of Governor Swineford is not new, but was before Congress in 15iti, and me beg learo to refer to the report of the Committee of Ways and Means of the IIouse of Representatives, before referred to (Forty-fourth Congress, first session, lieport No. (6:3). and to the action of Congress thereon. This complany has in every respect fulfilled its ageeement, as wo havo fully shown, and there was no ground for reseission of the lease in 18\%6, and there is none now. At the time the lease was about 10) bo anthorized hy Congress there was a great deal of discussion of this policy. Mr. Bontwell, then Secretary of the Treasury, was quite adverso to it, and favored a 
scheme not, mulike that which Governor Swineford now advocates. Congress, however, rejected it, and adopted the present plan.

At the time the Congressional investigation referred to was had the system of leasing had been in force and operation for nearly six years, a period quite amplo enough to develop all its advantages and disadvantages. 'The committee had before it quite a number of witnesses, and among them the unrelenting enemies of the company, who sought to profit by its downfall. Yet the committee found all charges of misconduct and of breach of contract false, and unanimously sustained the wisdom and policy of the system.

The committee, in its conclusion, in speaking of the policy of the law under which the lease was made, said:

"A difference of opinion may be properly entertained on this question. It is quite certain that the Govermment, as such, could not perform this trust. All experience teaches that governments are poor factors, and rarely pursue any industry involving the manufacture and sale of products with success or profit. We think Congress acted wisely in rejecting the recommendation of Mr. Boutwell to condnet this business of seal catching on Government account, and establishing at these islands a humanitarian institution for the care and moral training of the half-savage natives. The contract, as made, was the best disposition of this interest that could have been made, for it is certain that it has resulted in the receipt of very largo revenue to the Treasury, and in an amelioration of the physical aud moral condition of the natives. * * * The annual payment is $\$ 262,500$ tax, and $\$ 55,000$ rental, making an aggregate of $\$ 317,500$ every year. This sum is nearly $4 \frac{1}{2}$ per centum interest ou the original cost of the Territory of Alaska, including the two seal islands referred to. Certainly the Government has no right to reproach itself for a want of mercantile shrewdness in the purcliase of this Territory, nor in the promptadvantages which it has been enabled to obtain from it." (Page 12.)

The testimony of the witnesses before the committee established the wise policy of the act of Conuress, and the concurring testimony of the various agents of the Government and other officers is to the same effect.

We also respectfully refer to the other statements to the same effect contained in the Appendix.

We have in our possession the statements of a number of gentlemen engaged in various occupations, who have promptly given their views of our operations in Alaska and of the sections of the country with which they are familiar. This reply is already so extended that we will present in the Appendix only a fow of these as specimens. They are by no means exhaustive of the evidence which can be presented. To these, however, emanating as they do from gentlemen of the highest character in the business community and official circles, and entirely disinterested, we respectfully invite your earnest attention. The utmost reliance also is due to the letter of the Right Reverend Edmund de Schweinitz, bishop of the Moravian Church, a copy of which we also append (Appendix No. 11). The missionaries of that church have penetrated to various points in the interior of Alaska, and frequently report very fully to tho bishop as to all matters occurring in the country.

\section{X.-Conclusion.}

The violent assanlts and severe charges against the Alaska Conmercial Company in $\mathbf{1 8 7 6}$ were so effective as to induce the House of Representatives, as we have seen, to refer the matter for investigation to the Committee of Ways and Heans, and yet it appeared at last that all the complaints made were traced to the "persevering efforts" of a "disappointed bideler for the contract," who even assailed the official integrity of Mr. Boutwell, Secretary of the Treasury. Yet, as the committee announced, "he failed to state any facts which could weaken a confidence in the integrity with which the lessees had performed their agreement." It there appeared that the whole matter was the result of a conspiracy concocted in San Francisco, and carried out by the dissemination of false charges and libels through the medium of memorials, circulars, pamphlets, and newspapers.

The conspirators fiually fell out, and the very one who wrote all the scurrilous articles confessed it, and himself exposed the scheine.

These false charges, though so thoroughly unsupported before the committeo referred to, have from time to time been renewed, yet every time the honorable Secretary has ordered an investigation or report upon the subject by an agent or Government officer the charges have proved equally unfounded.

Our "operations" have not only been open to the view of the world, but have been under the inmediate observation of the agents of the Treasury Department and other officers of the Government at the immediate points of our operations. In their superintendence of our special transactions and personal observation of our general conduct for over seventeen years they bave found no cause of complaint. Their official reports to the Government impute to us ao blame. The charges now made are asper- 
sions from unknown and irrespousible sources, to which the governor has given his facile attention. A specification of these alone does, not seem to have been satisfactory to guberuatorial ideas of duty, lut they are supplemented by fierce denunciations colminating in the exhibition of this company as the devil-fish, so graphically described in another work of fiction by the celebrated Victor Hugo.

We are at a loss to muderstand how Governor Swineford could have been so de. ceived as to give credence to these old slanders, exhumed again for a further post mortem examination. It is curious, too, that whilst the exploded conspiracy just referred to called itself the "Anti-Monopoly Association," and purported to give an aceount of the "wrongs of Alaska," so now the goveruor's report comes again with the old outcry against mozopoly and again sonuds the refrain of the "wrougs of Alaska." History repeats itself. The violence of the attaclis seems to be in proportion to the woakuess of the evidence. The monopoly which the Alaska Commercial Company has had has been the monopoly which the temant eujoys of the premises leased from his landlord, at a large rental. The wrougs it has done Alaska have been the preservation and protection of its greatest natural resomrce-the fur-seal industry-and the furnishing of employment to a large number of its native population on better terms than elsewhere prevails. Wo have fulfilled our obligations to the Goverument and to the natives, and have observed the laws and the regulations of the Treasury Department.

In view, therefore, of these facts and our own conscionsness of rectitude in all of oux transactions, we believe that the confidence which has heretofore been reposed in us, and the approving judgment you have given in the past, will continue luring the entire time of our official relations.

Very respectfully,

The Alaska Commercial Company.

By Louis SLoss, President.

APPENDIX.

No. 1.

EXTRACT OF REPORT BY LIEUT. JOHN E. LUTZ, OF THE U. S. R. M., TO CAPT. M. A. HEALY, COMMANDING THE REVENUE STEAMER CORWIN.

\section{U. S. Revenue Marine Schooner Adele,} San Francisco, Cal., October 6, 1884.

SIR: I have the honor to submit the following report. In obedience to your orders of May 2:2, a copy of which is herewith transmitted, I landed from the Corwin at St. Paul Island June 1.

I found the affairs of this island in excellent condition, wholesome sauitary regula tions are enforeed, and unusually good health has prevailed during the past year. All of the natives are now living, rent free, in comfortable frame houses, which have been erected by the lessees of the islaud, in place of the damp and unhealthy "barrabhies" in which these people formerly dwelt. Too much can not bo said in commendation of the manner in which the Alaska Commercial Compans, the present lessees of the island, fulfill faithfully all the terms of their contract with the Government. The method of taking seal has been reduced to an admirable system, and every precuntion is taken to prevent a diminution of seal life.

The natives are treated exceedingly well, and none of them are permitted to remain in want of the necessaries of life. They are not required to work, although such as desire are given remunerative employment. By reason of the high price allowed for the labor of skinning seals, these people are able to earu in less than two months a sum amply sufficient to maintain them during the entiro year-a sum much larger, in faet, than the average amount received by the laboring men in the United States for a year's work. In addition to this, they are supplied free of charge with a quantity of fuel, salt meat, condensed milk, etc., while they havo no rent to pay.

In religion, they adhere firmly to the tenets of the Greek Church. While this church doubtless exercises a good influence on these people spiritualls, it drains their pockets systematically to the extent of some thousands of dollars anumally, not for the church at St. Paul alone hut for the benefit of the ehurch authorities in Sau Francisco, to whom the major portion is seut.

Like all other primitive people, these natives possess an inorlinate longing for intoxicating liguors of any discription. All means of gratifing that desire are now denied them, fortunately. They are allowed neither sugar nor hops and can not, 
therefore, make quass. Gambling is their favorite pastime, and is a habit which can not be checked. No bad effects are perceptible, however, as the stakes are usually small. The company retains to the eredit of every mau a sum sufficient to buy provisions for their families until such time as they can earn more on the seal field, thus preventing the men from squandering all of their money and leaving their families destitute. They would usually invest the whole of their earning in jellies, preserves, sweet crackers, silks, etc., but the company will sell them these articles in limited quantities, although encouraging them to buy useful and necessary supplies instead.

By precept and example on the part of the Government agents and the employes of the company, these natives are encouraged to lead au upright and industrious life. The welfare of these people and the interests of the Government are well taken $c$ of by Mr. H. A. Glidden, special agent in charge of the seal islands.

I am, sir, very respectfully, your obedient servant,

JoHN E. LuTz,

Third Lieutenant, U.S. R. M.

Capt. M. A. Healy, Commanding Revenue Steamer Corwin.

No. 2.

EXTRACT PROM REPORT OF CAPT, M. A. HEALY, COMMANDING REVENCE STEAMER CORWIN, TO HON, DANIEL MANNING, SECRETARY OF THE TREASURY.

\section{U. S. Revenug Marine Steamer Corwin, San Francisco, Cal., 1885.}

SIR: I have the honor to submit the following report of the Alaskan and Arctic cruise of the United States revenue steamer Corwin, under my command, during the summer of 1885 .

${ }^{*}$ * * Since the Territory of Alaska was ceded to the United States no officer of the Government has been on official duty in Alaskan waters more than I, ny first duty having been in 1868. From personal observations, covering most of the time from that date to the present year, I cau truly say that the condition of the natives has improved in a remarkable degree since the Alaska Commereial Company has obtained the lease of that portion of the country from the Government.

Before the company assumed control of the seal islands the natives were but little in advance of the Indians of Alaska.

Their habitations formerly were inud huts and their food and clothing such only as the country afforded. Edueation, even of the most primitave nature, was unknown and undreamed of, and they being satisfied to live from day to day, gave no thought whatever of the morrow.

Their huts have now given place to comfortable frame houses, giving them an air almost of luxurianee, when compared with their former abodes.

Carpets, furniture, and the ordinary comforts of the middle classes in the United States form the rule of the furnishings of their houses. In dress they border on the extravagant, silks with the women and broadcloths with the men being not infrequent, while many of the latter have neat sums of money placed to their credit.

Sehools are maintained on the islands, and attendanee at them is compulsory.

A church costing $\$ 3,000$ was ereeted on St. Paul Island (the mony having been advanced by the Alaska Commercial Company), and is now almost clear of debt. A doctor is employed on each of the islands of St. Paul and St. George and Oonalaska, solely for the care of the natives.

The general air of cleanliness, happiness, comfort, and prosperity attest in indisputable terms that the Alaska Commercial Company bave and do fulfill their obligations towards those people in a most serupulous and conscientions manuer, and the result might, I am sure, excite the wonder and envy of many missionaries laboring among a similar class.

I am, very respectfully, your obedient servant,

M. A. Healy, Captain, U. S. R. $M$.

Hon. Daniel Manning, Secretary of the Treasury, Washington, D. C. 
No. 3.

LETTER OF LOUIS SLOSS, PRESIDENT OF THE ALASKA COMMERCIAL COMPANY, TO MR. GEORGE R. TINGLE, UNITED STATES TREASURY AGENT RESIDING AT ST. PAUL, ALASKA.

San Francisco, December 5, 1887.

DeAr Sir: Various charges have recently been made against the Alaska Commercial Company in reference to its operations in Alaska, as well uuder its lease of tho islands of st. Paul and St. George as generally in other parts of the country not embraced in the lease. Among other charges are:

1. That it has ruduced the native population to a condition of helpless dependence, if not slavery, and that its oppression and robbery of the natives are notorious.

2. That it compels acceptance by the natives on pain of starvation of such begarly prices as manages invariably to keep them in debt and at its mercy.

3. That to effect a monopoly of the trade it has marked and mutilated the United States coin and refused to receive any other from the natives in payment of goods sold them.

4. That it has boyeotted and driven from the islands Government officers who refused to do the bidding of its agents.

5. That it is hostile to the settloment of the country, discourages immigration and the investment of capital in the development of its great natural resources.

6. That to the pernicious induence of the Alaska Commercial Company is due the fact that Alaska is not to-day largely populated with an industrious and enterprising people, and that additional millions are not invested in the country.

7. That it has committed flagrant violations of the law and executive orders in relation to the importation and sale of breech-loaking fire-arms by its agonts.

8. That it has not kept its agreement with the Government as to tho edueation of the young natives in English.

9. The lease by the Government to the Alaska Commercial Company should be rescinded, if possible, and if not, it should not be renewed.

As the agent of the Goverument sent to the islands and charged with the mavagement of the seal. fisheries in Alaska, and also the performance of other duties assigned to you by the honorable Secretary of the Treasury, you have had an opportunity of learning what truth there may be in the various charges above specified.

We should be much pleased to have you state the result of your own observation and such information from reliable sources as you may havo as to the company's operations and transactions on the Aleutran chain and the mainland, as well as upon the islands of St. Paul and St. George. Also what, in your opinion, would be the result of the abolition of the present leasing system and the substitution in its place of a plan in which the Government should take the place of the lessees on the two islands named ; that the natives alone should kill the fur seals, and that the skins should then be sold by the natives in open market in presence of the Government agent, who should collect a tax of $\$ 5$ on each skin sold.

As early a reply as your personal convonience will enable you to mako will be greatly appreciated.

Very respectfully and truly yours,

Mr. George R. 'IINGLe.

Louis SLoss,

President of the Alaska Commercial Company.

No. 4.

REPLY OF MR. GEORGE R. TINGLE, UNITED STATES TREASURY AGENT AT ST. PAUL, ALASKA, TO LOUIS SLOSS, PRESIDENT ALASKA COMMERCIAL COMPANY.

San Francisco, December 7, 1887.

Sin: Your letter of the 5 th instant was duly received, informing me that, "various charges have recently been made against the Alaska Comnorcial Company in referenee to its operations in Alaska, as well under its lease of the islands of St. Paul and St. George as generally in other parts of the eountry not embraced in the lease." Tou ask me to state the "result of my observations and such reliable information as I may have as to the company's operations in Alaska."

1 mat state that my opportunities as Treasury agent in charge of the fur-seal islands since the spring of 188.5, and interconrse with officers of the revoune-marine service in Alaskan waters, and acquaintance with the white peoplo and natives at various stations in the Territory, have been such as to enable me to speak advisedly 
and answer from personal knowledge the several questions you have propounded to me.

No. 1. "That it (Alaska Commercial Company) has redueed the native population to a condition of helpless dependence, if not slavery, and that its oppression and robbery of the natives are notorious."

In answer to this it might be sufticient to say the entire charge is false, but considering the gravity of the charges made against your company, I will treat them more at length. As to the first part of the charge, I have to say that in conversation with old Kerick Buterin, the most intelligent native on the island of St. Paul, and Antone Mellovedove, a bright, intelligent, young man, son of the old governor of the island under Russian rule, I learned that before the lease of the island to the Alaska Commercial Company the natives lived in miserable buts balf under ground, some of which are still standing unoccupied. They received from the Russians 10 cents a day for their labor in taking and curing seal skins, and packing on their backs was the only mode of collecting the skins and delivering then to the boats. Old Kerick has frequently told me he was the highest salaried man among the natives, being head carpenter, and the most be ever received from the Russians was $\$ 60$ per annum. The books in the Treasury agent's office on the island show his annual pay for sealing alone siuce the Alaska Commercial Company took charge to be over $\$ 500$ per annuii, and in addition the company pay him a monthly salary of $\$ 10$ for looking after the small boats, etc.; they also made him a present of a frame cottage, in which he has for years lived with his family. If this be dependence aud slavery, then the charge is true.

This man's case fairly represents the condition of the whole population on the two islands.

Under the lease the company is not required to furnish the natives houses, physiciaus, medicines, etc., free, yet it is a fact that comfortable frame houses were built and given rent free as fast as the material could be transported after the lease was made, and the natives were lifted from a condition of slavery aud privation, by jour company's generosity, to one of free American citizenship and comfort; to them, luxury. I have never seen greater care and more considerate treatment bestowed on any people in the States than the compauy's doctors show in ministering to the natives on the fur-seal islands as well as at Oonalaska; and that the natives on the main-land may have the benefit of a physician they send one every spring on the first vessel visiting the coast line, to the eastward of Oonalaska and north as far as St. Michaels. All this is a free-will offering to the uatives. The natives on the seal islands complete their year's work in less than three months, for which they receive in cash from your company over $\$ 500$ to the man; in addition you contribute to them, free, physicians, medicines, coal, salt salmon, salt to cure blubber, eight months' schooling annually, and comfortable houses, and they have fresh seal meat as long as the seals remain, which is nive montlis each year. The natives have absolutely nothing to do for nine months of the year, and have now on deposit drawing 4 per cent. interest, \$64,732.11. If this is "dependence and slavery," then the parties making charge No. 1 should turn their attention to any of the great cities of the highiy civilized States East, and reform the coudition of the laboring classes who toil for their employers ten hours cach day for tuelve months a year, receiving therefor less money than you pay the natives for three months' work, whilst the poor white laborer gets nothing for the comfort of his family except what he can pay out of his hard-earned wages.

I have neverknown an instance of abuse of natives by your agents or employés, and when the Treasury agent has occasion to reprimand a uative, no greater punishment ean be held over them than to threaten them with transportation to Sitka, where they could not get sour company to work for.

As to the second clause of No. 1, the charge of "oppression and robbery of the natives are notorious."

It must be a most malicious and reckless man who would give expression to so base a falsehood. Your compauy maintains a store on each of the seal islands, well stocked with goots such as are found in any well-regulated merchandise store; the goods are sold at reasonable prices, quite as low as the same goods could be bought at retail in the cities of this eoast. Your local agents each year submit to my inspection, if desired, your invoices, aud by close observation in the store and familiarity with prices eharged I have ample opportunity of knowing that your trading with Alaska natives is entirely just and fair, as much so as if opposition stores were established alongside of yours.

No. 2. "That it compels acceptance by the natives, on pain of starvation, of such beggarly prices as manages invariably to keep them in debt and at its mercy."

The natives on the fur-seal islands have but little to sell; the company, however, buy at fair prices for eash or goods anything they may bave to offer, whilst on the Aleutian chain the company send out from Oonalaska, in their vessels, huntiug parties, and place them on the best hunting grounds, free of any cost to them, charging only each native with his supply of provisions; at the close of the season they are returned to their homes in the same manuer, and each hunter is credited with his 
eatch, not at the "beggarly prices," ete., but the same price they are offered by the numerons white hunters who freely hunt and trade in Alaskan waters. In many cases the natives do not catch enough to pay in full the book account against them in the company's store, whilst the more fortunate hunter will keep square and always have a comfortable balance in the hands of the company, bearing interest. In fact, the natives, as a class, in Alaska, are better treated and more fiberally dealt with by your company than any set of laboring men I have ever known auswere, and my experience has been extensive. It is, to my own personal knowledge, the practice of your company's ageuts to see that the natives' actual wants are supplied, with or without money; and I have yet the first native to complain to me of oppression or ill-treatment on the part of any of the company's employés.

No. 3. "That to effect a monopoly of the trade, it has marked and mutilated the United States coin, and refused to receive any other from the natives, in payment of goods sold them."

The Alaska Commercial Company have by contract with the Goverument a monopoly of the fur-seal trade in Beriug Sea. The islands of St. Paul and St. George being a Government reservation, no person outside of Government officials and employés of the lessees are allowed, under regulations of the Secretary of the Treasury, to land on the islands. It is, however, within the power of the Secretary to grant permits for auy number of citizens he may see proper to establish stores on the furseal islauds, and supply the natives with goods, if they wish to experiment and take chances for profit. It is my opinion, however, the "monopoly" would retain the custom of the natives as it has their confidence and respect. Ontside of the seal islands the whole of Alaska is open to the free occupancy of any person courageous enough to establish himself in that vast field for "enterprise and eapital." "There are no restrictions except as provided by act of Congress. A store, or a dozen, may be established anywhere in Alaska alongside of the Alaska Compauy's stores and compete for business, as do the stores in this or any other city. The cry of monopoly comes from those who would like to possess the lease your company holds, and it is all false as to the defacing of United States coin. I have no knowledge that it has been defaced by any person for the purposes of trade. The cireulating wedium is golr and silver in Alaska. The usual punching and marking of coins is indulged in by natives and white people as well in Alaska as elsewhere. I saw a collection of such coins this summer in the hands of your agent, Dr. H. H. McIntyre, which was the accumulation of years at your various stations. The amount, though not large, was shipped to the city for sale as mutilated coin. I have never known your agents in Alaska to deface coin in any way.

No. 4. "That it has boycotted and driven from the islands Government officers who refused to do the bidding of its agents."

This charge is absolutely untrue, having no foundation whatever sinee I have been connected with the service. What was done prior to my coming to the islands, I cau only judge from the practice and deportment of your agents since $I$ have been in charge, and also from the records and journals on file in the Government offices on St. Panl and St. George. I have failed to find recorded by any Treasury agent who preceded mo in office the slightest complaint against the company's agents for interference with them in the discharge of their duty; there is no record of any complaints having ever been made against the compans's agents by a Government agent. I therefore have no hesitation in saying that before any tribunal in the land no such charge could be proven.

No. 5. "That it is hostile to the settlement of the country, discourages immigration and the investment of capital in the development of its great natural resources."

Your company, if hostile to the settlement of the country, takes a queer way of showing its hostility, for on every trip of your steamer St. Paul in the spring, when I have been a passenger, she has been crowded with persons, their luggaye, and even some with their store-goods going up to establigh themselves in the Territory.

know it has been and is the practice of your company to carry any person wishing to go to Alaska on any of sour vessels, whether for the purpose of prospectingr or locating. Aud just here I will say that the natives are carried by your vessels from place to place when desiring to visit, or for any purpose, free of any charge.

"The great natural resources" spoken of havo never yet been discovered by mo; it is true in southeastern Alaska, as I am told, there are some " natural resources."

Outside of that and the fur-seal islauds they do not exist. The fish interests will be of importance when devoloped. This industry is open to the world, and no impediment is placed in the way by your compauy, uor conld it, if so disposed, monfopolize the catch of salmon and coll-fish covering a coast-line of 3,000 miles within the boundaries of the salmon grouuds. Capital is as free to seek investment 1 Alaska as in any State or Territory of the United States, but I would advese any one contemplating investing to spend a summer on one of your vessels visiting your tracling stations along the coast and on the Aleutian chaiv, which, I feel sure, would convince the most venturesome that the "great uatural resources" possessed no attractions for additional capital or enterprise. 
No 6. "That to the pernicious influence of the Alaska Commercial Company is due the fact that Alaska is sot to-day largely populated with an industrious and enterprising people and that additional millions are not invested in the country."

My opportunities for observing the condition of the natives and their relations to your company have been the very best; and, determined that the department of the Govermment I have the honor to represent should be placed in possession of all the facts through my official reports, I would not have hesitated to arraign your company before the Secretary of the Treasury had I found auy violation of the law; there conlil be no acts of your company's agents or employés tending to a violation of the law which conld have escaped my notice, as I think I have been reasonably vigilant, and my official reports do not record any reflections whatever on your company. Indeed, you have in your dealings with the natives more than performed your part of the contract with the Government.

Instead of preventing the influx of "industrious and enterprising people," and the "investment of additional millions" in Alaska, you have shown to the people of the United States, by jour enterprise and nerve and great outlay of mouey necessary to maintain a footing on those rigorous shores and rivers penetrating the interior of a country scarcely inhabitable, that you, at least, had faith in the ultimate realization of remunerative returns. This same Alaska is open to all eomers, with no power of yours to prevent them doing so. Yet how few have availeul thenselves of the "great resources" or been stimulated by your example and enterprise. I consider your company, with its just mode of dealing with the natives, the greatest civilizer and benefactor Alaska has ever had.

No. 7. "That it has committed flagrant violations of the law and executive orders in relation to the importation and sale of breech-loading fire-arms by its agents."

As to this charge, I have only to say that I know of no such violation by your company's agents, but I do consider the law a dead letter when white traders, whalers, and Sitka merchants sell the natives all the breech-loading fire-arms they want. I do not see why jour company should not obtain a permit from the Secretary to do the same thing. The law should be so amended as to place the uative on the same footing with the white hunter in the matter of fire-arms, aud I so recommend in my report to the Department.

No. 8. "That it has not kept its agreement with the Government as to the education of the young natives in English."

The company's agreement is for eight months' schooling annually in English on each of the islands of St. Paul and St. George. My official report, on file in the Department at Washington, will show that this stipulation in the agreement has each year been satisfactorily performed; and ontside of the agreement, I know your company maintains a flourishing school at Oonalaska. Your teachers on the islands under my supervision take a great interest in their scholars. During the winter of 1885-'86 I was a daily visitor of the school taught by Mr. Gray on St. Paul. Average attendance was fifty-five, and with pleasure I bear witness to his faithfulness.

No. 9. "That the lease by the Government to the Alaska Commercial Company should be rescinded, if possible, and if not, it should not be renewed."

There has been nothing done by your company since my official connection with the fur-seal islands which would in the slightest degree warrant the Government in taking steps to vacate the lease with you, and from the reeords in my ofiice on the islands; which I have searched very closely from the commencement of your operatious thereon, I have failed to find any clue to fraud, and may add that my thorough investigations during the long winter months spent upou the islands were iu pursuance of verbal instructions from the then First Assistant Secretary Fairchild, to "look closely into all the past operations of the company." This parting injunction was prompted by the talk of those not informed as to your operatious, which, like the charges you submit to me, have no foundation in fact to stand on.

Having fully answered your question, I will say in conclusion, in reply to the last paragraph of your letter, that so far as I am familiar with your "operatious aud transactions" on the main-land and Aleutian chain, they are aud have always been characterized by fair dealing, liberality, and humanity; and the abolition of the present system of leasing the fur-seal islands and taking of the seal-skins by the nittives and selling them in open market, with a Treasury agent to "stand by and collect $\$ 5$ per skin "tax, is absurd and impracticable, and shows the mind that could conceive such a plan to be wholly unfit to grasp and deal with the fur-seal question. To protect and perpetuate the Gorernment's vast seal property it must be run as a monopoly, whether that mouopoly is operated by the Goverument or a corporation of American citizens or one individual. Otherwise the seals would soon be exterminated and the valuable fur lost to the people of the world.

I am, very respectfully,

Geo. R. Tingle.

Louis Sloss, Esq., President Alaska Commercial Company. 
No, 5.

STATEMENT OF LIABILITIES OF THE ALASKA COMMERCIAL COMPANY TO THE NATIVES-SHOWING THE SCRPLUS EARNINGS OF THE LATTER.

\section{At St, Paul Island on August 1, 1887.}

Artarnonoff, Kerick.

$\$ 2,804.44$

Arkosheft, Kerick's widlow

290.00

Arkosheff, Arseney.

443. 03

Austegoff, Peter..

500.00

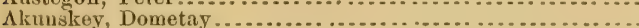

621.22

Butrin, Kerick

Butrin, Harp

$3,295.90$

614. 60

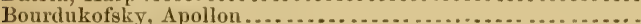

Bogilanoti, Nicoli

786.56

243.59

Emauoff, George . . . . . . . . . . . . . . . . . . . . . . . . . . . . .

Fratis, John...

Gromoff, Nicoli.

57 i). 75

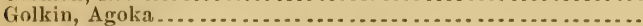

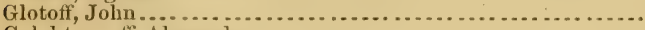

Golokteonoff, Alexander.

Haberoft, Paul.

Hopoff, John .

$2,444.29$

507.13

556.24

385. 17

212. 99

544.57

444. 27

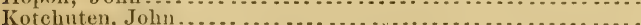

Kotchuten, Jacob

Kotchuten, Eupheme

Kozeroff

Kozeroft, Paul

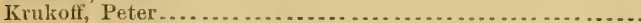

Krukoft, Nicoli

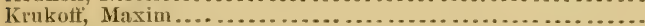

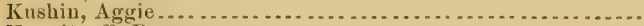

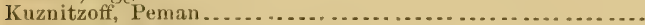

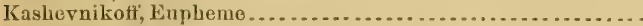

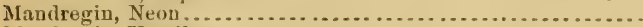

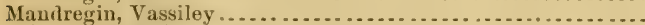

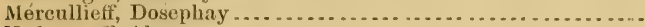

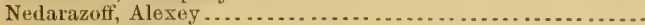

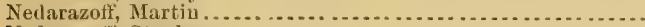

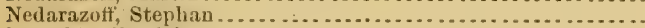

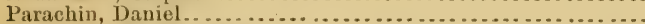

Pahomoff, Joseph's widow . . . . . . . . . . . . . . . . . . . .

Pankofi, Portin.

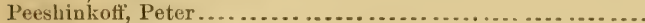

Popoff, Martin's widow . ..................................

Popoff, Matfay .............................................

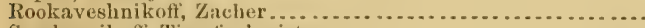

Serebrenikoff, Timotiay's sister.

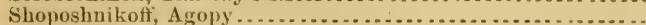

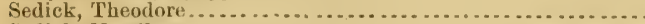

Sediek, Nassiley .... . . . . . . . . . . . . . . . . . . . . . . . . . . . .

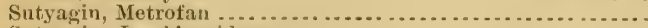

Sutyagin, Jacob's widow.

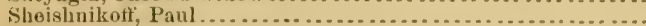

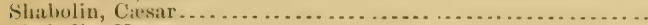

Shabolin, Necon ......................................

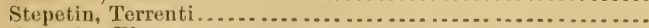

Stepetin, Elary...

Stepetin, Darofay

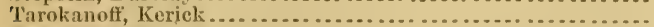

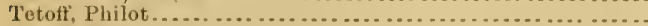

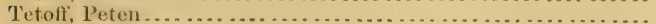

Tetoff, Neon ............

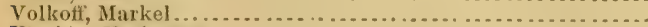

Viutkin, Yeolampy . . . . . . . . . . . . . . . . . . . . . . .

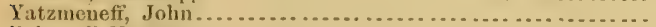

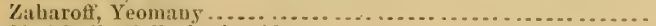

Shaishuikotf, Zachar's widow . . . . . . . . . . . . . . . . . . . .

4-4. 70

613. 60

500.89

616.22

619. 23

558. $\div 4$

575. 90

553. 90

446.03

611. 72

1, 079.22

55:3. 74

619. 60

328. 16

616. 60

526. 15

616. 60

559. 90

564. 74

765. 72

499. 89

560.90

285. 79

504. 89

616. 22

289. 00

269. 31

615.60

579.74

443. 03

288.00

4, 366,36

$5: 37.57$

$3-9.17$

738. 60

583.75

368. 70

556. 74

617. 60

ธ)1. 89

355.17

1, 519.39

(ilii. 60

(j21.22

503.56

264.62 
Melovidoff, Madam A.

Volkoff, Ellen $\$ 3,404,99$

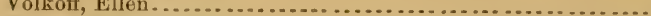

Vicooloff, Avelotia ... . . . . . . . . . . . . . . . . . . . . . . . . .

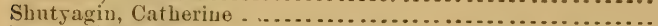

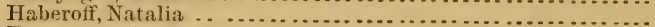

Terentova, Anna. . . . . .

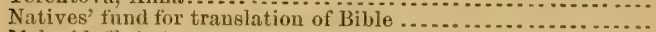

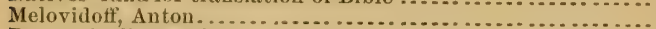

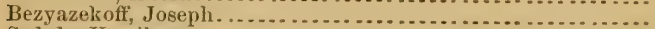

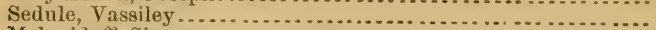

Melovidoff, Simeon.

492.00

30.00

$23 \% .93$

27.58

25.62

$1,876.56$

678. 60

520.74

520.74

462. 89

At St. George Island on August 1, 1887.

Golanin, Bores

Golanin, Gavril.

$\$ 352.14$

225. 23

406.88

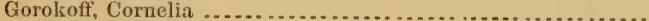

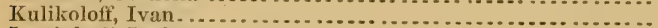

Lestinkoff, Inokenty

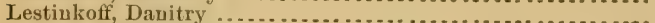

Merculieff, Sourvestian

Merculieff, Kouprian.

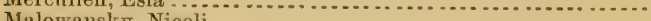

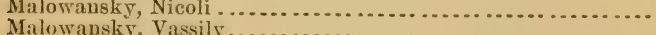

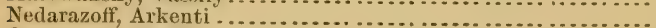

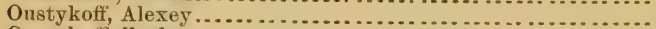

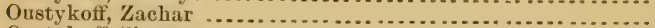

Oustykoff, Simeon . . . . . . . . . . .

Philemonoff, Simeon.

Philemonoff, Eoff .........

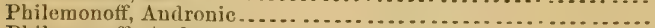

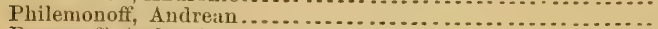

Resanzoff, Andronic ..... . . . . . . . . . .

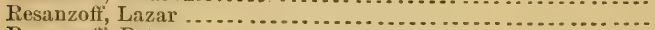

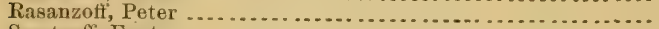

Swetzoff, Eustan . . . .

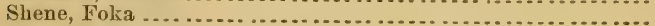

Vikoloff, Platon... . . . . . . . . . .

Vikoloff, Samnel's widow...

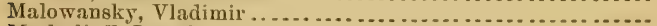

Merkulieff, Joseph . . . . . .

Leshanoff, Stepan.

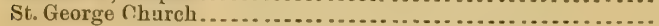

220.88

$1,968.50$

635.31

457.18

628.42

352. 61

225.00

2i1. 16

463.38

$40 \% .06$

350.07

211. 24

406. 79

407. 13

350.61

211.09

349.96

352. 61

407. 29

352.46

407. 62

402. 89

194.88

109. 42

109.42

109. 42

687.40

At Oonalaska Staton on Jandary $1,1887$.

Sheishnikoft, Alexander

$\$ 2,131,00$

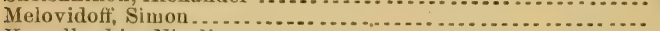

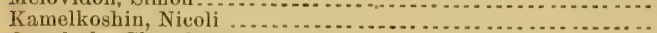

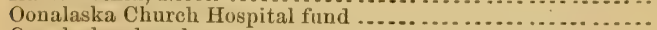

Oonalaska chureh ......................................

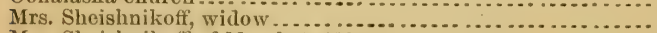

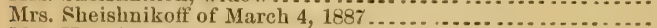

Mrs. Hennig, widow

$1,059.48$

1, 552.45

$1,409.33$

777. 06

$3,953.45$

$2,570.26$

$2,579.66$

$16,033.69$

At Kodiak Station on April 1, 1887.

Demedoff; Feodon

Famin, Nicoli

$\$ 2,692.75$

$1,893.60$

65:. 10

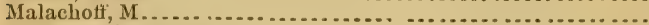

Debrowalsky, Peter .........

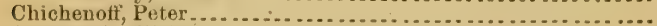

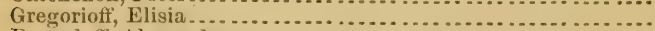

Demedoff, Alexander.

Stafieffi, W

Pawloff, Nicolai.

1, 082.90

2,590.00

761.98

399. 84

$1,695.88$

1, 588.43 
No. 6.

STATEMENT OF MR. EDWARD SCHIEFFELIN.

I reside in Alameda, Cal., and am engaged in prospecting for mines. In 1882 a small company of persons, of whom I was one, concluded to make an expedition to the Yukon River in Alaska, for the purpose of prospecting for mines. I had had some experience in that business and had heard encouraging accounts of that country. We fitted out our expedition in San Francisco, and went on a schooner, chartered tor the purpose, with our own supplies of all we deemed most desirable for the adventure. We carried up ou the schooner a small steamer, so that we could tranship our supplies at St. Michaels, and by this means reach the supposed mining regions, which were our ultimate destination. Whilst in San Francisco, before our departure, I accidentally met in a place of business Mr. Lew is Gerstle, president of the Alaska Commercial Company. On being introduced to him, and after a brief conversation about my intended excursion, he very promptly offered me any assistance I might desire, and gave me a letter of introduction and credit to the agents of that company in Alaska. This letter instructed the agents to advise and assist me in every way. I found the agents of the company very kind and obliging. In every respect their conduct and treatment was all that one gentleman could expect of another. They expressed great cordiality and offered every encouragement to me to advance on my expedition and to remain in the country.

On the way up we stopped a short time at Oonalaska and abont a week at St. Michaels. At the latter place we transferred part of our supplies to the small steamer and embarked for the Yukon River. I remained in the interior all that winter of 1882-'83. During that time I visited various stations on the Yukon and went back and forth to various points, prospecting for mines. After a pretty thorough exploration I came to the conclusion that the prospects were too poor to justify iny sojourn any longer and I abandoned the country, returning to San Francisco in 1883 . On the Yukon I found very few mines and ouly a few traders. I found in all places at which I stopped or visited that the relations between the Alaska Commercial Company and the inhabitants were of the most friendly nature. I heard no complaints and had no reason to suspect the existence of any unkind feeling against the company. I purchased some supplies from the company's agents at most reasonable rates, and found them ready to supply all others on the same terms. They treated strangers with great kindness and welcomed them to the country. All their dealings were conducted on a scale of fairness and liberality. I returned from St. Michaels to San Francisco on the U. S. revenue steamer Corwin, commanded by Captain Healy. I have never been in the employment of the Alaska Commercial Company.

ED. SCHIEFFELIN.

Sart Francisco, December, 1887.

No. 7.

LETTER OF INSTRUCTION OF LEWIS GERSTLI, PRESIDENT ALASKA COMIERCIAL COMPANY, TO M. LORENZ, AGENT A'T ST. MICHAELS.

San Francisco, May 7, 1886.

DEAlr Sir: We have been informed that a large number of miners have already started to the Yukon and Stewart River mines, aud it is probable that many others will be attracted to that section of the Territory in consequence of the supposed existence of rich diggings in that district. Considering that the company's station at St. Michaels is the nearest source of supply, an extra amount of groceries and provisions have been sent to you to meet the possible demands likely to be made upon you during the coming winter. It must not be understood, however, that the shipment referred to is made for the purpose of realizing profits bejond the regular schednle of prices heretofore established; our object is to simply avoid auy possible suffering which the large increase of population insufficiently provided with articles of food might occasion. Hence you are directed to store the supplies as a reserve to meet the probable contingency herein indicated, and in that case to dispose of the same to actual customers only and in such quantities as will enable you to relievo the wauts aud necessities of each and every person that may have occasion to ask for it.

In this connection we deem it particularly necessary to say to jou that traders in the employ of the company, or such others as draw their supulies from the stores of the company, doing business on their own account, must not be permitter to charge excessive profits, otherwise all business relations with such parties must 
cease, as the company can not permit itself to be made an instrument of oppression toward any one that they may come in contact with.

It is useless to acid that, in case of absolute poverty and want, the person or persons placed in that unfortunate position should be promptly furnished with the ineans of subsistence without pay, simply roporting such facts at your earliest convenience to the home office.

Asking jour strict compliance with the foregoing instructions, which we hope will be carried ont with due discretion on your part, I am, with kind regards to yourself and Mrs. Lorenz,

Yours, truly,

LEWIS GERSTLE, President.

\section{Mr. M. LoRenz,} Agent, St. Michaels, Alaska.

No. 8.

EXTRACTS FROM THE REPORT OF HENRY W. ELLIOTT TO THE SUPERINTENDFNT OF CENSUS, FROM VOL. VII, TENTH CENSUS UNITED STATES, 1880, PP. 26, 27.

It will be remembered that at the time of the question of leasing the islands was before Congress wuch opposition to the proposal was made, on several grounds, by two elasses, one of which argued against a "monopoly," the other urging that the Government itself would realize more by taking the whole management of the business into its own hands. At that time far away from Washington, in the Rocky Mountains, I do not know what arguments were used in the committee rooms or who made them; but sivce my careful and prolonged study of the subject on the ground itself, and of the trade and its condition, $I$ am now satisfied that the act of June, 1870, directing the Secretary of the Treasury to lease the seal islands of Alaska to the highest bidder, under the existing conditions and qualifications, did the best aud the only correct and profitable thing that could have been done in the matter, both with regard to the preservation of the seal life in its original integrity and the pecuniary advantage of the Treasury itself. To make this statement perfectly clear the following facts by way of illustration should be presented:

First. When the Government took possession of these interests in 1868 and 1869 the gross value of a seal skin laid down in the best market at London was less in some instances and in others but slightly above the present tax and royalty paid upon it by the Alaska Commercial Company.

Second. Through the action of the intelligent business men who took the contract from the Government, in stinulating and encouraging the dressers of the raw material and in taking sodulous eare that nothing but good skins should leave the islands, and in combination with leaders of fashion abroad, the demand for the fur by this manipulation and management has been wonderfully increased.

Third. As matters now stand the greatest and best interests of the lessees are identical with the Goverument; what injures one instantly injures the other. In other words, both strive to guard against anything that shall interfere with the preservation of the seal life in its original integrity, and both having it to their interest, if possible, to increase that life; if the lessees had it in their power, which they certainly have not, to ruin these interests by a for seasons of rapacity, they are so bouded and so environed that prudence prevents it.

Fourth. The frequent changes in the office of the Secretary of the Treasury, who has very properly the absolute control of the business as it stauds, do not permit upon his part that close, careful serutiny which is exercised by the lessees, who, unlike him, have but their nue purpose to carry out. The character of the leading men among them is enough to assure the public that the business is in responsible hands, and in the care of persons who will use every effort for its preservation and perpetuation, as it is so plainly their best end to serve. Another great obstacle to the success of the business, if controlled entirely by the Government, would be encountered in disposing of the skins after they had been brought down from the islands. It wonld not do to sell them up there to the highest bidder, since that wonld license the sailing of a thousand ships to be present at the sale. The rattling of their anchor chains, and the seraping of their keels on the beaches of the two little islands wonld alone drive every seal away and over to the Russian grounds iu a remarkably short space of time. The Government would thereforeneed to offer them at public anction in this country, and it wonld be simply history repeating itself, the Government would be at the mercy of any well-organized combination of huyers. The agents conducting the sale could not counteract the effect of such a combination as can the agents of a privatocor- 
poration, who may look after their interest in all the markets of the world in their own time and in their own way, according to the exigeneies of the season and the demand, and who are supplied with money which they can use without public seandal in the manipulation of the market.

On this ground I feel confilent in stating that the Treasury of the United States receives more money, net, muler the system now in operation, than it would by taking the exclusive control of the business. Were auy capable Govermment ofticer supplied with, say, $\$ 100,000$, to expend in "working the market," and intrusted with the disposal of 100,000 seal skins wherever he conld do so to the best advantage of the Government, and were this agent a man of first-class business ability and energy, I think it quite likely that the same suceess might attend his labor in the Lomdon market that distinguishes the management of the Alaska Commercial Company. But imagine the cry of frand and embezzlement that would be raised against him, however howest he might be! This alone would bring the whole business into positive dispute, and make it a mational scandal.

As matters are now conducted, there is no room for any scaudal-not one single transaction on the islands but what is as clear to investigation and accountability as the light of the noon-day sun; what is done is known to everybody, and the tax now laid by the Govermment upon and paid into the 'Treasury every year by the Alaska Commercial Company yields alone a handsome rate of interest on the entire purchase money expended for the ownership of all Alaska.

\section{No. 9.}

\section{STATEMINT OF CAPT. LEWIS W. WILLIAMS.}

I am the principal owner of a vessel engaged in the whaling business in the Arctic and Bering Seas, and am also acting as master. That has been my business for a number of years past. San Franciseo is my home, and my ship departs from that place with the necessary supplies, and returus there with her carroes of whalebone. The average leugth of my voyages is about eight months. I tonch at the St. Paul Island generally every trip to obtain the weather record kept there. It was for a time kept by the U. S. Signal Service, aud since then by the arent of the Alaska Commercial Company. I also get the mail there, the newspapers, etc., also any supplies I may desire. I have purchased tools there, and also at one time sought the professional assistance of the company's physician on the island. The company's agents and other employés on the islaud have always been very obliging and clever to mo on my visits there. They always set signals to guide me to a safe landing, for the place of landing depends on the condition of the weather. They set for me their signal flags by which I am enabled to tell where to seek landing. At one time one of the company's pilots came ont and piloted my ship in Oonalaska Harbor without any charge.

I have also been at Oonalaska with my ship about four different years. Have gono there for water, for codtish, and for mails. In taking water there the Alaska Commercial Company furnished we the use of their water pipes and force pump and gave me the water free of charge. I also got repairs to my vessel there by the company's employes and the necessary materials cheaper than I could have had the same work dome in San Francisco. The men on my sbip purchased articles there from the company's store. I heard the men speak of it among themselves on the ship, expressing astonishment at the low prices paid by them. They were fully as low as san Franciseo priees.

We were always treated with the greatest kindness, and alwajs cordially greeted.

The arrival of a vessel there is quite au eveut to all at Oonalaska, and every one comes out to see an arrival. Intercourse is free and one has an opportunity of learning all the news and the state of feeling existing all around.

Ialways found that the natives had a very friendly feeling for the Alaska Commereial Company, and I know that, in their employment by the company, the natives received fair wages for little work. In tact, the natives fale better than most laborers elsew here in the United States. They are gemerally well dressed aud seem contented, except, in one respect, and that is, they cau not get liquor. They are very anxious to procure it and I was oftered at one time by a native $\$ 20$ in gold for a bottle of whisky. The company discomraces their use of liquors and in erery way tries to prevent them from getting it, even refusing them sugar, except in very limited quantities for tea and coffee. By the nse of sngar they are enabled to make an intoxicating liquid called "quass," upon which they get into a beastly state. They complain of the company that it refuses them sugar for this purpose, hut not otherwise. They are satisfied with the prices they receive for skins and with the prices they pay for goods. The company has tried to educate the people. I saw a school-house there and learned 
that tro employes of the company themselves taught the native children. I have been frequently in company's stores and seen trading going on between the agents and the natives, as well as others.

I have seen coin passed back and forth, but I never saw any defaced or mutilated coin and never heard of any in use at any of the company's stations or stores. In 1886 my company sent up a tencler with supplies to meet one of my ships at Oonalaska, but as she missed the ship she lauded her supplies and they were taken charge of by the Alaska Company's agent, and afterwards our whalebone on the ship was transferred to the Alaska Commereial Company's vessels and bronght to Sau Francisco. The company treated us very liberally and for the services rendered charged very low rates. We saved money by the arrangement.

They carry people on the vessels at low rates and give good accommodations. I never saw anything in their conduct which showed any desire to keep ont immigrants from any part of Alaska; on the contrary, they reeeived all new-comers with a hearty welcome.

The natives, with their wives and children, constantly travel on the Alaska Commercial Company's ressels :unong the islands, free of all charge, and often from Oonalaska to St. Paul and the reverse.

San Francisco, December, 1887.

LEWIS W. WILLIAMS.

No. 10.

STATEMENT OF MR. WERNER STAUF.

I reside at San Francisco, Cal, and have since 1872, except the portion of time I was in Alaska. In $1876 \mathrm{I}$ went to Wood Island, near Kodiak, in Alaska, as the agent of the American-Russian Commercial Company, a corporation organized to supply Culifornia with ice. It also did a small business in purchasing the skins of wild animals. I remained there as agent of the company from 1876 to 1881, mclusive. In 1882, I went to Oonalaska as agent for the Western Fur and Trading Company, a California corporation, of which the old-established firm of Fanlkner, Bell \& Co., of San Francisco, were the general agents, and remained there during 1882 and part of $18 \times 3$. The business of the company was to purchase furs and trade with the hunters and others of Alaska. While there as its agent it had vessels of its own plyiug between San Franciseo and Oonalaska and also coasting along the Aleutian chain. It carried up supulies, consisting of groceries, clothing, hoots and shoes, provisions, and hardwarein a word, all the variety usually found in country stores. It had numerous stations supplied with these articles-in fact, at almost every point where the Alaska Commercial Company had a station in Alaska. At each place it had a subagent. It bonght peltries from the hunters and traders, giving in returu mostly goods, but sometimes cash. Its business amounted to from $\$ 75,000$ to $\$ 100,000$ a year.

The geveral plan of doing business was the same as that of the Alaskia Commercial Company. Both companies fitted ont hunting expeditions in search of sea-otter at their own expeuse, taking the general risk of success, for if unsuccessful the supplies furnished the hunters were rarely paid for. When these excursions were successful the hunters would be paid for their peltries fair prices, and would be enabled to pay for the supplies furnished them or their families in their absence. A limited credit was always given to those teemed reliable, and was always eagerly sought by the natives. The two companies paid about the same prices for these pelts, and obtained the same prices for their goods. The relation of the two companies was abont the same as that of competing establishments elsewhere. Their several agents were friendly and obliging to each other, yet each strove to do the best business he conld for his own company. I uever foumd the agents of the Alaska Commereial Company unfair or unreasonable, or gnilty of any dishonorable condnet. Other traders came there oceasionally every year, trying to buy furs and trying to barter their merchandise brought there for that purpose. Purchasers of furs can hardly ever buy for cash, and always do better by bartering their goods; that is, such supplies as are suitable to the place and as are clesired by the natives.

The prices paid by the Alaska Commercial Company for peltries, whilst I was in Alaska, were always fair and reasonable aud at times I thonght high, for my own company at the same prices lost money. During my entire time there I had ample opportunity to know of the treatment which the uative population received from the Alaska Commercial Company. I know that treatment was always kibl and liberal, and that their relations wero pleasant and agreealble. There are good and bad people there as elsewhere - some of the native people are indust rions, honest, and reliable; others are just the reverse. The natives are much more likely to take advantage of the company than the company is to take advantage of the natives. The company always cultivates friendly relations with the natives to secure their trade, for otherwise they would not be able to obtain from them the skins of the sea-otter, which is the principal thing sought on the Aleutian chain. 
I always found the agents of the Alaska Commercial Company fair and honorable in all their dealings, and thongh $I$ was in the employment of a rival company, I was al ways treated fairly aud with courtesy. That company always extended every hospitality to strangers, and afforded every facility to persons to reach the parts of Alaska where the eompany does business and the interior, whether they were miners, excursionists, missionaries, or settlers. I saw no act on the part of the company or its agents tending to discourago immigration. I know that the Alaska Commereial Company established at its own expense schools for the instruction of the native ehildiren at Oonalaska and other places. At Oonalaska, the free school was taught by the employés of the company. The house of H. Liebes ed Co., of San Francisco, has been engaged in dealiug and bartering for furs on the Aleutian chain for ten years or more last passed. They have had several vessels on the coast overy year carrying up supplies aud carrying back peltries. They had a storefor several years at Belkofsky. That firm seems to have been quite snecessful in the bnsiness. At all times there are occasional trathing vessels passing along the coast seeking to barter for furs. The hunters always keep well posted in prices, and go from place to place seeking the highest price.

I nover saw any mutilated coin in circulation in Alaska, and if the Alaska Commercial Company had encouraged its use in any way I would have known it. I know that no company conld secure trade or obtain any advantage in business on that coast by the use or circulation of mutilated coin, or by requiriug its payment for supplies.

The Alaska Commercial Company has never harl any trade of any kind with Southeastern Alaska, and consequently exercises no influence over its prosperity.

The Alentian chain and coast has no qualities calculated to invite any large immigration. The mines are not promising and there is nothing on which to base any expectation of success in agriculture. Even hay, to feed the fow horses and horned cattle there, is imported from San Francisco.

$I$ have never been in the employment of the Alaska Conmercial Company, and have no business relations with it.

San Francisco, December, 188\%.

Werner Stauf.

No. 11 .

LETTER OF REV. EDMUND DE SCHWEINITZ, BISHOP OF THE MORAVIAN CHURCII.

Betulehem, Pa., December 8, 188 .

Gentlemen : Your letter of the 28th of November has been received. The charges which the goveruor of Alaska has brought against you have filled me with astonishment. Not one of them is substantiated by the experiences which our mission boart has made in its relations to your company.

That you are said to have redueed the entire population of the Territory to a condition of absolute slavery is preposterous. I have never received from our missionaries the slightest hint of such a thing.

That you are said to have marked and mutilated the coin of the United States, and refused to receive any other from the natives in payment of groods sold them, is an accusation of which our missionaries know nothing, for they would undoubtedly have reported it if it were a fact; especially as they have the best opportunity of findiur ont the truth, because they live in the midst of the Esquimaux of westeru Alaskit and within a quarter of a mile of one of your trading posts.

That yon are said to have discountenanced every attempt at immigration or settlement, aud that no white man or native ean live in peace and comfort in that Territory except by your sufferance, I emphatically deny. You have aided us in furnish. iny our missionary settlement at Bethel, on the Koskokvim River; you have faithfully acted as our agents; you have anmually provided and shipped, at very reason. able prices, the supplies for our missionaries; your trader at the post near Bethel helps them in every way within his power. When the two explorers whou we sent to western Alaska prior to begimning a mission returued they both spoke in high terms of the free entertainment you had given them at Oonalaska, and of all the kindness they had received at your hauds.

The entire board approves of and indorses the sentimeuts I have expressed in this letter. I wrote to-day to Messrs. Weinland \& Hartuanu, and begr thom to send their testimonials.

I am, very respectfully and sincerely, yours,

EDMUND DE SCHWEINITZ,

Bishop of the Moravian Church and President of its Society for Propagating the Gospel among the Heathen.

The Alaska Commercial Compaxx. 
No. 12.

LETTER FROM THE REV. WILLIAI H. WEINLAND, WRITTEN AT REQUEST OF BISHOP DE SCHWEINITZ.

Gracehill, Iowa, December 13, 1887.

Gentlemex: The letter you wrote to Bishop de Schweinitz reached me last evening, and I have prepared the inclosed testimony, hoping it may be of service to you in proving false these groundless accusations.

Wishing sou the continued prosperity which you deserve,

I am, very sincerely yours,

William H. WeINLAND.

Gracehill, Washington County, Iowa, December 13, 1887.

\section{To whomever it may concern:}

In regard to the charges made by the goveruor of Alaska against the Alaska Commercial Company, the undersigned, for two years a resident missionary of the Moraviau Church, laboring on the Koskokvim River, Alaska, begs to submit the following:

The governor charges that the Alaska Commercial Company discountenauces every attempt at immigration or settlement; aud whenever it has obtained a foothold, neither white mau nor native can live in peace or comfort, except by its sufferance.

The writer first became acquainted with the officers of the Alaska Commercial Company on April 28, 1884, when, in company with the Rev. Adolphus Hartmann, of Canada, he was on his way to Alaska to iuspect that Territory, with a view to locating a Moravian mission. We had been sent from Bethlehem, Pa., by the Society for Propagating the Gospel among the Heathen, the principal missionary society of the Moravian Chureh. From Washiugton, D. C., transportation to Alaska had been furnished for us on the U. S. revenue-cutter Corvin, Capt. Mark Healy in command, and through the kindness of this gentleman we were introduced to the officers of: the Alaska Commercial Company. Upon learning our destination and business, they showed us every attention and kinduess possible, offered us free transportation on any of the vessels of the company, and also furnished us with letters of introduction to their various agents and traders in the Territory.

The company's agent at Oonalaska, Mr. Reudolph Nenmann, gave us all the information asked, and assisted us on our way to Nushagak, where Mr. John Clark, the company's agent, put himself to no small inconvenience to assist us in gathering information, and in other ways forwarding the cause which we represented. This was again our experieuce on the Koskokvin River, where the agents of the company did all in their power to assist us.

Upon our return to San Francisco, on September 12, 1884, we informed the president of the Alaska Commercial Company that we had decided to locate our mission on the Koskokrim River, near the company's trading post at Mumtrekhlagamute, and be at once offered such assistance in establishing the mission as the company might be able to give.

The following spring, the writer, in company with a party of missionaries, sailed directly to the Koskokvin River, aud during the following summer we located our mission at the place selected. On the 18th of August, 1885, Mr. Hans Torgersen, our carpenter, was accidentally drowned.

Being thus left without human assistance of any lind, we were thankful to have the agents of the company to turn to for advice and aid, and most nobly did they respond, offering us even their own houses until we could construct our own. The Alaska Commercial Company also acted as agents for our missionary society in the East, and, at great cost of time and care, selected our goods for us according to the commissions intrusted to them, so that we were as well pleased with the goods sent as if we ourselves had done the selecting.

We had constant business trausactions with their agents at Oonalaska, Nushagak, on the Koskokvim River, aud also on the Y'ukon Rıver, and we also found these agents courteous, gentlemanly, considerate, aud helpful to our mission, even as we found the officers of the company themselves.

Furthermore, we ourselves have witnessed the assistance which the company and its agents gave to prospentors aud miners, who visited our northwestern part of Alaska for the purpose of looking into the resources of the country aud having had a fair opportunity to judge, I testify that, in my estimation, the company has done all that could reasonably be expected of them in opening up the country, in encouraging the fishing industries started alongside of its own business, and in other ways encouraging such immigration and settlement in Alaskia as the climate and resources of the Territory will warrant. 
(2) It is further charged that the company has mutilated the coin of the United States, and refuse to take any other from the natives in payment of goods sold them. This charge I believe to be alsolntely falso and without the least founlation. Throughout north western Alaska but very little money is in circulation, and this is almost. exclusively confined to the company's agents and the few white people seattered through the country. Between the traders and the natives there is but little coin passerl, the trading being for the most part in kind, the natives receiving only the best grades of goods in exchange for their peltries.

Of the money which is in eirenlation in Alaska, the writer passed various amounts during his stay at Sau Franciseo, and had it been mutilated this fact would have been known by me without a doubt. I testify, therefore, that all the United States coin which I saw or handled in Alaska was not in any way mutilated.

(3) It is further charged that the Alaska Commercial Company has, by the beggarly prices paid for their peltries and by a system of coustaut oppression, reduced. the entire population of the Territory, both white and natives, to a condition of absolute slavery.

No one having the least personal knowledge of the true condition of the natives of northwestern Alaska, where most of the trading posts of the Alaska Commercial Compauy are established, could possibly make this charge, unless it be from pure malice. The wild, uncivilized tribes of Alaska, who live by fishing and hunting, reduced to slavery by a commercial company! As well speak of reducing the ocean to slavery. These wild tribes are not in any way depeudent on the company for the necessaries of life, for they live on the products of the country, which are as free to the natives as the air they breathe.

But furthermore, having lived for two years within half a mile of one of the company's trading posts, and having gained a personal insight into the manner in which the company deals with the natives, both at the three stations on the Koskokvim River, and at other stations north and south from there, and besides this, having had personal dealings with these natives, I testify that the company has treated the natives fairly, paying reasonable prires for the peltries bought. Furthermore, they have, in many ways, looked after the welfare of these, natives. In time of epidemics or isolated cases of sickness, the physicians in the employ of the company have done all in their power to relieve the suffering coming within their reach, and in times of famine the agents of the company have fed as many of the natives as they could procure food for.

As regards the oppression of the white population at the hands of the company, this can only refer to the employés of the company, for no other class of whites are within their porrer. The fact that these employes retire from active service in the Territory after terms of service of varying length, either with comfortable livings or handsome fortunes, according to their individual thrift or the lack of it, proves this charge false.

I therefore testify that, to the best of my knowledge, these charges are not in any way foumded on the actual state of affairs throughout the entire northwestern part of Alaska, where the most of the trading posts of the Alaska Commercial Company are situated. Sitka is not Alaska any more than is New Orleans the Unitorl States.

The Alaska Commerchal Company. Rev. William H. Weinland.

No. 13 .

STATEMIENT OF MR. GEORGE C. KING.

I am a resident of Alameda, Cal, and have been a resident there and at Oakland for ten years past. I am a miuer by profession and have been since 1849 , in various States and Territories, though I have a part of the time been merchandising.

In 18s1, in company with niue others, I fitted out the schooner $\|$. F. March for a mining expedition in Alaska. We left San Francisco 5th May, 1881, and proceeded directly to Golovin Bay, on Norton's Sound, without stopping, except for a few dars at Oonimak Island (one of the Aleutian Islauds), for fishing aud exploring the islauds. We found it unubabited and no signs of mineral. Wo arrived at Golovin Bay the early part of June of that year. We went up Fish River in one of our small boats alont 100 miles. We found and located a mine callerl Oomielak. We remainerl on the ground prospecting the mine for about a month, and returned to Golovin Bay to the sehooner, leaving some miners on the ground. I then crossed Norton's Sound with the schooner and erew to St. Michaels, remaining abont a day to send off some letters. Met there the agent of the Alaska Commereial Company. We then went to Good News Bay, about 40 miles south of the month of Koskokvim Bay. There I left the 
vessel and with two others went about 600 miles up the Koskokvim River in one of our small boats to Kolmakofski, to prospect for ciunabar there. We found it in small bodies but not sufficient to encourage us to remain. We returned to Good News Bay, within 30 miles of which we lost our small boat. We remained at Good News Bay waiting for the return of the schooner.

As we afterwards learned, the schooner was lost on Golovin Bay, and after waiting for her until Oetober, we worked our way back part of the way till met by Mr. Sipary, the Alaska Commercial Company's trader, who had come down about 200 miles to meet us and help us back to Kolmakofski, where he had a station. We arrived the 28th of January, 1882. We traveled mostly by sleds, drawn by the Eskimo dogs. We remained there till about the latter part of June, 1882 , not being able to get awas sonner on account of ice. Mr. Sipary brought us down to Koskokvim Bay to a vessel of the Western Fur and Trading Company by meaus of which we reached St. Michaels. There I met Mr. Neuman, agent of the Alaska Commercial Company, and applied for passage to Sau Francisco on one of its steamers. Mr. Neuman treated us very kindly and supplied all our wants whilst there, and gave us passage on the steamer Dora to San Francisco, touching at St. Paul, St. George, and Oonalaska. We were destitute of means, having lost our vessel and all of our supplies, and except with the aid of the Alaska Commercial Company's agents, would have been without help. We obtained supplies from them and all that was necessary. We received anything we asked for. On the way back we stopped at St. Paul and St. George Islands in the sealing season and went ashore to see the driving and killing of the seals.

We stopped at Oonalaska about a week, and observed everything there. Also prospected there for mineral; found some indications, but nothing sufficient to justify any locations.

Everywhere I visited then and aftervards, the relations between the native population and the agents of the Alaska Commercial Company were of a very friendly character. The natives were treated better than any of the laboring classes elsewhere to my knowledge; they seemed to be satisfied with the prices paid them for labor and furs and charges for supplies furnished them. I saw nothing of any defaced or mutilated coin, and heard of none whilst I was in the country. I learned, on St. Paul and also at Oonalaska, of the free schools at each place. carried on by the Alaska Commercial Company, and everything seemed kept in good condition. I saw no oppression or hard treatment of the natives and heard of none. The natives seem well clothed and provided for, and had a contented appearance.

In $1886 \mathrm{I}$ again visited Alaska. Went from San Francisco in a fishing schooner of a San Franciseo company to Oonga; remained there and in the neighborhood and along the Alentian chain and main-land abont four months. I was prospecting for wineral. I found some veins on the main-land of gold, silver, copper, and galena, but located none any where except at Oonga, a mine now owned by the Sitka Mining and Commercial Company, an incorporated company, the stock of which is owned at San Franciseo. During most of the time I was traveling on the vessels of the Alaska Commercial Company. Without the facilities offered by it I conld not have done anything. I found that I could purchase so reasonably from the company's stores that I did not take any supplies from San Francisco. They sold to me overything at San Fraucisco wholesale prices, with 25 per cent. added. I understood that was their general rule.

I saw nothing to indicate any disposition on the part of the company to prevent the going in of immigrants. On the contrary, they appeared to treat all with hospitality, offered the means of transportation to all points at which their vessels visited. I returned in the fall of 1886 to San Francisco by the Alaska Commercial Compauy's steamer. In March, 188\%, I went again on the same steamer of the company's to Oonga and went all aloug the Alentian chain and on the main-land prospecting; and the general facts before stated as to the Alaska Commercial Company are true of my last visit there. Through the facilities it offered I was enabled to pursue my business, and I made several other locations and discoveries, both on the main-land and islands. Some of these I consider promising, two of them now being developed.

G. C. KING.

San Francisco, December 13, $188 \%$.

No. 14.

STATEMENT OF CAPT. GEORGE F. BAULDRY.

I reside at San Francisco, and have so resided for ten years last past. Mr occupation is that of commauding a vessel belonging to the Pacific Coast Steam-ship Conpany (Goodall, Perkius \& Co.). I have been in that service for the last five years, en- 
gaged in whaling. In 1886 and $1887 \mathrm{I}$ was twice at St. Paul Island in Berivg Sea. Last year I was also at Oonalaska. I went there for tools and supplies, and the agents of the Alaska Commercial Company supplied me with all I desired at reasomabl rates, and were very courteons and obliging in all things. They invited me very cordially to stop at their stations and seemed desirous of encouraging our frequent visits. In other years I was prevented by the ice from visiting these places. We trok them letters and papers, and carried the mails also for them from Oonalaska to St. Panl.

From my opportunities of seeing the company's business at Oonalaska aud at Saint Paul I can confirm the statement made by Capt. Lewis W. Williams, which I bave read, in referenes to the same and the company's treatment of the natives. Whilst at rheir stations I saw trausactions between them and the eompany's agents in which money passed, and I got some money changed there myself. I saw no mutilated coin there and heard of none. That which I saw the natives receive from the company for skins bought was good United States coin. Some of the men on my ship boncrit supplies at the company's stores at Ooualaska and expressed themselves surpriserl at the cheapness of the prices. The prices I paid mpself were very low. The prices the company paid the natives for skins I thought high prices.

San Francisco, December, 1887.

GEORGE F. Bauldry.

No. 15.

STATEMENT OF CAPT. FLIJAH E. SMITH.

I reside in San Franciseo, and that has been my home for twenty-seven years. In the year 1865 I was in the employment of the Western Union Telegraph Company, aud went in that year to Alaska on an exploring expedition for the purpose of laying out the route for the telegraph line. I went first to Sitka aud then to St. Michaels, on Norton Sound, on the bark Golden Gate.

I went up agaiu in the year 1866 , in the same employment, and spent' the winter of 1866-'67 in Alaska. with my headquarters at Oonalakleet, a large Indian village at the head of Norton Somnd. I went up in the bark H. L. liutgers, whilst the ship Nightingaie carried un on her deck a small stern-wheel steamer, bnilt at San Fraucisco. I found the steamer unfit for the service and resorted to canoes, with which we moved about in summer, but in winter we traveled on sleds drawn by dogs. At that time there were Russian trading posts in various parts of the country. My explorations carried me far into the interior. During that winter (1866-'67) I went up the Yukon River from Oonalakleet to Nulato. I also visited Anvik that year.

In the years 1868 and $1869 \mathrm{I}$ was a member of the Pioneer Fur Company, composed of four Canadian Frenchmen, myself, and others, formed for the purpose of the fur trade in Alaska. This continued for two years, during which we traded in fur-seal skins and other pelts, around northwestern Alaska, from Nunivak Island north ward. We also bought and traded for walrus ivory. In 1870-'71 I was engaged in whaling in the Aretic and Bering Seas, with others, and traded on the Alaska coast and islands for furs and ivory. In 187: to 1874 I was in the employment of the Alaska Commercial Company, and commanded one of their vessels running from San Francisco to Alaska. I made one trip a year in 1872,1873 , and 1874 , stopping at Oovalaska and at the islands of St. Paul and St. George and also at St. Michaels. In 1874 I went into the business of whaling in the Aretic and Bering Seas on my own account and continued in the same business in 1875 and 1876 . Since then I have been in the employment of various shipping companies, as well as in the United States revenue service. I am very familiar with the Alentian chain of islands and the coast of Alaska from thence northward to St. Michaels and in fact to the Arctic Ocean. I have been through Bering Straits and around as far as Anxiety Point, on the northern coast of Alaska.

I an well acquainted with the Alaska Commercial Company and its agents in Alaska, as well as with its mode of doing business there, especially in connection with its trading with the natives, both on the Pribrylov Islands and on the Aleutian chain and elsewhere. Whilst I was in the company's employment my instructions were to treat the natives everywhere fairly and liberally in all matters, and I know those were the instructions to others in their employment. I know that, by its fair dealing, the company has made itself popular with the natives and others with whom it has business. In their purchases from the natives and in their sales of supplies and all dealings with them they have always, where $I$ have been, acted fairly and reasonably, and I never heard any complaints to the contrary. The only complaint I ever heard from the natives against the company was that they could not olstain as mneh sugar as they wanterl. They, therefore, could not make the intoxicating liquor they call "quass," which they manufacture in alosence of the usual spirituous liquors, $9984-26$ 
I have myself seen great improvements on the Aleutian chain of islands, in the natives, since they have been cut of frou the maunfacture of "quass." This quass is the worst of iutoxieating drinks, and I believe that if the company desired to take unfair advantages of the natives, they could find no more certaiu plau than by selling them plenty of sugar, with which to make "quass." The company, however, refuses to do so, and in every way eucourages them in sobriety and good morals. Whilst doing business on my own account, and for others, with the Alaska Commercial Company, I was always treated fairly and liberally.

In $18 \times 5$ one of my vessels was ship-wrecked, and in consequence of that I spent several weeks at Oonalaska, where I was treated with great kinduess by the agents of the Alaska Commercial Compans. Neither at that time nor at any previous time did I see any mutilated coin received or paid ont. I saw coin paid in transactions between the natives and the Commercial Company, but it was good, current coin of the United States. Had the company ever attempted to limit the nativen to the usu of mutilated coin in their dealing with the company, I should have known it. I saw no oppression of the natives, or any hard usage of them whatever, by the company.

San Francisco, December, 1887.

E. E. Sмiтh.

No. 16.

STATEMENT OF CAPT. A. H. M'GREgOR.

I am master of the whaling bark Atlantic, of New Bedford, Mass. I was in command of her on the coast of Alaska, in Bering Sea, in the spring of 1884 . I was canght in the ice-floe and held for six weeks, and grot stoved there. I came very near abandoning my ship. I was finally able to reach Oonalaska. Captain Healy, of the revenue vessel Corwin, came to me and piloted my ship into port. We beached her on the 15th June, 1884, and there repaired her. I found there Mr. Nenman, agent of the Alaska Commercial Company, in elarge of that company's business. He was very obliging, and afforded me every faclity possible. He furnished me with materials for repairs, and gave me the nse of the blacksmith shop and wharf free of any charge whatever, and also offered me a supply of water. He informed me that I could have trom the company's store auything they haul at San Franciseo wholesale prices, with the freight only added. I made some purchases on those terms. The survejors of the ship thought the expenses of her repair would be about $\$ 1,000$ to $\$ 1,500$. I3ut, with the assistance of Mr. Neuman and the labor I employed there, my expenses did not exceed $\$ 56$, and I was delayed only four or five days. He also eashed at the company's store my draft on the owners at San Francisco, and otherwise treated me and my crew with great kindness and hospitality.

San Francisco, December, 1887.

A. H. McGregor.

\section{No. 17.}

LETTER OF TIE SECRETARY OF THE MAVY, IN ACKNOWLEDGMENT OF SERVICES RENDERED BY THE ALASKA COMMERCIAL COMPANY.

\section{Navy Department, Washington, February 10, 1885.}

Gentlemex: I desire to conves, through you, the thanks of the Navy Department to your agent, Mr. Neuman, at Oonalaska and Mr. Laurence, at St. Michaels, for their kindness aud assistance to Lieut. George M. Stones, U. S. Navy, commanding the U. S. S. Oonalaska, and also especially to Captain Hague, commanding your steamer Dora, whose valuable assistance to the Ooralaska when in Aualga Pass last Oetober, contributed to the safety of that vessel.

With a high appreciation of the services rendered by Captain Hague and the courtesies of your agents, I have the honor to subscribe myself, Very respectfully,

The President and Directors of the

Wm. E. Chandler, Secretary of the Navy. Ataska Commercial Company. 
No. 18.

Binghamton, N. Y., December 12, 1887.

DEAr Sir: Inciosed you will find a letter from the Alaska Commercial Company, of San Francisco, addressed to myself. The contents of that letter is my excuse for thus addressing you.

As you will see by the tenor of the company's letter to myself, they are seeking data in refutation of serious charges made against them and their mode of doing business in the Territory of Alaska. Allow me to say that it is a pleasure to myself to be able, from my own observation, and from information carefully gleaned from others (both white and native) living in Alaska, to contradict the charges named in the company's letter to myself. I would also state my motive for seeking this informatiou-it was to be sent to the Daily Republican, a newsjaper published in Binghamton, N. Y. Knowing, from a long personal acquaintance with the editor, that nothing but what was reliable would be acceptable to the Republican, I was very careful and, so far as my surroundings would permit, thorough in my efforts to gain nothing in the way of news that was not borne out by facts.

I will now, so far as my personal knowledge goes, answer the questions in the order named in the company's letter:

First. "That we have, by paying ridiculously low prices for their furs, and by constant oppression aud abnses reduced the natives to a condition of absolute slavery."

This is unjust and untrue, for the hunters, both white and native, told me in 1883 that the company had been paying them as high as $\$ 140$ for their prime sea-otter skins; but that year (1883) the company was to pay them $\$ 80$ for all sea-otter skins just as they run, prime or inferior. These prices were in United States gold coin, the natives not being obliged to take store pay. In 1883 I saw a notice posted up in the company's store in Oonalaska, stating that all goods shonld be sold alike to natives and whites, both paying the same prices for the same goods. In 1886 , while sitting in the compauy's oftice in Oonalaska, in company with my brother, Capt. W. H. Kelle5, a little native girl led into the office a blind native. The old man stated that be had no money and nothing to eat. The clerk told him that he was not authorized to advauce him anything, as he had two sons who were well able to care for him.

The agent, Mr. Nimens, came in and the case was laid before him. Mr. Nimens questioned the old native in a kind manner; after doing so he told the clerk to advance the old blind man, from time to time, provisions as his necessities required. The clerk asked him to what amount, and Mr. Nimens replied \$200. The clerk replied that the old man had no means to repay the amount; Mr. Nimens replied, in an angry tone, "What, would you let this old native suffer for food because he can not repay? He has been in our employ in former years, and was a good man; now that he is old and blind he shall not suffer because he can not pay."

Again, in 1883, while in Oonalaska, I saw a native at work building a bidarkie, or canoe. I had frequent and long conversations with this native. I asked him where he got the sea-lion skin to cover his canoe; he said that it came from San Francisco. 1 asked him how much the company charged the natives for those skins; he said nothing, as the company always gave the hunters the skins, making no charge for them.

In 1836, while in Oonalaska, some of the crew from $\mathrm{my}$ brother's ship, while on shore, iu a most wanton manner eut and destroyed some sea-liou skins belonging to some natives. Mr. Nimens, the agent, stated the facts to my brother, saying that the company would pay for the skins, as they never allowed the natives to sufter any loss at the hands of a white man. My brother paid for the skins.

I never heard a native that was in the company's employ find one word of fault. On the contrary, I found them well clothed, with good, warm, comfortablo frame dwellings, and, to all appearances, comfortable and happy.

Second. "That no oue, white or native, ean live in the Territory in comfort and peace, except by the sufferance of this company; that we have prevented any attempt at settlement, and discouraged immigration."

This is not true, for different members of the company have told me that the whole Territory was open and free to every one, excepting the islands of St. Paul and St. George, which they had leased from the United States Government, aud under that lease held the exclusive right to kill seals on those two islands, and that, farther than that lease, they had no more rights in the Territory of Alaska than any other American citizen.

In 188:3 I made inquiries from the agent at Oonalaska regarling the salmon fisheries, telling him that I was going to start a fishery, and he not only gave me all the desired information, but referred me to tho company's offico in Sin Francisco for farther advice and information.

This did not look like discouraging immigration. 
Third. "That we have stamped and mutilated the coin of the United States, refasing to accept any other from the natives in payment of goods sold them."

This is something that I know little or nothing about, but to me it has the stamp of a lie on the face of it. I have seen the natives (and have made change for them) pay coin for goods that had no stamp or mark on the coin. This is the first time that I ever heard of the thing, and believe it to be a falsehood out of whole cloth.

On different occasions $I$ have fouud it necessary to visit Alaska to gret wood, water, and stores for my ship, also to ship oil and whaleboue by the company's steamers. At such and at all times I have received from the Alaska Commercial Company every assistance that lay in their power to render me. When at Oonalaska I havo used their wharf, foree-pump, and hose, they making no charge for the use of the same. Last year I insisted that I should pay for the use of the wharf, pump, and hose. They have taken whalebone on freight by their steamers for one-tenth of the amount that it wonld have cost me to ship in vessels owned and controlled by the house I sail for. They have furnished my ship with pilot bread at one-fourth of a cent per pound advance on San Francisco wholesale prices. This would not more than pay interest and insurance, leaving no charge for freight. Butter and sugar at one cent per pound advance.

Allow me to ask, does this look like oppression or a desire to prohibit immigration into the Territory? I have nothing to say against the treatment that $I$ have always received at the hauds of the Alask a Commercial Company and their agents.

I have been at several of their stations in the Territory, ancl have always found the natives well elothed and living in good frame houses, which many of the natives then owned, having paid from $\$ 500$ to $\$ 900$ for them, according to the size of the house. So far as I have been able to learn, after strict inquiry, the compans have never broken their lease by killing more seals than their contract called for; to my personal knowledge there are more seal in Bering Sea to-day than there were before the United States Government bought the Territory.

Again, the company sells no breech-loading rifles or fixed ammunition to the natives; they sell no spirituous liquors to the natives, and are so strict in this that they will not sell molasses or brown sugar for fear the natives will make "quass," selliug nothing but white sugar, and should the natives save up their sugar to make "quass" then the company stops their allowance of sugar altogether.

The inquiries that I have made, at different times, when in the Territory, have been close and searching; and it is my opinion, as a citizen and a tax-payer, that the Alaska Commercial Company have been a credit to themselves and a benefit to Alaska Territory.

Respectfully, yours,

\section{General N. L. JefFries,}

EdMund KELlex, Master Bark Eliza.

Washington, D. C.

Portland, Me., December 13, 1887.

SIR : In view of certain criticisms adverse to the Alaska Commercial Company, Mr. Louis Sloss has asked me to put in writing the opinions I formed on the points in question during my visit to Alaska in 1883. I do so briefly.

I spent nearly six weeks at Oonalaska, was twice at St. Paul Island and St. Michaels, and visited the native villages on the Siberian coast and on our own as far north as Point Hope. I was a close observer and in familiar intercourse with ofticials of the United States and of the company.

(1) I could not but observe with pleasure the greatly improved condition of the natives at Oonalaska, the Pribylov islauds, and St. Michaels, and the many comforts accruing to them from the wages of the company.

They had exchanged huts for comfortable houses; they had good medical attendance; were well fed and well clad, some even extravagantly so; goods of every kind wert to be had at reasonable prices, and some of the thrifty oues had, through the agency of the company, deposits in a San Franciseo bank. Finally, they were able to sup)port their ow priest, and were left unhampered in the practice of their religion.

(2) I was told the prices paid for different skins. I did not regard them as unfair, especially after I had seen what was paid for the same by other traders. I was also given to uuderstaml that the outfit and provisions were supplied by the company, which took care of the widows and orphans of hunters lost in their service.

(3) As far as 1 could learn or observe the natives were treated kindly ; were free to go or come, to work or not, as they listed. I can not recall any accusation of oppression from a reliable source.

(4) I met mauy natives who were not in the service of the company, especially on the main-land from St. Michaels northward. They were ready to trade with all comers. 
(5) The great bar to immigration in the islands and main-land north of the archipelago is the impossibility of obtaining supplies. White men settling there must either forego them aud live as the natives do, or, at immense expense and risk, charter boats to bring them from the States, as there are no regular packets. Until there are settlements large enough to pay the packets, the population of these sections of the Territory must remain small.

(6) I saw a great deal of silver coin at each of the stations. It was all furnished by the company's agent. I saw none that was mutilated or stamped.

Such were my opinions, such my observations, in 188*3. I have not ehanged the former, nor have I any hesitancy about the accuracy of the latter.

I have the honor to be, yours, truly,

$$
\text { P. F. HЕALY, S.J. }
$$

P. S.-If you think that Mr. Sloss would like a copy of this letter, I leg of you to have a copy sent to him, as writing is fatiguing to me.

General N. L. JewFries.

P. F. HEALY, S.J.

Carlisle, PA., January 25, 1888.

Dran Sins : Please write me the probable date of sailing of your, vessels to Kodiak and Oonalaska, that I may know when to forward the mail for the teachers.

Permit we to assure you that I do not at all sympathize with the tirade of Governor Swineford against your company.

In my last amuual report, sent to the United States Commissioner of Education in Washiugton, D.C., last November, in several places I have made mention of the assistance rendered the schools by jour agents and employés.

In public addresses aud newspaper correspoudence also I have not failed to make mention of your assistance.

I have never had any cause of complaint against the officers of the company.

I understand that Governor Swineford expects or hopes to lobby through this Congress a Territorial legislature for Alaska. In the present condition of affairs in Alaska, a legislature would place all the material interests of western Alaska in the hands of a few adventurers in southeastern Alaska, the unfairness of which you can understand as well as $\mathrm{I}$.

Very truly, yours,

SHELdON JACKSON,

Alaska Commercial Company,

United States General Agent of Education in Alaska.

310 Sansome Street, S. $F$.

Washington, D. C., January 26, 1888.

Mr. Leon Sloss, of San Fraucisco, Cal., being interrogated by N. L. Jeffries, attornoy for the Alaska Commercial Company of Sau Francisco, replied as follows:

1. Q. What is your age, residence, and occupation?-A. I am thirty years of age; I reside in San Francisco, and am a merchant; I am also purchasing agent for the Alaska Commercial Company.

2. Q. Have you visited any part of Alaska Territory; if so, what part or parts, and how often, and how long did you remain there?-A. I first visited Alaska in 1883; I went to Kodiak, from there to Oonalaska, and from there to St. Panl and St. George Islauds, where I remained two months; I returned again in 1884 and 1855 for the same period.

3. Q. Does your employment in the oftice of the Alaska Commercial Compans afford you an opportmuity of becoming familiar with the business of the company and its method of conducting it ? $-\Lambda$. It aftords me every opportunity; and I have also been a director of the company.

4. Q. What relation, if any, are you to Louis Sloss, the president of the Alaska Commereial Company?-A. I am his son.

5. Q. State whether or not you are at any time present at the meeting of directors or managers of the company when its methods and business affitirs are discussed and determined.-A. I am usually present.

6. Q. So far as you know or have learned from the opportunities afforded ron, what is the policy or action of the company in reference to the settlement of the Territory? -A. The company aftords every possible facility for its settlement, and carries emigrants, miners, and missionaries on its vessels cheaper than the regular passage rates to Sitka. 
7. Q. What are the relations of the company to the Territory of Alaska, separate from the islands of St. Paul and St. George, in Bering Sea?-A. The company bnys furs from native hunters and traders, and pays for them in goods and money, but has no exclusive control of or right to such trade.

8. Q. Do you know whether or not there are other companies and traders in that Territory engaged in the fur trade besides the Alaska Commercial Company and its agents?-A. Yes, sir ; Bowen and Calwell, at Kodiak; H. Liebes \& Co., of San Francisco; "McCollam Fishing and Trading Company," and the "Northwest Trading Company," none of whom are in any way connected with the Alaska Commercial Conpany; the whaling fleets also trade with the natives.

9. Q. What other industries besides the fur trade are maintained in Alaska, so far as you know?-A. Mining industr 5 , codfishing, salmon packing, herring fishing, and walrus hunting.

10. Q. In the late report of Governor Swineford, of Alaska (page 32), he states that the Alaska Commercial Company "at one time marked and mutilated the coin of the United States, and refused to receive any other from the natives in payment for goods necessary to their comfort and well-being;" what have yon to say in reference to that statement?-A. I have been in the office of the company since May, 187\%, and, in reference to this period of time, $I \mathrm{know}$, of my own personal knowledge, that the statement is false, and from my knowledge of the companj's business and methods, as well as from what I have been informed by the company and its agents in reference to the periorl prior to May, 1877, I am satisfied that the entire statement is withont foundation; I know that mutilated coin has been received by the company, throngh its agents, but it was not stamped or mutilated by the company or its agents or employés, or by its authority or sanction; and I know, also, that said mutilated coin was received by the company at its face value, and was sold in San Franciseo as bullion, as the vouchers on file in the company's office will show.

11. Q. Has the company any trade with the natives of the Yukon region ?-A. None whatever; the company has an agent at St. Michaels who buys furs from the traders and sells goods to them at fixed prices, but the company has no dealings whatever with the natives.

LEON SLOSS.

\section{The District of Columria,}

\section{City and County of Washington:}

Before the undersigned, a notary public within and for the district and county aforesaid, personally appeared the above-named Leon Sloss, who is personally known to me, and who signed the foregoing in my presence, and theneaud there declared before me on oath, being by me first duly sworn, that the answers to the foregoing interrogatories, propounded to him by the said $N$. L. Jeftries, are each aud all of them true. 1888 .

Witness my hand and official seal at Washington, D. C., this 28th day of January,

[SEAL.]

GeOrge W. BaGG, Notary Public.

\section{Washington, D. C., February 1, 1888.}

H. H. McIntyne, being interrogated by N. L. Jeffries, attorney for the Alaska Commercial Cimpiny, of San Francisco, Cal., answered as follows:

Q. What is your age, residence, and occupation?-A. Age, forty-three jears; residence, West Randolph, Vt.; superintendent of seal fisheries of Alaska since 1870 to this date; formerly special Treasury agent for Alaska.

Q. In the late report of Governor Swineford, of Alaska (page 32), it is stated as follows: "Its" (the Alaska Commercial Company's) "insatiable greed is such that is not content with robbing the poor native in the price it sets upon the product of his dangerous toil, but it robs him also in the exorbitant prices it exacts for the goods given in exchange. And there is no appeal; no alteruative. There are no other trading statious in all that vast section, and the natives must pay the prico asked and accept that which is offered-the first a 100 per cent. advance on the amount at which the same goods are sold to the whites, and the last low enuugh to add still another 100 per cent. to the company's profit. As, for instance, there is no timber on the Aleutian islands, and the native who goes out to hunt the sea-otter has no time to provide himself with fuel by gathering driftwood from the shores, as many are able to do. He must have fuel for the winter, and the company generonsly takes his sea-otter skins at half their real cash value and pays him in coal at $\$ 10$ per ton-coal of the same quality as that which it sells to the few white residents for $\$ 20$. The native who dares to sell his furs for cash to others than the agents of the company finds that his money has no purchasing power at, perhaps, the only trading station within a distance of several hundred miles, and is thus starved into submission." What 
have you to say in reference to that statement?-A. The Alaska Commercial Company has constant competition in the sea-otter trade at all points in Alaska, either from local traders or from itmerants, who go from point to point in small vessels, and at most points from both these classes. The compauy must thorefore pay as much as auy ono else will pay for the same skins; and sell goods, for the same reason, as low as ean be afforded, including coal, which is sold at the same price to the Aleuts as to the whites.

In regard to the large number of people on the mainland, the Alaska Commercial Company stands only in the relation of a wholesale trater. The goods aro sold to, and furs purchased from, retailers who go among the uatives.

Q. On the same page of the governor's report it is stated, "I have positive information of flagrant violations of the law and execntive orders in relation to the importation and sale of breech-loading fire-arms by its arents; its ofyression and robbery are notorious." What have you to say as to that statement?-A. There is not a word of truth in that statement.

Q. What do you know in reference to the policy, methods, or conduct of the Alaska Commereial Company as to the settlement and develojment of Alaska Territory ?-A. The company is decidedly in fitvor of the settlement and development of the Territory. It affords every facility for the trausportation of persous and property in its power. Missionaries representing nearly every Christian denomination are carried free with their goods; miners are carried at reasouable rates, aud if unable to pay are earried free; natives are transported from point to point by luubdreds free of charge.

It would be to the advantage of the company's trade it the Territory were more densely populated; the oflicers and managers of the company are stockholders aud interested in mining at Oonga and Oonalaska, and in salmon fishing at Karluk, Nushagak, and Kenai, and are actively assisting in the development of these euterprises.

I was for two years United States Treasury agent for Alaska, and as such I visited every point on the sea-coast from the British Colmmbia border to the most westerly islands, and all important points in Beriug Sea, and in $1870 \mathrm{I}$ entered the service of the Alaska Commercial Company, and since then I have been its general agent and superiutendent of the seal fisheries, and have repeatedly visited the principal points of the entire Territory, and I make this statement from personal knowledge of the 'Territory and of the operations of the company.

H. H. MCINTyre.

\section{District of Columira, Cit!y and County of Washington:}

Before the undersigned, a notary public within and for the district. city, and county aforesaid, personally appeared the above-named H. H. MeIntyre, and who, being well known, signed the foregoing instrument in my preseuce, and, being by me duly sworn, says, upon oath, that the answers by him made to the foregoing interrogatories by N. L. Jeffries are true.

Witness my hand and notarial seal this 1st day of February, A. D. 1838. [SEAL.] 


\section{THE SEAL ISLANDS.}

\section{[Extract from special report of the governor of Alaska for the year 1888.]}

Section 5 of the aet providing a civil government for Alaska proviles that the governor "shall from time to time inquire into the operations of the Alaska Seal and Fur Company, and shall annually report to Congress the result of such inquiries and any and all violations by said company of the agreement existing between the United States and said company." In view of this provision I have considered it my duty to inquire into the operations of that company-or rather of the Alaska Commercial Company, as was undoubtedly the intention of Congress-generally, instead of confining my inquiries merely to the question of whether or not it had violated its agreement with the Government.

The result of $m y$ inquiries into the operations of the compans, aside from its sealing business, together with my views as to how they affect the best iuterests of the Territory and the welfare of its people, I have enbodied as plainly and succinctly as possible in the foregoing pages. In doing so I have been governed by no other motive or desire than the good of the Territory, whose interests and welfare $I$ have esteomed it a paramount duty to guard and promote to the best of my understanding and limited ability.

So far from having been actuated by any personal feeling, I wish to say that if the system of leasing the seal islands, withont restriction as to trade in other parts of the Territory, is to be continued, very little in the way of reform is likely to be accomplished by dispossessing the jresent lessees in favor of some other individual or corporation. It is the system or principle that most merits condemnation; any other corporation granted the same exclusive privileges would naturally strive to make the most of the opportunities presented, and I cau see no prospective good to accrue to the Territory through the dispossession of one monopoly merely to make place for another and, possibly, worse one.

So far as its operations on the seal islands are concerned, it aftorls me pleasure to be able to report an altogether satisfactory condition of affairs-one which is wholly creditable, at least to the compauy. I am perfectly satisfied that the company is, and has been all along, faithfully complying with all the terms and conditions of its agreement with the Government; in fact, it is doing even more in the matter of providing for the wants and comfort of the natives than its contract requires.

I do not believe, as has frequently and persistently been charged, that, it has over taken in any one year more than the number of seals anthorized by law, for the smule reason, if there be no other, than that is has not been and is not now to its interest to do so. That could only be done hy and with the comnivance of the Govermment agents and the customs authorities at San Franciseo, and in the absence of any evidence it would not be right or proper to question the honesty of those officials.

The provision of the lease restricting the number of seals that may be killed to 100,000 aunually is its most valuable feature, as a moment's consideration will convince any person who is possessed of the slightest appreciation of the law of supply and demand. While I can not aver a positive knowledge in the premises, I nevertheless feel quite safe in asserting that the company has never violated either that or any other express provision of its lease or contract. It is true, I did not have an opportunity of visiting St. George, owing to the then prevailing had state of the weather, but I spent the best part of two days on St. Paul Island, where the principal rookeries are located, and where seventeen-twentieths of the seals are killed.

I was here aftorded every facility by the company's general agent for acquiring such information as I desired, the books of the company as well as those of the Treas. ury agent being open to me, while there was no restriction or espionage whatever to prevent me from obtaining any information the native people might wish to impart. I conversed freely with many of the nost intelligent Aleuts and creoles, and as all the killing is is done by them, for which they receive a compensation of 40 cents per skin, it is fair to assume that they would know of it had there been any violation of eontract in regard to the number killed; their accounts, however, show payment for the legitimate number only, and it is far from reasonable to suppose that the company would hazard the possession of so valuable a franchise by entering into collnsion not only with the Goverument agent, but with a hundred or more vatives for the purpose of defrauding the Government.

While I conld find no evidence upon which to base even a suspicion of fraud in the number of skins taken, careful observation and inguiry forces upon me the conclusion that the company was not only honest in its dealings with the Government, but, 
as I have said, had done and was doing much more for the comfort and welfare of the natives than its agreement enjoins upon it.

I found the natives all comfortably housed in neat oue-story frame louses built for them by the company, and which they are permitted to occupy for no other consideration than that the promises shall be kept elean. There are about sixty of these mative houses is the village of St. Panl, all presenting it neat, tidy exterior, and, so far as my observation extended, all well and cleanly kept on the inside. No offial or otfensive refuse of any kind is allowed around the houses. The streets are kept clean, and the sanitary regulations and conditions are better than those usually entorced in eastern villages.

The sehool-house is large enough to accommodate all the chiltren of school age on the island, and will compare most favorably in all respects with similar bnildings in the States and Territories. The school was having its anmal vacation at the time of my visit, but I met a number of native children who eonld speak Lnglish, and a few comparatively young men who conld read and write, aud was informed by the teacher and the Government agents that the school, which is kept open from September to May, was making excellent progress.

A dispensary in charge of a skillful physician is maintained by the company on each of the islands, both medical attendance and medicines lyeing supplied free of charge. The agreement with the Government requires the company to furnish the inhabitants of the two islands with 60 cords of fire-wood anuually, bint for some reason, or under some arrangement, coal is being furnished them iustead of wood, the allowance being 10 pounds per day to each house. This wonld be a little more than 1 tons for the year to each house, and allowing that only thirty of the houses are ocenpied, the cost to the company would be more than the value of the wood it originally agreed to furnish. This amount of coal is of course insufficient, and the people are compelled to buy enough fuel to make up the deficiency; that the company sells to them at the rate of $\$ 1.50$ per 100 pounds for coal, or three sticks of cord-wood for 50 cents.

In the event of a renewal of the company's lease, or the leasiug of the islands to auy other corporation or iudividual, I think a much more liberal provision for a free supply of fuel to the natives shonld be made. From the stores at St. Panl and St. George I assume that the conditions at St. George are the seme as at St. Paul, the same general agent being in control. The natives are furnished goods and provisions, if indeed not as the conpany claims at only 25 per cent. advauce on san Francisco wholesale prices, most assuredly at very much lower figures than have yet obtained anywhere else in Alaska.

There are 219 men, women, and children, exclusive of the few whites on St. Panl, aud 112 on St. George. These 331 people, of whom it is safe to say less than onethird are adults, are pard by the company each year, for not to exeeed three months' ictual labor, $\$ 40,000$, which is divided anong them, not exactly on a community plan, but in shares of the first, second, third, and fourth elass, the classes being arranged by and among themselves, and founded upon the relative skill of the workmen and value of labor performed.

As, for instance, of the $\$ 34,000$ paid the present year for killing and flaying the 85,000 seals taken on St. Paul, the men of the first class received \$5:6 each, those of the second class perhaps $\$ 50$ less, and the other two classes from $\$ 300$ to $\$ 400$ per man. These amounts, after the division is agreed upon, are placed to the credit of the individual persons composing the several classes on the books of the company, and can be dramn in cash whenever wauted, except that either on its own motion, or at the request of the Government agents, the company insists upon retaining an amount sufticieut to insure each individual $\$ 3$ per week during the long period of enforced idleness which intervenes between the close of one killing season and the commencement of another.

A number of the moro provident natives bave very considerable amonnts standing to their credit with the company, on which they are allowed 4 per cent. interest, and, by the means just stated, thu improvident ones are compelled to save enough for the support of themselves and families. If they do any extra work they are paid for it; the company likewise pays them 40 cents each for skins of the pup-seals, of which the law permits them to kill as many as may be needed for food-at least for as many as they desire to sell for that price after they are neatly tamned. Many of these pup skins, however, they make up into blankets, coats, caps, etc., which are eagerly sought for by the oflicers of the revenue steamers, but I was informed they were not allowed to sell them except throngh the ofice, and not even then withont first having obtained the Government agent's permission.

There are a great many blue and white foxes on St. Panl Island, and of these they are permitted to trap not to exceed 500 each winter, for the pelts of which the company allows them 40 and 60 cents each, respeetively. Tho people are seemingly much attached to the company's general agent, who struck me as being a man of the most humane and kindly feelings, and I beard no complaints from the natives concerning 
their treatment either by the agent or any one else connected with the company. So far as the relations existing between themselves and the company are concerned, they are probably as well if not better off than an equal number of white workmen to be found anywhere in the States.

On the other hand, it seems to me that the autbority exereised over them by the Govermment agents is rather arbitrary and oppressive. While at Oonalaska on my return trip from the Aretic, I was called on by a delegation claiming to represent the people of St. Paul Island, who complained bitterly of the restrietions placed upon their actions by the Government agents.

As I have stated, they are not permitted to sell anything without permission, aud the delegation in question complained that on days when the store was open the assistant agent assumed the right to act as clerk not only, but also to decide for them what they should and should not buy. They claimed that he had discharged the second chief from the position to which he had been elected for no other reason than that he had gone fishing without first having obtained permission; that no one is permitted to leare the islands without consent of the agent, and instauced cases where they had been refused permission to receive visits from friends and relatives, though the company was perfectly willing they should come, and offered to give them free transportation on its steamers.

In flaying seals a fow of the skins are accidentally cut, and these, together with those which are pronounced "stagy," are rejected by the company. These skins, the delegation claimed, would be of use to the people in various ways, but iustead of being allowed to keep them they are cut up and thrown away by order of the Gove ernment agents. This is the delegation which $I$ bave referred to as complaining that the fire-arms sold to them by the company had been taken away from them, for what reason they professed not to know. I know nothing of my owu personal knowleige concerning the truth of the statements made to me by the complainiug delegation, but I do know that the natives of the islands are not permitted to sell property reeognized on all hands as belonging to themselves without first obtaining permission of the Goverument agents.

It it would seem to me, in view of the fact that none but Gevernment vessels and ofticials and those of the company are allowed to call at or land upon these islands, that the natives might be permitted to sell without let or hindrance that which is admittedly their own; uor does it appear to me at all necessary to their well being that they should be restricted to the enjoyment of only such rights aud privileges as the Government agents in their wisdom may see fit to prescribe. On the contrary, it seems to me that the duty of these agents, so far as their relations to aud with the natives are concerned, lies in the direction of protecting them in the full enjoyment of all their just rights and privileges, and not in the way of their abrilgement.

In my last annual report I submitted very briefly my views as to the policy which should, in my opinion, be adopted by the Government in regard to the fur-seal industry. A visit to the rookeries has not served to chauge or modify those views. I can see no good reason why the present monopoly of the business may not be abolished, not only without loss to the Government, but to its very great ad vantage so far as the amount of revenne to be derived is concerned. The present system of farming out the rookeries is not only obnoxisus to every sense of right and justice, but, as I think I have shown, is in a very great degree inimical to the best interests of the Territory. But if it be concluded that the plan briefly outlined in my last report is impracticable, then I respectfully suggest that the law authorizing the lease of the seal islancls should be so amended as to positively prohibit the lessees, under penalty of forfeiture, from engaging either as a corporation or as individuals, directly or indirectly, in anv other business than the taking of fur seals within the limits of Alaska Territory.

If it is considered that there is no other way of dealing with the question so as to perpetuate the industry, and at the same time secure a revenue to the Govermment, if the business must be movopolized in order to prevent its destruction, then on behalf of Alaska, in this my last ofticial report, I beg and pray that the monopoly thus created and perpetuated by Congress may be restrieted to the leased islauds, aud not be permitted to spread itself all over the Territory to the detriment of almost every other interest within its borders.

Very respectfully,

A. P. Swineford, Governor of Alaska. 
House Ex. Doc. No. 296, Fiftieth Congress, first sersion.

\author{
FUR-BEARING ANIMALS IN ALASKA.
}

\title{
L E T T E R
}

FROM

\section{THE SECRETARY OF THE TREASURY,}

IN RESPONSE TO

A resolution of the Mouse calling for information in regard to the lease of the right to take fur seals in Alaska.

If $\mathrm{x}$ 4 4, 1888.-Referred to the Committee on Merchant Marine and Fisheries and ordered to be printed.

\section{Treasury Departurent, \\ OFFICE OF THE SECRETARY, Washington, D. (Y., Mlay 3, 1888.}

Sin: 1 have the honor to acknowledge the receipt of a copy of a resoIution, adopted on the 27 th ultimo, requesting the Secretary of the Treasury-

To inform the House of Representatives what contracts or leases of the right to talio fur seals or other fur-bearing animals in Alaska have been made by the Treasury Department, to whom made, for what length of time, for what considerations, and upon what conclitions, and when the same will expire; and also to inform the House what sums of money have been exprended by the Goverument to prevent the unlawful killing and extermination of fur seals and fur-bearing animals in Alaska, and for the enforcement of the laws in relation thereto; aud what sums have been received by the Government on account of any leases of the right to take fur seals and fur-bearing animals in Alaska, and on account of aby and all other Government charges for the taking and shippiug of such furs from Alaslia; and also to inform the Honse as to whether or not the terms and conditions of any such contracts or leaves for the taking of fur seals and other fur-bearing animals in Alaska havo been violated and to what extent; and whether or not other persons and ressels than thoso anthorized by the laws of the United States to do so havo been engaged in taking fur seals and other fur-bearing animals in Alaska and transporting such fur from there, and who and to what extent.

In response to said resolution, I have the honor to state, that the lease of the right to take fur seals in Alaska for the term of twenty years from the 1st day of May; 1870, was made on August 31, 1870, to the Alaska Commercial Company, a corporation established under the laws of the State of California, upon conditions and for considerations specified in the copy of the lease herewith submitted, marked A, 
and that the condition in the lease relative to a tax of 55 cents per gallon on seal oil was rescinded by a letter dated February 16, 1874, of Hon. W. A. Richardson, then Secretary of the Treasury, a copy of which accompanies the copy of lease.

I have the honor further to state that the total receipts from the sources mentioned in the resolution, from May 1, 1870, to June 30, 1887, were $85,059,065.67$, and the expenditures during the same period $\$ 209,901.94$, as shown in detail for each year, in the statement herewith marked B; that the records of this Department so far as I am advised do not show any violation of the terms and conditions of said lease by the lessees, and that other persons and vessels than those authorized by the laws of the United States to do so have been reported and seized for engaging in taking fur seals during the past three years, as exhibited in the statement marked C, also submitted herewith.

Respectfully yours,

C. S. FAIRCHILD, Secretary.

Hon. JoHN G. CARLisLe, Spealier of the House of Representatives.

\section{Exhibit A.}

Copy of lease from the United States to the Alastia Commercial Company of the right to talie fur seals in Alaska, delivered August 31, 1870.

This indenture, in duplicate, made this third day of August, A. D., eighteen huudred and seventy, by and between William $A$. Richardson, Acting Secretary of the Treasury, ia pursuance of an act of Congress, approved July 1st, 1870, entitled "An act to prevent tho extermination of fur-bearing animals in Alaska," and tho Alaska Commercial Company, a corporation duly established under the laws of the Stato of California, acting by John $\mathrm{F}$. Miller, its president and agent, in accordance with a resolution of said corporation duly adopted at a meeting of its board of trustees held January 31st, 1870. Witnesseth :

'That the said Secretary hereby leases to the said Alaska Commercial Compans, without power of transfer, for the term of tiventy years from the first day of May, 1870, the right to engage in the lusiness of taking fur seals on the islands of 'St. George and St. Paul within the Territory of Alaska, and to send a vessel or vessels to said islands for the skins of such seals.

And the said Alaska Commercial Company, in consideration of their right under this lease, hereby covenant and agree to pay for each year during said term, and in proportion cluring any part thereof, the sum of $\$ 55,000$ into the Treasury of the United States, ju aceordance with the regulations of the Secretary to bo made for this purpose under said act, which payment shall be secured by deposit of United States bonds to that amount; and also covenant aud agree to pay anuually into the Treasury of the United States under said rules and regulations, a revenue tax or duty of $\$ 2$ upon each fur-seal skin taken and shipped by them, in accordance with the provisions of the act aforesaid; and also tho sum of $62 \frac{1}{2}$ cents for each fur-seal skin taken and shipped, and 55 cents per gallon for each gallon of oil obtained from said seals for sale on said island or elsewhere and sold by said company. And also covenant and agree, in accordance with said rules and regulations to furnish, free of charge, the inhabitants of the islands of St. Paul aud St. George aunually, during said term, 25,000 dried salmon, 60 cords fire-wood, a sufficient quantity of salt, and a sufficient number of barrels for preserving the necessary supply of meat.

And tho said lessess also hereloy covenant and agree during the term aforesaid, to maintain a school on each island in accordance with said rules and regulations and suitablo for the education of the natives of said islands for a period of not less than eight months in each year.

And the said lessees further covenant and agreo not to kill upon said island of St. Paul more than 75,000 fur seals, and upon the island of St. George not more than 
25,000 fur seals per annum; not to kill any fur seal upon the islands aforesaid in any other month except the months of June, July, September, and October of each year; not to kill such seals at any time by the use of fire-arms or otber means tending to drive the seals from said islands; not to kill any female seal or any seal less than one year old; not to kill any seal in the waters adjacent to said islands or on the beaches, eliffis, or rocks where they haul up from the sea to remain.

And the said lessees further covenant and agree to abide by any restriction or limitation upon the right to kill seals under this lease, that the act preseribes or that the Secretary of the Treasury shall judge necessary for the preservation of such seals.

And the said lessees hereby agree that they will not in any way sell, transfer, or assign this lease; and that any transfer, sale, or assignment of the same shall be void aud of no effect.

And the said lessees further covenant and agree to furnish to the several masters of the vessels employed by them certified copies of this lease to bo presented to the Government revenue officers for the time being in charge of said islands, as the authority of said lessees for the landing and taking said skins.

And the said lessees further covenant and agree that they, or their agents, shall not keep, sell, furnish, give, or dispose of any distilled spirits or spirituous liquors on either of said islands to any of the natives thereof, such person not being a physician and furnishing the same for use as medicine.

And the said lessees further covenant and agree that this lease is accepted subject to all neerfful rules and regulations which shall at any time or times hereafter be made by the Secretary of the Treasury for the collection and payment of the rentals herein agreed to be paid by said lessees; for the comfort, maintenance, education, and protection of the natives of said islands, and for carrying into effect all the provisions of the act aforesaid, and will abide by and conform to said rules and regulations.

And the said lessees, accepting this lease with a full knowledge of the provisions of the aforesaid aot of Congress, further covenant aud agree that they will fultill all the provisions, requirements and limitations of said act, whether herein specifically set out or not.

In witness whereof the parties aforesaid hare hereunto set their hands and seals the day and year above written.

\section{WILLIAM A. RichaRDSON, Acting Secretary of the Treasury. \\ Alaska Commercial Company, [Shal.] By JNo. F. MILLer, President.}

Executed in the presence of-

J. H. SAVILLE.

Treasury Department, Office of the Secretary, Washington, D. C., February 16, 1874.

SIR: Referring to your letter of the 15th ultimo, relative to the taking of seal-oil on the islands of Saint Paul and Saint George by the Alaska Commercial Company, upon which oil a tax of 55 cents per gallon was agreed to bo paid by tholease entered into between the United States and said company, I have to say that upon due consideration I have decided to waive the collection of tax upon such seal-oil as may be taken by said company and shipped from said islands; such waiver to stand in full force until otherwise ordered by the Department.

I am, very respectfully,

WM. A. RICHARDSON,

Secretary.

II. M. Hutchunson, Esq.,

Of Alaska Commercial Company, Washington, D.C. 


\section{Exнiвiт B.}

Statement of the receipts and expenditures of the Government relating to seal fisheries of Alaska, as appears from the books of the Register of the Treasury.

RECEIPTS.

From tax on seal-skins and rental for right of taking seal furs in Alaska:

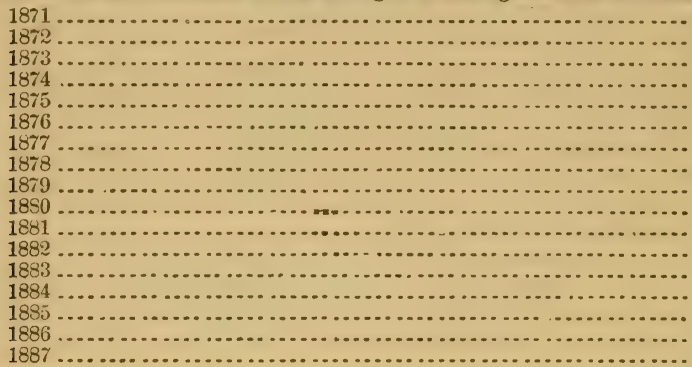

Sale of seal-skins taken by Government agents, 1874 Forfeiture for unlawfiul taking fur seals, 1886.
$\$ 101,080.00$ $322,863.38$ $307,181.12$ $327,081.25$ $317,494.75$ $317,584.00$ $291,155.50$ $253,255.75$ $317,447.50$ $317,400.25$ $317,594.50$ $316,885.75$ 317, 295. 25 $251,875.00$ $317,400,25$ $317,489.50$ $317,452.75$

$5,028,536.50$ $29,529.17$ $1,000.00$

\section{EXPENDITURES.}

Buildings at seal fisheries, Alaska, 1872

Collecting information respecting fur trade of Alaska, 1875

$6,000.00$ 787. 51

Salaries and traveling expenses of agents at seal fisheries, Alaska:

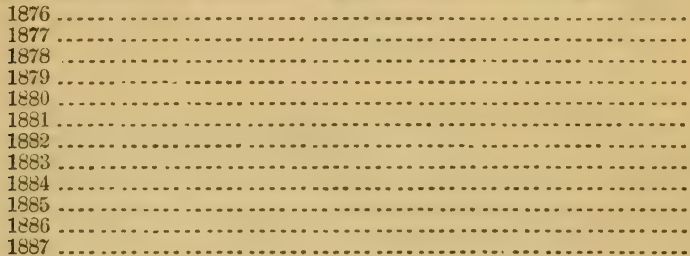

$\$ 2,752.68$

$8,080,49$

$10,892.50$

$16,381.78$

9,571. 02

4, 248.09

$15,263.06$

11, 090. 32

13, 811.64

$13,102.61$

7, 937.49

$16,174.13$

$129,305.81$

Protection of sea-otter hunting grounds and seal fisheries, Alaska:

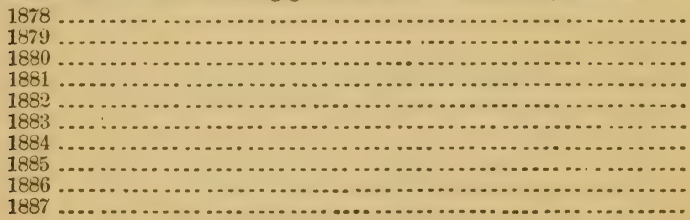

$15,546.00$

$2,681.52$

$22,902.88$

619.12

$19,559.10$

$20,000,00$

$25,000,00$

$25,000, \mathrm{c}$ ก

15. 000.00

$17,500.00$

$163,808.62$

Treasury Departarent,

Register's Office, May 1, 1888. 


\section{Exhibit 0.}

\section{List of vessels seized under orders of the Treasury Department.}

\begin{tabular}{|c|c|c|c|}
\hline Date. & Vessel seized. & By what vessel seized. & Commanding officer. \\
\hline 1884 & For violation of section $1956, R . S$. & & \\
\hline $\begin{array}{l}\text { Sept. } 1 \\
1886 .\end{array}$ & Hamburg schooner Adele......... & Revenue steamer Corwin ..... & Capt. M. A. Healy. \\
\hline July 17 & American schooner San Diego.... & ...... do ... & Capt. C. A. Abbey. \\
\hline Aug. 1 & & ...... do ... & Do. \\
\hline & $\begin{array}{l}\text { British schooner Carolema......... } \\
\text { British schooner Onward ......... }\end{array}$ & (a..... do & $\begin{array}{l}\text { Do. } \\
\text { Do. }\end{array}$ \\
\hline July 2 & British schooner Anna Beek..... & Revenue steamer Rush & Capt. L. G. Shepard. \\
\hline & British schooner $/ \mathrm{m}$.P. Say ward & ...... do .................. & Do. \\
\hline $\begin{array}{l}12 \\
16\end{array}$ & British schooner Dolphin .......... & ....... do .................... & Do. \\
\hline $\begin{array}{l}16 \\
17\end{array}$ & & 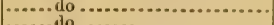 & Do. \\
\hline Aug. 6 & & 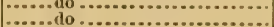 & $\begin{array}{l}\text { Do. } \\
\text { Do. }\end{array}$ \\
\hline & American schooner Annio ........... & ......do do........... & Do. \\
\hline & British schooner Alfred Adams... & ...... do & Do. \\
\hline & American schooner Alpha ......... & 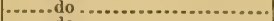 & Do. \\
\hline & $\begin{array}{l}\text { American schooner Kate and } \\
\text { Anna. }\end{array}$ & & \\
\hline & American schooner San Jose ...... & ;.....do ................... & Do. \\
\hline & 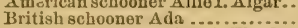 & Revenue steamer Bear... & Capt, W. A. Healy. \\
\hline Sept. 2 & American schooner Sylvia Handy. & pendo & Do. \\
\hline & For violation of section 1961, $R$. S. & & \\
\hline June 30 & American schooner Challenge.... & Revenue steamer Rush....... & Capt. L. G. Shepard. \\
\hline
\end{tabular}

1885, no seizure. 








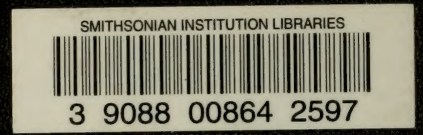

